\title{
Planning in een markteconomie : indicatieve planning, industriebeleid en de rol van de publieke onderneming in Frankrijk in de periode 1981-1986
}

Citation for published version (APA):

Groenewegen, J. P. M. (1989). Planning in een markteconomie : indicatieve planning, industriebeleid en de rol van de publieke onderneming in Frankrijk in de periode 1981-1986. [Doctoral Thesis, Maastricht University]. Eburon. https://doi.org/10.26481/dis.19890407jg

Document status and date:

Published: 01/01/1989

DOI:

10.26481/dis.19890407jg

Document Version:

Publisher's PDF, also known as Version of record

Please check the document version of this publication:

- A submitted manuscript is the version of the article upon submission and before peer-review. There can be important differences between the submitted version and the official published version of record.

People interested in the research are advised to contact the author for the final version of the publication, or visit the DOI to the publisher's website.

- The final author version and the galley proof are versions of the publication after peer review.

- The final published version features the final layout of the paper including the volume, issue and page numbers.

Link to publication

\footnotetext{
General rights rights.

- You may freely distribute the URL identifying the publication in the public portal. please follow below link for the End User Agreement:

www.umlib.nl/taverne-license

Take down policy

If you believe that this document breaches copyright please contact us at:

repository@maastrichtuniversity.nl

providing details and we will investigate your claim.
}

Copyright and moral rights for the publications made accessible in the public portal are retained by the authors and/or other copyright owners and it is a condition of accessing publications that users recognise and abide by the legal requirements associated with these

- Users may download and print one copy of any publication from the public portal for the purpose of private study or research.

- You may not further distribute the material or use it for any profit-making activity or commercial gain

If the publication is distributed under the terms of Article $25 \mathrm{fa}$ of the Dutch Copyright Act, indicated by the "Taverne" license above, 
PLANNING IN EEN MARKTECONOMIE 



\title{
PLANNING IN EEN MARKTECONOMIE
}

Indicatieve planning, industriebeleid en de rol van de publieke onderneming in Frankrijk in de periode $1981-1986$

\section{PROEFSCHRIFT}

\author{
ter verkrijging van de graad van \\ doctor aan de
}

Rijksuniversiteit Limburg te Maastricht, op gezag van de Rector Magnificus, Prof. Dr. F.I.M. Bonke, volgens het besluit van het College van Dekanem in het openbaar te verdedigen op vrijdag, 7 april 1989 om 16.00 uur

door

Joannes Petrus Maria Groenewegen geboren te Nootdorp in 1949 
Promotores

: Prof. Dr. W. Albeda

: Prof. Dr. H. Schreuder

Beoordelingscommissie : Prof. Dr. J.A.H. Maks (voorzitter)

: Prof. Dr. H. Booij

Dr. P.K. Keizer

: Prof. Dr. C.J. van der Weijden 
Voor Marga

Maaike

Matthijs

Joost 


\section{SCHEMA'S}

3.1 Het "Organizational Failures Framework"

3.2 Een classificatje van 'governance structures'

3.3 Het ontstaan wan diverse 'governance structures'

3.4 Een analysemodel van de industriêle organisatie 56

3.5 Samenvatting van de dynamische markttheorie $\quad 59$

$\begin{array}{ll}3.6 & \text { Vijf concurrentiekrachten van Porter }\end{array}$

3.7 Nadere specificatie van de vijf concurrentiekrachten van Porter 61

3.8 De ingredienten van een theorie van economische organisatievormen 63

$\begin{array}{ll}3.9 & \text { De Franse versie van het model van Scherer }\end{array}$

3.10 De netwerkbenadering 66

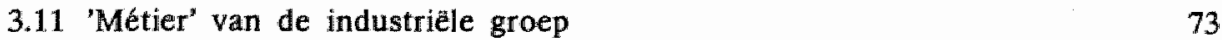

3.12 Statistische en monografische 'filière" $\quad 86$

3.13 Algemeen politiek-economisch model ('public-choice'-benadering) 88

3.14 Typollogie van beleidsnetwerken $\quad 89$

4.1 Faktoren van invloed op de duur van de cyclus van Hafsi 119

4.2 Typollogie van relaties tussen de overheid en de $\begin{array}{ll}\text { publieke onderneming } & \mathbf{1 2 0}\end{array}$

$\begin{array}{lll}4.3 & \text { Faktoren die gedrag van contractanten beïnvloeden } & 124\end{array}$

$\begin{array}{lll}5.1 & \text { De strategie van het Negende Plan } & 177\end{array}$

5.2 De totstandkoming van het Negende Plan 181

6.1 Factoren van invloed op de ondernemingsstructuur 201

6.2 Instanties betrokken bij het industriebeleid in $1981 \quad 207$

$\begin{array}{lll}6.3 & \text { Overheidssteun aan de Franse industrie in } 1981 & 209\end{array}$

7.1 De filière électronique $\quad 252$

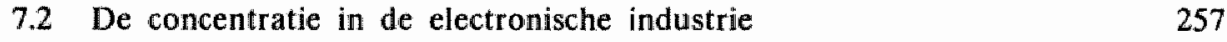

7.3 Structuur van de telecommunicatie-ondernemingen in Frankrijk $\begin{array}{ll}\text { in 1975-1976 } & 260\end{array}$

$\begin{array}{lll}7.4 & \text { Aandeelhouders van CII eind } 1966 & 264\end{array}$

7.5 Aandeelhouders van CII na het 'Yalta de l'électronique 266

$\begin{array}{ll}7.6 & \text { De fusie CII-HB in } 1975\end{array}$

$\begin{array}{lll}7.7 & \text { Deelname van Saint-Gobain in CII } & 274\end{array}$

$\begin{array}{ll}7.8 & \text { Aandelenbezit in CII in } 1981\end{array}$

7.9 Reorganisatie Thomson en CGE: eerste fase 289

7.10 Reorganisatie in de telecommunicatieindustrie: CIT-TT 292

7.11 Positieve en negatieve resultaten in de 'filière électronique'
in 1986 


\section{TABELLEN}

Tabel 5.7 Scenario's van het Negende plan

Tabel 5.8 Vergelijking van de verschillende scenario's gedurende de planperiode

Tabel 5.10 De budgetten voor de PPE

Tabel 5.11 De sub-programma's van PPE no. 1

Tabel 6.1 Het ontstaan van de industriēle groepen in Frankrijk

Tabel 7.1 Steunverlening aan de Franse electronische industrie in de periode 1967-1971 


\section{BIJLAGEN}

5.1 De essenties van het model Fifi

5.2 Het planningsproces voor 1981

5.3 Tabel 5.1: Samenstelling van de toegevoegde waarde van de ondernemingen (m.u.w. de GEN) van 1974-1982

Tabel 5.2: De ontwikkeling van de sallarissen en de produktiviteit in enkele geindustrialiseerde landen tussen 1975-1981

Tabel 5.3: Gemiddelde leeftijd van de kapitalalgoederenvoorraad in de Franse industrie

Tabel 5.4: Handelsbalans per zone in MF in 1981-1982

Tabel 5.5: De penetratiegraad van industriêle produkten in de periode $1970-1983$

Tabel 5.6: De exportgraad van industriële produkten in de periode $1970-1983$ 


\section{LIJST VAN AFKORTINGEN}

\begin{tabular}{|c|c|}
\hline ADI & : Agence de l'Informatique \\
\hline BIPE & : Bureau d'Information et de Prévision Economiques \\
\hline BCRD & : Budget Civil Recherche et de Développement \\
\hline BNP & : Banque National de Paris \\
\hline BRD & : Bonds Republiek Duitsland \\
\hline BRP & : Bureau de la Recherche Pétrolière \\
\hline CII & : Compagnie de l'Informatique Internationale \\
\hline CDF & : Charbonnage de France \\
\hline CEA & : Commissariat à l'Energie Atomique \\
\hline CEPII & : Centre d'Etudes Prospectives et d'Information Internationales \\
\hline CEPREMAP: & $\begin{array}{l}\text { Centre d'Etudes Prospectives d'Economie Mathématique Appliquées à } \\
\text { la Planification }\end{array}$ \\
\hline CERC & : Centre d'Etudes des Revenus et des Coûts \\
\hline CES & : Conseil Economique et Social \\
\hline CF & : Cahiers Français \\
\hline CFDT & : Conféderation Française Démocratique du Travail \\
\hline CFTC & : Conféderation Française du Travail Chrétienne \\
\hline $\mathrm{CGC}$ & : Conféderation Générale du Cadres \\
\hline CGCT & : Compagnie Générale de Construction Téléphonique \\
\hline CGE & : Compagnie Générale d'Electricité \\
\hline CGP & : Commissariat Général du Plan \\
\hline CGT & : Conféderation Général du Travail \\
\hline CGT-FO & : Conféderation Général du Travail Force-Ouvrière \\
\hline CIASI & $\begin{array}{l}\text { : Comité Interministérial pour l'Aménagement des Structures } \\
\text { Industrielles }\end{array}$ \\
\hline CIDISE & $\begin{array}{l}\text { Comité Interministérial pour le Développement des Investissements et } \\
\text { le Soutien de l'Emploi }\end{array}$ \\
\hline CIFRE & : Convention Industrielle de Formation pour la Recherche \\
\hline CNP & : Commission Nationale de la Planification \\
\hline CNES & : Centre National d'Etudes Spatiales \\
\hline CNET & : Centre National d'Etudes des Télécommunications \\
\hline CNI & : Commission Nationale sur l'Industrie \\
\hline CNPF & : Conféderation National du Patronat Français \\
\hline CNR & : Conseil National de la Résistance \\
\hline CNRS & : Centre Nationale pour la Recherche Scientifique \\
\hline CNT & : Caisse Nationale des Télécommunications \\
\hline CODEVI & : Comptes pour le Développement Industriel \\
\hline CODIS & : Comité de Développement des Industries Stratégiques \\
\hline CRITT & : Centre Régional d'Innovation et de Transfert de Technologie \\
\hline CSF & : Compagnie Générale de Télégrafie sans Fil \\
\hline CSRT & : Conseil Supérieur de la Recherche et de la Technologie \\
\hline DATAR & : Délégation de l'Aménagement du Territoire et à l'Action Régionale \\
\hline
\end{tabular}




\begin{tabular}{|c|c|}
\hline DIELI & : Direction des Industries Electroniques et de l'Informatique \\
\hline DGA & : Délégation Gênérale pour l'Armément \\
\hline DGT & : Direction Général des Télécommunication \\
\hline DMS & : (Modèle) Dynamique Multi-Sectoriel. \\
\hline DNRD & : Dépense Nationale de Recherche et de Développements \\
\hline DP & : Direction de la Prévision (van het Ministerie van Financiën) \\
\hline EDF & : Electricité de France \\
\hline EGP & : Electronique Grand Public \\
\hline EMC & : Entreprise Minière et Chimique \\
\hline EMS & : European Monetary System \\
\hline ENA & : Ecole Nationale d'Administration \\
\hline EPIC & : Etablissements Publics à charactère Industriel et Commercial \\
\hline EPST & : Etablissements Publics à charactère Scientifique et Technologique \\
\hline ERAP & : Entreprise de Recherches et d'Activités Pétrolières \\
\hline FDES & : Fonds de Développement Economique et Social \\
\hline FIFI & : (Modèle) Physico-Financier \\
\hline FIM & : Fonds Industriel de Modernisation \\
\hline FSAI & : Fonds Spécial d'Adaptation Industrielle \\
\hline GAP & : Groupe Administration de Programme \\
\hline GdF & : Gaz de France \\
\hline GE & : General Electric \\
\hline GEN & : Grands Entreprises Nationales \\
\hline GIP & : Groupements d'Intérêts Public \\
\hline GSI & : Groupe Stratégie Industrielle \\
\hline IDI & : Institut de Développement Industriel \\
\hline INSEE & : Institut National de la Statistique et des Etudes Economiques \\
\hline LCT & : Laboratoire Centrale de Télécommunications \\
\hline LMT & : Le Matérial Téléphonique \\
\hline LNE & : Le Nouvelle Economiste \\
\hline LOP & $\begin{array}{l}\text { : Loi d'Orientation et de Programmation pour la Recherche et le } \\
\text { Développement Technologique }\end{array}$ \\
\hline MF & : Millions de Francs \\
\hline $\mathrm{MdF}$ & : Milliard de Francs \\
\hline MIR & : Ministère de l'Industrie et de la Recherche \\
\hline MRI & : Ministère de la Recherche et de l'Industrie \\
\hline MRICE & : Ministère de Redéploiement Industriel et du Commerce Extérieur \\
\hline NIC's & : Newly Industrializing Countries \\
\hline NIE & : New Institutional Economics \\
\hline ORTF & : Organisation Radio et Télévision Française \\
\hline PAFE & : Plan d'Action Filière Electronique \\
\hline PAP & : Programme d'Action Prioritaire \\
\hline PCF & : Parti Communist Français \\
\hline PDG & : Projection Detaillée Glissante \\
\hline PEON & $\begin{array}{l}\text { (Commission Consultative pour) Production d'Electricité d’Origine } \\
\text { Nucleair }\end{array}$ \\
\hline
\end{tabular}


PIB : Production Interieur Brute

PME : Petits et Moyens Entreprise

PMI : Petits et Moyens Entreprises Industriel

PPE : Programmes Prioritaires d'Exécution

PS : Parti Socialiste

PVD : Pays en Voie de Développement

SNECMA : Societé Nationale d'Etude et de Construction de Moteurs d'Aviation

SNIAS : Société Nationalle Industrielle Aerospatiale

SPI : Secteur Public Industriel

TOF : Tableau d'Opérations Financières

VGE : Valéry Giscard d'Estaing 


\section{LIJST VAN GEINTERVIEWDE PERSONEN}

\section{Bedrijisleven}
M. Bechet,
CFDT
J.N. Dubus,
Régie Nationale des Usines Rénault
E. Lemaitre,
Régie Nationale des Usines Rénault
J. Lemettre,
Sain-Gobain
J.C. Mailly,
CGT-FO
P.L. Marger,
Compagnie Gênéral d'Electricité (CGE)
M. Ranque,
Thomson

\section{Overheidsorganisaties}

R. Branche, Délégation a l'Aménagement du Territoire et l'Action Régionale (DATAR)

R. Delorme, CEPREMAP, Université de Lille

G. le Guelte, Commissariat Général du Plan

J.P. Husson, l'Ambassade de France

J. Montfort, I'INSEE

M. Sauzay, Ministère de l'Industrie

B.Soulage, Commissariat Général du Plan

Chr. Stoffaës, Ministère de l'Industrie

D. Strauss-Kahn, Commissariat Général du Plan

S. Thierry, Commissariat Générall du Plan

\section{Universiteiten}

W. Andreff, Université de Grenoble

R. Arena, Université de Nice, LATAPSES

J. de Bandt, Université de Paris-Nanterre

P. Barbet, Universite Paris-Nord (CREI)

M. Bauer, Ecole Nationale Supérieur des Mines de Paris

B. Bellon, Université Paris-Nord, Centre de Recherche et Economie Industrielle (CREI)

L. Benzoni, Ecole Nationale Supérieure des Télécommunications

F. Bidlault, Ecole Supérieur de Commerce de Lyon
A. Cotta,
Universite Paris-Dauphine
P. Dubois,
Université de Paris VII
T. Hafsi,
I'ESSEC
F. Jenny,
l'ESSEC
P. Maillet,
Université de Lille (CREI)
M. Marchesnay, Université de Montpellier
J. Perrin, Université Aix-en-Provence
M. Rainelli, Université de Nice, LATAPSES
R. Real, Université de Grenoble 
R. Rollet, Université de Lille, Centre de Recherches Européennes et Internationales (CREI)

P. Romani, Uniwersité de Nice, LATAPSES
A. Weber, I'ESSEC
R. Zarader,
Université Paris-Nord (CREI) 


\section{Inhoud}

Lijst van schema's tabellen en bijlagen

Lijst van afkortingen

Lijst van geinterviewde personen

1. PROBLEEMSTELLING EN METHODE

1.0 Probleemstelling 1

$1.1 \quad$ Over de methode 3

2. DE THEORIE VAN INDICATIEVE PLANNING

2.0 Inleiding 11

$2.1 \quad$ Hayek's coördinatieprobleem 11

2.2 Informatie in de markteconomie 12

2.0 Informatiebronnen 12

2.2.1 De wereld van de neoklassieken en die van Arrow en Debreu 13

2.2 .2 De informatiemarkt $\quad 15$

2.2.3 Institutionele informatie 16

2.3 Theorieen van de indicatieve planning 19

2.3.0 Inleiding 19

2.3.1 Een ex ante integraal coherent indicatief plan; Massé en Meade 19

2.3.2 Geaggregeerde indicatieve planning; Massé en Harrod 26

2.3.3 Indicatieve planning in een complexe, open markteconomie;

3. THEORIEEN VAN ONDERNEMINGSSTRATEGIEEN EN $\begin{array}{ll}\text { INDUSTRIEBELEID } & 37\end{array}$

$\begin{array}{lll}3.0 & \text { Inleiding } & 37\end{array}$

3.1 Theorieën van ondernemingsstrategieën 39

$\begin{array}{lll}3.1 .0 & \text { Inleiding } & 39\end{array}$

3.1.1 Ondernemingsstrategieën in de wereld van de neoklassieken 40

3.1.1.0 Inleiding 40

3.1.1.1 Orthodoxe neoklassieke theorie en de structuralistische

3.1.1.2 Principaal-agent-benadering 41

3.1.1.3 De 'nieuw institutionele economie'; de transactiekosten
van Williamson

3.1.1.4 Kritiek op de transactiekostentheorie 48

3.1.2 De behavioristische lijn 55

3.1.2.0 Inleiding $\quad 55$

3.1.2.1 Wisselwerking tussen structuur, gedrag en resultaat:

3.1.2.2 De dynamische markttheorie van De Jong (1981b) 57

3.1.2.3 Een bedrijfskundige benadering: Porter (1980; 1985)

3.1.2.4 L'école française d'économie industrielle 64

3.1.2.5 'Filière' en ondernemingsstrategie 66

$\begin{array}{lll}3.2 & \text { Het industriebeleid in een markteconomie } & 75\end{array}$ 
3.2.0 Inleiding 75

3.2.1 'L'Etat regulateur' en 'L'Etat développeur' 75

3.2.1.0 Inleiding 75

3.2.1.1 De ideaaltypen van de 'developmental' en de 'regulatory state" 76

3.2.1.2 Het generieke industriebeleid van de 'regulatory state' 78

3.2.1.3 Het specifieke industriebeleid van de 'developmental state' 80

3.2.1.4 "Filière" en specifiek industriebeleid 81

3.2.1.5 'L'Etat développeur' en de industriële groep 86

4. DE THEORIE VAN DE PUBLIEKE ONDERNEMING 98

4.0 Inleiding 98

4.1 De publieke onderneming gedefinieerd 98

4.2 Theoretische gronden voor het bestaan van publieke

$\begin{array}{lll}4.3 & \text { Effectiviteit en efficièntie } & 102\end{array}$

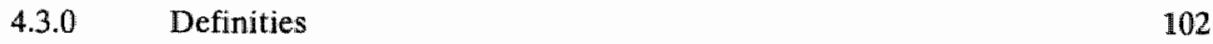

$\begin{array}{lll}\text { 4.3.1 Effectiviteit; } & \text { een meetprobleem } & 104\end{array}$

4.3.2 Efficiëntie: een meetprobleem 105

$\begin{array}{lll}4.3 .2 .0 & \text { Kosten per eenheid produkt } & 105\end{array}$

4.3.2.1 "Productivité gllobäle des facteurs. (PGF) 106

$\begin{array}{ll}\text { 4.4 De resultaten van de publieke onderneming } & \\ \text { institutioneel verklaard } & 108\end{array}$

$\begin{array}{lll}4.4 .0 & \text { Inleiding } & 108\end{array}$

4.4.1 De omgeving van de partikuliere onderneming 108

4.4.2 De omgeving van de publieke onderneming 110

4.4.2.0 Inleiding 110

4.4.2.1 De publieke onderneming in het centraal geleide stelsel 111

4.4.2.2 De omgeving van de publieke onderneming in een markteconomie 113

4.4.2.3 De autonomie van de publieke onderneming 113

4.4.2.4 De veranderende relatie tussen de overheid en de

4.4.2.5 De planverbintenis; de planningsowereenkomst;

4.5 Voorwaarden voor het effectief en efficiënt funktioneren van
publieke ondernemingen

INTERMEZZOI Wat de theoretische inzichten te bieden hebben 129

INTERMEZZO III De Frans historisch-culturele context 134

II.0 Inleiding 134

II.1 'L'Etat c'est ....' 134

II.2 De 'corps d'état' 136

5. DE FRANSE INDICATIEVE PLANNEN 139

$\begin{array}{ll}5.0 & 139\end{array}$

5.1 De historisch-culturele context 139

5.2 Het Eerste tot en met het Vierde Plan 141

5.2.0 Het Eerste Plan (Plan Monnet 1946-1953) 141 
5.2.1 Het Tweede Plan (1954-1957) en Derde Plan (1958-1961) 143

5.2.2 Het Vierde Plan (1962-1965) 146

$\begin{array}{lll}5.2 .3 & \text { Een tussenbalans } & 147\end{array}$

5.3 Het Vijfde Plan (1966-1970) 149

$5.3 .0 \quad$ Inleiding 149

5.3.1 Het planningsproces $\quad 150$

$\begin{array}{lll}\text { 5.3.2 De inhoud van het Plan } & 153\end{array}$

$\begin{array}{lll}5.3 .3 & \text { Het industriebeleid } & 155\end{array}$

$5.4 \quad$ Het Zesde Plan (1970-1975) 156

$\begin{array}{lll}5.4 .0 \quad \text { Inleiding } & 156\end{array}$

5.4.1 Het planningsproces $\quad 156$

5.4.2 Het industriebeleid 158

5.5 Het Zewende (1976-1981) en Achtste Plan (1981-1985) 160

5.6 Het Negende Plan (1984-1988) 164

5.6.0 Inleiding $\quad 164$

5.6.1 Positie van Frankrijk in mei 1981 en het Plan Intérimaire 165

5.6.2 Instituties en scenario's van het Negende Plan 169

5.6.3 De Eerste Wet op het Plan: de doeleinden 175

5.6.4 De Tweede Wet op het Plan: de middelen 179

$\begin{array}{lll}5.6 .5 & \text { Conclusies } & 184\end{array}$

6. HET FRANSE INDUSTRIEBELEID 195

6.0 Inleiding 195

6.1 Het industriebeleid in de Vijfde Republiek 195

$\begin{array}{lll}6.1 .0 \quad I n l e j d i n g & 195\end{array}$

6.1.1 'La politique industrielle Gaulienne' (1958-1969) 196

$\begin{array}{ll}6.1 .2 & \text { 'L'impératif industriel', politique industrielle } \\ & \text { Pompidolienne (1969-1974) }\end{array}$

$\begin{array}{lll}6.1 .2 .0 & \text { Inleiding } & 198\end{array}$

6.1.2.1 Concentratie; de industriële groep 198

6.1.2.2 'Grands Programmes': speerpunten 201

6.1.3 'La politique industrielle Giscardienne' (1974-1981) 202

$\begin{array}{ll}6.1 .3 .0 \quad \text { Inleiding } & 202\end{array}$

6.1.3.1 'Redéploiement industriel': deux jambes 202

6.1.3.2 De institutionele vormgeving; interdepartementale commissies;
contracteconomie

6.1.3.3 De balans van een neo-liberaal industriebeleid 206

6.1.4 'Les Trois Mitterandismes' (1981-1986) 212

$\begin{array}{ll}6.1 .4 .0 & \text { Inleiding . } \\ 6.12\end{array}$

$\begin{array}{ll}\text { 6.1.4.1 'L'Etat développeur socialiste Française' } & 212\end{array}$

$\begin{array}{ll}\text { 6.1.4.2 "Les trois Mitterandisme" } & 213\end{array}$

6.2 De rol wan de publieke onderneming in het Franse
industriebeleid

$\begin{array}{lll}6.2 .0 & \text { Inleiding } & 228\end{array}$

6.2.1 De publieke onderneming in historisch perspectief 228

$\begin{array}{lll}6.2 .2 & \text { De nationalisatie in } 1982 & 230\end{array}$

$\begin{array}{lll}6.2 .2 .0 & \text { Het nationalisatieproces } & 230\end{array}$

6.2.2.1 'Contrats de Plan' 233 
6.2.2.2 'Prêt participatif' en 'loi de respiration' 235

$\begin{array}{lll}6.2 .2 .3 & \text { De publieke onderneming en het conjunctuurbeleid } & 238\end{array}$

6.2.2.4 De publieke onderneming en het structuurbeleid 239

6.2.2.5 De publieke onderneming en het sociale beleid 241

$\begin{array}{lll}6.2 .2 .6 & \text { Conclusies } & 243\end{array}$

7. DE FILIERE ELECTRONIQUE 249

$\begin{array}{lll}7.0 & \text { Inleiding } & 249\end{array}$

7.1 De branches van de 'filière électronique' 251

7.2 De branches van de telecommunicatie en computers

$\begin{array}{lll}7.2 .0 & \text { Inleiding } & 251\end{array}$

7.2.1 De telecommunicatieindustrie voor $1981 \quad 251$

$\begin{array}{ll}7.2 .1 .0 & \text { De actoren in historisch perspectief }\end{array}$

$\begin{array}{lll}7.2 .1 .1 & \text { De industriële groepen } & 256\end{array}$

7.2.1.2 De machtsverhoudingen in de telecommunicatiesector rond 1981261

$\begin{array}{lll}7.2 .2 & \text { De computerindustrie voor } 1981 & 262\end{array}$

$\begin{array}{lll}7.2 .2 .0 & \text { De actoren in historisch perspectief } & 262\end{array}$

7.2.2.1 De balans van de 'filière électronique' 268

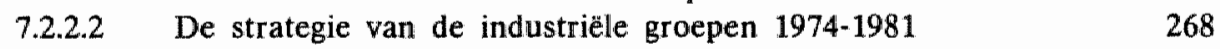

7.2.2.3 'La politique industrielle Giscardienne' met betrekking tot
de computerindustrie

$\begin{array}{lll}\text { 7.2.2.4 De balans in } 1981 & 275\end{array}$

$\begin{array}{lll}7.3 & \text { De 'filière électronique' na } 1981 & 278\end{array}$

$\begin{array}{lll}7.3 .0 & \text { De nationalities } & 278\end{array}$

7.3.1 'Plan d'Action Filière Electronique' 281

7.3.2 Veranderingen in de machtsverhoudingen binnen

7.3.3 Het belleid met betrekking tot de publieke

$\begin{array}{ll}\text { 7.3.3.0 De 'contrats de plan' } & 287\end{array}$

7.3.3.1 'Yalta de la télécơmmunication' 288

7.3.3.2 Herstructureringen in de halfgeleiders, en de computerindustrie, in de kantoorautomatisering en in de 'productique*' 292

7.3.4 De ontwikkelingen bij Thomson, Bull, CGE en Matra $\begin{array}{ll}\text { nader bekeken } & 293\end{array}$

$\begin{array}{lll}7.3 .4 .0 & \text { Inleiding } & 293\end{array}$

$\begin{array}{lll}7.3 .4 .1 & \text { Thomson } & 294\end{array}$

$\begin{array}{lll}7.3 .4 .2 & \text { Bull } & 296\end{array}$

$\begin{array}{lll}7.3 .4 .3 & \mathrm{CGE} & 297\end{array}$

$\begin{array}{lll}7.3 .4 .4 & \text { Matra } & 298\end{array}$

$\begin{array}{lll}7.4 & \text { Conclusies } & 298\end{array}$

8. CONCLUSIES 306

$\begin{array}{lll}8.0 & \text { Inleiding } & 306\end{array}$

$\begin{array}{lll}8.1 & \text { Indicatieve planning } & 307\end{array}$

$\begin{array}{lll}8.2 & \text { Het industriebeleid } & 312\end{array}$

$\begin{array}{lll}8.3 & \text { Publieke ondernemingen } & 315\end{array}$ 
8.4 Een oordeel over de effectiviteit 318

8.5 Een oordleel over de besproken theoretische concepten 319

$\begin{array}{lll}8.5 .0 & 319\end{array}$

8.5.1 Theorieën met betrekking tot de indicatieve planning 321

8.5.2 Theorieën met betrekking tot ondernemingsstrategieën 322

8.5.3 Theorieën met betrekking tot de rol van de overheid 323

8.5.4 Theorieen met betrekking tot de publieke onderneming 323

$\begin{array}{lll}8.5 .5 & \text { Slot } & 324\end{array}$

SAMENVATTING 327

$\begin{array}{ll}\text { SUMMARY } & 331\end{array}$

RESUME

$\begin{array}{ll}\text { DANKWOORD } & 339\end{array}$

REFERENTIES $\quad 341$

$\begin{array}{ll}\text { CURRICULUM VITAE } & 365\end{array}$ 


\section{PROBLEEMSTELliNG EN METHODE}

\subsection{Probleemstelling}

De economische orde van een land staat voor de talk de handelingen van de economische actoren zodanig op elkaar af te stemmen, dat een min of meer evenwichtige ontwikkeling resulteert. Werkloosheid, inflatie, lange rijen voor de winkels en dergelijke duiden erop, dat het coördinatiemechanisme zijn taak niet naar behoren vervult (Driehuis en v.d. Doel 1979).

De economische orde is op te vatten als de organisatie van het economische proces; als het kader, waarbinnen het proces zich voltrekt. $\mathrm{Zij}$ omvat het geheel van instituties, dat het gedrag van de actoren richting geeft, dat hun gedrag "bindt". alsmede de organisatiestructuur van een land. Hodgson $(1988 \mathrm{a}, 10)$ definieert

"(...) a social institution (...) as a social organization which, through the operation of tradition, custom or legal constraint, tends to create durable and routinized patterns of behaviour".

Instituties zijn een uitdrukking van de waarden van een samenleving en kunnen worden opgevat als de spelregells voor de (economische) actoren; zij zijn vastgelegd in gewoonten, conventies en juridische regels. Over het algemeen wordt in de literatuur geen onderscheid gemaakt tussen instituties en economissche organisatievormen (vergelijk Groenewegen 1982). Met Admiraal (1987) zijn wij van mening, dat het zinvoll is zulks wel te doen, omdat beide aan een verschillende dynamiek onderhevig zijn en niet gelijkelijk voor beleid vatbaar zijn.

Economische organisatievormen, zoals de onderneming, de vakbond, de branche organisatie en dergelijke, dragen zorg voor de coördinatie van economische activiteiten. Partijen, i.c. de overheid en de marktpartijen, kunnen organisatievormen creèren en veranderen, waarbij zij de spelregels in acht dienen te nemen. Anders gezegd: in de concrete organisatievormen worden de instituties van de samenleving weerspiegeld; de organisaties kunnen door de actoren aan veranderende omstandigheden worden aangepast, $z i j$ het dat daarbij de spelregels van de samenleving in acht moeten worden genomen [1].

In een markteconomie worden voortdurend organisatievormen gecreëerd en veranderd met het doel de uitkomst van het economisch proces beter af te stemmen op de eigen doeleinden. Zo sluiten ondernemingen kartelovereenkomsten af, fuseren, gaan over tot integratie of desintegratie enzovoort. Wij zouden naar analogie van Lambers (1958) kunnen spreken van interne ordening, omdat het initiatief van de 
marktpartijen zelf komt. In een markteconomie poogt ook de overheid door het invoegen, of veranderen van organisaties het economisch proces af te stemmen op haar doeleinden. Wij spreken dan van externe ordening [2].

In deze studie staat de vraag naar de effectiviteit van de externe ordening centraal. Wij richten onze aandacht daarbij op de organisatie van het economisch proces in het kader van het industriebeleid van de overheid [3].

Sedert ongeveer het midden van de jaren zeventig stagneert de economische ontwikkeling in veel markteconomieën, hetgeen voor een belangrijk deel te wijten is aan het uitblijwen van een adequate aanpassing van de industriële structuur aan veranderende comparatieve voordelen (W.R.R. 1980, L'INSEE 1981). De economische crisis is voor een belangrijk deel een industriële crisis. Overheden hebben gepoogd door middlel van industriebeleid het gedrag van de marktpartijen te beïnloeden, met het doel de ontwikkeling van de industriële structuur te veranderen qua sectorale opbouw, regionale spreiding, ondernemingsgrootte en vervlechtingen van industriële activiteiten. Met name aan de vervlechtingen wan de onderlinge leveringen wordt in toenemende mate aandacht besteed (aandachtsgebiedenbeleid in Nederland, 'filière-beleid' in Frankrijk, programma's als Esprit in Europa). Het gaat daarbij niet alleen om vervlechtingen van de onderlinge leveringen tussen ondernemingen, maar ook om relaties van financiële, technologische en persoonlijke aard. In hoofdstuk 3 zal worden betoogd, dat economieën met een hecht netwerk van industriële vervlechtingen over een sterke concurrentiepositie kunnen beschikken, waardoor de overheid van het betreffende land in staat is een effectief conjunctuuren structuurbeleid te voeren.

Van essentieel belang voor het behoud van een sterke concurrentiepositie is de voortdurende aanpassing van de industriële structuur aan veranderende comparatieve woordelen. In markteconomieën is dat in de eerste plaats de verantwoordelijkheid van de ondernemers: zij nemen strategische beslissingen met betrekking tot de omvang en richting van de investeringen en -daarmee samenhangend- met betrekking tot de organisatie van de markt, welke van essentieell belang zijn voor een adequate aanpassing van de industriële structuur. Zo hebben strategieën van vertikale integratie, het opbouwen van netwerken met gespecialiseerde sub-contractors, het opzetten van joint ventures e.d. grote invloed op de ontwikkeling van de industriële structuur in termen van organisatorische vervlechtingen. Blijven dergelijke strategische beslissingen uit, dan kan een 'verbrokkelde' industriële structuur ontstaan met enkele geavanceerde speerpunten, die in een geïsoleerde positie verkeren ten opzichte van de andere industriële activiteiten.

Als de intern geordende markt niet resulteert in de gewenste ontwikkeling van de industriele structuur, kan de overheid pogen door middel van externe ordening de strategie van ondernemingen te beïnvloeden. Ons onderzoek richt zich op het industriebeleid van de overheid, dat is georiënteerd op het creëren van hechte industriële netwerken, die zich efficiënt aanpassen aan veranderende comparatieve voordelen.

Ter beïnvloeding van de strategie van ondernemingen staat de overheid in een 
markteconomie een scala van instrumenten ter beschikking, variërend van een generiek Keynesiaans vraagbeleid gecombineerd met mededingingsbeleid tot het selectief nationaliseren van ondernemingen. Wij richten de aandacht op het instrument, dat ons naar de "rand van de markteconomie" brengt, namelijk selectieve nationalisatie in het kader van een indicatief plan. Indicatieve planning is een economisch stelsel, waarbij de overheid poogt de strategie van ondernemingen af te stemmen op nationale doeleinden zonder de autonomie van de ondernemers met betrekking tot hun strategische beslissingen principieel aan te tasten. Selectieve nationalisatie is ons inziens het meest vergaande instrument, waarmee de overheid op marktconforme wijze kan pogen de strategie van specifieke sleutelondernemingen af te stemmen op de doeleinden van het indicatieve plan [4].

In ons onderzoek wordt nagegaan, hoe de overheid de organisatie van het indicatieve plan, het industriebeleid en de genationaliseerde ondernemingen vorm moet geven, opdat het beleid ook de gewenste effecten heeft. Daartoe wordt gebruik gemaakt van theoretische inzichten, die worden geconfronteerd met het Franse industriebeleid in de periode 1981-1986. Toen poogde namelijk de socialistische regering de in het kader van het Negende Nationale Plan ontwikkelde doeleinden met betrekking tot de ontwikkeling van de industriële structuur te realiseren door beïnloeding van de strategie van selectief genationaliseerde ondernemingen. Om de marktcomformiteit van het industriebeleid te waarborgen werd de organisatievorm van de 'planningsovereenkomst' (contrat de plan) in het leven geroepen: tussen de overheid, i.c. het Ministerie van Industrie, en de genationaliseerde ondernemingen werd onderhandeld over de afstemming van de ondernemingsstrategie op de plandoeleinden; de rechten en plichten van beide partijen werden vastgelegd in een overeenkomst.

Onze probleemstelling luidt:

Hoe heeft de Franse overheid in de periode 1981-1986 het industriebeleid in het kader van het Negende Plan met behulp van selectief genationaliseerde ondernemingen worm gegeven, waarom kreeg het beleid die vorm en is het beleid effectief geweest?

\subsection{Over de methode}

Onze probleemstelling betreft een ordevraagstuk: verklaard moet worden hoe en waarom de externe organisatievormen van het indicatieve plan, het industriebeleid en de publieke onderneming tot stand zijn gekomen en beoordeeld moet worden, of het beleid de gewenste effecten heeft gehad. Zo'n ordevraagstuk kan niet los van de historisch-culturele context worden bestudeerd:

"Policy does not operate in a vacuum. Its effectiveness and its character can be understood only by appreciation of the economic, political and social conditions of the nation, the soil in which pollicy is cultivated" (Kikkawa 1983, 236). 
Het industriebeleid in de periode 1981-1986 dient in het perspectief van de historie van de Franse economische orde te worden geplaatst, waarin indicatieve planning, voluntaristisch industriebeleid en publieke ondernemingen van oudsher een centrale rol hebben gespeeld. Voor de beantwoording van het eerste deel wan onze probleemstelling -de vormgeving van het industriebeleid in de desbetreffende periode- zal met name de historie vanaf 1945 moeten worden geanalyseerd [5]. Zo'n analyse geschiedt op basis van theoretische concepten, die de onderzoeker 'met zich draagt' (Zuidema 1973). De werkelijkheid wordt vanuit die theoretische denkstructuren beschreven, of zo men wil 'gevormd".

Vraag is nu vanuit welke theoretische denkstructuren het Franse industriebeleid beschreven dient te worden? Met welke theoretische receptuur kan het ordevraagstuk van het industriebeleid in het kader van een indicatief plan en met de publieke onderneming als centraal instrument, het best worden aangepakt?

Over de vraag hoe dergelijke ordevraagstukken in zijn algemeenheid benaderd dienen te worden heeft Zuidema $(1973,1982)$ belangwekkende dingen geschreven:

"Wie enig inzicht wil krijgen in vraagstukken van economische orde, moet dat doen door concrete problemen aan te vatten op verschillend vlak en op verschillende gebieden tegelijk. Hij moet deze vraagstukken nu eens globaal en dan weer gedetailleerd aanpakken met een open oog voor wat uit hoofde van niet economisch onderzoek als controles te leveren is. Hij moet de série à l'américaine spelen" (Zuidema 1982, 111).

In het beoefenen van de economie als een 'série a l'américaine' dient de onderzoeker de "theorie van het globale, het algemene" voortdurend bij de "theorie van het gedetailleerde, het specifieke" te houden. De concepten in de algemene theorieën zijn tot op zekere hoogte 'leeggehaald', waardoor zij op diverse plaatsen en tijden toepasbaar zijn. Zo is bijv. in de theorie van economische stelsels op hoog abstractieniveau de consistentie getoond tussen beslissings-, informatie-, en motivatiestructuren (Cave en Hare 1981). Er zijn ook theorieën, die zich op een lager abstractieniveau bewegen, dat wil zeggen theorieën waarbij de concepten zijn ingevuld met specifieke condities van plaats en tijd. Zo betrekken bijv. theoriee̊n uit de leer van de industriële organisatie en het strategisch management meer specifieke markt- en omgevingsfactoren in de analyse, waardoor van een meer plaats- en tijdgebonden theorie sprake is. Zuidema (1982) spreekt in dit verband van algemene en specifieke theorieèn. Welke theorie relevant is, hangt ten nauwste samen met de vraagstelling van de onderzoeker. Voor de vraag bijvoorbeeld, of het mogelijk is in een markteconomie met onafhankelijke actoren, die alleen beslissingen nemen op basis van prijsinformatie tot een algemeen evenwicht te komen, is de zeer algemene theorie van Arrow en Debreu van een volledig stelsel van voorwaardelijke toekomstmarkten bruikbaar [6].

Voor de vraag welke consistente informatie-, motivatie- en besluitvormingsstructuur past bij een stelsel van parametrische planning, is ook een algemene theorie bruikbaar [7].

Voor andere vraagstellingen, bijv. de verklaring van de inflatie in Frankrijk in 1984, 
zijn meer specifieke theorieẻn nodig, die algemene concepten als 'demand pull' en 'cost push' invullen met specifieke condities van plaats en tijd.

Voor de beantwoording van onze probleemstelling betreffende het hoe, het waarom en de effectiviteit van concrete economische organisatievormen, zullen wij zowel gebruik moeten maken van algemene als van meer specifieke, geìndividualiseerde theorieên. Algemene theorieën zijn noodzakelijk, omdat zij om met Zuidema (1982) te spreken, een ingang leveren, een vergelijkingsbasis, een criterium. Zij ordenen de complexe werkelijkheid. Algemene theorieën zijn noodzakelijk, maar niet voldoende. Voor de verklaring van specifieke probleemstellingen moeten algemene theow rieën worden ingevuld met condities van plaats en tijd: het algemene moet plaats maken voor concrete condities van economische, politieke, sociale, psychollogische of van wat voor aard dan ook.

"Het algemene ontleent zijn zin aan de toepassingsmogelijkheid in individuele gevallen. Inzicht in het individuele geval wordt verkregen door vergelijking met het passende algemene geval en via dat laatste met andere vergelijkbare gevallen" (Zuidema 1982, 99).

Ook in ons onderzoek zullen wij de weg van de wisselwerking tussen algemeen en specifiek moeten gaan. Voor de behandeling van ordevraagstukken dient de economie beoefend te worden als een 'série à l'américaime': de 'bal van het algemene' en de 'bal van het specifieke' dienen voortdurend op elkaar te worden betrokken.

Het is overigens geen gemakkelijk spel.

Op algemeen niveau is de werkelijkheid namelijk keurig geordend naar discipline. De psychologie, sociologie, politicologie, economie, de juridische en cultuur-historische wetenschappen hebben op algemeen theoretisch niveau alle hun werkterrein afgebakend. Op dat niveau kan elke discipline veronderstellingen maken met betrekking tot aspecten van de werkelijkheid, welke geacht worden bestudeerd te worden door collega's uit de aangrenzende wetenschappen. Op specifiek niveau kan de nauwkeurige scheiding tussen disciplines echter niet gehandhaafd blijven.

"Wij zoeken een weg om de concrete problemen aan te vatten door deze te
spiegelen in theoretische problemen die, naar wij menen, zich daartoe lenten
omdat zi door aanpassing op een concreet probleem dat van interesse is,
kunnen worden toegespitst. Aangezien in het veld van de theoretische
problemen gedifferentieerd is tussen vakgebieden en binnen elk vakgebied,
moet het concrete probleem als het ware in meer dan een algemeen geval
worden geplaatst, als het ware op het snijpunt van een aantal benaderings-
wegen, verklaringssystemen" (Zuidema 1982, 108 en 1019).

Anders gezegd: er zijn algemeen-theoretische probleemstellingen denkbaar, zoals die van Arrow en Debreu, die op algemeen theoretische niveau moeten worden behandeld. Er zijn ook probleemstellingen, zoals die van de onderhavige studie, die een wisselwerking tussen algemeen en specifiek niveau vereisen. De probleemstelling bepaalt de relevantie van de theorie [8].

Voor de beantwoording van onze probleemstelling zullen algemene concepten uit algemene theorieen met specifieke condities van plaats en tijd moeten worden 
ingevuld. Bii het 'afdalen' naar specifiek niveau zullen de 'traditionele' grenzen tussen de disciplines op het algemene niveau overschreden moeten worden. Van het specifieke niveau zal de weg terug moeten worden bewandeld naar algemene theoretische concepten uit aangrenzende disciplines. Voortdurend dienen het algemene en specifieke op elkaar betrokken te zijn.

Onze probleemstelling vereist, dat wij met andere woorden de 'empirische cyclus' doorlopen, waarbij wan essentieel belang is, dat bij het bewandelen van de weg van inductie naar algemene concepten de bereidheid bestaat, indien nodig, over de grenzen van de eigen discipline heen te kijken.

Hoe zou een onderzoek als hierboven bedoeld er schematisch uit kunnen zien?

"The first step (....) is the "socialization" of the theorist. (...) the participantobserver attempts to remain close to the concrete form of the system. (...) In remaining close to the reality of the system studied, the theorist is in an unique position to receive a wide variety of recurrent themes (importance of ceremony, target profits/markup-pricing) that appear in a variety of contexts. (...) These themes may take the form of an accepted practice (ceremonies), a cultural norm (conspicious consumption), or a particular mode of production (competitive capitalism) (...)" (Wilber and Harrison, 1978, 75 en 76).

Op basis van de "themes" worden hypothesen geformuleerd,

"(...) (which) are tested by consulting a wide variety of data (previous case studies, survey data, personal observations, and so forth). Evidence or support of the hypotheses or interpretation is evaluated by means of contextual validation". (Wilber en Harrison, 1978, 76).

Blijkt voor de beantwoording van de probleemstelling één of enkele variabelen van invloed, dan spreken Wilber en Harrison van een 'one-sided picture' op basis waarvan een model kan worden geconstrueerd, dat scherp onderscheid maakt tussen endogene en exogene variabelen en dat de onderzoeker in staat stelt tot exacte uitspraken te komen. Blijkt dat sprake is van diverse verklarende factoren, die in verschillende disciplines 'thuishoren', en onderling verweven zijn, dan spreken Wilber en Harrison van een 'many-sided picture'. Ook nu zal de onderzoeker proberen de variabelen in een model onder te brengen, maar dat model is van fundamenteel andere aard dan de modellen gebaseerd op een one-sided picture:

"However since new data are constantly coming in and since the system itself is evolving, the model is continually being revised and can neither be completed nor rigously confirmed" (Wilber en Harrison 1978, 76).

Gedurende dat proces vergelijkt de onderzoeker het door hem gevonden patroon voortdurend met nieuwe cases

"(...). thereby using one case to suggest things to look for in another. One potential result of such a process of comparison is the development of a typology" (Wilber en Harrison 1978, 78).

In plaats van te komen tot exacte uitspraken zal de onderzoeker in het geval van een 'many sided picture' gemakkelijk blijven steken in een moeras van beschrijvingen op 
specifiek niveau. Wellicht bestaat de mogelijkheid zich daaruit te ontworstelen en op te klimmen tot het algemenere niveau van de typologie of de configuratie, waarin condities op meer algemeen niveau kunnen worden geformuleerd, waaronder bijw. strategieën van ondernemingen, of interventies van de overheid effectief kunnen zijn [9].

Ook voor de behandeling van het tweede deel van de probleemstelling - het beoordelen van de effectiviteit van het beleid - is de 'economiebeoefening als série $d$ l'américaine' de aangewezen weg.

Echter, een afdoend antwoord mag niet worden verwacht. Effectiviteit van beleid laat zich namelijk niet eenduidig vaststellen, vanwege de complexiteit yan het aantal variabelen, of in termen van Wilber en Harrison: vanwege de 'many sidedness of the picture'.

In de eerste plaats doet zich het probleem voor van de criteriakeuze: industriebeleid kan gericht zijn op het realiseren van verschillende doeleinden (op doelvariabelen, zoals economische groei, export, werkgelegenheid, of op instrumentvariabelen, zoals het verhogen van de investeringen). Uit het complex van doeleinden zijn even zoveel criteria af te leiden op grond waarvan de effectiviteit kan worden beoordeeld. In de tweede plaats levert een vergelijking tussen doeleinden en realisaties nog geen inzicht in de effectiviteit van specifieke beleidsmaatregelen. Als de Franse overheid zich met de publieke ondernemingen tot doel stelde de export in specifieke sectoren op te voeren en zulks blijkt achteraf inderdaad te zijn gebeurd, mag dan worden geconcludeerd dat selectieve nationalisatie een effectief instrument is gebleken? Probleem is, dat naast het overheidsbeleid tal van andere factoren een rol spelen, die voor de beoordeling van het beleid moeten worden meegewogen. Voor het vaststellen van de effectiviteit van het overheidsbeleid beschikken wij in de economie nu eenmaal niet over een laboratorium, waarin kan worden nagegaan welke ontwikkelingen zich zouden hebben voorgedaan, zonder dat de overheid beleid zou hebben gevoerd. Ook bij de beoordeling van het effect van overheidsbeleid langs model matige weg doet zich dat probleem voor, hetgeen Van der Zwan (1980) deed spreken van 'institutionele vervuiling' van de economische analyse (vergelijk Van Eijk 1980).

Een gedetailleerde micro-analyse, waarin de totstandkoming en ontwikkeling van het beleid in haar economische en socio-politieke context wordt geanalyseerd, kan licht werpen op de invloed van het overheidsbeleid op de feitelijke gang van zaken. Of het opstellen van een indicatief plan en het nationaliseren van ondernemingen inderdaad van invloed is geweest op de strategie van ondernemingen, kan alleen worden beoordeeld als de nationalisaties, de controle en sturingsmogelijkheden, de onderhandelingen over het 'contrat de plan', de informatieverdeling, de relaties tussen de managers en de ambtenaren en dergelijke, in de analyse worden betrokken.

Een afdoend antwoord op de vraag, of het overheidsbeleid effectief is geweest vereist een gedetailleerde beschrijving en verklaring van de invloed van het beleid in kwestie op de gedragingen van de andere actoren en zo mogelijk een vergelijking 
van de resultaten wan dat beleid met een situatie, waarin het beleid afwezig was. Gelet op de complexiteit van de factoren, die van invloed zijn op de totstandkoming van het owerheidsbeleid, gelet op de complexiteit van factoren, die naast het overheidsbeleid van invloed zijn op het beleid van de onderneming en gelet op de problematiek rond het inschatten van ontwikkelingen, die zich waarschijnlijk zouden hebben voorgedaan in geval van afwezigheid van het onderzochte beleid, zal een uitspraak over de effectiviteit van een specifieke categorie van overheidsbeleid altijd met zeer grote voorzichtigheid gepaard moeten gaan.

In ons onderzoek is in de eerste plaats gepoogd een zo nauwkeurig mogelijke analyse te geven van de feitelijke gang van zaken rond het Franse industriebeleid in de periode 1981-1986. In de tweede plaats is gepoogd een verklaring te geven van de vormgeving en veranderingen van dat beleid gedurende de betreffende periode en op de derde plaats is getracht het beleid te beoordelen op haar effectiviteit. Conform de methode van de economiebeoefening als série à l'américaine zijn in het onderzoek zowel algemene als specifieke theorieên gebruikt, waarbij op voorhand niet vaststond, of en waar de serie zou eindigen. Zoals reeds opgemerkt heeft Zuidema (1979) erop gewezen, dat de onderzoeker de werkelijkheid altijd beschrijft, analyseert en ordent vanuit een specifieke denkstructuur. Altijd werkt de onderzoeker in de empirie met een aantal algemene theorieën in zijn achterhoofd, die hij tracht in te vullen met specifieke condities. Tegelijkertijd structureert hij met die theorieën de empirie. Wordt het onderzoek uitgevoerd als een série à l'américaine dan kan het 'afdalen" uit de algemene theorie van bijv. de economische discipline naar de empirie van bijv. de rol van een genationaliseerde onderneming in een specifieke sector, leiden tot het plaatsen van zo'n ordevraagstuk op het 'snijvlak wan een aantal benaderingswegen, verklaringssystemen' (Zuidema 1982, 109). Vanaf dat snijpunt kan de weg naar het algemene weer worden gegaan, waarbij op voorhand niet moet worden uitgesloten dat algemene concepten uit aangrenzende disciplines relevant blijken.

Theorie en empirie dienen voor het onderhavige soort probleemstellingen voortdurend op elkaar betrokken te zijn. Voor de verslaglegging is echter gekozen voor een schematische tweedeling: in de eerste hoofdstukken worden theoretische concepten uit diverse disciplines besproken, die relevant zijn gebleken voor de analyse van de indicatieve planning (hoofdstuk twee), het industriebeleid (hoofdstuk drie) en de strategie van publieke ondernemingen (hoofdstuk vier); in de hoofdstukken vijf tot en met zeven wordt de Franse empirie geanalyseerd, waarna op basis van de besproken theoretische inzichten en het geanalyseerde empirische materiaal in hoofdstuk acht conclusies worden getrokken. 


\section{Noten behorend bij hoofdstuk 1}

[1] Zo gezien is de markt op te vatten als "(...) a set of social institutions in which a large number of commodity exchanges of a specific type regularly take place, and to some extent are facilitated and structured by those institutions" (Hodgson 1988a, 174).

De ruil op de markt betreft het afsiuiten van een overeenkomst met betrekking tot de overdracht van eigendomsrechten.

"Markets, in short, are organized and institutionalized exchange" (Hodgson $1988,174)$.

[2] Lambers (1958) maakte geen onderscheid tussen instituties en organisatievormen en sprak derhalve van interne en externe institutionalisering.

[3] Industriebeleid kan worden gedefinieerd als het samenstel van overheidsmaatregelen, dat is gericht op het realiseren van doeleinden met betrekking tot de opbouw van het produktieapparaat qua sectoren, ondernemingsgrootte. regionale spreiding, of mate en aard van de verwlechtingen tussen activiteiten (vergelijk 3.2.1). Wat de invalshoek van de vervlechtingen betreft gaat het om complexe netwerken van relaties, waarbij naast industriële, ook dienstverlenende activiteiten (onderwijs, toeleverende dienstensectoren) een rol spelen. Wanneer wij spreken van "industriebeleid" heeft zulks derhalve niet alleen betrekking op de "secundaire sector" en de industriële bedrijfsklassen en subgroepen van de Standaard Bedrijfstakindeling, mar op activiteiten van verschillende aard, die zijn vervlochten in netwerken (vergelijk het 'fillièreconcept $t^{*}$ in 3.2.1.4).

[4] De Jong $(1987,18)$ schrijft over marktconformiteit: "Beleid is marktconform wanneer het erop gericht is de markt in stand te houden of haar werking te verbeteren. Het is marktvervangend wanneer het de markt uitschakelt of de marktwerking belemmert". Structuurvormend en -aanpassend beleid acht De Jong marktconform " (...) omdat beide noodzakelijkerwijze worden opgezet en uitgevoerd vanuit de voorstelling, dat bij geslaagd beleid de ondernemingen de hun toekomende rol in het toekomstige marktproces zullen kunnen vervullen. Dat is bij structuurconserverend beleid niet zo: daar ligt de voorstelling aan ten grondslag dat de beleidsvoerende instanties in staat zouden zijn de marktwerking uit te schakelen, op te houden of tegen te houden". (De Jong 1987, 25).De Jong zelf classificeert 'indicatieve planning' en 'selectieve nationalisatie' als marktvervangend, hetgeen volgens ons kwestieus is, omdat beide vormen van structuurbeleid zeer wel gericht kunnen ziln op verbetering van de marktwerking (vergelijk paragraaf 2.3 .3 en 3.2 ). De definitie van de WRR $(1980,174)$ lijkt beter te operationaliseren: "Marktconform betekent (...) dat de onderneming primair zelf verantwoordelijk blijft voor haar beslissingen en daarvan ook alle gevolgen moet dragen".

[5] 'Vanaf 1945 krijgt de 'planification à la française' vorm (vergelijk hoofdstuk 5). Hoewel het industriebeleid een veel langere historie heeft (zie hoofdstuk 6), zal de historische analyse zich wat dat betreft vooral richten op de periode na 1958 , omdat vanaf de toetreding tot de EEG het beleid worm moest worden gegeven in een open economie: Wat de historische analyse van de publieke ondernemingen betreft is 1945 een goede startdatum, omdat vanaf die tijd de belangrijkste nationalisaties plaatsvonden (zie hoofdstuk 6). 
[6] Voor een uiteenzetting van de wereld van Arrow en Debreu zie 2.2.1.

[7] Voor een bespreking van het model van parametrische planning zie 4.4.2.1.

[8] Machlup (1967) stelt zich na een bespreking van de "marginalist, behavioral" en 'managerial theories of the firm' de vraag welke theorie nu de juiste is: "I conclude that the choice of the theory has to depend on the problem we have to solve" (Machlup 1967, 30 en 31), waaraan hij in een noot fijntjes toevoegt:

"As a matter of fact, it will also depend on the research techniques which the appointed analyst has learned to master; we can eliminate this bias by assuming an ideal analyst equally adept in all techniques".

[9] Een typologie is een classificatie; een configuratie is op te vatten als "(...) clusters of attributes (...) that are internally consistent, such that the presence of some attributes can lead to the reliable prediction of others" (Mintzberg 1983, 57). 


\section{DE THEORIE VAN INDICATIEVE PLANNING}

\subsection{Inleiding}

De economische orde dient de handelingen van de actoren zodanig te coördineren, dat een evenwichtige ontwikkeling plaatsvindt. Investeringsbeslissingen op microniveau dienen bijw. te resulteren in een produktiecapaciteit, die is afgestemd op de ontwikkeling van de toekomstige vraag. Met het indicatieve plan wordt gepoogd de handelingen wan de actoren in een markteconomie beter te coördineren door hen wan extra informatie te voorzien. Over de informatie, die de marktpartijen behoeven om de toekomstplannen op elkaar af te stemmen handelt paragraaf 2.1. In een markteconomie staan de marktpartijen diverse informatiebronnen ter beschikking (2.2), waarvan het indicatieve plan er één is. Over de rol van zo'n plan in een markteconomie zijn een drietal theorieën ontwikkeld: in 2.3 wordt de theorie van Meade besproken, die is gebaseerd op de abstracte wereld van Arrow en Debreu, vervolgens komt de Keynesiaanse benadering van Harrod aan de orde, waarna het hoofdstuk wordt afgesloten met de benadering van Estrin en Holmes.

\subsection{Hayek's coördinatieprobleem}

De Oostenrijke school heeft met betrekking tot de theorievorming over de werking van het marktproces in een wereld met onzekerheden en verwachtingen belangwekkende bijdragen geleverd [1]. Een centrale rol spelen de denkbeelden van Hayek, die de problematiek van het coördineren van economische handelingen van onafhankelijke actoren in een markteconomie uiteen zette in zijn 'Economics and Knowledge' uit 1937. Volgens Hayek dient de economische theorie antwoord te geven op de vraag, hoe in een onzekere wereld de toekomstplannen van de individuele actoren zodanig op elkaar kunnen worden afgestemd, dat evenwichten resulteren.

Voor de vroeger in de leerboeken zo gelliefkoosde Robinson Crusoe bestaat een dergelijk coördinatieprobleem niet. Dan is immers sprake van één plan en én handeling, die in é̉n brein worden gecoördinneerd (vergelijk Lowe 1977). Hayek constateert, dat de neoklassieke theorie met opvallend gemak de analyse van het individu doortrekt naar het optimaliserend gedrag van een veelheid van actoren. Het coördinatievraagstuk wordt omzeild door te veronderstèllen, dat het prijsmechanisme de relevante informatie aan de actoren overdraagt. Daarmee wordt voorbijgegaan aan de fundamentele vraag "(....) how knowledge is acquired and communicated" (Hayek $1937,45)$. 
Over welke 'knowledge' moeten de actoren beschikken, opdat hun toekomstplannen efficint op elkaar kunnen worden afgestemd?

"It appears that the concept of equilibrium merely means that the foresight of the different members of the society is in a special sense correct. It must be correct in the sense that every persom's plan is based on the expectation of just those actions of other people which those other people intend to perform, and that all these plans are based on the expectation of the same set of external events, so that under certain conditions nobody will have any reason to change his plans" (Hayek 1937, 41).

Enerzijds gaat het om de afstemming van de verwachtingen op ontwikkelingen van de 'external events' (preferenties, technologische ontwikkelingen en dergelijke), anderzijds om een onderlinge afstemming van het toekomstig gedrag van de marktpartijen; hun plarinen moeten 'mutually compatible' zijn.

Meade (1971) spreekt in dat verband over markt- en omgevingsonzekerheid [2]. Marktonzekerheid betreft onbekendheid bij de individuelle marktpartijen van het toekomstig gedrag van de andere marktpartijen. Het gaat daarbij zowel om onzekerheid met betrekking tot de vraag naar het produkt, als met betrekking tot het gedrag van de concurrenten. Marktonzekerheid betreft onzekerheid over toekomstig gedrag, waarover in de economie in principe informatie aanwezig is. De marktpartijen kunnen weten wat hun toekomstplannen zijn en in principe zou die informatie aan de andere marktpartijen kunnen worden overgedragen. Wij zullen zien, dat het indicatieve plan daarbij een belangrijke rol kan spelen.

Met omgevingsonzekerheid is het anders gesteld. Dat betreft onzekerheid met betrekking tot de ontwikkeling van factoren, waarover geen of zeer gebrekkige informatie bestaat. Klimaatveranderingen, technologische veranderingen, verschuivingen in de preferenties zijn daar voorbeelden van.

Welk antwoord heeft de economische theorie sedert 1937 op Hayek's coôrdinatievraagstuk gegeven? Daartoe bespreken wij in de volgende paragraaf de informatiebronnen, die de marktpartijen ter beschikking staan en gaan na hoe diverse economische theoriën daarop hun licht hebben laten schijnen.

\subsection{Informatie in de markteconomie}

\subsubsection{Informatiebronnen}

Marktpartijen kunnen informatie betrekken uit diverse bronnen:

- informatie, die aan de marktpartijen wordt geleverd door de veranderingen in de relatieve prijzen;

- informatie, die door de marktpartijen zelf wordt geproduceerd, bijwoorbeeld gegevens over de ontwikkeling van de vraag, of de produktiviteit van de produktiefactoren;

- informatie, die de marktpartijen vergaren via contacten met andere actoren met wie zij in netwerken relaties van witeenlopende aard onderhouden (vergelijk 3.2);

- informatie, die als marktgoed op de 'informatiemarkt" wordt aangeboden en gevraagd. Ondernemingen produceren informatie, waarvoor een prijs op de markt 
tot stand komt. Door schaalvoordelen en specialistische kennis kunnen zij de informatie tegen lagere kosten produceren dan de individuele marktpartijen;

- informatie, die tot de marktpartijen komt via de normen, waarden, regels en conventies wan de maatschappij, waarvan de betrokkenen deel uitmaken. Newman (1976) spreekt van "institutionele informatie", waarvan de kwaliteit varieert met de stabiliteit van instituties. Normen en waarden beïnvloeden de verwachtingen van de actoren, verschaffen informatie over waarschijnlijk gedrag van anderen;

- informatie, die wordt geproduceerd door een buiten de markt staand orgaan, bijvoorbeeld de overheid, en aan de marktpartijen wordt verkocht, of om niet ter beschikking wordt gesteld. Bijvoorbeeld informatie over de verwachte ontwikkeling in diverse macro-indicatoren, over het industriebeleid van andere landen, over de mogelijke en gewenste ontwikkeling van de industriële structuur en dergelijke. Dat soort informatie kan worden gepubliceerd in een indicatief plan.

Aangezien met de produktie van informatie schaarse middelen zijn gemoeid, dient het als een taak van de economische theorie te worden beschouwd te verklaren wanneer de economische actoren zelf informatie produceren, wanneer zij informatie als goed op de markt kopen, hoe de prijs daarvan tot stand komt etc. Ook zou de theorie inzicht moeten verschaffen in de taak, die in een markteconomie als het ware "overschiet" poor een externe organisatie, die een indicatief plan opstelt.

In het navolgende gaan wij eerst in op de rol van de prijs als informatiedrager in de neoklassieke theorie, waarna in 2.2 .2 het functioneren van de informatiemarkt aan de orde komt.

\subsubsection{De wereld van de neoklassieken en die van Arrow en Debreu}

In het neoklassieke model van de markteconomie worden de beslissingen op decentraal niveau genomen, wordt informatie via prijzen overgedragen en wordt verondersteld dat de partijen zich rationeel gedragen [3]. De modellen van de diverse marktvormen worden in de neoklassieke theorie gekenmerkt door single-exit situaties (Latsis 1972), door logische tijd in plaats van historische tijd (Robinson 1980) en door actoren, die beschikken over alle relevante informatie. In zo'n theoretische wereld, waarin de aard van de actor en zijn omgeving nauwkeurig zijn vastgelegd, wordt door theoretici verondersteld, dat na een exogene verstoring het economisch proces naar een nieuw evenwicht tendeert.

Op de structuur van neoklassieke model van volledig vrije mededinging is kritiek geoefend: 0. a. blijft onduidelijk hoe de prijzen als enige informatiedrager in het modiel in staat zijn alle relevante informatie tijdig aan de actoren over te dragen.

Om op $t_{0}$ optimale beslissingen te kunnen nemen met betrekking tot de investeringen in nieuwe produktiecapaciteit, moet de actor namelijk geïnformeerd zijn over de toekomstige evenwichtsprijs, die wordt bepaald door de toekomstige vraag- en aanbodverhoudingen. De economische theorie staat voor de taak duidelijk te maken, hoe in een markteconomie prijzen in staat zijn over markt- en omgevingsonzekerheid informatie over te dragen, opdat onafhankelijk genomen beslissingen op decentraal niveau resulteren in toekomstige evenwichten.

In het model van Arrow en Debreu [4], zoals dat in het kader van de algemene 
evenwichtstheorie is ontwikkeld, wordt duidelijk gemaakt hoe prijzen informatie met betrekking tot markt-en omgevingsonzekerheden kunnen overdragen. Hun probleemstelling luidt, of in een economische orde een algemeen evenwicht tot stand kan komen, als onafhankelike actoren beslissingen nemen louter en alleen op basis van prijsinformatie. In de Arrow en Debrew-wereld handelen maximaliserende individuen op markten, waar goederen worden verhandeld, die niet alleen worden onderscheiden naar hun fysieke eigenschappen, maar ook naar het tijdstip en de plaats van beschikbaarheid, alsmede naar de ongevingstoestand. Met dat laatste wordt de state of nature bedoeld: het geheel van die omgevingsfactoren, dat niet door de actor kan worden beinvloed. De diverse states of nature zullen zich in de tijd volgens een specifiek pad ontwikkelen, dat ex ante door geen van de marktpartijen kan worden gekend. Verondersteld wordt, dat de actoren wel alle mogelijke omgevingspaden kunnen kennen. Voor elk omgevingspad worden door de marktpartijen op $t_{o}$ contracten afgesloten; er bestaat in de wereld van Arrow en Debreu voor elk punt op elk denkbaar omgevingspad een zogenaamde voorwaardelijke toekomstmarkt. Op elk punt van het omgevingspad bestaat een markt waarvoor partijen contracten afsluiten, die in de toekomst nageleefd moet worden als het betreffende omgevingspad zich inderdaad voordoet. In de Arrow en Debreu-wereld bestaat met andere woorden een volledig stelsel van voorwaardelijke toekomstmarkten waar op $t_{0}$ evenwichtsprijzen tot stand komen, die de actoren van alle relevante informatie met betrekking tot de toekomst voorzien [5]. Tijd en onzekerheid worden uitgeschakeld.

"The assumption that all intertemporal and all contingent markets exist has the effect of collapsing the future into the present" (Hahn 1980, 132).

De veronderstelling van het bestaan van een volledig stelsel van voorwaardelijke toekomstmarkten is essentieel voor de theorie van Arrow en Debreu.

"Once these markets are incomplete, rather terrible things happen to theory. The economy will now have trading on every date- we are dealing with a sequence economy. Agents' actions at any date will now depend on their beliefs concerning furure events (e.g. rain or shine, war or peace, cold or no cold) and on the prices that will rule given these events. But we have no theory of expectations comparable to our theory of household or firm choice; (....)" "What is required is an equilibrium notion that reflects the sequential character of actual economies in an essential way" (Hahn 1980,132).

Daartoe moeten volgens Hahn de transactiekosten [6], verwachtingen en onzekerheid een expliciete plaats in de evenwichtsanalyse krijgen. Met andere woorden: de algemene theorie dient met meer specifieke condities te worden ingevuld. Daardoor wordt de theorie voor grote problemen geplaatst, omdlat de wijze waarop verwachtingen worden gevormd en het leerproces, dat de actoren in de loop van de tijd doorlopen in de theorie moeten worden geintegreerd.

Theorieên, die om met Zuidema te spreken, de scheiding tussen proces en omgeving anders trekken en historische tijd in de analyse introduceren worden geconfronteerd met het vraagstuk, hoe in een onzekere wereld de actoren verwachtingen vormen en hoe het marktmechanisme de plannen van economische actoren op elkaar zou kunnen afstemmen. 
Specifieke economische theorieën zullen moeten verklaren hoe marktpartijen pogen onzekerheid te reduceren in een wereld, waarin prijzen gebrekkig informatie overdragen met betrekking tot heersende schaarsteverhoudingen en nagenoeg geen inzicht verschaffen in toekomstige verhoudingen van vraag en aanbod. Het blijkt, dat in werkelijkheid zowel de marktpartijen zelf als de overheid een belangrijke rol spelen als producenten en verspreiders van informatie als aanvulling op het prijsmechanisme.

\subsubsection{De informatiemarkt}

Een volledig stelsel van voorwaardelijke toekomstmarkten komt in werkelijkheid niet tot stand, omdat de transactiekosten prohibitief zijn. Het afsluiten van contracten $n_{z}$ die een groot aantal omgevingspaden betreffen, brengen voor de partijen hoge kosten van informatieverzameling, onderhandeling en controle op de naleving met zich mee. Hoewel een aantal toekomstmarkten zijn ontstaan [7], zullen de prijzen door de afwezigheid van een volledig stelsel van voorwaardelijke toekomstmarkten in werkelijkheid altijd onvolledige informatie verschaffen.

De marktpartijen kunnen ter reductie van hun markt- en omgevingsonzekerheid een beroep doen op eén van de andere genoemde informatiebronnen: zij kunnen zelf informatie produceren, of deze op de markt kopen. Ook dan komt geen wereld van volledige informatie tot stand, omdat sprake is van een onderproduktie van informatie, hetgeen verband houdt met enkele specifieke eigenschappen van het goed 'informatie' [8]. Wat de aanbodkant van de markt betreft doet zich het probleem voor, dat eenmaal verkochte informatie door de koper tegen relatief geringe kosten kan worden doorverkocht voor een prijs, die het voor de oorspronkelijke producent onmogelijk maakt zijn investeringen terug te verdienen. Met het afsluiten van contracten, waarin de wederkoop wordt uitgesloten kunnen zulke hoge kosten gemoeid zijn, dat de overeenkomst niet tot stand komt. Voor de koper doet zich het probleem voor, dat de verkoper altijd in het bezit van de informatie blijft. Ook dan geldt, dat met betrekking tot het uitsluiten van het gebruik van die kennis prohibitieve contractkosten kunnen zijn gemoeid. Het is ook mogelijk, dat de onderneming louter en alleen door middel van zijn strategiekeuze ongewild informatie onthult voor zijn concurrenten. Een onderneming, die bijv. een ingenieursbureau heeft laten onderzoeken of recente technologische ontwikkelingen voor zijn produktieproces van belang kunnen zijn, 'onthult' voor zijn concurrenten die informatie door bijw. een joint venture met een specialist in een specifieke nieuwe technologie aan te gaan. Marktstrategieën van 'geînformeerden' kunnen door 'niet geïnformeerden' worden geìmiteerd. De onmogelijkheid gemaakte kosten terug te verdienen ('inappropriability' Arrow 1962) en de informatie alleen ten eigen bate te kunnen aanwenden, leidt ertoe dat niet de optimale hoeveelheid middelen wordt gealloceerd voor de produktie van informatie: informatie wordt 'ondergeproduceerd'.

Ook aan de vraagkant kent de informatiemarkt problemen. Arrow $(1962,616)$ spreekt van de informatieparadox. Informatie, die op de informatiemarkt wordt aangeboden is voor de potentiële koper onbekend, totdat hij de informatie in zijn bezit heeft. Hij kan dus pas bepalen welke prijs hij voor de informatie over heeft als de inhoud hem bekend is. In dat geval zal hij het goed niet meer kopen.

In welke mate bovengenoemde eigenschappen ertoe leiden, dat de onderneming de 
informatie niet produceert of koopt, hangt af van de mogelijkheid anderen van de informatie uit te sluiten, hen te beperken in de mogelijkheid van imitatie, of hun toetreding tot de betreffende markt te belemmeren.

Van groot belang voor het functioneren van de informatiemarkt kan het bestaan van een vertrouwensrelatie tussen koper en verkoper zijn. Is sprake van een langdurige relatie en hebben beide partijen belang bij een continuering, dan kunnen bovengenoemde problemen met betrekking tot hoog oplopendle contractkosten en de informatieparadox worden overwonnen [9].

Als de informatiemarkt niet goed functioneert kunnen de marktpartijen pogen in de markt instituties en organisaties te voegen, waardoor zij beter in staat zijn de resultaten van hun inspanningen naar zich toe te trekken. Volgens de property rights-benadering [10] zijn marktpartijen bereid de eigendomsstructuur te veranderen, als zij daardoor beter in staat zijn de opbrengsten wan eigen inspanningen uitsluitend aan henzelf te laten toekomen. Zij zijn bereid daartoe kosten te maken als die opwegen tegen de te verwachten opbrengsten. Verbetering van de eigendomsrechten betreft bijvoorbeeld het organiseren van een patentsysteem. De recente school in de economische theorie, die institutionele veranderingen verklaart op grond wan het maximaliserend gedrag. van de actoren, wordt de 'new institutional economics' (NIE) genoemd [11]. In de recente ontwikkelingen in de NIE (vergelijk bijw. Langlois 1986) wordt voortgebouwd op de neoklassieke traditie van het methodologisch individualisme (Hodgson 1988, Heijdra et al. 1988): uitgangspunt is het rationeel handelende individu, dat op de markt winst of nut maximaliseert. Newman (1976) spreekt van een 'market for reforms', waar hervormingen van de institutionele structuur worden gevraagd en aangeboden en een prijs tot stand komt. Die prijs kan voor een individuele marktpartij te hoog zijn, waardoor een hervorming niet tot stand komt. Ook is sprake van 'free riding": andere marktpartijen zullen van de hervorming voordeel hebben zonder dat zij een prijs. betalen. Net als op de informatiemarkt is op de 'markt van institutionele hervormingen' sprake wan onderproduktie, waardoor een taak voor de overheid is weggelegd (vergelijk North 1984).

Samengevat kan worden gesteld, dat de marktpartijen het functioneren van de informatiemarkt zullen trachten te verbeteren, maar dat het doorvoeren van dergelijke veranderingen kan uitblijven wanwege het niet efficiënt functioneren van de 'markt van hervormingen'. De overheid valt dan de taak toe het collectieve goed van een adequate institutionele structuur te produceren.

In een markteconomie beschikken de marktpartijen ook zelf over een scala van mogelijkheden de appropriability-problematiek te verminderen en de middelen voor de produktie van informatie efficiënter te alloceren. Vormen van interne ordening, zoals kartels, fusies, joint ventures, vertikale integratie en het opbouwen van netwerkrelaties maken het woor de onderneming mogelijk afspraken te maken over de aanwending van informatie. Samenwerkingsverbanden met concurrenten, leveranciers en afnemers kunnen ertoe leiden, dat imitatie niet of later plaatsvindt.

\subsubsection{Institutionele informatie}

Welke informatie door de marktpartijen zelf wordt geproduceerd en op de markt wordt gekocht, alsmede welke initiatieven marktpartijen ontplooien tot verandering 
van de organisatorische structuur, wordt mede beïnvloed door de aanwezigheid van de zogeheten institutionele informatie.

Economische actoren nemen beslissingen in een maatschappelijke context van heersende waarden en normen. Die instituties bevatten informatie voor de marktpartijen op grond waarvan verwachtingen met betrekking tot het gedrag van andere marktpartijen worden gevormd [12].

"We stress that, in referring to the role of institutional structures in providing information, we take a broad sociological view of these structures, including any social contract or convention which limits individuals' expectations of possible social interaction - whether or not they relate to economic exchange alone or can be enforced by legal sanctions. In general, it is by placing limits on spontaneous social behaviour that institutional structures supply information, providing individuals with guidance to 'acceptable' behavioural decisions or constraints on their ability to undertake "unacceptable decisions"' (Newman 1976, 475).

Newman poogt de prijs vari het goed informatie, zoals die op de informatiemarkt tot stand komt (Market Supplied Information: MSD), mede te verklaren aan de hand van de beschikbaarheid van institutionele informatie in de samenleving. In zijn verklaring van de prijs van informatie spelen twee elementen een rol: enerzijds de relatie tussen de institutionele informatie en de prijs van de marktinformatie, anderzijds de mogelijkheid de institutionele structuur te veranderen, waardoor de appropriability van hervormingen verbeterd wordt. Newman gaat ervan uit, dat in een specifieke economische orde actoren voor het kunnen nemen van beslissingen een zeker minimum aan informatie nodig hebben. Is die orde stabiel, dan ligt in het model van Newman de behoefte aan informatie vast. De prijs van de marktinformatie wordt bepaald door de mate, waarin de vraag naar informatie het aanbod overtreft.

De institutionele structuur verschaft de actoren informatie - richtlijnen voor hun handelen - waarvan de kwaliteit wordt bepaald door de stabiliteit van de structuur. Hoe stabieler de structuur, hoe 'meer' informatie zij verschaft en hoe minder informatie de marktpartijen via andere kanalen behoeven. Van een efficiènte informatiestructuur is sprake als de institutionele structuur 'veel' informatie verschaft, er sterke prikkels bestaan informatie te produceren en de actoren voor het nemen van hun beslissingen relatief weinig informatie behoeven. De institutionele structuur zal door de marktpartijen worden veranderd als de verwachte baten de te betalen prijs overtreffen. Zoals gezegd veronderstelt Newman het bestaan van een 'market for reforms' waar de prijzen van institutionele hervormingen door middel van vraag en aambod tot stand komen. De vraag wordt bepaald door de prijs en de discrepantie tussen de gewenste en feitelijke institutionele structuur. Om redenen van eenvoud wordt het aanbod aan de prijs gekoppeld. Een belangrijke factor in het geheel vormt de snelheid van de hervorming: is de prijs hoog dan zal de gewenste snelheid ook hoog zijn, opdat snel de vruchten van de hervorming kunnen worden geplukt. Daar staat tegenover, dat de prijs stijgt naarmate de hervorming sneller moet worden ingevoerd. In het model van Newman worden de prijs en de snelheid van de hervorming simultaan op de market for reforms bepaald.

Newman heeft zo de vraagstelling van de neoklassieken naar evenwicht op de informatiemarkt uitgebouwd tot het complexe vraagstuk 
...." (...) whether there exist some time-path of the prices of both MSI and reform which will be consistent with continuing equilibrium in both the information market and the market for reform over time" (Newman 1976,483).

Samengevat komt de benadering van Newman op het volgende neer:

1. Het evenwicht wordt verstoord door een exogene schok in de verwachtingen: er ontstaat een discrepantie tussen de gewenste en feitelijke institutionele structuur.

2. Individuen bieden institutionele veranderingen aan en vragen daarnaar, totdat evenwicht op de markt van hervormingen bestaat.

3. Het effectieve aanbod van institutionele informatie is door de institutionele veranderingen gedaald (kwaliteit is gekoppeld aan stabiliteit).

4. Afhankelijk van de reacties bij de vragers en de aanbieders zal de prijs van informatie (MSI) stijgen of dallen.

5. Al naar gelang de feitelijke en gewenste structuur weer meer op elkaar worden afgestemd, daalt de prijs van de institutionele hervormingen en zijn de veranderingen genoemd onder 3) en 4) navenant.

6. In de nieuwe long run is de feitelijke en gewenste institutionele structuur weer aan elkaar gelijk. De prijs van de marktinformatic wordt bepaald door de nieuwe institutionele informatie. In elke institutionele 'setting' bestaat een evenwichtsprijs van de marktinformatie, waarvan de hoogte afzonderlijk is van de kwaliteit van de institutionele structuur.

Uit de benadering van Newman blijkt, dat het opnemen van de wisselwerking tussen te verklaren economische variabelen (i.c. de prijs van informatie als marktgoed) en één van de data (i.c. de institutionele structuur), leidt tot een complexe analyse, die alleen 'strak' kan blijven als rigoreuse veronderstellingen worden gehanteerd, zoals bijv. die met betrekking tot de vraag en het aanbod op de markt van hervormingen [13]. De analyse is abstract, maar daardoor voor concrete ordeningsvraagstukken nog niet irrelevant [14]: zij maakt duidelijk, dat voor de verklaring van de prijs van informatie als marktgoed de institutionele informatie cen belangrijke variabele is, waarvan de kwaliteit wordt bepaald door de stabiliteit van de institutionele structuur. Is sprake van geen of van trendmatige veranderingen dan kunnen de actoren verwachtingen vormen, die in belangrijke mate gefundeerd zijn op veranderingen uit het verleden. Is daarentegen sprake van grote en/of snelle veranderingen in de normen, regels, conventies, internationale ontwikkelingen en dergelijke, dan verkeren marktpartijen in het ongewisse ten aanzien van de reacties van de andere marktpartijen en de overheid. De behoefte aan informatie stijgt in een onzekere, turbulente omgeving. In zijn algemeenheid kan wordlen gesteld, dat in de jaren na de eerste oliecrisis (1973) de institutionele informatie aan kwaliteit heeft ingeboet. De behoefte aan additionele informatie is gestegen en de vraag is in welke mate daarin door de markt wordt voorzien. Is dat niet in voldoende mate het geval dan kan onzekerheid enerzijds worden gereduceerd door samenwerking en thet opbouwen van netwerkrelaties (vergelijk 3.2) en anderzijds is een belangrijke functie weggelegd voor informatieverschaffing door een externe organisatie via een indicatief plan. 


\subsection{Theorleën van de Indicatieve planning}

\subsubsection{Inleiding}

In 2.1 is uiteengezet welke informatie de marktpartijen behoeven om beslissingen te kunnen nemen, die kunnen resulteren in evenwichten. De informatie betreft de markten omgevingsonzekerheid. Op het niveau van een algemene theorie als die van Arrow en Debreu kan een volledig stelsel van voorwaardelijke toekomstmarkten worden verondersteld; op specifieker niveau blijken marktpartijen zelf informatie te produceren, op de markt te kopen, en via de institutionele structuur te ontvangen. Is die informatie tezamen niet voldoende voor het nemen van efficiënte beslissingen, dan zou aanvullende informatie kunnen worden verschaft door middel van een indicatief plan.

In deze paragraaf bespreken wij een drietal theorieën van indicatieve planning, die een verklaring geven voor die aanvullende rol:

- Op zeer algemeen niveau formuleerde Meade (1971) een sluitend model van indicatieve planning, gebaseerd op de wereld van Arrow en Debreu. In 2.3 gaan wij nader in op het model van Meade voorafgegaan door een bespreking van de aanzetten tot theorievorming van Pierre Massé, die beschouwd wordt als de grondlegger van de theorie van indicatieve planning in Frankrijk.

- In het midden van de jaren zestig paste Massé zijn theorie aan bij zijn bevindingen met de eerste indicatieve plannen in Frankrijk en formuleerde een theorie, warin het plan vooral bestaat uit macro-economische indicaties. Harrod (1972) ontwikkelt in het verlengde daarvan zijn 'theory of aggregative indicative planning' (2.3.2).

- Estrin en Holmes (1983a) formuleerden een 'alternative justification for indicative planning; een theorie op specifieker niveau, waarin de rol van het indicatieve plan wordt verklaard uit de beperkte rationaliteit van de actoren en hun opportunistisch gedrag, alsmede door de complexiteit en onzekerheden in de omgeving (2.3.3).

\subsubsection{Een ex ante integraal coherent indicatief plan; Massé en Meade}

\section{De ideeën van Pierre Massé}

De eerste plannen kregen in Frankrijk gestalte zonder dat sprake was van een theoretische onderbouwing. In 1959 bij het begin van het Derde Plan, werd Pierre Masse "Commissair au Plan"; hij gaf de eerste aanzetten tot het on twikkelen van een theorie van de indicatieve planning.

In aanvulling op het bekende marktfalen met betrekking tot externe effecten en collectieve goederen, wijst Massé op een derde reden voor corrigerend overheidsoptreden in een markteconomie, namellijk het gebrekkig coördinatievermogen van de markt met betrekking tot de toekomstplannen van de marktpartijen. Volgens Massé is een aanvullend coôrdinatiemechanisme nodig, dat de plannen van de individuele actoren coherent maakt bij een eensluidende visie op de ontwikkeling van de omgevingsfactoren. Van de drie theoretisch mogelijke organisatievormen -toekomstmarkten, directieve planning en een zogenaamde 'Algemeen Marktonderzoelk' ('Marché généralisé')- acht Massé de laatste in een markteconomie realiseerbaar (Massé 1965a). Het algemeen marktonderzoek maakt de markt doorzichtiger door het verzamelen en 
operibaar maken van de kennis, verwachtingen en plannen van de individuele actoren met betrekking tot de toekomstige ontwikkelingen in hun eigen sectoren. Daarna worden de plannen tot een coherent geheel gesmeed

"(...) by welding the individual forecasts and plans into a consistent whole, corresponding to a common view of future economic development" (Lutz, 1969, 58).

Van belang is enerzijds het ontwikkelen van een eensluidende visie op de toekomstige ontwikkelingen en anderzijds het daarbinnen op elkaar afstemmen van de individuele plannen (vergelijk Hayek 1937). Massé sprak van 'consultation', waarbij in sectorcommissies door de belanghebbenden (werkgevers, werknemers, ambtenaren, vertegenwoordigers van consumentenorganisaties en deskundigen) informatie wordt verstrekt aan het Planbureau over de verwachte ontwikkeling met betrekking tot de omgevingsvariabelen en over de toekomstplannen van elk van de actoren. Het Planbureau staat voor de taak de diverse sectorplannen tot een coherent geheel te smeden ('concertation') en het resultaat te publiceren in een indicatief plan. Zo'n plan wordt dus vooraf (ex ante) opgesteld en bevat informatie over de plannen van alle actoren (integraal), die onderling op elkaar zijn afgestemd (coherent) [15].

Uit concurrentieoverwegingen kan de informatie in het Plan niet luiden in microtermen, maar altijd in indicaties betrekking hebbend op het mesoniveau van de sector. Za'n indicatief plan is een ex ante integraal coherent plan.

Volgens de ideeën van de Franse planners verschaft het plan belangrijke informatie aan de marktpartijen; informatie die van henzelf afkomstig is, mar voortheen niet voor een ieder kenbaar was. Het stelsel van indicatieve planning behoudt alle voordelen van de markt, maar voegt daaraan een element toe: extra informatie in de vorm van een coherent beeld van toekomstige sectorale ontwikkelingen. Zo'n indicatief geplande markteconomie zal volgens Massé efficiënter werken dan een markteconomie zonder plan.

"It does not replace the market and the price system. It supplements the information supplied by the price system. It improves the market mechanism by reducing uncertainties" (Massé 1965b).

In het model van indicatieve planning wordt verondersteld, dat de actoren de jujste informatie over hun plannen zullen verstrekken en zich ook conform de verschafte informatie zullen gedragen. Die veronderstelling is gebaseerd op de idee, dat de marktpartijen zelf belang hebben bij de evenwichtige ontwikkelingen, die met behulp van het indicatieve plan zouden kunnen worden gerealiseerd. Uit eigen belang zullen zij bereid zijn aan de centrale de juiste informatie te verschaffen en na terugkoppeling bereid zijn hun plannen bij te stellen, opdat inderdaad evenwichten op alle markten ontstaan (Massé 1965a). De instrumenten om het plan te verwezenlijken worden in dat verband 'endogeen" genoemd; Lutz (1969) spreekt van een 'self-implementing character': het indicatieve plan verwerkelijkt als het ware zichzelf. Als de marktpartijen zich in hun gedrag alleen laten leiden door de indicaties van het Plan dan wordt ook wel van 'pure' indicatieve planning gesproken.

Naast de 'pure' indicatieve planning kan ook de zogenaamde incitatieve planning worden onderscheiden. In dat model heeft de overheid doeleinden ontwikkeld met 
betrekking tot de uitkomsten van het economische proces qua omvang van de econo* mische groei, regionale spreiding, sectorale ontwikkelingen, inkomenswerdeling enz. Door middel van marktconforme 'incentives' zoals belastingen en subsidies, poogt de overheid het gedrag van de actoren af te stemmen op de doeleinden van het Plan. Of de ondernemingen op de financiële prikkels reageren hangt uiteraard af van hun eigen financiële posities. Het informatie-uitwisselingsproces maakt duidelijk wat het resultaat zal zijn als de individuele plannen worden gerealiseerd, zodat de overheid kan nagaan welke prikkels nodig zijn om het gedrag te beinvloeden in de richting van de doeleinden wan het Plan.

\section{De algemene theorie van J.E. Meade}

De theorie van indicatieve planning van Meade (1971) is gebaseerd op de denkbeelden van Arrow en Debreu, welke hij aanvulde met de veronderstelling, dat gedurende de eindige planperiode de bevolking qua omvang en samenstelling niet veranderde. Het volledige stelsel van voorwaardelijke toekomstmarkten werd door Meade de 'full set of contingency markets' genoemd, waarnaast hij twee andere theoretische coördinatie. systemen presenteerde, die hetzelfde stelsel van evenwichtsprijzen opleverden: "full set of conditional forward markets' en het 'system of indicative planning".

\section{Conditional forward markets}

In het stelsel van 'conditional forward markets' bestaat in tegenstelling tot de 'contingency markets" de mogelijkheid op elk gewenst tijdstip in de toekomst te betalen voor het gecontracteerde goed. De agenten dienen dan niet alleen informatie te hebben over de toekomstige prijzen op de 'spor'markten, maar ook over de interestvoet op de kapitaalmarkt. Meade completeerde het stelsel van markten met een verzekeringsmarkt, waar agenten zich tegen de gevolgen van omgevingsgebeurtenissen kunnen indekken. Het inkomen kan namelijk per omgevingspad verschillen, hetgeen voor een agent moeilijkheden kan veroorzaken bij het nakomen van al zijn verplichtingen. Heeft hij, om in de voorbeeldensfeer van Meade te blijven, een contract afgesloten op $t_{3}$ een zonnebril te kopen als op $t_{2}$ de zon schijnt en tevens in een arbeidscontract het recht verworven op $t_{2}$ arbeid tegen loon te verrichten als het op $t_{2}$ regent, dan heeft de betrokkene op $t_{3}$ geen middelen, maar wel de verplichting de bril te kopen als op $t_{2}$ de zon heeft geschenen. Om dat soort problemen te voorkomen bestaat in de wereld van Meade een verzekeringsmarkt, waar de premies de evenwichtsprijzen zijn.

Ook kan de agent zich indekken tegen een ongewenste inkomensontwikkeling, als gevolg wan het zich voltrekken van een voor hem ongunstig omgevingspad. Het inkomen is in de wereld van Meade afhankelijk van het marginaal produkt en dat kan per omgevingspad verschillen. Zo zal bij de ene technologische ontwikkeling de produktiviteit van de faktor arbeid hoger zijn dan bij de andere technologie.

Het risico van een ongunstig omgevingspad kan niet voor de gehele gemeenschap worden uitgebannen, maar wel over alle leden van de gemeenschap worden gespreid, of worden verschoven naar actoren die minder risicomijdend zijn. In de wereld van Meade funktioneren efficiënte verzekeringsmarkten, die in werkelijkheid om redenen 
van 'moral hazard' en 'adverse selection' overigens niet altijd zullen voorkomen [16]. In het stelsel van "conditional forward markets" van Meade hebben de agenten op $\mathrm{t}_{0}$ perfekte informatie over de evenwichtsprijzen op alle voorwaardelijke toekomstmarkten, over de evenwichtsprijzen op de kapitaalmarkt (interest) en op de verzekeringsmarkt (premies).

\section{Indicatieve planning}

Indicatieve planning is in theorie een coordinatiemechanisme, dat hetzelfde stelsel van evenwichtsprijzen kan voortbrengen als een volledig stelsel van voorwaardelijke toekomstmarkten. Onder dezelfde theoretische voorwaarden als die van de Arrow en Debreu-wereld laat Meade een centraal planbureau informatie verzamelen over de plannen van de economische agenten bij diverse omgevingspaden. Gelijk een veilingmeester inventariseert de centrale de overschotten en tekorten, die bij uitvoering wan de plannen zouden ontstaan. De informatie over die toekomstige onevenwichtigheden wordt weer aan de economische actoren doorgegeven met de vraag wat nu hun toekomstplannen zijn. $\mathrm{Na}$ 'a giant higgle-haggle' komen na een aantal informatieronden de evenwichtsprijzen, interestvoeten en premies tot stand. Dit geheel van prijzen wordt gepubliceerd in het indicatieve plan. In tegenstelling tot het stelsell van voorwaardelijke toekomstmarkten sluiten de partijen in het stelsel van indicatieve planning geen contracten af, omdat publikatie van de evenwichtsprijzen op zich reeds voldoende is om de evenwichten te realiseren. Immers, de consumenten zullen niet bereid zijn meer te betalen dan de evenwichtsprijs, terwijl de producenten niet daaronder zullen willen verkopen. Door de informatieoverdracht via de centrale over elkaars plannen wordt in een stelsel van indicatieve planning de marktonzekerheid geëlimineerd. De omgevingsonzekerheid blijft bestaan. Daarover bestaat geen informatie, die door een economische organisatie kan worden overgedragen. Wel moeten de actoren aangeven op welke wijze zij hun winst, respectievelijk nut bij diverse mogelijke omgevingspaden zullen maximaliseren. $O p t_{0}$ moeten zij dat kenbaar kunnen maken voor alle perioden, waarover het indicatieve plan zich uitstrekt en voor alle mogelijke omgevingspaden. Meade wijst erop dat met behulp van een econometrisch model in principe dezelfde resultaten kunnen worden bereikt, maar dat een indicatief plan efficiënter is [17].

De introductie van de overheid in het model betekent geen principiële wijziging. Well wordt het coördinatieproces gecompliceerder. Immers, als in de eerste afstemmingsronden blijkt, dat er van een bepaald goed bijw. een overschot is, kan nu worden overwogen de prijs te verlagen, de belasting te verlagen, of de aankopen van de overheid te vergroten. De actoren moeten bekend maken hoe zij op elk van die maatregelen zullen reageren.

Meade heeft analoog aan Arrow en Debreu een algemene theorie geconstrueerd als antwoord op de vraag, of een stelsel van indicatieve planning mogelijk is, waarin de plannen van de agenten ex ante op elkaar kunnen worden afgestemd. Stellen wij ons de vraag, of een systeem van indicatieve planning ook in werkelijkheid zou kunnen functioneren, dan zullen de algemene concepten moeten worden ingevuld met condities van plaats en tijd. Meade heeft daarmee zelf een begin gemaakt door volgens de methode van afnemende abstractie de gevolgen te laten zien van het verlaten van de 
veronderstellingen, waarop zijn model is gebaseerd. Wat gebeurt met de marktonzekerheid als de veronderstellingen van de constante bevolking, de eindige planperiode, het onbeperkte aantal omgevingspaden en de marktvorm van de volledig vrije mededinging komen te vervallen?

\section{Onveranderlijke bevolking}

De veronderstelling van een onveranderende bevolking was nodig om tot een sluitend systeem te komen, waarbij de plannen op $t_{0}$ ook in de toekomst kunnen worden gerealiseerd. Verandert in de betreffende periode de samenstelling van de bevolking, dan zijn de individuele plannen niet meer op elkaar afgestemd. De prijzen zijn geen perfekte informatiedragers meer; de marktonzekerheid wordt niet volledig geèlimineerd. In werkelijkheid kan met behulp van extrapolaties de bevolkingsontwikkeling worden geschat en de invloed daarvan op de economische variabelen kan met behulp van economische modellen worden nagegaan. De ervaring leert dat dergelijke schattingen met zeer grote voorzichtigheid gehanteerd moeten worden.

\section{Plamperiode}

In het model van Meade betreft de planningsprocedure een afgebakende periode tussen Now en Kingdom Come. Het hanteren van een specifieke periode laat voor de marktpartijen de onzekerheid nà die periode onverlet. Beslissingen, die binnen de periode worden genomen hebben echter veelal ook consequenties voor de daarop volgende jaren. Het probleem van het bestaan van een planhorizon wordt des te knellender, als men bedlenkt, dat de consumenten en producenten met eigen horizonten werken, die veelal afwijken van die van het nationale plan. De onmogelijkheid de indicatieve planning in werkelijkheid te beperken tot een bepaalde periode tussen Now en Kingdom Come, laat noodzakelijkerwijs een deel van de onzekerheid van de marktpartijen voortbestaan. Ook een zogenaamd rollend plan lost het vraagstuk van de planningshorizon niet principieel op.

\section{"Onbepaalde situaties"}

In het algemene model van indicatieve planning komen voor alle goederen en diensten evenwichtsprijzen tot stand. In werkelijkheid zal met aggregaten gewerkt moeten worden en zall informatieverzameling op microniveau plaats moeten maken voor het afstemmen van toekomstplannen op het mesoniveau van de sector. In werkelijkheid kunnen niet alle micro-actoren worden geconsulteerd en zal contact bestaan met vertegenwoordigers bijv. met de brancheorganisatie. De informatie in het plan heeft dan geen directe verbinding meer met de beslissingen op microniveau, hetgeen het richtinggevende karakter van de indicaties aanzienlijk zal beperken. Van diverse zijden [18] is erop gewezen, dat het verschaffen van informatie op mesoniveau juist voor het microniweau grote problemen kan opleveren. Stel, dat een vraagstijging in de staalsector van $5 \%$ per jaar wordt geprojecteerd, dan is daaruit voor de actor op microniveau geen beslissing met betrekking tot produktie en investeringen af te leiden. Als de marktaandelen gelijk zijn en iedereen produceert tegen dezelfde kosten, dan zou ieder zijn produktie met $5 \%$ kunnen uitbreiden. Het is waarschijnlijker, dat produktie- 
capaciteiten verschillen, informatie en kennis ongelijk verdeeld zijn en de ene onderneming van een nieuwere technologie gebruik maakt dan de andere. De individuele onderneming zou ervan kunnen uitgaan, dat zijn concurrenten de extra $5 \%$ voor hun rekening nemen en besluiten zelf niet tot produktieuitbreiding over te gaan. Hij kan ook menen door snel te handelen de gehele vraagstijging naar zich toe te trekken en zijn produktiecapaciteit derhalve sterk uitbreiden. Het verschaffen van informatie op mesoniveau leidt niet tot eenduidige beslissingen op microniveau. Integendeel: er ontstaat een "onbepaalde situatie", die kan resulteren in over- of ondercapaciteit. Onbepaalde situaties kunnen worden weggenomen doordat de marktpartijen afspraken maken over marktverdeling, produktie en investeringen, of door regulering van bovenaf. In beidle gevallen komt de indicatieve planning als 'perfekt compromis' van de markteconomie en van de centraal geleide economie op de tocht te staan.

\section{Beperkt aantal omgevingspaden}

In het model van indicatieve planning gaat Meade ervan uit, dat de actoren hun plannen kenbaar maken bij elk denkbaar omgevingspad. Het aantal mogelijke combinaties zal de rekencapaciteit van de actoren snel te boven gaan. In werkelijkheid bestaan geen actoren met een onbeperkte rationaliteit, die op $t_{0}$ voor alle mogelijke omgevingspaden kunnen aangeven wat hun maximaliserend gedrag zal zijn. In werkelijkheid is sprake van 'bounded rationality" [19]. Bovendien zijn aan het informatieuitwisselingsproces kosten verbonden, die noodzaken tot het voorleggen van slechts één of enkele van de meest waarschijnlijke omgevingspaden. Daaraan zijn volgens de critici van de indicatieve planning grote gevaren verbonden, die duidelijk zijn verwoord door vertegenwoordigers van de Oostenrijkse school. In de gedachtengang van de Neo-oostenrikers beschikt elk van de marktpartijen over specifieke kennis met betrekking tot produktietechnieken, marktvraag, gedrag van concurrenten en dergelijke. Deze informatie is ongelijk over de marktpartijen verdeeld. Zij hebben uiteenlopende verwachtingen en maken verschillende toekomstplannen. Wordt nu door een centrale instantie gepoogd informatie te verzamelen over verwachtingen met betrekking tot het omgevingspad en over de daarbij behorende plannen, dan heeft de centralle te maken met subjectieve waarschijnlijkheden. Het probleem van het meten van de subjectieve waarschijnlijkheden, waarmee de diverse actoren hun visies geven, is moeilijk oplosbaar. Op een of andere manier zou dan namelijk rekening moeten worden gehouden met het feit, dat de ene aćtor een beter oordeel heeft over de toekomst dan de andere. Wordt van een ongewogen oordeel uitgegaan, dan zullen degenen, die zelf winden dat zij een beter oordeel hebben, zich niet naar de planprognosen richten. Wordt, a la Massé, gepoogd het planningsproces te laten uitmonden in "a common view about the future", dan impliceert het welslagen van zo'n poging, dat sprake is van een zogenaamde 'perfekte mobiliteit van de ondernemersfaktor". Daarmee wordt bedoeld, dat alle ondernemers een identieke toekomstverwachting hebben en voor zichzelf geen voordelen ten opzichte van de concurrenten zien weggelegd (Lutz 1969). Als zich in werkelijkheid een ander omgevingspad zou voltrekken, dan blijken alle marktpartijen verkeerde plannen te hebben ontwikkeld. Het gevaar bestaat, dat bij een poging een integraal coherent plan op te stellen "alle eieren in het verkeerde mandje komen te liggen". 


\section{Diverse marktvormen}

In werkelijkheid handelen marktpartijen veelal niet op markten wan 'pure and perfect competition", maar is sprake van met name oligopololde marktyormen. Voor de centra* le ontstaan in een stelsel van indicatieve planning grote problemen als sprake is van "imperfekte" markten. Zo zal in geval van een monopolie het planbureau door marktonderzoek de vraagcurve van de monopolist moeten achterhalen. In het informatieproces moet de monopolist aan de centrale de prijs en hoeveelheidscombinaties doorgeven, waarbij hij zijn winst maximaliseert. Hoe betrouwbaar is de door het planbureau geschatte vraagcurve? Als de monopolist van een andere curve uitgaat, zijn de antwoorden op de vragen van het centrale planbureau van weinig waarde. Overleg tussen planbureau en monopolist over de meest waarschijnlijke vraagcurve is dan noodzakelijk. Zo'n overleg is in een monopoloïde situatie misschien nog denkbaar. Geheel anders ligt de zaak in geval van een oligopolie. De essentie van een oligopolie is gelegen in de interdependentie van het gedrag van de marktpartijen. Het is dan niet meer voldoende elke oligopolist de vraag voor te leggen wat zal worden aangeboden bij diverse prijzen en omgevingspaden. Een veronderstelling ten aanzien van het gedrag van de andere oligopolisten zal daaraan moeten worden toegevoegd. In een oligopolie kan elke actor bij elke informatieronde in principe al zijn actieparameters veranderen. Zou het planbureau de vraag naar de toekomstplannen voorleggen onder een reeks van veronderstellingen met betrekking tot de actieparameters van de andere oligopolisten, dan zou daarmee het wezen van het oligopolie teniet worden gedaan. Wellicht zullen de actoren bereid zijn hun plannen bekend te maken bij een specifieke constellatie van de actieparameters van de andere oligopolisten, maar dan dienen zij er zeker van te zijn dat die zich ook daadwerkelijk zo zullen gedragen. Zo'n afstemming van gedrag kan echter alleen in een kartel zijn beslag krijgen [20].

Wij constateren, dat bij het invullen van de algemene theorie van Meade met specifieke condities van plaats en tijd, het indicatieve plan steeds een deel van de onzekerheid van de marktpartijen niet kan wegnemen. Het laten vallen van de veronderstellingen met betrekking tot de onveranderlijkheid van de bevolkingssamenstelling en de onbeperktheid van het aantal omgevingspaden, ontnam het indicatieve plan de mogelijkheid a la het model van Meade de marktomgevingsonzekerheid volledig weg te nemen. Op zich is dat nog geen kwalijke zaak. Integendeel: als het plan extra informatie zou verschaffen over mogelijke omgevingspaden, dan zou een bijdrage aan een efficiënte allokatie kunnen worden geleverd. Echter, de noodzaak tot aggregatie van het informatieproces en het verschaffen van indicaties op mesoniveau tezamen met het bestaan van marktimperfekties, leiden tot grote problemen voor de indicatieve planning. Problemen, die alleen kunnen worden opgellost via beheersing van de markt door middel van een kartel of door middel van centrale overheidsplanning. Het zijn vooral de critici van de Neo-oostenrijkse school geweest, die erop hebben gewezen, dat een indicatief plan in de vorm van een ex ante integraal coherent plan, een poging is tot combinatie van twee onverenigbare elementen uit de markteconomie en het centraal geleide stelsel. De combinatie van centrale informatie (mesoniveau) en decentrale beslissingen leidt tot onbepaalde situaties voor het microniveau, die alleen zijn op te lossen door marktregulering. 
Het blijkt mogelijk op algemeen theoretische niveau een theorie van een integraal coherent plan te ontwikkelen. Informatie wordt dan direkt op microniveau vergaard en teruggekoppeld, zodat informatie in het plan leidt tot éenduidize beslissingen op microniveau. Worden de algemene theoretische concepten specifieker ingevuld, dan blijken voor het microniveau 'onbepaalde situaties' te kunnen ontstaan, waardoor het plan geen richtsnoer voor het handelen meer biedt. Bovendien bergt het streven naar een gemeenschappelijke visie op de ontwikkeling van de omgevingswariabelen het gevaar in zich, dat de gehele economie op het verkeerde been wordt gezet. Een ex ante integraal coherent plan, zoals Massé dat aanvankelijk voor ogen stond is terecht door de Neo-oostenrijkers bekritiseerd [21].

\subsubsection{Geaggregeerde indicatieve planning; Massé en Harrod}

\section{Veranderende ideeèn wan Pierre Massé}

Op het eerste gezicht bestaat tussen de nieuwe ideeën van Massé van het begin wan de jaren zestig en de eerder besproken integrale coherente indicatieve planning geen groot verschil. De terminologie van Massé bleef nagenoeg gelijk. Zo merkte Massé (1965b, 265) over het consultatieproces op:

"The Plan is worked out through a concerted effort by representatives of economic and social forces: civil servants, management (agricultural, industrial, commercial), trade unions and workers. This collaboration makes for more coherent forecasting and decisions, and it creates a feeling of togetherness which is favourable for the implementation of the Plan".

Nadere analyse leert (vergelijk Lutz 1969), dat veranderde omstandigheden Massé hebben doen afstappen van het integrale coherente indicatieve plan op mesoniveau en hebben gebracht tot de opvatting de consultatie in de sectorcommissies te laten uitmonden in een plan met indicaties op macroniveau. Wat de veranderde omstandigheden betreft wijst Massé (1965b, 48) op de toegenomen onzekerheid voor de planners als gevolg van het grotere discretionaire inkomen van de consumenten, de toegenomen complexiteit van de economische structuur en de grotere openheid van de economie, waardoor het instrumentarium van de overheid om de sectordoeleinden langs indicatieve weg te realiseren aanzienlijk wordt beperkt. Flexibiliteit en aan-

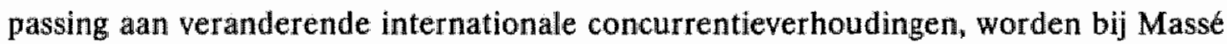
het devies in plaats van het ex ante opstellen van een consistent plan op mesoniveau. In het begin van de jaren zestig wordt in Frankrijk een intensieve discussie gevoerd over de 'flexibele' planning, waarin Blloch Lainée (1959) zich tegenover Massé opstelt. Bloch-Lainée stond een vorm van democratische planning voor, waarbij de sociaalleconomische doeleinden zouden moeten worden gerealiseerd door middel van een netwerk van contracten tussen de overheid en de ondernemingen. Met betrekking tot de ondernemingen, die zich contractueel binden tot planconform gedrag moest de overheid bereid zijn tot ondersteunende matregelen. Massé was daarentegen van mening, dat zo'n netwerk van contracten een te strak keurslijf zou worden; de ondernemingen moesten alert en flexibel op veranderingen kunnen reageren en alleen macroindicaties via het Plan als richtsnoer voor hun handelen meekrijgen. 
Harrod (1973) formaliseert de gedachte van Massé, waaraan Estrin en Holmes (1983a) de naam 'aggregative indicative planning' verlenen. Een naamgeving, die ons inziens niet duidt op het niveau waarop het planningsproces zich afspeelt, maar duidt op het niveau waarop de plandoeleinden worden geformuleerd. Harrod verbindt de gedachten van Massé met zijn Keynesiaanse groeitheorie voor een gesloten economie. Het indicatieve plan is bij Harrod een instrument ter beïnloeding van de verwachtingen. De economische groei kan daardoor een stabieler verloop krijgen en zich bewegen op het potentiële groeiniveau van de desbetreffende economie.

De theorie van Harrod is van Keynesiaanse snit: de economische groei wordt bepaald door de investeringen, die op hun beurt afhankelijk zijn van de verwachtingen van de ondernemers. In het indicatieve plan kan een consistent beeld worden geschetst van de toekomstige ontwikkeling op macroniveau conform de potenties van de economie. Zo'n indicatief plan kan de onzekerheid van de marktpartijen verminderen, waardoor een investeringsvriendelijk klimaat ontstaat, waarin grotere risico's ten aanzien van investeringen in technologische vernieuwingen genomen kunnen worden.

De algemene theorie wan de economische dynamiek, die aan de geaggregeerde indicatieve planning ten grondslag ligt, wordt door Harrod (1973, hoofdstuk 2) in drie vergelijkingen samengevat:

(1) $\mathrm{G}_{\mathrm{a}}=\frac{\mathrm{s}}{\mathrm{C}}$

$\mathrm{G}_{\mathrm{a}}$ is de groeivoet per tijdseenheid van het nationaal inkomen $(\Delta \mathrm{Y} / \mathrm{Y})$;

$s$ is het deel van het inkomen, dat wordt gespaard;

$C$ is de groei van het kapitaal per dezelfde tijdseenheid gedeeld door de groei van de produktie in die tijd (capital-output ratio).

De feitelijke groei $\left(G_{a}\right)$ is afhankelijk van de gerealiseerde investeringen, die per definitie gelijk zijn aan de gerealiseerde besparingen. Vergelijking (1) is een definitievergelijking.

(2) $\mathrm{G}_{\mathrm{w}}=\frac{\mathrm{s}_{\mathrm{d}}}{\mathrm{C}_{\mathrm{r}}}$

$\mathrm{G}_{w}$ is de "warranted' of gewenste groeivoet: die groei, waarbij de door de economische actoren gewenste besparingen worden gerealiseerd en de wensen van de producenten met betrekking tot de groei van kapitaalgoederen ook uitkomen:

"(.....) the growth rate of the economy, which is consistent with people saving that they want to save and having the capital goods that they require for their purposes" (Harrod 1973,19).

(3) $G=\frac{s_{\sigma}}{C_{r}}$

$G_{n}$ is de natuurlijke groeivoet, $n l$. die groei van het nationaal inkomen, waarbij de beroepsbevolking volledig wordt ingezet en de 
technologische ontwikkelingen in de produktie van de goederen en diensten wordt toegepast. $G_{n}$ is op te vatten als de groei conform de potentie van de economie. De $\mathrm{s}_{\sigma}$ is dat deel van het nationaal inkomen, dat moet worden gespaard om de economie volgens de potenties te laten groeien.

De 'warranted' en de 'natural' groeivoet zijn beide normatief van aard, zij kunnen afwijken van elkaar en wan de feitelijke groeivoet.

Als het verschil tussen de feitelijke en de gewenste groeivoet groot is, kan het zogenaamde instabiliteitsprincipe in werking treden. Stel dat de $G_{a}>G_{w}$, omdat de $s>s_{d}$ of $\mathrm{C}<\mathrm{C}_{\mathrm{r}}$, of beide omstandigheden zich voordoen. Als de feitelijke besparingen groter zijn dan de gewenste, kan die omstandigheid zich voordoen bij de huishoudens, of bij de ondernemingen. In het eerste geval zullen de huishoudens meer hebben gespaard dan zij wensten en derhalve een groter deel van hun inkomen gaan uitgeven aan consumptieve bestedingen, waardoor de feitelijke groei zich verder verwijdert van de 'gewenste'. Als de besparingen bij de ondernemingen groter uitvallen dan gewenst, zullen zij of meer dividend uitkeren of meer orders plaatsen. In beide gevallen verwijdert de $G_{a}$ zich verder van de $G_{w}$.

Doet zich de omstandigheid voor dat $\mathrm{C}<\mathrm{C}_{\mathrm{r}}$, dan zullen de ondernemingen meer orders plaatsen om de kapitaalgoederenvoorraad in overeenstemming te brengen met het niveau dat bij hun plannen past.

Uit het bovenstaande blijkt, dat het prijsmechanisme volgens Harrod niet aan de economische actoren die informatie doorgeeft, welke leidt tot het convergeren van de feitelijke en de 'gewenste' groei. Integendeel: de geconstateerde afwijkingen tussen s en $\mathrm{s}_{\mathrm{d}}$ en $\mathrm{C}$ en $\mathrm{C}_{\mathrm{r}}$ worden geïnterpreteerd als een tekortschietende vraag in plaats van te hoog gestelde verwachtingen.

"The market thus seems to give a perverse signal to the investor, and this is the source of Harrod's problem" (Sen 1970, 12; zie ook Black 1968, 307).

Harrod besteedt veel aandacht aan het vraagstuk welke fiscale en monetaire instrumenten kunnen worden ingezet om de drie groeivoeten nader tot elkaar te brengen. Nauwkeurige invulling van de algemene concepten met specifieke condities wan plaats en tijd is dan noodzakelijk.

Het is wolgens Harrod onjuist te denken, dat de problemen van onevenwichtige groei alleen met monetaire instrumenten kunnen worden opgelost. Het gevaar is groot dat een 'demand pull'-inflatie ontstaat als niet tegelijkertijd de aanbodzijde van de economie wordt geprikkeld zich tijdig aan de veranderende vraag aan te passen. Indicatieve planning is een belangrijk complementair instrument, waarmee het gevaar van een 'demand pull'-inflatie kan worden bezworen. Het indicatieve plan kan namelijk volgens Harrod het gedrag aan de aanbodzijde van de economie zodanig beïnvloeden dat geen discrepantie ten opzichte van de vraag ontstaat. Het planbureau berekent daartoe de potentiěle groei voor bijvoorbeeld de komende vijf jaar. In het indicatieve plan wordt deze groei vertaald naar sectoren. Uit consultatie met branche-organisaties en ondernemingen moet duideiijk worden welke groei in de diverse sectoren mogelijk is. $\mathrm{Na}$ diverse consultatieronden wordt een realiseerbaar indicatief plan opgesteld. 
"The objective is that this final plan shall seem, within limits, more or less feasible to the various sectors, and that they will act upon it" (Harrod, 1973).

De marktpartijen moeten zich op basis van het plan een idee kunnen vormen met betrekking tot de marktvraag.

Publikatie van de $G_{n}$ en bijbehorende $G_{w}$, moet ertoe leiden, dat die groeivoeten in het verwachtingspatroon van marktpartijen worden overgenomen.

Indicatieve planning is zo gezien een instrument om te voorkomen, dat de economie zich ontwikkelt beneden haar potenties.

"Indicative planning is intended to help achieve a path of economic griowth which is as smooth, stable, and rapid as is consistent with the growth of the natural resources available to the economy, improvements in technology, and the savings attainable at full employment" (Black 1968, 305).

Het aangrijpingspunt voor het indicatieve plan vormen de verwachtingen van de ondernemers. De ondernemers moeten hun eigen verwachtingen vervangen door die van het plan. Langs die weg kan de verwachte groeivoet, op basis waarvan de ondernemers investeringsbeslissingen nemen, in overeenstemming worden gebracht met de gewenste groeivoet. Daardoor kunnen onevenwichtigheden in de groei worden verminderd. Onzekerheid en risico voor de marktpartijen worden verminderd

"'..... "raising the return to the savers and reducing the required returns for investors" (Estrin en Holmes 1983a, 20).

Het plan vormt ook het kader voor het afstemmen van de $G_{n}$ en de $G_{w}$. De overheid kan in een aantal gevallen de produktiviteitsgroei als gevolg van een technologische ontwikkeling beter voorzien dan individuele marktpartijen (stijging $G_{n}$ ) en pogen door middel van beïnvloeding van de verwachtingen van de marktpartijen $G_{W}$ daarmee in overeenstemming brengen.

\section{Kritilek}

Soortgelijke kritiek van Neo-oostenrijkse snit, zoals wij bij Meade hebben besproken, is ook op Harrod mogelijk: als het indicatieve plan éen variant voorschotelt kan een plan alleen in geval van afwezigheid van omgevingsonzekerheden dienst doen. Echter, in geval van omgevingsonzekerheid kan het planbureau de natuurlijke groei niet meer met zekerheid berekenen. Het gevaar bestaat, dat in geval van een onjuiste schatting van bijvoorbeeld de technologische ontwikkeling, door alle marktpartijen onjuiste beslissingen worden genomen. Het hangt van het vertrouwen in het plan af, of veel actoren zich ernaar richten en in welke mate de gevolgen dus desastreus kunnen zijn [22].

Een tweede vorm van kritiek betreft het ontbreken van een microeconomische basis in de planningsprocedure. Sectoraal kunnen wraag en aanbod op elkaar zijn afgestemd, maar voor de ondernemer op micro-niveau kan van een tekort of een overschot sprake zijn. Op het geaggregeerde niveau kan het plan coherent zijn en zou het endogene instrument van de "zelf-realisatie" kunnen werken. Echter,

"Even though the plans appear to selfjustifying in an aggregate sense, expectations would be unrealized in particular sectors, leading to excessive 
profits for certain producers and losses for others. The fact that, in some sense, expectations in the aggregate will be realized cannot be generalized to the expectidions of particular producers about their specific markets" (Estrin en Holmes 1983a, 22).

Een derde vorm van kritiek betreft de geslotenheid van de economie in het model van Harrod. In een open economie kunnen binnenlandse onevenwichtigheden worden gecompenseerd door importen of exporten. Onevenwichtigheden op de betalingsbalans kunnen dan een zorgerikind worden. Verlaten wij het model van de gesloten economie, dan zullen de planners de concurrentieverhoudingen met het buitenland in hun projecties moeten verwerken. In een open economie neemt de onzekerheid voor de planners toe en de vraag dringt zich op of indicatieve planning onder zulke omstandigheden nog wel mogelijk is.

\subsubsection{Indicatieve planning in een complexe, open markteconomie; de visise van} Estrin en Holmes

\section{Het Plan als informatiebron}

Duidelijk is, dat een indicatief plan in de vorm van een integraal coherent plan met indicaties op sectorniveau in een open en complexe economie noch mogelijk, noch functioneel is.

Weliswaar is de geaggregeerde planning van Harrod tot op zekere hoogte een antwoord op de toegenomen complexiteit van de economie, maar ook deze vorm van indicatieve planning wordt voor een open economie minder adequaat geacht.

\footnotetext{
"The problems become more complex in an open economy, since an accurate forecast of domestic variables no longer necessarily implies that the proportions of the economy as a whole will be in balance. Moreover, the imbalance between demand and supply at the micro-economic level and differences between ruling domestic and world prices could lead to the purchase of certain goods abroad, so that the structural problems will be manifested in a balance of payments disequilibrium. This is another aspect of the argument that, if world markets are exogeneous to the domestic economy, aggregate indicative planning may have no impact or worsen the allocation of resources when there is environmental uncertainty" (Estrin en Holmes 1983a, 22).
}

Uit de kritiek op de theorieesn van indicatieve planning wordt duidelijk, dat in een moderne markteconomie het indicatieve plan altijd 'beperkt' zal moeten zijn. Markteconomieẻn worden gekenmerkt door actoren, die door middel van organisatorische arrangementen pogen het marktproces te beheersen. De actoren hebben te maken met een complexe, onzekere omgeving, waarin de informatie ongelijk is verdeeld, partijen zich opportunistisch gedragen en waarin veellal sprake is van oligopoloïde marktstructuren. Kan een indicatief plan in zo'n wereld een bijdrage leveren aan de afstemming van de plannen op microniveau? Een sceptische houding kan worden aangetroffen bij de aanhangers van de theorie van de rationele verwachtingen [23] en de Neo-oostenrijkers. Zij wijzen op het feit, dat de marktpartijen leren van hun ervaringen en zich op den duur een gedrag eigen maken, dat kan leiden tot evenwichtige situaties [24]. De marktpartijen beschikken zelf over de beste informatie; voor complle- 
mentaire informatie via een indicatief plan is geen plaats. Bij deze opvatting kunnen twee kanttekeningen worden geplaatst.

- Dat marktpartijen van hun fouten kunnen leren kan juist zijn. Echter, de ervaringsfeiten zijn alleen relevant voor hun gedrag als de omgevingsvariabelen zich langs stabiele lijnen ontwikkelen. Anders hebben de lessen uit het verleden weinig waarde voor de toekomst.

- Informatie is niet kosteloos; informatie is een economisch goed, dat in veel gevallen schaalvoordelen kent, waardoor de produktie in gespecialiseerde partikuliere ondernemingen ter hand kan worden genomen (de schaalvoordelen betreffen bijvoorbeeld de ontwikkeling van econometrische modellen en het verzamellen van data). Echter, zoals uiteengezet (zie 2.2.2) wordt informatie door de markt 'ondergeproduceerd', hetgeen verband houdt met de specifieke eigenschappen van het goed 'informatie'. Informatie geproduceerd door een externe organisatie en gepubliceerd in een indicatief plan zou dat 'gat' kunnen vullen.

Welke informatie is relevant voor de beslissingen op microniveau en wordt niet geproduceerd door de actoren zelf, noch door de aanbieders op de informatiemarkt en evenmin door de institutionele structuur?

"The planners should forecast variables that agents have a limited capacity to project for themselves, that are closely correlated in a known way with factors influencing private decisions, and for which economies of scale in data processing and information can be achieved" (Estrin en Holmes 1983a, 66). [25]

Het gaat om projecties van macrovariabelen, zoals de groei van het BNP, de consumptieve bestedingen, de exporten en dergelijke. Voor de individuele ondernemers bevatten dergelijke indicatoren belangrijke aanwijzingen woor te verwachten ontwikkelingen in de eigen sector. Welke informatie van belang is, hangt in hoge mate af van de structuur van de desbetreffende economie. Is sprake van een hechte industriële structuur met binnenlandse sectoren, die een trekpaardfunctie vervullen welke veel intermediaire goederen afnemen van andere binnenlandse sectoren, dan kan informatie over de verwachte ontwikkeling van die "trekpaarden" zeer nuttig zijn. In het indicatieve plan zou de economische structuur van een land zodanig in kaart kunnen worden gebracht, dat clusters van economische activiteiten zichtbaar worden. Informatije over eéeén element van de cluster is dan van belang voor de andere elementen. Een externe institutie verkeert veelal in een gunstige positie interdependenties te signaleren, waartoe individuele marktpartijen minder goed in staat zijn. In dat verband wordt wel een vergelijking getrokken tussen het indicatieve plan en de publikaties van de OECD. De OECD beschilkt over modellen, die de interdependenties tussen de industrielanden in acht nemen. Daardoor kan zij informatie produceren die kwalitatief verschilt van de informatie die beschikbaar komt bij pure aggregatie van de nationale modellen. Door haar 'bird eye's view' kan de OECD wijzen op te verwachten onevenwichtigheden, op grond waarvan de nationale regeringen hun beleid kunnen bijstellen. Op nationale schaal kan het indicatieve plan in een moderne markteconomie een soortgelijke functie vervullen. De externe organisatie kan op basis van het overheidsbeleid, de plannen van de grote ondernemingen, de ontwikkelingen in het buitenland 
en dergelijke, mogelijke toekomstige onevenwichtigheden voor de marktpartijen zichtbaar maken.

Samengevat:

"Plans would not supply detailed information about every good in every conceivable circumstance, but concentrate on leading indicators. These would be largely macroeconomic variables, but governments' and firms' imprecise information about the future would also be pooled over particular markets to highlight expectational inconsistencies and broaden opportunity sets"' (Estrin en Holmes 1983a, 54) [26].

Het zou overigens een misvatting zijn de informatieproblematiek alleen te beschouwen in termen van informatiescharste. $\mathrm{Er}$ is ook sprake wan een informatie-'overload', waaruit de marktpartijen de voor hen relevante elementen moeten selecteren. Instituties, die de verwachtingen met betrekking tot het gedrag stabiliseren en routines en conventies tot stand brengen, zijn voor de actoren onmisbaar bij het hanteren van de grote hoeveelheden informatie.

In de drie hierboven besproken theorieën van Meade, Harrod en Estrin en Holmes is de essentie van het indicatieve plan gelegen in de produktie en verspreiding van informatie door middel van een breed opgezet intensief consultatieproces met alle belanghebbenden. Ter afsluiting van dit hoofdstuk bespreken wij de wijze, waarop ideaaltypisch zo'n consultatieproces vorm zou kunnen worden gegeven.

"Door de middellange termijnplanning kan enerzijds verwezenlijkt worden, dat ook op de kortere termijn de grote beslissingen niet overgelaten worden aan een onpersoonlijk marktmechanisme, maar het resultaat zijn van de democratische besluitvorming. Anderzijds kan de gehele economie op een meer consistente wijze gericht worden op de doelstellingen zoals een natie die wil realiseren: economische groei, maar niet ten koste van waarden als een schone gezonde omgeving en een aanvaardbare inkomens- en vermogensverdeling. Langs deze weg is onze 'consumptiemaatschappij" om te vormen tot een 'gedemocratiseerde planeconomie"' (Albeda (1971, 108).

In een gedemocratiseerde planeconomie zijn de doeleinden van het indicatieve plan het resultaat van een intensief consultatieproces, waarbij alle belanghebbenden zijn betrokken. Consultatie dient voor het centrale Planbureau de informatie te leveren op basis waarvan de doeleinden kunnen worden geformuleerd. Zo kan een consultatieproces inzicht verschaffen in de strategieën van ondernemingen, in de eisen van de vakbonden, in mogelijke knelpunten op sectoraal- en regionaal niveau. Tevens kan de consultatie leiden tot de noodzakelijke legitimatie van het plan: de belangengroepen kunmen zich door hun betrokkenheid identificeren met de doeleinden van het plan, waardoor zij mogelijk eerder bereid zijn aan de uitvoering medewerking te verlenen. Zulks is vooral van belang als ingrijpende herstructureringen van de industrielle structuur worden beoogd.

Om het consultatieproces wettelijk inhoud te geven en tevens af te bakenen ten opzichte van de verantwoordelijkheden van het parlement, stellen Albeda en Vos (1977b) een 'grondwet op de overlegstructuur' voor.

"In deze grondwet zouden regels ter versterking van de democratische besluitvorming tussen en binnen pressiegroepen kunnen worden opgenomen en 
voorts een opsomming van de belangen die aan meer gelkwalificeerde besluitvorming van de parlementaire democratie moeten worden overgelaten. Bij dit laatste kan men onder andere denken aan de besluitworming over de doelstellingen van het zogenaamde facettenbeleid en over de doelstellingen van de indicatieve planning".

In het centrale indicatieve plan wordt het overheidsbeleid voor de komende jaren geschetst. Indicaties met betrekking tot het macrobeleid, industriebeleid, regionaal en sociaal beleid worden in het plan opgenomen. In bijlagen kumnen ter informatie de resultaten van onderzoekingen op specifieke deelterreinen worden opgenomen (technologische ontwikkelingen, concurrentiepositie, sectorstudies).

"Een dergelijk plan vormt dan bij uitstek het kader voor een 'georiênteerde markteconomie'. Het laat de gedecentraliseerde besluitworming intakt, maar het geeft wel indicatief de randvoorwaarden aan, waarbinnen de bedrijfsgenoten hun beslissingen moeten nemen en hun verantwoordelijkheid kumnen waarmaken. Wel lijkt het van groot belang de maatschappelijke belangengroeperingen inspraak te verlenen ten aanzien van de uitgangspunten woor een dergelijk centraal economisch plan" (Fernhout 1980, 207).

Fernhout stelt voor in het kader van het indicatieve plan ook zogenaamde bedrijfstakplannen te ontwikkelen door raden, waarin de sociale partners zitting hebben. Bij wet dient nauwkeurig geregeld te worden welke elementen in die bedrijfstakplannen opgenomen moeten worden en hoe de informatievoorziening gegarandeerd moet worden. Dat laatste heeft vooral betrekking op informatie over strategische ondernemingsbeslissingen, die uit concurrentieoverwegingen geheim dienen te blijwen.

De doeleinden van de bedrijfstakplannen zouden door middel van overeenkomsten kunnen worden gerealiseerd.

"De overeenkomst is bij uitstek het instrument om tegengestelde belangen zo niet tot verzoening dan toch in ieder geval tot consensus te brengen".

Essentieel in dat verband is de autonomie van de marktpartijen; overeenkomsten in het kader van een indicatief plan dienen altijd het resultaat te zijn van vrije onderhandelingen, anders komt de marktconformiteit van het instrumentarium in gevaar. De idee van een wettelijk kader van sectorplannen en overeenkomsten tussen overheid en belangengroepen en ondernemingen, speelde een belangrijke rol bij de vorm* geving van het 9de Franse Plan en van de relatie tussen de overheid, i.c. het 'Ministère de 'Industrie', en de genationaliseerde industriële groepen.

Gewapend met de theoretische inzichten van Meade, Harrod en van Estrin en Holmes, alsmede met de ideeên over democratische besluitvorming, consultatie en de rol van de 'overeenkomst', zal in hoofdstuk vijf de Franse empirie van de na-oorlogse indicatieve planning worden geanalyseerd, waarbij specifieke aandacht zal worden besteed aan het Negende Plan (1984-1988). 


\section{Noten behorend bij hoofdstuk 2}

[1] Eén van de belangrijkste voormannen van de Neo-oostenrijkse School is Kirzner. Zie Hodgson (1988a) voor een kritische karakterisering.

[2] Van der Zwan (1982) spreekt van markt- en technische condities.

[3] Hodgson (1988a, xviii) karakteriseert de neoklassieke theorie aan de hand van rationele, maximaliserende agenten, de afwezigheid van informatievraagstukken en een theoretische focus op de tendens naar evenwicht.

[4] Het modell van voorwaardelijke toekomstmarkten wordt o.a. uiteengezet in Hahn (1980).

[5] In het centrale leerstuk van de neoklassieke theorie, het model van volledig vrije mededinging zonder toekomstmarkten, wordt verondersteld, dat de prijzen die informatie overdragen. Volgens Van der Zwan (1982), die zich baseert op Richardson (1960), leidt die veronderstelling in het prijsconcurrentiemodel tot een "conceptuele ongerijmdheid". Prijzen zijn volgens Van der Zwan in het prijsconcurrentiemodel 'momentaan' en reflecteren alleen bestaande schaarsteverhoudingen. Voor het nemen van beslissingen, die in toekomstige evenwichten moeten resulteren, behoeven de actoren informatie over toekomstige schaarsteverhoudingen.

[6] Transactiekosten kunnen worden opgevat als de kosten verbonden aan het gebruik van een specifiek coördinatiemechanisme, bijv. de kosten van informatie, wan thet controleren van contracten en dergelijke. De hoogte van de transactiekosten is medebepalend voor de soort van coördinatiemechanisme, dat de actoren kiezen. Voor een uitgebreide bespreking van het begrip transactiekosten zie paragraaf 3.1.1.3.

[7] Voor een uiteenzetting over de kosten van toekomstmarkten: zie Van der Weijden (1988, 24-31).

[8] Voor een overzicht van de 'Economics of Information' zie o.a. Hirschleifer (1973).

[9] In 3.1 zal het belang van netwerken voor het opbouwen van vertrouwensrelaties worden besproken.

[10] Zie Demsetz (1967), Alchian en Demsetz (1972) en Furubotn en Pejovich (1974). In de kern van de zaak "a primary function of property rights is that of guiding incentives to achieve a greater internalization of externalities" (Demsetz 1967,348 ).

[11] De "nieuw institutionele economie" wordt uitgebreider besproken in 3.1.1.3, alwaar de verklaring van de ondernemingsstrategie met betrekking tot de organisatie van de markt aan de orde komt. De NIE is een recente stroming in de economische theorie, waarin het neoklassieke methodologische individualisme wordt toegepast op de verklaring van de ontwikkeling van instituties en organisaties. Belangrijke terreinen van onderzoek zijn de economische geschiedenis, public choice, economie van de regulering, industriële organisatie en de contracteconomie. De resultaten van het onderzoek van de NIE kunnen met name in de Journal of Institutional and Theoretical Economics (JITE) en de Journal of Economic Behavior and Organization worden aangetroffen.

[12] Het belang van instituties als informatiedragers voor de stabilisatie van de verwachtingen van de actoren wordt duidelijk uiteengezet in Hodgson (1988a, hoofdstuk 8). 
[13] Vergelijk Goudzwaard (1970) over de noodzaak de wisselwerking tussen endogene variabelen en de "datakrans" in de analyse te betrekken.

[14] Kritiek op de nieuw institutionele economie wordt besproken in 3.1 (vergelijk Hodgson $1988 \mathrm{a}$, deel II en III).

[15] In de Franse literatuur wordt het begrip 'planning' in een zeer ruime betekenis gebruikt. Ook als in het Plan alleen sprake is van informatieuitwisseling van de plannen van de actoren, waaruit onbewust een coherent plan voort kan komen (zie het begrip 'pure indicatieve plan'op blz. 28) wordt van 'planning' gesproken. Ook als die (onbewuste) afstemming van de plannen geen onderdeel van het Plan meer kan uitmaken, maar 'slechts' macro- en sectorinformatie kan worden verstrekt (vergelijk 2.3.3) wordt nog steeds van indicatieve "planning" gesproken, terwijl eigenlijk slechts sprake is wan informatieverstrekking als collectief goed. Dit gebruik van het begrip 'planning" is niet conform veel gangbare definities (vergelijk Kreukels 1980; Schreuder 1985; Dekker 1989), waarin veelal sprake is van een bewuste afstemming van gedrag op doeleinden. Voor de behandeling van het algemene vraagstuk betreffende de mogelijkheden van sturing van maatschappelijke ontwikkelingen verwijzen wij naar Popper (1973) en de discussies daaromtrent weergegeven in o.a. Dekker (1989).

[16] 'Moral hazard' en 'adverse selection' zijn begrippen uit de literatuur over de verzekeringsmarkt. Als een individu zich heeft verzekerd vermindert de prikkel zich zorgvuldig te gedragen, of sterker: verzekering kan aanleiding geven tot gedrag, dat juist de schade veroorzaakt ('moral hazard': brandverzekering kan brandstichting uitlokken).

De verzekeraar zou risicogroepen een hogere premie willen laten betalen dan de groepen, die een lager risico vormen. Door een ongelijke informatieverdeling dient de verzekeraar veelal af te gaan op informatie wan de verzekerde zelf en aangezien de mogelijkheid van opportunistisch gedrag bestaat, zall de verzekeraar zich kosten moeten getroosten de verstrekte informatie op juistheid te controleren. Als die kosten hoog oplopen zal voor een gelijke premie voor iedereen worden gekozen, hetgeen de groepen met een lager risico kan doen besluiten uit de markt te stappen, waardoor de verzekeraar met de risicogroepen blijft zitten ('adwerse selection').

[17] "Econometric forecasting involves both estimating indirectly the formation of expectations and their effect on behaviour and also altering the way in which expectations are formed. Forward markets and indicative planning kill both birds with one stone" (Meade 1971, 144).

[18] Zie Richardson (1960), Lutz (1969), Cave en Hare (1981), v.d. Zwan (1982).

[19] 'Bounded rationality' is een concept geintroduceerd door Simon en duidt op de 'limited computational capacity of the human mind', (vergelijk 3.1.1.3).

[20] "Der Übergang zu einer kartelähnlichen Marktstruktur mit einer Festlegung der Marktanteile der Firmen unter behördlicher Aufsicht wäre also die Folge einer indikativen Koördinierung im Oligopol (...) Dafür diese Konsequenz indes die Rolle des Betriebsgeheimnisses im allgemeine verantwortlich ist, ist sie nicht streng auf das Oligopol i.e.s. beschränkt, sondern muss darüber hinaus überall gelten, wo bei heterogener Konkurrenz solche Betriebsgeheimnisse von Bedeutung sind. Die Entwicklung zur Kartellierung müsste daher einen sehr weiten Bereich des ökonomischen System umfassen" (Mikus 1974).

[21] Andere fundamentele kritiek met betrekking tot o.a. het opportunistisch gedrag van de actoren en het vertrouwen in het plan kan worden aangetroffen in Miller (1979). 
[22] Miller (1979) zet uiteen, dat het vertrouwen van de actoren in het Plan snel zal verdwijnen als de doeleinden keer op keer niet worden gerealiseerd.

[23] Voor een bespreking van de theorie van de rationele verwachtingen zie bijv. Willis 1982.

[24] Op de idee, dat de actoren op microniveau een leerproces doormaken en beslissingen nemen, waaruit een efficiënte organisatiestructuur van de markt resulteert ('spontaneous order') komen wij in hoofdstuk 3 terug (vergelijk Hodgson 1988a, 137).

[25] Hodgson (1988a, 269) merkt in dat verband op:

"However, not all information is of the same rank or generality. Whilst individuals are privy to detailed information which cannot all be aggregated and processed by a central authority, some sorts of information can be collected and handled centrally in a meaningful way".

[26] Bij de bespreking van het 9de Franse Plan zullen wij nader ingaan op de door Estrin en Holmes bedoelde 'leading indicators' (zie met name 5.6.4 en 6.2.4). 


\section{THEORIEEN VAN ONDERNEMINGSSTRATEGIEEN EN INDUSTRIEBELEID}

\subsection{Inleiding}

In hoofdstuk 1 is uiteengezet, dat markten "dubbel geordend" zijn: interne ordening vindt plaats door de marktpartijen zelf, externe ordening door de overheid. De aldus ontstane markten behoeven niet het gewenste resultaat te leveren, waardoor kan worden besloten mieuwe organisaties in te voegen, of bestaande af te breken dan wel te wijzigen. Het element van het marktresultaat waar in deze studie de aandacht naar uitgaat, betreft de aanpassing van de industriële structuur van een economie aan veranderende comparatieve voordelen. Door veranderingen in de omgevingsfaktoren, zoals de technologie, preferenties, opkomst van nieuwe industrielanden en dergelijke, blijken comparatieve voordelen van tijdelijke aard te zijn. Door tijdig de juiste aanpassingen in de industriële structuur door te voeren, kan een economie comparatieve voordelen behouden. In een markteconomie dient een dergelijke 'adaptive efficiency" in de eerste plaats het resultaat te zijn van de strategische beslissingen van de ondernemers; hun beslissingen met betrekking tot de omvang en richting van de investeringen, alsmede met betrekking tot de organisatie van de markt zijn van groot belang voor het behoud van een dynamisch efficiënte structuur [1]. Over deze ondernemingsstrategieèn handelt paragraaf 3.1 .

Het kan zijn, dat de 'régulation inintentionelle' (Lemettre 1983, 71) resulteert in een voor de betrokken marktpartijen positief marktresultaat, maar vanuit meso- of macrostandpunt echter als inefficiënt wordt beoordeeld. Dan behoeft de intern geordende markt aanvulling met een 'régulation intentionelle'.

Een overheid, die met behulp van een industriebeleid de strategie van ondernemingen wil beïnvloeden met het doel gewenste aanpassingen in de industriële structuur te bewerkstelligen, zou als volgt te werk kunnen gaan:

- De overheid poogt inzicht te krijgen in de bestaande industrièle structuur qua sectorale opbouw, regionale spreiding, ondernemingsgrootte en verwlechtingen van industriële activiteiten. Het laatstgenoemde aspect heeft recent meer aandacht gekregen, omdat een hecht netwerk van industriële activiteiten de overheid een grotere autonomie zou geven met betrekking tot haar conjunctuur- en structuurbelleid.

Als industriële activiteiten nauw verbonden zijn in industriêle groepen of netwerken van actoren, kan een efficiënte coördinatie van transacties plaatswinden [2]. De recente belangstelling voor netwerken van industriële vervlechtingen betreft de 
nauwe relatie tussen producenten, toeleveranciers, afnemers, opleidingsinstituten, onderzoekinstellingen e.d. Daardoor kan een snelle diffusie van informatie in het algemeen en van technologische kennis in het bijzonder plaatsvinden, waardoor snelle aanpassingen in het gehele systeem mogelijk zijn. Het bestaan van hechte industriele netwerken kan de effectiviteit van het structuurbeleid van de overheid ten goede komen (vergelijk paragraaf 3.2.1.4).

Ook wat het conjunctuurbeleid betreft kunnen netwerken van belang zijn: in geval van een hecht netwerk van intermediaire leveringen tussen binnenlandse producenten zal een vraagimpuls eerder leiden tot een stijging van de binnenlandse produktie, dan tot een toename van de importen (vergelijk de situatie in Frankrijk in de periode 1981-1983, zie hoofdstuk 6).

In paragraaf 3.2.1.4 zal worden besproken op welke wijze de overheid zich een beeld kan vormen van de opbouw van de bestaande industriële structuur.

- De overheid poogt inzicht te krijgen in de mogelijke toekomstige veranderingen van de comparatieve voordelen en de consequenties daarvan voor de bestaande industriële structuur. Wat impliceert bijv. de opkomst van de nieuwe industrielanden (NIC's) voor de aanpassing van de sectorale opbouw van de economie? In welk opzicht dient de industriële structuur veranderd te worden; wat is met andere woorden de gewenste toekomstige industriële structuur? Echter, de mogelijkheden van de overheid om toekomstige veranderingen in de comparatieve voordelen ex ante in te schatten, mogen niet te hoog worden aangeslagen. Niet alleen kan de wraag worden gesteld, of toekomstige technologische ontwikkelingen, de opkomst van nieuwe industrielanden en dergelijke, door een centrale overheid überhaupt onderkend kunnen worden, de vraag is ook, of tussen industrielanden ex ante op voldoende specifiek niveau onderscheid tussen comparatieve voordelen gemaakt kan worden. Kan bijvoorbeeld door verwachte ontwikkelingen in het DNA-onderzoek een conclusie worden getrokken met betrekking tot de verandering in comparatieve voordelen van landen als Nederland, Japan of Frankrijk?

Schenk en Kamann $(1987,239)$ schrijven:

"Comparatieve voordelen zijn binnen ruwe grenzen, bijwoorbeeld binnen het geheel van ontwikkelde industrielanden, "rather similar when looking at broad aggregates of products; $(. .$.$) when studying the fine structure of production, the$ comparative advantages are too complex to be explained or predicted either by central planners or by academic economists with the help of available methods of analysis" (Lindbeck 1981, 394).

Deze visie wordt bevestigd door de prioriteiten, die de industrielanden met betrekking tot hun industrie- en technologiebeleid in de jaren 80 stellen: op alle lijstjes keren dezelfde speerpunten terug: bio-technologie, nieuwe materialen, electronica, etc. (Roobeek 1988a). Een overheid, die een specifiek industriebeleid wenst te voeren, dat gelet op de comparatieve voordelen is gericht op de realisatie van een specifiek gewenste structuur, zal grote problemen ondervinden bij het ex ante onderkennen van de veranderingen in de voordelen op zo'n specifiek niveau, dat daaruit concrete beleidsmaatregelen zijn af te leiden.

- Naast inzicht in de bestaande en gewenste industriële structuur is inzicht nodig in de structuur, die op grond van de strategieën van de ondernemingen is te ver- 
wachten. Zullen ondernemers investeringsbeslissingen nemen en de organisatie van de markt zodanig aanpassen, dat nieuwe comparatieve voordelen ontstaan? Inzicht in de te verwachten industriële structuur kan alleen worden verkregen als de overheid op de hoogte is van de strategische plannen van de microeenheden. Afhankelijk van de aard en de omvang van de discrepantie tussen de gewenste en de te verwachten industriële structuur kan bijv. een zeer interveniërend industriebeleid adequaat worden geacht, of juist een meer voorwaardenscheppend beleid. Op de diverse vormen van industriebeleid wordt in paragraaf 3.3 nader ingegaan.

- Het industriebeleid, dat op grond van een vergelijking tussen gewenste en te verwachten ontwikkelingen adequaat wordt geacht, zal niet altijd mogelijk blijken. Wordt van de overheid bijw. een initièrend en organiserend beleid gevraagd, dan stelt zulks zeer specifieke eisen aan de attitude en competentie van het overheidsapparaat. In paragraaf 3.3 worden ideaaltypen uit de politicologie geschetst, die licht kunnen werpen op de eisen, die aan de overheid dienen te worden gesteld als sprake is van een interveniërend beleid, of juist van een beleid op afstand.

Het bovenstaande overziende blijkt de fundering van een marktconform industriebeleid uit twee elementen te bestaan: enerzijds dient de theorie inzicht te verschaffen in ondernemingsstrategieèn, anderzijds moet de theorie licht werpen op de eisen, die worden gesteld aan het overheidsapparaat en aan de organisatorische vormgeving van de relatie tussen de overheid en het bedrijfsleven.

\subsection{Theorieën van ondernemingsstrategleën}

\subsubsection{Inleiding}

Industriebeleid is gericht op het beïnvloeden van strategische ondernemingsbeslissingen. Van Cayseele en Schreuder (1988) zetten uiteen, dat de relatie tussen de onderneming en haar omgeving in de literatuur wordt aangeduid als het "strategische probleem". Zij citeren Teece $(1984,87)$ :

"The basic idea behind strategic management (is) that a firm needs to match its capabilities to its ever changing environment if it is to attain its best performance"".

Strategische beslissingen betreffen de continuiteit van de onderneming (Perez 1983); concreet gaat het om investeringsbeslissingen met betrekking tot $R$ en $D$, de omvang en aard van de produktiecapaciteit, de interne organisatie van de onderneming, de organisatie van de markt en de organisatie van de bredere socio-politieke omgeving. Wat de organisatie van de markt betreft, zullen ondernemingen pogen onzekerheden in het gedrag van concurrenten, afnemers en leveranciers te reduceren door middel van bijv. kartelafspraken en verticale integratie. Wat de organisatie van de sociopolitieke omgeving betreft zijn voor de onderneming relaties met onderzoek- en onderwijsinstellingen, verenigingen van werknemers, politieke organisaties en dergelijke van belang.

In 3.1.1 gaan wij na, welke inzichten in het "strategisch probleem" worden geboden door de theorieën van neoklassieke snit, waarbij de meeste aandacht zal uitgaan naar 
de zogeheten nieuw institutionele economie. Theorieèn van meer behavioristische aard komen in 3.1.2 aan de orde: de 'structure-conduct-performance'-benadering en de Franse variant daarop, de dynamische markttheorie en de bedrijfskundige benaderingen.

Afgesloten wordt in 3.1 .3 met een karakterisering van de p'école française de l'économie ind'ustrielle', waarbij de aandacht met name uitgaat naar het concept van de 'filière' en van de 'groupe industrielle', omdat die in het industriebeleid in de periode 1981-1986 een centrale rol speelden.

\subsubsection{Ondernemingsstrategileèn in de wereld van de neoklassieken}

\subsubsection{Inlelding}

In deze paragraaf laten wij theorieën de revue passeren, die economische organisatievormen, of breder: institutionele ontwikkelingen, verklaren op grond van een neoklassieke visie. Welke inzichten verschaft de neoklassieke theorie ons met betrekking tot de strategie van ondernemingen en het functioneren van overheden in marktecontomieën? Welke inzichten worden geleverd met betrekking tot de richting en omvang wan de investeringen wan grote structuurbepalende ondernemingen en welke strategieën ontwikkelen deze ondernemingen met betrekking tot de organisatie van de markt? Wij bespreken eerst de orthodoxe neoklassieke theorie en de structuralistische versie van het 'structure-conduct-pefformance-paradigma' (3.1.1.1). $\mathrm{Na}$ in 3.1.1.2 kort te zijn ingegaan op de principaal-agent-benadering, worden in 3.1.1.3 de recente ontwikkelingen in de zogeheten nieuw institutionele economie (NIE) besproken. Aan de kritiek op de NIE wordt een aparte paragraaf gewijd (3.1.1.4).

\subsubsection{Orthodoxe neoklassieke theorie en de structuralistische versie van het SCP- paradigma}

De bijdrage van de orthodoxe neoklassieke theorie [3] aan het "strategische probleem" is niet groot, hetgeen overigens geen verbazing behoeft te wekken. Immers, vraagstukken van marktorganisatie behoren in principe niet tot de probleemstelling van de neoklassieke microtheorie. Probleemstellingen van "received microtheory" zijn optimalisatievraagstukken: gegeven het gedrag van de actor (beslisregel van maximalisatie) en gegeven zijn omgeving (marktvorm van volledig vrije mededinging, oligopolie, monopolie en dergelijke), welke optimale combinatie van ' $P$ ' en ' $Q$ ' resulteert dan? In de wereld van de neoklassieke economie is de marktorganisatie exogeen en constant (Williamson 1985a, Van der Zwan 1982).

Strategisch ondernemingsgedrag komt in de neoklassieke wereld niet voor. Onzekerheid bestaat niet, omdat de prijzen alle relevante informatie overdragen; het gedrag van de actoren kan volledig worden 'voorspeld', omdat de theoreticus zogeheten 'single-exit-situaties' heeft gecreëerd (Latsis 1972).

Voor zover de ontwikkeling van de onderneming door de neoklassieke theorie wordt verklaard geschiedt zulks op grond van schaalvoordelen. Overigens is die verklaring niet logisch consistent in een wereld, waarin contractkosten zijn uitgebannen, omdat in zo'n wereld tussen de actoren voor elke transactie een contract zou worden afgesloten en er in het geheel geen ondernemingen zouden bestaan. 
"Thus orthodoxy holds that the allocation of economic activity as between firms and markets is a datum: firms are production functions: markets are signaling devices: contracting is accomplished through an auctioneer; and disputes are disregarded because of the presumed efficacy of court adjudication. The economic purposes served by organizational variety do not arise within -indeed, are effectively beyond the reach of- this framework" (Williamson 1984, 195).

De traditionele classificatie van Structure-Conduct-Performance wijkt niet principieel af van die neoklassieke wereld: de structuur is exogeen en determineert het gedrag, hetwelk in een specifiek resultaat uitmondt. Vanwege de directe causale verbanden geldt, dat de marktstructuur het resultaat bepaalt (het zogeheten "Bain-Mason-paradigma; zie Bidault 1984 en Chevalier 1977, introduction).

In principe kan de marktstructuur worden gekenmerkt aan de hand van een veelheid van elementen, maar dan resulteert het onderzoek slechts in uitspraken over uniek gedrag, dat voortvloeit uit een unieke structuur, hetwelk leidt tot een unieke uitkomst. Bain (1956) tilt de theorie uit het moeras van case-studies door de structuur te kenmerken aan de hand van de concentratiegraad, mate van produktdifferentiatie en de toetredingsbarrières (vergelijk Scherer 1970, introduction en De Jong 1981b, hoofdstuk 2). Als bijv. de toetredingsbarrières relatief hoog zijn, dan stijgt de concentratie met monopoliewinsten als resultaat. Omgekeerd: als de uitkomst niet efficiënt is, ligt de oorzaak in het ontbreken van een structuur met een voldoende mate van concurrentie. Bain en Mason zijn 'Structuralisten': de structuur bepaalt het gedrag en daarmede de uitkomst [4].

Onderzoekingen in de structuralistische traditie betreffen bijw. de relatie tussen marktstructuur en prijsflexibiliteit, of tussen marktstructuur en innovatie. Steeds weer blijkt het uitermate moeilijk over dergelijke relaties uitspraken te doen, niet alleen vanwege problemen met betrekking tot het vaststellen van de concentratiegraad, maar vooral omdat de wereld, waarin ondernemingen opereren, fundamenteel verschilt van de SCP-classificatie. Er is namelijk in werkelijkheid geen sprake van een éenrichtingsverkeer tussen structuur en gedrag, mar van een wisselwerking, waarbij de structuur het gedrag conditioneert en het gedrag de structuur mede kan bepalen (Arena 1983; vergelijk 3.1.2).

\subsubsection{Principaal-agent-benadering}

Een andere recente ontwikkeling, die dicht bij de neoklassieke micro-theorie staat, betreft de zogeheten "principaal-agent-benadering".

"An agency relationship is said to arise between two (or more) parties when one, designated as the agent, acts for or on behalf of the other, designated the principal $_{n}$ in a particular domain of decision problems" (Ross 1973, geciteerd naar Schreuder 1985b, 14).

Aangezien het doel van selectieve nationalisatie de creatie van 'agenten' wan de overheid is, zou de 'principaal-agent-theorie' voor onze probleemstelling relevante inzichten kunnen bieden.

In de principaal-agent-literatuur kan onderscheid worden gemaakt tussen een analy- 
tische en een positieve stroming. De eerstgenoemde richt zich op het ontwerpen van een optimaal contract (optimal sharing rules) tussen principaal en agent in verschillende situaties van onzekerheid, informatieongelijkheid, contractvormen, aantal partijen en aantal perioden. De analytische benadering is deductief van aard, waarbij in een gegeven situatie en een gegeven handelingsprincipe wan de actoren het optimale contract wordt berekend. De analytische stroming heeft geleid tot het construeren van uitermate complexe contracten, bedoeld om het gedrag van de agent af te stemmen op de doeleinden van de principaal, maar de verregaande vorm van abstractie en het buiten beschouwing laten van de contractkosten leiden tot een groot verschil tussen de uitkomsten van de theorie en de feitelijk waar te nemen relaties tussen 'principals" en 'agents' (vergelijk Booij 1987, 94). Arrow (1985, 48) merkt in dat verband op:

"Sharecropping incentive compensation to executives and other employees, the role of dismissal as an incentive, coinsurance, and other aspects of insurance all find a place in this (principaal-agent-JG) literature not found in standard economic analysis. But it is perhaps more useful to consider the extent to which the principal-agent relation in actuality differs from that in the models developed to date. Most importantly, the theory tends to lead to very complex fee functions. It turns out to be difficult to establish even what would appear to be common-sense properties of monotonicity and the like. We do not find such complex relations in reality"'.

Door de verregaande abstractie blijven de hypothesen moeilijk toetsbaar.

De positieve stroming is meer beschrijwend van aard en poogt een verklaring te geven van de diverse soorten contracten, die in de empirie kunnen worden waargenomen, alsmede van de invloed daarvan op het gedrag van de actoren. Later is daar ook de analyse van andere determinanten van het gedrag van de actoren bijgekomen: 'disciplining mechanisms' als de markt voor eindprodukten, de kapitaalmarkt, de interne en externe arbeidsmarkt, alsmede interne en externe informatie- en monitoringsystemen, zouden de actoren dwingen tot efficiènt gedrag. Met name is in het agency-onderzoek de aandacht uitgegaan naar de relatie tussen de onderneming (managers/agenten) en de kapitaalmarkt (aandeelhouders/principalen) (vergelijk Barney en Ouchi 1986, 206-208).

Probleem is echter, dat die "disciplining mechanisms" niet aansluiten bij de concepten van de analytische stroming, waardoor de gewenste integratie tussen beide stromingen is uitgeblewen. Schreuder $(1985 b, 38)$ conclludeert:

"In summary the current status of agency research is rather far removed from the methodogical ideal of the interplay of inductive and deductive approaches, analytics and empirics".

Omdat beide stromingen in de agency-literatuur niet de interne en externe factoren van de ontwikkeling in contractuele relaties onderzoeken, maar comparatief-statisch. van aard zijn, is de principaal-agent-benadering minder relevant voor probleemstellingen, die de ontwikkeling van organisaties en contractuele relaties in de loop van een specifieke periode willen analyseren. Ook het keuzevraagstuk van actoren met betrekking tot de verschillende organisatievormen behoort niet tot de probleemstellingen van thet agency-onderzoek: de relatie 'principal-agent' is gegeven. 
Samengevat kan worden gesteld, dat de analytische agency-benadering nauw aansluit bij de neoklassieke microtheorie; toegevoegd wordt het vraagstuk van het optimale contract bij asymmetrisch verdeelde informatie. De positieve stroming is meer empirisch van aard, maar impliciet wordt aangenomen, dat de combinatie van contracten, markten en informatie- en monitoringsystemen leildt tot efficiènt gedrag. Schreuder (1985b, 43) wijst er terecht op, dat de efficięnte werking van die 'disciplining mechanisms' niet als uitgangspunt moet worden genomen, maar juist aan een empirisch onderzoek onderworpen dient te worden (vergelijk Spierings 1988).

\subsubsection{De 'nieuw institutionele economie'; de transactiekosten van Wulliamson}

De verklaring van de instituties en de organisatie van de markt staat centraal in de 'new institutional economics' (NIE) [5]. Het begrip 'new institutionalist' is afkomstig van Williamson (1975) [6], die daarmee het onderscheidende element van zijn 'transaction cost economics" (TCE) ten opzichte van de "received microtheory" wilde benadrukken: instituties zijn in de transactiekostentheorie te verklaren en niet exogeen en constant.

Transactiekostentheorie steunt op pionierswerk van Commons (de transactie is uitgangspunt en niet de produktie- of consumptieeenheid), Alchian (eigendomsrechten), Coase (transactiekosten), Hayek (belang van informatie en idiosyncratische kennis), Simon (beperkte rationaliteit) en Arrow (informatie- en contractkosten).

Startpunt van de analyse in de transactiekostentheorie is niet de microhuishouding maar de 'transactie', door Williamson $(1981,1544)$ gedefinieerd als 'when a good is transferred across a technologically separable interface' (vergelijk 3.1.1.4). In navolging van de institutionalist Commons gaat Williamson uit van economische transacties en stelt zich de vraag met behulp van welke economische organisatievormen de actoren de transacties zullen coôrdineren. Voor de actoren is sprake van een economisch keuzevraagstuk: elke organisatievorm brengt namelijk transactiekosten met zich mee, welke combinatie van economische organisatievormen minimaliseert die kosten? Om te verduidelijken welke factoren bij die keuze een rol spelen ontwikkelt Williamson in zijn 'Markers and Hierarchies' van 1975 het 'Organizational Failures Framework'. In vergelijking met de neoklassieke theorie brengt Williamson veranderingen aan ten aanzien van de eigenschappen van de actor, alsmede ten aanzien van de omgeving, waarin de actor opereert.

Kort gezegd komt het erop neer, dat de actoren behept zijn met 'bounded rationality', waardoor niet alle relevante informatie kan worden verzameld en verwerkt. Met betrekking tot het afsluiten van contracten op de markt impliceert beperkte rationaliteit de onmogelijkheid op $t_{0}$ voor de gehele toekomst voorwaardelijke contracten te kunnen afsluiten, zoals in de Arrow en Debreu wereld (vergelijk 2.2.1). De actoren in Williamsons wereld onderscheiden zich ook van hun neoklassieke collega's door hun 'opportunistic behaviour": sommige actoren verschaffen bewust onvolledige of onjuiste informatie en buiten informatieongelijkheid uit door anderen te misleiden. Het mogelijke opportunistische gedrag van de actoren kan voor de anderen kosten met zich meebrengen om uit te zoeken wie eerlijk handelt en wie niet; in sommige gevallen zal het zelfs in het geheel niet mogelijk zijn tussen de actoren zo'n onderscheid te maken. 
Wat de omgeving betreft, gaat Williamson uit van onzekerheid en complexiteit en van de veel woorkomende marktstructuar van "small numbers", waardoor opportunistisch gedrag mogelijk wordt. Tot slot kan in de gedachtengang van Williamson 'information inpactedness" optreden, namelijk als de ene partij over meer informatie beschikt dan de andere en het yoor laatstgenoemde hoge kosten met zich brengt uit te zoeken, of de verstrekte informatie juist is.

In het 'Organizational Failures Framework' zijn markten en hiërarchieën alternatieve organisatievormen; de actoren worden verondersteld transactiekosten te minimaliseren; de transactiekosten zijn afhankelijk van genoemde eigenschappen van de actoren, van de aard wan de transactie en van de kenmerken van de omgeving. Tot slot plaatst Williamson de actoren in een 'atmosphere": er zijn andere factoren dan de transactiekosten, die voor de verklaring van economische organisatievormen van belang kunnen zijn. De wijze, waarop de transactie is georganiseerd kan namelijk zelf 'object of value' zijn, waardoor normen en waarden verklarende variabelen worden [7]. De bouwstenen van het "Orgamizational Failures Framework' zijn samengevat in schema 3.1.

\section{Schema 3.1 Het 'Organizational Failures Framework'}

HUMAN FACTORS

ENVIRONMENTAL

FACTORS

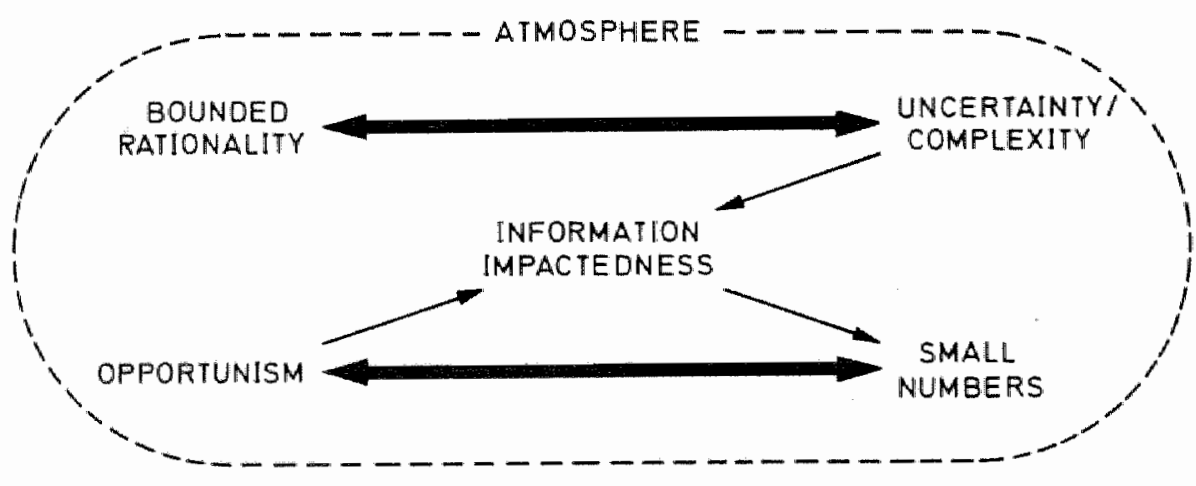

Bron: Williamson $(1975,40)$.

Na zijn Markets and Hierarchies uit 1975 heeft Williamson een groot aantal artikelen gepubliceerd, waarin enerzijds de dichotomie van de markt en hiërarchie plaats maakt voor een continuüm van 'governance structures' en anderzijds scherper inzicht wordt verschaft in de factoren, die van invloed zijn op de hoogte van de transactiekosten. In Williamson (1979) wordt de dichotomie van markt en hiërarchie vervangen door een continuüm van 'governance structures' met de 'spot market' aan de ene kant en de 'internal organization' aan de andere kant. Daartussen bevinden zich alle denkbare 'governance structures', welke zijn op te vatten als impliciete of expliciete contracten 
tussen partijen, betreffende de coördinatie van een transactie [8]. Het criterium voor de lokatie op het continuüm is de mate van autonomie van de partijen: die is het grootst op de spotmarkt en het meest ingeperkt in een hierarchie.

De transactiekostentheorie beoogt de diverse economische organisatievormen te 'matchen' met de eigenschappen van diwerse typen van transacties, die worden geclassificeerd aan de hand van drie kenmerken: de zogenaamde 'asset specificity", de frequentie, waarmee de transactie plaats windt en de onzekerheden, waarmee de partijen worden geconfronteerd.

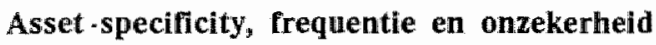

Er is sprake van 'asset specificity' als partijen duurzame investeringen hebben gedaan, die niet of tegen zeer hoge kosten alternatief kunnen worden aangewend. Met betrekking tot bijw. de levering van intermediaire goederen komt het in toenemende mate voor, dat het produkt aan specifieke eisen van de afnemer moet voldoen. Het gaat dan niet alleen om 'just in time deliveries', maar veeleer om eisen ten aanzien van technische specificaties en kwaliteit. Investeert een ondernemer in specifieke produktiecapaciteit en in specifiek gekwalificeerd personeel, waarmee alleen specifieke goederen kunnen worden gemaakt voor - in het uiterste geval - één afnemer, dan ontstaat een situatie, die gelijkt op een bilateraal monopolie. Partijen zijn op elkaar aangewezen, omdat de aanbieder voor zijn investeringen geen alternatieve aanwending heeft, terwijl de afnemer andere producenten niet gemakkelijk tot dergelijke specifieke investeringen zal kunnen bewegen. In de wereld van Williamson maakt 'faceless contracting' plaats voor een situatie, waarin 'painwise identity of parties matters'.

Asset specificity komt in diverse vormen voor:

- De lokatie wan de produktie kan zodanig worden gekozen, dat voor beide partijen de transportkosten worden geminimaliseerd ('site specificity'), in welk geval gemeenschappelijk eigendom volgens Williamson de meest efficiënte organisatievorm zal zijn.

- Het produkt kan zeer specifieke eigenschappen hebben, waardoor het maar in éen toepassing kan worden gebruikt. Williamson geeft het voorbeeld van de stempel voor een munt. Overigens kan in het geval van zo'n 'physical specificity' het marktcontract toch een efficiënte organisatievorm zijn tussen de eigenaar van de stempel en de eigenaar van de produktiecapaciteit van munten. In geval van het niet naleven van het contract kan de eigenaar van de stempel opnieuw de producenten van munten laten wedijveren.

- Werknemers kunnen in de loop der tijd specifieke ervaring opdoen in het werken in teamverband of in het omgaan met specifieke apparatuur ('human asset spectficity"), waardoor een interne arbeidsmarkt een efficiènte organisatievorm van de arbeidsrelatie kan worden (Williamson 1980).

- Als een producent zijn produktiecapaciteit uitbreidt ten behoeve van de vraag van één specifieke afnemer ('dedicated assets'), dan ontstaat voor beide een situatie, die gelijkt op een bilateraal monopolie.

"Asset specificity" is geen uitzondering, maar met name door recente technologische ontwikkelingen regel geworden op de arbeidsmarkt en op tal van intermediaire goederenmarkten. 
Naast "asset specificity" spelen onzekerheid en frequentie in de transactiekostentheorie een belangrijke rol: actoren worden geconfronteerd met markt- en omgevingsonzekerheid, terwijl transacties niet eenmalig zijn, maar in de toekomst steeds opnieuw moeten worden gecoördineerd tussen marktpartijen. Marktpartijen kunnen pogen onzekerheid het hoofd te bieden door het afsluiten van lange termijn contracten, Waarin diverse ontbindende voorwaarden zijn opgenomen met betrekking tot de ontwrikkeling van omgevingsfactoren als de technologie, preferenties en dergellike. Informatie, onderhandelings- en controlekosten blijken voor dergelijke contracten echter snel tot grote hoogte te kunnen oplopen. Het alternatief van een reeks opeenvolgende korte termijn contracten kent ook problemen: degene aan wie op $t_{0}$ het eerste contract wordt gegund (de zogenaamde 'first mover') kan tot het moment van de contractvernieuwing $\left(t_{1}\right)$ zoveel ervaring met het specifieke produktieproces opdoen, dat hij zich op $t_{1}$ in een voordelige positie ten opzichte van zijn concurrenten bevindt. Er vindt in de loop van het contractproces een ontwikkeling plaats van een situatie met veel aanbieders naar een situatie met 'small numbers' [9].

Williamson maakt in zijn analyse duidelijk hoe governance structures, die op het continubim dichter bij de hiërarchie liggen, op transactiekosten kunnen besparen in situaties van 'asset specificity, uncertainty and frequency'. Beperkte rationaliteit speelt de hièrarchie minder parten, omdat in de organisatie, in tegenstelling tot de markt, niet de noodzaak bestaat op $t_{0}$ een beslissing te nemen, waarin met alle mogelijke toekomstige ontwikkelingen rekening wordt gehouden; hiërarchieën bieden de mogelijkheid van 'sequential decision making': toekomstige ontwikkelingen kunnen tot op zekere hoogte worden afgewacht, alvorens weer een volgende beslissing wordt genomen. Door het interne controlesysteem werpt opportunistisch gedrag in een hiêrarchie minder vruchten af, het misbruik maken van een informatievoordeel zal in een hiërarchie minder snel voorkomen, omdat de controle- en beloningssystemen prikkelen tot gedrag conform de doelstellingen van de organisatie. Daarmee is niet gezegd, dat hiërarchieën geen transactiekosten kennen. Integendeel: elke coördinatie van transacties gaat gepaard met kosten, maar de ene organisatievorm is efficiënter dan de andere, afhankelijk van de specifieke situatie.

Een typologie van transacties en 'governance structures' op basis van 'asset specificity' en trequentie is weergegeven in schema 3.2 .

De transactie specifieke investeringen nemen toe van niet specifiek via gemengd tot idiosyncratisch. Voor niet specifieke investeringen zullen de transactiekosten van de markt relatief gering zijn, omdat in dat geval een klassieke marktcontract mogelijk is warin vooraf alle rechten en plichten van de partijen gemakkelijk kunnen worden vastgelegd. Die mogelijkheid wordt minder naarmate de 'asset specificity" toeneemt. Een tri-laterale organisatie zal economisch efficient zijn als de partijen, vanwege de geringe frequentie van de transacties geen schaalvoordelen kunnen bereiken met een bi-laterale structuur. 
Schema 3.2 Een classificatie van 'governance structures'

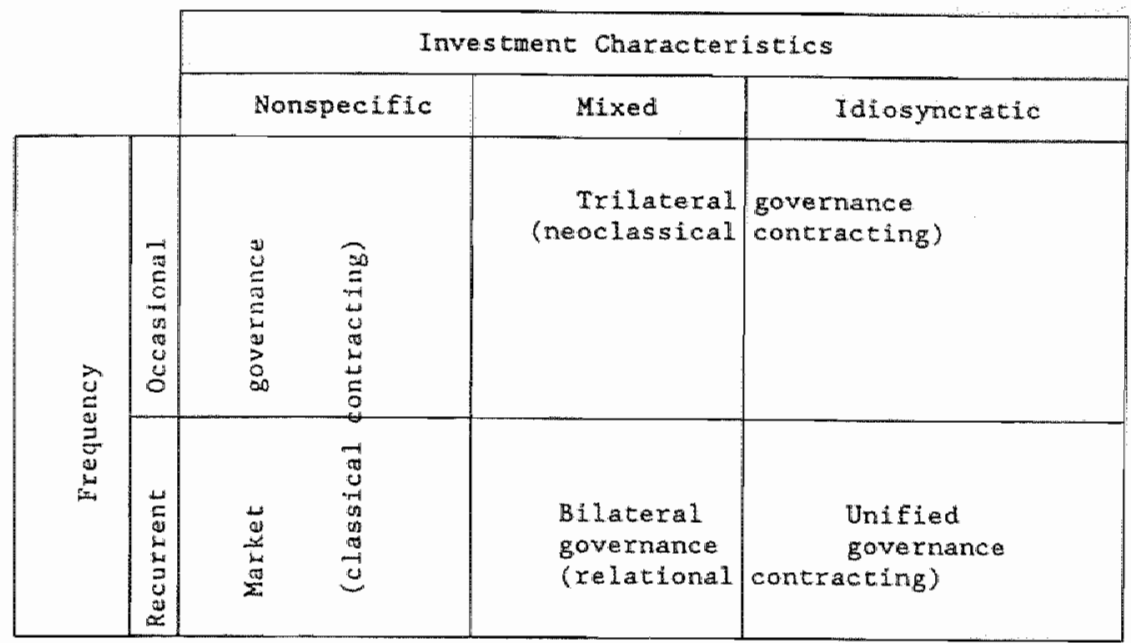

Bron: Williamson 1979

In schema 3.3 zijn de factoren, die in de transactiekostentheorie van invloed zijn op de keuze van de actoren nog eens samengevat.

Schema 3.3 Het ontstaan van diverse "governance structures"

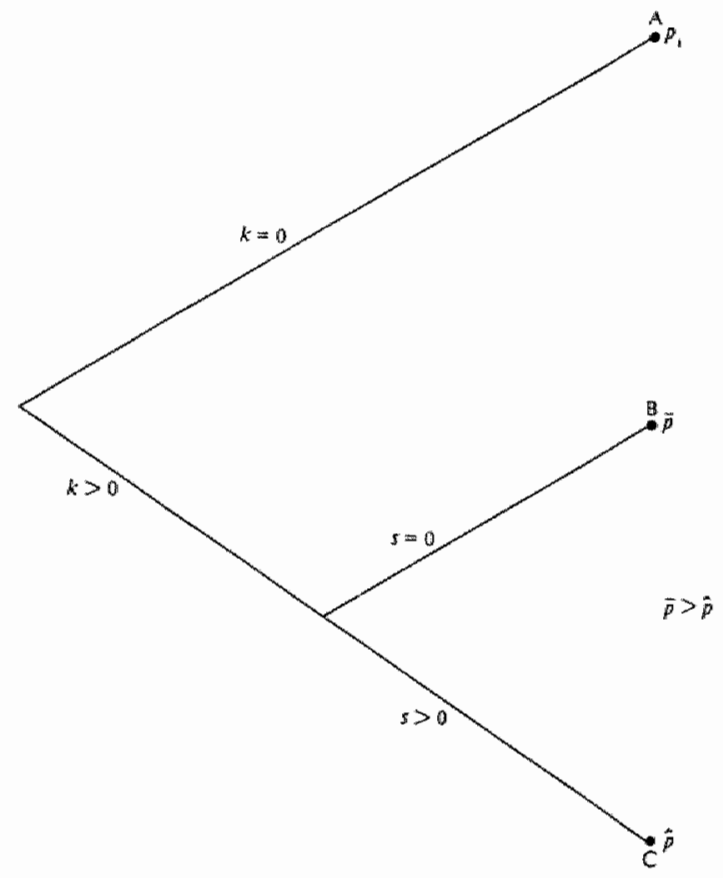

Bron: Williamson 1987 
De " $k$ " is een maatstaf voor de 'transaction specific assets': $k=0$ betekent, dat de investeringen zonder kosten ook voor andere doeleinden kunnen worden aangewend. In dat geval voldoet het klassieke marktcontract (A). De "s" duidt op de "safeguards", die partijen door middel van de contracten in de relatie aanbrengen met het doel hun transactiespecifieke investeringen te beschermen tegen zogenaamde "hold ups" [10]. De prijzen, die de partijen in hun onderhandeling overeenkomen $\left(\mathrm{p}_{1}, \mathrm{p}\right.$ en $\left.\hat{\mathrm{p}}\right)$ lopen op naarmate ' $k$ ' groter is en ' $s$ ' kleiner. Als $k>0$ en $s=0$ zal $\hat{p}$ tot stand komen (B), die boven p zal liggen, omdat in het geval van $s>0$ de verkoper over een safeguard beschikt.

Williamson verklaart het ontstaan en de ontwikkeling van economische organisatievormen op grond van transactiekostenminimalisatie. De multidivisionele onderneming, de multinationale onderneming, het conglomeraat, de interne arbeidsmarkt etcetera, zijn alle ontstaan, omdat zij op een of andere manier, de kosten verbonden aan het voltrekken van een economische transactie, verminderden. Zo zou het conglomeraat bijw. zijn voortgekomen uit het inefficiënt functioneren van de kapitaalmarkt, waardoor het management zich aan de controle van de eigenaren kon onttrekken. Het conglomeraat biedt een alternatief door de zwakke controle van de individuele aandeelhouders te vervangen door de controle vanuit één centrale [11].

Met betrekking tot het ontstaan van de multinationale onderneming zoekt Williamson de minimalisatie van de transactiekosten in de technologieoverdracht: door direkte investeringen in het buitenland worden de hoge kosten van technologieoverdracht naar zelfstandige buitenlandse ondernemingen vermeden [12].

Voor onze probleemstelling lijkt de transactiekostentheorie interessante perspectieven te bieden: als namelijk de strategie van ondernemingen met betrekking tot de organisatie van de markt wordt bepaald door de hoogte van de transactiekosten, zou daarin voor een interveniërende overheid een belangrijk aangrijpingspunt voor beleid kunnen zijn gelegen.

\subsubsection{Kritiek op de transactiekostentheorie}

Van diverse zijden is kritiek geoefend op de transactiekostenbenadering [13]. Deze kritick betreft het operationaliseringsprobleem wan de begrippen 'transactie' en 'transactiekosten'; de methodologische individualistische grondslag van de transactiekostentheorie; de veronderstelde inefficièntie van de zogenaamde 'peer groups' en de kritiek op de 'functionalistische' inslag van de transactiekostentheorie.

Een eerste punt van kritiek betreft de onduidelijkheid van de begrippen 'transactie' en 'transactiekosten'.

\section{Ondnidelijke begrippen}

Als de hoogte van de transactiekosten verklarend zijn voor de organisatievorm, dan moeten die kosten kunnen worden afgebakend van andere kosten. Vastgesteld moet kunnen worden welke de kosten zijn van het coördineren van een specifieke transactie als gebruik wordt gemaakt van organisatievorm $x, y$ of $z$.

Williamson blijkt vanaf zijn 'Markets and Hierarchies' (1975) niet in staat een scherpe definitie van transactie en transactiekosten te geven [14]. 
Met het begrip transactiekosten is het evenmin duidelijk gesteld. In het verlengde van Arrow's $(1969,48)$ ruime omschrijving van transactiekosten als de "costs of runting an economic system", stelt Williamson $(1985 \mathrm{~b}, 19)$

"Transaction costs are the economic equivalent of friction in physical systems".

Met deze analogie komt Williamson niet verder dan het aangeven van de bronnen van transactiekosten ('asset specificity', onzekerheid) en het onderscheiden van diverse categorieën van kosten verbonden aan de transactie. Ex ante is sprake van 'costs of drafting, negotiating and safeguarding an agreement'; ex post is naast de normale kosten verbonden aan elke organisatie ook sprake van 'maladaption costs incurred when transactions drift aut of alignment' en van 'haggling costs incurred if bilateral efforts are made to correct ex post misalignments" en van "bonding costs of effecting secure commitments" (Williamson 1985) [15].

Om vast te kunnen stellen, of de ene 'govermance structure' efficiënter is dan andere 'governance structure' is het noodzakelijk de transactiekosten nauwkeurig te kunnen specificeren en te kunnen onderscheiden van de kosten verbonden aan de produktie van het goed of dienst. Dow $(1987,17)$ wijst er in dat verband op, dat het voor een comparatieve analyse voldoende is als van een organisatie de netto voordelen ten opzichte van de andere potentiële "governance structures" worden vastgesteld. Daartoe is het volgens Dow $(1987,17)$ noodzakelijk

"'(...) to provide a substantive classification of the resources sacrificed, and the benefits obtained, by applying a governance structure to a transaction. Only in this way can we distinguish transaction costs from more mundane costs".

In het kader van de transactiekostentheorie moet worden aangetoond, dat onder de veronderstelling dat de overige kosten gelijk blijven een specifieke 'governance structure' is ontstaan, omdat deze de transactiekosten verminderde en daardoor de concurrentiepositie van de onderneming verbeterde. Williamson $(1984,201)$ wijst erop, dat daarbij het vermogen van de organisatie 'to respond effectively to disturbances' essentieel is [16]. Om die waarde te kunnen bepalen is een rigorous met benefit assessment (Dow 1987, 18) nodig. Omdat het concept van de transactiekosten onvoldoende is geoperationaliseerd en een onafhankelijk criterium voor het vaststellen van de efficientie ontbreekt, dreigt het gevaar van een tautologie: omdat de actoren de transactiekosten minimaliseren zijn de bestaande organisatievormen ook de meest efficiënte [17]. Van diverse zijden is erop gewezen, dat zo'n tautologie alleen voorkomen kan worden als expliciet duidelijk wordt gemaakt, welk selectiemechanisme zorg draagt voor het overleven van de meest efficiente organisatievormen. Op de problematiek van het ontbreken van zo'n selectiemechanisme komen we bij de bespreking van het functionalisme terug.

\section{Methodologisch individualisme; beperkte rol van de overheid}

De nieuw institutionele economie is gelijk de neoklassieke microtheorie gebaseerd op het methodologisch individualisme (vergelijk Hodgson 1988a). Uit het gepostuleerde rationele maximaliserende gedrag van de individuen 
"(...) emerge rules or institutions that provide the foundations for a spontaneous social order" (Heijdra 1988, 311).

Met de psychologie van de actoren en andere niet-economisch verklarende variabelen behoeft de nieuw institutionele economist zich niet bezig te houden, omdat

"( ...) methodologically individualist in the sense that it embraces a type of situational analysis whereby the intentional maximizing behavior of individuals is sufficient to yield predictable outcomes, including (unintended) configurations of rules and institutions" (Heijdra et al. 1988, 312).

Het methodologisch individualisme heeft er bij Williamson toe geleid, dat de roll van de overheid sterk onderbelicht is gebleven.

In de wereld van Williamson creëren individuen op basis van een afweging van kosten en baten organisatievormen, die het afsluiten van transacties in goede banen leiden. 'Hostages' en 'arbitration' zijn daarvan voorbeelden. In geval van een 'hostage" [18] ontstaat door de wederzijdse afhankelijkheid een sterke band tussen de partijen, waardoor het risico van ingebreke blijwen tot een minimum beperkt wordt. Arbitrage door derden is een andere mogelijkheid eventuele conflicten op te lossen zonder een beroep te doen op formele juridische regels, die van overheidswege worden opgesteld en uitgevoerd.

"Thus, in Williamson"s view, a system of exchange and contract is possible and sustainable without the state" (Hodgson 1988a, 155).

De kritiek op het buiten slluiten van de overheid betreft enerzijds de rol, die de overheid speelt bij het invoeren en handhaven van de juridische regels en anderzijds de mogelijkheid, dat overheidsorganisaties transactiekosten kunnen verlagen ten opzichte van particuliere organisaties.

Wat de rol van de overheid met betrekking tot de juridische regels betreft, volgt Williamson de 'property rights school' en onderkent niet, dat wetten het gecombineerde resultaat zijn van gewoonten en tradities enerzijds en overheidsactiviteiten anderzijds. Williamson's analyse is gebaseerd op de idee, dat een hecht sociaal stelsel ontstaat als onafhankelijke individuen hun eigen belangen nastreven, waarmee hij grote verwantschap toont met de "spontaneous social order" van Hayek (vergelijk Heijdra et al. 1988, 298 e.v.). Williamson zelf werkt deze gedachte niet verder uit, maar binnen de NIE is een stroming te onderkennen, die wel de vraag stelt met betrekking tot de rol van de overheid ten aanzien van het contractproces en waarom instituties via het politieke proces zouden worden veranderd. North $(1978,1981,1986)$ analyseert de rol van de overheid in een markteconomie en het proces van institutionele verandering met behulp van het neoklassieke instrumentarium van kostenminimaliserende individuen. Hij ziet in het contractproces een belangrijke rol weggelegd voor de overheid als derde $_{\mathrm{i}}$ die met behulp van een juridisch apparaat de naleving van contracten kan afdwingen. Bestaat zo'n neutrale derde niet, dan kunnen voor de marktpartijen de transactiekosten zo hoog oplopen, dat het contract niet tot stand komt. Zijn de mogelijkheden van opportunistisch gedrag groot en de kosten van 'third party enforcement' relatief hoog, dan is de overheid de aangewezen instantie, die voor marktpartijen de transactiekosten kan verlagen door ervoor te zorgen, dat naleving van de contracten via haar apparaat gemakkelijk kan worden afgedwongen. 
"It is for this reason that the whole development of the new institutional economics must be not only a theory of property rights and their evolution but a theory of the political process, a theory of the state, and of the way in which the institutional structure of the state and its individuals specify and enforce property rights" (North 1986, 223).

De overheid krijgt in de analyse wan North een plaats, omdat zij een bijdrage kan leveren aan de verlaging van de transactiekosten voor de marktpartijen.

Waardoor vinden veranderingen plaats in de institutionele structuur, die de overheid heeft ontwikkeld ten behoeve van het afdwingen van de naleving van contracten? Ook nu past North neoklassieke inzichten toe: individuen zijn bereid de bestaande instituties te veranderen als de opbrengsten groter zijn dan de kosten. Als door een verandering in de relatieve prijzen partijen nieuwe contracten willen afsluiten en de bestaande instituties zijn efficiënt in het effectueren van hun eigendomsrechten, dan zullen de partijen geen reden hebben middelen aan te wenden ten einde die bestaande structuren te veranderen. Blijken daarentegen de transactiekosten verbonden aan het opstellen en controleren van de contracten zo hoog op te lopen, dat geen contract tot stand komt, dan is er voor de partijen wel een reden kosten en opbrengsten van het veranderen van de institutionele structuur via het politieke proces tegen elkaar af te wegen [19] (vergelijk de 'market for reforms' in Newman (1976), zie hoofdstuk 2). Verwaarlozing van de positie van de overheid in de transactiekostentheorie van Williamson heeft er ook toe geleid, dat de mogelijkheid van publieke organisaties de transactiekosten te verlagen ten opzichte van particuliere organisaties, geheel buiten beschouwing is gebleven.

"(...) the transaction costs analysis he (Williamson $\mathrm{JG}$ ) uses to explain why the firm replaced the market in many economic activities can also be used to explain why the developmental process of minimizing transaction costs could be continued by replacing the firm with the state in many areas where the firm earlier replaced the market" (Dugger 1983, 107) [20].

De overheid als afnemer van geavanceerde militaire projecten (walrusonderzeeër), of als opdrachtgever van gecompliceerde infra-structurele werken (peilerdam), is behept met beperkte rationaliteit, opereert in een onzekere, complexe wereld en wordt geconfronteerd met zich opportunistisch gedragende leveranciers, die een informatievoordeel bezitten. De transactiekosten van een contract tussen de overheid en een particuliere onderneming kunnen zeer hoog oplopen. Internallisering van de transactie in de overheidsorganisatie door middel van een publieke onderneming zou op transactiekosten kunnen besparen bijv. doordat de mogelijkheden van "internal auditing" groter worden (vergelijk hoofdstuk 4).

\section{Hierachieën versus 'peer groups' [21]}

Een derde punt van kritiek betreft de vooringenomenheid van Williamson met betrekking tot de inefficiëntie van organisatievormen als de coöperatie en het arbeiderszelfbestuur [22]. Alleen hiërarchieën beschikken volgens Williamson over effectieve selectiemechanismen (auditing, experience rating), waardoor de meest getalenteerde werknemers op de juiste plaatsen terecht komen. Organisaties als coöperaties en arbeiderszelfbestuur worden door Williamson beschouwd als peer groups met een loose 
metering structure, welke volop gelegenheid bieden tot opportunistisch gedrag. Critici zoals Dow (1987) en Putterman (1987) wijzen erop, dat juist ook hierarchieën inefficiènt kunnen functioneren, omdat het management ten opzichte van de andere belangengroepen, zoals de aandeelhouders en vooral de werknemers, over een informatievoordeel beschikt en zich mede door de situatie van "kleine aantallen" in een goede positie voor opportunistisch gedrag bevindt. In de transactiekostentheorie wordt veel aandacht besteed aan het opportunistisch gedrag van werknemers, met name in peer groups, terwijl het zogenaamde downward opportunism wan het management onderbelicht blijft.

Opportunistisch gedrag komt bij alle groeperingen in de onderneming voor, hetgeen aanleiding zou moeten zijn systemen van reciprocal monitoring in te voeren, waarin de diverse groepen elkaar controleren en aanzetten tot efficiënt gedrag [23].

\section{Functionalisme}

Centraal in de kritiek op de transactiekostentheorie staat haar functionalistische inslag (Dugger 1983; Granovetter 1985; Dow 1987). Over het al dan niet functionalistisch zijn van de 'new institutional economics' in het algemeen en van de transactiekostentheorie van Williamson in het bijzonder, is enige verwarring ontstaan, die voor een deel voortvloeit uit verschillend gebruik van het begrip 'functionalistisch". Williamson (1987a, 38 e.v.) onderscheidt vier soorten van functionalisme [24], waarvan het zogeheten 'full functionalism' door hem de enige sluitende functionele verklaring wordt geacht [25].

"An institution or behavioural pattern $X$ is explained by its function $Y$ for group $Z$ if and only if:

(1) $Y$ is an effect of $X$;

(2) $Y$ is beneficial for $Z$;

(3) $Y$ is unintended by the actors producing $X$;

(4) $Y$ - or at least the causal relation between $X$ and $Y$ - is unrecognized by the actors in $Z_{*}$

(5) $Y$ maintains $X$ by a causal feedback loop passing through $Z$ ".

Van het functionalisme in deze stringente betekenis van Elster zullen weinig voorbeelden in de sociale wetenschapen worden aangetroffen [26].

Heijdra et all. $(1988,308)$ beschouwen als de kern van het functionalistische paradigma de opvatting, dat:

"all institutions or behavioral patterns have a function that explain their presence. A particularly virulent form of functionalism is "objective teleology" in which a purpose is postulated without a purposive actor".

Deze extreme vorm van het functionalisme mist een micro-theoretische grondslag, waarmee kan worden verklaard hoè 'governance structures' in werkelijkheid worden gecreẻerd. Volgens Heijdra et al. (1988) kent de neoklassieke theorie wel zo'n basis in de vorm van het methodologisch individualisme [27].

Volgens die opvatting ontstaan instituties, regels en organisaties als gevolg van spontaan gedrag van de individuen in de samenleving. $\mathbb{E r}$ wordt in dit verband gesproken van de 'invisible hand explanations' van de NIE (zie blz. 69). 
Van groot belang is nu de vraag, of de instituties, regels en organisaties, die uit de handelingen van de micropartijen voortkomen efficiënter zijn, of dat ook inefficiënte regels en organisaties het resultaat van het institutionaliseringsproces kunnen zijn. Wat het antwoord op die vraag betreft, blijkt de NIE geen homogeen gezelschap: er zijn onderzoekers, zoals bijv. Posner (1977), die van mening zijn, dat concurrentie tussen maximaliserende individuen leidt tot efficiënte structuren, (conform Hayek"s spontaneous order), terwijl auteurs als Buchanan wijzen op rivaliserende belangengroepen, waarvan de concurrentiestrijd in inefficiënte structuren kan resulteren (zgn. "Wirginia school'-variant van de NIE; vergelijk Stigler (1971) en Peltzmann (1976) [28]. Of efficiente 'governance structures' ontstaan hangt af van het bestaan van adequate selectiemechanismen.

"Until an explicit mechanism capable of generating efficient governance structures and sustaining them over time is identified, the claim that observed structures are efficient will remain unpersuasive, given the inability of researchers to establish efficiency through direct observation" (Dow 1987, 26).

Wat zo'n 'expliciet mechanisme' betreft, doet Dow (1987) drie mogelijkheden aan de hand: intentionaliteit, leerprocessen en het concurrentiemechanisme. Alle drie kennen echter hun beperkingen.

\section{Intentionaliteit}

Economische organisatievormen worden ontworpen door een 'zichtbare' hand; de actor kan ex ante beoordelen, welke economische organisatie voor zijn type transacties het meest efficiënt is, dat wil zeggen tegen de laagste kosten in staat is aanpassingen aan veranderende omstandigheden te realiseren. Probleem is echter, dat het uitgangspunt van de beperkte rationaliteit zo'n ex ante kennis in de weg staat.

"this leaves a dilemma: if bounded rationality rules out comprehensive contracting, than good intentions alone cannot ensure adaption of efficient governance structures either"

(Dow 1987, 27) [29].

\section{Leerproces}

Door 'organisational learning' overleeft de meest efficiënte organisatievorm. Deze wisie is twijfelachtig, omdat in organisaties 'routines' ontstaan, waardoor rigiditeiten - versterkt door 'sunk costs' - aanpassingen op basis van een leerproces in de weg staan. Dow $(1987,29)$ wijst erop, dat in een organisatie incentives bestaan om juist eenmaal in gang gezette projecten te continueren [30]. Partijen in een organisatie kunnen juist informatie achterhouden, of verstoren, met het doel verworven posities te behouden, waardoor geen sprake is van een leerproces, waaruit de meest efficiënte organisaties overblijven.

\section{Concurrentiemechanisme}

Onder de tucht van de concurrentie worden efficiènte organisatievormen geïmiteerd; als de marktpartijen niet tot de meest efficiënte 'governance structures' overgaan, zullen zij van de markt gedrukt worden. De concurrentie draagt zorg voor een selectie, 
maar of zo'n selectie aannemelijk is, hangt in hoge mate af van de omgeving; is sprake van frequente, eenvoudige taken en wan vrije toe- en uittreding, dan is het aarschijnlijk $k$, dat in de concurrentiestrijd de meest efficiënte ondernemingen overleven. Als echter sterk geintegreerde ondernemingen opereren op sterk geconcentreerde markten met hoge toe- en uittredingsbarrières, is twijfel omtrent het selectieproces van de 'survival of the fittest' op zijn plaats [31].

\section{Concluste}

Gebleken is, dat de transactiekostentheorie operationaliseringsproblemen kent, waardoor een onafhankelijk criterium ter beoordeling wan de efficientie van economische organisatievormen ontbreekt en een cirkelredenering van 'What is, is best dreigt. De transactiekostentheorie is gebaseerd op het methodologisch individualisme, waardoor andere verklaringen dan het maximaliserend of minimaliserend gedrag van individuele actoren buiten beschouwing blijven en met name de rol van de overheid sterk wordt onderbelicht. Zoals wij in 3.1.2.4 bij de bespreking van de L'école française d'économie industrielle zullen zien, kunnen bij de verklaring van economische organisatievormen naast economische efficięntiefactoren tal van andere variabelen in het spel zijn. Naast historische en culturele factoren kunnen ook politieke, sociologische en psychologische variabelen een rol spelen. Beantwoording van de vraag welke factoren voor de verklaring van 'governance structures' relevant zijn en of de betreffende organisatievorm efficiënt is, dient het resultaat te zijn van nauwkeurig multidisciplinair micro-onderzoek en een gedetailleerde kosten- batenanalyse.

Williamson staat op het standpunt, dat de 'core purpose en de 'main issue' van 'governance structures' het verbeteren van de efficientie is. Hij en anderen [32] zetten in hun verklaring van het ontstaan van organisatievormen wel uiteen, welke functie die 'governance structures' voor de actoren vervullen, maar verzuimd wordt een causale verkllaring te leveren [33], waarin de interactie tussen factoren van verschillende aard (economisch, sociologisch, historisch etc.) zichtbaar wordt gemaakt. Het aanvoeren van argumenten waarom de ene governance structure kosten bespaart ten opzichte van een andere organisatievorm geeft de transactiekostentheorie een comparatief-statisch in plaats van een dynamisch verklarend karakter [34]. Het is duidelijk, dat van de diverse 'govermance structures' steeds kan worden aangegeven, dat zij een functie vervullen in een wereld vol onzekerheid en bevolkt met zich opportunistisch gedragende actoren. Maar dat is iets anders dan een verklaring geven van het causale proces, waaruit zij zijn ontstaan.

Hoewel Williamson ook van mening is, dat 'a more fully developed theory of the selection proces' noodzakelijk is (Williamson 1985, 22-23), is hij er vooralsnog van overtuigd, dat machtsconstellaties weliswaar aanpassingen in de richting van efficiënte organisaties enige tijd kunnen vertragen, maar dat uiteindelijk ( ...) 'the distribution of power within the firms endogenous is and is determined by efficiency needs (Williamson en Ouchi 1981, 363-364) [35]. Daar staan andere opvattingen tegenover. Zo zet Willman (1983) uiteen, dat de machtsverhoudingen tussen bijv. werkgevers en werknemers exogeen wordt bepaald door de situatie op de arbeidsmarkt. Dow $(1987,31)$ wijst erop, dat juist in een organisatie, waarin partijen door hun idiosyncratische kennis veroordeeld zijn tot bilaterale ruilsituaties geen van de partijen een prikkel 
heeft buiten de organisatie efficiëntere 'govemance structures' te construeren. Immers, het elders opbouwen van dergelijke relaties is niet gemakkelijk, omdat anderen bewogen moeten worden te investeren in "asset specificity".

"The implication for transaction cost analysis is that when asset idiosyncrasy is significant, sunk cost will partially insulate internal organization from market forces, and hence selection pressures toward efficiency will be attenuated" (Dow 1987, 31).

Alvorens kan worden geconcludeerd, dat economische organisatievormen het resultaat zijn van efficiëntiestreven van individuele actoren en dat in het economisch systeem sprake is van selectiemechanismen, die ervoor zorg dragen dat de meest efficiente organisatievormen overleven, dient uit onderzoek te blijken welk complex van interdependente variabelen mogelijk een rol heeft gespeeld. De transactiekosten= thearie kan daarbij een belangrijke heuristische funktïe vervullen en biedt voor zo'n multi-disciplinair onderzoek waardevolle concepten, die voor nadere invulling met specifieke gegevens van plaats en tijd in aanmerking komen [36].

\subsubsection{De behavioristische lijn}

\subsubsection{Inleiding}

Het 'behaviorism' wordt door Machlup (1967) omschreven als de theoretische benadering, waarbij niet a priori wordt uitgegaan van ondernemingsgedrag gericht op éen specifiek doel, zoals bij het winstmaximaliserend gedrag in de marginalistische theorieèn

"Instead we are directed to observe how businessmen really act and by what process they reach decisions" (Machlup 1967,4).

Op basis van die feitelijke waarnemingen zou een 'behavioral theory of the firm' kunnen worden geconstrueerd. Op basis van empirisch onderzoek is door 'behavioristen' geconstateerd, dat een diversiteit van ondernemingsdoelen voorwerp is van onderhandeling tussen wisselende coalities van groepen binnen de onderneming. Vergroting van de groei van de omzet, de winst, het dividend, het loon, de investeringen en het marktaandeel zijn voorbeelden van doeleinden, waarover de groepen strijd leveren. In de zogenaamde 'managerial theory of the firm' wordt benadrukt, dat het management beschikt over discretionaire ruimte ten opzichte van de aandeelhouders, welke hen de mogelijkheid biedt eigen doeleinden te realiseren, waaronder uitbreiding van hun staf, verhogen van salaris en onkostenvergoedingen en dergelijke (vergelijk de principaalagent-problematiek in 1.2.1 en Dow (1987); Putterman (1987)). Omdat het management niet onbegrensd haar eigen doeleinden kan nastreven, maar naar een evenwicht tussen de belangen van de diverse participanten dient te zoeken, kan worden gesteld dat $_{\text {}}$ ondernemingen een optimale mix van diverse doeleinden nastreven volgens een zoekproces, dat is gericht op 'satisficing' in plaats van op maximalisatie of minimalisatie van één doel (Hagedoorn 1984). Lambers (1967) leidde in dat verband uit de algemene doelstelling van 'het verwerven van een blijvend inkomen voor de participanten' een aantal sub-doelstellingen af: vergroting of behoud van het marktaandeel, 
vergroting van de winst, verhoging van de $\mathrm{R}$ en $\mathrm{D}$ uitgaven etc, waaruit de ondernemer een optimale mix moet samenstellen (vergelijk Schotman 1984, hoofdstuk 3).

In behawioristische theorieèn van de onderneming is ruimte voor een groot aantal gedragsalternatieven van het management en de andere belanghebbenden. Kan op basis van het waargenomen veelsoortige gedrag een theorie worden geconstrueerd? In deze paragraaf bespreken wij achtereenvolgens de behavioristische versie van het SCP-benadering van Scherer, de dynamische markttheorie van De Jong en de meer bedrijfskundige benadering van Porter. Wij sluiten af met een bespreking van de 'l'école française d'économie industrielle', waarin de netwerkbenadering (filière, mésosystème) een centrale plaats inneemt.

\subsubsection{Wisselwerking tussen structuur, gedrag en resultaat: Scherer (1970)}

Schema 3.4 Een analysemodel van de industriële organisatie [38]

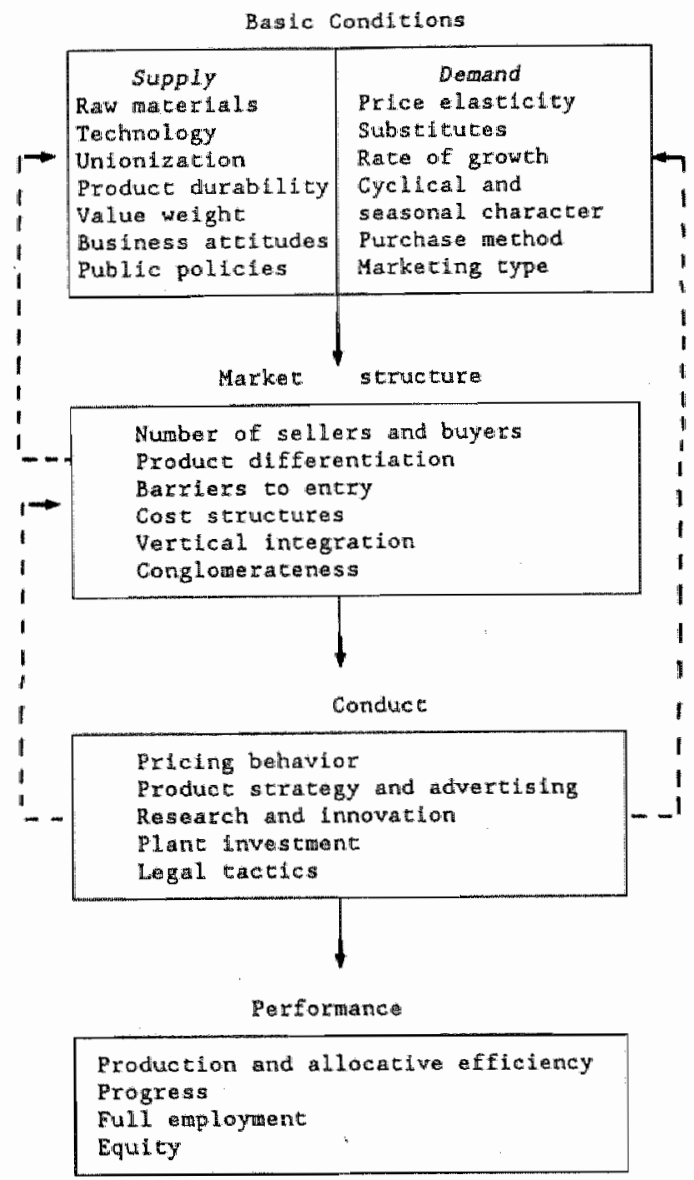

Bron: Scherer 1970, 4 
Scherer (1970, introduction) noemt zichzelf een behaviorist, omdat hij in tegenstelling tot Bain (1956) het gedrag van de marktpartijen expliciet als schakel tussen de structuur en het resultaat in zijn theorie opneemt. Volgens Scherer zal nauwgezet microeconomisch onderzoek van het gedrag van de actoren niet alleen leiden tot betere voorspellingen, maar ook inzicht verschaffen in het vraagstuk waaróm een specifieke structuur leidt tot een specifieke uitkomst. Hoewel Scherer zichzelf een behaviorist noemt is in zijn benadering geen grote plaats ingeruimd voor het strategisch management [37].

Scherer $(1970,4)$ presenteert 'a model of industrial organization analysis' (zie schema 3.4).

Het resultaat van het marktproces in termen van efficiënties, macro-ontwikkelingen en verdeling wordt bepaald door het gedrag van de actoren, hetwelk afhankellijk is van de marktstructuur en de 'basic conditions', waaronder bijv. de normen en waarden ten aanzien van concurrentie en samenwerking. De onderbroken pijlen geven aan dat ook van een omgekeerde invloed sprake is. Die wisselwerking tussen gedrag en structuur krijgt een meer expliciete plaats in de benadering van De Jong (1981b).

\subsubsection{De dynamische markttheorie van De Jong (1981b)}

De dynamische markttheorie (DMT) verschaft inzicht in de krachten, die steken achter de marktontwikkeling en werpt licht op de mogelijkheden en beperkingen van de ondernemers hun omgeving, i.c. de marktstructuur, te beïnvloeden. De krachten, die in de DMT een rol spelen zijn van andere aard dan de factoren die wij in de transactiekostentheorie zijn tegengekomen: de technologische ontwikkeling, de marktverzadiging en de activiteit van de ondernemers als groep zijn de basis actoren, terwijl de wisselwerking tussen gedrag en structuur leidt tot een inhoud van het concept 'marktstructuur', dat afwijkt van dat van Scherer.

\section{Probleemstelling en enkele begrippen}

Verklaring van de ontwikkeling van de marktstructuur in een bedrijfstak is de probleemstelling van de DMT. Daartoe wordt de theoretische produktlewenscyclus als analytisch kader gehanteerd: vier fasen van introduktie, expansie, rijpheid en stagnatie kunnen elk worden gekarakteriseerd aan de hand van de aard van het produkt, de technologische ontwikkeling en de marktverzadiging, die tezamen resulteren in de zogeheten structurele concentratiegraad; vergelijking van die graad met de feitelijke concentratiegraad kan inzicht verschaffen in de strategieen van ondernemers ten aanzien van de organisatie van de markt. Alvorens een en ander nader toe te lichten worden twee centrale begrippen nader gespecificeerd: marktstructuur en marktsituatie.

De Jong (1981b, 103-105) zet uiteen, dat in een dynamische benadering structuurkenmerken enerzijds als 'actieveld' en 'actieresultaat' van het ondernemersgedrag dienen te worden opgevat, maar anderzijds ook als randvoorwaarden, die het gedrag van actoren conditioneren. Om die tweelledigheid in zijn theorie te kunnen inbrengen, makt De Jong onderscheid tussen de marktstructuur, die door ondernemers voortdurend kan worden gevormd en omgevormd en de marktsituatie, die conditionerend werkt. 
"Het begrip marktstructuur wordt hier beperkt tot het aantal en de geledingen van de totale groep actuele aanbieders en vragers en hun potentiële equivalenten, alsmede tot de onderlinge verhoudingen tussen deze marktpartijen" (De Jong 1981b, 104).

Marktstructuur duidt op het aantal marktpartijen, de grootte, de onderlinge grootteverhoudingen, mate van concurrentie, collusie en samenwerking. De marktsituatie betreft een samenhangend geheel van vraag- en aanbodfaktoren, dat op een gegeven moment, of gedurende een korte periode de markt van een specifiek produkt kenmerkt (produktdifferentiatie, toetredingsbarrières en dergelijke). De marktontwikkeling is de opeenvolging van marktsituaties tijdens de produktlevenscyclus, die in theorie een 'zekere eenheid van karakter' hebben. Deze conditioneren het gedrag van de ondernemers in die 'periode': niet dat het gedrag door de situatie wordt gedetermineerd, zoals in de structuralistische SCP-benadering, maar wel legt de marktsituatie beperkingen op met betrekking tot het effectief gebruik van de actieparameters door de ondernemers. Door het onderscheid marktstructuur en marktsituatie wordt de structuur 'versmald' tot die elementen van de omgeving, die de ondernemers voortdurend kunnen omvormen. Daardoor worden ook elementen, die in de SCP-benadering ook tot de marktstructuur behoren (schaalwoordelen, structurele toetredingsbarrières) door de DMT daar niet toegerekend en onder de marktsituatie gevat. Wat is nu de plaats van de ondernemersstrategie met betrekking tot de organisatie van de markt in de DMT? Wij bespreken eerst de krachten, die achter de marktontwikkeling schuil gaan om vervolgens de mogelijkheden en beperkingen van ondernemersstrategieèn duidelijk te maken.

\section{Krachten achter de marktontwikkeling}

Vier krachten worden onderscheiden:

- Technologie

De technologische ontwikkeling heeft invloed op de aanbodzijde van de markt: een voortdurend technologische ontwikkeling gedurende de levenscyclus wordt verondersteld, die leidt tot een mechanisatie en toename van het constant kapitaal, waardoor de optimale ondernemingsgrootte in de loop van de cyclus groeit.

- Verzadiging

Onderscheid wordt gemaakt tussen de feitelijke marktomvang $\left(M_{a}\right)$ en de potentiële omvang, zoals gepercipieerd door de ondernemers (Md). In de loop van de cyclus vindt een ontwikkeling naar marktverzadiging plaats.

- Handelingen van de ondernemers als groep.

"De ondernemers kunnen steeds de marktstructuren vormen en omvormen. De wijze en snelheid van reaktie van de ondernemers op de veranderingen in de conditionerende faktoren bepalen tot op grote hoogte hun succes of mislukking. Tegelijkertijd drijven zij door hun handelingen als groep (de succesrijke ondernemers bepalen daarbij tempo en marsroute) de marktontwikkeling vooruit in overeenstemming met techniek, marktverzadigingsgraad en extern werkende oorzaken" (De Jong 1981b, 105).

- Externe oorzaken

Ontwikkelingen buiten de bedrijfstak kunnen van invloed zijn op de marktontwik- 
keling binnen de bedrijfstak. Zo zal bijv. de innovativiteit van de machinebouwsektor van invloed zijn op de optimale ondernemingsgrootte in de andere bedrijfstakken. De krachten achter de marktontwikkeling zijn van invloed op de zogeheten 'structurele concentratiegraad".

\section{Structurele en feitelijke concentratiegraad}

De structurele concentratiegraad is een norm, die aangeeft hoeveel ondernemingen optimaal in de bedrijfstak kunnen opereren, gelet op de optimale ondernemingsgrootte en de omvang van de markt. Op grond van een vergelijking van die norm met de feitelijke concentratiegraad kunnen uitspraken worden gedaan over te verwachten ondernemingsstrategieën met betrekking tot de organisatie van de markt.

Zijn er op de markt meer ondernemingen dan de norm aangeeft, dan zal de concentratie plaats vinden door middel van prijsconcurrentie, kartelvorming, fusie en dergelijke. Is het omgekeerde het geval, dan is sprake van toetredingsbarrières. Eén en ander is samengevat in schema 3.5 .

Schema 3.5 Samenvatting van de dynamische markttheorie

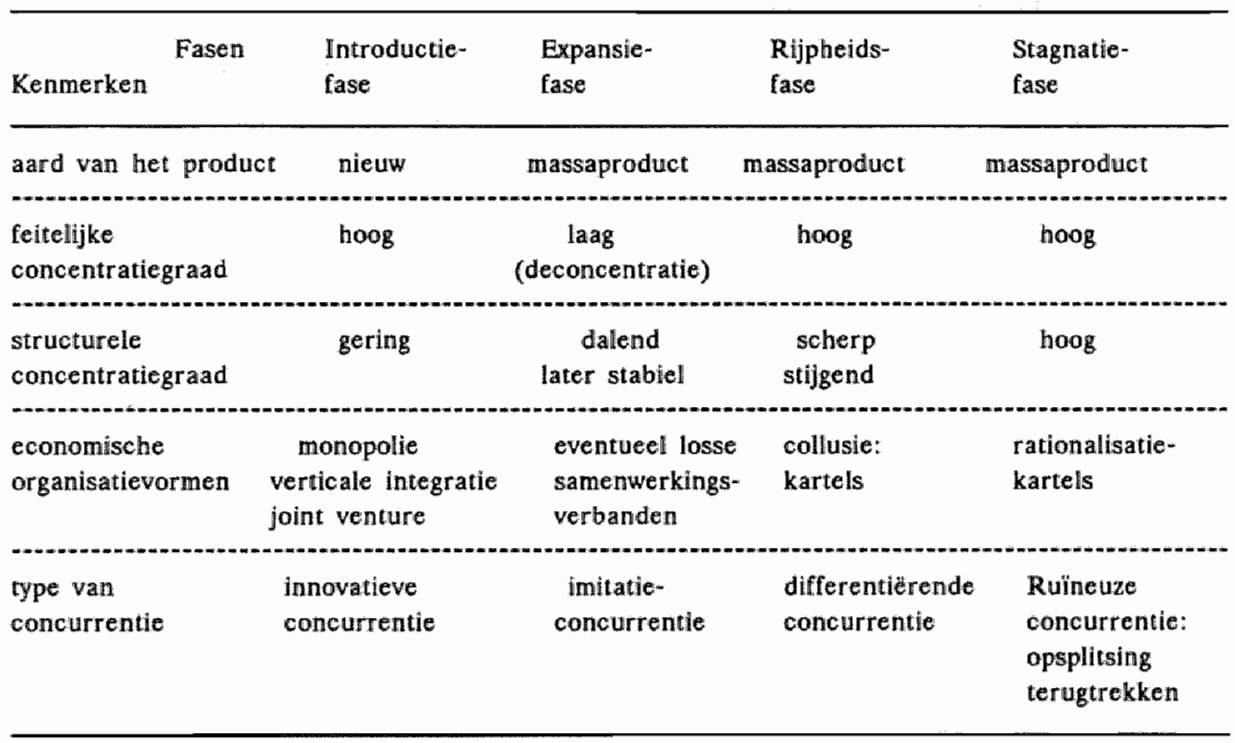

Het basismodel van de DMT kent vanzelfsprekend operationaliseringsproblemen (wat is de relevante markt, hoe de concentratiegraden te berekenen?), maar dat neemt ons inziens niet weg dat de DMT een denkstructuur verschaft, waarmee het strategische gedrag van ondernemingen met betrekking tot de organisatie van de markt kan worden geanalyseerd. Duidelijk wordt welke invloed exogene faktoren als de technologie en de preferenties hebben, hoe het collectieve ondernemersgedrag de marktontwikkeling al dan niet kan 'voortdrijven', hoe het ondernemersgedrag enerzijds wordt geconditioneerd, maar hoe anderzijds van vrijheidsgraden sprake is. De introduktie 
wan de dynamiek, de wisselwerking tussen structuur en gedrag, en het verlaten wan de neoklassieke actor mel één beslisregel, heeft tot gevolg dat de theorie niet meer tot eenduidige uitspraken komt in de trant van structuur ' $S$ ' leidt tot gedrag ' $G$ ' en uitkomst ' $P$ '.

De DMT resulteert in zogenaamde 'geconditioneerde' uitspraken in de trant van: 'gelet op de asymmetrische grootteverhoudingen, het bestaan van een nauw oligopolie, een homogeen produkt, identieke kostenfuncties, een stagnerende markt en een geringe prijselasticiteil, zal in de toekomst concentratie plaatswinden, waarbij niet de weg wan een prijzenoorlog voor de hand ligt, maar fusies zullen worden aangegaan'. (vergelijk De Jong 1981b, 153).

\subsubsection{Een bedrijfskundige benadering: Porter (1980; 1985)}

Vanaf het midden van de jaren zeventig is meer aandacht ontstaan voor het strategisch gedrag van (groepen) ondernemingen. Theorievorming op het terrein van ondernemingsstrategieên draagt veellal een normatief karakter: managers dienen in concrete situaties de concepten toe te passen volgens de receptuur van de onderzoeker, opdat zij een hoger rendement kunnen realiseren. De theorie biedt de manager een conceptueel kader, waarmee de situatie van de bedrijfstak en de positie van de betreffende onderneming in kaart kunnen worden gebracht en geeft vervolgens aan uit welke strategieën kan worden gekozen ter werbetering van de concurrentiepositie [39]. Wat de analyse van de bedrijfstak betreft onderscheidt Porter (1980) vijf essentiële krachten, die zijn weergegeven in schema 3.6 .

Schema 3.6 Vijf concurrentiekrachten van Porter

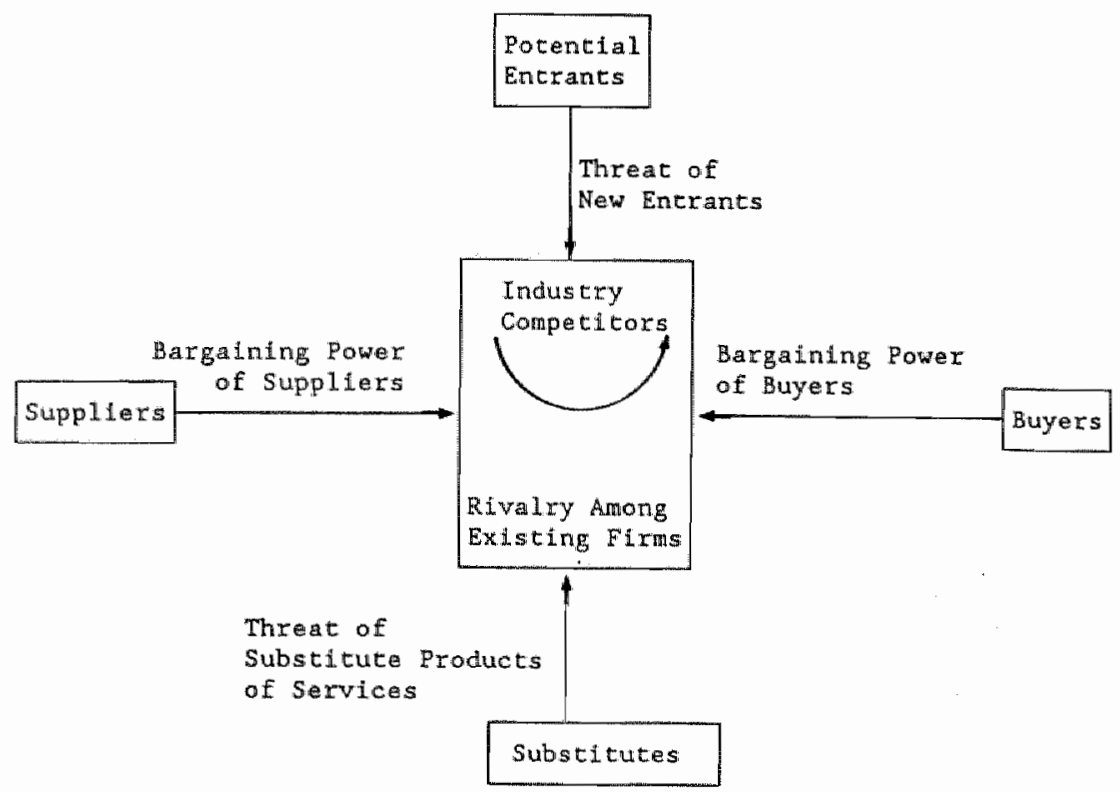

Bron: Porter $(1980,5)$ 
De winstmogelijkheden van de ondernemingen in de bedrijfstak worden bepaald door de combinatie van de vijf krachten: zo wordt de hoogte van de prijzen van de eindprodukten bepaald door de macht van de afnemers, de concurrentie tussen de aanbieders en de dreiging van substituten. Welke krachten werkzaam zijn in een specifieke bedrijfstak wordt bepaald door de structuur (concentratiegraden) en de onderliggende economische en technologische karakteristieken van het produkt en het produktieproces, die van invloed zijn op de efficiènte schaal, benodigde $\mathrm{R}$ en $\mathrm{D}$, substitutie van grondstoffen etc. (zie schema 3.7).

\section{Schema 3.7 Nadere specificatie van de vijf concurrentiekrachten van Porter}

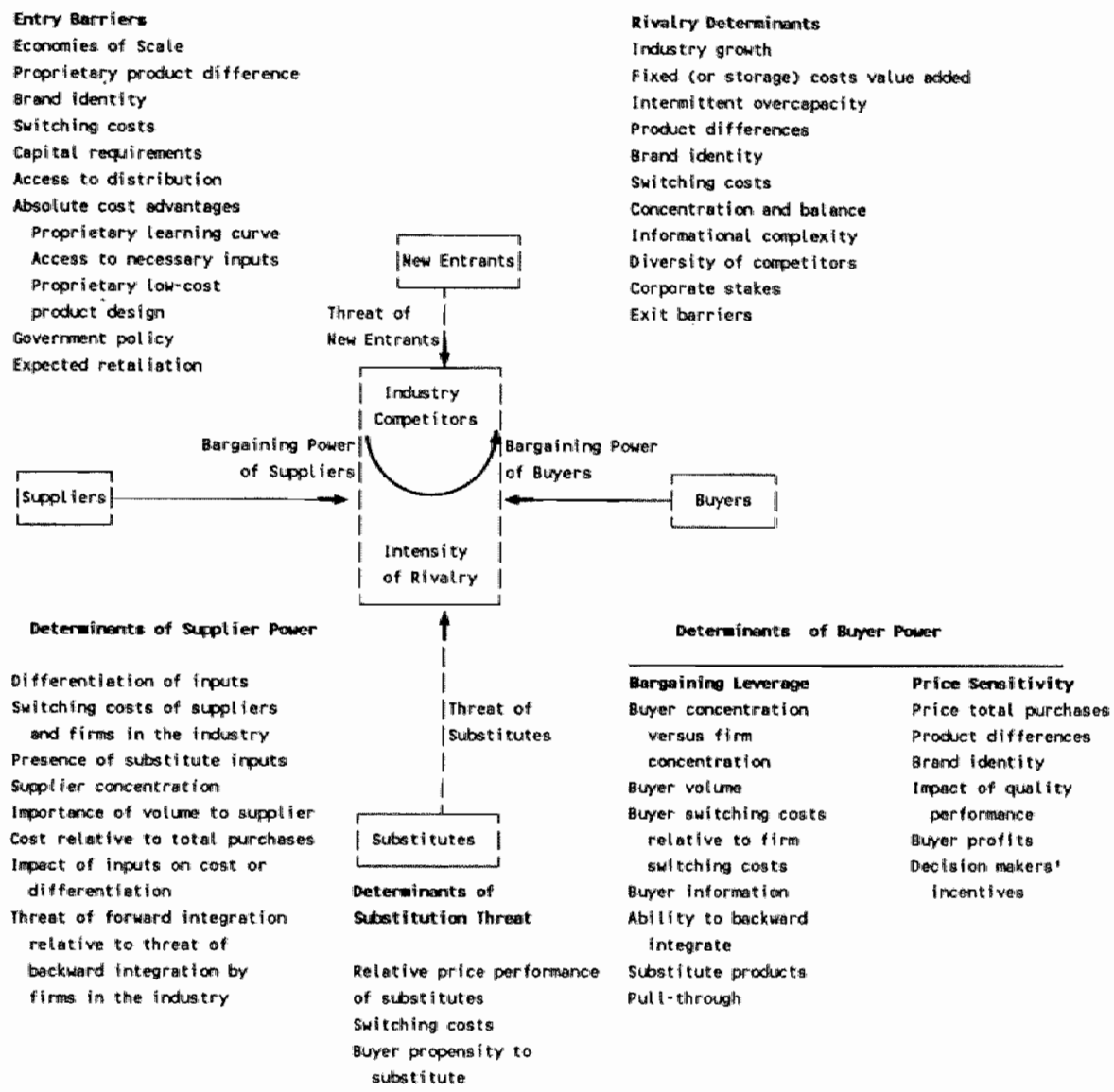

Bron: Porter $(1980,7)$

Wat de positie van de onderneming in de bedrijfstak betreft, ontwikkelt Porter (1985) het concept van de waardeketen ('value chain'), hetwelk een methodiek is voor het bepalen van de concurrentiepositie van de onderneming aan de hand van het ontleden 
van de activiteiten en hun onderlinge relaties. Desaggregatie van de strategisch relevante ondermemingsactiviteiten kan een beter inzicht verschaffen in het kostenverloop en in de bestaande en potentièle bronnen van differentiatie. Een analyse volgens de 'value chain' heeft met name oog voor de interdependenties, de synergieen tussen de activiteiten wan de ondernemingen tussen de 'value chain" van de onderneming en die van haar afnemers en toeleveranciers (Porter 1985, 48-52) [40].

In verband met het bovenstaande zijn nog twee andere concepten uit de benadering van Porter vermeldenswaard: de 'strategic group' en de 'mobility barrier'.

Met behulp van het eerste concept kan de heterogeniteit van de markt in kaart worden gebracht: ondernemingen binmen de bedrijfstak kunnen worden geclusteerd tot groepen, die dezelfde strategie ontwikkelen. Nauw verbonden daarmee is het concept van de "mobility barrier": niet alleen toetreding, ook uittreding of algemener: mobiliteit en derhalve ook belemmering van mobiliteit worden relevant voor de analyse (Van der Weijden 1987, 103).

De theorie van strategisch management levert niet alleen concepten voor de analyse van de ontwikkellingen in een bedrijfstak en de positie van een specifieke onderneming, maar toont ook de keuzevraagstukken waar het management na zo'n analyse voor wordt geplaatst. Keuzen zullen moeten worden gemaakt in verband met het bestaan van een aantal 'trade-offs' (Romme 1987):

- de onderneming kan pogen een sterkere concurrentiepositie te veroveren door zich geheel te richten op een 'uniqueness perceived by the customer' (differentiatie in Porter 1980), of de onderneming kan pogen een kostenvoordeel te realiseren door zich geheel te richten op de produktie van massagoederen;

- ondernemingen, die aan het begin van de produktlevenscyclus staan en in een relatief onzekere omgeving opereren, staan voor de keuze zich door middel van grote investeringen vast te leggen op eén van de potenties van het nieuwe produkt (belemmert mobiliteit), of zich nog niet te binden en diverse opties open te houden. In een vroeg stadium kiezen voor één potentie kan een 'first mover advantage' (Williamson 1975) opleveren, doordat het leerproces eerder start, de consument zich aan een specifiek merk bindt, patenten worden verkregen, of de levering van een specifieke grondstof veilig kan worden gesteld;

- ondernemingen staan voor de keuze een groot aantal activiteiten te ontplooien met het doel daartussen synergie-effecten te creëren (vergelijk 'economies of scope' in Teece 1980), of het aantal complementaire activiteiten juist te beperken, omdat eventuele problemen met éen activiteit zijn weerslag hebben op de ermee verbonden activiteiten.

Samenvattend kan worden gesteld, dat de economische inbreng in de theorieën van strategisch management sterk verbonden blijkt met en haar vertrekpunt heeft in de behavioristische SCP-benadering. Diverse hierboven besproken concepten zijn ten behoeve van het management ontwikkeld, waarmee de situatie van de bedrijfstak en de concurrentiepositie van de eigen onderneming kunnen worden geanalyseerd. Daarbij wordt de analyse niet a priori beperkt tot één of enkele verklarende variabelen, maar wordt uitgegaan van een breed scala relevante factoren, waardoor in de theorieên van strategisch management diverse disciplines worden geïntegreerd. Een interessante aanzet daartoe is gegeven door Barney en Ouchi (1986). Zij trekken parallel- 
len tussen economische microtheorieèn en organisatietheorieën (zie schema 3.8) en wijzen op het belang van een 'multi level analysis' van organisatievraagstukken. In zo'n aanpak verbreedt de analyse zich vanaf het individu, via de groep, de intergroeprelaties, de organisatie, de interorganisationale relaties tot uiteindelijk de relatie tussen de organisatie en de omgeving. Parallel daarmee verbreedt de disciplinaire basis zich van de psychologie, wia de sociologie tot de politicologie en anthropologie. Barney en Ouchi $(1986,432)$ constateren, dat zulk "multi-niveauonderzoek $k^{\text {ti }}$ zeldzaam is, hetgeen zij wijten aan de identificatie wan een specifieke wetenschap met een specifiek analyseniveau, waardoor elk niveau zijn eigen veronderstellingen, taal en methode kent. Integratie van verschillende denkstructuren blijkt uiterst moeilijk, waardoor het begrijpelijk is dat de theorie of de weg van integrale, maar zeer abstracte theoriees n heeft gekozen, of één analyseniveau als uitgangspunt heeft genomen zonder van daaruit de 'série à l'américaine' te spelen [41].

Een interessante poging concepten van verschillend analyseniveau uit diverse disciplines te integreren tot een theoretisch kader ter verklaring van het ontstaan en de dynamiek van economische organisatievormen is ondernomen in de Franse 'Theorie Economie Industrielle'.

Schema 3.8. De ingrediënten van een theorie van economische organisatievormen

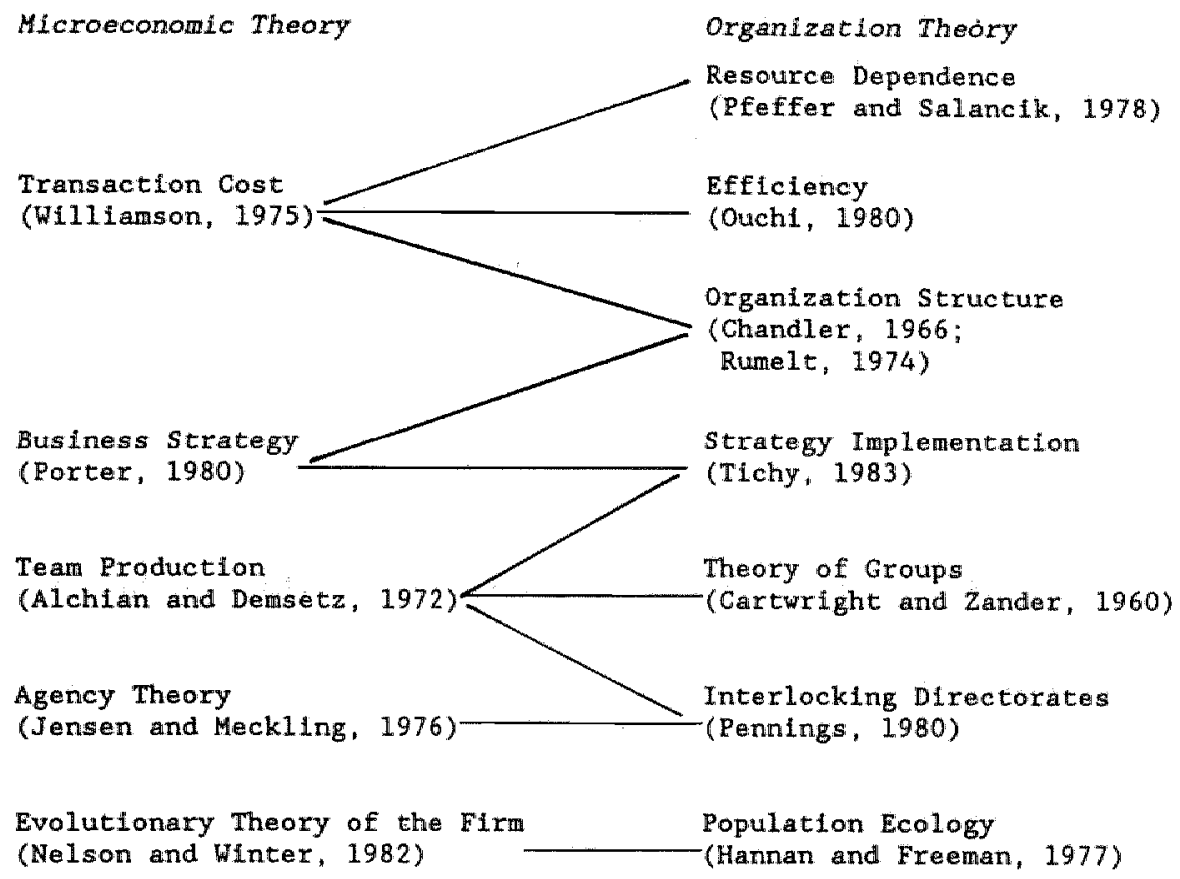

Bron : Barney en Ouchi $(1986,14)$ 


\subsubsection{L'école françalse d'économie industrielle}

In Frankrijk is de 'Théorie Economie Industrielle" (TEI) aanvankelijk in de voetsporen getreden van de SCP-benadering. Vanaf het midden van de jaren zeventig werden echter eigen accenten gelegd (Bellon 1983; Marchesnay 1984); accenten, die verband houden met de specifieke kenmerken van de Franse industriële structuur, de rol van de overheid in het economisch leven en de gevolgen van de economische crisis vanaf 1975.

Wat de industriële structuur betreft, blijken familieondernemingen in de Franse structuur relatief belangrijk te zijn, waardoor de problematiek rond de scheiding van eigendom en kapitaal (Berle en Means these) geen grote rol speelt in de Franse theorievorming. Daarentegen maakt de bestudering van de vorming van industriële groepen langs historische, financiële en institutionele lijnen wel een belangrijk onderdeel uit van het onderzoeksprogramma van de TEI (Bellon 1980), evenals het bestuderen van de industrièle groep op meer abstract theoretisch niveau (Montmorillon, 1986).

Wat de rol van de overheid betreft, blijkt 'L'Etat' sterk initięrend en organiserend op te treden. Het ligt voor de hand, dat de rol van de overheid in het theoretische conceptuele kader voor de verklaring van de strategie van ondernemingen een belangrijke plaats heeft gekregen.

Wat de gevolgen van de economische crisis betreft blijkt, dat in Frankrijk vanaf 1975 in toenemende mate werd gezocht naar een theoretische onderbouwing van een specifiek industriebeleid, dat is gericht op het creèren van hechte netwerken van industriële structuren, die Frankrijk een sterkere concurrentiepositie moeten verschaffen (vergelijk hoofdstuk 6). Concepten als 'filière' en 'mésosystème' werden ontwikkeld, die zowel bruikbaar werden geacht voor het analyseren van ondernemingsstrategieën (zie 3.1.2.5) als voor het ontwikkelen van een specifiek industriebeleid (zie 3.2.2.1).

Het hebben van enerzijds meer oog voor de invloed van historische faktoren op het gedrag van actoren en andlerzijds het hechten van een groter belang aan de invloed van met name het overheidsbeleid op de ontwikkeling van de structuren, leidden tot onderstaande Franse versie van het schema van Scherer.

Het verschill tussen de Franse en de Angelsaxische benadering blijkt uit de toelichting van Bellon (1983, 50-51).

"Notons que, contrairement à la perspective angllosaxonne, les conditions de
base et les structures ne sont pas posées comme existant en soil. Elles sont le
produit de l'histoire: évolution technologique (dimension objective), dynamique
conflictuelle des firmes, des groupes, des Etats (dimension subjective)".

In tegenstelling tot de Angelsaxische industriële economie heeft in Frankrijk sterk de nadruk gelegen op de invulling van de algemene concepten met specifieke condities van plaats en tijd [42], waarbij de verschillende elementen van de economische en socio-politieke omgeving in acht moeten worden genomen.

"Chaque firme (groupe) doit eêtre étudiée sous l'angle du contrôle (public, privê majoritaire ou minoritaire, interne), et sous l'angle des structures de production (intégration verticale, structure congloméralle) de facon que les objectifs des offreurs puissent eêtre mis en évidence" (Bellon 1983, 50) [43]. 
Schema 3.9 De Franse versie van het model van Scherer

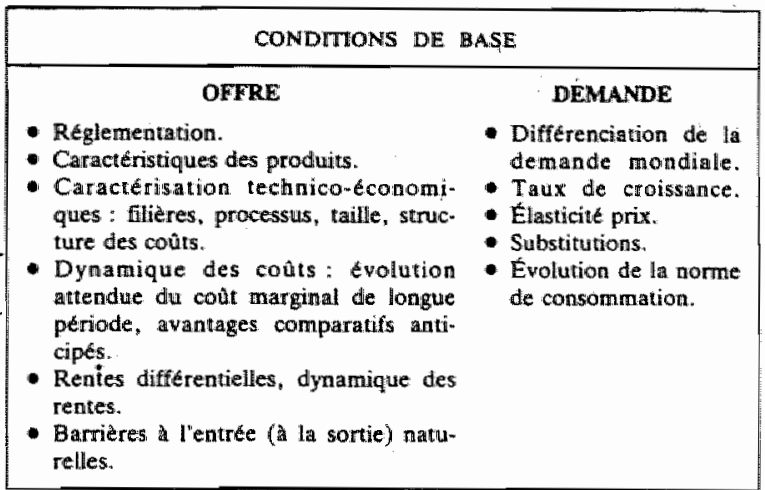

\section{STRUCTURE DES MARCHES}

- Typologie des produits et des marchés: dimension locale, nationale, régionale ou internationale des marchés.

- Nombre de vendeurs et d'acheteurs.

- Structure de contröle des principaux offreurs, fonction objectif des entreprises.

- Structure de production des principaux offrewrs (integration verticale, dimension congloméralle).

- Structure des réseaux de distribution.

- Dynamique des rapports de forces.

- Présomption de concurrence réelle, existence d'une concurrence potentielle.

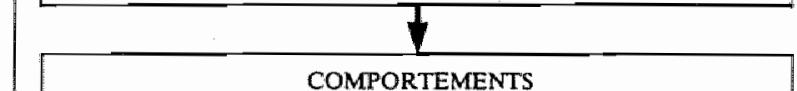

- Stratégie de production (qualité, durée, différenciation, innowation, investissements, génération de capital).

- Stratégie de prix (concurrence VS non-concurrence, ententes, collusion, discrimination, squeeze, dumping).

- Stratégie de R/D (part de la R/D, utilisation du potentiel scientifique, concurrence par innovation).

- Strategie de publicité.

- Strategie de barrières a lientrée.

\section{PERFORMANCES}

- Dynamique de la concurrence (profilt-incitation a l'entrée, entrée, sortie, niveau des prix).

- Technologie (positionnement sur le marche mondial, Evolution de la productivité, innovation, balance technologique).

- Emploi (evolution quantitative et qualitative).

- Echanges exterieurs.

- Coûts sociaux (conditions de travail, pollution, risques).

- Intérêts privés VS intérêts publics.

Bron: Bellon $(1983,14)$

Een concept, dat zowel in het kader van de analyse van de ondernemingsstrategie als voor het ontwikkelen van een 'véritable politique industrielle' vanaf 1975 in het centrum van de (Franse) belangstelling heeft gestaan is de 'filière". 


\subsubsection{5 'Filière' en ondernemingsstrategle}

De 'filière' is een theoretisch concept, dat enerzijds is ontwikkeld voor het beschrijven van de industriële structuur van een land (de zogenaamde statistische 'filière" zie 3.2.2.1) en anderzijds voor analyseren van de ondernemingsstrategie in een onzekere, complexe omgeving. In deze paragraaf wordt het 'filiere"-concept besproken als kader van de analyse van ondernemingsstrategieën met betrekking tot de organisatie van de markt.

De 'filière' kan worden opgewat als het netwerk van relaties, dat een actor met zijn omgeving heeft opgebouwd. Het gaat daarbij zowel om de onderlinge leveringen (bijv. subcontracting), de financiele verbindingen (bijv. wederzijdse deelnemingen), de uitwisseling van technische kennis (bijv. in nationale of internationale technologieprogramma's), als om relaties van meer persoonlijke aard (bijv. het lidmaatschap van eenzelfdle 'corps d'état' (zie intermezzo II). Onderzoek in de netwerkrelatie is multidisciplinair van aard en poogt inzicht te verschaffen in de strategie van de actoren en de gevolgen van hun gedrag voor de dynamiek van het systeem als geheel [44].

Schema 3.10 De netwerkbenadering

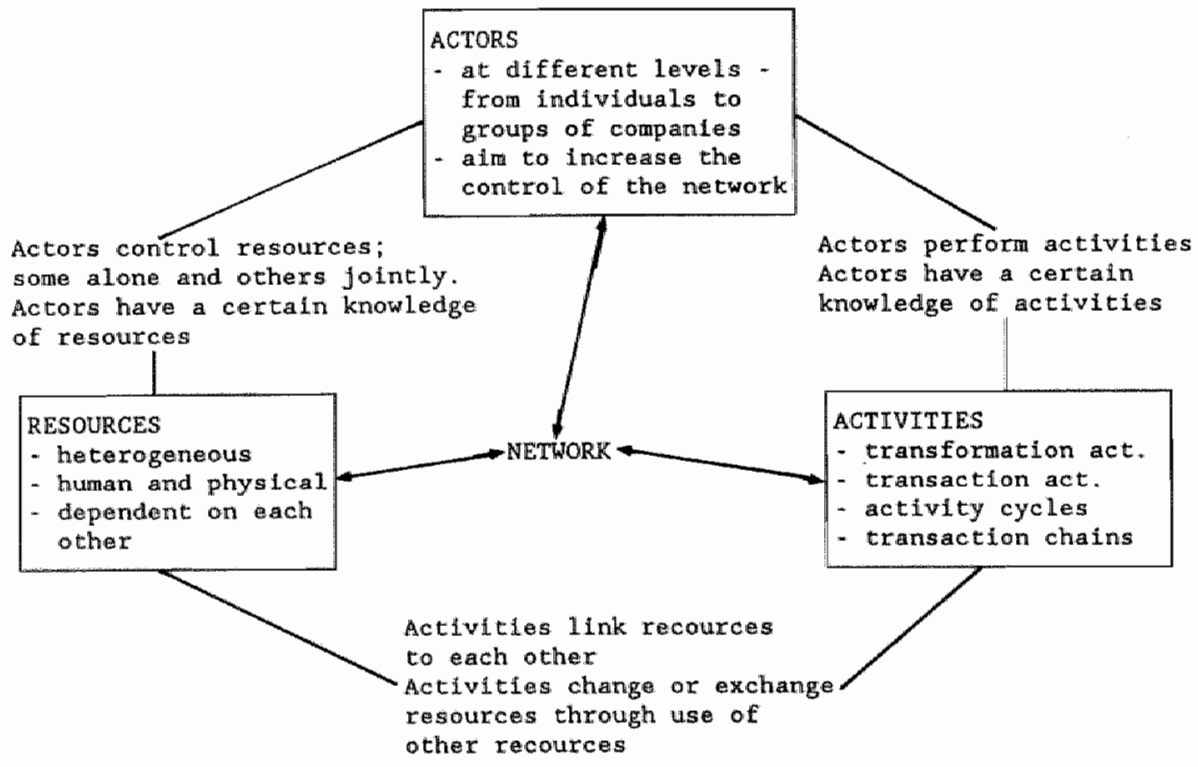

Bron: Hakansson (1986)

Netwerken zijn gebaseerd op arbeidsverdelingen tussen actoren, die interdependente activiteiten ontplooien. Ondernemingen krijgen componenten geleverd van subcontractors, werken samen met universiteiten in onderzoekprojecten, zijn nauw betrokken bij de vormgeving van beroepsopleidingen, hebben relaties met lokale, nationale en 
internationale overheidsinstanties etc. De actoren kunnen zowel individuen, groepen, ondernemingen, als groepen van ondernemingen betreffen. Naast ondernemingen worden ook actoren als vakbonden, politici, bureaucraten en wetenschappers in de analyse betrokken. In de netwerk-benadering wordt de analyse niet a priori afgebakend tot het gedrag van éen actor, bijv. de onderneming, maar wordt de analyse naar bevind van zaken uitgebreid tot in principe alle actoren, die door hun strategisch gedrag invloed uitoefenen op de dynamiek van het metwerk als geheel. Actoren pogen de onzekerheid te verminderen door beheersing van het metwerk, waarwan zij deel uitmaken. In de netwerk-benadering staat de analyse van de strategie van de actoren gericht op het verkrijgen, behouden, of uitbreiden van de beheersing van het netwerk centraal. In hoeverre een actor daartoe in staat is hangt af van zijn machtsbasis, waarvan kennis en informatie een essentieel element vormen.

De actoren ontwikkelen twee soorten activiteiten:

- transformatieactiviteiten, die het bewerken van inputs tot een output van een hogere waarde betreffen.

- transactieactiviteiten, waarbij het gaat om handelingen met betrekking tot het verkrijgen van inputs en het afzetten van de output.

In een netwerk ontstaan ketens wan activiteiten, die vanuit een oogpunt van beheersing van het netwerk, of vanuit een oogpunt van het industriebeleid van de overheid van essentieel belang zijn.

Een overheid, die een voluntaristisch industriebeleid wil voeren met betrekking tot de ontwikkeling van netwerken of 'filieres', dient nauwkeurig op de hoogte te zijn van de strategie van de actoren en de gevolgen daarvan voor de dynamiek van het mesosysteem alls geheel. Die kennis is niet alleen van belang voor het beantwoorden van de vraag, of de markt faalt en door middel van een industriebeleid correctie behoeft, maar voorall ook voor de beantwoording van de vraag welke instrumenten daarbij effectief kunnen zijn.

Geheel in lijn met het "pattern model" van Wilber en Harrison (zie hoofdstuk 1) start een netwerkanalyse met een multidisciplinair onderzoek naar de interdependenties op microniveau tussen variabelen van economische, politieke, sociologische of wat voor aard dan ook. Groot belang wordt daarbij gehecht aan het verkrijgen van historisch inzicht, omdat de machtsbasis en de strategie van de actoren dan beter begrepen kunnen worden. In tegenstelling tot de transactiekostentheorie (vergelijk Johanson en Mattson 1987) poogt de onderzoeker greep te krijgen op de dynamiek van het systeem, hetwelk het resulaat is van interne (bijv. de ondernemingscultuur), strategische (bijw. afsluiten van een joint venture) en externe krachten (bijw. de technologische ontwikkeling). Centraal staat de analyse van interdependente relaties (bijv. tussen twee ondernemingen, die een kartelovereenkomst afsluiten) en de gevolgen daarvan voor de dynamiek van het systeem als geheel (kartelvorming leidt bijv. tot een monopolie, hetgeen innovaties kan vertragen, waardoor het systeem als geheel zich minder snel aanpast).

Alvorens nader in te gaan op de strategie van de onderneming met betrekking tot de organisatie en de beheersing van het netwerk, besteden wij eerst aandacht aan de begripsvorming in de Franse literatuur. 


\section{De filière}

Van het concept 'filière" bestaat een groot aantal definities, die zich op een uiteenlopend niveau van abstractie bewegen en verschillende variabelen betreffen. De verwarring, die ook in Frankrijk zelf rond het 'filière'-concept bestaat, heeft ons inziens enerzijds te maken met de verschillende aard van de variabelen, die in de analyse een verklarende rol kunnen spelen (technische, economische, socio-politieke en historische) en anderzijds met het verschil in niveau van analyse van waaruit de onderzoeker de analyse start (micro, meso en macro).

Perez (1983, 70) definieert de 'filière' als een

"Ensemble des operations effectuées à partir d'une matière première jusqu' à la consommation directe ou indirecte de produits issus de cette matière, a partir de ces operations".

Wat de aard van de relevant geachte variabelen betreft, maakt Perez onderscheid tussen de technologische, economische en de organisatorische invalshoek.

De technologische invalshoek betreft de koppeling tussen produktiestadia, waarbij specifieke grondstoffen en intermediaire produkten in technische zin noodzakellijk zijn (geen ijzer zonder ijzererts). De economische invalshoek betreft de waardetoevoeging tussen de stadia, terwijl vanuit de organisatorische invalshoek wordt geanalyseerd op welke wijze de transacties tussen de stadia worden gecoördineerd (markt, hierarchie of samenwerking) [45].

Volgens De Bandt $(1985,82)$ dient de organisatorische invalshoek centraal te staan:

"Par ailleurs, cette conception (de filière J.G.) met fortement l'accent sur l'aspect organisationnel du sous-système: organisation des relations entre des agents hétếrogènes et modalités d'organisation des relations de coopération, qui sont susceptibles de générer des effets de synergie."

Wij merken op, dat de analyse van het organisatorische aspect van de 'filière' zich niet a priori dient te beperken tot de marktstructuur, maar ook de zogeheten saciopolitieke structuur dient te betreffen. In hun streven de omgeving te beheersen pogen ondernemers immers niet alleen de marktstructuur te beïnvloeden, maar wordt ook gepoogd greep te krijgen op pressiegroepen (vakbonden), afdelingen van ministeries en politici (vergelijk hoofdstuk 7 ).

Wat het vertrekpunt van de analyse betreft kan onderscheid worden gemaakt tussen het micro-, meso- en macroniveau.

Op microniveau wordt het gedrag van de beslissingseenheid geanalyseerd.

"En termes de gestion, la filière est le champ privilégié d'insertion de l'entreprise dans son environnement, qui doit se préoccuper dorénavant de ses partenaires et interlocuteurs en amont et en aval autant, sinon plus, que de produits ou de marchandises sur des marchés" (Laurent 1985).

De strategieèn van ondernemingen met betrekking tot de produkt-marktmix, voor- en achterwaartse integratie, aangaan van samenwerkingsverbanden en dergelijke, behoren tot het microniveau van de 'filiere'.

Het mesoriveau betreft de economische en socio-politieke structuur, welke voor de actor enerzijds het kader vormt, waarbinnen hij handelt, maar dat anderzijds mede door zijn gedrag wordt beïnvloed. 
"La filière est devenue le lieu d'expression de ce qui fait la dynamique du système capitaliste" (....) en tant que niveau intermédiaire (ou sous-systeme) entre le système productif dans son ensemble et l'entreprise (Laurent 1985; zie ook Arena 1983 en Rainelli 1983).

Op het mesoniveau kan de 'filiere" worden opgevat als een subsysteem, warvan De Bandt (1987) zegt:

"We call sub-system (in french 'meso-système') any industry, defined by a specific product category, provided account being taken of

i. both the horizontal and vertical dimensions, including the production of the capital goods,

ii. the various agents or units which are contributing to the production of the product, either directly (the production units at various stages of the production process) or indirectly (the agents which are supplying various kinds of inputs: services to enterprises, finance, R./D., training... or which are moulding the market and/or consumer behaviours: distribution, advertising...), to the extent that those agents are more of less specific,

iii. all kinds of relations among agents, be they market or non-market, competitive or cooperative relations".

Het introduceren van de 'filière' als een mesosysteem maakt het mogelijk de dynamiek van de 'filière" te analyseren.

"La fillière est constituée de plusieurs sous-systèmes plus ou moíns dépendants (les entreprises, les industries) qui poursuivent leurs objectiffs propres et réagissent aux actions d'autres systèmes. Il y a donc, dans la filière, différents acteurs-décideurs qui forment un ensemble non homogène; ces jeux entre systèmes conduisent à une hiérarchie entre entreprises, entre industries. Ces échanges et ces relations de luttes-concours entre acteurs (materialisés par exemple par l'exploitation des espaces stratégiques), ainsi que l'intégration au système productif assurent la dynamique de la filtère" (Laurent 1985) [46].

Het is van belang in dit verband op te merken, dat de 'filiere' op mesoniveau een theoretische constructie kan zijn en geen concrete beslissingseenheid behoeft te betreffen. Jacquemin en Rainelli (1984) stellen in dat verband:

"Les filières n'existent pas en tant que telles. Elles sont une construction de l'observateur, comme tout niveau intermédiair."

In die visie bevinden de actoren zich alleen op het microniveau van de onderneming. Ons inziens is het echter ook mogelijk, dat op mesoniveau van beslissingsbevoegde actoren sprake is: brancheorganisaties, kartels en publiekrechtelijke bedrijfsorganisaties, zijn voorbeelden van actoren, die als eenheid beslissingen kunnen nemen en als zodanig een aanhechtingspunt voor het industriebeleid kunnen vormen. Aan de andere kant moet worden benadrukt, dat het construeren van 'filières' op mesoniveau, veelal netwerken zal opleveren, die alleen 'constructions de l'observateur' zijn en geen beslissingseenheden.

Wat het macroniweau betreft wordt het 'filière'-concept gehanteerd als

"Un outil de politique économique; on parle de stratégies de filières par exemple en l'opposant aux stratégies de créneaux" (Laurent 1985) [47]. 
De 'filière" geeft een beschrijving van de opeenvolgende produktiestadia van een goed of dienst, welke qua opbouw en dynamiek sterk wordt beinvloed door omgevingsfactoren als de technologische ontwikkelingen en veranderingen in de preferenties enerzijds en door de strategieën van de actoren, waaronder de overheid, anderzijds. De analyse van de 'filière" maakt interdependenties, complementariteiten, afhankelijkheidsrelaties en daardoor strategische knooppunten zichtbaar, welke voor de strategie van de ondernemingen en het industriebeleid van de overheid van grote betekenis kunnen zijn.

De netwerk- of 'filière'-benadering is multi-disciplinair, waarbij de analyse zich op diverse analyseniveaus afspeelt. In dat opzicht is van een waarlijk institutionele evolutionaire ontwikkeling sprake (vergelijk bijlage 3.1): Veel van de kritiek, die in 3.1.1.4 is uitgeoefend op de 'new institutional economics' wordt door de institutionele benadering van de netwerkanalyse ondervangen [48]: de analyse is dynamisch, multi-disciplinair en het methodologisch individualisme makt plaats voor een systeembenadering (zie Hodgson 1988a).

\section{De strategie van de onderneming in de 'frilière'}

Aangezien de nationalisaties in 1982 voornamelijk grote industriële en financiële groepen betroffen, bespreken wij in het navolgende enkele theoretische inzichten met betrekking tot de strategie van die groepen in het kader van hun 'filière'. Eerst wordt kort de ontwikkeling van onderneming naar industriële groep geschetst, waarna wordt onderzocht wie op welke gronden de strategische beslissingen binnen de industriële groep nemen. Langs die weg kan duidelijk worden welke kenmerken de industriele groep als 'tegenspeler" van 'l'Etat' vertoont.

\section{Van manager-eigenaar naar industriële groep}

De klassieke onderneming, waarin de eigenaar tevens de manager is wordt gekenmerkt door (Alchian en Demsetz 1972):

- een eigenaar, die de technische kennis bezit om het produkt en het produktieproces te beoordelen;

- een eigenaar, die het kapitaal inbrengt, contracten afsluit met de werknemers, hun beloning op grond van hun prestaties vaststelt en recht heeft op het residu;

- een eigenaar, die het recht heeft zijn eigendomsrechten te verkopen.

De onderneming maakt een groei door, waarbij onderscheid kan worden gemaakt tussen 'une croissance patrimoniale, financière et contractuelle' (Montmorillon 1986). De onderneming kan haar eigendom uitbreiden door middel van interne (investeren van ingehouden winst) en externe groei (overname). De groei van de onderneming kan ook van financiële aard zijn: door middel van meerder- en minderheidsdeelnemingen koopt zij niet direkt de activa van andere ondernemingen, maar "les titres financiers représentatifs de ces actifs', waardoor zij zich de beschikkingsmacht over de produktiecapaciteit van andere ondernemingen verschaft.

De groei van de onderneming kan ook plaats vinden door middel van het afsluiten van contracten, waarin het gemeenschappelijk gebruik van middelen, of het verlenen van specifieke diensten wordt geregeld tussen partners, die voor de overige activiteiten zelfstandig blijven. 
Als gevolg van de "croissance patrimonial, financière et contractuelle' ontstaat een onderneming, die is samengesteld uit divisies, die haar eigendom zijn, uit meerder- en minderheidsbelangen en uit 'relaties' met diverse partners op basis van samenwerkingscontracten. Met name door de "croissance contractuelle" is geen sprake meer van de traditionele onderneming gebaseerd op eigendom, maar van een industriële groep.

"Quels qu'ils soient, ces éléments sont en liaison les uns avec les autres: liaison patrimoniale, liaison financière ou liaison contractuelle. Et ces relations sont dotées de stabilité (ce qui ne veut pas dire qu'elles soient rigides ou définitives). L"agencement de ces interrelations - ou organisations - produit une unité complexe (ou système ou groupe) qui se dégage en tant que telle" (Montmorillon 1986, 57).

Vanuit een oogpunt van industriebeleid zijn de strategische beslissingen van indwstriële groepen van groot belang: door de diverse organisatievormen, waaruit de groep is opgebouwd kunnen industriële netwerken ontstaan, die het concurrentievermogen van het desbetreffende land aanzienlijk kunnen vergroten.

Wat zijn de karakteristieken van de industriële groep, welke doeleinden streeft zij na, wie neemt de strategische beslissingen, welke zijn de gevolgen voor de ontwikkeling van de industriële structuur en hoe kunnen de strategieèn door de overheid worden beînvloed, zijn de vragen die nu voorliggen.

\section{Le pouvoir managerial}

De eigenaar-manager verenigt het eigendom en de expertise in éen persoon. Hij is in staat de handelingen van de andere actoren te richten op eén gemeenschappelijk doel. Met de groei van de onderneming wordt de besluitvorming complexer, de competentie-eisen gesteld aan het management groter en het afstemmen van de belangen van de diverse groepen binnen de onderneming moeilijker. In geval van een scheiding van management en eigendom - een corporatieve onderneming - zal in plaats van de eigenaar een manager worden aangewezen, die de marginale produktiviteit van elk van de produktiefaktoren zou moeten vaststellen en zou moeten controleren of de teamleden zich niet schuldig maken aan 'shirking' (Alchian en Demsetz 1972). Het vaststellen van de prestaties van de produktiefaktoren en het 'monitoren' van hun gedrag, brengt enerzijds extra contractkosten met zich mee, maar vergroot anderzijds de produktie. De manager (monitor) heeft recht op het residu, het recht de incentives woor de individuele teamleden te veranderen, alsmede de samenstelling van het team. Het management van de onderneming kan worden opgevat als

"(...) comme composé du petit nombre d'individus qui est à même de prendre les décisions constitutives du groupe industriel, c'est-à-dire de déterminer les métiers du groupe et par là quels éléments en feront partie, comment ils seront reliếs les uns aux autres, et quel degré d'autonomie ils garderont; ce sont les responsables des décisions stratégiques qui conditionnent le devenir à moyen terme de l'ensemble du groupe" (Montmorillon 1986, 164).

De veel besproken scheiding tussen eigendom en management (Berle en Means) leidt ertoe, dat de kennis ('le pouvoir de capacité') bij het management komt te liggen, waardoor de macht tot het nemen van de strategische beslissingen van de eigenaar overgaat naar de manager. Om een beeld te kunnen vormen van de aard van die 
strategische beslissingen worden de karakteristieken van de industriële groep nader bezien.

\section{Karakteristieken van de groep}

Zoals gezegd is de industriële groep samengesteld uit ellementen, die in een specifieke relatie met elkaar worden gebracht en van zo'n uiteenlopende organisatorische aard zijn, dat een zeer complex geheel ontstaat. Het management bepaalt de strategie van de groep, waaronder ook de vorming en omvorming van de structuur van de groep begrepen dient te worden. Het management bepaalt uit welke elementen de groep is samengesteld ('choix des éléments; l'effet d'agrégation'), welke funktie en mate van autonomie de diverse onderdelen hebben ('choux de leur activité; l'effet de localisation') en tot slot bepalt het management hoe de interactie tussen de diverse onderdelen verloopt ('l'effet d'interaction'). Bij de keuze van de samenstellende delen speelt de hoogte van de transactiekosten een belangrijke rol, waarbij het niet zozeer gaat om een minimalisatie van transactiekosten in een statische omgeving, als wel om het zoeken naar die combinatie van organisatievormen, die de kosten van aanpassing aan veranderingen in de omgeving reduceert (zie 3.1.2.3) [49]. Bij het ontwikkelen van de strategie met betrekking tot de organisatie van de markt gaat het voor het management steeds om de keuze tussen 'acheter, faire, faire faire ou faire avec".

De keuze van de combinatie van de elementen, waaruit de groep is opgebouwd, dient een synergie-effekt teweeg te brengen (l'effet d'agrégation).

Wat het 'effet de localisation" betreft kan worden opgemerkt, dat het creẽren van min of meer autonome elementen binnen de groep de centrale de mogelijkheid biedt conflicten als het ware te isoleren binnen de afzonderlijke locaties. Een conflict met de werknemers over het arbeidscontract speelt zich af binnen het onderdeel van de groep, een conflict met de overheid met betrekking tot bijv. het milieubeleid idem dito [50].

Wat het 'effet d'interaction' betreft kan onderscheid worden gemaakt tussen

"(...) les flux de biens et services, les flux de moyens de financement et les flux de savoirs, quil vont tisser le support concret de la cohésion de l'ensemble dans la réalisation du project du pouvoir managerial" (Montmorillon 1986, 80).

Samengevat kunnen wij stellen, dat het management door middel van het vaststellen en bijstellen van de structuur van de groep, ('effet d'agrégation, de localisation et d'interaction') de autonomie van de onderdelen, hun bijdrage aan het doel van de groep en hun relaties met de andere onderdelen, of met de markt, vaststelit. Het management organiseert de industriële groep, teneinde de doeleinden van de groep te realiseren.

Waar is die strategie uiteindelijk op gericht?

Eliasson (1984), Porter (1985), Montmorillon (1986) en anderen zetten uiteen, dat de strategie van een onderneming gericht dient te zijn op het verkrijgen, behouden en versterken van een specifieke kunde ('core business, technological base, le métier'), die het resultaat is van een langdurig leerproces.

Uitgaande van de transactie wordt in schema 3.11 aangegeven hoe een 'métier' kan zijn verbonden met een specifieke vraag, welke is opgebouwd uit een aantal funkties. De 
taak van het management van een industriêle groep valt in drie onderdelen uiteen:

- 'la gestion stratégique' (de keuze van de 'métiers' en de centrale doelstelling: 'le projer"),

- 'la gestion des métier" (strategie met betrekking tot $\mathrm{R}$ en $\mathrm{D}$, financièn en controle) en de

- 'gestion dú consensus' (gericht op het realiseren van een cohesie tussen de onderdelen van de groep, gericht op de realisatie van het groepsproject).

Wat de strategische 'métier'--keuze betreft, zal de manager een analyse moeten maken van de kennis en kunde van de groep in vergelijking met de concurrentie. Wat het beleid met betrekking tot haar centrale competentie betreft, zal het management specifieke aandacht moeten besteden aan de uitgaven en richting van de $R$ en $D$ (potentiële complementariteiten), aan het financiële beleid (autonomie van de onderdelen) en aan het personeelsbeleid gericht op het creëren van een toegewijd kader:

"l'encadrement apparaît alors comme la colonne vertébrale de cette cohésion, réseau d'autant plus indispensable que le groupe a perdu toute homogénéité institutionelle (status divers et fluctuants des éléments) ou organisationelle (groupes d'individus aux intérêts souvent contradictoires). La gestion de l'encadrement apparaît donc comme indispensable au pouvoir managerial qui y trouvera le "matériale propre à la mise en oeuvre de son projet" (Montmorillon 1986, 121).

Het binden van het kader aan de groep is van essentieel belang voor het realiseren van een 'circuit d'information interne', waardoor kan worden voorkomen, dat afdelingen van geìsoleerde 'baronnies et principeautés' ontstaan.

Schema 3.11 "Métier' van de industriële groep

Transactions

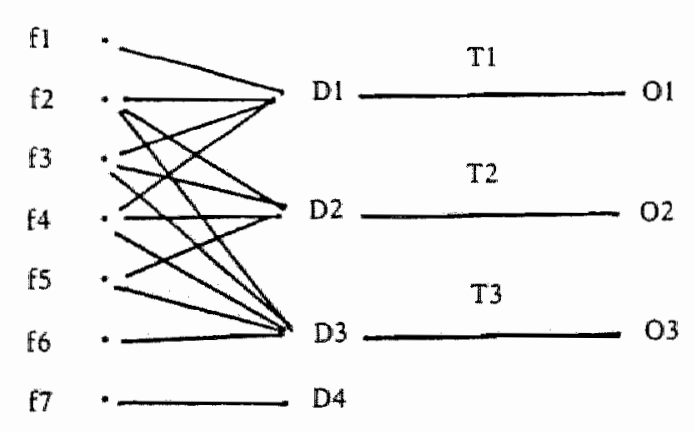

fonctions attendues demandes specifiques

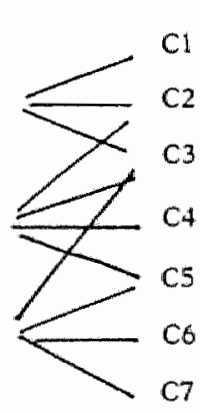

offres spécifiques compétences

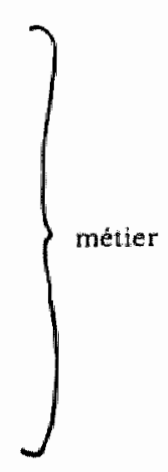

maîtrisées ou réunies

Bron: Montmorillon 1986, 99.

Met betrekking tot de realisatie van het projekt en de controle op de voortgang is het voor het management van essentieel belang te beschikken over de juiste informatie, niet alleen in de zin van behaalde resultaten, maar ook in de zin van verwachte ontwikkelingen. 
"Sans information sur le groupe et hors le groupe, le groupe n'existerait pas: l'information est le support même du pouvoir managerial de sa capacité à prétoir et à contrôler" (Montmorillon 1986, 124).

Wat de "gestion du consensus" betreft kan onderscheid worden gemaakt tussen de interne consensus (diwerse belangengroepen binnen de groep zijn overtuigd van het belang van het projekt) en de externe consensus (erkenning door de samenleving van het belang van de groep voor het allgemeen belang: 'justification finale du powvoir managerial'). De consensus ontstaat niet vanzelf op basis van het charisma van het management, maar dient een expliciet onderdeel van het beleid te zijn; de participatie van diverse belangengroepen in de besluitvorming van de onderneming kan daarbij een belangrijke rol spelen.

Door bovenbeschreven kenmerken van de industrie̋le groep wordt duidelijk, dat de concurrentie tussen groepen veelal een concurrentie van 'small numbers' zal zijn (Williamson 1975). De groep dient voortdurend te streven naar een verbetering van het 'metier', welke voortdurend moet worden aangepast aan veranderingen in de omgeving ('concurrence industrielle'). Daarnaast dient de groep haar activiteiten voortdurend af te stemmen op de ontwikkelingen in de vraag en indien mogelijk de vraagontwikkeling te beheersen ('concurrence commerciale'). Naast de traditionele produktiekosten (schaal-marktomvang), speelt voor de groep de kosten van het beheersen en samenvoegen van competenties een centrale rol vergelijk de 'value chain' in Porter (1985), zie ook Jarillo (1988, 35).

Naast de interne coördinatie van haar eigen competenties tot een 'metier', dient de groep complementaire activiteiten via de markt of via samenwerkingsverbanden op elkaar af te stemmen. De andere activiteiten, die nodig zijn om het eindprodukt op de markt te brengen kan de groep via de markt coördineren (dus met ondernemingen, die niet tot haar groep behoren), of met ondernemingen, waarmee zij een specifiek samenwerkingsverband aangaat (zoals een 'co-traiteur' die wel tot de groep wordt gerekend). Als het activiteiten betreft, die nauwkeurig op de 'hard core' van de groep moeten worden afgestemd (dezelfde hoogwaardige technologie), kunnen de transactiekosten van de markt zo hoog oplopen, dat de groep naar specifieke 'governance structures' zoekt. Naarmate de technologische ontwikkelingen onvoorspelbaarder zijn en sneller verlopen, neemt de noodzaak tot het opbouwen van een flexibele organisatie toe: de hierrarchie wordt een relatief kostbaar coördinatiemechanisme. Het management zall activiteiten uit haar eigen produktieenheden willen stoten, waarvan slechts een beperkt aantal via de markt kan worden gecoobrdineerd: het management zal de structuur van de groep veranderen ten gunste van de 'croissance contractuelle'. Om de coördinatie door middel van specifieke samenwerkingsverbanden vorm te kunnen geven, om met andere woorden de kosten van het organiseren van de competenties te kunnen drukken ten opzichte van de concurrentie, dient de industriële groep te kunnen putten uit een reservoir van potentiële partners. Het bestaan van een hoogwaardig 'tissu industriel' is voor het concurrentievermogen van de industriële groep derhalve van groot belang. Industriele groepen ontplooien zelf activiteiten met betrekking tot het opbouwen van een hoogwaardig netwerk van industriële partners, maar zoals wij zullen zien kan daarin ook een belangrijke rol voor het industriebeleid van de overheid zijn weggelegd. 
Samenvattend kunnen wij stellen, dat het concurrentievermogen van de industriele groepen niet alleen wordt bepaald door de hoogte van de traditionele produktiekosten, maar met name door de mogelijkheden haar competentie tegen relatief geringe kosten te kunnen organiseren. Daarbij speelt de organisatie van de markt, of zo men wil de opbouw van het industriële weefsel in termen van mesosystemen, netwerken, of 'filières' een belangrijke rol.

\subsection{Het industriebeleid in een markteconomie}

\subsubsection{Inleiding}

Economisch structuurbeleid betreft de opbouw van de economische structuur qua primaire, secundaire, tertiaire en quartaire sector; het CBS heeft in de Standaardbedrijfstakindeling de industriële sector onderscheiden naar bedrijfsklassen, -groepen en subgroepen, die tezamen de industrielle sector vormen. Industriebeleid heeft betrekking op die industriële sector, maar over een exacte definitie van dat beleid lopen de meningen uiteen. Voor ons doel kan het industriebeleid worden gedefinieerd als het samenstel van overheidsmaatregelen, dat is gericht op de realisatie van doelstellingen met betrekking tot de opbouw van het produktieapparaat qua sectoren, regionale spreiding, ondernemingsgrootte en mate van vervlechtingen tussen industriële activiteiten (netwerken). Zoals eerder opgemerkt leidt de invalshoek van de vervlechtingen ertoe, dat industriebeleid betrekking heeft op in principe alle activiteiten, die met de voortbrenging van industriële produkten uit de standaardbedrijfstakindeling in verband staan. Ook de dienstverlening door partikuliere en publieke ondernemingen of overheidsinstanties, alsmede de activiteiten van meso-organisaties als PBO's, brancheverenigingen en dergelijke, komen in de 'filière'-benadering van industriebeleid binnen het viziler.

In 3.0 werd geconcludeerd, dat de fundering van een marktconform industriebeleid uit twee elementen zou moeten bestaan: enerzijds dient de theorie inzicht te verschaffen in de ondernemingsstrategieën waarop het beleid moet aanhaken, anderzijds moet de theorie licht werpen op de eisen, die aan de inrichting, kennis en kunde van het overheidsapparaat moeten worden gesteld, alsmede aan de organisatorische vormgeving van de relatie tussen de overheid en het bedrijfsleven.

In deze paragraaf besteden wij aandacht aan die twee pijlers van de fundering van het industriebeleid en maken daartoe onderscheid tussen enerzijds het generieke industriebeleid gevoerd door 'L'Etat régulateur' en anderzijds het specifieke beleid, dat vorm wordt gegeven door een meer voluntaristische "L'Erat developpeur".

\subsection{1 'L'Etat regulateur' en 'L'Etat développeur'}

\subsubsection{Inlelding}

In zijn analyse van de rol van het Japanse Ministery of International Trade and Industry (MITI) met betrekking tot het sturen van industriële ontwikkeling maakt Johnson (1982) onderscheid tussen de 'developmental' en de 'regulatory' state'. "Zowel de "regulatory" als de 'developmental state" zijn markteconomieèn: het instrumentarium van de overheid dient in beide typen marktconform te zijn, hetgeen impliceert dat de 
autonomie van de actoren wordt gerespecteerd en dat de onderneming primair zelf verantwoordelijk blifft voor haar beslissingen en daarvan ook de gevolgen dient te dragen: De overheid onthoudt zich daarbij dan ook van het beschermen van falende ondernemers (WRR 1980).

Het anderscheid tussen beide madellen is gelegen in de relatie tussen de overheid en de marktpartijen, in de wijze waarop de overheid intervenieert en het doel waarop zij zich richt. Doel en instrument hangen nauw samen, hetgeen tot uitdrukking komt in twee versichillende besluitvormings- informatie- en motivatiestructuren.

De 'developmental state' is het ideaaltype van de voluntaristische overheid, die expliciete doeleinden ontwikkelt met betrekking tot de structurele ontwikkelingen, zelf initiatieven neemt en economische subsystemen in hun ontwikkelling wil beheersen. De 'regulatory state" daarentegen intervenieert niet direct in het economisch proces, maar waakt over een goed functionerend marktmechanisme.

In het navolgende bespreken wij de ideaaltypen van de 'developmental' en de 'regulatory state' (3.2.1.1), het generieke beleid van de 'regulatory state' (3.2.1.2) en het specifieke beleid van de 'developmental state' (3.2.1.3), waarbij de aandacht in het bijzonder uitgaat naar het concept van de 'filiere'. In 3.2.1.4 besteden wij in het kader van de relatie tussen de overheid en bedrijfsleven aandacht aan de theorie van het corporatisme.

\subsubsection{De ideaaltypen van de 'developmental" en de 'regulatory state'}

\section{Structuur versus proces}

In de 'developmental state' worden expliciete economische doeleinden geformuleerd met betrekking tot de structurele ontwikkeling van de economie. De doeleinden, waarin het economisch proces moet uitmonden zijn in eerste instantie in algemene termen gesteld: terugdringen van de werkloosheid, verkleinein van het financieringstekort, verbeteren van de betalingsbalans, vergroten van de concurrentiekracht van het bedrijfsleven etc. Vervolgens wordt nagegaan wat een en ander impliceert in

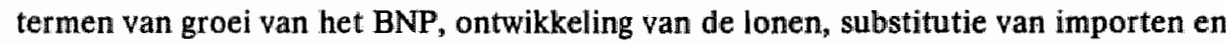
dergelijke. De gewenste uitkomsten van het economisch proces worden vervolgens in mesotermen geformuleerd. Dat wil zeggen: in termen van de mogelijke en gewenste ontwikkeling van de industriële structuur qua sectorale opbouw, ondernemingsgrootte, regionale spreiding en vervlechtingen van economische activiteiten. De mesodoeleinden kunnen ook naar microniveau worden vertaald bijv. in termen van de reorganisatie van een bedrijfstak rond een genationaliseerde onderneming. In de 'developmental state' worden doeleinden geformuleerd met betrekking tot de structurele ontwikkeling van de economie. Deze doeleinden worden gepubliceerd in een indicatief plan en aan alle betrokkenen kenbaar gemaakt.

In tegenstelling tot de geplande markteconomie staan in de 'regulatory state' niet de doeleinden centraal, waarin het marktproces moet uitmonden, maar is het beleid van de overheid gericht op het proces zelf. De overheid ziet toe op het efficiënt functioneren van het marktmechanisme: voorkomen van machtconcentraties en het zorgdragen voor een prijsmechanisme, dat flexibel veranderende schaarsteverhoudingen reflecteert, behoren tot de taak van de overheid. Verder dient zij institutionele verstarrin- 
gen op te heffen, opdat de produktiefaktoren snel op veranderende schaarsteverhoudingen kunnen reageren. Ook kan de overheid in een 'regulatory state' zorgdragen voor de produktie en verspreiding van informatie, die vanwege de hoge transactiekosten niet door de markt worden voortgebracht. Naast ervoor te waken dat op microniveau de markt efficiënt werkt, dient de overheid tevens de verantwoordelijkheid voor het intern en extern evenwicht op zich te nemen.

Doeleinden van economisch beleid in een "gereguleerde markteconomie" betreffen niet de structurele, maar de conjuncturele ontwikkeling.

\section{Consultatie en coordinatie versus 'arm's length'}

Elke economische orde en zeker open markteconomieën hebben te maken met onvoorziene ontwikkelingen in de markt- en omgevingsvariabelen. De kracht van de 'developmental state' is zeker niet in de eerste plaats gelegen in het formuleren van gedetailleerde doeleinden, welke coûte que coûte gerealiseerd moeten worden. Van veel groter belang is het vermogen doeleinden en strategie tijdig aan te passen aan veranderende omstandigheden, teneinde een sterke concurrentiepositie te kunnen behouden. Belangrijk daarbij is de wijze, waarop de doeleinden tot stand komen, hoe informatie van micro, via meso naar macroniveau stroomt en terug. De consul tatie van de marktpartijen door de overheid, die het indicatieve plan opstelt, vormt daarbij een essentiële rol. Voor het formuleren van de doeleinden behoeft de centralle informatie over de produktiemogelijkheden en strategieën op microniveau. Die informatieproduktie vindt in het ideaaltype van de "developmental state plaats in een intensief consultatieproces met alle belanghebbenden. Het consultatieproces is niet alleen van groot belang voor de produktie van informatie, maar ook voor de legitimatie van de doeleinden. Zijn doeleinden in naww overleg met betrokkenen tot stand gekomen, dan worden deze eerder als legitiem ervaren, hetgeen van essentieel belang is voor de realisatie van de doeleinden.

Het organiseren van het consultatieproces, het verwerken van de informatie en het formuleren van de doeleinden, waarin het economisch proces zou moeten uitmonden, vereist een zeer deskundig coördinatiebureau. Vanuit dat centrale punt moet niet alleen de strategie van de grote structuurbepalende ondernemingen worden getoetst op conformiteit met de plandoeleinden, maar dient ook het belleid van de verschillende departementen afgestemd te worden op de doeleinden van het indicatieve plan. Consultatie en coordinatie zijn wezenskenmerken van de 'developmental state'.

In de 'regulatory state' is geen plaats voor een centraal coordinerend instituut. De dominante coobrdinerende instantie is het Ministerie van Financiën, dat verantwoordelijk is voor het korte termijn conjunctuurbeleid.

\section{Instrumentarium}

Voor het realiseren van de doeleinden heeft de 'developmental state" de beschikking over een instrumentarium, dat kan variëren van de publikatie van het indicatieve plan ("pure" indicatieve planning zie hoofdstuk 2) via de indicatieve planning tot de zogeheten contractuele planning, waarbij de overheid en de marktpartijen hun rechten en plichten regelen bij overeenkomst (vergelijk Vermaat 1980). 
Omdat de "developmental state" een markteconomie is dient de autonomie van de actoren gerespecteerd te worden, maar omdat ook sprake is van plandoeleinden en cen instrumentarium, waarmee het gedrag van de actoren kan worden gestuurd in de richting van de plandoeleinden, zouden wij van een zogenaamde "geplande markteconomie" kunnen spreken: een 'Etat développeur' (Bauer en Cohen 1985).

Mededingingsbeleid, Keynesiaans macrobeleid en deregulering zijn de instrumenten, waarmee de 'regulatory state" de markt reguleert. De "planrationaliteit' van de geplande markteconomie, dat will zeggen de mate waarin de doeleinden van het indicatieve plan worden gerealiseerd (effectiviteit), maakt in een gereguleerde markteconomie plaats voor 'marktrationaliteit' (efficiëntie). De hierboven beschreven ideaaltypen zijn theoretische constructies, die tonen hoe op consistente wijze vorm moet worden gegeven aan een orde, die pretendeert een 'geplande markteconomie' te zijn. De voorwaarden worden getoond, waaraan moet zijn voldaan, opdat een concrete orde in werkelijkheid haar coördinerende taak naar behoren kan vervullen. Als een overheid een 'rôle développeur' wil vervullen dan verschaft het model van 'L'Etat développeur' inzicht in de wijze, waarop de economische orde moet worden gericht. Of zulks in werkelijkheid kan worden gerealiseerd hangt overigens niet alleen af van de politieke will, maar ook van de historisch-culturele en socio-politieke situatie van het land in kwestie (vergelijk hoofdstuk 5 en 6 ).

\subsubsection{Het generieke industriebeleid van de 'regulatory state'}

Als de instrumenten niet zijn gedifferentieerd naar sectoren, ondernemingsgrootte, regio's, of clusters van activiteiten, dan is sprake van generiek beleid. Een investeringspremie, die van toepassing is op de investeringen in alle ondernemingen (groot, klein, in het noorden en in het zuiden, in de staal en de electronica), is een voorbeeld van generiek beleid [52]. Diverse categorieèn van overheidsbeleid kunnen tot het generieke industriebeleid worden gerekend, waarbij overigens ter diskussie staat of in al die gevallen wel van industriebeleid kan worden gesproken [53]. Wat het generieke beleid betreft wordt veelal gewezen op Keynesiaans macrobeleid gericht op handhaving van voldoende effectieve vraag, op generiek kostenverlagend beleid gericht op het vergroten van de investeringsruimte van de ondernemingen en op het toepassen van een mededingingsbeleid gericht op het realiseren van een 'concurrentiële' marktstructuur, alsmede op de maatregelen, welke tot doel hebben de markt doorzichtiger te maken (informatie), marktfalen weg te nemen (eigendomsrechten) en marktverstarring uit de weg te ruimen (deregulering). Indirekt hebben genoemde vormen van beleid invloed op het gedrag van de actoren en daarmee op de ontwikkeling van de industriële structuur.

Het volgende idee steekt achter bovengenoemde vormen van beleid: als sprake is van voldoende concurrentie, van voldoende "discretionaire ruimte" voor de ondernemers, van voldoende afzetperspectieven, van voldoende informatie en van adequate eigendomsrechten, dan zullen de ondernemers strategische beslissingen nemen, die resulteren in een efficiënte aampassing van de industriele structuur.

Wij geven er de voorkeur aan het macro- en mededingingsbeleid niet tot het industriebeleid te rekenen en alleen het beleid gericht op het vergroten van de financiële 
ruimte van de ondernemingen ter stimulering van de investeringen als generiek industriebeleid aan te merken.

Het generieke beleid gericht op financielle lastenverlichting voor de onderneming, is gebaseerd op het neoklassieke denkbeeld, dat de investeringen afhankelijk zijn van de gerealiseerde winsten, of ruimer gesteld: van de beschikbaarheid van eigen vermogen, dat weer bepalend is voor de mogelijkheden van het aantrekken van vreemd vermogen. Met name vanuit de dynamische theorieèn (vergelijk 3.1.2.2), waarin ondernemingsstrategieën zijn gebaseerd op verwachtingen ten aanzien van de toekomstige vraag, op het gedrag van concurrenten etc., wordt gewezen op de beperkte relevantie van neoklassieke theorie voor industrie-politieke vraagstukken (vergelijk De Jong 1987).

Is nu zo"n kostenverlagend generiek industriebeleid effectief? Leidt met andere woorden lastenverlichting tot investeringem en tot een adequate aanpassing van de industriële structuur? Generiek kostenverlagend beleid verruimt volgens de dynamische theorie weliswaar de financiële mogelijkheden van de onderneming, maar het is volkomen onduidelijk hoe die ruimte zal worden aangewend. Ondernemingen, die met een grotere financiele ruimte worden geconfronteerd kunnen tot investeringen in nieuwe richtingen overgaan, maar het is evenzeer mogelijk, dat zij bestaande produktiecapaciteit uitbreiden, louter en alleen met het doel een strategische barrière voor potentiêle toetreders op te werpen (vergelijk Daems en Douma 1984). Ondernemingen met meer financiële ruimte kunnen zich ook op het overnamepad begeven, waaruit oligopolistische machtsposities kunnen voortvloeien.

Op theoretische gronden kan niet worden geconcludeerd, dat een winstvergrotend generiek beleid effectief is in de zin, dat daardoor de investeringen worden gestimuleerd, die voor de aanpassing van de industriële structuur van belang zijn [54]. Ook het empirisch onderzoek omtrent de vraag naar effectiviteit van generiek industriebeleid levert geen ondubbelzinnige resultaten op. Schenk en Kamann (1987) vermelden, dat modelmatige en simulatieonderzoekingen voor Nederland tot een positief oordeel komen (zie bijw. Schotman 1985), terwijl survey-onderzoekingen concluderen, dat generiek beleid ineffectief is (zie Vermeend 1983 en Hoogstraten 1986).

Veel gehoord is de opvatting, dat effectiviteit van generiek beleid weliswaar met veel vraagtekens omgeven mag zijn, maar het positieve is, dat generiek beleid, in tegenstellling tot specifiek beleid, een non-discriminatoir karakter zou hebben. Specifiek beleid richt zich op specifieke sectoren of ondernemingen, waardoor concurrentievervalsing optreedt; generiek beleid hanteert de stelling: "gelijke monniken, gelijke kappen". In tegenstelling tot de alom heersende opvatting, dat generiek beleid "neutraal" zou zijn, wijzen Schenk en Kamann op de impliciete versterking van de status quo als gevolg. van generiek beleid:

"De economische structuurontwikkeling gaat gewoon haar al dan niet stagnerende gang, en een generiek beleid voorziet de ontwikkeling dus impliciet van het stempel "goedgekeurd". Beleid dat ex ante niet specifiek is, kan daardoor ex post gezien wel degelijk specifiek zijn" (Schenk, Kamann 1987, 234).

Concluderend zouden wij kunnen stellen, dat de 'regulatory state' de ambitie heeft zorg te dragen voor een efficiente marktwerking, waarin ondernemingen in staat worden gesteld hun verantwoordelijkheid voor de lange termijn investeringen waar te maken. 
Naast voldoende mededinging, die prikkelt tot efficiënte allocatie is het marktmechanisme ingebed in een macrobeleid, dat de lange termijn afzetverwachtingen positief beinvloed en wordt door middel van het prijs-, belasting-, subsidie- en loonbeleid zorggedragen voor voldoende ruimte, waaruit de investeringen kunnen worden gefinancierd. Echter, zeker in tijden van telatief grote onzekerheid (technologische ontwikkelingen, gedrag van concurrenten, owerheidsbeleid etc.) kunnen markten te beperkte kwaliteiten blijken te bezitten voor het ontwikkelen van een lange termijn planningshorizon en het scheppen van de juiste condities voor het aangaan van lange termijn verplichtingen (vergelijk WRR 1980, Hare 1985 en Cowling 1987). Als de markten in de 'regulatony state' tekort schieten [55] in de zin, dat onvoldoende investeringen tot stand komen in richtingen die voor de aanpassing van de industriele structuur noodzakelijk worden geacht, dan zou een specifiek industriebeleid kunnen worden overwogen.

\subsubsection{Het specifieke industriebeleid van de 'developmental state'}

Er is sprake van specifiek industriebeleid als het instrumentarium is verbijzonderd naar sectoren (bijv. horizontaal steunbeleid voor de scheepsbouw), naar ondernemingsgrootte, (bijv. loonkostensubsidies voor Onderzoek en Ontwikkeling in het Midden- en Kleinbedrijf), naar regio (bijv. investeringspremie's voor het noorden des lands), of naar cluster van activiteiten (bijw. het vertikale steunbeleid voor de 'filiere électronique' (zle hoofdstuk 7).

Het is mogelijk, dat het specifieke beleid wordt ingepast in een 'overall'-toekomstbeeld van de industriele structuur. De 'Visions' van MITI (Johnson 1982) kunnen als zodanig worden geïnterpreteerd, terwijl het 'Ministère de la Recherche et de l'Industrie' in de periode 1982-1983 plannen in die richting koesterde met de ontwikkeling van de 'Loi sur l'Industrie" (zie hoofdstuk 6). Ook de denkbeelden van de WRR (1980), waarin sprake was van een sectorstructuurplan met een schets van de "mogelijke en gewenste ontwikkeling van de toekomstige sectorstructuur", beoogde een geïntegreerd beeld van de toekomstige sectorstructuur te schetsen.

Het is ook mogelijk, dat het specifieke beleid een meer ad hoc karakter heeft en dat steun wordt gegeven aan een sector of onderneming zonder dat een coherent sectorstructuurplan is opgesteld.

Zoals bij de bespreking wan het Negende Plan (hoofdstuk 5) en van het specifieke industriebeleid van Mitterrand (hoofdstuk 6) uiteengezet zal worden, werd in 1981 in Frankrijk nadrukkelijk gekozen voor een "overall, gedecentraliseerd industriebeleid; naast de produktie van algemene en sectorale informatie zou het Negende Plan en de 'Loi sur l'Industrie" een regionalisatie van het specifieke industriebeleid behelzen, waarin de begrippen 'filière' en 'mésosystème' een centralle rol zouden spelen.

In thet navolgende wordt uiteengezet welke rol het concept van de 'filiere' in het specifieke beleid kan spelen, waarna in 3.2.1.5 ingegaan wordt op de relatie tussen het centrale coördinatiebureau van 'L'Etat développeur' en het bedrijfsleven, i.c. de industriele groepen. 


\subsubsection{4 'Fillere' en specifiek industriebeleid}

In Frankrijk heeft het vraagstuk van de theoretische onderbouwing van 'het specifieke industriebeleid in de 'l'Ecole de l'économie industrielle' een belangrijke plaats ingenomen, waarbij is gepoogd aan de hand van het 'fillere'-concept nader inhoud te geven aan de twee door de WRR genoemde peilers [56]. In 3.1.2.5 is de 'filière' reeds ter sprake gekomen als concept ter analysering van de strategie van ondernemingen (netwerkbenadering); in deze paragraaf zullen wij de 'filière' bespreken als statistisch concept en ons afvragen welke informatie met behulp van dat concept kan worden geproduceerd ten behoeve van een overheid, die de ontwikkeling van de industriele structuur wil sturen in een door haar gewenste richting. Deze paragraaf wordt afgesloten met een voorstell beide concepten van de 'filiere' (de statistische en de netwerkbenadering) te integreren, waardoor mogelijk een theoretisch analysekader ontstaat voor het opzetten van een specifiek (gedecentraliseerd) industriebeleid.

\section{De statistische 'fillière'}

De economische werkelijkheid wordt in statistische zin geordend in nomenclaturen (Duprat 1983, 75-76) bijv. in de 'nomenclature d'activité, 'nomenclature de' produit', of de 'nomencluture de filière'. De nomenclaturen kunnen open zijn, dat wil zeggen elke nieuwe economische activiteit wordt als nieuwe categorie toegevoegd. Zij kunnen ook gesloten zijn, dat wil zeggen nieuwe activiteiten moeten in bestaande categorieën worden ondergebracht. Nomenclaturen kunnen derhalve zeer gedetailleerd, maar ook sterk geaggregeerd zijn.

Voor het beschrijven van de complexe industriele werkelijkheid is het dienstig basisactiviteiten of -produkten te hergroeperen tot min of meer homogene groepen: de zogenaamde statistische bedrijfseenheden. Veel gebruikte criteria daarbij zijn de aard van het produkt (voedingsmiddellenindustrie), de aard van het produktieproces (chemische sector) en de gebruikte grondstof (houtindustrie). L'INSEE [57] onderscheidt bijv. de 'branche' en de 'secteur'. Een 'branche' is een statistische bedrijfseenheid gebaseerd op de 'nomenclature de produit":

"Une branche se définit comme le regroupement de toutes les unités pro" duisant le même bien ou le même service; ces unités sont distinguées au niveau, le plus fin, fraction d'établissement si nécessaire" (Montfort 1983, 3).

De 'secteur' daarentegen is geen verzameling van homogene produkten, maar van gelijksoortig geachte activiteiten en is derhalve gebaseerd op een 'nomenclature d'activités".

"Un secteur rassemble les entreprises ayant la même activité principale" (Montfort 1983, 3).

Op basis van de ondierlinge leveringen tussen branches worden input-outputtabellen ('Tableaux d'Entrées et Sorties") (TES) opgesteld.

Een statistische 'filiere' is een zodanige bewerking van de TES, dat zichtbaar wordt welke branches qua onderlinge leveringen in belangrijke mate met elkaar zijn verbonden. Zo'n beeld van de bestaande industriële structuur kan voor de overheid zeer 
Waardevolle informatie bevatten ten aanzien van de branches, die ten opzichte van de andere een sleutelpositie innemen. Op dergelijke branches zou de overheid haar beleid kunnen richten.

Er doen zich met betrekking tot het construeren van statistische "filières' echter een aantal problemen voor, waarvan wij eerst die van de onduidelijkheid rond het brancheconcept zullen bespreken.

Een overzicht van de worsteling welke de microtheorie met het branche-concept heeft doorgemaakt kan worden aangetroffen in Reynaud-Cressent (1983). De criteria van de substitutie (Robinson en Kaldor) en die van Chamberlin, waarin de branche een 'l'ensemble des monopoles riveaw' is, zijn onvoldoende nauwkeurig te operationaliseren.

"Le concept de branche de N.. Kaldor, fondé sur l'ordre de préférence, est à la fois un concept mouvant et subjectif: en effet, le noyau de la branche varie selon les rivaux de chaque firme.

Le concept de J. Robinson, comme celui de E.H. Chamberlin, se heurte a l'impossibilité de mesurer de facon efficace la substituabilité des produits."

Door de Amerikanen Bain en Machlup wordt het criterium van de kruiselasticiteit voorgesteld, waaraan de laatstgenoemde een kwalitatief criterium toevoegt: als ondernemingen door het opwerpen van toetredingsbarrières, of door het organiseren van een gezamenlijke lobby er blijk wan geven gezamenlijke belangen te verdedigen, dan kunnen zij tot dezelfde branche worden gerekend. Ook nu moet worden geconstateerd, dat het criterium moeilijk kan worden geoperationaliseerd.

Ook zijn pogingen ondernomen de branche te definiëren vanuit de aanbodzijde: de ondernemingen, die een gelijksoortige technologie gebruiken vormen een homogene groep: een branche. Ook dat criterium blijkt beperkingen te kennen:

"Fonder le concept de branche sur la technologie limite la branche à ce qui est commun à toutes les firmes. En conséquence, les stratégies d'int'egration en amont et en aval sont exclues. L'analyse d'une branche se réduirait alors à l'étude du facteur commun: la croissance horizontale. Le concept semble trop était et statique" (Reynaud-Cressent 1983).

Robinson onderkent blijkbaar ook die beperkingen als zij schrijft:

"Une branche peut être considérée comme un groupe de firmes ayant certaines caractéristiques techniques communes. Elles peuvent être reliées par l'emploi des mêmes méthodes de production, ayant affaire aux mêmes fournisseurs, ou approvisionnant les mêmes acheteurs, exploitant la même force de travail, ou, plus simplement, par un sentiment historique établi qu'elles sont membres d'une industrie" (geciteerd naar Reynaud-Cressent 1983, 93).

Het brancheconcept is door de toevoeging à la Robinson geen strak omlijnd concept meer, maar betreft een verzameling ondernemingen met gezamenlijke kenmerken. Als in het kader van het construeren van een statistische 'filiere" wordt gesproken over het "hergroeperen van branches", dan kan uit het bovenstaande worden afgeleid, dat het noodzakelijk is vooraf te expliciteren wat onder een 'branche' verstaan dient te worden. Als een 'filiere' wordt opgevat als een keten van opeenvolgende produktie- 
stadlia, dan kan in navolging van Reynaud-Cressent de branche als volgt worden geinterpreteerd:

"Une branche serait alors constituée par l'ensemble des firmes qui se situent toutes, au minimum, sur les mêmes stades de production".

De "harde kern" van de branche bestaat uit eenheden, die in horizontale concurrentie met elkaar staan, dezelfde technologie gebruiken en in gelijke mate zijn geìntegreerd. Om die 'harde kern' bevindt zich een 'limitrophe amont et aval' van ondernemingen die zich op één van de genoemde criteria onderscheiden.

Hoe kan op basis van statistische branches van de TES een 'filiere' worden geconstrueerd? Hoe kan op basis van verbindingen tussen de branches van de TES een beeld van de industriële structuur qua vervlechtingen en stategische branches worden gereconstrueerd? Naast de studies van LATAPSES (zie Torre 1985) is vooral die van L'INSEE van belang.

In de statistische 'filière' kunnen drie segmenten worden onderscheiden:

- 'amont', het achterwaartse segment, dat bestaat uit branches, die voornamelijk de branches stroomafwarts van grondstoffen en intermediaire produkten voorzien

- 'aval", het voorwaartse segment bestaande uit branches, die voornamelijk van stroomopwaarts gelegen branches afnemen

- "centre", het verwerkende segment, waarbij noch de achterwaartse, noch de voorwaartse leveringen domineren.

Montfort en Dutailly (1983) hebben de TES, waarin 90 branches worden onderscheiden gehergroepeerd tot 'fillières' op basis van twee clusteringmethoden (vergelijk Roelandt 1986), waarvan wij de methode 'amont-aval' bespreken [ 58 ].

- aval Eerst worden de finale bestedingscategorieën over de intermediaire leveringen verdeeld; vervolgens wordt een branche ' $B$ ' geaggregeerd met een andere branche ' $A$ ' als deze de belangrijkste afnemer ' $A$ ' is en de levering een specifieke drempel van het total van de leveringen van 'A' ( $k$-waarde) te boven gaat. De $k$-waarde wordt vastgesteld op basis van een iteratief proces, waarbij na elke ronde de samengevoegde branches uit de tabel worden verwijderd.

- amont Eerst worden de importen toegerekend volgens de technische coëfficiênten van de binnenlandse intermediaire leveringen. Een branche 'A' wordt geaggregeerd met een branche ' $B$ ' als ' $A$ ' de belangrijkste leverancier is van ' $B$ ' en de leverantie een specifieke drempelwaarde van de totale input van ' $B$ ' overstijgt.

Montfort en Dutailly hergroeperen de TES tot 19 'filières' (zie Montfort 1983).

De onderzoekers van L'INSEE hebben vervolgens onderzocht hoe per 'filière' in de periode 1970-1981 de werkgelegenheid, alsmede de binnenlandse vraag en de import/export zich hebben ontwikkeld (zie Montfort en Dutailly 1983).

Ongetwijfeld levert de statistische 'filiere' inzicht in de vervlechtingen van de industriële structuur van een land, er wordt een beeld verschaft op een niveau tussen macro en micro en in die zin zou van een mesoniveau kunnen worden gesproken. Informatie in de vorm van 'filières' kan voor de overheid zeer relevant zijn: zichtbaar wordt hoe branches zijn vervlochten, of de penetratie van het buitenland in strategisch geachte 'filieres' groot is en dergelijke. 
Daar staat tegenover, dat de methodiek van de statistische "filière" een aantal problemen kent, die haar bruikbaarheid voor een specifiek industriebeleid ernstig beperken.

\section{Enkele beperkingen van de statistilsche methode}

Het langs statistische weg construeren van 'filières" heeft " (....) l'avantage de la rigueur des chiffres" (Morvan 1985), maar kent ook een aantal beperkingen, die enerzijds werband houden met de wijze, waarop het cijfermateriaal tot stand komt en anderzijds met het feit, dat in een statistische analyse de actoren onzichtbaar blijven.

\section{Statistische problemen:}

- Statistieken zijn gebaseerd op het verzamelen van gegevens op empirisch microniveau. Op basis van enquêtes verschaffen ondernemers informatie over hun leveranties en dergelijke. De registratie op microniveau is vaak gebrekkig, terwijl ondernemers niet dezelfde statistische categorieèn gebruiken voor overeenkomstige produkten.

- De nomenclature, die L'INSEE gebruikt dateert van 1973.

- L'INSEE wordt vaak geconfronteerd met een toerekeningsprobleem: een branche op het laagste niveau van de nomenclature kan vaak niet eenduidig aan één "filièrex worden toegerekend.

- Vanuit een oogpunt van industriebeleid is het van groot belang te weten of een verandering in de industriële vervlechting het gevolg is van relatieve prijsveranderingen, of van technologische veranderingen. De input-outputtabel luidt in monetaire grootheden, waardoor ook een tabel in constante prijzen niet de substitutie-effecten als gevolg van prijsveranderingen onderscheidt van substitutie-effecten als gevolg van technologische veranderingen. Bovendien kunnen technologische ontwikkelingen prijseffecten met zich mee brengen.

- De relaties in de inpult-outputtabellen kennen vaste technische coëfficiënten, waardoor in feite een constante produktietechnologie wordt verondersteld. Vanuit een oogpunt van industriebeleid is het van grote betekenis inzicht te hebben in de effecten van de technologische ontwikkelingen op de industriële structuur.

- De input-outputtabel verschaft een statistisch beeld van de onderlinge leveringen gemeten naar lopende produktie. Inzicht in de opeenvolging in de tijd tussen diverse produktiestadia blijft buiten zicht.

- Het criterium van de onderlinge levering in monetaire grootheden laat andersoortige organisatorische vervlechtingen buiten beschouwing. Zo worden financiële en organisatorische vervlechtingen niet zichtbaar en is de technologie 'embodied".

Samengevat blijkt de statistische methode behept met een aantal problemen, waarvan in verband met onze probleemstelling met name het statische en én-dimensionale karakter van de vervlechtingen, alsmede het aggregatieniveau problematisch zijn. Immers, voor het voeren van een industriebeleid dient de overheid vooral inzicht te krijgen in de dynamiek van de industriële structuur, in de complementariteit van de vervlechtingen naar technologische, financiële en organisatorische dimensies, en dïent 
zij bovenal inzicht te krijgen in de mogelijke aangrijpingspunten voor beleid. Dat wil zeggen: inzicht in het concrete microniveau van de onderneming of de industriële groep, die de strategische beslissingen neemt, welke voor de ontwikkeling van de industriële structuur van groot belang zijn.

In het onderzoek in Frankrijk is gepoogd aan die tekortkomingen het hoofd te bieden door het construeren van 'filières', in de zin van multi-dimensionele netwerken, waarin nauwkeurig de diverse actoren, hun machtsbasis, hun onderlinge relaties etc. worden beschreven. Dergelijke monografieèn worden wel 'filières monografiques' genoemd (vergelijk 3.1). Montfort $(1985,25)$ merkt over de beperkingen van de statistische en de relevantie van monografieẽn op:

"L'optique retemue ici (bij de statistische 'filière' JG) est de caractère technologique (achat, vente). C'est aussi une optique externe (en ce sens que la demande finale joue un rôle). Le probleme de mesure statistique semble sousjacent dans toute la littérature que j'ai pu lire. Les nomenclatures sont ce qu'elles sont depuis 1973. Notre information est insuffisante et la restera très certainement pour des questions de moyens. Ainsi, les monographies sont loin d'avoir perdu leur intérêt".

De vraag, of de statistische en monografische 'filière' niet zouden kunnen worden geintegreerd, is aan de orde gesteld door Rainelli (1983).

"En effet, si l'observateur s'intéresse aux comportements, il ne peut remonter aux structures. Mais s'il privilegie ces dernières, il construit une scène vide, où aucun acteur n'a de place. Cependant, une telle constatation ne doit pas, selon nous, être assimilé a un échec; elle plaide plutôt pour la constitution de deux économies industrielles. De fait, ces deux courants analytiques existent déjà, mais ils sont peu percus, en raison de l'oecumenisme qui a accompagné le développement récent et rapide de l'économie industrielle. La question en débat n'est plus, dès lors, simplement mèthodologique; en effet, l'affrontement entre tenants de la branche et partisans de la firme ne présente que peu d"intérêt. Ill est crucial, en revanche, de préciser les domaines de validité des deux constructions alternatives du niveau intermédiaire."

Ons inziens is echter een verbinding denkbaar: delen van een statistische 'filières" zouden met netwerkanalyse zodanig in kaart kunnen worden gebracht, dat de actoren op meso- en microniveau zichtbaar worden (concrete ondernemingen, onderzoekinstellingen, bracheorganisaties, afdelingen van ministeries en dergelijke) Door na te gaan tot welke statistische "filiere' het desbetreffende netwerk behoort, zou het effect van de strategieën van de actoren op de leveranties van andere branches kunnen worden nagegaan (vergelijk schema 3.12). Een ander begrip, dat in dit verband in de Franse literatuur kan worden aangetroffen is dat van de 'pôles de compétivité'. Aglietta en Boyer (1982, 310) definiëren dergelijke clusters van ondernemingen als volgt:

"(...) comme des sous-ensembles du système productif composés d'entreprises qui ont acquis des positions dominantes dans la concurrence internationale, at partir desquelles s'exercent des effets d'entraînement qui bénéficient à une grande variété d'autres activités".

Voor het ontwikkelen van een specifiek industriebeleid is het van essentieel belang dergelijke trekpolen te identificeren en meso-organisaties te ontwikkelen, die de verbindingen 'amont' en 'aval' vanuit de 'pôles de compétivitế' stimuleren en organiseren (vergelijk Laganier 1985, Aglietta en Boyer 1982 en Wassenberg 1987). 
Schema 3.12 Statistische en monografische 'fuliere"

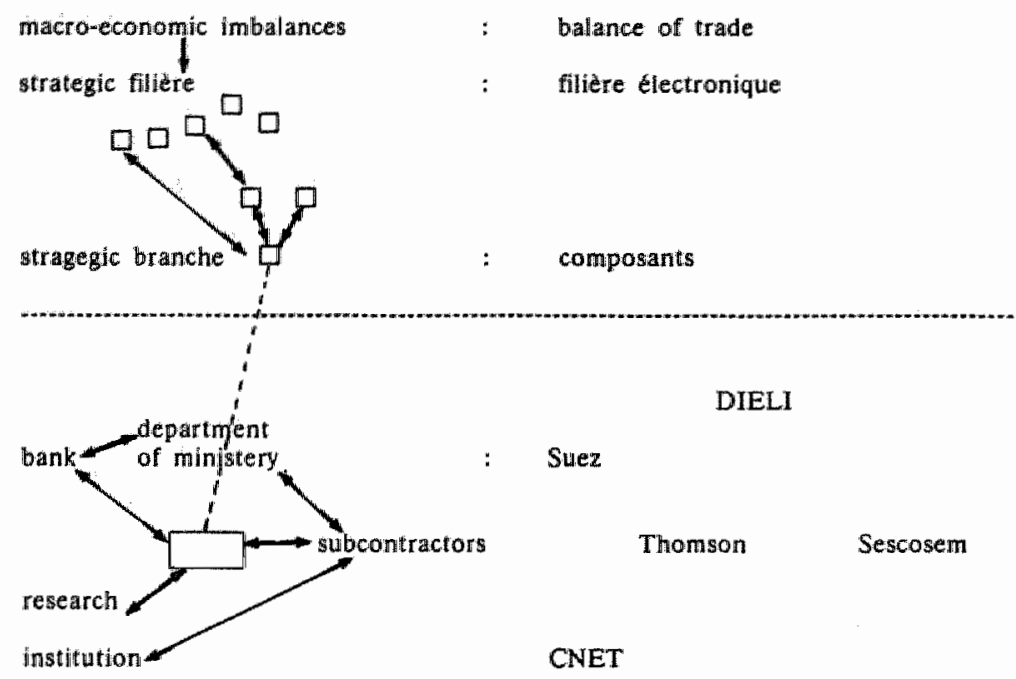

Bron: Groenewegen 1987a.

Gieconcludeerd kan worden, dat het concept van de "filiere" ingevuld met statistisch materiaal een één-dimensionaal inzicht verschaft in vervlechtingen van de industrièle structuur uit het verleden. In de 'filière monografique' kunnen netwerken zichtbaar worden gemaiakt vanuit diverse invalshoeken (financieel, technologisch en organisatorisch) en kan op basis van inzicht in de strategische beslissingen van de microactoren een beeld worden gevormd wan de te verwachten ontwikkeling van de industriële structuur. Of die informatie ook daadwerkelijk zal kunnen worden geproduceerd hangt in belangrijke mate af van de kennis, kunde en organisatie van de overheid en van de relatie tussen de overheid en het bedrijfsleven.

\subsubsection{5 'L'Etat développeur' en de Industriële groep}

Uiteengezet is in 3.1.2.5, dat ondernemingen en industriële groepen pogen onzekerhedlen te reduceren door beheersing van de netwerken, waarin zij participeren. Daartoe worden niet alleen 'governance structures' met toeleveranciers, afnemers en concurrenten gecreẻerd, maar wordt ook gepoogd de socio-politieke omgeving beheersbaar te maken. De industriëlle groepen participeren daartoe direkt, of indirekt via hun belangenorganisaties in de officiële en informele netwerken, waarin doeleinden van beleid worden geformuleerd, strategieën worden ontwikkeld en gecoordineerd en waarin de uitvoering van beleid aan de orde komt.

Voor het verkrijgen van inzicht in het funktioneren van het overheidsapparaat en in de relatie tussen de bureaucratie en de diverse belangengroepen, waaronder de industriële groepen, zouden concepten uit de 'public choice theory' relevant kunnen zijn. Blijken zal echter, dat die benadering voor onze probleemstelling minder relevant is en dat theorieen over het neo-corporatisme meer houvast bieden. 


\section{Public choice theory}

De peiler binnen de 'new institutional economics', die de relatie tussen de overheid en de partikuliere sector analyseert, namelijk de "public choice theory", kent door de sterk 'individualistische inslag' voor onze probleemstelling grote beperkingen.

Kenmerkend voor de 'public choice'-benadering is immers het uitgangspunt van het maximaliserende individu: de kiezer maakt een rationele afweging met betrekking tot de verwachte opbrengsten, de bureaucraat maximaliseert het budget, de omvang van de afdeling van het ministerie of de produktie van het collectieve goed en de politicus is uit op het verkrijgen van een maximaal aantal stemmen. Het is derhalve niet verwonderlijk, dat de public choice zich een sterke positie heeft verworven binnen de 'new institutional economics'. De betekenis van de 'public choice'-benadering is gelegen in de analyse van het gedrag van politici, de bureaucraten en de kiezers en in het effect daarvan op de ontwikkeling van het economisch proces. Uit de weergave in schema 3.16 blijkt echter, dat de modellen vooral macro-relaties betreffen en dat economische actoren op meso- en microniveau onzichtbaar blijven.

De informatieoverdracht vindt veelal uitsluitend plaats via de stemmen, waardoor de informatieoverdracht en gedragsbeïnvloeding tussen politici, bureaucraten en managers via andere kanalen buiten de analyse blijft.

Voor het bestuderen van de relatie tussen het management van de industriële groepen, de politici en de topambtenaren bieden de concepten van de public choice onvoldoende houvast. Voor het bestuderen van die relaties lijken de meer politicologische theorieèn, die het neo-corporatisme betreffen relevanter te zijn (Albeda en Ten Hove 1986c, Cawson, Holmes en Stevens 1985, Dercksen 1986 en Dekker 1989).

\section{Neo-corporatisme}

Ter onderscheiding van het staatscorporatisme, zoals dat in Italië, Spanje en Portugal heeft bestaan, wordt in de literatuur het begrip 'neo-corporatisme" gehanteerd, waarmee wordt gedoeld op een sociaal-economisch stelsel, waarin de centrale overheid nauw is verweven met de diverse belangenorganisaties. Van het neo-corporatisme zijn diverse definities en classificaties in omloop (vergelijk Dekker 1989, bijlage $C$ voor een uitgebreide bespreking van de diverse definities). Lehmbruch (1982, 5 en 6) combineert de diverse opvattingen tot de volgende typering:

"We might define a fully 'corporatized' polity by the following characteristics. 1a) Interest organizations are strongly co-opted into government decisionmaking (as measured by representation in advisory committees, procedures of 'remiss', 'Vernehmlassung' or consultation and other appropriate indicators). 1b) Large interest organizations (in particular, labour unions) are strongly linked to political parties (as measured by role cumulation, etc.) and take part in policy in a sort of functional division of labour ... . 2a) Most interest organizations are hierarchically structured, and membership tends to be compulsory. 2b) Occupational categories are represented by non-competitive organizations enjoying a monopoly. 3) Industrial relations are characterized by strong 'concertation' of labour unions and employers' organizations with government which implies that unions refrain from strongly employing the strike weapon or other highly conflictual tactics". 


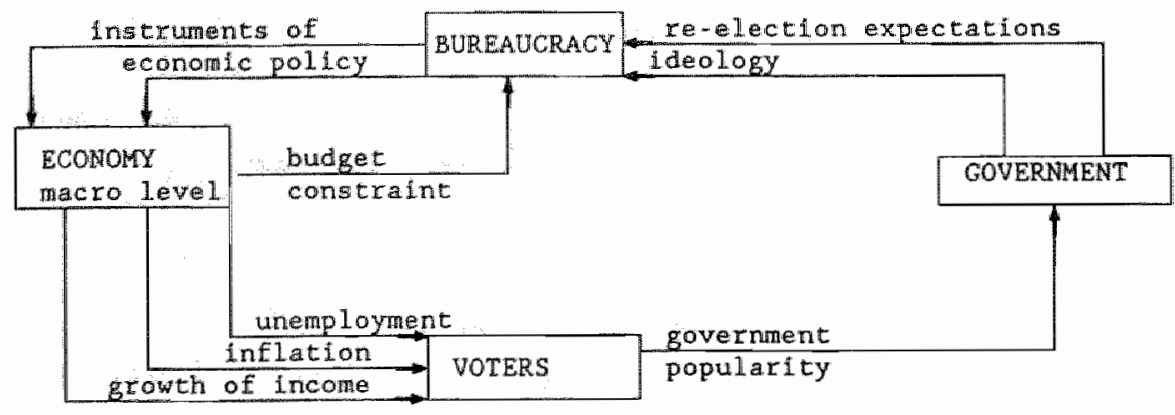

Bron: Van der Winden $(1981,12)$

Het corporatisme in de diverse markteconomieèn vertoont elementen van die typering, maar elk land kent zijn eigen specifieke kenmerken.

Wat de Franse situatie betreft, is het de vraag of wel van corporatisme sprake is, omdat in Frankrijk een zeer sterke relatie tussen het overheidsapparaat en de grote ondernemingen bestaat en de vakbeweging aan de besluitworming nagenoeg niet deelneemt (vergelijk Intermezzo II). Voor een situatie, waarin het overheidsapparaat initiatieven neemt en tezamen met de grote ondernemingen een actieve rol speelt in het sturen van de ontwikkelingen in de richting van nationale doeleinden, reserveert Cawson het begrip technocratisch corporatisme (vergelijk Dekker 1989, bijlage C) Het overheidsapparaat bemand met veranderingsgezinde wilskrachtige bureaucraten werkt in nauw overleg met de managers van de grote industriële groepen aan de realisatie van de nationale doeleinden.

"The state is neither directive nor coupled to an autonomous private sphere, but it is intermeshed in a complex way which undermines the traditional distinction between public and private" (Cawson 1982, 66)

De vervaging van de grenzen tussen publiek en particulier in het technocratische corporatisme heeft enerzijds gevolgen voor het funktioneren van de parlementaire democratie (vergelijk Intermezzo II) en anderzijds voor de mogelijkheden van industriele groepen het overheidsapparaat te beheersen. Van belang daarbij is enerzijds de positie van het centrale coobrdinatiebureau binnen het overheidsapparaat (vergelijk de karakterisering van de 'developmental state' in 3.2.1.1) en anderzijds de machtspositie van de desbetreffende industriêle groep.

Cawson, Holmes en Stevens (1985) ontwikkelen een matrix (zie schema 3.14), waarin enerzijds de positie van de coördinerende instantie ten opzichte van de andere instituties van het overheidsapparaat en anderzijds de monopoliegraad van de betreffende ondernemingen of industrielle groep een rol spelen. Wat de positie van de coördinerende 'agency', zowel binnen het overheidsapparaat als ten opzichte van de ondernemingen betreft, is het van essentieel belang, dat deze niet alleen de wil heeft met 
betrekking tot de ontwikkeling van de industriële structuur initiatiewen te nemen en mesosystemen te organiseren, maar ook de kennis, de kunde en de (financiële) middelen. Toegang tot de informatie op meso- en microniveau is daartoe een vereiste, expertise een voorwaarde en een effektief instrumentarium ter coördinatie van de plannen van de ministeries en de ondernemingen een noodzaak. Bij de inrichting van 'L'Etat développeur' dient er met name voor gezorgd te worden dat de coördinerende instantie qua informatie en financiën een onafhankelijke positie kan innemen. Eigen onderzoekafdelingen en/of de mogelijkheid onderzoek uit te besteden is een voorwaarde voor het verkrijgen van zo min mogelijk verstoorde informatie van belanghebbenden; financiële onafhankelijkheid is een voorwaarde voor het vrijwaren van de lange termijn plandoeleinden voor de gevolgen van het korte termijn conjunctuurbeleid van het Ministerie van Financiën.

Zo'n coördinerend orgaan van 'L'Etat dêveloppeur' kan echter alleen effectief opereren in een context van "tegenspelers", die overtuigd zijn van het belang van de coördinatie en derhalve positief staan tegenover het uitwisselen van informatie en het realiseren van de plandoeleinden. Er dient in het netwerk sprake te zijn van wederzijds vertrouwen. Zo'n attitude kan echter niet bewust worden gevormd, maar kan wel het resultaat zijn van een lange historie, waarin overheid en bedrijfsleven in onderling overleg de richting van de industriële ontwikkeling hebben bepaald.

Schema 3.14 Typologie van beleidsnetwerken

AUTONOMY OF STATE AGENCY

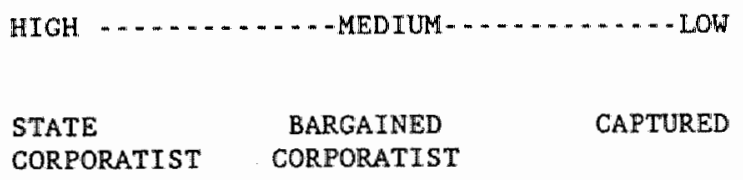

HIGH

CORPORATIST CORPORATIST

MONOPOLY:

CLOSURE IN

STATE-GROUP

RELATIONSHIP

STATIST INTERVENTIONIST COMPETITIVE

Bron: Cawson, Holmes, Stevens (1985, 14)

In het ideaaltype van 'L'Etat développeur' is de coördinatie van het beleid van de ministeries en de ondernemingen steeds toegedacht aan een centraal orgaan. In werkelijkheid zal in de relatie tussen overheid en bedrijfsleven veelal sprake zijn wan een aantal 'state agencies', die ieder specifieke projekten realiseren op bijv. het terrein van energievoorziening, het transport, de telecommunicatie en dergelijke. Als in de matrix van Cawson, Holmes en Stevens zo'n overheidsinstantie geen monopolist tegenover zich vindt, dan kan sprake zijn van een 'statist, interventionalist -' of een 'competitive network' afhankelijk van de autonomie van het agentschap binnen het overheidsapparaat. 
Van een "statist network' is sprake als de overheidsinstantie de vraag op de betreffende markt volledig beheerst, over de benodigde expertise beschikt en voor de financiering van het projekt niet afhankelijk is van de jaarlijkse begrotingsperikelen van het Ministerie van Financiên (vergelijk de positie van de Direction des Télécommunication in de Franse telecommunicatiesector, zie hoofdstuk 7).

In een 'interventionalist network' is sprake van een overheidsinstantie , die qua informatie of financièn afhankelijk is van andere onderdelen van het overheidsapparaat. Het agentschap formuleert bijv. het beleid met betrekking tot het betreffende onderdeel van de industriele structuur, maar is voor de beïnvloeding van het gedrag van de ondernemingen afharkelijk van bijv. het subsidiebeleid van het Ministerie van Economische Zaken. Zo"n zwakkere overheidsinstantie stimuleert het ontstaan van een belangengroep van ondernemingen, die in een 'interventionalist network' door het agentschap geconsulteerd moet worden (vergelijk de positie van de 'Délégation a I'Informatique' in de Franse computerindustrie, zie hoofdstuk 7).

In geval van een 'competitive network' is geen sprake van een sterke centrale overheidsinstantie: afdelingen van ministeries concurreren met elkaar, terwijl belangenorganisaties van de ondernemingen op de politici en bureaucratie druk uitoefenen. Omdat noch aan overheidszijde noch aan ondernemingszijde sprake is van een sterke machtsconcentratie, wordt het 'competitive network' gekenmerkt door een grote mate van autonomie aan beide zijden en door instabiele gelegenheidscoalities.

Als sprake is wan een monopoliepositie van een onderneming, of van een belangenorganisatie van een groep van ondernemingen, dan kan sprake zijn van een 'captured, bargained of statist corporatism'.

In geval van een "captured corporatism" vindt de monopolist een verdeelde overheid tegenover zich, waardoor zij gemakkelijk de verantwoordelijke overheidsinstantie(s) kan manipuleren met name op het terrein van de informatieverschaffing (vergelijk het Plan Calcul, zie hoofdstuk 7).

In geval van een 'bargained corporatism' is sprake van een gesloten front van overheidsinstanties, waardoor een 'capture' vanuit de onderneming kan worden voorkomen. De monopolist heeft in het onderhandelingsproces well invloed op de inhoud en de uitvoering van het beleid en verkeert in de positie beleidsafspraken te effectueren, of omdat een monopoliepositie wordt ingenomen, of omdat de belangenorganisatie over volldoende macht over de aangesloten ondernemingen beschikt.

Is sprake van 'statist corporatism" dan is de onderneming een creatie van de overheidsinstantie, die de betreffende markt volledig beheerst, over de noodzakelijke expertise en financiële middelen beschikt: de overheidsinstantie is in staat het mesosysteem natr eigen inzichten te organiseren.

Wanneer de overheid voornemens is als een 'Etat développeur' de strategie van industriële groepen te beïnvloeden, dan dient zij zich goed rekenschap te geven van de positie van haar tegenspeler en van de positie, die haar agentschap binnen het overheidsapparaat inneemt. In 3.1.2.5 is beschreven hoe het management van een sterke industriële groep competenties weet te vormen tot een 'métier', hoe het management waakt over de coherentie, zorgt voor aanpassingen en een combinatie van economische organisatievormen selecteert, die tezamen het complexe geheel van de groep vormen. De informatie en expertise van het management is gebaseerd op een lang. 
durig leerproces en is ingebed in een interne en externe consensus. Daarbij poogt het management de groep zoveel mogelijk af te schermen van de buitenwereld (concurrenten en overheid), of die buitenwereld zoveel mogelijk te beheersen, teneinde zo goed mogelijk in staat te zijn haar 'projekt' te realiseren.

Gelet op de complexiteit van de groep, de specifieke expertise van het management en de interne en externe consensus, dient de overheid in het kader van het industriebeleid de strategie van zo'n groep als uitgangspunt te nemen en 'slechts' te onderzoeken welke de gevolgen van de ondernemingsstrategie zijn voor de ontwikkeling van de industriële structuur ('primat du projet productif'). Vanuit die visie dient de rol van de overheid in de eerste plaats gericht te zijn op het scheppen van voorwaarden, waardoor de groep in staat is haar projekt te realiseren en zich tijdig kan aanpassen aan veranderende omstandigheden. De overheid kan daartoe informatie produceren en verspreiden, het afsluiten van contracten vergemakkelijken door institutionele belemmeringen weg te nemen, zich opwerpen als makelaar en zo aktief mogelijke partners bij elkaar brengen, of een stapje verder gaan en zogenaamde 'niches' opsporen en deze tot ontwikkeling brengen. Met dat laatste wordt bedoeld, dat de overheid een markt creërt, die door haar wordt afgeschermd en georganiseerd, waarna de ondernemingen zelfstandig op de wereldmarkt kunnen opereren. Veel van de Franse 'Grands Programmes' zijn langs die lijn opgezet. Wij zullen zien, dat het organiseren van dergelijke specifieke projekten een duurzame vertrouwensrellatie vereist tussen de overheid, i.c. de topambtenaren van het Ministerie van Industrie en de managers van de industriële groepen. Is in de branche of 'filière", die de overheid van strategisch belang acht geen geschikte onderneming aanwezig, dan zou de overheid in haar interventie nog een stapje verder kunnen gaan. Zij zou initiatief kunnen nemen tot het creëren van een industriële groep als onderdeel van een departement (vergelijk de 'Direction Générale des Télécommunications' in Frankrijk), of over kunnen gaan tot het selektief nationaliseren van die industriële groepen, die de competenties voor het gewenste projekt wel in huis hebben, maar deze niet aanwenden in de richting, die de overheid met haar industriepolitiek voor ogen staat.

Over de theoretische aspecten van dergelijke publieke ondernemingen handelt het volgende hoofdstuk. 


\section{Noten behorend bij hoofdstuk 3}

11] De strattegische beslissingen van ondernemingen betreffen tal van aspecten (ver* gelijk Mintzberg 1987a en 1987b). Voor onze probleemstelling betreffende de effectiviteit van publieke ondernemingen voor het realiseren van industriepolitieke doeleinden zijn met name de strategieẻn met betrekking tot de investeringen en de organisatie van belang.

[2] Door de 'institutionele arrangementen" kan echter ook verstarring optreden, waardoor tijdige aanpassing aan veranderingen in de omgeving uitblijft. Hodgson (1988a, 264) wijst erop, dat de onderneming succesvol kan zij̄n in het beheersen van zijn omgeving door diverse institutionele arrangementen te creëren, maar daardoor tegelijkertijd problemen van rigiditeit en inertie kan scheppen, waar* door flexubiliteit verloren gaat. In elk economisch systeem speelt het vraagstuk van stabiliteit en verandering, van beheersing versus de noodzaak van aanpassingen.

[3] Met Hodgson (1988a, preface) karakteriseren wij de neoklassieke theorie aan de hand van:

- rationele maximaliserende individuen, waarvoor de preferenties zijn gegeven (methodologisch individualisme)

- er is geen sprake van een informatievraagstuk (geen onzekerheid)

- de theoretische analyse is gericht op het analyseren van stabiele evenwichten (geen historische tijd).

[4] Van der Weijden (1987, 102) wijst erop, dat over Bain een genuanceerder oordeel meer conform de feiten zou zijn: ook Bain onderkende het belang van het gedrag, maar omdat over gedrag zo weinig bekend is komt bij Bain het accent op de structuurelementen te liggen. Bain is een 'pragmatisch structuralist'.

[5] In hoofdstuk 1 is een onderscheid gemaakt tussen instituties en organisaties. In de literatuur van de NIE is dat niet gebruikelijk en wordt veelal van 'institutions' gesproken, waarmee wordt gedoeld op zowel de gedragspatronen, conventies en gewoonten als op de concrete organisatie, zoals de onderneming, de vakbond en dergelijke.

[6] Heijdra et al. (1988, 296) schrijven de naam 'new institutional economics' toe aan Coase (1984) en Langlois (1986). Zoals zal blijken heeft de 'new' institutionele economie niets van doen met de "old' institutionele theorie van Veblen en Ayres (vergelijk Hodgson 1988b), terwijl het zogeheten 'neo-institutionalisme' (vergelijk Gruchy 1972 en Groenewegen 1982) veell verwantschap met de netwerkbenadering vertoont (vergelijk 3.1.2.4).

[7] Williamson (1975) verwijst naar Tittmus (1971), die verschillende systemen van bloeddonorschap onderzocht. In Engeland kregen de donoren geen vergoeding, in de Verenigde Staten wel. Bij vergelijking van die twee systemen bleek, dat commercialisering welliswaar het aanbod kan vergroten, maar dat ook het risico van de levering van inferieur bloed en aantasting van de waarden van de samenleving wordt verhoogd.

Uit het onderzoek van Tittmus bleek dat in geval van commercialisering de donoren minder zorgvuldig zijn met het verschaffen van gegevens omtrent recente contacten met besmettelijke ziekten en omtrent gewoonten, die de kwaliteit van het bloed belinvloeden (alcoholgebruik, drugs).

[8] Wij gebruiken in het navolgende de begrippen 'governance structure' en 'economische organisatievorm' als synoniem. 
[9] Williamson (1985) spreekt van de zogeheten 'fundamental transition'.

[10] Van een 'holdup'-situatie is sprake als de ene actor door het verbreken wan het contract de ander in onoverkomelijke moeilijkheden brengt, omdat geen andere leverancier of afnemer bestaat.

[11] "I submit, however, that organizational innovations (the conglomerate JG), which in the 1930 s were just getting underway, have mitigated capital market failures by transferring functions traditionally imputed to the capital market to the firm utself" (Williamson 1975, 136).

[12] De transactiekostentheorie is op een grote varieteit van orgarisaties toegepast: vertikale integratie (Kllein, Crawford en Alchian 1978), clan-relaties in de onderneming (Ouchi 1980), organisatiecultuur (Jones 1983), strategische netwerken (Jarillo 1988), de Japanse 'keiretsu' (Goto 1982), de Japanse 'sogo shosja' (Roehl 1983).

[13] Francis, Turk, Willman (1973); Dugger (1983); Granovetter (1985); Perrow (1986); Dow (1987); Putterman (1987); Hodgson (1988a); Groenewegen 1988a.

[14] Williamson (1979), 102) stelt:

"the 'appropriate' level of transactional detail is not well defined and may vary with circumstances".

Williamson $(1979,233)$ merkt op, dat 'the concept (van transactiekosten JG) wants for definition', hetgeen later resulteert in de opmerking dat van een transactie sprake is

"When a good is transferred across a technologically separable interface (Williamson 1981, 1544).

Imai en Itami $(1984,287)$ spreken van een 'transfer of the right to use goods'.

[15] Dahlman $(1979,148)$ zet uiteen, dat al die categorieẽn zijn terug te voeren op de kosten, verbonden aan het gebrek aan informatie.

[16] Zie ook Dow (1987, 18), die stelt dat het voordeel van een specifieke organisatievorm is gelegen in "(...) the value to the parties of the adaptations to changing circumstances which that structure makes possible $\mathrm{e}^{\mathrm{m}}$.

[17] Door Dugger (1983) kernachtig omschreven als "What is, is best'.

[18] "A 'hostage' refers to a class of arrangements where, for example, both parties to an agreement are committed to specific and non-salvageable costs" (Hodgson $1988 \mathrm{a}, 155)$.

[19] De kritiek op deze neoklassieke theorie van het institutionaliseringsproces komt verderop bij de bespreking van het functionalisme aan de orde.

[20] Het is opvallend, dat Williamson nooit expliciet op de argumenten van Dugger heeft gereageerd. Wellicht beschowwt hij deze "echte" institutionalist als een empiricist (zie blz. 71 e.v.).

[21] 'Peer groups' betreffen niet-hierarchische georganiseerde associaties van werknemers, waarin volgens Williamson de voordelen van risicospreiding, respect en identificatie met het collectieve doel niet opwegen tegen de nadelen van 'free riding' en hoge besluitvormingskosten.

[22] Vergelijk de kritiek van Dow (1987) en Putterman (1987) weergegeven in Groenewegen (1989a).

[23] Dow (1987) en Putterman (1987) wijzen er ook op, dat het geringe aantal "peer 
groups" geen teken van hun inefficiëntie behoeft te zijn. De onmogelijkheid de toekomstige voordelen van de organisatie toe te rekenen aan de individuele deelnemende partijen ("appropriability"-problematiek) verhindert het ontstaan wan zo"n organisatie (vergelijk Groenewegen 1989a).

[24] - De "Panglossian view": "rall is for the best in this best of all possible worlds".

- Malinowski's opvatting, dat "all social phenomena have beneficial consequences (intended or unintended, recognized or unrecognized) that explain them"

- Merton's principle houdt in, dat "whenever social phenomena have consequences that are beneficial, unintended and unrecognized, they can also be explained by these consequences".

[25] Williamson baseert zich op Elster (1983) en is van mening dat de in noot 24 genoemdle vormen van functionalisme "hopelessity naive" (Panglossion view) respectievelijk too elastic, in that any outcome can eventually be rationalized (Malinowski) zijn. Het functionalisme van Merton betreft fenomenen, die onbedoelde en onherkenbare gevollgen opleveren, waardoor een reproductive feedback onmogelijk wordt. Deze bezwaren worden ondervangen door het 'full functionalism' van Elster (1983, 57).

[26] Volgens Williamson $(1987 \mathrm{a}, 42-44)$ is de multidivisionele onderneming én van de weinige organisatievormen, waarop een 'full functionalist'-verklaring van toepassing is.

[27] Heijdra et al. (1988) pogen daarmee de beschuldiging van Elster (1983) te weerleggen, dat neoklassieke theorie aan dezelfde 'objective teleology' mank gaat als het Marxisme.

[28] Zie Gray $(1987,44)$.

[29] Williamson $(1987 \mathrm{~b}, 618)$ antwoordt, dat zijn opvatting van beperkte rationaliteit, die van Simon (1961, XXIV) is: de actor is 'assumed to be intendedly rational, but only limitedly so'. De 'intentie' resulteert bij Williamson in de beslisregel van. minimalisatie van de transactiekosten, terwijl de' 'beperking' tot uitdrukking komt in 'bounded rationality'. Overigens impliceert zulks o.i. niet, dat de resulterende organisatievormen ook efficiënt zijn.

[30] Williamson (1975, hoofdstuk 7) wijst ook op die tendensen binnen hièrarchieën.

[31] Skepsis met betrekking tot de "natuurlijke" selectie van de meest efficiènte organisatievormen is ook gerechtvaardigd als sprake is van beperkte 'appropriability-mogelijkheden'.

[32] Zie bijv. Williamson (1980) over de verklaring van de interne arbeidsmarkt en Monteverde en Teece (1982) over de verklaring van achterwaartse integratie.

[33] Ook is in veel studies een proxy van de transactiekosten gerelateerd aan empirische datamateriaal (Armour and Teece 1978; Daems 1982), hetgeen aanwijzingen geeft, maar geen verklaringen (vergelijk Douma 1987).

[34] Zo'n meer dynamische verklaring, waarin een complex van variabelen in de analyse wordt opgenomen kan worden aangetroffen in de netwerkbenadering (zie de bespreking van de filiere in 3.1.2.5).

[35] In Williamson en Ouchi (1983) is sprake van 'a decade or so'.

[36] Vergelijk bijv. Roehl (1983, 133), die concludeert dat de typologie van 'governance structures' zeker nuttig is 'in aiding researchers in their analysis'. De transactiekostentheorie levert een denkstructuur, waarmee de complexe werke- 
lijkheid kan worden gestructureerd. Zie ook Dow (1987, 34): "However, it is essential that functionalist premises be used only as a heuristic guide to the generation of empirical hypotheses, and not as a tautological rationalization for the status quo".

[37] Scherer (1980) schrijft: "This book explores systematically the field of economics known as industrial organization. The name is a curious one, distinctive mainly in its inability to communicate to outsiders what the subject is all about. It has little or nothing to say about how one organizes and directs a particular industrial enterprise, although there are industrial organization courses in business and engineering schools that deal with such matters. Rather, the field is concerned with how productive activities are brought into harmony with society's demands for goods and services through some organizing mechanism such as a free market, and how variations and imperfections in the organizing mechanism affect the degree of success achieved by producers in satisfying society's wants".. Zie Porter (1981, 385-390) en Van Cayseele en Schreuder (1988).

Van der Weijden (1987, 102) merkt op, dat in dat beeld van de industrial organization omstreeks 1980 verandering komt (zie 3.1.2.3).

[38] De terminologie is overigens verwarrend: Van Cayseele en Schreuder (1988) maken een bruikbaar onderscheid tussen:

- industriële economie, waaronder de economische analyse van marktstructuur en ondernemingsgedragingen op bedrijfstak- (of sector-) niveau wordt verstaan

- industriële organisatie is ruimer, omdat de aard van de analyse niet puur economisch behoeft te zijn.

- De specifieke Nederlandse term "externe organisatie" (vergelijk De Jong 1987) verruimt de analyse tot "de bestudering van de vraagstukken van maatschappelijke-economische organisatie en de verschijnselen die zich tussen de afzonderlijke bedrijfshuishouding en haar ' $U m w e l t$ ' - daaronder begrepen de overige bedrijfshuishoudingen - voordoen" (Dreesman 1979, 48, geciteerd. naar Van Cayseele en Schreuder 1988, 4). De externe organisatie is qua niveau van analyse noch beperkt tot de bedrijfstak, noch tot de bindingen met andere ondernemingen die in dezelfde markt opereren.

[39] Onderscheid wordt gemaakt tussen concurrentie- en ondernemingsstrategie.De concurrentiestrategie op specifieke markten ('competitive' of 'business strategy') van de verschillende 'business units' moet binnen de onderneming tot een geheel worden gesmeed ('corporate strategy'). Zie Van Cayseele en Schreuder (1988, 5 en 16).

[40] Het gaat daarbij overigens niet alleen om het ontrafelen van het technisch produktieproces.

"A firm's value chain and the way it performs individual activities are a reflection of its history, its strategy, its approach to implementing its strategy, and the underlying economics of the activities themselves" (Porter 1985, 36).

Zo'n analyse impliceert een integratie van diverse disciplines.

[41] Vergelijk Zuidema (1982), die de verklaring zoekt in de angst van de onderzoekers hun beschermende theoretische afgebakende wereld te verlaten.

[42] "L'économie industrielle nous fournit ainsï un guide méthodologique minimum. Certes, chacune des industries n'est pas susceptible de se conformer systematiquement àà ce crible d'analyse mais la démarche générale nous permettra de poser les questions les plus importantes qui constituent un préalable à la définition d'une véritable politique industrielle" (Bellon 1983, 53). 
[43] De integratie van het strategische management wordt daarbij essentieel geacht: "Il convient donc, en utilisant les instruments de l'économie industrielle, de décrire soigneusement les stratégies des acteurs, de les mettre en perspective, de chercher à savoir pour qui ou contre qui elles sont mises en oeuvre. Plus précisément, on sse demandera si les stratégies de prix, de production, d'innovation, de distribution correspondent à une dynamique du progrès, ou bien si elles sont marquées par une rigidite structurelle, organisationnelle ou stratégique qui conduit a des prix élevés, au renforcement des tensions inflationnistes et à un mauvais rapport qualite-prix (Bellon 1983, 51).

[44] Met betrekking tot het begrip "filière" bestaat in Frankrijk veel onenigheid. Voor een indruk van de verscheidenheid van definities wordt verwezen naar Annex 1 in Laurent (1986). De Bandt (1985; 1987) stelt voor het begrip "filière" te reserveren voor de statistische fillière a la Montfort en Dutailly (1983) (zie 3.2.2.1) en het begrip "mésosystème" te gebruiken voor de meer-dimensionele benadering van vervlechtingen, waarin met name het organisatorische aspect centraal staat. Wij gebruiken de begrippen filière en mésosystème als synoniem voor netwerk (vergelijk De Bandt 1983, 34). Als de statistische filière wordt bedoeld zullen wij daar steeds expliciet over zijn.

[45] De Bandt $(1983 c, 34)$ spreekt van " $(. .$.$) une notion principalement technique, (...)$ une succession de relations d'échanges marchands, (...) un ensemble organisé d'interrelations".

[46] Laurent (1985) vat de onderneming op als een subsysteem van de filiere; vergelijk Hodgson $(1988 \mathrm{a}, 262)$ over 'the firm as a system'.

[47] Voor het begrip 'crémeau' zie hoofdstuk 6 .

[48] Als wij spreken van de "institutionele benadering", dan duiden wij op het "oude" institutionalisme van Veblen en Commons en het zo door Gruchy (1972) beschreven "neo institutionalisme" van o.a. Galbraith (1967). Daarenboven vatten wij de meer instrumentele benadering van bijk. Tool (1978) ook onder de institutionele benadering (vergelijk Hodgson 1988 b en Groenewegen 1982).

[49] Vergelijk Jarillo $(1988,38)$.

[50] Overigens zijn in dat verband ook duidelijke tegengestelde ontwikkelingen gaande, waarbij met betrekking tot de arbeidsvoorwaarden en het overheidsbeleid niet de samenstellende delen, maar de groep als geheel als tegenpartij wordt gekozen. Zo bepalen bijv. de demokratiseringswetten in Frankrijk (lois Auroux), dat werknemers vertegenwoordigd zijn in het 'comite du groupe', dat toegang heeft tot informatie met betrekking tot de groep als geheel. Zo wordt het structuurbeleid van de socialisten in Frankrijk na 1981 duidelijk geënt op de strategie van de groep en worden na de nationallisaties de overeenkomsten ook afgesloten met de groep en niet met de afzonderlijke onderdelen.

[51] Zie Jarillo (1988) voor een uiteenzetting van de reductie van transactiekosten door middel van het cree̊ren van netwerken. Op Jarillo is overigens dezelfde kritiek van toepassing als wij in 3.1.4 op Williamson hebben gegeven: er wordt geen causale, maar een functionalistische verklaring gegeven.

[52] Het is mogelijk, dat aan een generieke maatregel specifieke voorwaarden worden verbonden met betrekking tot bijv. de creatie van werkgelegenheid of milieuverbetering.

[53] Petit" (1983) reserveert de categorie "politique industrielle' voor het specifieke industriebeleid (zie 3.1.1.3) en gebruikt voor het generieke beleid de term "politique d'offre". 
[54] Ook wat het effect van een stimulerend macrobeleid (verwachtingen omtrent toekomstige cash flows worden positiever) op de investeringen betreft, draagt de theorie geen duidelijke positieve verbanden aan.

[55] De mate waarin daarvan sprake is wordt in belangrijke mate bepaald door specifieke karakteristieken van de betreffende orde (vergelijk bijv. Cowling 1987 over de terughoudendheid van de financiële wereld in Engeland lange termijn verplichtingen aan te gaan).

[56] Dat het met het 'mesoniveau' en de 'mesotheorie' problematisch is gesteld, blijkt uit Admiraal (1979) en de WRR (1980). De WRR (1980) stelt de vraag naar de theoretische fundering van het industriebeleid aan de orde, maar plaatst in haar aanhef "De theoretische basis van het sectorstructuurbeleid: een mesotheorie?" nadrukkelijk een vraagteken. Als ideeëncomplexen waaruit een mesotheorie zou kunnen worden opgebouwd, worden de 'industriall economics' (vergelijk 3.1) en de input-outputmadellen genoemd (vergelijk hetgeen in 3.2 .2 .3 over de zgn. 'statistische filière' wordt opgemerkt).

[57] L'INSEE is het Franse bureau voor de statistiek (Institut National de la Statistique et des Etudes Economique).

[58] Voor een bespreking van de andere methode, waarbij het effect van een verandering in de finale vraag op de diverse sectoren wordt nagegaan zie Montfort en Dutailly (1983). 


\section{DE THEORIE VAN DE PUBLIEKE ONDERNEMING}

\subsection{Inlleiding}

De publieke onderneming is een centraal instrument in het industriebeleid van de Franse regering in de periode 1981-1986.

In dit hoofdstuk worden theoretische inzichten besproken, die licht kunnen werpen op de effectiviteit en efficiëntie van publieke ondernemingen als instrument voor het industriebeleid van 'L'Etat' développeur' in een markteconomie.

$\mathrm{Na}$ in 4.1 de publieke onderneming te hebben gedefinieerd en in 4.2 de theoretische gronden woor het bestaan van publieke ondernemingen te hebben besproken, wordt in 4.3 ingegaan op de begrippen effectiviteit en efficiëntie. In 4.4 worden theorieën besproken, die inzicht kunnen verschaffen in de oorzaken wan de mogelijke verschillen in prestaties tussen publieke en partikuliere ondernemingen, waarna in 4.5 voorwalarden worden geformuleerd, waaronder de publieke onderneming een effectief en efficiènt instrument zou kunnen zijn in handen van 'L'Etat développeur'.

\subsection{De publieke onderneming gedefinieerd}

"Il n'existe pas actuellement une définition unique de l'entreprise publique, mais plutôt une palette de définitions. Ces dernières sont utilisées en fonction du caractère économique, social ou financier du secteur public que l'on entend privilégier" (Haut Conseil du Secteur Public 1984, 19).

In de economische definities van de publieke onderneming komt steeds het element van de prijs van de te verkopen goederen en diensten aan de orde, alsmede de beheersing van de onderneming door de overheid (Delion 1981,14). Een voorbeeld is de definitie van de OECD.

"Les entreprises publiques sont des entreprises qui, comme les entreprises commerciales, produisent des biens et des services en vue de leur vente à un prix qui doit couvrir approximativement leur prix de rewient, mais qui sont propriété de l'Etat ou placées sous son controôle" (geciteerd naar Andreff 1984, vol. 1, p. 2).

De 'contróle de l'Etat' is ook in de Franse wetgeving van 21-6-1976 van groot belang: de publieke ondernemingen worden aldaar omschreven als:

"Des personnes morales, quel que soit leur statut juridique, dans lesquelles l'Etat ou des organismes déjà soumis au contrôle de la Cour détiennent ... une participation au capital, permettant d'exercer un pouvoir prépondérant de décision ou de gestion" (geciteerd naar Mescheriakoff 1985, 1596). 
In andere definities komt meer het instrumentele karakter van de publieke onderneming tot uiting:

"L'exploitation publique est une unité de production quil se caractérise par deux traits:

- sa propriété et sa gestion relèvent, pour tout ou partie, de l'Etat ou des collectivités publiques,

- son fonctionnement n"est pas guidé uniquement par la recherche du plus grand profit, mais aussi par la recherche de l'intérêt générall, ce qui peut maintenir le gain monétaire dans certaines limites, ou peut justifier dans certains cas des pertes" (geciteerd naar Andreff 1984, vol. 1, p. 2).

Het palet van definities kan volgens de 'Haut Conseil" worden teruggebracht tot twee uitgangspunten:

- de institutionele benadering, gebaseerd op jurisprudentie van de 'Conseil d'Etat', beschouwt elke onderneming, waarin de staat direkt of indirekt $50 \%$ van het kapitaal, of het stemrecht bezit als een publieke onderneming,

- de "machtbenadering', die de sector van de publieke ondernemingen beschouwt als

"L"ensemble des entreprises dans lesquelles les pouvoirs publics exercent directement ou indirectement une influence dominante" (Haut Conseil du Secteur Public 1984, 78).

De 'Haut Conseil' merkt op, dat beide benaderingen hun beperkingen kennen: de institutionele definitie biedt weliswaar een scherp criterium, maar laat de ondernemingen, waarin de overheid wel invloed heeft, maar waarin zij geen meerderheid van de aandelen bezit, buiten beschouwing. Omgekeerd zullen er publieke ondernemingen zijn in de institutionele zin des woords, maar waarover de overheid geen werkelijke controle heeft, omdat de onderneming een sterke machtsbasis heeft opgebouwd, gebaseerd op bijvoorbeeld de produktie van een strategisch economisch goed en/of financiële onafhankelijkheid (vergelijk 4.4.2.4).

Algemeen is de opvatting, dat de machtdefinitie niet operationeel is: elke onderneming moet apart worden onderzocht, terwijl zich de vraag voordoet op basis van welk criterium de 'influence dominante' moet worden vastgesteld.

In de praktijk worden in het algemeen op basis van de institutionele definitie de volgende categorieèn tot de publieke onderneming gerekend (Mazzolini 1979, 10-12):

- Genationaliseerde ondernemingen, die volledig eigendom van de staat zijn, bijv. Renault.

- Overheidsbedrijven, waarvan de funktie en status in een aparte wet is geregeld, bijv. Elf-ERAP.

- Corporatieve ondernemingen, waarin de overheid direkt, of indirekt tenminste $50 \%$ van de aandelen bezit. In dit verband wordt ook de opvatting aangetroffen, dat de overheild over een 'pouvoir préponderant' beschikt als zij een 'minorité de blocage' heeft van $34 \%$, walmee bellangrijke besluiten, die een $2 / 3$ meerderheid vereisen kunnen worden tegengehouden.

- Staatsholdings, die aandelen bezitten van een groot aantal ondernemingen en toezicht houden op het staatsbelang in die ondernemingen, bijv. Istituto per la Ricostruzione (IRI) in Italiè. 


\subsection{Theoretische gronden voor het bestaan wan publieke andernemingen}

In de literatuur wordt erop gewezen, dat de publieke onderneming kan worden gebruikt als instrument voor het corrigeren wan het 'marktfalen', van de 'marktimperfecties' en voor het realiseren van doeleinden van conjunctuur-, structuur-, facetten-, en sociaal beleid.

Het 'marktfalen" duidt op het onvermogen van de markt collectieve goederen en diensten te kunnen produceren, op haar onvermogen externe effekten te incorporeren, of op het onvermogen een natuurlijk monopolie te kunnen reguleren. Dat zijn gevallen, waarin het marktmechanisme met partikuliere ondernemingen niet in staat is de middelen efficiënt te alloceren: de produktie zou in die gevallen beter aan publieke ondernemingen kunnen worden overgelaten.

Van 'marktimperfecties' is sprake als de marktstructuur machtsconcentraties vertoont, waardoor inefficiënties ontstaan. In het algemeen kunnen marktimperfecties worden gecorrigeerd met behulp van de mededingingswetgeving, maar ook zou een publieke onderneming uitkomst kunnen bieden als concurrent van zittende partikuliere onderneming(en).

Wat het conjunctuurbeleid betreft, kan de publieke onderneming door middel van een anti-cyclisch investeringsbelejd een bijdrage leveren aan een minder cyclische economische groei; lage tarieven van de publieke onderneming kunnen een bijdrage leveren aan de inflatiebestrijding, terwijl een bewust beleid gericht op importsubstitutie de betalingsbalans kan verbeteren.

De publieke onderneming kan ook een belangrijk instrument zijn voor de realisatie van de doeleinden van het structuurbeleid:

- Strategische verlieslijdende basissectoren (in de jaren zeventig: ijzer en staal, kolen, zware chemie) zouden zonder nationalisatie in buitenlandse handen vallen, waardoor de industriële structuur ernstige gaten zou kunnen gaan vertonen als de buitenlandse eigenaren de produktie verminderen, of zelfs geheel staken.

- Publieke ondernemingen in strategische sectoren kunnen een voortrekkersrol vervullen door een stimulerend investeringsprogramma uit te voeren en door specifieke ondersteunende relaties met het toeleverende Midden- en Kleinbedrijf te onderhouden (technologieoverdracht, steun bij export); tevens kunnen publieke ondernemingen een bijdrage leveren aan de versterking van regionale structuren.

- Publieke ondernemingen kunnen door het uitvoeren van specifieke diversificatieprogramma"s een bijdrage leveren aan het creëren van een hecht industrieel netwerk van onderling verbonden 'filières'.

Wat het facettenbeleid betreft, kan de publieke onderneming door haar investeringsbeleid een bijdrage leveren an het realiseren van doeleinden met betrekking tot het milieu, energieverbruik, positie van de ontwikkelingslanden en dergelijke.

Wat het sociaal beleid betreft kan de publieke onderneming een voorbeeldfunktie vervullen ten aanzien van de loonontwikkeling, de secundaire arbeidsvoorwaarden en de demokratisering van de besluityorming. Ook kan zij in herstructureringsgebieden worden gebruikt als (tijdelijke) buffer voor de opvang van ontslagen werknemers. De vraag dringt zich op, of voor het realiseren van bovengenoemde doelstellingen het oprichten van publieke ondernemingen, dan wel het nationaliseren van partikuliere ondernemingen, noodzakelijk is. 
Als de overheid specifieke doeleinden met betrekking tot bijw. de ontwikkeling van de industriële structuur heeft ontwikkeld, dan staat haar in principe een scala van instrumenten ter beschikking, waarmee zij de strategie van de partikuliere ondernemingen op marktconforme wijze kan trachten te beïnvloeden. Haar instrumentarium varieert van generieke belasting-en subsidieprikkels, via specifieke premies tot het afsluiten van contracten, waarin partijen hun gedrag vastleggen. Als het scala van instrumenten echter niet effectief is, kan de overheid overwegen een publieke onderneming te creëren.

In hoofdstuk 3 is uiteengezet, dat het generieke beleid over het algemeen weinig effectief is en dat centralistisch specifiek beleid op onoverkomelijke informatievergarings en -verwerkingsproblemen stuit.

Specifiek beleid kan alleen effektief zijn als de overheid over gedetailleerde informatie beschikt over de strategische plannen van de onderneming, haar marktpositie, de ontwikkelingen in de desbetreffende sector etcetera. Die informatie moet voor een belangrijk deel worden verschaft door de ondernemingen, die op grond daarvan later specifieke steun zullen ontvangen. In zo'n situatie is sprake van een groot 'capturegevaar', waarbij de onderneming het beleid van de overheid bepaalt in plaats van andersom (vergelijk 3.2.1.5). De onderneming kan in geval van specifiek beleid in een positie komen, waarin zij de overheid, die zich eenmaal heeft gecommitteerd, gemakkelijk kan "chanteren" met dreigementen van ontslag, terugtrekken uit de branche en dergelijke (vergelijk de "hold-up" in 3.1.1.3).

De onzekerheid omtrent het effect van haar beleid op de strategische beslissingen wan de ondernemingen, zou de overheid kunnen trachten te reduceren door contracten af te sluiten, waarin de wederzijdse rechten en plichten zo nauwkeurig mogelijk worden geregeld. Het is met name met betrekking tot het afsluiten van dergelijke sturende overeenkomsten, dat de overheid ten aanzien van publieke ondermemingen grotere mogelijkheden zou hebben dan met partikuliere ondernemingen.

Uit hoofdstuk 3 is gebleken, dat de strategie van het management van industriële groepen is gericht op het perfectioneren van het 'métier' van de groep. Gelet op de complexiteit van die taak is het management van een partikuliere groep niet bereid haar doelstellingen extra te compliceren door met de overheid te onderhandelen over een contract, waarin de afstemming van haar strategie op de industriepolitieke doelstellingen wordt geregeld. De ondernemingsleiding zal daartoe alleen bereid zijn als zij, óf dringend om financiēle steun verlegen zit, of als zij een projekt onder handen heeft, waarvan de risiko's de grenzen van de onderneming overstijgen. Alleen in die gevallen zal de onderneming bereid zijn met de overheid in onderhandeling te treden, informatie uit te wisselen, haar strategie bij te stellen in de richting van de overheidsdoeleinden en een en ander vast te leggen in een contract: Ervan uitgaande, dat de microeconomische kennis niet bij de overheid, maar alleen bij het management van de onderneming aanwezig is en voor de overheid moeilijk toegankelijk is, kunnen de contractkosten hoog opllopen als de overheid ex ante opportunistisch gedrag op basis van informatieongelijkheid door middel van een contract zou willen uitschakelen. In het contract zullen diverse ontbindende voorwaarden met betrekking tot omgevingsen marktonzekerhedien moeten worden opgenomen. Door oplopende contractkosten zullen die voorwaarden niet tot in détail kunnen worden geregeld; achteraf zullen 
formuleringen multi-interpretabel blijken en aan de hand van microgegevens nader moeten worden ingevuld. Veelal zal de overheid af moeten gaan op door de onderneming verstrekte informatie en deze slechts marginaal kunnen toetsen.

Geconcludeerd kan worden, dat alleen de ondernemingen in nood en de ondernemingen, die zeer risicovolle projekten op stapel hebben staan, bereid zullen zijn hun strategie vast te leggen in een contract met de overheid. De grote structuurbepallende ondernemingen, die over voldoende financielle mogelijkheden beschikken zullen niet genegen zijn hun strategie te compliceren door het afsluiten van contracten met de overheid, terwijl daarentegen hun strategie veelal wel van essentieel belang zal zijn woor de realisatie van de doeleinden met betrekking tot de ontwikkeling van de industriële structuur.

De gedachte is $\mathrm{nu}$, dat selectieve nationalisatie van ondernemingen, die zich op sleutelposities in de strategische 'filières' bevinden aan de genoemde problemen het hoofil kan bieden. Alle genationaliseerde ondernemingen zijn namelijk verplicht aan de onderhandelingstafel te verschijnen, hun strategie te presenteren, informatie te verschaffen over de markt, de sector, en dergelijke en te onderhandelen over een contract, waarin dle voorwaarden worden geregeld met betrekking tot de afstemming van de strategie op de plandoeleinden. Anders gezegd: omdat voor de overheid in een markteconomie de kosten van het reguleren van partikuliere ondernemingen zeer hoog kunnen oplopen, kan internalisering van transacties met die ondernemingen in de overheidshiërarchie efficiënter zijn (vergelijk Davies en Brucato, 1987, 10). De vraag, die nu voor ligt is van tweeërlei aard:

- welke inzichten verschaft de theorie ons met betrekking tot de mogelijkheden en beperkingen van de overheid om de strategie van de publieke ondernemingen af te stemmen op haar doeleinden? Worden die doelleinden gerealiseerd door gebruik te maken van de publieke onderneming dan is nationalisatie een effectief instrument te noemen;

- welke inzichten verschaft de theorie ons met betrekking tot het effect, dat van nationalisatie uitgaat op de efficiëntie van de produktie van de onderneming. Veel gehoord is de opvatting, dat de publieke onderneming in vergelijking met de partikuliere minder efficiënt zou produceren, hetgeen verband zou houden met het ontbreken van voldoende markttucht.

Zo gezien kan er sprake zijn van een 'trade-off' tussen doeltreffendheid (de publieke onderneming draagt bij aan het realiseren van nationale doeleinden) en doelmatigheid (door de nationalisatie ontstaat een situatie, waarin de onderneming de middelen minder efficient alloceert).

Alvorens die stelling aan een nader onderzoek te onderwerpen, worden eerst de begrippen "effectiviteit' en 'efficiëntie" nader toegelicht.

\subsection{Effectiviteit en efrieientie}

\subsubsection{Definities}

In de Angelsaxische literatuur wordt onderscheild gemaakt tussen doeltreffendheid (effectiveness) en doelmatigheid (efficiency). In de Franse literatuur wordt het begrip 'l'efficacitê' gehanteerd: 
"Il suppose qu'une mission est confiee: est efficace quil produit le résultat attendu. Porter un jugement sur l'efficacitế revient à apprécier le degré de réalisation des objectifs" (Leray 1983b, 613).

Die doeltreffendheid dient onderscheiden te worden van

"L'efficience': la capacité à obtenir un effet avec un minimum de moyens" (Delion 1981, 14).

Het begrip 'I"efficience" wordt echter in de Franse literatuur zelden gebruikt. Soms wordt onderscheid gemaakt tussen 'efficacité au sense instrumentale' (effectiviteit) en "efficacité au sense économique' (efficiëntie) (Hafsi 1984, 110), maar meestal moet de lezer wit de context opmaken wat met 'efficacite' wordt bedoeld.

In de economische theorie wordt binnen het efficiëntiebegrip onderscheid gemaakt naar het niveau (micro-macro) en naar de aard van de analyse (statisch-dynamisch) [vergelijk Buck (1982), 2].

Wij bespreken in het navolgende eerst de begrippen statische en dynamische efficiëntie en gaan daarna in op de problemen, die zich voordoen bij toepassing daarvan op de publieke onderneming.

Micro statische efficiëntie wordt gerealiseerd in een wereld, waarin de middelen gegeven en constant zijn. Onderscheid wordt gemaakt tussen technische en allocatieve efficiëntie. De technische efficiëntie duidt op de allocatie binnen een economische eenheid, waarbij de middelen zodanig moeten worden gecombineerd, dat met minimale inzet van bijv. arbeid en kapitaal een bepaalde output wordt gerealiseerd [1]. Of vanuit de consument gedacht: met een minimale inzet van goederen a en b een bepaald nutsniveau wordt bereikt. Technische efficientie betreft het optimaal toepassen van alle beschikbare middelen, hetgeen ook een kwestie is van organisatie en motivatie. Daarom prefereert Leibenstein (1966) de term X-efficiëntie boven die van technische efficiêntie.

Of een onderneming technisch efficiënt produceert blijkt uit het kostenpeil. Als een bepaalde produktie bij gegeven prijzen van de produktiefaktoren leidt tot hogere kosten per eenheid produkt dan het minimaal mogelijke, dan is sprake van een bepaalde mate technische inefficiëntie.

Allocatieve efficiëntie betreft de mate, waarin de geproduceerde goederen en diensten overeenkomen met de preferenties van de soeverein (individuele consument, producent of centrale overheid). In een allocatief efficiënte wereld bestaan geen tekorten of overschotten.

Macro efficiëntie is thet geaggregeerde evenbeeld van micro efficièntie: als de consumenten of de planners van mening zijn dat de allocatie van middelen overeenkomt met de preferenties en als de economische eenheden technisch efficiènt opereren, dan kan de levensstandaard van de gehele economie niet worden verhoogd door een herallocatie van de gegeven middelen.

Owerigens roept het meten van allocatieve efficiëntie nogal wat problemen op, omdat het vaststellen van de 'behoeften van de samenleving' aggregatie van individuele nutten en derhalve interpersonele nutsvergelijking vereist. Aangezien voor dat vraagstuk geen bevredigende oplossing is gevonden, wordt ervan uitgegaan dat de behoeften van de samenleving voor een deel via het politieke proces in beleidsdoelstellingen van de overheid wordien vertaald. Zo gezien neemt de allocatieve efficièntie 
toe naarmate de produktie meer in overeenstemming is met de doeleinden van het overheidsbeleid.

Dynamische efficièntie impliceent de introductie van een tijdsdimensie. Het gaat om een zodanige allocatie van de middelen, dat de produktie in de tijd overeenkomt met de ontwikkeling van de preferenties en de produktietechnologie. Het economisch systeem dient voor het realiseren van dynamische efficientie over een zodanig aanpassingsvermogen te beschikken, dat veranderingen in de technologie (technische efficiêntie) en in de preferenties (allocatieve efficiëntie) worden geregistreerd en aan de actoren worden overgedragen, opdat in de tijd gezien de produktie op microniveau qua combinatie van produktiefaktoren en qua produktiepakket overeenkomt met de genoemde veranderingen.

Dynamische efficiëntie met betrekking tot de industriële structuur betekent, dat de industriéle produktie zich voortdurend aanpast aan veranderingen in de technologie (produktieproces) en aan veranderende voorkeuren (produkten). Dynamische efficiëntie betreft een proces, waarbij onder een gegeven tijdvoorkeur, de transformatiecurve zo snel mogelijk naar rechts wordt geschoven en waarbij het voor de toekomst gewenste goederenassortiment wordt geproduceerd. De veranderingen in preferenties, technologische ontwikkeling en dergelijke moeten daartoe tijdig aan de actoren worden kenbaar gemaakt (informatiesysteem) en de aanpassing van hun gedragingen moet adequaat worden gecoördineerd (coördinatiesysteem).

\subsubsection{Effectiviteit; een meetprobleem}

Om de effectiviteit van een publieke onderneming te kunnen vaststellen dienen de doeleinden, die zij moet realiseren nauwkeurig vastgesteld te worden. Idealiter zou de effectiviteit op maatschappelijk niveau weergegeven moeten worden in een sociale welvaartsfunctie, waarin de verschillende variabelen nauwkeurig zijn omschreven en de coëfficiënten ter bepaling van de relatieve gewichten duidelijk zijn geẽxpliciteerd. In de praktijk doen zich problemen voor met betrekking tot de operationalisering van de variabelen en het vaststellen van deze coëfficiënten.

Uit de in 42 genoemde theoretische gronden yan het bestaan yan publieke ondernemingen kan worden afgeleid, dat de doeleinden kunnen liggen op het gebied van structuur-, conjunctuur-" facetten- en sociaal beleid. Op elk van die terreinen kunnen in principe indicatoren worden ontwikkeld, maar de operationalisering daarvan is zeker niet probleemloos (vergelijk Schreuder 1981, hoofdstuk 5). Schreuder, die in het kader van de vraag naar de maatschappelijke verantwoordelijkheid van ondernemingen de vraag stelt op welke wijze de bijdrage van ondernemingen aan de welvart kan worden gemeten en hoe zij daarover zouden moeten rapporteren, maakt duidelijk dat naast situationele indicatoren ook belevingsindicatoren gehanteerd dienen te worden. De eerstgenoemde geven aan of een bepaald verschijnsel voorkomt, de laatstgenoemde betreffen percepties, attituden en gevoelens van individuen (Schreuder 1981,134). Van ondernemingen zou de welvaartsbijdrage gemeten kunnen worden door aan de hand van die twee groepen van indicatoren een 'arbeids-, consumptie- en milieuprofiel' op te stellen. Zeker met betrekking tot de indicatoren opconsumptie- en milieugebied doen zich grote operationaliseringsproblemen voor (Schreuder 1981, 201-218). 
Redwood en Hatch (1982) hebben voorgesteld voor de beoordeling van de effectiviteit van publieke ondernemingen o.a. 'consumers performance indicators' te ontwikkelen. Consumentenorganisaties zouden die indicatoren betreffende de eigenschappen van het produkt (kwaliteit, prijs, beschikbaarheid en dergelijke) kunnen opstellen.

Zoals gezegd, dient in principe voor elk doel van de publieke onderneming een indicator oritwikkeld te worden.

Omdat de realisatie van verschillende doeleinden tegenstrijdigheden kan oproepen (stimulering van de investeringen vanuit het structuurbeleid kan bijvoorbeeld strijdig zijn met het facettenbeleid), zou idealiter voor het beoordelen van de effectiviteit van een publieke onderneming een sociale welvaartsfunktie voor handen moeten zijn, waarvan de factoren en coëfficiënten bekend zijn en van waaruit op ondernemingsniveau indicatoren zijn te ontwikkelen.

Idealiter zou één centraal orgaan, of ministerie verantwoordelijk moeten zijn voor de desbetreffende onderneming en in staat moeten zijn aan de hand van gedetailleerde doeleinden en indicatoren tot een oordeel omtrent de effectiviteit te komen.

In werkelijkheid is geen sociale welvaartsfunktie voor handen. Uit de hoofdstukken 6 en 7 zal blijken, dat de nationale doeleinden niet, of nauwelijks voor vertaling naar microniveau in aanmerking komen, dat indicatoren derhalve vaag zullen zijn, en dat coëfficiënten om tot een afweging te kunnen komen ontbreken.

Een objectief oordeel van de effectiviteit van een publieke onderneming op basis van een welvaartsfunktie zal in werkelijkheid niet mogelijk blijken. Om zo dicht mogelijk in de buurt van een objectief oordeel te komen moet er naar worden gestreefd de doeleinden op microniveau zo scherp mogelijk te expliciteren, de relatieve gewichten zo duidelijk mogelijk aan te geven en de afweging in handen te leggen van éen verantwoordelijk ministerie.

\subsubsection{Efficiëntie: een meetprobleem}

\subsubsection{Kosten per eenheid produkt}

Technische efficiëntie zou gemeten kunnen worden aan de hand van de kosten per eenheid produkt (Borcherding, Pomerekne, Schneider, 1982).

Diverse studies tonen aan, dat de publieke onderneming tegen hogere kosten per eenheid produkt produceert dan haar partikuliere tegenvoeter [2]. Zo'n verschil behoeft echter nog niet te duiden op een minder efficiênte kombinatie van produktiefaktoren, een slechte organisatie, of een geringe motivatie van de werknemers. Het is namelijk zeer wel mogelijk, dat de hogere kosten voortvloeien uit de specifieke overheidsdoeleinden, die de publieke onderneming moet vervullen. Moet de publieke onderneming, bijv. in het kader van het 'filière'-beleid, een netwerk met nationale 'subcontractors' opzetten, dan zal zij extra kosten moeten maken om bijv. de nationale toeleveranciers op hetzelfde technologische peil te brengen als de buitenlanders.

Extra kosten worden ook gemaakt als de publieke onderneming een voorbeeldfunktie moet vervullen met betrekking tot het sociaal beleid, of de demokratisering van de besluitvorming. Voor een oordeel over de technische efficiëntie zou derhalve een nauwkeurig inzicht moeten bestaan in de extra kosten, die de publieke onderneming moet maken in verband met het vervullen van haar specifieke taak [3]. Voor het 
verkrijgen van een goed beeld van het funktioneren van de onderneming zouden de extra kosten moeten worden gecompenseerd. Voor bovenstaande voorbeelden geldt, dat die extra kosten niet altijd gemakkelijk zijn vast te stellen (vergelijk Delion 1981, 23 en 24).

Wanneer geen of onvoldoende compensatie door de overheid wordt geboden, vertoont de publieke onderneming hogere kosten per eenheid produkt, hetgeen echter niet op inefficiènte allokatie van produktiemiddelen hoeft te duiden.

Het kan ook zijn, dat het verschil in kosten per eenheid produkt niets te maken heeft met de eigendomsstructuur, maar alles met de marktvorm, waarin de desbetreffende ondernemingen opereren. De kosten wan een partikuliere onderneming in een concurrentiemarkt mogen in een vergelijkend onderzoek niet zomaar worden vergeleken met de kosten van een publieke onderneming in een monopoliemarkt. (Bijvoorbeeld de kosten van een geprivatiseerde producent van telecommunicatieapparatuur, die op een concurrentiemarkt opereert met die van een publieke onderneming op een beschermde monopoliemarkt). Het is zeer wel mogelijk, dat het efficiëntieverschil voortkomt uit het ontbreken van de markttucht en niets van doen heeft met de eigendomsstructuur. Zo gezien is het een owerweging waard een natuurlijk monopolie op te splitsen in een aantal met elkaar concurrerende ondernemingen, hetgeen enerzijds kan leiden tot efficientieverlies als gevolg van een produktie op een suboptimale schaal, maar anderzijds efficiëntiewinst kan opleveren als gevolg van het introduceren van concurrentiedruk (vergelijk Millward 1982, 242).

De kritiek op de kostenmaatstaf is ook van toepassing op twee andere maatstaven: de winst- en verliescijfers en het criterium van de marktaandelen. Winstcijfers kunnen de waarheid omtrent de efficiëntie versluieren als bijv. een monopolist in staat is een hoge prijs te zetten, of als omgekeerd door de bevriezing van de prijzen van overheidswege een onderneming verlies maakt. Het is ook mogelijk, dat twee ondernemingen dezelfde winstcijfers tonen, maar dat de éen betere arbeidsvoorwaarden biedt voor de werknemers dan de ander. Wat de publieke onderneming betreft geldt ook nu, dat specifieke doelstellingen ertoe kunnen leiden, dat de desbetreffende maatstaf een lagere waarde aangeeft, maar dat zulks niets zegt over een al dan niet doelmatige allocatie van de produktiefaktoren.

\subsubsection{1 'Productivité globâle des facteurs' (PGF)}

Bovengenoemde bezwaren kunnen ten dele worden ondervangen door de produktiviteit van de onderneming te meten (vergelijk NEDO 1976, Leray 1983b, Bishop en Kay 1988). Het zou vanuit een oogpunt van informatie aantrekkelijk zijn als de produktiviteit van de produktiefactoren afzonderlijk zou kunnen worden gemeten. Zo'n partiële analyse is echter problematisch, omdat de produktiviteit van de ene factor alleen kan worden vastgesteld als de hoeveelheid van de andere factor niet verandert. Als bijv. de de produktie en de hoeveelheid arbeid gelijk blijven dan zou op grond van een partiële analyse geconcludeerd worden, dat de arbeidsproduktiviteit niet is veranderd. Als echter tegelijkertijd de kapitaalgoederenvoorraad is uitgebreid dan is in werkelijkheid de arbeidsproduktiviteit gedaald. Een partiêle analyse geeft alleen een goed beeld als de andere produktiefactor constant blijft. In werkelijkheid zal aan die ceteris paribus 
voorwaarde moeilijk voldaan kunnen worden, waardoor is voorgesteld in plaats van de partiele produktiviteit de totale factorproduktiviteit te meten.

Daartoe is als maatstaf de "Productivité globâle des facteurs" (PGF) ontwikkeld aan de hand waarvan kan worden nagegaan, of in een bepaalde periode efficiênter is geproduceerd en aan wie de produktiviteitsstijging ten goede is gekomen.

De PGF meet voor een bepaalde periode de toename van de totale produktiviteit ten opzichte van de produktiviteit in een basisperiode. De PGF is gebaseerd op 'volumina" (hoeveelheid van een goed, of produktiefaktor tegen de prijs van de basisperiode), waardoor het prijseffekt op de produktiviteitsberekeningen wordt geélimineerd.

De berekening van de PGF kan in drie stappen worden gesplitst:

- berekening van de totale produktiviteit opgevat als de ratio van de output- en inputindex

$$
\begin{aligned}
0_{t}-0_{t-1}: I_{t}-I_{t-1} & 0_{t}=\text { volume van de output in periode } t \\
\frac{0_{t}}{0_{t-1}}=\frac{q_{t}}{q_{t-1} \cdot P_{t-1}} & P_{t}=\text { volume van de input in periode } t \\
q & =\text { aantal eenheden produkt } \\
P_{t-1} & =\text { prijs in de basisperiode }
\end{aligned}
$$

- berekening van het 'surplus de productivité globale', dat wil zeggen het verschil van de verandering in de output ten opzichte van de verandering in de input $\left(O_{t}-O_{t-1}\right)-\left(I_{t}-I_{t-1}\right)$ tegen basisprijzen.

- Ook de PGF biedt geen inzicht in de bijdrage van de afzonderlijke produktiefaktoren aan de produktiviteitsontwikkeling. Wel is het mogelijk na te gaan welke groeperingen van de produktiviteitsstijging hebben geprofiteerd. Daartoe wordt onderscheid gemaakt tussen het deel van het ondernemingsresultaat, dat het gevolg is van ontwikkelingen buiten de onderneming (algehele loondaling, rentestijging, etcetera: de zogenaamde 'inheritance') en het deel, dat het gevolg is van het management van de onderneming.

Aan de hand van de ontwikkeling van de prijzen kan worden nagegaan wie wan de produktiviteitsstijging hebben geprofiteerd: zijn de verkoopprijzen, de inkoopprijzen, de lonen, de interesten, of het dividend gestegen?

Hoewel de PGF bezwaren van de partiële berekeningen ondervangt [4], vertoont ook deze methode een aantal min of meer ernstige tekortkomingen:

- als de prijzen in het basisjaar in tegenstelling tot die van het boekjaar een winstelement bevatten, wordt de berekening van het surplus daardoor verstoord;

- een efficiẻnte overschakeling van de ene grondstof op een andere als gevolg van veranderende relatieve prijzen, kan resulteren in een daling van het surplus;

- goed management kan resulteren in bijv. een prijsdaling van de inkoopprijzen (kwantumkorting), hetgeen in de PGF-methode echter als een externe oorzaak ('inheritance'van de toeleverancier) naar voren komt;

- de PGF betreft de verkopen van de onderneming, die echter mede afhankelijk zijn van het algemene conjunctuurklimaat; 
- een onderneming met een lage bezettingsgraad kan door middel van een prijsverlaging zijn verkoop vergroten. De PGF registreert een en ander als een verbetering van de totale produktiviteit.

Naast deze theoretische bezwaren kent de PGF ook problemen van meer praktische aard, die met name het vaststellen van conventies betreffen ten aanzien van de definitie van het produkt (SNCF hanteert bijv. het aantal tonnen/personen per kilometer), de kwaliteitsstandaarden en dergelijke (yergelijk NEDO 1976) [5].

De PGF is in Frankrijk ontwikkeld in het kader van de 'contrats de programmes', die in 1966 werden afgesloten met enkele publieke ondernemingen (vergelijk hoofdstuk 6). EdF heeft de PGF ook voor interne management doeleinden gebruikt om duidelijk te maken welke relatie er bestond met de afnemers, leveranciers, werknemers en 'aandeelhouders'. Ook het 'Centre d'Etude des Revenues et des Couts' (CERC) gebruikte de PFG voor haar produktiviteitsberekeningen, evenals het INSEE (vergelijk NEDO 1976).

\subsection{De resultaten van de publieke onderneming institutioneel verklaard}

\subsubsection{Inleiding}

"The economic consequences of government and private ownership depend in a large measure on the underlying structure of property rights. If there are dissimilarities in the rights to use resources, there will be differences in constraints, rewards, costs, and incentives. If the differences in rights are systematic, the choices of utility maximizing of decision-makers will differ systematically" (Davies en Brucato 1987, 11).

In deze paragraaf stellen wij de vraag aan de orde, of het voor een efficiënte allocatie van de produktiemiddelen uitmaakt, of de produktie is georganiseerd in partikuliere, dan wel in publieke ondernemingen.

In tal van publikaties van veelal neoklassieke aard (zie Perotin en Estrin 1986) wordt het standpunt ingenomen, dat niet het eigendom een rol speelt ten aanzien van de 'performance', maar de mate van concurrentie, waaraan de onderneming is blootgesteld. Meer institutionele economische theorieèn verklaren daarentegen efficiëntieverschillen tussen partikuliere en publieke ondernemingen uit de verschillen in eigendomsrelatie en uit de verschillen in de relaties, die partikuliere en publieke ondernemingen onderhouden met hun economische en socio-politieke omgeving. In 4.4.1 wordt eerst de omgeving van de partikuliere onderneming nader bezien, waarna in 4.4 .2 de omgeving van de publieke onderneming aan bod komt.

\subsubsection{De omgeving van de partikuliere onderneming}

De manager van een onderneming wordt in een markteconomie met een efficiënte kapitaalmarkt in theorie gecontroleerd door de aandeelhouders [6]. In ruil voor het vooruitzicht op dividend en koerswinst ontvangt het management risikodragend kapitaal. De kapitaalverschaffer heeft het recht op een deel van het residu en op het mogen verkopen van zijn recht zonder toestemming van zijn mede-eigenaren. De ontwikkeling van het dividend ten opzichte van de koers en de koersontwikkeling zelf 
in vergelijking met die van andere ondernemingen, zijn woor de aandeelhouder de indicatoren van de kwaliteiten van het management en van de mate, waarin de belangen van de aandeelhouders worden gediend. Er is tussen de eigenaren en de managers sprake van een zogenaamde principaal- agent-relatie, waarbij kosten moeten worden gemaakt om het management te controleren en te motiveren tot gedrag, dat strookt met de belangen van de eigenaren.

Specifieker ingevuld in 'behavioral managerial theories of the firm" blijkt sprake van een complex van diverse strijdige doelstellingen. Het management van de onderneming staat voor de taak een evenwicht te zoeken, waarbij hij streeft naar een zo groot mogelijke discretionaire ruimte voor zichzelf.

Zoals in 3.1.2 ter sprake is gekomen heeft het management de tak zorg te dragen voor de consensus tussen de diverse belangengroeperingen. Cyert en March (1963) zetten uiteen hoe het management door middel van financiële tegemoetkomingen, secundaire arbeidsvoorwaarden, toezeggingen met betrekking tot de strategie en dergelijke, de discretionaire ruimte voor een deel aanwendt om de coalitie van de verschillende belangengroepen in stand te houden. Gesproken wordt in dit verband van slack, dat kan worden gedefinieerd alls ..payments to the various groups of the coalition over and above those required for the efficient working of the firm (.........).

Zoals eerder opgemerkt kunnen institutionele theorieën, waarin 'behavioral' en 'managerial' aspecten aan de orde komen, het inzicht verdiepen in het funktioneren van ondernemingen, maar daar staat een verlies aan 'strakheid van analyse' tegenover. (Buck 1982, 115) zegt het zo:

"With such an imprecise theory, it is impossible to define the efficiency properties of a capitalist system made up of firms operating along behavioral lines. Of course, it would be riddled with $X$-inefficiency and the allocation of resources would certainly not be Pareto-optimal, given the absence of marginal calculations. Investment and research decisions (and thus micro- and macrodynamic efficiency) are seen to depend not on a detailed calculation of their impact on profit, but on political factors in an instable coalition".

De mate, waarin het management de discretionaire ruimte kan aanwenden als 'slack' wordt bepaald door de 'tucht', die van de marktwerking uitgaat. Naast de situatie op de afzetmarkt speelt daarbij de controle vanuit de kapitaalmarkt een belangrijke rol. Voor de individuele aandeelhouder kunnen de controlekosten echter snel te hoog worden, waardoor het van het funktioneren van andere partijen op de kapitaalmarkt afhangt, of het management zich voldoende gecontroleerd weet. Opereren op de kapitaalmarkt bijv. gespecialiseerde ondernemingen, die ondernemingen overnemen waarvan de prijs beneden de potentiële waarde ligt, dan gaat van de kapitaalmarkt zeker een druk uit op het management. Voor partikuliere ondermemingen kan echter ook sprake zijn van een gemakkelijk manipuleerbare economische- en socio-politieke omgeving, waardoor van een markttucht geen sprake is. Het bestaan van efficiënt werkende markten mag niet worden verondersteld, maar dient onderzocht te worden. Alleen als inzicht bestaat in de relaties van de desbetreffende onderneming met de concurrenten, leveranciers en afnemers, kan worden geconcludeerd tot de aan- dan well afwezigheid van markttucht. Van essentieel belang daarbij is het inzicht in het netwerk van relaties met de marktpartijen en de socio-politieke omgeving. De relaties 
met andere marktpartijen blijven onderhevig aan de markttucht (Jarillo 1988, 35), relaties met bijv. afdelingen van ministeries kunnen beschermende situaties creêren.

\subsubsection{De omgeving van de publieke onderneming}

\subsubsection{Inleiding}

Door de specifieke relatie met de overheid heeft de publieke onderneming met een andere omgeving te maken dan haar partikuliere collega. Door de onoverdraagbaarheid van de aandelen is sprake van een fundamenteel verschil in de uitoefening van de eigendomsrechten [7], hetgeen tot gevolg heeft, dat de contante waarde van toekomstige winsten of verliezen, welke het resultaat zijn van beslissingen in het heden, niet tot uitdrukking kan worden gebracht. De belastingbetalers (de eigenaren van een publieke onderneming) hebben zeer beperkte mogelijkheden hun waardering of afkeuring over het beleid van de managers van een publieke ondernemingen te laten blijken: het uitbrengen van de stem op een politieke partij, of het verlaten van het land zijn te indirecte manieren om invloed op het beleid te kunnen uitoefenen.

"These circumstances imply higher transaction costs for government ownertaxpayers which lessens their incentive to monitor public managerial behavior and enforce contracts since they would incur relatively large costs with little individual reward. Higher transaction costs imply more discretionary and opportunistic behavior by government executives and officials because it is less costly for them to engage in such behavior" (Davies en Brucato, 1987, 12).

De publieke onderneming wordt niet gecontroleerd door de actoren op een efficiënte kapitaalmarkt; een publieke onderneming moet gecontroleerd worden door een overheidsinstantie. Daarbij doen zich twee problemen voor: enerzijds is snel sprake van een zogenaamde 'soft budget constraint', anderzijds zal de overheid veelal niet als één geheel optreden, maar zal de publieke onderneming met een veelvoud van principalen te maken hebben.

Publieke ondernemingen hebben met een 'soft budget constraint' (Kornai 1980) te maken, omdat de overheid als grootste, of enige aandeelhouder de onderneming van financiële middelen voorziet. Zeker als de onderneming specifieke overheidsdoeleinden moet realiseren is de overheid bereid voortdurend tekorten te dekken, waardoor de druk op het management om efficient te produceren vermindert. Een dergelijke situatie kan overigens ook ontstaan met betrekking tot partikuliere ondernemingen, die van de overheid financiele steun ontvangen [8].

Wat de controlle van de overheid op de publieke onderneming betreft, blijkt het management te maken te hebben met politici en ambtenaren, die door middel van de publieke onderneming pogen hun eigen doelleinden te realiseren. 'Public choice'-theorieën wijzen op het korte termijn stemmenbejag van politici en op de strategie van ambtenaren hun budgetten te vergroten, waardoor de publieke onderneming bijv. niet haar tarieven mag aanpassen aan kostenstijgingen, of in een bepaald kiesdistrict niet tot ontslag van werknemers mag overgaan. De ambtenaren van het ministerie, onder wiens verantwoordelijkheid de betreffende onderneming valt ('Ministère de tutelle') kunnen het management door ad hoc interventies dwarsbomen, waardoor de lange termijn strategie in gevaar komt [9]. 
De specifieke relatie met de overheid kan ertoe leidlen, dat het management wordt geconfronteerd met een inconsistent geheel van doelstellingen en sterk oplopende besluitvormingskosten. Alleen een bekwaam en goed geïnformeerd overheidsapparaat, dat het management scherp kan controleren op effektief en efficiënt gedrag zou in overleg met het management van de publieke onderneming een consistent beleid kunnen ontwikkelen, dat is afgestemd op de realisatie van de plandoeleinden. In 4.4.2.2 zullen wij theorieën bespreken, die inzicht kunnen verschaffen in de faktoren, die in de machtsstrijd tussen het management van de publieke onderneming en de ambtenaren van het 'Ministere du tutelle" een rol spelen. Alvorens daartoe over te gaan richten wij de aandacht op theorieën van meer algemene aard, die zijn ontwikkeld in het kader van het sturen van genationaliseerde ondernemingen in centraal geleide stelsels; het afstemmen van het gedrag van het management van de staatsbedrijven op de centrale plandoeleinden betreft informatie- en motivatievraagstukken, die ook van belang zijn voor het verkrijgen van inzicht in de sturingsproblematiek van publieke ondernemingen door een 'Etat développeur" in een markteconomie.

\subsubsection{De publieke onderneming in het centraal geleide stelsel}

Probleem in centraal geleide economieën, waar de ondernemingen planopdrachten van de centrale ontvangen, is de werking van het zogeheten 'ratchet principle'.

" (...) la prime attribuée au collectif de l'entreprise dépendait de la capacité de celle-ci à atteindre les objectifs du plan. Cela incitait les entreprises à cacher leur potentiel en essayant de négocier des objectifs en dessous de celui-ci" (Hafsi 1984, 137).

Het 'ratchet principle' [10] werkt allerlei inefficiënties in de hand: het management zal zich niet inspannen meer en zuiniger te produceren dan de planopdracht aangeeft, omdat daarmee de basis zou worden gelegd voor een hogere planopdracht in de volgende periode (vergelijk Groenewegen 1988c). Om aan die inefficiënties het hoofd te bieden zijn modellen ontwikkeld, waarin het management wordt gestimuleerd de juiste informatie te verschaffen en zich maximaal in te spannen. In het model van Weitzman (1976) stellen de planners een planopdracht $(\bar{y})$ met bijbehorende bonus $\bar{B}$ voor, waarop de managers een tegenplan $(\hat{y})$ kunnen indienen. Het beloningssysteem is zo geconstrueerd, dat de managers worden aangezet een tegenplan in te dienen, dat hun werkelijke produktiemogelijkheden reflekteert, terwijl zij tevens worden aangespoord alles in het werk te stellen het tegenplan ook te realiseren.

De coëfficiènt 'a' geeft aan, hoeveel de bonus zal stijgen als een hoger tegenplan door het management wordt voorgesteld $(\hat{Q})$, hetgeen een prikkell is de ware produktiegelijkheden te onthullen. $\widehat{B}=\bar{B}+a(\hat{y}-\bar{y})$.

De feitelijke bonus (B) is gebaseerd op de gerealiseerde produktie (y) in relatie tot het tegenplan $(\hat{Y})$ op de volgende wijze:

$$
\begin{aligned}
(\hat{B}+b(y-\hat{y}) & \text { als } y \geq 9 \\
B=(\hat{B}+c(y-9) & \text { als } \bar{y} \leq y \leq \hat{y} \\
(0 & \text { als } y<\bar{y}
\end{aligned}
$$


De coëfficienten worden zodanig vastigesteld ( $c>a>b>0$ ), dat de manager zijn bonus maximaliseert als hij een tegenplan indient conform zijn produktiemogelijkheden (met andere woorden: de centrale de juiste informatie verschaft) en dat plan daadwerkelijk realiseert (met andere woorden: zich maximaal inspant). De manager ontvangt de hoogste bonus (c) als het tegenplan volledig wordt gerealiseerd. Omdat $b<a$ wordt de manager gestimuleerd het tegenplan af te stemmen op zijn werkelijke produktiemogelijkheden. Immers, de beloning voor een produktie boven het tegenplan is lager dan de beloning voor het indienen wan een tegenplan, dat de doeleinden bevat boven het oorspronkelijke plan.

Anders gezegd: door 'a' tussen ' $b$ ' en ' $c$ ' vast te stellen wordt verstoring van informatie over de werkelijke produktiemogelijkheden zwaarder gestraft, dan een grotere produktie, als aangenomen in het tegenplan, later wordt beloond. Aangezien Weitzman zijn model construeert in een neoklassieke werelld van volledig geinformeerde managers kunnen zij hun bonus maximaliseren door een tegenplan in te dienen conform hun produktiemogelijkheden en dat plan ook realiseren. Wordt de veronderstelling van volledige informatie losgelaten, of wordt de hoeveelheid te verkrijgen inputs afhankelijk gesteld van de hoogte van de produktiedoeleinden in het tegenplan, dan gaat het 'ratchet principle' wederom een rol spelen (vergelijk Cave en Hare 1981, 70-173) [11].

De problematiek van het 'ratchet principle' is zowel in theorie als in praktijk ondervangen door het invoeren van de zogeheten 'parametrische planning' [12]. Aan die vorm van sturing van de publieke ondernemingen door de centrale ligt het decentrale planningsmodel van Lange en Taylor (1936) ten grondslag. Zij construeerden een model, waarmee werd aangetoond dat het theoretisch mogelijk is een centraal geleide economie efficiënt te laten functioneren op basis van decentrale beslissingen van de managers van de publieke ondernemingen.

In het Lange en Taylor-model functioneert een consumptiegoederen- en een arbeidsmarkt. Op die markten reageren producenten en consumenten op marktprijzen. Wat de kapitaalgoederen betreft, reageren partijen op door de centrale vastgestelde prijzen. Het betreft hier 'prijzen' in een wijdere betekenis: 'terms on which alternatives are offered'. De consumenten, werknemers en managers reageren op gegeven prijzen en wel volgens in het model vastgelegde gedragsregels. Consumenten en werknemers vertonen maximaliserend gedrag, terwijl de managers van de bedrijven opdracht krijgen de winst te maximaliseren. Hiertoe moet aan twee eisen worden voldaan. Ten eerste moeten de marginale produktiviteiten per uitgegeven geldeenheid voor alle produktiefaktoren aan elkaar gelijk zijn. Dit resulteert in minimale gemiddelde produktiekosten. Ten tweede moet de produktie-omvang zo worden vastgesteld, dat de marginale kosten gelijk zijn aan de marktprijs van het produkt, hetgeen de afstemming van de produktiebeslissingen op de consumentenbehoeften bewerkstelligt. Wanneer blijkt, dat deze beslissingen leiden tot bijwoorbeeld een vraagoverschot van de ondernemingen naar een bepaalde produktiefaktor, dan verhoogt de overheid de prijs. Bij een vraagtekort geldt het omgekeerde.

Kritiek op het model van Lange en Taylor betreft vooral de vraag, waarom de managers in een socialistische economie zich zouden gedragen volgens de regels van het model van volledig vrije mededinging. Immers, door het ontbreken van partikulier 
eigendom ontbreekt bij de ondernemers de prikkel tot maximaliserend gedrag. In algemene theorieën kan dat motivatieprobleem worden ondtervangen door het ontwerpen van een zogenaamde 'synthetische indicator' waaraan de beloning van het management wordt gekoppeld. Probleem met dat soort algemene theorieen blifft de vertaling naar de empirie. Voor wat het model van parametrische planning betreft gaat het vooral om het vraagstuk, hoe de centrale in werkelijkheid de hoogte van de parameters kan vaststellen en hoe in een centraal gelleide economie de verkopersmarkten vervangen kunnen worden door kopersmarkten. De hierboven aangestipte theorieën geven aan dat

"A solution exists at a theoretical level; but it is subject to many practical difficulties and is hardly likely to be adopted in practice" (Cave en Have 1981, 1976).

\subsubsection{De omgeving van de publieke onderneming in een markteconomie}

De nationalisatie in een markteconomie leidt niet tot het opheffen van de ondernemingen als zelfstandige juridische identiteit:

"... Ia jurisprudence est unanime pour reconnaître qu'une mesure de nationalisation affectant les actions d'une société laisse subsister celle-ci en tant que personne juridique distincte de l'Etat qui y procède" (Hervouët 1983, 2).

De publieke onderneming is zo gezien een autonome partij, die met de overheid contracten kan afsluiten, waarin wordt geregeld of en onder welke voorwaarden haar strategie wordt afgestemd op de plandoeleinden. Uit de bespreking van de aard van de autonomie in 4.4.2.3 wordt de conclusie getrokken, dat de autonomie van de industriële groepen, die op de internationale markten moeten opereren, weliswaar juridisch vorm kan worden gegeven, maar dat in werkelijkheid de autonomie voortdurend voorwerp zal zijn van een machtstrijd tussen het management van de industriële groep en de ambtenaren van het 'Ministere du tutelle". In 4.4.2.4 worden theorieën besproken, die inzicht kunnen verschaffen in de faktoren, die op het verloop van de machtstrijd van invloed zijn. Een mogelijkheid tot formalisering van de onderhandelingen tussen de ondernemingsleiding en de overheid is gelegen in het bij wet regelen van de procedure en inhoud van de overeenkomsten, die tussen beide moeten worden afgesloten (4.4.2.5) [13].

\subsubsection{Autonomie van de publieke onderneming}

In het vraagstuk van het effect van de eigendomsrelatie op de effectiviteit en de efficièntie van de overheid en de publieke onderneming staat het begrip "autonomie" centraal. Zoals in hoofdstuk 6 nader zal worden uiteengezet, is de autonomie van de in 1982 in Frankrijk genationaliseerde industriële groepen van meet af aan uitgangspunt, maar ook voortdurend onderwerp van discussie geweest. Mauroy, de eerste premier onder Mitterrand, beschouwde voor de publieke ondernemingen de autonomie als 'une nécessaire condition de leur efficacité' en 'un secteur public fort composé d'entreprises autonomes figurait au premier rang des moyens nécessaires à une intervention efficace de l'Etat' [14]. Autonomie wordt blijkbaar noodzakelijk geacht 
voor een efficiente interventie van de overheid. Ondanks het uitdrukkelijke voornemen de autonomie van de publieke ondernemingen te waarborgen, vinden er onder het ministerschap van Chevènement (Minister van het 'Ministère de la Recherche et de IIIndustrie van juni 1982 tot maart 1983) dermate scherpe interventies plaats, dat de 'Presidents Directeurs Générales' (PDG's) van de in 1982 genationaliseerde ondernemingen op 11-2-'82 een bezoek aan Mitterrand brengen, alwaar zij hun ongerustheild uitspreken met betrekking tot het verloren gaan van hun autonomie. Daarop wordt in de ministerraad nog eens uitdrukkelijk vastgelegd 'de veiller a la pleine autonomie de gestion des entreprises publiques", teneinde de gebreken van een "bureaucratie tatillone" en de omvorming wan de publieke onderneming tot een 'appendice de l'administration' te voorkomen [15]. Dat neemt niet weg, dat ook in 1983 en 1984 regelmatig de autonomie van de publieke onderneming aan de orde gesteld moest worden [16].

Wat dient nu verstaan te worden onder de autonomie van de publieke onderneming; nationalisatie betekent immers, dat de overheid met de onderneming specifieke doeleinden voor ogen heeft, waarop haar strategie moet worden afgestemd, hetgeen impliceert dat haar beslissingsruimte wordt ingeperkt. Hoever kan een overheid daarmee gaan zonder de autonomie aan te tasten?

De 'Conseil d'Etat' dicht in 1972 de publieke ondlerneming ten opzichte van de staat een zekere onafhankelijkheid toe:

"Il s'agit de constater officiellement l'existence d'un groupe humain, ou vouloir qu"une activité publique soit exercée avec une certaine indépendance intellectuelle ou morale par rapport à l'Etat" (geciteerd naar Mescheriakoff 1985,1578 ).

Daardoor wordt de autonomie tot

"(...) une notion complexe, qui d'abord, affirme l'existence d"une individualité économique et sociale particulière, et qui qualifie ensuite, certains liens entre celle-ci et l'Etat" (Merscheriakoff 1985, 1578).

Wat die 'certain liens' tussen de overheid en de publieke onderneming betreft kunnen in principe twee visies worden onderscheiden.

De van origine Angelsaxische opvatting, waarin de leden van de Raad van Bestuur van de publieke onderneming worden beschouwd als vertegenwoordigers van de overheid, die beschikken over

"un mandat qui les oblige a agir dans le sens de l'intéreêt général, sous peine de révocation en cas de manquement grave à cette obligation" (Mescheriakoff 1985,1579 ).

De onderneming moet een bepaalde taak vervullen in het algemeen belang (bijv. de voorziening van energie); is die taak in de wet vastgelegd, dan bestaat tussen de overheid en ondernemingsleiding in principe geen verschil van mening over competenties en bevoegdheden. Controle vindt a posteriori plaats.

Stat de overheid met de publieke onderneming de vervulling van een specifieke taak voor ogen en zijn de taken, bevoegdheden en verantwoordelijkheden (nog) niet tot in detail geregeld, dan wordt de van oorsprong Franse visie actueel: er is sprake van een 'cogestion', waarbij de overheid a priori een controle uitoefent. 
In de Angelsaxische opvatting is de autonomie gelegen in de onathankelijkheid van de bestuurders van de publieke onderneming; in de Franse versie betreft de autonomie de afbakening tussen de beslissingsbevoegdheden van de ondernemingsleiding en de overheid.

Bij de bespreking van dat afbakeningsvraagstuk baseert Mescheriakoff (1985) zijn "éléments pour une théorie de l'autonomie des entreprises publiques" op de wetgeving, die bestaat ten aanzien van de relatie tussen de onderneming (zowel partikulier als publiek) en de ondernemer. Weliswaar wordt de 'entreprise' door de 'entrepreneur' als instrument gebruikt, maar dat neemt niet weg, dat sprake is van twee juridische identiteiten, waarbij de onderneming een zekere autonomie kent ten opzichte van de ondernemer.

"L'entreprise est un instrument aux mains de l'entrepreneur; peut-on parler de l'autonomie d'un outil, de l'autonomie d'un marteau par rapport au forgeron?" (Mescheriakoff 1985, 1606).

De ondernemer is vrij de onderneming te gebruiken, maar gelijk de smid vrij is de hamer te hanteren. Instrumenten stellen namelijk hun gebruiksregels en als deze niet in acht worden genomen keert het instrument zich tegen de gebruiker. Daarop duidde wellicht ook Mauroy met zijn uitspraak over de autonomie van de in 1982 genationaliseerde groepen, die bij onoordeelkundig gebruik hun concurrentiepositie zouden kunnen verliezen, waardoor de 'hamer' van generlei waarde meer zou zijn. Een stapje verder gaat de opvatting, dat het instrument, i.c. de onderneming, ten opzichte van de eigenaar, i.c. de ondernemer, een 'eigen belang' heeft, op grond waarvan deze als een aparte juridische identiteit met een eigen autonomie moet worden beschouwd.

"Le droit contemporain considère que l'entreprise a un intérêt propre a poursuivre et à défendre cet objet. L'exposé des motifs du projet de loi sur le règlement judiciaire précisait par example que le droit des entreprises en difficulté doit être repensé en fonction de l'intérêt de l"entreprise elle-même, source d'activité économique et d'emploi" (Mescheriakoff 1985, 1607).

Zo gezien kan de onderneming tegen de ondernemer in het geweer komen als zij meent, dat in haar gebruik als instrument haar belangen worden geschaad [17]. Worden de juridische inzichten van het algemene geval van de ondernemer en de onderneming toegepast op het specifieke geval van de relatie tussen de 'Etat entrepreneur' en de "entreprise publique", dan ligt de vraag voor welk 'intérêt spécifique' de publieke onderneming kan verdedigen als haar domein van autonomie ten opzichte van de overheid. Het ligt voor de hand de specifieke taak, die de onderneming is opgedragen als het specifieke ondernemersbelang te beschouwen. Probleem is echter, dat de Staat als wetgever ("L'Etat Puissance') het recht heeft naar eigen inzichten die aan de publieke onderneming gedelegeerde taak te veranderen. Voorwaarde daarbij is wel, dat de 'L'Etat Puissance' kan aantonen dat zulks in het algemeen bellang gebeurt [18].

Ook met betrekking tot de nationalisatie van partikuliere ondernemingen eist de Grondwet (art. 34), dat de aktie van 'L'Etat Puissance' wordt gerechtvaardigđ op grond van het algemeen belang en bij de wet gestalte krijgt [19]. 
Samengevat komt de relatie tussen de 'Etat-entrepreneur' en de 'entreprise publique' erop neer, dat de 'Etat Puissance' bij machte is het 'intérêt specifique' van de onderneming -en daarmee haar domein van autonomie-inhoud te geven onder de restrikties, die vanuit de gebruiksmogelijkheden van het instrument en vanuit het algemeen belang worden gesteld. Kan met andere woorden duidelijk worden gemaakt, dat de publieke onderneming een 'specifiek belang' heeft, dat kan worden onderscheiden van het 'algemeen belang', dan is daarin een mogelijkheid gelegen de autonomie van de onderneming aan te geven. Heeft daarentegen de overheid de mogelijkheid het ondernemingsbelang tot een algemeen belang te verklaren, dan is de "autonomie" van de publieke ondlerneming een lege doos, die naar behoefte door de overheid kan worden gevuld.

De kern van het vraagstuk van de autonomie blijkt te steken in het feit, dat niet voor alle publieke ondernemingen het 'intérêt spécifique' gelijk is; het is zinvoll in dit verband onderscheid te maken tussen de publieke ondernemingen, die een 'service public' vervullen en de ondernemingen, die dat niet doen. Het verschil blijkt duidelijk uit een vergelijking van de nationalisatiewet van 11-2-1982, waarin de industriële groepen werden genationaliseerd en de wet van 30-12-1982, waarin opnieuw de funktie van de Franse Spoorwegen (SNCF) werd vastgelegd. Art. 3 in de wet op de nationalisatie bepaalt dat

"la législation commerciale est applicable aux sociétés pour autant qu'elle est compatible avec les dispositions de la présente loi" (geciteerd naar Mescheriakoff 1985,1618 ).

hetgeen impliceert dat het 'l'intérêt' van de desbetreffende ondernemingen niet identiek is met "lintérêt public".

" (...) l'entreprise reste maîtresse de sa production spécifique, c'est là le contenu de son autonomie. Certes l'application de ce principe peut créer des difficultés, mais le juge commercial est précisément là pour les trancher" (Mescheriakoff 1985, 1618).

Dat is niet het geval met betrekking tot de publieke ondernemingen, die een publicke dienst verzorgen. De verantwoordelijkheid voor de realisatie van de 'service public" door de desbetreffende publieke onderneming berust niet bij de onderneming, maar bij de overheid. Art. 5 van de wet, die de taak van de SNCF regelt, stelt die verantwoordelijkheid nadrukkelijk vast, hetgeen vorm wordt gegeven door een 'cahier des charges", waarin voor de onderneming nauwkeurig de taken, dienstverlening, tarieven etcetera, staan geregeld.

"Il n'existe donc pas d'intérêt de l'entreprise qui soit distinct de l'intérêt public dont l'Etat a la charge. Dans ces conditions, ou est l'autonomie de l'entreprise?" (Mescheriakoff 1985, 1619).

In het 'Cahier des charges' van de SNCF en de andere ondernemingen, die een publieke dienst verlenen, wordt hen ook autonomie verleend, maar aangezien geen 'l'intérết spécifique de l'entreprise' bestaat

"(...) on voit que la réalité de l'autonomie réside dans la volonté de l'Etat de ne pas mettre lui-même en oeuvre l'intérêt général dans toute son étendue, mais elle est toujours susceptible d'être remise en cause" (Mescheriakoff 1985 , 1619). 
In geval van een conflict tussen de publieke onderneming en de staat, zal de 'juge commercial" uitspraak moeten doen als het een publieke onderneming betreft, die conform de wet van 30-12-1982 een 'intérêt spécifique" en dus een specifiek domein van autonomie heeft. Over de grenzen van die autonomie zal voortdurend strijd worden geleverd. Daarbij kan de autonomie van de publieke onderneming zich ontwikkelen naar het maximum (de onderneming beslist geheel zelfstandig over haar strategie, de overheid is slechts aandeelhouder), of worden gereduceerd tot het minimum (door het ontbreken van een 'intérêt spécifique' neemt de overheid alle strategische beslissingen).

"Un équilibre est donc à trouver entre la nécessaire contribution aux objectifs - de la politique industrielle, qui est l'une des raisons d'être de la nationalisation, et l'autonomie de gestion sans laquelle l'entreprise cesse d'être capable d'affronter la concurrence. Cet équilibre peut être trouvé par la voice du contrat et du plan d'entreprise".

De idee is dat de onderneming haar strategie alan de overheid voorlegt in de vorm van cen 'Plan d'entreprise', hetwelk het uitgangspunt vormt voor de onderhandelingen over het 'contrat de plan'.

Heeft ' $L$ Etat Puissance' partikuliere ondernemingen genationaliseerd en deze ondernemingen hebben een erkend specifiek belang, dan is de overheid in de relatie tot die ondernemingen op te vatten als een 'Etat personne civile', die op voet van gelijkheid en op basis van onderhandelingen contracten met de publieke onderneming kan afsluiten, waarbij de autonomie moet worden gerespecteerd [20]. Voor de in 1982 genationaliseerde industriële groepen waren de 'contrat de plan' bedoeld als contracten tussen de overheid en de publieke ondernemingen, die enerzijds de autonomie van de ondernemingen zouden waarborgen en anderzijds de overheid de mogelijkheid zouden bieden de ondernemingsstrategie af te stemmen op de doeleinden van haar beleid [21].

\subsubsection{De veranderende relatie tussen de overheid en de publieke onderneming}

Als de overheid met betrekking tot het funktioneren van de publieke onderneming over perfekte informatie zou beschikken en het democratisch mechanisme zou perfekt werken, waardoor de preferenties van de kiezers exact in het overheidsbeleid worden omgezet, dan zou de druk op het management van een publieke onderneming gelijk zijn aan die op een partikuliere onderneming in een perfekt werkende markt. Echter, evenals de markt kent ook het budgetmechanisme zijn imperfekties; genoemd zjjn het 'many-principals-agent'-probleem en de 'soft budget constraint'. In die imperfekte wereld zal het management van de publieke onderneming pogen voor haar organisatie een zo groot mogelijke autonomie te realiseren door haar omgeving van concurrenten en de overheid zo veel mogelijk beheersbaar te maken. In 4.4 is gesteld, dat de effectiviteit van de publieke onderneming wordt bepaald door de wijze waarop de overheid de specifieke doeleinden van de onderneming formuleert en de uitvoering controleert en beheerst. Haar tegenspeler in deze is het management, dat een strategie voor de groep kan hebben uitgezet, welke niet strookt met de doeleinden van het overheidsbeleid. De vraag is nu door welke factoren de beheersbaarheid van de onderneming wordt bepaald. Waarvan is de dominantie van de onderneming, of de overheid afhankelijk? Deze vraag is van centralle betekenis: als de publieke ondlerneming domi- 
neert kan zij geen instrument zijn in handen van een 'Etat développeur' en bestaat het gevalar van een 'captured corporatism', of van een overheid, die ad hoc intervenieert met alle inefficiënties van dien; als daarentegen de overheid domineert bestaat de mogelijkheid, dat zij een gelijkwaardige vervanger wan de machttucht kan zijn, zij het dat zij bij het gebruik van de publieke onderneming als beleidsinstrument zekere spelregels in acht moet nemen.

In het navolgende bespreken wij een institutionele theorie, die inzicht verschaft in het complex van faktoren, die bij de analyse van de relatie tussen de overheid en de publieke onderneming in acht moet worden genomen.

Hafsi (1984) heeft op basis van drie case-studies een theorie geformuleerd met betrekking tot de ontwikkeling van de relatie tussen de publieke onderneming en de overheid. Uitgangspunt is het streven van elke organisatie naar vergroting van zijn 'potentieel', dat wil zeggen van haar vermogen in het ruilverkeer een 'waarde' aan te bieden, waardoor zij sterker komt te staan ten opzichte van haar tegenspelers. Om het 'jeu de potentiel" met succes te kumnen spelen dient de onderneming over kennis, over een competentie te beschikken, die voor de andere organisaties van belang is.

Hafsi zet uiteen, dat in de eerste fase na de oprichting van de publieke onderneming deze zich volledig identificeert met de doeleinden van de overheid. Het "Ministère de tutelle' stelt een 'directeur politique' aan, die fungeert als intermediair tussen de ambtenaren van het ministerie en het management van de onderneming. De 'directeur politique' is een verlengstuk van de 'Ministère de tutelle'. De doeleinden en de strategie van de onderneming zijn politiek bepaald; de managers van de publieke onderneming voeren het beleid uit. De onderneming heeft in die fase veelal een bureaucratische structuur, die correspondeert met de overheidsstructuur. Als de onderneming een meer eigen identiteit heeft gekregen zal de samenwerking plaats maken voor confrontatie: naast een 'stratégie économique' (het efficiënt realiseren van de doeleinden) ontwikkelt het management ook een 'stratégie institutionel', gericht op het verkrijgen van een grotere autonomie. In het streven van het management naar een eigen identiteit verliezen de 'directeurs politiques' zowel het vertrouwen van het management als van de ambtenaren van het controlerende ministerie. Hun bemiddelende intermediaire rol gaat verloren, waardoor de afstemming van de ondernemingsstrategie op de overheidsdoelstellingen in gevaar komt. In de confrontatiefase wordt een nieuw "afstemmingsforum" gecreeerd: het contract, waarover ambtenaren en management met respectering van wederzijdse posities onderhandelen. Naarmate de onderneming een grotere expertise krijgt en over eigen financièle middelen beschikt, wordt het voor de overheid kostbaarder een gedetailleerd contract af te sluiten, dat haar voldoende sturings- en controlemogelijkheden biedt. Immers, ex ante de strategie vastleggen en de ontbindende voorwaarden omschrijven, vereist niet alleen een juist beeld van de positie, strategie en omgeving van de onderneming, maar ook de mogelijkheid deze voortdurend te monitoren. Naarmate de onderneming een specifieke expertise (métier) ontwikkelt en de omgeving complexer wordt, stijgen voor de overheid de contractkosten en krijgt de onderneming meer mogelijkheden autonoom haar strategie uit te zetten.

"Les relations Etat-entreprises publiques ont donc un cycle de vie.. Elles naissent coopératives, elles se développent conflictuelles, puis disparaissent. 
Ce cycle se reproduit partout, quel que soit le pays et quel que soit le secteur industriel considérés" (Hafsi 1984, 77) [22].

Op grond van zijn case-studies komt Hafsi naar eigen zeggen niet alleen tot de conclusie dat de 'cycle du vie' een universeel fenomeen is, maar identificeert hij ook de faktoren, die van invloed zijn op de snelheid, waarmee de cyclus wordt doorlopen. In schema 4.1 zijn die faktoren gehergroepeerd in drie categorieën (vergelijk Hafsi 1981, 84).

Schema 4.1 Faktoren van invloed op de duur van de cyclus van Hafsi

falktoren

vertenging van de

verkorting vain de

cyclus als:

cyclus als:

1. De activiteiten van de onderneming zijn vam essentieel belang woor de ontwikkeling van de economie van het land
- er meerdere aanbieders zijn

- de overheid de enige afnemer of leverancier is

- het stopzetten van de produktie op korte termijn geen grote schade met zich brengt (mate van asset specificity)
- sprake is van een monopolie

- er veel afnemers of deveranciers zijn

- als het stopzetten well grote schade meit zich brengt, i.v.m. lange leerprocessen niet snell kan worden vervangen idiosyncratische kennis)
2. middellen en aard wan de activiteiten van de onderneming
- de overheid subsidieert

- de owerheid hell management aanstelt

- de resultatem van de onderneming aan de overheid ter beoordeling worden voorgelegd
- de onderneming zelf over financièle beschikt

- het management door intermediaire commissies wordt aangesteld.

- de onderneming over belleid en resultaten niet expliciet verantwoording aflegt; de onderneming goede resultaten boekt; de ondermeming in technisch geavanceerde sectoren opereert, gediversificeerd is en unternationaal opereert
3. de wijze warop het besluitwormingssysteem is geinstititionaliseerd
- de omgeving onduidelijk

is en de coalitic binnen de onderneming verdeellder
- de omgeving nauwkeurig in regels is vastgelegd: en de coalitie eensgezinder 
De faktoren onder 1 en 2 kunnen in tal van bedrijfskundige theorieèn worden aangetroffen, de derde categorie behoeft enige toelichting.

In schema 4.2 wordt enerzijds onderscheid gemaakt met betrekking tot de aard van de omgeving van de publieke onderneming ('context') en anderzijds met betrekking tot de mate van eensgezindheid van de groeperingen, die in de onderneming participeren (interne coalitie) en de groepen binnen de overheid (externe coalitie). De context betreft in principe alle faktoren, die de strategie van de onderneming beïnvloeden, waarbij overigens sprake is van een wisselwerking tussen gedrag en omgeving. De context betreft niet alleen de marktstructuur, maar ook de socio-politieke structuur, waaronder de formele regels, die de informatieuitwisseling, onderhandelingsprocedure, controle, sancties, interne besluitvormingsprocedures en de taakstelling ('mission') regelen, alsmede de informele relatie tussen het management en de ambtenaren en politici. In Frankrijk blijkt met name het informele circuit een zeer belangrijke rol te spelen: de relaties tussen leden van de 'corps d'érat' bepalen in belangrijke mate de relatie tussen de publieke onderneming en de overheid (vergelijk intermezzo II). Elk element van de context kan 'précis" of "vague" zijn. Zo kunnen de formele regels zeer gedetailleerd en stringent zijn, maar ook zo algemeen, dat diverse interpretaties mogelijk zijin; zo kan de 'mission' zeer specifiek zijn, maar ook kan van een zeer algemeen omschreven opdracht sprake zijn; zo kunnen de relaties met de overheid en andere instanties zeer nauwkeurig zijn vastgelegd, of daarentegen geheel ter invulling aan het management worden overgelaten.

Schema 4.2 Typologie van relaties tussen de overheid en de publieke onderneming

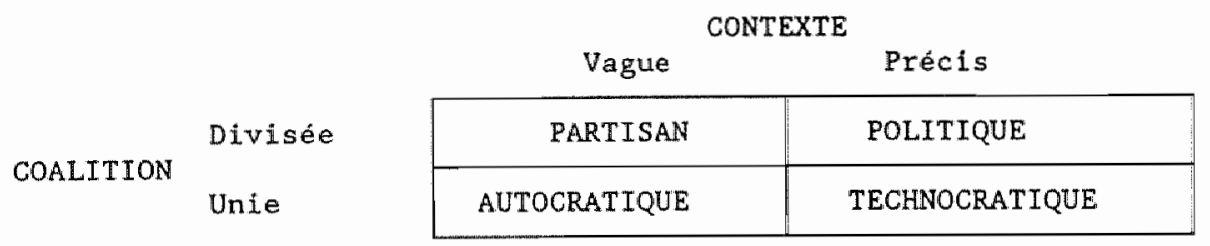

Bron: Hafsi $(1984,70)$

De tweede dimensie van de matrix betreft de aard van de coalitie van de actoren in de publieke ondermeming. De groepen binnen de onderneming kunnen sterk verdeeld zijn, maar het is ook mogelijk, dat grote overeenstemming met betrekking tot de te volgen strategile bestaat, waardoor de onderneming naar buiten toe éen front kan maken. Confrontatie van de twee dimensies levert vier typen op:

- "autocratique": de doeleinden zijn voor de dominante coalitie duidelijk, echter de regels vanuit de overheid niet, waardoor de overheid in de onderhandeling over de specifieke invulling een sterk gesloten front tegenover zich vindt;

- 'politique": voor de onderhandelingen tussen en met de verdeelde groepen in de publieke ondernemingen bestaan duidelijke expliciete regels; 
- 'technocratique': door een sterke coalitie in de onderneming en een duidelijk context, ontstaat een instabiele situatie, waarin voor de onderneming weinig manoevreerruimte beschikbaar is voor het uitzetten van haar eigen strategie;

- 'partisan', betreft de situatie waarin de onderneming de onduidelijke context niet kan 'witbuiten', omdat zij intern verdeeld is.

Gedurende de cyclus op weg naar autonomie vindt tussen de publieke onderneming en de overheid een machtstrijd plaats, waarbij de positie van beide actoren afhankelijk is van de factoren, die zijn vermeld in schema 4.1 .

Als de onderneming bijv. een essentiële taak vervult voor 's lands economie en die taak is door langdurige leerprocessen, die er aan ten grondslag liggen niet gemakkelijk over tẻ nemen en als de onderneming bovendien een goede financiële positie heeft opgebouwd, dan zal de weg naar autonomie snel zijn afgelegd. Als daarentegen de overheid.de middelen beschikbaar stelt en de enige afnemer van de onderneming is, dan zal de cyclus langere tijd in beslag nemen. Het ligt voor de hand, dat publieke ondernemingen, die op de internationale markt concurreren in technologisch geavanceerde sectoren, grotere mogelijkheden hebben hun 'asset specificity' uit te buiten en informatie naar de overheid te verstoren, dan de ondernemingen die op een afgeschermde markt waar de overheid de enige afnemer is.

Samengevat komt de theorie van Hafsi erop neer, dat de relatie van de publieke onderneming met de overheid altijd de fasen van samenwerking, confrontatie en autonomie doorloopt. De snelheid, waarmee die autonomie wordt bereikt hangt af van de machtsrelatie tussen het interne en externe systeem. Die relatie hangt op haar beurt weer af van economische, sociale, technische en financiële relaties, maar wordt ook in belangrijke mate bepaald door de aard van de coalitie en de duidelijkheid van de context. Op grond van de case-studies heeft Hafsi zijn theorie geformuleerd; 'themes' (vergelijk hoofdstuk 1) die voor nadere analyse in hoofdstuk 7 in aanmerking komen betreffen de omstandigheden, waarin conflicten tussen overheid en publieke ondernemingen eerder zullen voorkomen naarmate (vergelijk Hafsi 1984, 76):

- de externe context onduidelijker is

- de externe coallitie (politici, belangengroepen, ambtenaren) verdeelder is

- het interne systeem een front vormt

- de publieke onderneming een strategische funktie vervult in "s lands economie

- de strategische beslissing in kwestie een 'politieker' karakter draagt (bijv. het belang voor de politieke onafhankelijkheid van een land, wapensystemen).

Op grond van bovenstaande theoretische inzichten kan worden geconcludeerd, dat in de empirie rekening moet worden gehouden met een machtstrijd tussen het management en de overheid, waarin na een fase van conflicten de publieke onderneming sneller een autonome positie zal veroveren naarmate de onderneming een specifieke 'mission' vervult, of de onderneming een specifiek 'métier' heeft ontwikkeld.

In plaats van het aangaan van een kostbare machtstrijd, die zowel de effectiviteit als de efficiëntie niet ten goede zal komen, wijzen de theoretische inzichten op de noodzaak te zoeken maar een organisatievorm, waarbij de onderneming haar strategie ter versterking van haar 'métier' kan voortzetten en de overheid de mogelijkheid krijgt dije strategie af te stemmen op haar (industriepolitieke) doeleinden. De planningsovereenkomst zou zo'n organisatievorm kunnen zijn. 


\subsubsection{De planverbintenis; de planningsowereenkomst; het relationele contract}

Meijknecht (1979) hanteert in verband met het afstemmen van de ondernemingsstrategieen op het overheidsbeleid het begrip 'planverbintenis'. In het privaatrecht wordt thet begrip verbintenis gebruikt voor een vermogensrechtelijke betrekking tussen twee of meer personen, die ten dienste staat van de belangen van de betrokken partijen. Het begrip planverbintenis duidt erop, dat het twee-dimensionale karakter wordt uitgebreid met het gemeenschapsbelang vertegenwoordigd door de overheid. Als afstemming van een verbintenis op het (economisch) beleid van de overheid een juridisch relevante rol heeft gespeeld bij haar totstandkoming en daardoor tevens bij haar inhoudsbepaling en/of bij haar nakoming, dan spreekt Meijknecht van een 'planverbintenis. (Meijknecht 1979, 68). De verbintenis dient dan niet twee, maar drie belangensferen ten goede te komen: die van beide partijen en die van de overheid. Het gemengde karakter van de planverbintenis brengt met zich mee, dat zowel het privaatals het publiekrecht van toepassing zijn. De afstemming van een verbintenis tussen twee private rechtspersonen op het overheidsbeleid kan door de overheid worden gestimuleerd door (financiêle) prikkels, maar kan ook het resultaat zijn van overleg, overreding, of van 'spontaan' gedrag (vergelijk de 'pure' indicatieve planning in hoofdstuk 2). Er is derhalve niet alleen sprake van een planverbintenis als de ondernemingsstrategie op het overheidsbeleid wordt afgestemd door middel van een overeenkomst tussen de overheid en de onderneming, er is ook sprake van een planverbintenis als twee ondernemingten hun overeenkomst afstemmen op het overheidsbeleid zonder dat zij daartoe met de overheid zelf een overeenkomst afsluiten.

Wat de overeenkomsten tussen de overheid en de partikuliere of publieke ondernemingen betreft, kan onderscheid worden gemaakt tussen enerzijds overeenkomsten, die kunnen worden afgesloten als reaktie op en ter uitvoering van een wettelijke regeling zonder dat daaraan van ondernemerszijde nog beleidselementen behoeven worden toegevoegd [23], en anderzijds overeenkomsten, waarbij zo'n pasklare publiekrechtelijke achtergrond ontbreekt. Die laatstgenoemde overeenkomsten kunnen het karakter dragen van een kaderafspraak, waarin de overheid en de onderneming globale afspraken maken over het door hen beide te voeren beleid. Dergelijke overeenkomsten gaan ook wel door het leven onder de naam van 'programmaovereenkomst'. Het is ook mogelijik, dat de overheid met én of meer ondernemingen overeenkomsten afsluit, die specifieker van aard zijn en bijv. concrete investeringsplannen betreffen. (Meijknecht $(1979,185)$ merkt in dat verband op:

"Dat neemt niet weg dat het mijns inziens verre de voorkeur verdient indien ook deze overeenkomsten niet zomaar incidenteel tot stand zouden komen, maar in het kader van enige vorm van economische planning. Bij voortschrijdende indicatieve planning kan telkens door beide partijen met de nieuwe ontwikkelingen rekening worden gehouden zodat een uitwisseling van relevante informatie en de verwerking daarvan zowel in individuele belleidsovereenkomsten alls in het economisch plan mogelijk wordt. De overeenkomst dient hiertoe dan alle ruimte te laten".

Dergelijke overeenkomsten vertonen gelijkenis met het 'relational contract' van McNeil (1987). [24]

McNeil onderscheidt het "discrete contract" van het "relational contract". De eerstge- 
noemde duidt op een relatie, die ex ante door partijen zo nauwkeurig mogelijk wordt ingevuld: er wordt met zoveel mogelijk "contingencies" rekening gehouden. In tegenstelling tot die rigide contracten laten partijen in het relationele contract ruinte voor nadere invulling en aanpassingen: ex ante wordt het kader gecreëerd, waarbinnen in de loop van de tijd de rellatie nader geconcretiseerd moet worden. Het relationele contract determineert het gedrag van de partijen niet, maar legt de speelruimte vast, waarvan de grenzen overigens weer door de betrokkenen kunnen wordlen veranderd (vergelijk Crozier en Friedberg 1977, 101).

Op een continuüm van het discrete contract naar het relationele contract kunnen de contracten, die in werkelijkheid tussen partijen worden afgesloten, worden afgezet, waarbij een tweetal dimensies kunnen worden onderscheiden:

- de meetbaarheid van de grootheden, waarover de partijen afspraken hebben gemaakt. Die meetbaarheid moet in discrete contracten groot zijn, omdat geen aanpassingen achteraf mogelijk zijn. Partijen dienen ex ante zeer nauwkeurig een evenwichtige relatie vastgelegd te hebben. Is echter sprake van minder goed meetbare faktoren, zoals respect en affiniteit, en kunnen onevenwichtigheden enige tijd voortbestaan zonder de reciprociteit op lange termijn in gevaar te brengen, dan schuift het contract op het continuüm in de richting van het relationele extreem;

- de planning is in discrete contracten een ex ante aangelegenheid, waarbij de inhoud van het contract tot in detail wordt geregeld, terwijl in relationele contracten planning een continue aangelegenheid is, waarbij vooral het planningsproces centraal staat.

In de contractuele relatie tussen de overheid en ondernemingen is sprake van een groot aantal markt- en omgevingsonzekerheden, waardoor het contract de vorm van een relationeel contract zal moeten krijgen.

Welke faktoren dienen nu bij een bestudering van de concrete rellatie tussen het Ministerie van Industrie en de publieke ondernemingen, j.c. het 'contrat de plan', in acht te worden genomen? In het kader van de 'agency theory' (vergelijk 1.2.1) hanteren Fama en Jensen (1983) een voor die vraag relevante indeling van het besluitvormingsproces, zoals zich dat tussen de aandeelhouders en de managers voltrekt:

1. het initiatief tot een beslissing wordt door de principaal aan de agent gelaten;

2. de ratificatie daarvan behoort in geval van een efficiënte relatie tot de competentie van de principaal;

3. de uitvoering van de beslissing is de taak van de agent, terwijl

4. de monitoring weer tot het domein van de principaal behoort.

Fama en Jensen formuleren de hypothese, dat scheiding van eigendom en leiding efficiènt kan plaatsvinden als het "decision management" (stap 1 en 3) en de 'decision control' (stap 2 en 4) worden gescheiden. Hoe de relatie tussen de partijen vorm wordt gegeven en welke faktoren daarop van invloed zijn, komt in de 'agency theory' echter niet aan de orde (vergelijk 3.1.1.2). Voor het begrijpen van contractuele relaties tussen partijen, i.c. de relatie tussen een ministerie en de leiding van een publieke onderneming, is inzicht in die faktoren wel geboden. Noorderhaven (1987) onderscheidt in dat verband faktoren op drie niveaus, die elk kunnen worden ingedeeld in zogeheten 'harde en zachte' faktoren. 
Op het niveau van de individuele partijen spelen normen en waardlen een rol, alsmede krachten, die de naleving van het contract bevorderen als gevolg van 'locking in'effecten (Williamson 1981,555 ). Op het niveau van de relatie spelen naast culturele faktoren (de langdurige relatie heeft een waarde in zichzelf gekregen; er ontstaat een 'shared culture') ook meer grijpbare zaken een rol, zoals de 'private ordering' Williamson (1983, 520 e.y.): partijen maken zelf afspraken en roepen zelf organisaties in het leven, die het risico van handelingen, die in strijd zijn met het contract beperken (bijv. de instelling van arbitragecommissies). In tegenstelling tot het derde niveau is de "private ordening" niet juridisch afdwingbar.

Schema 4.3 Faktoren die gedrag van contractanten beînvloeden

\begin{tabular}{|c|c|c|c|}
\hline & & $\begin{array}{l}\text { "soft" v.s. } \\
\text { soft factors }\end{array}$ & $\begin{array}{l}\text { hard" factors } \\
\text { hard factors }\end{array}$ \\
\hline \multirow{3}{*}{ leve1 } & $\begin{array}{l}\text { individual } \\
\text { party }\end{array}$ & $\begin{array}{l}\text { norms and } \\
\text { values }\end{array}$ & $\begin{array}{l}\text { self-enforcement } \\
\text { mechanisms }\end{array}$ \\
\hline & relation & $\begin{array}{l}\text { culture of } \\
\text { the relation }\end{array}$ & private ordering \\
\hline & envi ronment & $\begin{array}{l}\text { business } \\
\text { practices }\end{array}$ & court ordering \\
\hline
\end{tabular}

Bron: Noorderhaven $(1987,9)$

Het schema van Noorderhaven (1987) biedt een overzicht van de faktoren, die bij de bestudering van contractuele relaties in acht moeten worden genomen. Het betreft een breed scala van faktoren, dat inzicht kan bieden in het gedrag van de partijen tijdens het concretiseren van het relationele contract.

"A contract, than, is the set of factors that, by determining the distribution of
competence and responsibility, influence the behaviour of parties relative to
the proces of an exchange. These factors are the formal and informal, written
and unwritten agreements between parties, supplemented by generally
accepted business practices of the branche, private ordering arrangements, the
culture of the relation itself, selfenforcement mechanisms, and norms and
values of the individual parties" (Noorderhaven 1987, 10).

Dit algemeen theoretisch concept van een contract dient aan de hand van de genoemde faktoren voor elke concrete relatie met specifieke condities van plaats en tijd te worden ingewuld. In de hoofdstukken 6 en 7 zal zulks geschieden ten aanzien van de 'contrats de plan', die in de periode 1982-1986 zijn afgesloten tussen het 'Ministère de I'Industrie'. en de genationaliseerde industriële groepen. 


\subsection{Voorwaarden voor het effectief en efficiënt funktioneren van publieke ondernemingen}

In hoofdstuk 2 is geconcludeerd, dat het indicatieve plan in een open en complexe markteconomie een producent en verspreïder van informatie is, waarbij le Plan als consultatieplatform yoor alle belangengroepen dienst kan doen.

Uit het in hoofdstuk 3 besproken ideaaltype van 'L'Etat développeur' is gebleken, dat de coördinatie van de planning in handen moet zijn van één 'pôle central de la turelle". Eveneens is in hoofdstuk 3 uiteengezet, hoe de strategie van industriële groepen is gericht op het versterken van het 'métier' en hoe het management zich daarbij een specifieke expertise eigen maakt. Tevens is duidelijk geworden, dat de industriële groep die kennis zal gebruiken voor het beheersen van haar omgeving, waaronder ook het overheidsbeleid moet worden begrepen. Eén en ander impliceert, dat in de relatie tussen de overheid en de publieke onderneming zorg gedragen moet worden voor:

- de mogelijkheid, dat het management autonoom een lange termijn strategie ontwikkelt gericht op versterking van het 'métier' van de groep

- een zodanige formulering van de nationale doeleinden, dat een vertaling naar ondernemingsniveau mogelijk wordt en indicatoren kunnen worden ontwikkeld ter beoordeling van de effectiviteit van de betreffende onderneming. In 4.3 . is uiteengezet dat zulks niet zonder problemen is

- een afstemming van de financiering van de publieke onderneming op de inhoud en planningshorizon van het nationale plan en de ondernemingsplannen. Delion (1981) wijst er in dit verband op, dat de overheid moet beschikken over een

" (...) compréhension intime de ses (van de publieke ondernemingen JG) capacités et de son marché, pour apprécier des projets ou des résultats, et même pour réduire au maximum le contrôle lui-même en connaissance de cause. Dès lors il faut recourir à un contrôle-dialoque, fondé sur l'étude en commun et la négociation entre le contrôleur et le contrôle. Il devrait aboutir d'abord à l'approbation sous forme de contrats des plans d'entreprise établis dans toutes les entreprises publiques, puis à l'approbation symétrique de constats périodiques de résultats. Ces plans toutefois n'auraient pas tant à retracer des objectifs que des critères: ceux que l'entreprise et l'Etat reconnaîtraient l'un et l'autre comme pertinents pour juger de son efficacitét" (Delion 1981, 27).

Er dient dus sprake te zijn van een platform van voortdurende informatieuitwisseling, hetwelk de mogelijkheid biedt overeenkomsten aan te passen aan veranderende omstandigheden.

- een coördinatie van het beleid van de diverse afdelingen van de ministeries door een 'Ministere de tutelle'

- een concretisering van de wederzijdse rechten en plichten in een 'contrat de plan'. Dat vereist een nauwkeurige afstemming van de doeleinden en financiering van het nationale indicatieve plan op de ondernemingsplannen qua planningshorizon en inhoud. Concreet: publieke ondernemingen moeten voor het uitzetten van cen lange termijn strategie ook garanties hebben wat de financiering betreft;

- een afstemming van de ondernemingsstrategie op de doeleinden van het indicatieve plan op basis van overleg uitmondend in een overeenkomst, die een expliciete financiële compensatie kent voor extra kosten, die de publieke onderneming moet 
maken. Het beleid met betrekking tot de publieke onderneming van de afdelingen van diverse ministeries, dient door één centrale instantie of ministerie te worden gecoördineerd;

- een zodanige informatie en expertise bij de overheid (i.c. het Ministère du tutelle'), dat zij in het overleg over de 'contrat de plan' een gelijkwaardige partner van de industriele groep vormt. In dit verband is door Delion $(1981,26)$ voorgesteld schakels te creèren tussen de overheid en de publieke onderneming [25], die enerzijds de publieke onderneming van informatie en advies voorzien met betrekking tot het effect van hun strategie voor de plandoeleinden en anderzijds de overheid informeren over de 'rentabilité sociale' en de compensatie, die de publieke onderneming voor haar extra taken dient te krijgen [26].

\section{Noten behorend bij hoofdstuk 4}

[1] The technical efficiency of a firm indicates the extent to which the firm produces its output at minimum cost. This requires both an appropriate choice of technology in the production process, and that the factor inputs are employed in proportions reflecting their respective prices" (Bishop en Kay 1988, 19).

[2] Er zijn tal van vergelijkende onderzoekingen gedaan naar de efficiëntie van partikuliere en publieke ondernemingen \{zie o.a. Porter, Scully en Slottje (1986) en Davies en Brucato (1987)\}. Groot probleem is steeds dat langs economische weg de resultaten in termen van winst, prijsstelling e.d. niet eenduidig zijn toe te wijzen aan het al dan niet publiek zijn van de onderneming (zie Boot 1987).

[3] Vergelijk de kritiek in hoofdstuk 3 op het vergelijken van de efficiëntie van verschillende economische organisatievormen in het kader van de transactiekostentheorie.

[4] Leray $(1983 \mathrm{~b}, 635)$ is zelfs zeer positief:

"Elle permet une réflexion sur la stratégie qui inspire, consciemment ou non, la gestion, elle montre l'interdépendence des diverses politiques menées par une firme: politique de production, choix des combinaisons de facteurs, politiques d'approvisionnement et de sallaires, politique de rémunération des apporteurs de capitaux. Elle met donc en lumière lles dimensions de la firme autres que sa dimensilon strictement productive et elle permet de tester la cohérence de ces multiples politiques coherentes; il est possible de concevoir plusieurs ensembles de coherentes alternatives comprenant la politique de production, celle d'approvisionnement, celle des salaires, une politique d'investissement et de productivité, etc., sous la contrainte d'un compte de surplus équilibré. C'est donc une approche, entrêmement riche et ouverte, à la fois du fonctionnement de la firme et de son efficacité, puisque celle-ci est sanctionnée par un surplus de productivité globale maximum, c'est-â-dire par l'obtention d'un volume d'avantage global, allant aux partenaires économiques et sociaux, le plus élevé possible. Elle jette déjà un éclairage sur une notion plus large de l'efficacité"."

[5] Bishop en Kay $\left(1988_{*} 19\right)$. verduidelliken, dat in de berekening van de output rekening moet worden gehouden met met de diverse activiteiten van de onderneming:

"The output measures for British Airports Authority for example, consists of total air traffic movements, weighted at $20 \%$, and total passengers carried $(80 \%)$. 
Ook wijzen zij erop, dat een index van de inputs niet altijd gemakkelijk beschikbaar is en dat de toevlucht moet worden genomen tot een proxy van de uitgaven gedeeld door de prijs.

Door de theoretische en praktische bezwaren is de PGF slechts in een beperkt aantal ondernemingen toegepast.

[6] In de meeste West-Europese landen gaat ook van de Raad van Commissarissen en de Ondernemingsraad een belangrijke controllerende werking uit. Omdat het onderscheid tussen de publieke en partikuliere onderneming met name het functioneren van de kapitaalmarkt betreft, gaat daarnaar in eerste instantie onze aandacht wit.

[7] "A crucial difference in property rights between private firms and public enterprises is the fact that ownership of government firms is not normally transferablle. There are no daily sales of shares (changes in ownership), no proxy fights, no tender offers and take-over attempts, and no outright raids on public enterprises" (Davies en Brucato 1987, 11).

[8] De zogenaamde "repeteergevallen", die van de overheid steun blijwen ontvangen, omdat er al eenmaal zoveel ingestopt is (vergelijk hoofdstuk 6 en 7).

[9] Zo gezien is in geval van de publieke onderneming geen sprake van een 'principaal-agent'-relatie, maar van een 'many-priscipals-agent'-probleem ' (vergellijk Davies en Brucato 1987).

[10] Als een bedrijf in een directief centraal geleid stelsel een specifieke output heeft geproduceerd met een specifieke combinatie van produktiemiddelen, dan geldt die prestatie als uitgangspunt voor de onderhandelingen over de nieuwe planopdracht. De mogelijkheden worden als het ware vastgepind ('ratchet' is palletje) op het eenmaal gepresteerde niveau.

[11] Groves (1973) heeft op die problematiek een algemeen theoretisch antwoord geformuleerd door de bonus van de manager niet alleen afhankelijk te stellen van zij.n eigen produktie, maar ook van die van de andere producenten. De gedachte is, dat de manager dan efficiënt met de produktiemiddelen zal omgaan, omdat inefficiënties tot gevolg hebben, dat voor de andere producenten minder middelen beschikbaar zijn, waardoor hun produktie en dus het aigemene welvaartsniveau lager zal zijn. Nadeel van het beloningssysteem van Groves betreft de zeer indirecte band tussen prestatie en beloning, waardoor in werkelijkheid 'free riding" zall optreden.

[12] De indirecte parametrische planning is ingevoerd in bijv. Hongarije en Polen (vergelijk Groenewegen 1988b).

[13] Vergelijk de Contrats de Plan, die in Frankrijk na 1982 werden afgeslloten tussen het Ministerie van Industrie en de genationaliseerde industriẻle groepen (zie 6.2.2.1).

[14] Zie Hervouët (1983).

[15] Zie Hervouët (1983).

[16] Vergelijk hoofdstuk 7.

[17] "Ainsi le fondement de l'autonomie de l'entreprise réside dans un intérêt propre à poursuivre son objet social et l'effectivité de cette autonomie repose sur la suprématie de son intérêt par rapport à ceux des différents groupes qu'elle comprend et notamment celui de son entrepreneur" (Mescheriakoff 1985, 1609). 
[18] "Dans la conception française issue de la pensée révolutionnaire, ill (L'Etat Puissance JG) gère l'intérêt public et sa sphère de compétence se limite à cet intérết que l'on appelle selon les cas, utilité publique ou nécessité publique** (Mescheriakoff 1985,1615 ).

[19] "Le pouvoir prépondérant de l'Etat-entrepreneur ne peut donc pas maitre du libre jeu du marché ou de stipulations contractuelles telles qu"elles sont prévues dans le Code civil" (Mescheriakoff 1985, 1605).

[20] Delion $(1981,27)$ is minder genuanceerd als hij stelt: "L'Etat peut légitimement imposer (...) à toute entreprise publique, tout objectif d'intérêt général, au nom d'une efficacité nationale supérieure, mềme s'il est contraire ane gestion interne optimale".

[21] Boublil (1981, 12) wijst erop, dat de nationalisatie niet mag leiden tot een "étatisation, maar dat de ondernemingen (...) 'restent régies par le droit commercial".

[22] Hoewel Hafsi zijn case-studies nawwgezet heeft uitgevoerd en verschillende sectoren in diverse landen heeft bekeken, lijkt zo'n pertinente uitspraak methodologisch onjuist.

[23] Bijv. een overeenkomst om een investeringspremie in de wacht te slepen (Meijknecht 1979, 166).

[24] Vergelijk voor een stapsgewijze karakterisering van het relationele contract: McNeil (1987). Voor een definiëring van het contract in traditioneel sociologische zin, waarin de rol van normen en waarden sterk wordt benadrukt zie Lindenberg en Vos (1985, 559). Vergelijk ook Williamson (1979).

Noorderhaven (1987) zet uiteen, dat het concept van McNeil, tesamen met de inzichten van de 'agency-theorie', de ingrediënten vormen van een definitie van "contract", waarbij met een grote diversiteit van faktoren rekening kan worden gehouden; zie ook Noorderhaven (1988).

[25] Delion spreekt van "cellules de reflexion stratégique sectorielle associées au travail de programmation des entreprises publiques correspondantes".

[26] "Ultérieurement elles prépareraient les décisions des autorités de tutelle sur les pllans des entreprises du secteur économique public et les constats d'exécution de ces plans" (Delion 1981, 26). 


\section{Intermezzo I Wat de theoretische inzichten te bieden hebben}

1. De coördinatie van de handelingen van de marktpartijen vindt plaats op zogeheten dubbel geordende markten, waar het gedfag richting wordt gegeven door enerzijds instituties, zoals normen en waarden, afspraken en regels en anderzijds door organisatievormen, die worden gecreëerd door de marktpartijen en door de overheid. Voor de behandeling van concrete ordevraagstukken dient de onderzoeker algemene en specifieke theorieën in wisselwerking te hanteren.

De theoretische concepten kunnen afkomstig zijn uit diverse disciplines en bieden harddvatten, waarmee de complexe werkelijkheid tegemoet getreden kan worden. Classificaties en typologieën uit de economische, sociologische, of politicologische theorieën kunnen waardevol blijken bij de analyse van het hoe, waarom en de effectiviteit van het industriebeleid in het algemeen en van de publieke onderneming in het bijzonder. Gedurende het gebruik kan blijken, dat concepten minder relevant zijn, of aangescherpt moeten worden, dat classificaties verfijning behoeven, of dat hypothetische verbanden wel of niet bevestigd worden. Die bevindingen dienen tot een terugkoppeling op de theoretische concepten te leiden. In hoofdstuk 8 zullen wij aan de wisselwerking tussen theorie en empirie nader aandacht besteden.

2. Wat de theorie van de indicatieve planning betreft speelt in de afstemming van de plannen van de actoren de informatieoverdracht een essentiëlle rol. Uit algemene theorieën van Meade en Harrod kan worden afgeleid welk een complex vraagstuk het elimineren van markt- en omgevingsonzekerheid is en welke hoge eisen met betrekking tot de informatievergaring, -verwerking en -verspreiding aan een systeem van indicatieve planning worden gesteld. De meer institutionele theorie van Estrin en Holmes maakt duidelijk welk een belangrijke rol in een markteconomie voor een centraal orgaan kan zijn weggelegd met betrekking tot de produktie en verspreiding van informatie. Die rol houdt verband met de specifieke eigenschappen van informatie als collectief goed.

Een diepgaand en breed consultatieproces met alle betrokkenen is in een systeem van indicatieve planning van essentiële betekenis voor de produktie en verspreiding van de juiste en adequate informatie.

3. Industriebeleid in een markteconomie dient gebaseerd te zijn op inzicht in de strategie van de ondernemingen enerzijds en op inzicht in het functioneren van het overheidsapparaat anderzijds.

Van de besproken ondernemingsstrategieèn uit de wereld van de neoklassieken leek de transactiekostentheorie veelbelovende concepten te bieden. Echter, gebleken is, dat die kern van de "Nieuw Institutionele Economie" (NIE) grote operationaliseringsproblemen kent, waardoor een onafhankelijk criterium ter beoordeling van de efficiëntie van economische organisatievormen ontbreekt en een cirkelredenering van 'What is, is best' dreigt. De transactiekostentheorie is gebaseerd op het methodologische individualisme, waardoor andere verklaringen dan het maxi- 
maliserend, of minimaliserend gedrag van individuele actoren, buiten beschouwing blijven en met name de rol van de overheid sterk wordt onderbelicht. Uit de bespreking wan de diverse theoretische inzichten is gebleken, dat in geval van de analyse van concrete ordevraagstukken uit onderzoek moet blijken welk complex van interdependente factoren verklarend is voor de ondernemingsstrategie. Daarbij dient de transactiekostentheorie niet op een functionalistische wijze te worden gehanteerd, maar kunnen haar concepten van een belangrijke heuristische waarde blijken: zij levert concepten, die in een multi-disciplinair onderzoek voor nadere invulling met condities van plaats en tijd in aanmerking komen. Relevant voor het verkrijgen van inzicht in de ondernemingsstrategieën zijn ook concepten uit de zogenaamde behavioristische lijn van economische organisatietheorieën, waarin de behavioristische versie van de SCP-benadering, de dynamische markttheorie en de bedrijfskundige benaderingen geintegreerd zouden kunnen worden in de zogeheten netwerkbenadering. In de Franse 'Theorie Economie Industrielle' spelen in dat verband de concepten van de 'filière' en het 'mésosystème' een centrale rol. De ontwikkeling van de industriêle groep, die door middel van beheersing van haar markt- en socio-politieke omgeving onzekerheden poogt te reduceren, is van groot belang in het kader van de netwerkanalyse. De industriele groep bouwt een complex van 'governance structures' op, dat alls een netwerk rond haar kernactiviteiten wordt gevlochten. Daarmee maakt zij zich qua informatie en expertise tot een moeilijk te beinvloeden actor in het economische proces.

Inzicht in ondernemingsstrategieẻn in het kader van industriebeleid vereist multidisciplinair onderzoek naar het gedrag van actoren in netwerken: welke actoren zijn relevant, wat is hun machtsbasis, welke zijn de gemeenschappelijke belangen, welke dymamiek treedt op gedurende de levenscyclus van de betreffende markt enz.? Zoals uit de bespreking van de 'filiere' is gebleken, zal de netwerkbenadering een bruikbaar handvat leveren, waarmee de complexe werkelijkkheid tegemoet kan worden getreden.

Wat het inzicht in het functioneren van het overheidsapparat betreft, is de 'publicchoice'-theorie voor onze probleemstelling behept met grote beperkingen, die nauw verband houden met haar individualistisch methodologische grondslag. De actoren op meso- en microniveau blijwen onzichtbaar. De theorieën, die het neocorporatisme betreffen, bieden meer houvast: met name concepten, die de positie van het centrale coördinatieorgaan binnen thet overheidsapparaat in relatie tot positie van de industriẻle groep in kaart brengen, kunnen voor onze probleemstelling waardevol zijn (vergelijk schema 3.14). Veranderingen van de machtsposities in specifieke netwerken kunnen met behulp van genoemde concepten in kaart worden gebracht, waardoor inzicht kan worden verkregen in de dynamische van het netwerk. Ook theoretische inzichten als die geboden door Hafsi (1984) werpen licht op de economische en socio-politieke factoren, die tot verandering in de relaties in een netwerk kunnen leiden (vergellik Durand 1988).

Naast de genoemde theoretische inzichten, die bruikbaar zijn bij de analyse van concrete ordevraagstukken, is met betrekking tot de bestudering en beoordeling van het overheidsapparaat ook houvast te verwachten van ideaaltypen als 'L'Etat développeur". 
Het ideaaltype van 'L'Etat développeur' maakt duidelijk onder welke voorwaarden de overheid effectief mesosystemen kan sturen. Het gaat daarbij niet alleen om de politieke will en om de inpasbaarheid van de organisatie in de historisch-culturele context, maar ook om het vermogen een effectieve overheidsorganisatie op te zetten, de vereiste informatie te vergaren en te verwerken, alsmede om het ontwikkelen van een effectief instrumentarium, waarmee de strategie van de industriële groepen kan worden beinnloed. Wat de organisatie betreft, is uit het ideaaltype van 'L'Etat développeur' gebleken, dat de coördinatie in handen moet zijn van éen centrale overheidsinstantie, die het beleid van de diverse ministeries coördineert. Wat de informatie met betrekking tot de industriële structuur betreft, moet worden geconstateerd, dat het concept van de statistische filiere grote beperkingen kent en de ontwikkeling van concepten als 'pôle de compétivité' en 'filière monographique' nog in de kinderschoenen staan.

Wat de ontwikkeling van een effectief instrumentarium betreft, kan uit het concept van de industriële groep worden afgeleid, dat gelet op de complexiteit van de groep, de specifieke expertise van het management en de interne en externe consensus, de overheid alleen in staat moet worden geacht effectief industriebeleid te voeren als de industriële groep sterk van haar afhankelijk is. Daarvan zou sprake kunnen zijn in geval van de ontwikkeling van kostbare nieuwe technologieẻn, als de overheid de vraag op de markt domineert, of als zij de markt voor de betreffende onderneming effectief kan afschermen. Voor het verkrijgen van inzicht in de mogelijkheden van de overheid de strategie van de industriële groep te kunnen beïnvloeden kunnen de classificaties van de dynamische markttheorie van De Jong (1981a) en van de cyclus van Hafsi (1984) relevant zijn, omdat de mogelijkheden van de overheid technologische ontwikkelingen te starten, markten af te schermen, e.d. varieert met de cyclus van het produkt (zie ook Durand 1988).

4. Het industriebeleid kent vele vormen, waarbij op grond van theoretische inzichten enige kanttekeningen geplaatst kunnen worden:

- het generieke kostenverlagende beleid heeft geen sturende invloed op de strategie van ondernemers; hoogstens worden projecten, die al op stapel stonden vervroegd uitgevoerd, of wordt in de richting, die het management reeds had gekozen meer geiSSxnvesteerd. Over de aanwending van de extra financiele ruimte bestaat echter geen enkele zekerheid. Generiek kostenverlagend beleid bevat geen prikkel de richting van de investeringen te veranderen en zal derhalve in veel gevallen de status quo bevorderen. Voorwaardelijk generiek beleid plaatst de overheid voor onoverkomelijke problemen met betrekking tot de vergaring en verwerking van informatie.

- centraal georganiseerd specifiek beleid brengt met zich mee, dat de overheid informatie over het microniveau behoeft. Echter, de theoretische concepten waarmee de bestaande, de te verwachten en de gewenste structuren in kaart kunnen worden gebracht, zijn dermate zwak ontwikkeld, dat een specifiek intervenierrende overheid veelal zal zijn aangewezen op ad hoc informatie van de betrokken ondernemingen. Ook nu zal de informatieproblematiek de overheid opbreken, nog afgezien van de mogelijkheden van opportunistisch gedrag van de 
ziljde van de ondernemingen. Alleen in geval van zeer nauwe relaties van wederzijdse afhankelijkheid tussen de overheid en bedrijfsleven kan een grote verstoring van informatie worden woorkomen (vergellik de fase van 'coopération" in de cyclus van Hafsi 1985 , zie 4.4.2.4).

- in principe kan de informatieproblematiek worden gereduceerd door het specifieke beleid te decentraliseren. Mesosystemen kunnen op regionaal niveau rond infrastructurele projecten worden georganiseerd, waarin ondernemingen, lokale en regionale overheden, vakbonden, onderzoekcentra en onderwijsinstellingen participeren (vergelijk Schenk en Kamann 1987).

5. De theoretische inzichten met betrekking tot de publieke onderneming betreffen de problematiek van de effectiviteit en de efficiëntie van de publieke onderneming als instrument van industriebeleid, de autonomie, de dynamiek in de relatie tussen de overheid en de publieke onderneming en de planningsovereenkomst.

Uit de theoretische inzichten is gebleken, dat zowel het meten van de effectiviteit als de efficie̋ntie met grote problemen gepaard zal gaan. Om de effectiviteit te kunnen vaststellen dienen de doeleinden op het microniveau van de onderneming gespecificeerd te worden. Gelet op de uiteenlopende redenen van nationalisatie ligt het in de lijn van de verwachtingen, dat sprake zal zijn van conflicterende doeleinden, waardoor zelden of nooit van dè effectiviteit van de publieke onderneming gesproken zal kunnen worden. Om ervoor te zorgen, dat de doeleinden van het macro- en mesoniveau van 'L'Etat développeur' vertaald worden naar het microniveau van de onderneming en tevens worden voorzien van adequate indicatoren, waarmee de ontwikkelingen geevalueerd kunnen worden, dient sprake te zijn van een intensieve informatieuitwisseling tussen overheid en onderneming. Niet moet worden verwacht, dat daarmee de problemen rond het opstellen van indicatoren voor de effectiviteit en van criteria voor de efficiëntie kunnen worden opgelost; het is een institutionele voorwaarde om de meningsverschillen en conflicten zo veel mogelijk te voorkomen en zo effiènt mogelijk te kunnen behandelen.

Uit de theoretische inzichten is gebleken, dat de planningsovereenkomst zo'n consultatieplatform kan bieden, waarbij het bestaan van éen deskundig coördinerend overheidsorgaan, van financiële meerjarenafspraken en van expliciete compensatieregelingen, in geval de publieke onderneming specifieke taken moet vervullen, voorwaarden zijn voor het efficiënt kunnen functioneren van de planningsovereenkomst. De theoretische inzichten van het discrete en relationele contract geven een classificatie van factoren, die bij de analyse van concrete planningsovereenkomsten van belang kunnen zijn. In de planningsovereenkomst zal de autonomie van de publieke onderneming moeten worden geregeld. Juridisch-theoretisch is het 'intérêt specifique' de basis voor de autonomie, maar dat zal in geval van meningsverschillen en conflicten specifiek moeten worden ingevuld. De theoretische inzichten van Hafsi (1984) geven aan onder welke omstandigheden de cyclus van samenwerking, conflict naar autonomie snel of langzaam zal worden doorlopen: 
Samenvattend kan worden gesteld ${ }_{m}$ dat de besproken theoretische inzichten op het gebied van de indicatieve planning, ondernemingsstrategie, industriebeleid en de publieke onderneming enerzijds concepten en classificaties leveren, die houvast bieden bij het analyseren van het hoe en waarom van concrete ordevraagstukken, en anderzijds ideaaltypen leveren, die van nut zijn bij het beoordelen van de consistentie en effectiviteit van het beleid. 


\section{Intermezzo II De Frans historisch-culturele context}

\section{II.0 Inlelding}

Om te kunnen beoordelen off een specifieke organisatievorm effektief zou kunnen zijn, dient voor alles een beeld te bestaan wan de omgeving, waarin de betreffende organisatie wordt ingepast. Welke economisch- politieke instituties hebben in het verleden een dominante rol gespeeld, op welke voorwaarden waren de machtsverhoudingen gebaseerd, welke ontwikkelingen hebben zich daarin voorgedaan en welke veranderingen zijn te verwachten? In het navolgende zullen de belangrijkste kenmerken van het Franse economisch-politieke systeem de revue passeren. In II.1 wordt de relatie tussen de overheid en het bedrijfsleven geschetst, waarna in 11.2 aandacht aan de zogenaamde 'corps d'état' wordt besteed.

\section{III.1 L'Etat c"est .....}

In Frankrijk ontstond relatief wroeg een eenheidsstaat met een sterk centraal gezag; centrale sturing vanuit Parijs is nog altijd kenmerkend voor Frankrijk hoewel met het Negende Plan serieuze stappen in de richting van decentralisatie lijken te zijn genomen.

Vanaf Colbert, minister onder Lodewijk XIV, intervenieert de Franse overheid diepgaand in de industriële ontwikkeling door beheersing van de im- en export, oprichting van publieke ondernemingen als partikulier initiatief uitbleef en gerichte financiële steun op contractbasis aan partikuliere ondernemingen.

\section{Hoe 'L'Etat' te karakteriseren?}

Politicologische studies wijzen uit, dat aan de Franse staat een principieel andere conceptie ten grondslag ligt dan bijv. aan de Amerikaanse, waarin sprake is van een meer open verbinding van de overheid met de diverse belangengroepen in de samenleving (Zysman 1977). In de Amerikaanse conceptie heeft elke sociale groepering zijn 'agency' in de vertegenwoordigende lichamen.

"In France, by contrast, one does, in fact, speak of the state (l"état) as a powerful, independent force in political life, and the almost metaphysical notion of l'état as the unified authority of the society has a powerful symbolic value in French politics" (Zysman 1977).

De Franse staat is geconcipieerd als een instrument van de centrale macht, die daarmee als het ware buiten de samenleving om haar doeleinden kon realiseren.

"Thus from the beginning the state was an instrument of centrallizing power, created apart from the society, almost in opposition to it, and thus at least partially autonomous" (Zysman 1979, 194).

Dat gold ten tijde wan de koningen, van Napoleon en dat geldt in de twintigste eeuw. Die conceptie van 'L'Etat' brengt met zich dat in de Vijfde Republiek (1958-heden) de President en de Eerste Minister tesamen met de top van de bureaucratie en het bedrijfsleven de initiatieven nemen en de ontwikkeling van de samenleving richting 
geven. Het parlement en de buiten-parlementaire oppositie oefenen slechts marginale invloed uit. Het initiatief en de organisatie van de grote maatschappelijke projekten is voorbehouden aan 'L'Etat'. Overigens zegt de mogelijkheid van het nemen van dergelijke initiatieven nog niets over de richting en de aard van de interventies. Gebleken is, dat de staat haar macht gebruikt om zowel gevestigde belangen te verdedigen ('situations acquises') als om vernieuwingen met betrekking tot de industrielle structuur in gang te zetten.

"The French state, then, has the structural potential for autonomous action, but structure does not determine how or whether that potential is used. A political explanation will always be required to explain the direction of state activity" (Zysman 1979, 199).

Aan de andere kant is het bedrijfsleven in Frankrijk altijd ontvankelijk geweest voor de interventies en de bescherming van de overheid. In de literatuur wordt veelall gewezen op het gebrek aan "entrepreneurs': de Franse ondernemer geeft de voorkeur aan een door branche-organisaties, kartels of de overheid gecontrolleerde markt boven een scherp concurrerende omgeving.

"Nowhere is the economic man of liberal theory so little at home as in France, and nowhere has the cold accountancy of economic laws been so succesfully eliminated. In the preponderance of the administrative function over that of the entrepreneur, of group solidarity over the principle of competition or tradition over initiative, and in the loyalty to established routine and the respect for all "situations acquises" regarded as positions of licensed privilege, the way of life of an ancient state has survived in that of contemporary France" (Luethy 1957, 27).

In Frankrijk was sprake van 'comportements anti-industrialiste traditionels' (Stoffaës, 1983b), gericht op het behoud van 'situations acquises'. Vaak wordt in dat verband gewezen op verschillen, die zouden bestaan tussen de latijns-katholieke levensfilosofie en de calvinistische-angelsaxische levenshouding [1].

Die anti-industriële traditie werd versterkt door het stagneren van de bevolkingsgroei vanaf de 19 de eeuw, waardoor groeiende markten voor consumptiegoederen uitbleven.

"Ce malthusianisme développe un cercle vicieux de la non-industrialisation" (Stoffaës, 1983b).

Overigens heeft de Franse geschiedenis ook perioden gekend, waarin een meer liberale wind woei, zoals tijdens het 'Second Empire' (1851-1870).

Ook tijdens de daarop volgende Derde Republiek (1870-1940) was veelal sprake van een terughoudende overheid: enerzijds maakte de voortdurende wisseling van kabinetten het uitzetten van een door de politiek gesteund lange termijn beleid onmogelijk, anderzijds overheerste bij de toenmalige bureaucratie de opvatting, dat de rol van de overheid in het economisch leven minimaal en neutraal moest zijn. Zo schrijft Kuisel (1981, 14) bijwoorbeeld over het Ministerie van Handel en Industrie van die dagen:

"Industrial promotion, other than a rare subsidy, consisted largely of organizing exhibitions, looking after the Chambers of Commerce, gathering economic statistics, and distributing decorations to businessman".

De overheid had rond 1900 noch de wil, noch de kennis en kunde om het economisch proces actief te sturen. Wel zorgde de overheid voor protectie tegen buitenlandse 
concurrenten en onder die beschermende paraplu ontstond in Frankrijk een kleinschalige gevarieerde industrie. Met name na de Tweede Wereldoorlog werd gepoogd 'L'Etat développeur' op consistente wijze vorm te geven: initiatieven werden ontwikkeld om doeleinden, middelen en institutionele structuur zodanig op elkaar af te stemmen, dat de overheid de richting van de economische ontwikkelingen bepaalde, maar dat de markt voor de efficiënte allocatie zorg kon dragen [2].

In de hoofdstukken vijf tot en met zeven zullen wij nagaan in hoeverre ' $L$ 'Etat' daarin is geslaagd en welke instituties en organisaties daarbij een positieve en/of negatieve roll hebben gespeeld.

\section{II.2 De 'corps d'état"}

Toen de universiteiten, die in de Middeleeuwen de elitevorming voor hun rekening namen, verzuimden te voorzien in de behoefte van de overheid aan hooggekwalificeerde ingenieurs en ambtenaren, namen de ministeries in de 18 de eeuw initiatief tot het oprichten van eigen opleidingsinstituten. In 1747 werd de 'Ecole Nationale des Ponts-et-Chausées' opgericht, dat zich overigens nu heeft gespecialiseerd in de luchten ruimtevaart en de electronica. In 1794 ontstond de militaire 'Ecale Polytechnique', ook wel ' $\mathrm{X}$ ' genoemd vanwege het symbool van de twee gekruisde zwaarden.

Verder zijn bekend de 'Ecole Central des Arts' et Manufactures, Ecole Nationale Supérieur des Mines de Paris, Ecole Nationale Supérieur des Telecommunications en de Ecole Nationale d'Administration.

Belangrijk voor een goed begrip van de besluitworming in het Franse economischpolitieke systeem is het inzicht in de rol van de 'corps détat'.

Karpik (1987) onderscheidt 'bestuurlijke' corps (Inspection des Finances, Conseil d'Etat en Cour des Comptes) en 'technische' corps (Corps des Mines, Corps des Ponts et Chaussées, etc.).

De 'corps d'état' organiseren voor hun leden de carrière, waarbij de overstap van de bureaucratie naar het bedrijfsleven een belangrijke element vormt ('pantouflage').

Een 'corps' beheerst een specifiek terrein binnen het bureaucratisch- industriële complex. Vanuit een oorspronkelijk expertise (bijvoorbeeld de mijnbouw voor het 'corps des mines') heeft elk corps haar werkterrein aangepast aan nieuwe ontwikkelingen: zo beheerst het 'corps des mines' tegenwoordig ook de nucleaire sector. De 'corps d'état' beheersen de sleutelposities op de betreffende ministeries en in de relevante industriele groepen. Verandert een corpslid van positie dan geldt het principe van "renvoyer l'ascenseur'; betreft het een positie in bijvoorbeeld het electriciteitsbedrijf 'Electricité de France", dan kan die funktie alleen worden opgevuld door een nieuw lid afkomstig van het corps des mines uit het Ministerie van Industrie.

Friedberg (1979), die een nauwkeurige sociologische studie heeft gemaakt van de netwerken van het 'corps des mines' schrijft:

"Mitglieder des Korps "schwärmten" ganz einfach auf die verschiedenen Industriesektoren aus, die direkt oder indirekt unter der Aufsicht des Korps standen, und besetzten dort leitende Stellen" (Friedberg 1979, 112).

De 'corps d'étar' hebben hun werkterrein in de loop der jaren uitgebreid, waardoor een 
grote kennis van specifieke netwerken is ontstaan. Door het bezit van die informatie en kennis is een corps in staat de sleutelposities in het netwerk te beheersen [3]. Door de scherpe selectie wordt het lidmaatschap van een "corps' als een kwaliteitslabel aangemerkt. De selectie voor de 'grands corps' loopt via de Ecole Polytechnique of de Ecole Nationale d'Administration (ENA). (Karpik 1987). Tot de voorselectie voor de

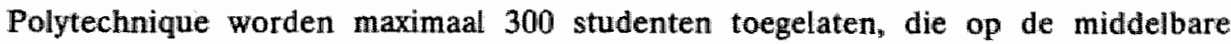
scholen uitzonderlijke prestaties hebben geleverd met name met betrekking tot de mathematische vakgebieden. $\mathrm{Na}$ twee jaar als een 'taupe' te hebben doorgebracht beslist een toelatingsexamen over de toetreding tot de echte studentenelite. De onderlinge competentiestrijd blijft ook na de toelating bestaan, omdat van elke lichting een rangorde wordt opgesteld en alleen op de beste studenten liggen de felbegeerde topposities te wachten. De topposities in Frankrijk zijn voorbehouden aan degenen, die de 'Ecole Polytechnique' (een ' $X$ ') hebben gecombineerd met een andere Grand Ecole, waartussen wederom een scherpe hiërarchie bestaat: $z o$ is een ' $X$ '-Mines hoger gerangschikt dan een $X$-HEC (Haute Ecole de Commerce).

De Ecole Nationale de l'Administration (ENA) is van recenter datum dan de Ecole Polytechnique en is speciaal opgericht voor het opleiden van de (politieke) bestuurders van Frankrijk (les énarques). Het toelatingsexamen wordt meestal voorbereid op het 'Institut des Etudes Politiques'. ENA heeft een groot aantal stageplaatsen binnen het overheidsapparaat, waardoor haar studenten gemakkelijker dan die van de Ecole Polytechnique toegang hebben tot het bestuurlijke apparaat van Frankrijk. Ook bij ENA geldt een scherpe hiërarchie tussen de afgestudeerden: de tien tot vijftien besten gaan naar de 'Conseil d'Etat', 'Inspection des Finances', of het 'Cour des Comptes'.

Omdat het in de Vijfde Republiek voor de bureaucraat mogelijk is geworden ook politieke funkties te vervullen en na verloop van tijd weer in de bureaucratie terug te keren, betreft het netwerk van de 'corps d'état' niet alleen de relatie tussen de bureaucratie en het bedrijfsleven, maar

"The pattern that emerges is one of closely interconnected, indeed interllocking elites, administrative, industrial, financial and political; indeed the relatively limited nature the industrial-financial- administrative elite in France, concentrated in Paris, means that contacts may exists and pressure be brought to bear without formal mechanisms for interest representation. The extent to which there is interlinking, through common training and early career patterns, through common corps memberships, through family and marital connections and through overlapping memberships of conseils d'administration between the big industrial groups, the banks and the administration probably ought to be considered at least as much as any formal institutions" (Cawson, Holmes en Stevens 1985).

De positieve kanten van de netwerken van de 'corps d'état" zijn ongetwijfeld gelegen in de relatief gemakkelijke informatieuitwisseling tussen verschillende economische actoren en in het creêren van een stabiele omgeving, waardoor langlopende risikovolle projekten opgestart kunnen worden [4].

De medaille heeft ook een keerzijde.

De Franse staat in het algemeen en de Franse bureaucratie in het bijzonder wordt veelal gekarakteriseerd als een rigide hiërarchie met scherpe afgebakende taken en competenties. Daarin zou eén van de oorzaken zijn gelegen van het onvermogen van 
de Franse overheid flexibel op maatschappelijke ontwikkelingen te anticiperen: in Frankrijk lijken sociale problemen niet zonder crisis te kunnen worden opgelost (vergelijk Zysman 1977).

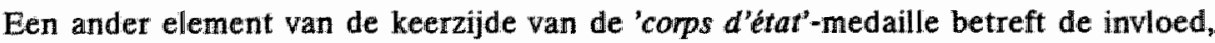
die van de gevestigde beschermende relaties uitgaat op de strategie van de ondernemingen en met name op die van de grote industriële groepen. Uit hoofdstuk 6 en 7 zall blijken dat de industriële groepen goed kunnen participeren in lange termijn projekten $_{s}$ die worden beheerst door een 'corps d'état' en waar de overheid zich voor lange tijd aan verbonden heeft. Komt het op een concurrentiestrijd op de wereldmarkt van massaprodukten aan, dan blijken veel grote Franse groepen zich moeilijk te kunnen handhaven.

\section{Noten behorend bil] Intermezzo II}

[1] Paysans ou aristocrates, les Francais préfèrent le prestique au profit, la terre à la machine, l"Administration au commerce" (Stoffaès, 1983b).

[2] "Der Staat will bestimmte Produktionen (Erzeugnisse, Techniken), also sorgt er dafur: entweder indirekt so, dass seine Interventionen die private Herstellung profitabel macht ('L'Etat-légistaleur', 'L'Etat-financier', 'L'Etat-client'); oder direkt, durch die Herstellung in eigener Regie (L'Etat-producteur'). Anders gesagt: Der Staat dominiert den Markt (jedenfalls so lange er sich's leisten kann)" (Dannebaum 1984, 33).

[3] "Dieses Einflusspotential beruht immer ausschliesslicher auf seinen Handlungsmöglichkeiten als autonomes Personalwirtschaftssystem, auf seinen Făhigkeiten, durch die Lenkung der Ausbildung und der Verwendung der Bergbauingenieure jene Experten- und Beziehungsnetze zu schaffen und zu unterhalten, die es jedem seiner Mitglieder ermöglichen, die institutionell und geselIschaftlich gegebene Abschottungen zu überspringen, vielfache Relais in normalerweise kaum oder nur schwer miteinander kommunizierenden Tătigkeitsbereichen zu mobilisieren und so die informellen Kanäle herzustellen, uber die Informationen, Ideen, Initiativen und Einfluss relativ problemlos oder zumindest. leichter als gewöhnlich ausgetauscht werden können. Ein Bergbauingenieur ist heute nur noch in den seltendsten Fallen ein Spezialist für Bergbauprobleme: seine "Spezialkenntnis" beruht in zunehmendem Mass auf seiner "Beziehungsfähigkeit" innerhalb der von seinem Korps geschaffenen Informations- und Beziehungsnetze" (Friedberg 1979, 131-132).

[4] "Contacts and relations between the two (industrie en bureaucratie J.G.) are easy, frequent, direct, and informal with a constant flow of information both ways, giving especially the state an opportunity to be well informed and build up the kind of industrial and economic expertise it needs for its interventions". 


\section{DE FRANSE INDICATIEVE PLANNEN}

\subsection{Inleiding}

Het socialistische industriebeleid werd ingebed in een nationaal indicatief plan. Frankrijk heeft vanaf 1945 negen nationale plannen gekend; het Negende Plan liep tot 1988. In dit hoofdstuk worden deze plannen geanalyseerd wat betreft het planningsproces en de inhoud, met specifieke aandacht voor het industriebeleid, zoals dat in het kader van de indicatieve plannen gestalte kreeg.

In 5.1 word de historische context geschetst, waarin de planning in 1945 van start ging. De ontwikkeling naar het hoogtepunt van de 'planification a la Framçaise' komt in 5.2 aan de orde. Paragraaf 5.3 is gewijd aan het proces van 'déplanification', zoals dat vanaf het midden van de jaren zestig gestalte kreeg. In 1981 gingen de socialisten over tot een restauratie van het systeem van indicatieve planning; in 5.4 wordt het Negende Plan aan een analyse onderworpen en geconfronteerd met de voorwaarden, die in hoofdstuk twee op basis van de theoretische inzichten zijn geformuleerd.

In hoofdstuk 6 komen het industriebeleid en de rol van de publieke onderneming aan de orde.

\subsection{De historisch-culturele context}

In het begin van de 20ste eeuw werd in Frankrijk een corporatieve benadering voorgestaan.

"Freed from prejudice and taught by hard experience we can say: individualism and collectivism are doctrinal quarrels. We must undertake a national policy which will not obstruct free and fruitful initiatives; it will result from the coordination of individual efforts and from collective effort. It will assure simultaneously the development of our national wealth and private wealth. This is the policy of groups, unions and federations" (Clementel, minister van Handel en Industrie, geciteerd naar Kuisel 1981).

Het sturen van het marktmechanisme op basis van corporatieve netwerken was in Frankrijk rond 1920 het antwoord op het falen van het individualisme van de onzichtbare hand, het collectivisme en determinisme van het Marxisme en het constructivisme van het etatisme. Anders gezegd: enerzijds werd het niet juist geacht de coördinatie van de economische beslissingen over te laten aan het marktmechanisme, dat werd gekenmerkt door een voortschrijdende concentratie in het bedrijfsleven; anderzijds zou het een illusie zijn te menen, dat de overheid die coördinerende functie zou kunnen vervullen op basis van een centraal plan. De oplossing ligt in het midden: de markteconomie moet worden aangevuld met een nieuw coördinatiemechanisme. Het 
zou daarbij owerigens mogelijk zijn binnen eenzelfde economische orde onderscheid te maken tussen sectoren waar het marktmechanisme voor de coördinatie zorg draagt en sectoren waar planning en overleg de coördinatiemechanismen zijn. Die centrale gedachte wan de neo-liberale planners in het Frankrijk van 1920 vinden wij in grote lijnen terug in de ideeën van Jean Monnet in 1944 en Mendès-France in 1950.

"The goal was a "transparent economy" that could be managed. Manipulation of credit and taxes, obligatory corporatist associations, and long-term industrywide contracts or codes were the means of management." (Kuisel 1981, 107).

Echter, tot de Tweede Wereldoorlog owerheerst in het concrete beleid de liberale opvatting. De corporatieve planmatige aanpak werd doorkruist door de verkiezingsoverwinning in 1919 van het rechtse 'Blac National'. Een vruchtbare pollitieke en sociale voedingsbodem voor een corporatieve orde kwam daarmee te vervallen. Hetzelfde lot waren de planningsideeen van het Volksfront van Leon Blum in 1936 beschoren.

Tijdens de Tweede Wereldoorlog onder de regering Vichy kreeg de economische planning daadwerkelijk gestalte. De Vichy-planners beschouwden hun systeem ('societế communautaire") als een juiste middenweg tussen het oorlogsdirigisme en de liberale markteconomie. Enerzijds heeft de economische sturing van Vichy veel emotionele weerstand tegen een planmatige aanpak opgeroepen, anderzijds bood hun aanpak handvatten voor de 'Consell National de la Résistance' (CNR), die in de eerste jaren na de oorlog de inrichting van een meer planmatige orde voor zijn rekening nam. De Raad was een platform voor alle groeperingen, die voor een planmatiger sturing van de economie waren.

"The platform .... (of the Résistance) called for planning by the state, nationalization, big public investments, 'economic and social democracy' and state control over cartels, prices, or capital movements" (McArthur and Scott 1969 , 38).

De CNR en daarna De Gaulle gaven de modernisering van het industriële apparaat de hoogste prioriteit. Frankrijk moest zich aan de kop wan het economische peloton in de wereld nestelen. In tegenstelling tot de vooroorlogse periode stonden modernisering en dynamiek voorop. Algemeen was de opvatting, dat de herstructurering van de industrie niet aan het marktmechanisme kon worden overgelaten: de ondernemers werden als de eerstverantwoordelijken voor het economische debacle in de jaren dertig gehouden en bovendien werden velen beschuldigd van collaboratie. Algemeen was de opvatting, dat voor de wederopbouw en industrialisering van de Franse economie een aanvullend coördinatiemechanisme nodig was.

"(...) d'une intensification de la production nationale selon les lignes d'un plan arrêté par l"Etat après consultation des représentants de tous les éléments de cette production" (CNR, geciteerd naar Petit 1983, 16). 


\subsection{Het Eerste tot en met het Vierde Plan}

\subsubsection{Het Eerste Plan (Plan Monnet; 1946-1953)}

In 1947 werd het eerste nationale Plan gepresenteerd door het 'Commissariat Général du Plan' (CGP): 'Rapport Général sur le Premier Plan de Modernisation et l'Equipment'. Meestal wordt gesproken van het 'Plan Monnet" naar de grondlegger van de Franse planning: Jean Monnet.

Het Plan Monnet werd niet gekenmerkt door een integrale aanpak. Integendeel: kolen, electriciteit, staal, cement, landbouwmachines en transport waren de prioriteitsectoren. Later werden daaraan toegevoegd: petroleum, basischemie, kunstmest, scheepsbouw en synthetische vezels. Voor die basissectoren werden investerings- en herstructeringsprogramnma's opgezet. Met strakke hand werden de plannen voor de kolen-, electriciteits- en transportsector omgezet in opdrachten van de overheid aan de genationaliseerde ondernemingen. Het was de bedoeling met de partikuliere ondernemingen in de sectoren met een olligopolistische marktstructuur (bijv. de staal) contracten af te sluiten, die pasten in de herstructureringsprogramma's. Daar kwam echter niet veel van terecht. Toch had de overheid de eerste jaren na de oorlog een grote greep op de particuliere sector, omdat zij na de nationalisatie van de grote banken de kredietverlening beheerste (vergelijk paragraaf 6.2). Ook de middelen van het Marshallplan stroomden via overheidskanalen (met name via het CGP) naar het bedrijfsleven. Bovendien konden de sectoren, waarin een groot aantal partikuliere ondernemingen werkzaam waren, de eerste jaren na de oorlog door de overheid ook worden beheerst via de grondstoffenvoorziening en via de leveranties van de genationaliseerde ondernemingen.

Voor de uitvoering van het Plan Monnet stonden de overheid voldoende middelen ter beschikking (Ullmo 1975, 344). Het Plan Monnet is qua uitvoering meer directief dan indicatief, terwijl pragmatisme voorop stond:

"There was no pretence at any underlying theory or sophisticated strategy, merely the aim of restoring the economy to pre-war levels of activity in the shortest possible time" (Hough 1982, 111).

Dat neemt niet weg, dat het plan wat de totstandkoming betreft wel de basis legde voor de latere 'économie concertée'. In de sectorale "moderniseringscommissies" participeerden vertegenwoordigers van de verschillende belangengroepen. Degenen, die voor de uitvoering van het plan zorg moesten dragen, werden intensief bij de voorbereiding betrokken. Massé wijst erop, dat het Monnet daarbij niet alleen te doen was om het aantrekken van deskundigheid bij het opstellen van het plan, maar dat participatie bij het opstellen van het plan er ook toe moest leiden, dat het plan als het ware spontaan door de betrokkenen zou worden uitgevoerd [1].

"' (...) travaillant ensemble à élaborer le Plan, ceux qui auraient ensuite à le réaliser en feraient spontanément leur affair. L'intervention du gouvernement: n'aurait pas aỉnsi à faire lourdement sentir au moment de l'exécution du Plan" (Massé 1965a, 155) [2].

Het Plan Monnet wordt over het algemeen als een economisch succes beschouwd. Weliswaar zal de inflatie door de indrukwekkende investeringsprogramma's zijn aan- 
gewakkerd, maar daar staat tegenover dat het plan de beperkte financiële middelen effectief heeft weten te sluizen naar een beperkt aantal basissectoren.

"The foundation of the plan was the basic sectors. It was a certain foundation. In these sectors the planners could project future demands reliably and, with the active cooperation of the Ministery of Finance, control investment and output effectively" (Cohen 1969, 149).

Ook in psychologisch opzicht was het Eerste Plan een succes: in tegenstelling tot de vooroorlogse jaren werd de particuliere sector veel ontvankelijker voor de idee van modernisering en economische groei. Het plan werd gedragen door de vertegenwoordigers van alle belangengroeperingen, waardoor er een sterke mobiliserende werking van uit ging. Voor de nationale overheid bood het plan het kader voor de coördinatie van het economisch beleid op middellange termijn.

Het Plan Monnet kreeg gestalte in de uitzonderlijke situatie van de eerste jaren van herstel na de oorlog. Ondanks het specifieke karakter van die periode werd door het Plan Monnet de toon gezet voor de volgende indicatieve plannen:

- Het plan is een instrument van neo-liberale snit om de economische groei te stimuleren. Het is zeker geen middel om een socialistisch planeconomie te realiseren.

- Het partikulier eigendom blijft de basis van de Franse economische orde.

- Om een modern produktieapparaat op te kunnen bouwen dienen oligopolistische marktstructuren te worden beworderd.

- Selectieve nationalisatie kan in een markteconomie voor de overheid een effectief instrument zijn bij het richting geven aan de ontwikkeling van de industriële structuur.

- Het plan is complementair ten opzichte van de markt: participatie van de belangengroepen bij de totstandkoming van het plan legt de basis voor een gemeenschappelijke visie ten aanzien wan toekomstige ontwikkelingen van de industriële structuur, waardoor de marktpartijen een richtsnoer voor hun handelen wordt geboden.

Het Eerste Plan kon mede een succes worden door de persoon van Monnet. Hij bleek in staat het CGP buiten de politiek en bureaucratie te houden. Een klein bureau, bemand met deskundigen, bleek in staat effectief als makelaar in de overlegeconomie op te treden (vergelijk de kenmerken van de developmental state beschreven in hoofdstuk 3.2.1.1). Het CGP kon die rol ten opzichte van de ministeries en sociale partners met gezag spelen, omdlat de Marshallhulp was gekoppeld aan de lange termijn doelstellingen van het plan. Echter, ook in de eerste jaren na de oorlog werd reeds duidelijk, dat het CGP zich in een spanningsveld bevond. Zo deden zich conflicten voor met de genationaliseerde banken, die niet bereid waren de kredietverlening op te voeren uit vrees voor het aanwakkeren van de inflatie. Om onafhankelijker van de banken te worden willde het CGP een eigen fonds stichten, hetgeen echter op ernstige bezwaren stuitte van het Ministerie van Financiën (Kuisel 1981, 240). Ook waren de eerste tekenen van spanning zichtbaar tussen het korte termijn conjunctuurbeleid van het Ministerie van Financiën en de lange termijn doelstellingen van het plan. Het intomen van de inflatie stond op gespannen voet met het stimuleren van investeringen gericht op het opvoeren van de groei. Een spanning, die alle navolgende plannen zou kenmerken. 
Tot ongeveer 1950 oefende het CGP daadwerkelijk invloed uit, daarna verloor zij steeds meer terrein aan het Ministerie van Financiën.

\subsubsection{Het Tweede (1954-1957) en Derde (1958-1961) Plan}

In tegenstelling tot het Eerste Plan was het de bedoeling met het Tweede en Derde Plan een zogenaamd integraal plan te construeren. Niet enkele sectoren werden als speerpunt geselecteerd, maar de evenwïchtige ontwikkeling van alle sectoren stond centraal. Gedurende het Tweede en Derde Plan werd op de ministeries en de gespecialiseerde onderzoekinstellingen het kader van topambtenaren gevormd, dat het plan beschouwde als een adequaat instrument voor de modernisering van het industriële apparaat en voor de bevordering van de economische groei. Petit $(1983,21)$ spreekt van 'une nouvelle idéologie industrielle', gedragen door de 'hauts fonctionnaires' van de diverse 'Grands Ecoles' (vergelijk Intermezzo II).

"Dans ce context modifié le plan va viser des développements sectoriels ayant une cohérence globale pour obtenir une croissance maximum respectant les ếquilibres intérieurs" (Petit 1983, 6).

Voor het opstellen van zo'n geïntegreerd beeld van de toekomstige ontwikkeling is een eerste vereiste, dat alle overheidsbeslissingen in het plan worden verwerkt. Niet alleen de beslissingen betreffende de infrastructuur, maar ook de gevolgen van het korte termijn conjunctuurbeleid voor de ontwikkeling van de diverse sectoren zoudlen in het plan zichtbaar moeten worden gemaakt.

Een tweede vereiste betreft de participatie van alle economische actoren bij het opstellen van het plan. Immers, niet alleen de plannen van de overheid, maar zeker ook die van de ondernemers en de werknemersorganisaties zijn van grote invloed op de toekomstige ontwikkelingen op meso- en macroniveau. Het tot stand komen van een integraal plan vereist derhalve een besluitvormingsproces, waarin alle economische actoren participeren. Zo'n participatie kon in principe in de verticale en horizontalle moderniseringscommissies van het CGP gestalte krijgen (vergelijk 2.3.1). De verticale sectorale commissies ontwikkelen, met inachtneming van de regeringsplannen, toekomstbeelden van hun sectoren, die in de horizontale commissies tot een coherent geheel kunnen worden gesmeed, waarna het plan ter goedkeuring aan het parlement wordt voorgelegd. De 'économie concertée' betreft in essentie die participatie- en afstemmingsgedachte, waarbij de overheid bewust partner wordt in het economisch proces (Albeda 1977a, 1180). Informatieuitwisseling, overleg en afstemming van de plannen onder leiding van het CGP' is de kern van de 'économie concertée'. Deze procedure draagt er in theorie toe bij, dat de marktpartijen zich ook bij de uitvoering van het plan "'gebonden" voelen.

De feitelijke gang van zaken rond het Tweede en Derde Plan liep andlers. Het plan ningsproces bleek langs twee lijnen gestalte te krijgen: enerzijds was sprake van een "brede" consultatie in de moderniseringscommissies onder leiding van het CGP, anderzijds werd een beleid ontwikkeld op basis van een "smalle" consultatie tussen de topambtenaren van het Ministerie van Financièn, het CGP en de managers van de grote ondernemingen. Daarbij speelden de relaties in de 'corps d"état' een essentiéle rol (vergelijk Cohen 1969). 
Het overleg in de moderniseringscommissies leidde tot een aantal niet bindende "actions de base, , die de aanbodzijde van de economie betroffen. Door middel van stimulering van Onderzoek en Ontwikkeling, concentratie en specialisatie, modernisering van het distributiesysteem en dergelijke, moest het produktieapparaat wan de Franse industrie worden gemoderniseerd (Cohen 1969, 137). Via de "smalle" consultatie kreeg de meer directe bemoeienis van de overheid met een aantal sectoren gestalte. Die operaties hadden alleen kans van slagen als zij aansloten bij de strategie wan de grote ondernemingen en de gewenste winsten opleverden (vergelijk de conclusiles in hoofdstuk 3). Om die afstemming te bereiken overlegden ambtenaren wan het Ministerie van Financiën, het CGP en de managers van de grote ondernemingen direct met elkaar. Het overleg in beperkte kring had sterk de voorkeur van de 'hauts fonctionnaires'.

"As the managers of the state and the giant corportions see it, broad representation would bring in peasant and shopkeeper groups, nostalgic for an irrational past; trade unionists nostalgic for an irresponsible future; and politicians all too eager to serve those groups. It would complicate matters, perhaps even destroy the system" (McArthur en Scott 1969, 70-74).

Uit de smalle consultatie resulteerden een aantal specifieke maatregelen op het terrein van de belastingen en fusies (Cohen 1969, 136-143).

De maatregelen, die de ondernemingen direct in hun strategische beslissingen raakten, kwamen dus buiten het brede consultatieproces tot stand. Aan het officiële nationale Plan van die tijd wordt dan ook geen grote invloed op de ondernemingsstratgie toegekend (McArthur en Scott 1969). Drie factoren zijn daarbij van invloed. In de eerste plaats was het 'integrale' plan in zeer vage, algemene bewoordingen gesteld. Doeleinden in de trant van $5 \%$ groei van het BNP, evenwicht op de betalingsbalans, en dergelijke zijn voor de ondernemers op microniveau informatie in te geaggregeerde vorm. (Vergelijk de opvatting van Estrin en Holmes met betrekking tot de relevantie van verschillende typen van informatie op verschillende aggregatieniveau; zie hoofdstuk 2). In de tweede plaats bleek het Ministerie van Financiën voortdurend ad hoc korte termijn plannen te ontwikkelen gericht op beteugeling van de inflatie en herstel van het betalingsbalansevenwicht. Er kan bezwaarlijk van een integraal plan worden gesproken, als het conjunctuurbeleid buiten het plan om gestalte krijgt. Tot slot moet worden vastgesteld, dat het ontbrak aan voldoende gegevens betreffende de input- en outputrelaties om voldoende nauwkeurig de effecten van wijzigingen in de finale vraag, of in de produktie van specifieke sectoren te kunnen doorrekenen. Het was derhalve ook moeilijk de vertikale plannen te integreren tot een coherent geheel.

Het behoeft dan ook geen verbazing te wekken, dat zich tijdens de uitvoering van het tweede plan grote onevenwichtigheden voordeden (Estrin en Holmes 1983a, 65). Sommige sectoren (automobiel, woningbouw, chemie) schoten hun doel ver voorbij, hetgeen leidde tot een grotere import dan gepland, waardoor de inflatie werd aangewakkerd. Andere sectoren bleven onder de plandoeleinden. De opzet van een integraal plan mislukte, maar de directe selectieve interventie buiten het planningsproces om nam daarentegen wel steeds vastere vormen aan: de ambtenaren van het Ministerie van Financièn en de managers van de grote ondernemingen namen vanaf de tweede helft van de jaren vijftig het voortouw van het CGP over. 
Ter verklaring van deze verzwakking van de positie van het CGP kunnen diverse factoren worden aangedragen:

- In vergelijking met de relatief eenvoudige economische structuur van wak na de oorlog, was de structuur rond 1950 , zowel qua aantal sectoren als diversiteit in de marktvormen ingewikkelder geworden. Afstemming van alle sectorale plannen werd daardoor bemoeilijkt. Dat probleem wordt bij de volgende plannen steeds groter.

- Het CGP verloor een belangrijke machtbasis door het beëindigen van de Marshallhulp en door de toenemende interne financiering door de ondernemingen.

- Het CGP werd door zowel politiek links, het centrum, als rechts hevig bekritiseerd. Volgens het politieke centrum bevorderde het plan de inflatie, volgens rechts werd afgekoerst op een stelsel van centrale planning en volgens links was het Tweede Plan een instrument in handen van de managers van de grote ondernemingen. $\mathrm{Om}$ die reden stapte de communistische vakbond CGT uit het overleg in de moderniseringscommissies [3].

- Aan het welslagen van het korte termijn anti-inflatiebeleid werd door de politiek grote waarde gehecht. Het anti-inflatie programma van de regering-Pinay in maartdecember 1952 en het expansieprogramma van de regering-Faure in 1953-1954 domineerden het economisch beleid, terwijl zij op geen enkele wijze waren afgestemd op de lange termijn planning van de structurele ontwikkeling.

- Een vijfde factor betreft de opvolging van Monnet in 1953 door Hirsch, die een minder gezaghebbend figuur was.

Door de kritiek van diverse zijden en het ontbreken van een duidelijk planningsconcept, verkeerde het CGP in het begin van de jaren vijftig in een moeilijke positie. Het stelde zich terughoudend op: de groeidoelstellingen werden zeer bescheiden gehouden (vrees voor inflatie), waardoor er geen mobiliserende kracht meer van uit ging (Liggins 1975 , 355). Van een integrale aanpak was geen sprake: belangrijke organisaties als de vakbond CGT participeerden niet in de planvoorbereiding en de ministeries gingen bij de beleidsuitvoering hun eigen-korte-termijn-weg.

Het Derde Plan vertoonde dezelfde kenmerken als het Tweede: vrijblijvende 'taches impératives' werden in het plan opgenomen en de politieke ondersteuning liet veel te wensen over. Nadat het plan in 1959 (!) was gepubliceerd, moest het reeds in 1960 door een interimplan ('60-'61) worden vervangen als gevolg van de ontwikkelingen in Algerije. Wijzer geworden door de slechte ervaringen met het Tweede Plan, werd in het Derde Plan bewust naar een evenwichtige opzet gestreefd. Daartoe werd de groeidoelstelling bescheiden gehouden om de importen te drukken en werden de investeringen gestimuleerd met het doel een betere concurrentiepositie te verwerven. Echter, ook toen domineerde het korte termijn anti-inflatiebeleid hẹt economische beeld. Van 1952 tot 1953 domineerde het Plan-Pinay, terwijl in 1957 het Plan-Gaillard buiten het nationale Plan om het conjunctuurbeleid bepaalde. Quinet en Touzery $(1986,47)$ schrijten over het Plan Gaillard:

"C'est un des premiers exemples, avec le Plan Pinay de 1952, où une action coordonnée destinée à pallier une situation conjoncturelle impréwue porte le nom de plan et comporte des mesures à moyen terme qui ne s'inscrivent pas dans la stratégie du Plan. Ce ne sera pas le dernier". 
Toch wordt het Derde Plan beschouwd als een eerste stap op weg nar een coherent plan met een positieve invloed op de ondernemingsbeslissingen [4].

Het is van belang op te merken dat het Derde Plan werd ontwikkeld en grotendeels uilgevoerd in een vrijwel gesloten economie. Zeker tot de oprichting van de EEG, maar ook nog een aantal jaren daarna, heerste in Frankrijk de opvatting, dat de import zich diende te beperken tot de produkten die Frankrijk (inclusief haar oude kolonies) niet zelf in voldoende mate kon produceren. Export was slechts nodig voor de financiering van de noodzakelijke importen.

"This conception of the role of foreign trade was expressed in the statement that 'the originality of the protection of French foreign trade in the Third Plan lies in taking the imports as a constraint and deriving exports as a result of this "constraint"' (Balassa 1981, 205).

\subsubsection{Het Vierde Plan (1962-1965)}

Het Vierde Plan werd voorbereid onder politiek gunstige omstandigheden. Met de terugkeer van De Gaulle in 1958 werd de stabiliteit van de Vijfde Republiek ingeluid. In 1961 werd een 'Conseil Supérieur du Plan' gecreëerd, die was samengesteld uit ongeveer zestig personen uit diverse geledingen van de samenleving. De Gaulle beschouwde de realisatie van de doeleinden van het plan als een plicht voor alle Fransen ('ardent obligation'); een verplichting die zeker voor de regering gold [5].

In het Vierde Plan is sprake van doeleinden, die door de marktpartijen moeten worden gerealiseerd, zonodig met behulp van interventies door de overheid op brancheniveau [6].

Het Vierde Plan gaf een gedetailleerd beeld in fysieke grootheden van de positie van alle sectoren aan het einde van de planperiode (Gascuel 1962, 127 e.v.). Dat gedetailleerde beeld werd geconstrueerd met behulp van input-outputtabellen. Het plan verschafte een projectie van de economische en sociale situatie aan het eind van de planperiode, waarbij de coherentie tussen de binnenlandse sectoren voorop stond. Het Vierde Plan werd ontwikkeld in de geest van Massé, waarbij een coherent sectoraall toekomstbeeld [7] een element van 'self implementation' (Lutz 1969) in zich had, terwijl de owerheid zich verplicht voelde zich ten volle voor de realisatie van de plandoeleinden in te zetten.

De overheid kon daartoe planningsovereenkomsten afslluiten en selectief financiële middelen toewijzen. Elk investeringsproject, tenzij voor $100 \%$ door het bedrijfsleven zelf gefinancierd, zou door het CGP op zijn conformiteit met de plandoeleinden worden getoetst. Vervolgens zou door middel van selectieve belasting- en subsidieprikkels van het Ministerie van Financiën voor de realisatie zorg moeten worden gedragen.

Het Vierde Plan bood in principe de mogelijkheid voor de industriele sector zo'n selectief industriebeleid te voeren. In werkelijkheid zou zo'n coherent industriebeleid niet ontstaan. Een belangrijke verklaring daarvoor is de steeds zwakker wordende positie van het CGP en de groeiende (financiële) onafhankelijkheid van het bedrijfsleven. Bovendien bleek het indicatieve beeld van de sectoren te weinig operationale betekenis te hebben voor een specifiek industriebeleid. Het accent lag te zeer op het 
realiseren van een gelijkmatige groei voor alle sectoren en voorzover er prioriteiten gesteld werden (staal, chemie, bouw, openbare werken, telecommunicatie en consumentenelectronica) waren deze te globaal om een doelgericht industriebeleid op te kunnen baseren.

Over het algemeen wordt het Vierde Plan toch als een hoogtepunt van de Franse indicatieve planning beschouwd. Gewezen wordt dan op de resultaten: de groei van het BNP van 24\% komt overeen met de plandoelstelling, de investeringen van de ondernemingen lagen op $29 \%$ ( $32 \%$ gepland) en "les equipements collectifs" op $51.5 \%$, terwijl $50 \%$ was gepland; de consumptieve bestedingen van de huishoudens waren gedurende de planperiode met $25 \%$ gestegen terwijl $23.5 \%$ was voorzien (Ullmo 1974 , 16). Echter, ten aanzien van de import en export werden minder gunstige resultaten geboekt: beide kwamen boven de plancijfers uit met een betalingsbalanstekort als saldo. Verder bleek het voor enkele prioriteitsectoren niet mogelijk de doelstellingen te realiseren en schoten de overheidsuitgaven over de gestelde grenzen heen.

"However, despite any misgivings about details, the IVth Plan did represent a high point for French planning, not only because its forecasts were very accurate, but because the planners were actually being allowed to perform the useful task of providing coherent information to decision makers about the medium term" (Estrin en Holmes 1983a, 66).

Wij menen bij dit positieve geluid een kanttekening te moeten plaatsen: Frankrijk werd tijdens de uitvoering van het Vierde Plan geconfronteerd met een sterk oplopende inflatie en Giscard d'Estaing, de toenmalige Minister van Financièn, voelde zich in september 1963 genoodzaakt door middel van het zogenaamde Stabilisatie Plan in te grijpen. Dat korte termijn plan kwam buiten elke planningsprocedure om tot stand.

"en apparance, le IVe Plan a vu sa fin compromise par le plan de stabilisation de septembre 1963 et ceux qui à cette époque ont suivi la politique économique ont eu l'impression que le plan de stabilisation était mis en oeuvre sans prendre en compte le IVe Plan" (Ullmo 1970, 76).

Het korte termijn beleid van de regering domineerde het lange termijn beleid vastgelegd in het plan. Een en ander had te maken met de ontwikkelingen op de betalingsbalans en met de stijging van het prijsniveau.

\subsubsection{Een tussienbalans}

Het Eerste Plan nam een uitzonderingspositie in, zowel qua inhoud (prioriteiten) als omstandigheden, waaronder het tot stand is gekomen (bundeling van krachten ten behoeve van het economisch herstel, sterke positie van het CGP, groot aanzien van Monnet). Het Tweede Plan was nog geen voorbeeld van de integrale planning, zoals Massé deze voor ogen stond. Van een plan als platform voor alle belangengroepen, waar na een intensief proces van 'consultation' en 'concertation' een integraal plan met een eenduidig toekomstbeeld en een sectorale afstemming tot stand komt, was nog geen sprake.

Analyse van het Twreede Plan maakt duidelijk dat de totstandkoming van de doeleinden niet het resultaat was van een breed consultatieproces in de moderniseringscommissies, maar dat met name de maatregelen gericht op de modernisering van de 
industrie uit de koker kwamen wan een kleine technocratische elite verbonden door de relaties in de 'corps d'état'. Belangenorganisaties van boeren, middenstand, kleine en middelgrote ondernemingen, consumenten en vooral de werknemers, stonden grotendeels buiten die consultatie. Wat de uitvoering betreft was sprake van een direkte verbinding tussen ambtenaren en managers, welke gestalte kreeg in een vooral ondernemings-specifiek industriebeleid.

Ook het Derde Plan vertoonde tekortkomingen, maar wordt in het algemeen beschouwd als een stap in de goede richting. Het Vierde Plan werd uitgevoerd in een stabiel politiek klimaat, waarin grote waarde werd gehecht aan de participatie van alle -belangengroepen in het planningsproces. Wat de formele organisatie betreft was het Vierde Plan het toonbeeld van de planning, zoals deze Massé voor ogen stond. Conform die ideeẻn verschafte het plan een projectie van sectorale samenhangen aan het einde van de planperiode. Wij vragen ons af, of een integraal coherent plan, als het Vierde Plan pretendeerde te zijn, wel adequat is in een economie, die in toenemende mate wordt geconfronteerd met buitenlandse concurrentie. Enerzijds ontbrak het de regering in een open economie aan middelen in de sfeer van importquota en tarieven om een effectieve bijdrage te kunnen leveren aan de realisatie van de sectorale doeleinden, anderzijds is het de vraag of de informatie in een coherent plan voor de marktpartijen nog wel zo relevant is. Niet meer de coherentie tussen de sectoren dient voorop te staan, maar juist de selectiviteit op grond van comparatieve voordelen. Gesteld kan worden dat het Vierde Plan, qua inhoud goed past bij de idleeen van indlicatieve planning, die Massé aanvankelijk koesterde. Ideeën, die passen bij een gesloten economie met een relatief eenvoudige structuur. Coherentie is dan haalbaar, terwijl de overheid haar 'plicht" de sectorale doelstellingen te realiseren zou kunnen nakomen. Wel is overigens het gevaar groot, dat zij zich daarbij niet kan beperken tot maatregelen in de sfeer van importrestricties, belastingen, subsidies en vergunningen. De kans is groot, dat in samenspraak met kartels tot marktverdelingsafspraken wordt overgegaan, hetgeen een efficiënte marktwerking in de weg kan staan.

De ontwikkelingen in het begin van de jaren zestig eisen een verandering van het indicatieve plan, zowel qua inhoud als qua wijze van totstandkoming. Twee elementen spelen een rol:

- In een open economie zijn marktpartijen geïnteresseerd in informatie in termen van prijzen en niet in termen van hoeveelheden.

- Voor het verkrijgen van een sterke concurrentiepositie speelt de hoogte van de prijzen een doorslaggevende rol. Aangezien de lonen daarin een zeer belangrijke component vormen, dient de loon- en inkomensontwikkeling onderdeel van het planningsproces te worden.

Het wordt derhalve uitermate belangrijk de planningsprocedure te verbreden tot een daadwerkelijke consultatie van de belangengroepen, waarin met name de vakbeweging intensief participeert. De analyse van het planningsproces vanuit die invalshoek staat in de navolgende bespreking van het Vijfde tot en met het Negende Plan centraal, terwijl wat de inhoud wan de plannen betreft de aandacht zich richt op het industriebeleid. 


\subsection{Het Vifde Plan (1966-1970)}

\subsubsection{Inleiding}

Het Vijfde Plan markeerde een verandering. Het Vierde Plan kende doeleinden per sector en de overheid was gehouden deze te realiseren door het gedrag van de ondernemers te sturen in de richting van de doeleinden. In het Vijfde Plan maakten de doeleinden plaats voor projecties en de ondernemers werd nadrukkelijk als eerstverantwoordelijken voor de ontwikkeling van de industriële structuur gesteld. De overheid had nog slechts een voorwaardenscheppende taak. De ondernemers dienden door middel van hun investeringsbeslissingen zorg te dragen voor een voortdurende aanpassing van de industriële structuur aan veranderende comparatieve voordelen. Zoals uiteengezet, was in Frankrijk echter sprake van een ondernemersklasse, die zich bij voorkeur onder bescherming van de overheid en branche-organisaties richtte op de ontwikkeling van technisch hooggekwalificeerde produkten, maar bij wie de verkoopbaarheid, marktstrategie en het maken wan winst op de tweede plaats kwamen (vergelijk McArthur en Scott 1969; Zysman 1977). Zo'n houding konden ondernemers zich veroorloven in een gesloten economie met een overheid als beschermer van de 'situarions acquises'. In Frankrijk overheersten in het begin van de jaren zestig nog steeds de relatief kleine familiebedrijven met een centrallistische organisatiestructuur, die een sterke voorkeur hadden voor regulering van de markt. De branche-organisaties, die onder de werkgeversorganisatie (CNPF) ressorteerden, vervulden een kartelachtige marktregulerende rol en bleken krachtige handhavers van de status quo. De strategische ondernemingsplanning was meer gericht op het maken van marktver* delingsafspraken, dan op het ontwikkelen van een lange termijn beleid, gericht op handhaving in een onzekere wereld met scherpe concurrentie. Dit proces van interne ordening leverde in Frankrijk geen industriële structuur met ondernemingen, die de concurrentieslag met de buitenlanders aan konden.

De ondernemers in Frankrijk zijn in de jaren zestig zeker geen voorstander van het openen van de grenzen voor de buitenlandse concurrenten. Zij hebben een sterke voorkeur voor het behouden van hun beschermde posities (Balassa 1981, 208). Initiatieven tot versterking van de concurrentiekracht van de Franse industrie kwamen dan ook niet in de eerste plaats van de ondernemers; de staat, op te vatten als de President, ministers en de 'hauts fonctionnaires' namen de initiatieven tot verandering, waarbij in hun visie 'Le Plan' een belangrijke mobiliserende rol zou kunnen spelen. Het Vijfde Plan probeerde ondernemersland ervan te doordringen, dat open grenzen noodzaakten tot een aanvallende, anticiperende marktstrategie, gericht op het vergroten van marktaandelen en het maken van winst.

"Dans le monde de la compétition où nous sommes entrés sans esprit de retour, l'objectif fondamental de Ve Plan est d'asseoir sur des bases solides la capacité concurrentielle de notre économie, en vue de préserver son indépendance, d'assurer son expansion dans l'équilibre et de faire d'elle le support d'un progrès social réel et durable" (Vde Plan, geciteerd naar Molitor 1980, 840).

Het Vijfde Plan poogde een mentaliteitsverandering bij de ondernemers tot stand te brengen: open grenzen vereisen concurrentiekracht, hetgeen selectiviteit vereist. Met klem werd erop gewezen, dat de coherentie van de voorgaande plannen plaats moest maken voor selectiviteit. 
In het navolgende zullen wij nagaan in hoeverre het Vijfde Plan zich heeft aangepast qua planningsprocedure en qua inhoud. Wat het eerste betreft zullen wij specifiek aandacht besteden aan de participatie van de vakbeweging, wat het tweede betreft. zullen wij met name ingaan op het industriebeleid, zoals dat in het kader van het Plan gestalte heeft gekregen.

\subsubsection{Het planningsproces}

De consultatie en participatie van de leden van de samenleving, of hun belangengroepen kan enerzijds gestalte krijgen via de informatieuitwisseling in de moderniseringscommissies en anderzijds via de invloed van het parlement op het plan. Albeda (1971) spreekt in dat verband van sociaal-economische democratie en van politieke democratie.

Wat de rol van het parlement betreft, markeert het Vijfde Plan een belangrijke verandering. Bij de totstandkoming van de eerste drie plannen speelde het parlement geen rol van betekenis. Bij het Vierde Plan lag dat anders. De Gaulle wilde het plan wortelen in de Franse samenleving, waarvoor hij een parlementaire discussie over het plan een vereiste achtte. In juli 1962, enkele maanden nadat het plan in werking was getreden (!), werd het Vierde Plan door het parlement aangenomen. Probleem voor het parlement betrof haar beperkte mogelijkheden tot wijziging van het plan. Zij kreeg een consistent geheel voorgeschoteld, dat na moeizaam overleg tot stand was gekomen. Een wijziging in één onderdeel van het plan zou een wijziging van alle andere onderdelen vergen. Om dat probleem te voorkomen stelde het parlement voor, vanaf het Vijfde Plan het planningsproces in twee fasen te verdelen: in de eerste fase worden de grote lijnen voor de planperiode ('Grandes Options') door het parlement vastgesteld, waarna in de tweede fase het afstemmingsproces in de commissies plaats vindt.

Door het CGP, het DP en het INSEE werden op basis van regeringsvoorstellen doeleinden voor het plan ontwikkeld en enkele groei- scenario's opgesteld. Na bespreking in de moderniseringscommissies, werd door het CGP een rapport over de opties opgesteld ten behoeve van de regering. Deze stelle de 'Options' vast, legde ze ter advisering voor aan de 'Conseil Economique et Social' (CES), waarna het parlement haar goedkeuring verleende in december 1964. Daarmee was de eerste fase van het planningsproces afgesloten.

Bezien wij het planningsproces van het Vijfde Plan nader, dan blijkt echter, dat de 'Options' niet werden vastgesteld na intensief overleg in de moderniseringscommissies. De 'Options' met betrekking tot de macrodoeleinden werden in de kleine kring van de regering geformuleerd; de moderniseringscommissies hadden daar geen reële invloed op. Het bleef met name voor de vakbeweging moeilijk in het proces van informatieuitwisseling en overleg reële invloed uit te oefenen, hetgeen ook verband hield met de ambivalente houding van een groot deell van de vakbeweging ten opzichte van het Nationale Plan.

Met name de CGT ('Conféderation Générale du Travail') met een communistische inslag en de CFDT ('Conféderation Franģaise Democratique des Travailleurs') beschouwden het plan in de eerste plaats als een middel om een socialistische samenleving te organiseren. Van strategische aard was de vraag, of deelname in de moderni- 
seringscommissies de vakbeweging juist met het kapitalisme zou vereenzelvigen, of dat participatie beschouwd kon worden als een tussenstap op weg naar de socialistische samenleving (Albeda 1977, 1182). Aan de ene kant bestond de opvatting, dat participatie de mogelijkheid kon bieden de economische ontwikkelingen bij te sturen in een voor de arbeiders gunstige richting, aan de andere kant waren velen de mening toegedaan dat de vakbeweging zich op geen enkele manier moest inlaten met een planningsproces, dat werd gedomineerd door de technocraten van de ministeries, de managers van de grote ondernemingen en het CGP.

In de jaren zestig ontwikkelde zich ook een derde weg in het denken over de positie van de vakbond. Door een aktief participerende vakbond kon het bewustzijn wan de arbeiders worden geactiveerd, waardoor via de politieke kanalen fundamentele invloed op de doelstellingen van het plan zou kunnen worden uitgeoefend. Zo gezien was het plan beduidend meer dan een onzekerheidsreduktor. Het zou een platform voor politieke keuzen moeten worden waar het partikuliere eigendom van de produktiemiddellen ter discussie kon worden gesteld en veranderingen gestalte konden krijgen, die de maatschappij in de richting van het socialisme zouden sturen. Daarbij stond de vakbeweging de volgende procedure voor ogen: de vakbeweging ontwikkelle een 'Tegenplan', dat in de democratische besluitvorming werd ingebracht als tegenhanger van de 'Options' van de regering. Het uiteindelijke plan moest het resultaat zijn van het bediscussiëren van diverse alternatieven. Tegelijkertijd kon het Tegenplan dienen als een platform, waarop "Links Frankrijk" zich zou kunnen verenigen.

Op het moment, dat het parlement de keuze voor het Vijfde Plan kreeg voorgelegd werd in 1964 zo'n Tegenplan opgesteld. In plaats van een groei van $5 \%$ zou volgens het Tegenplan een groei van $5.6 \%$ mogelijk zijn, als gevolg van meer overheidsinterventie. De militaire uitgaven ('Force de frappe') moesten omlaag en andere collectieve bestedingen omhoog. De investeringen moesten op basis van het plan gericht worden op geselecteerde industrieën. Selectieve nationalisatie zou een middel zijn om nieuwe sectoren in hun ontwikkeling te stimuleren. Nationalisatie van de bouwgrond en van grote monopolies was een belangrijk onderdeel van het Tegenplan. De arbeidsduur moest worden verkort. Het geheel werd gecompleteerd met een prijs- en inkomensbeleid. De regering daarentegen zat op de lijn van hoge winsten, meer investeringen, geen arbeidstijdverkorting, geen inkomensbeleid. Politiek is het Tegenplan gestrand op het feit, dat in de CES de CGT koos voor totale afwijzing van het plan in plaats van het steunen van het linkse alternatief (Cohen 1969).

In de tweede fase werden de opties per sector en branche ingevuld. De moderniseringscommissies stonden voor de taak voor hun sector een projectie te maken voor het eindjaar van de planperiode met 1962 als basisjaar. Een en ander had betrekking op 66 branches en werd uitgevoerd aan de hand van een wragenlijst van het CGP. In principe werden de commissies voor dezelfde taak gesteld als bij het Vierde Plan, alleen was hun werk uitgebreider en gedetailleerder. In de eerste plaats moest een schets worden gegeven van de algemene situatie van de sector aan het einde van de planperiode in fysieke en financiële termen (produktieomvang, importen, exporten, investeringen en dergelijke). Vervolgens moest de verwachte prijsontwikkeling worden aangegeven in vergelijking met de projectie van het algemene prijspeil. Ook werden de aankopen van en leveranties aan de andere sectoren, alsmede de toegevoegde waarde en de ver- 
deling over de produktiefactoren, door de commissies onderzocht. Tot slot moest inzicht worden verschaft in de investeringen en hun financiering, de ontwikkeling van de arbeidsproduktiviteilt, de werkgelegenheid en de uitgaven voor onderzoek en ontwikkeling.

Nadat zo'n gedetailleerd beeld van de sectoren was geschetst, werd informatie uitgewisseld tussen de verticale en horizontale commissies met het doel tot een coherent geheel van alle sectoren te komen. De mogelijkheid werd open gehouden, dat na de sectorale invulling de noodzaak zou kunnen blijken de opties bij te stellen. Door het CGP werd het coherente plan voorgelegd aan de regering, waarna het via de CES bij het parlement belandde. In november 1965 werd het Vijfde Plan goedgekeurd (vergelijk bijlage 5.1 yoor een schematisch overzicht van de planningsprocedure).

Hoe was het gesteld met de mogelijkheden voor de vakbeweging via de moderniseringscommissies in de tweede fase van het planningsproces de eigen idleeẽn naar voren te brengen en daardoor daadwerkelijk de inhoud van het plan te beĩnvloeden? Die mogelijkheden moeten niet hoog worden aangeslagen. Het aantal verticale commissies was in de loop der jaren sterk toegenomen en het bemannen van alle posten door deskundige personen vormde voor de vakbeweging een groot probleem. Daaraan zou nog te ontkomen zijn door zich op de horizontale commissies te concentreren, waarvan het aantal veel geringer was. Het probleem voor de vakbeweging was echter niet alleen een vertegenwoordigingsprobleem. Ook het ontbreken van voldoende informatie speelde de vakbeweging parten. De informatie werd in de commissies verschaft door de ondernemers en de vakbeweging was niet in de gelegenheid een en ander op juistheid en volledigheid te controleren. Bovendien kan de vraag worden gesteld, of de horizontale commissies wel de aangewezen plaats waren om reële invloed uit te oefenen. Als een ambitieus groejprogramma bijvoorbeeld onevenwichtigheden bleek te veroorzaken, dan had een horizontale commissie niet de macht om daarin daadwerkelijk verandering te brengen. $\mathrm{Zij}$ kon erop wijzen en aanbevelingen doen, meer niet.

"The horizontal commissions try to make the best of their responsible, but powerless, position. They try to reconcile the necessity of producing a balanced, detailed plan to the reality of their limited power by making cuts that are not sure to be respected" (Cohen 1969, 226).

Er zijn ten tijde van het Vijfde Plan aanwijzingen, dat de positie van de moderniseringscommissies verder zal verzwakken. Zo is er in het voorgaande reeds op gewezen, dat in het Vijfde Plan de sector- en brancheprojecties nog puur indicatief waren. Alleen op macroniveau werd van doeleinden gesproken. Het ligt voor de hand, dat zo'n verandering in de inhoud van het plan de positie van de moderniseringscommissies alanzienlijk verzwakte. Zij vormden voor de vakbeweging dan ook steeds minder een forum om daadwerkelijk invloed uit te oefenen. De nieuwe fillosofie van het Vijfde Plan deelde de ondernemers een grote verantwoordelijkheid toe met betrekking tot de modernisering van de industrièle structuur door middel van hun investeringen. Strategische beslissingen met consequenties voor de werkgelegenheid, arbeidsomstandigheden en dergelijke, werden steeds minder onderwerp van discussie in de moderniseringscommissies, maar aan de ondernemers gelaten. De vakbeweging 
verkeerde in een zwakke positie gelet op haar beperkte inbreng in commissies, die bovendien niet tot wezenlijke beslissingen bewoegd waren (Ullmo 1970, 36-39).

Het is derhalve niet verwonderlijk, dat de vakbeweging een ambivalente houding innam ten opzichte van deelname aan het planningsproces. De CGT trok zich na een korte naoorlogse periode van participatie in 1948 reeds terug. Bij de voorbereiding van het Vierde Plan nam de CGT weer deel aan het overleg in de moderniseringscommissies. De CGT heeft altijd kritisch gestaan tegenover de "planification a la française" en beperkte haar deelname veelal tot de eerste fase van het proces; als de opties van de regering moesten worden geconcretiseerd trokken de CGT-leden zich terug en distancieerden zich van het regeringsbeleid. De andere vakverenigingen (CFDT, CFTC, CGC, CGT-FO), waarvan de CFDT en de CGT-FO de grootsten zijn, hebben tot en met de eerste fase van het Zesde Plan steeds aan het overleg in de moderniseringscommissies deellgenomen (vergelijk 5.4.1). Met name de CFDT is altijd een groot voorstander geweest van de 'democratische planning'. Zij leverde bijvoorbeeld bij de voorbereiding van het Vde Plan 200 van de 290 vakbondvertegenwoordigers (Bauchet 1966, 76). Aanvankelijk werd door de CFDT het planningsproces beschouwd als een mogelijkheid de eigen opvattingen via het plan te verwezenlijken. Later werd het nut van het plan vooral gezien in zijn informatiefunktie.

Ook de werkgevers hebben een ambivalente houding ten opzichte van het Plan getoond: de grote scepsis van vlak na de Tweede Wereldoorlog, maakte plaats voor enthousiasme toen de 'smalle concertation' gestalte kreeg. De werkgeversorganisatie, Conféderation National du Patronat Français (CNPF), kon zich vanaf het Vijfde Plan volledig vinden in het overheidsbeleid.

\subsubsection{De inhoud van het plan}

Wij hebben geconstateerd, dat de veranderende omstandigheden in het begin van de jaren zestig niet alleen noopten tot een verandering van de planningsprocedure, maar ook eisen stelde ten aanzien van de inhoud van het plan.

Op het eerste gezicht vertoonde het Vijfde Plan geen grote verschillen met zijn voorganger; ook bij het Vijfde Plan moest het consultatieproces leiden tot "' "rransparency" en "coherence' uitmondend in 'a common view" of future development"' (Lutz 1969).

Echter, er was wel degelijk sprake van een veranderd inzicht, hetgeen bleek uit de wijze, waarop het toekomstbeeld van de sectoren en branches werd gepresenteerd: namellijk als projecties en niet meer als doeleinden.

In tegenstelling tot voorgaande plannen werd daarmee aangegeven, dat de ontwikkelingen op sectorniveau afhankelijk waren geworden wan zoveel factoren, die buiten de macht wan de overheid lagen, dat de pretentie van 'doeleinden' niet meer gerechtvaardigd was. Doeleinden maakten plaats voor projecties op sectorniveau, die "slechts" een informatieve funktie vervulden. Zij maakten de marktpartijen duidelijk welke ontwikkelingen de sector moest doormaken wilden de macrodoeleinden verwezenlijkt kunnen worden. Alleen voor de sector "IJzer en staal" (Plan Sidérurgique) en de kolensector (Plan régression) werden wel duidelijk doeleinden gesteld.

"Pour l'ensemble des autres branches, ill était marqué clairement que les travaux qui les concernaient avaient un caractère prévisionnel" (Ullmo $1970,345)$. 
Heeft informatieverschaffing via het plan nog zin als op sectorniweau slechts vage "prévisions" worden gegeven?" Massé verdedigde het nieuwe "flexibele" plan in dezelfde termen als hij de voorgaande plannen had verdedigd: informatie over mogelijke sectorale ontwikkelingen vermindert de onzekerheid en verbetert daardoor het investeringsklimaat. Lutz merkt daarover op:

"The claim continued to be made that 'the mere existence of the projection ... is a reducer of uncertainty', but what this claim meant in the new theory of the Plan was evidently much less than is meant in the old" (Lutz 1969, 159).

In de visie van Massế kunnen ook macro-economische doelstellingen een belangrijke "réducteur d'incertitude' zijn. Van belang is daarbij de wil en de mogelijkheid van de overheid geplande doelstellingen daadwerkelijk te realiseren, zodat de marktpartijen hun strategie daarop af zullen stemmen. Wat dat betreft is de poging van het Vijfde Plan vermeldenswaard het korte termijn beleid af te stemmen op de lange termijn macrodoelstellingen door middel van zogenaamde 'clignotants'. Een stelsel van 'waarschuwingslampjes" werd ontwikkeld, die op "rood" sprongen als de feitelijke ontwikkeling van een macrovariabele te zeer afweek van de geplande ontwikkeling. Met name moesten de 'clignotants' een signaal zijn voor de beleidsmakers als het binnenlandse korte termijn beleid uit de pas liep met de doelstellingen van het plan. Maandelijks gaven de volgende indicatoren een rood of een groen signaal:

- het prijspeil: als gedurende drie achtereenvolgende maanden de prijsontwikkeling $1 \%$ boven die van de handelspartners lag, sprong het licht op rood;

- de betalingsbalans: als gedurende drie maanden het dekkingspercentage onder de 90\% lag was een kritieke drempel overschreden;

- het Bruto Binnenlands Produkt en de industriële produktie mochten niet onder een groei van $2 \%$ op jaarbasis komen;

- de investeringen mochten niet beneden de $2.5 \%$ zakken;

- de werkgelegenheid: gedurende drie achtereenvolgende maanden mocht niet meer dan $2.5 \%$ van de beroepsbevolking een baan zoeken.

In principe vormden de indicatoren een goed systeem om de ontwikkelingen van de macrovariabelen te 'monitoren' en het beleid, of de doelstellingen tijdig bij te stellen. Echter, "automatische" korrekties bleven uit. Een belangrijke oorzaak was gelegen in de veronderstelde trendmatige ontwikkeling gedurende de planperiode. De bandbreedte was zo dicht bij die trends gelegd, dat enkele 'clignotants' bij voortduring brandden (Seibel 1975, 163), waardoor er geen waarschuwende werking meer van uit ging.

Naast de invoering van de "waarschuwingslampjes" kende het Vijfde Plan een tweede noviteit: een eerste poging werd ondernomen te plannen in 'waarden' in plaats van hoeveelheden (Lutz 1969, 163; Seibel 1975, 160-161). Het was de bedoeling antwoord te geven op de vraag, of de geplande fysieke ontwikkeling niet tot financielle onevenwichtigheden zou leiden. In het Vijfde Plan wordt met behulp van zogeheten 'Tableaux d'Opérations Financières' (TOF) de financiële consistentie van de projecties nagegaan. Dat gebeurde overigens op nogal primitieve wijze [8].

Tegelijkertijd werd experimenteel onderzoek verricht naar de financiële situatie van 
de ondernemingen in diverse sectoren, ten einde de prijsprojecties te kunnen verbeteren. Nagegaan werd, of de prijsprojecties van de sectoren consistent waren met de financiële behoeften van de ondernemingen, gegeven de projecties van de investeringen. De resultaten van die consultaties op microniveau konden worden vergeleken met de desaggregatie van de te verwachten finale vraag met behulp van input- outputtabellen. Massé (1965b) wees erop, dat zo'n analyse van groot nut kan zijn bij het opstellen van een coherent plan.

Samengevat blijkt het Vijfde Plan qua procedure de lijn van het Vierde Plan voort te zetten; echter van daadwerkelijke participatie van de vakbeweging was geen sprake. Wat de inhoud betreft vindt een ontwikkeling plaats van sectordoeleinden naar sectorprojecties, waardoor de macrodoeleinden een centraler plaats innamen. Een eerste aanzet wordt gegeven tot planning in termen van waarden.

\subsubsection{Het industriebeleid}

Het industriebeleid in Frankrijk kreeg langs twee lijnen vorm: enerzijds werd beleid geformuleerd en uitgewerkt binnen het kader van het indicatieve plan, anderzijds was sprake van interventies van de overheid in sectoren en ondernemingen buiten het plan om.

Het industriebeleid, dat binnen het kader van het indicatieve plan gestalte kreeg maakte in de loop van de tijd een ontwikkeling door: het Plan Monnet was selectief en directief gericht op enkele speerpunten, conform de situatie van wederopbouw. In het Tweede tot en met het Vierde Plan werd de nadruk in het industriebeleid gelegd op het bereiken van sectorale coherentie. De omstandigheden ten tijde van het Vijfde Plan waren duidelijk veranderd, hetgeen zijn weerslag had op de inhoud van het plan, waaronder het industriebeleid. Dat njeuwe beleid kreeg langs twee wegen inhoud: - het fusiebeleid, dat was gericht op het creëren van eén of twee 'Champions Nationales' per sector, die efficiënt op zo'n schaal zouden kunnen produceren, dat zij tegen de grote buitenlandse ondernemingen zouden zijn opgewassen [9].

Wij zullen het fenomeen van het ontstaan van grote Nationale Kampioenen (veelal in de vorm van industrielle groepen) bespreken in hoofdstuk 6, alwaar het industriebeleid geanalyseerd wordt, dat buiten het officiële plan om tot stand kwam.

- het installeren van twee commissies, die voor het concretiseren van het nieuwe industriebelleid van groot belang waren: 'Le Comité de Developpement Industriel' en 'Le Comité des Entreprises Publiques' (Comité Nora).

De eerstgenoemde commissie kreeg de taak een schets te maken van de gewenste ontwikkeling van de Franse industriële structuur op middellange en lange termijn, algemene maatregelen voor te stellen ter bevordering van een positief industrieel klimaat en aanbevelingen te doen met betrekking tot de coördinatie van het verbrokkelde industriebeleid van de regering. In haar rapport stelde de commissie de marktwerking centraal. Door middel van het indicatieve plan kon de overheid de ondernemers voor hun lange termijn beslissingen van extra informatie voorzien. Verder diende de overheid te waken voor voldoende concurrentie en een regionale evenwichtige ontwikkeling. 
De Nora-commissie rapporteerde in 1967 over het beleid, dat de regering moest voeren ten aanzien van de publieke ondernemingen. Ook daarin kwam de nieuwe aanpak tot uitdrukking. In plaats van strakke voorschriften diende de overheid de publieke ondernemingen autonoom hun beleid te laten vaststellen. Door middel van contracten ('Contrat de Programme') kon op basis van onderhandeling het gedrag van de publieke onderneming op de plandoeleinden worden afgestemd (vergelijk hoofdstuk 7 ).

Hoe luidt het oordeel over het Vijfde Plan als informatiebron voor de ondernemingen ten behoeve van hun strategische industrièle belissingen? Het Plan blijkt wat dat betreft vage en te geaggregeerde informatie te bevatten, hetgeen door McArthur en Scott (1969) wordt verklaard uit onvoldoende kennis over sectoren en branches. Bovendien is het de vraag of de politieke wil bestond tot een gecoördineerd specifiek industriebeleid te komen. Selectie betekent immers (pijnlijke) keuzen. Volgens Estrin en Holmes (1983a) en Delors (1982) was de regering in de jaren zestig bewust uit op het presenteren van vage sectorale plannen. Hoe vager de plannen hoe groter de mogelijkheid om buiten het plan om direct met het management van de grote ondernemingen de interventies in de industriële sector te regelen. Stoléru (1969) daarentegen zette in zijn geruchtmakend boek uiteen, dat het plan in een open economie juist wel scherpe criteria zou moeten bieden op basis waarvan een selectief industriebeleid zou kumnen worden gevoerd. Criteria, die aansloten bij de comparatiewe voordelen van de Franse industrie. De selectie van prioriteiten en financiële steunverlening zou niet op een onduidelijke manier buiten het plan om moeten plaatsvinden, maar diende gebaseerd te zijn op een intensieve consultatie van de betrokkenen; keuzen moesten volgens Stolêru duidelijk in het plan worden geëxpliciteerd.

\subsection{Het Zesde Plan (1970-1975)}

\subsubsection{Inleiding}

In het Zesde Plan werd meer nadruk gelegd op die ontwikkeling van de macrovariabelen ten koste van de sectorprojecties. Ook nu werd in het Plan het belang van een versterking van de industriële sector benadrukt. Omdat het industriebeleid in toenemende mate buiten het officiële planningsproces om gestalte kreeg en doordat de vakbeweging zich tijdens de voorbereiding van het Plan uit het overleg terugtrok, kreeg de "déplanification" met ingang van het Zesde Plan duidelijk vorm.

\subsubsection{Het planningsproces}

Met behulp van een econometrisch model, Fifi geheten, werd een beeld geschetst van de economische toestand aan het eind van de planperiode (1975) in geval van ongewijzigd beleid. De commissies hadden de taak voor de in de projectie geschetste problemen oplossingen aan te dragen, welke met behulp van het model werden doorgerekend. Van de rapporten van de diverse verticale commissies makte het CGP een coherent geheel. Drie varianten werden aan de regering voorgelegd: een scenario met een groei van $5.5 \%, 6 \%$ en $6.5 \%$. Na advies van de CES koos het parlement voor een optie van $5.9 \%$ groei. Vervolgens werd aan de commissies gevraagd de voorwaarden te 
formuleren, waaraan voor hun sector moest worden voldaan, opdat de gewenste groei zou kunnen worden gerealiseerd. Ook van die studies maakte het CGP een coherent geheel - het Plan -, dat langs dezelfde weg als de 'Options' witeindelijk bij het parlement belandde. Een half jaar te laat werd het Zesde Plan goedgekeurd. Bij de planvoorbereiding speelde het model Fifi, waarin voor het eerst expliciet met de openheid yan de Franse economie rekening werd gehouden, een belangrijke rol (zie bijlage 5.1). De veranderingen in planningstechnieken (Fifi) hebben er toe geleid, dat de participanten in het planningsproces meer inzicht kregen in de interdependenties in het economisch verkeer (Bonnaud 1975, 10). Een econometrisch model als Fifi vergroot de mogelijkheden snel de gevolgen van diverse beleidswarianten door te rekenen. De betekenis van Fifi in het planningsproces wordt in het algemeen groot geacht in de eerste fase van het planningsproces als de opties worden voorbereid. Naarmate het proces verder ging en politieke keuzen moesten worden gemaakt, werd de invloed van Fifi minder en overheersten politieke argumenten. Een voorbeeld vormt de belastingdruk.

In het Zesde Plan nam de stabilisatie van de belastingdruk een belangrijke plaats in. De politiek hechtte daar sterk aan om psychologische redenen: de wil de inflatie terug te dringen en de omvang van de collectieve sector te beperken, werd met de hoogte van de belastingdruk geïdentificeerd. Op basis van Fifi werd voorgesteld de belastingstructuur zodanig te veranderen, dat belastingverhogingen nagenoeg niet ten laste kwamen van de concurrerende sector. Door verhoging van de belasting met 1 a $2 \%$, kwam geld vrij voor investeringen in de sociale infrastructuur zonder dat zulks gevaar voor de concurrentiepositie op zou leveren. Deze door de planners bedachte constructie bleek achteraf politiek niet haalbaar. Het planningsproces was ten tijde van het Zesde Plan niet van dien aard, dat de visies van de politici en de belangengroepen reeds in een vroeg stadium in de berekeningen met Fifi verdisconteerd konden worden (Liggins 1975, 148). Om die mogelijkheden wel te hebben zou het planproces een continu, open proces moeten zijn, waarbij veranderende voorkeuren in de politiek en bij de marktpartijen bij voortduring in het model kunnen worden werwerkt. In principe kan het gebruik van economische modellen de participatie dan ten goede komen.

Aan de andere kant kan het intensief gebruik van econometrische modellen in thet planningsproces tot een 'technocratisering' leiden, die de participatie niet ten goede komt. Wij hebben erop gewezen, dat Fifi niet werd beschouwd als een neutraal instrument en Albeda vraagt zich in dat verband af, of en zo ja, hoe de belangengroepen in de toekomst meer betrokken zouden kunnen worden bij het construeren en veranderen van econometrische modellen, zodat het model meer wordt beschouwd als een "objectieve" weergave van het functioneren wan het economische proces. Een niet zo gemakkelijke opgave, gegeven de samenstelling van de moderniseringscommissies.

"Men zou veel tijd moeten besteden, reeds gedurende de ontwikkelingsfase van het model, om de erachter liggende redenering begrijpelijker te maken. Bovendien wordt reeds thans geklaagd over het feit, dat de plancommissies zich te veel moeten bezighouden met techniek, en bijgevolg aan de echte "issues" niet toekomen. Daarbij komt nog dat, voor zover men er in slaagt 
de deelnemers aan de planprocedure volledig "mee te nemen" in het technisch procédé, dan toch voor de commissieleden het gevaar optreedt, dat zij zich juist door hun verbeterende inzicht verwijderen van hun achterban" (Albeda, 1977a, 1182).

In haar rapport naar aanleiding van de gebeurtenissen in mei 1968, stelde het CGP voor de nadruk van de participatie te leggen op de eerste fase van het planningsproces als de opties worden bediscussieerd en de tweede fase meer aan de technici over te laten. Zoals bij de bespreking van het Zevende Plan zal blijken werd dat advies in de wind geslagen.

Na de CGT kreeg nu ook de CFDT steeds meer moeite met deelname aan het planningsproces. In de tweede fase van thet Zesde Plan trokken alle vakverenigingen zich terug, Volgens de secretaris-generaal van de CFDT markeerde het Zesde Plan een fundamentele breuk met de Franse planningstradities: de doeleinden van het plan werden ondergeschikt gemaakt aan de werking van het marktmechanisme (CoenenHuther 1979, 58), hetgeen o.a. bleek uit het industriebeleid, zoals dat in het kader van het Zesde Plan vorm kreeg.

\subsubsection{Het industriebeleid}

Qua inhoud werd de lijn van het Vijfde Plan doorgetrokken: accent op de macrovariabelen, planning in waarden, geen doeleinden per sector en branche. De opties werden ook in het Zesde Plan door de commissies op hun implicaties voor de sectoren en branches bekeken. Daartoe werden de zeven industriële sectoren, die aanvankelijk werden onderscheiden, opgedeeld in 36 branches (Liggins 1975, 191-203). Voor elke branche werd een 'Tableau économique" opgesteld en werd de consistentie van alle sectoren en branches met de macroprojecties getoetst. Voor elke branche ontstond op die wijze een projectie voor het jaar 1975 , waaruit bleek hoe het overheidsbeleid voor de diverse sectoren en branches zou kunnen witwerken. Zo bleek bijvoorbeeld, dat de werkgelegenheid in de landbouw, kolen- en transportsector daalde en de groei van de investeringen in die sectoren onder het plangemiddelde lag. De telecommunicatie vertoonde een tegengesteld beeld (Liggins 1975, 198-201).

Wat het industriebeleid betreft stond het Zesde Plan in het teken van het 'Impératif Industriel" (Ullmo 1970, 347).. In het kader van het Zesde Plan werd de lijn van het generieke industriebeleid doorgezet, maar tevens werd gepoogd het specifieke beleid met betrekking tot een beperkt aantal sectoren tot een consistent geheel te maken. Met name het beleid van de diverse ministeries en andere publieke instellingen diende beter gecoördineerd te worden, waartoe een aantal organisatorische veranderingen werden doorgevoerd.

Het verminderd accent op de coherentie tussen de sectoren en het toenemend belang van de coördinatie van het industriebeleid vanuit één centraal punt, leidde tot de instelling van één Industriecommissie voor alle sectoren (Ullmo 1975, 38). De Industriecommissie kende 22 verticale subcommittees en enkele werkgroepen. In 1969 werd het Ministerie van Industrie opgericht, in 1970 gevolgd door een interdepartementale commissie voor het industriebeleid. Ook werd in 1969 het IDI opgericht, dat in de praktijk vooral de financier van het Midden- en Kleinbedrijf werd (Hough 1979, 198). Verder werden in de jaren 1970, 1971 en 1972 meer fondsen aan het Ministerie 
van Industrie verstrekt ten koste van de FDES: een poging de macht van het Ministerie van Financiën enigszins te breken.

Een andere belangrijke organisatorische verandering met betrekking tot het industriebeleid betrof de invoering van de reeds genoemde 'Contrats de programmes'. Daarmee was het in principe mogelijk geworden het specifieke belleid, zoals verwoordt in de prioriteiten van het Nationale Plan, gestalte te geven door met de daarvoor in aanmerking komende publieke (en particuliere ondernemingen) overeenkomsten af te sluiten, waardoor hun strategie kon worden afgestemd op de plandoeleinden.

Leidden deze institutionele wijzigingen tot een coherent industriebeleid? Werden in het Zesde Plan gedetailleerde industriële prioriteiten gesteld, die door middel van contracten met particuliere en publieke ondernemingen konden worden gerealiseerd? Wat de selectiviteit en prioriteit met betrekking tot de doeleinden betreft, werden in het Zesde Plan inderdaad een viertal prioriteitensectoren aangewezen:

"Le VIe Plan comporte quartre programmes sectoriels prioritaires qui visent l'informatique et l'électronique, les industries mécaniques, la chimie et les industries agricoles et alimentaires" (Ullmo 1970, 350).

Een coherent industriebeleid komt op basis van het indicatieve plan echter niet tot stand.

Eên van de belangrijkste oorzaken van het mislukken bleef de hoge mate van aggregatie van de doeleinden (Ullmo 1970, 350; Bonnaud 1975, 103). Met name voor heterogene sectoren als de chemie en de machinebouw zouden de doeleinden nauwkeuriger moeten worden gespecificeerd.

Hoewel in het kader van het Plan de bovengenoemde vier prioriteiten waren geselecteerd, werden er ook zogeheten 'actions spécifiques" ontwikkeld voor een tiental andere sectoren, waaronder de vliegtuigmotoren, de textiel en de houtindustrie. Onduidelijk was hoe die sectoren zich verhoudden tot de prioriteitssectoren.

Niet alleen de doeleinden waren in het kader van het plan onvoldoende gespecificeerd, ook het instrumentarium was onduidelijk en vertoonde inconsistenties. Voor de prioriteiten werden geen meerjarenplannen opgesteld, zodat bij elke begroting moest worden gestreden voor de financiële middelen. Dominante lobbiles bleken te overheersen en de middelen woeiden vooral naar de traditionele probleemsectoren (staal

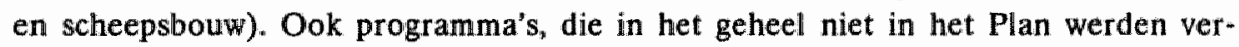
meld, zoals het roemruchte Concorde-project, slokten grote sommen geld op.

Ook de contracten, die met de particuliere, maar vooral met de publieke ondernemingen zouden moeten worden afgesloten om de ondernemingsstrategie af te stemmen op de plandoeleinden, komen op een enkele uitzondering na niet tot stand (vergelijk 6.2.1).

Het Zesde Plan bleek niet het kader voor een coherent generiek en specifiek industriebeleid te bieden: de selectiviteit is niet consistent en gedetailleerd genoeg, terwijl de werkelijke prioriteiten buiten het plan om werden vastgesteld (vergelijk hoofdstuk 6) [10].

Aan de voorwaarden voor het ontwikkelen van een coherent plan met betrekking tot de ontwikkeling van de industriële structuur in het kader van een National indicatief plan, is in het Zesde Plan niet voldaan. Met name ontbrak het aan een consistente prioriteitstelling met meerjarenplannen, financiële garanties en een actieprogramma 
op meso- en microniveau (Bonnaud 1975, 107). In hoofdstuk 3 is gebleken, dat een volontaristisch industriebeleid alleen kans van slagen heefi als binnen het overheidsapparaat een sterk ministerie, of planbureau de coördinatie voor zijn rekening neemt en zich gesteund weet door het politieke apparaat, dat de wil heeft de ontwikkeling van de industriële structuur te plannen 'd 'I'Etat développeur'. Van zo'n situatie was ten tijde van het Zesde Plan geen sprake.

In een klimaat, waarin de politiek zich geen duidelijk voorstander toonde van een coherent industrieplan als onderdeel van het Nationale Plan, kon het Ministerie van Financien haar centrale positie handhaven, waardoor het korte termijn conjunctuurbeleid domineerde ten opzichte van de lange termijn plandoelstellingen. Ook wat de financiële steun aan de industrie betrof, bleef het Ministerie van Financiën met de FDES een centrale rol spelen, maar van een combinatie gericht op lange termijn doelstellingen was geen sprake. Die coördinatie van het industriebeleid was echter wel dringend gewenst gelet op het aantal ministeries en instellingen, dat in de jaren zestig met het industriële sector van doen had. De commissaris van het CGP zou coördinerend kunnen optreden, omdat hij voorzitter was.van belangrijke commissies van de FDES van de 'Crédit National' en van de 'Banque de France', maar zoals uiteengezet was echter de positie van het CGP en haar commissaris vanaf het Vijfde Plan verzwakt, zodat in feite het Ministerie van Financiën met de middelen van de FDES "inhoud" gaf aan het industriebeleid.

Het ontbreken van expliciete doelstellingen en een sterke coördinerende instantie voor het industriebeleid, opende de weg voor informele lobbies. De ondernemers en met name het management van de grote industriële groepen wisten de weg buiten het officiële planningsproces om naar de topambtenaren van met name het Ministerie van Financiën uitstekend te vinden (vergelijk hoofdstuk 6 en 7).

Het beeld ontstaat van een Plan, waarin vanaf de jaren zestig de macrodoelstellingen in toenemende mate door de sociale partners werden beschouwd als doelstellingen van thet regeringsprogramma, waartegenover in de diverse overlegcommissies geen alternatieven konden worden gesteld, die op reële wijze konden worden bediscussieerd. Het 'Plan Nation' werd daardoor een 'Plan de Govemement' [11].

\subsection{Het Zevende (1976-1981) en Achtste Plan (1981-1985)}

De 'déplanification' krijgt zijn beslag; lange tijd was het zelfs de vraag, of er wel een Zevende Plan zou komen. De planvoorbereiding werd zodanig geminimaliseerd, dat de belangengroepen in feite buiten spel werden gezet en de 'technocraten' volop gelegenheid kregen de economische ontwikkeling buiten het plan om te sturen. In tegenstelling tot een eerder CGP-advies de voorbereidende fase van de optiekeuze uit te breiden, is die fase voor het Zevende Plan zowell qua tijdbeslag als scala van onderwerpen juist ingeperkt. Gedurende twee maanden werd in vier commissies gelegenheid geboden over de opties van gedachten te wrisselen. Ook voor de tweede fase waren de participatiemogelijkheden beperkter dan ooit (Coenen-Huther 1979).

Dat het plan tot een regeringsplan en een regeringsaangelegenheid was geworden bleek ook uit de instelling van de "Conseil Central de Planification'. In 1974 werd die Raad door president Giscard d'Estaing ingesteld; naast de president (voorzitter), 
maakten de ministers van Arbeid en Financiēn, alsmede de commissaris van het CGP deel uit van de Raad. In principe kwam de Raad maandelijks bijeen met het doel het korte termijn beleid af te stemmen op de lange termijn doelstellingen van het plan (Gamby-Balladur 1981, 26). Het Plan werd daardoor teruggebracht tot onderwerp van gesprek in de zeer kleine kring van een deel van het kabinet, de president en de commissaris van het CGP.

Wat de inhoud van het Zevende Plan betreft, hebben de zogeheten 'Programmes d'Action Prioritaires" (PAP's) de aandacht getrokken. Zij kunnen worden beschourwd als opvolgers van de zogenaamde 'programmes finalisés' van het Zesde Plan: met betrekking tot een beperkt aantal prioriteitenprogramma"s werden de doeleinden voor het etnde van de planperiode aangegeven. Het betrof vijfentwintig prioriteitenprogramma"s, waarvoor de overheid financiële middelen reserveerde gedurende de gehele planperiode (12\% van het budget). De vijfentwintig prioriteiten betroffen algemene thema"s als "versterking van de spankracht van de economie, evenwicht op de betalingsbalans, volledige werkgelegenheid, verminderen van ongelijkheden, verbetering van de kwaliteit van het bestaan en het bevorderen van onderzoek". Daarbinnen werden concrete programma's geformuleerd variërend van het verbeteren van het telefoonnet, het aanleggen van een rivierverbinding tussen de Noordzee en de Middellandse Zee tot het versterken van de positie van de consument in het economische verkeer (Coenen-Huther 1979, bijlage 7).

Naast de PAP's kende het Zevende Plan een macro-economisch deel, waarvoor in de voorbereidende fase twee scenario's waren ontwikkeld. Zowel met betrekking tot de ontwikkeling van de wereldhandel, de export, de productiviteit en dergelijke, als met betrekking tot het regeringsbeleid, werden uiteenlopende veronderstellingen gehanteerd (Postma 1977, 411). Op basis van de scenario's werd het Zevende Plan opgesteld. Gekozen werd voor een groeipercentage van $5.7 \%$ per jaar. Gedurende het eerste deel van de planperiode moesten de consumptieve vraag en de investeringen van de publieke ondernemingen de motor van de economische groei zijn; tijdens het tweede deel van de planperiode zouden de particuliere investeringen de fakkel moeten overnemen. Hayward (1982) zet uiteen, dat de economische ontwikkelingen in de tweede helft van de jaren zeventig de macro-economische doeleinden van het plan doorkruisten en dat premier Raymond Barre met het "Rapport sur l'Adaptation du VIreme Plan" (1978) de doeleinden van het Zevende Plan geheel ter zijde schoof. Het industriebeleid van het Zevende Plan vertoonde dezelfde tekortkomingen als het yoorgaande plan. Op basis van de werkzaamheden van de sectorcommissies van de Industriecommissie (Groups Sectoriels d'Analyse de Prévision) werden een aantal prioriteiten aangewezen en werd tevens ook zeer voorzichtig aangegeven welke sectoren voor de toekomst van Frankrijk niet meer zo'n prominente rol zouden kunnen spelen. De prioriteiten betroffen sectoren, waarin de overheid van onds intervenieerde, zoals de staall- en de computerindustrie en sectoren, waarin de overheidsvraag een grote trekkracht kon uitoefenen (telecommunicatie), alsmede sectoren die van strategisch belang werden geacht, zoals de machinebouw.

"However, as in the VIth Plan, there is no clear indication of why these sectors were singled out for special attention, nor does even the degree of detail provide something that could be implemented as it stands" (Estrin en Holmes 1983a, 188). 
Dat wil niet zeggen, dat de regering geen initiatieven ontplooide. In het reeds genoemde rapport over de aanpassing van het Zevende Plan schetste Barre het beleid van het Zevende Plan: in de toekomst zouden niet meer gehele industrielle sectoren worden gesteund, maar slechts individuele ondernemingen, die daarop vanuit een oogpunt van nationaal belang aanspraak konden maken. Dat belang kon zijn gelegen in de mogelijkheden van innowatie, in de regionale betekenis, of in de bijdrage aan de export. Met deze ondernemingen zou de regering contracten afsluiten ('Contrats de Croissance' en 'Contrats de Progrès'), teneinde de wederzijdse rechten en plichten duidelijk te regelen. Het proces van herstructurering van grote delen van de industrie diende niet met allerlei conserverende overheidssubsidies te worden geremd. In 1979 werd een poging ondernomen dat industriebeleid met betrekking tot de strategische ondernemingen in een coherent kader te plaatsen door de oprichting van de CODIS (Comité Développement des Industries Stratégiques). Zoals wij in hoofdstuk 6 zullen zien, werd dit industriebeleid in kleine kring van ministers, topambtenaren en managers vorm gegeven. De tri-partite sectorcommissies hadden in het Zevende. Plan geen rol van betekenis en voor zover zij funktioneerden was van participatie van de zijde van de vakbeweging geen sprake. Het socialistische blad 'Faire' (april 1976, 53) schrijft in dat verband:

'"(...) l'avis de la commission n'aura qu'un rôle très mineur voir nul. D"une autre manière concrète, il faut d'ailleurs comprendre combien ces commissions sont sous-informées, combien les indications statistiques qui leur sont données sont savamment sélectionnées et combien, en définitive, leurs travaux sont toujours en retard par rapport à ceux des experts de l'administration qui font véritablement le plan"'.

Het CGP kreeg vooral een taak ten aanzien van het coördineren van onderzoek met betrekking tot internationale ontwikkelingen, waardoor voor de marktpartijen adequate informatie beschikbaar zou komen. Sedert 1978 werd zij daarbij terzijde gestaan door het CEPII (Centre d'Etudes Prospectives et d'Information Internationales).

Het Achtste Plan werd onder president Giscard d'Estaing voorbereid, maar kon niet worden uitgevoerd, omdat in mei 1981 Mitterrand de verkiezingen won en het Achtste Plan terzijde werd geschoven. Wat voor planning stond het duo Giscard-Barre voor ogen?

In het "Rapport sur les Options du VIIJ Plan" $(1979,20)$ werd expliciet gesteld, dat veranderende omstandigheden een ander type planning vereisten:

"A nouveaux problèmes, nouveaux instruments: la planification d'aujourd'hui dans un monde tres different de ce qu'il était il y a 15 ou 30 ans, doit franchir une nouvelle étape. Au-delà des fonction permanentes d'information, de dialogue et de coherence, la planification doit s'adapter a un monde plus incertain, en se faisant plus stratégique et plus sélective".

De verandering kreeg wat de macroprojecties betreft vorm door het vervangen van projecties door scenario's. De voorgaande plannen waren

"(...) traditionellement axées sur l'élaboration d'une projection centralle normative, entérinée par le gouvernement et par le parlement, qui s'engageaient, par la même à mettre en ceuvre pour autant que cela dépendit d'eux, les moyens nécessaires à la réalisation des objectifs" (Gauron en Maurice 1980, 894-895). 
Door de toegenomen onzekerheden werd daar in het Achtste Plan vanaf gezien. Het 'Plan prévisionnel' maakte plaats voor een 'Plan stratégique'. Gekozen werd voor het schetsen van diverse scenario's, waarbij duidelijk de verschillende veronderstellingen met betrekking tot de exogene variabelen werden geexpliciteerd. In dit verband is het op zijn plaats aandacht te besteden aan de zogenaamde 'Projections Détaillées Glissantes' (PDG).

De tendens in de ontwikkeling van de inhoud van het plan van een integraal coherent beeld met doeleinden op sector- en brancheniveaw, via branche-projecties en macrodoeleinden naar uiteindelijk een schets van kwalitatieve scenario"s, gaat gepaard met een streven naar pluriformiteit in de toekomstbeelden. Barre is van mening, dat de regering niet het alleenrecht heeft op het doorrekenen van varianten met een macromodel. De PDG-benadering, toegepast sinds 1979, houdt in dat sociale partners en marktpartijen gebruik kunnen maken van centrale informatiefaciliteiten. Het macromodel geeft de projecties van gewenste variabelen op basis van de invulling van de exogene variabelen door de desbetreffende gebruiker, bijvoorbeeld de vakbeweging of een grote onderneming. Vervolgens wordt met verfijndere modellen nagegaan welke de implicaties zijn voor de branche of produktgroep, waarin de betrokkene is geinteresseerd. De 'déchiffrage' van het Plan wordt dus aangevuld met de PDG's: een planinhoud, die goed lijkt te passen bij een open en complexe economie, waarin de actoren in een onzekere omgeving opereren.

Hoe staat de regering Barre formeel tegenover de participatie van belangengroepen in het planningsproces?

"(...) la communication ne peut plus être à sens unique. Pour être bien appliqué, un projet doit avoir été élaboré et concu avec ceux-là mèmes qui auront à le mettre en oeuvre. C'est dire que les procédures de concertation qui, depuis ses débuts, ont fait l'originalité de la planification francaise sont aujourd'hui d'une importance particulière" (Rapport sur les Options 1979, 22).

Bij nadere beschouwing blijkt, dat in de visie van Giscard en Barre de 'l'orginalité de la planification française* geen terugkeer betekende naar een intensieve consultatie in verticale en horizontale moderniseringscommissies, maar dat de CES de instantie is waar de beleidsvoornemens van de regering besproken kunnen worden, waardoor

"In sum the eight plan is to become even more a plan of the government than its two predecessors. The decline in the scope and ambition of French planning seems destined to continue" (Cave en Hare 1981, 83).

Wat het industriebeleid betreft werden in het "Rapport sur les Options' de instelling van 'groupes de travail' aangekondigd: werkgroepen samengesteld uilt deskundigen en vertegenwoordigers van belangengroepen. Deze groepen hadden

"(...) pour seul object d'éclairer les entreprises en ayant en vue leur développement compétitif. Tout vision malthusienne ou corporatiste ne peut en effet que porter préjudice a l'economie du pays" (Rapport sur les Options 1979, 63).

De werkgroepen zouden specifieke deelonderwerpen bestuderen, hetgeen belangrijke informatie voor de marktpartijen zou kunnen opleveren. Verder werd met betrekking 
tot het industriebeleid de lijn van het "Rapport sur l'Adaption du VIe Plan' (1978) voortgezet.

\subsection{Het Negende Plan}

\subsubsection{Inlelding}

In de studie ' $M a i$ 1981' naar de economische, sociale en culturele situatie in Frankrijk in mei 1981 (Bloch Lainée 1981) werd een beeld geschetst van 'La Crise de la planification française. Geconstateerd werd, dat juist vanaf het begin van de jaren zeventig de economische actoren werden geconfronteerd met onverwachte ontwikkelingen in hun omgéving, waardoor de behoefte aan een 'réducteur d'incertitude' in de vorm van een indicatief plan groter was dan ooit. Daarbij is consultatie van alle betrokken partijen dringender gewenst dan ooit.

"La nécessité s"imposait de construire une information économique et sociale et une planification permettant de concevoir une stratégie explicite et d'énoncer clairement des programmes essentiels, constituant des références et des repères pour tous les membres du corps social - particuliers, entreprises publiques et privêes institutions -. Cette construction qui inciterait a l'initiative et orienterait les acteurs en face d'un avenir aléatoire est à peine amorcée. Sa réalisation demande du temps. Un grand retard est à combler" (Bloch Lainée, 1981).

Het denken in 'Links Frankrijk' over een indicatieve planning aangepast aan de eisen van een open, moderne markteconomie had reeds vorm gekregen in de loop van de jaren zestig ('Colloques de Grenobles', Nizard 1973). 'Autogestion, nationalisation et planification' waren de kernthema's, die ook terugkeerden in de ' 110 propositions', waarmee Mitterrand in 1981 de verkiezingsstrijd inging. Decentralisatie van de besluitvorming werd in het traditioneel centralistisch bestuurde Frankrijk van grote betekenis geacht. Grotere betrokkenheid van de burgers eist grotere verantwoordelijkheid op decentraal niveau. Democratisering van de paternalistisch bestuurde ondernemingen moest via nieuwe wetten gestalte krijgen, waarbij de genationaliseerde sector een voorbeeld diende te stellen (vergelijk 6.3). De voornaamste functie van de genationaliseerde ondernemingen ligt op industrieel terrein, namelijk het fungeren als spill van de modernisering van het produktiexapparaat.

In het 'Linkse denken' werden de decentralisatie, democratisering en nationalisatie ingepast in een nieuw kader van indicatieve planning. De verkiezingsleuzen van de socialisten werden in het 'Plan Intérimaire" (1982-1984) nog eens herhaald. De nieuwe aanpak werd vastgelegd in de 'Loi portant réforme de la planification' dd. 27-7-82, die is voorbereid door de 'Commission sur la Réforme de la Planification' onder voorzitterschap van Christian Goux. Het Negende Plan werd volgens die nieuwe wet voorbereid en uitgevoerd.

In het navolgende bespreken wij eerst de economische situatie van Frankrijk in 1981, het 'Plan Intérimair' en de Hervormingswet (5.6.1). In 5.6.2 worden de scenario's van het CGP toegelicht, die ten behoeve van de consultatie werden opgesteld. De doeleinden van het Negende Plan komen in 5.6 .3 aan bod, waarna de middelen, waaronder het industriebeleid, in 5.6 .4 worden besproken. 


\subsubsection{Positie van Frankrijk in mell 1981 en het 'Plan Interimaire'}

In het "Plan Interimaire (Strategie pour deux ans 1982-1984") werd de socialistische visie op het neo-liberale belleid van Giscard en Barre witeengezet. Aan het Plan lag geen diepgaande consultatie ten grondslag; het 'Plon Intérimaire' was meer een uitwerking van het verkiezingsprogramma van de linkse coalitie var socialisten en communisten. De liberalisatie van de prijzen, de bezuinigingen op de overheidsuitgaven, het versterken van de koers van de franc en het onderwerpen van de Franse ondernemingen aan de internationale concurrentie, hadden niet de beoogde resultaten opgeleverd. Nieuwe investeringen, die tot een efficièntere produktie en vergroting van de concurrentiekracht hadden moeten leiden waren uitgebleven. De industriele investeringen (excl. energie, transport en telecommunicatie) daalden als percentage van het BNP van $3.73 \%$ in 1973 tot $2.41 \%$ in 1982 . Wat de uitgaven voor onderzoek betreft nam Frankrijk in 1970 een positie in achter de VS en de UK, maar voor de BRD en Japan. In 1980 is Frankrijk qua onderzoekuitgaven afgezakt naar een vijfde plaats met $1.8 \%$ van het BNP ten opzichte van $2.4 \%$ voor de VS, $2.1 \%$ voor de UK en de $\mathrm{BRD}$ en $2 \%$ voor Japan. De negatieve ontwikkeling van de investeringen en de onderzoeksuitgaven wordt wel in verband gebracht met een verkleining van de winstmarges van de ondernemingen als gevolg van de relatief sterk gestegen loonkosten, rentelasten en handhaving van hoge dividenden (vergelijk tabel 5.1 en 5.2 in bijlage 5.3).

De relatief hoge en aanhoudende inflatie en het grote tekort op de betalingsbalans kunnen worden opgevat als symptomen van problemen in de economische structuur, met name in de industriële sector. Kort gezegd komt het erop neer, dat in Frankrijk de industriële structuur zich sedert de tweede helft van de jaren zestig onvoldoende heeft aangepast aan veranderende omstandigheden op de wereldmarkt. Twee relaties zijn in deze van belang (vergelijk Aglietta, Orléans en Oudiz 1981):

- de inkomenselasticiteit van de vraag naar importgoederen: de relatie tussen de groei van het bruto nationaal produkt en de import;

- de verhouding tussen die inkomenselasticiteit en de elasticiteit van de export. Die verhouding geeft het effect aan van de groei van het bruto nationale produkt op de betalingsbalans, onder de veronderstelling dat het bruto nationale produkt van het desbetreffende land even snel groeit als de wereldeconomie.

Aglietta, Orléans en Oudiz (1981) leggen een verband tussen de verhoudingen tussen de genoemde inkomenselasticiteiten en de specialisatie-indicator van Lafay (1981). De gedachte is, dat een land dat zich in specifieke sectoren heeft gespecialiseerd en zich daarin een sterke positie op de wereldmarkt heeft verschaft, een toename van de vraag op de wereldmarkt vertaald ziet in een toename van de vraag naar haar produkten (relatief hoge inkomenselasticiteit van de export). Als de binnenlandse vraag aantrekt kan de binnenlandse industrie een relatief groot deel voor haar rekening nemen (relatief lage inkomenselasticiteit van de import). De ondernemingen kunnen winsten realiseren, waarmee investeringen in proces- en produktieinnovaties kunnen worden gefinancierd. Door de innovaties stijgt de produktiviteit en wordt het produkt verbeterd: de concurrentiepositie wordt versterkt. In dat geval wordt gesproken van een 'cercle vertueux': een deugdzame cirkel. "Deugdzaam", omdat die categorie van landen 
een rellatief onafhankelijk economisch beleid kan voeren: als bijvoorbeeld in het geval van onderbezetting van de produktiecapaciteit gekozen wordt voor stimulering van de vraag, dan leidt zulks tot een vergroting van de vraag naar binnenlandse produkten, waardoor de onderbezetting inderdaad kan afnemen. Een sterke munt is voor landen met een deugdzame cirkel geen probleem, omdat de prijs van de import relatief laag is, hetgeen de inflatie drukt. De loonkostenstijging en de stijging van de prijzen van de intermediaire goederen kan daardoor beperkt blijven. Een sterke munt kan de prijs van de export weliswaar verhogen, maar door de rem op de binnenlandse prijsstijging zal dat effect beperkt blijven. Belangrijk is de positie van de ondernemingen van een land met een 'cercle vertueux' op de wereldmarkt: omdat zij over discretionaire ruimte beschikken (Van der Zwan 1982) kunnen zij voortdurend produkt- en procesinnowaties initiëren, waarmee zij zich steeds opnieuw een sterke uitvalsbasis verschaffen. Een (tijdelijk) hoge prijs als gevolg van een sterke munt belemmert dan de export niet op de langere termijn.

Landen met een 'cercle vicieux', waartoe volgens Aglietta, Orléans en Oudiz (1981) ook Frankrijk behoort, zijn slechter af. Zij worden gekenmerkt door een verouderde produktiestructuur (vergelijk tabel 5.3 in bijlage 5.3), hetgeen zich uit in een relatief hoge importelasticiteit en een relatief lage exportelasticiteit. Wordt de binnenlandse vraag gestimuleerd, dan resulteert een verslechterende betalingsbalans. Stijgt de vraag op de wereldmarkt, dan zal een 'cercle-vicieux'-lland slechts in beperkte mate kunnen meeprofiteren. De ondernemingen met een verouderde produktiecapaciteit staan op de internationale markt onder hevige druk. De prijzen laten hen geen winstmarge, waardoor de financiële middelen voor nieuwe investeringen ontbreken. Pogingen van de ondernemers de prijs op de binnenlandse markt op te schroeven, worden na verloop van tijd langs twee wegen afgestraft: enerzijds stijgen de produktiekosten door de loon-prijsspiraal, anderzijds neemt de penetratie van buitenlandse ondernemingen op de binnenlandse markt toe. Omdat de financiële middelen ontbreken blijven investeringen uit, de ontwikkeling van de arbeidsproduktiviteit rakt achter, de geringe winstmarges worden verliezen. De regering van een land met een vicieuze cirkel kan geen autonoom conjunctureell beleid voeren: vraagstimulering vertalt zich onmiddellijk in betalingsbalanstekorten. De regering-Giscard werd daarmee geconfronteerd en de regering-Mitterrand op nog duidelijker wijze.

De beperking die de betalingsbalans oplegt, ontneemt de regering van een "cerclevicietux ${ }^{*}$ land niet alleen de mogelijkheid een stimulerend korte termijnbeleid te voeren, ook de structurele groeimogelijkheden worden er in belangrijke mate door bepaald. Geen enkell land kan immers langdurig leven met een blijvende betalingsbalansonevenwichtigheid. Anders gezegd: elk land heeft een "betalingsbalansevenwichtige groei", die wordt bepaald door de genoemde import- en exportelasticiteiten (Thirlwall 1982). Hoe hoger de importelasticiteit, hoe lager de betalingsbalansevenwichtige groei.

Een sterke industriële sector is de basis voor een 'cercle vertuetw', anders gezegd: een zwakke industriêle structuur leidt via de betalingsbalans tot een 'constraint'. Vooruitlopend op hoofdstuk 6, waarin het Franse industriebeleid nader wordt geanalyseerd, kan worden gesteld dat de Franse overheid sterk intervenieerde in sectoren, waarin zij als vrager dominant was: luchtvaart, spoorwegmaterieel, nucleaire energie, telecom- 
municatie en wapens. In die sectoren ontstonden succeswolle Franse ondernemingen, die de concurrentie op de wereldmarkt aankonden. Daarnaast vertoont de Franse industriele structuur een aantal zwakke plekken: traditionele sectoren als de machinebouw, textiel, leer en hout; kapitaalintensieve industrieên als de chemie en de ijzer en staal, maar ook sectoren, die hoge uitgaven voor Onderzoek en Ontwikkeling vergen, zoals de electronica, zijn in Frankrijk sterk onderontwikkeld gebleven. Het beleid, waarbij een beperkt aantal speerpuntsectoren onder overheidsbescherming tot sterke ontwikkeling kwam, staat bekend als de zogenaamde 'créneaux'-benadering. Nadeel van deze benadering is het geissoleerde karakter van de industriële successen. Tussen de speerpunten en de andere delen van de industriële structuur ontstond geen hecht netwerk van industriële activiteiten, waardoor met name geen concurrerend Midden en Kleinbedrijf ontstond. Anders gezegd: de specialisatie in de Franse industrie heeft niet plaatsgevonden rond clusters van complementaire activiteiten (zogenaamde 'pôles de compétivité"), maar de specialisatie heeft gestalte gekregen binnen enkele geisoleerde branches (vergelijk hoofdstuk 3 ).

Soulage $(1983,5)$ constateert dan ook:

"L'image du commerce extérieur de la France renvoie en fait à la politique industrielle suivi depuis plus de 10 ans".

Het 'Plan Intérimaire' stond in plaats van de 'créneaux'-benadering een fundamenteel andere aanpak voor: enerzijds dienden de afzetperspectieven van de Franse ondernemingen rooskleuriger te worden, waartoe de regering een stimulerend conjunctuurbeleid voorstelde ('relance"), anderzijds diende tegelijkertijd de industriele structuur versterkt te worden, opdat de Franse ondernemingen de internationale concurrentie zouden aan kunnen en de vruchten van de vraagvergroting zouden kunnen plukken. De noodzaak tot modernisering van de Franse industrie en het opvoeren van de uitgaven voor het onderzoek werden in het "Plan Intérimaire" sterk benadrukt. Het selectief nationaliseren van sleutelindustrieën zou volgens het plan de regering de mogelijkheid bieden de investeringen en de uitgaven voor onderzoek daadwerkelijk op te voeren in een richting, die strookt met de doeleinden, neergelegd in het nationele indicatieve plan. Het 'Plan Intérimaire' wijst een industriebeleild in termen van 'crêneaux de specialisation' van de hand en kiest voor een 'filière'-belleid gericht op de versterking wan de gehele industriële structuur (Bauchet 1986, 90).

De 'relance" werd direct na de verkiezingsoverwinning geconcretiseerd. Het minimumloon (SMIC) en de sociale uitkeringen werden fors verhoogd. De lasten voor het bedrijfsleven stegen sterk als gevolg van het instellen van de vijfde vakantieweek, een verkorting van de werkweek naar 39 uur en een stijging van belastingen. Stijgende lasten werden met stijgende prijzen gecompenseerd, waardoor de concurrentiepositie verslechterde. De 'relance' leidde tot een begrotingstekort in 1982 van $95 \mathrm{mdF}$, hetgeen een stijging ten opzichte van 1981 van $35 \%$ betekende. Het tekort werd met buitenlandse leningen gefinancierd, waardoor de schulden opliepen en een speculatiegolf ontstond tegen de franc. De speculatie ten aanzien van een verdere devaluatie van de franc werd aangewakkerd door het steeds groter wordende tekort op de betalingsbalans. De stimulering van de vraag leidde tot een toename van de importen in plaats van een vergroting van de binnenlandse produktie. De problemen ontstonden mede, 
omdat Frankrijk als enige in 1981-1982 overging tot een vragsstimulering, terwijl de andere landen een restrictief beleid yoerden. Daarenboven was sprake van de fundamentele misvatting, dat een conjuncturele vraagstimulering vertaald kon worden in een binnenlandse produktiestijging, als maar tegelijkertijd de industriële structuur zou worden versterkt. Industriêle structuuraanpassingen betreffen echter altijd een langere termijn dan conjuncturele impulsen, zodat een volgtijdig onderscheid in het beleid had moeten worden aangebracht: eerst versterking van de industriële structuur, daarna eventueel een met andere landen gecoördineerd stimuleringsbeleid. Toen de "relance" vrijwel direkt inflatie en betalingsbalansproblemen opriep, ontstond een speculatie tegen de franc. Wisselkoersen zijn nu eenmaal niet alleen het resultaat van vraag en aanbod van valuta op grond van economische transacties, maar ook het resultaat van verwachtingen omtrent het toekomstige koersverloop. Door de vraagstimulering, het betalingsbalanstekort, het begrotingstekort en de aangekondigde nationalisatie was een speculatiegolf ontstaan, die de reserves aan buitenlandse valuta fors aantastten. De rente moest hoog worden gehouden om voldoende kapitaal aan te trekken. Op 4 oktober 1981 devalueerde de franc met $8.5 \%$ ten opzichte van de D-mark, gepaard gaande met een eerste bijstelling van het beleid. Een deel van de begroting van 1982 , namelijk $15 \mathrm{MdF}$, werd op 7 oktober 1981 bevroren en op 10 november volgde een verhoging van de premie van de ziektekostenverzekering van $1 \%$. Op 13 juni 1982 volgde de tweede devaluatie van $10 \%$ ten opzichte van de $\mathrm{D}$-mark en het beleid werd toen duidelijk een slag steviger in de richting van de 'rigueur' gedraaid. Met name de eerste minister Pierre Mauroy was een sterk voorstander van een loon- en prijsstop van vier maanden, die tot een beperking van de import en bestrijding van de inflatie moest leiden. Tegelijkertijd stelde Mitterrand de grens van het begrotingstekort op $3 \%$ van het BNP. Eind 1982 waren nieuwe maatregelen dringend noodzakelijk, maar de op handen zijnde gemeenteraadswerkiezingen zorgden ervoor dat verder restriktief beleid pas in maart 1983 wan kracht werd. Tot die tijd werd een strijd gestreden tussen enerzijds de gematigden (Delors, Rocard en Mauroy), die voor handhaving van Frankrijk in de EMS waren en inzagen dat daartoe een aanpassing van het belleid in de richting van de BRD onvermijdelijk was (vergelijk Holman en Poot 1983) en anderzijds Chevenement, de minister van Onderzoek en Industrie. Laatstgenoemde was voorstander van protectie en herstructurering van de Franse industrie achter gesloten grenzen met zonodig uittreding uit de EG. Mitterrand hakte in maart 1983 definitief de knoop door en koos voor de weg van bezuiniging, inflatiebestrijding, terugdringen van het handelstekort en integratie van het Franse beleid in het kader van de EMS. De overtuiging won veld, dat verdere devaluaties de concurrentiepositie niet konden verbeteren. Integendeel: devaluatie leidt tot een stijging van de importprijzen, waardoor de loon- en prijsspiraal in beweging wordt gezet. Tevens was inmiddels duidelijk geworden, dat van een structureel probleem sprake was met betrekking tot de concurrentiekracht van de Franse industrie. Begrepen werd, dat Frankrijk niet in staat was een eigenzinnig stimuleringsbeleid te voeren in een open relatie met de wereldmarkt, zoals voorgesteld in het 'Plan Intérimair". De 'relance' van het 'Plan Intérimair' was op een fiasco uitgelopen, waardoor het Plan "(...) fut très rapidement obsolete et oublié" (F.O. 1984). De opvatting had postgevat, dat het conjunctuurbeleid moest worden afgestemd op het beleid van de sterkste partner in de EMS, i.c. de BRD; van een meer 
autonome aanpak kon pas sprake zijn, nadat het structuurbeleid vruchten heeft afgeworpen. Deze visie is terug te vinden in het Negende Plan.

\subsubsection{Instituties en scenario's van het Negende Plan}

\section{'Loi portant réforme de la Planification' (Hervormingswet).}

De ideeën met betrekking tot de hervorming van de indicatieve planning werden geconcretiseerd in de 'Loi portant réforme de la Planification'. De wet werd voorbereid door de 'Commission de Réforme de la Planification', waarvan de voorzitter en de secretaris respectievelijk Christian Goux en Xavier Greffe in Le Monde van 17 maart 1982 schreven, dat de nationale indicatieve planning "(..) sera nationale, démocratique et contractuelle". Bedoeld werd, dat alle bellanghebbenden bij het planningsproces betrokken dienen te worden, dat de burgers in de regio's en de werknemers in de ondernemingen actief in het planningsproces moesten kunnen participeren en dat in een moderne democratische markteconomie een plan alleen kon worden uitgevoerd op basis van contracten met de economische partners. Verder wezen Goux en Greffe erop, dat de planning 'continue' moest zijn, waardoor voortdurend aanpassing aan veranderende omstandigheden mogelijk zou zijn.

Zoals in hoofdstuk 2 is uiteengezet, dienen in een open, complexe economie in de aanvang van het planningsproces algemene doeleinden geformuleerd te worden: herstel van de betalingsbalans, stimulering van de groei, modernisering van het produktieapparaat, en dergelijke. De in algemene termen geformuleerde doeleinden dienen in de loop van de het planningsproces nader geconcretiseerd, of bijgesteld te worden. Daartoe dient het planningsproces een continu karakter te hebben. Voorstellen betreffende die continue planning van de Commissie-Goux werden in de 'Loi portant réforme de la planification' geconcretiseerd.

Het planningsproces zelf werd nu ook bij wet geregeld: in de Eerste Wet op het Plan worden de doeleinden vastgelegd, in de Tweede Wet de middelen. Beide wetten dienen aan het parlement ter goedkeuring te worden voorgelegd. De realisatie van de in de loop van het planningsproces geconcretiseerde doelstellingen dient onder andere gestalte te krijgen in de planningsovereenkomsten (contrats de plan) met de voornaamste economische actoren te weten de regio's en de genationaliseerde ondernemingen.

In het kader van het Negende Plan is overgegaan tot een decentralisatie van de besluitvorming: de regionalisering. Frankrijk werd daartoe ingedeeld in regio"s, die binnen het kader van het nationale Plan over een beperkt aantal aangelegenheden zelfstandig kunnen beslissen. Daartoe werd een regionale Raad gekozen en kreeg elke regio de beschikking over een eigen budget. Ten einde thet regionale beleid af te stemmen op de nationale plandoeleinden werd met de regio's overlegd en onderhandeld over een planningsovereenkomst. Vermeldenswaard is in dit verband de ondertiteling van het Negende Plan: in tegenstelling tot voorgaande plannen is het Negende Plan niet meer alleen een 'Plan de développement économique et social', maar ook een "Plan culturel'. Daarmee werd aangegeven, dat de regionalisering tot doel had bij het formuleren van de plandoeleinden expliciet rekening te houden met de culturele verschillen tussen de diverse regio's (Regard sur l'Actualité 1984) [12]. 
De punningsowereenkomsten werden ook met een andere belangrike economische actor afgesloten: de genationaliseerde ondernemingen; op basis wan het "contrat de plaw' zou de strategie van de onderneming afgestemd moeten worden op de plandoeleinden.

Na de verkiezingsoverwinning in me 1981 werd Michel Rocard benoend tot Minister van het "Ministere du Plan et de "Amenagement du Territoire". De brede consultatie ter vorbereiding van het plan werd worm gegeven door de instelling wan een 'Commission Nationale de Plamification" (CNP), waarin naast de Minister van Planning en Ruimtelike Ordening (voorzitter) en de 'Commissai au Plan' ongeveer tachtig personen zitting hadden. De commissie samengesteld utt vertegenwoordigers van de regio's, vakbonden, werkgevers, middenstand, genationaliseerde ondernemingen, gezissorganisaties en uit personen a titre personel. De doelstelling van de Nationale Commissie iuidde:

"Comme Indique la loi portant réforme de la planification, la Commission de caractère conswltatif est chargée de conduire les consultations nécessaires a l'élaboration de chaque plan et a participer au suivi de son execution" (Commissariat Genéral du Plan 1983b, Lettre du 9jeme Plan no. 1, 3).

De CNP ving haar werk an na van de regering een 'Document d'Orientation' te hebben ontvangen, waarin richthinen waren opgenomen, die waren vastgesteld na consultatie van de regio's en bestudering van de scenario's van het CGP. In het navolgende wordt eerst de inhoud van de scenario"s besproken en vervolgens de procedure van de tot stanckoming van de Eerste Wet op het Plan, warin de doeleinden werden vastgelegd.

\section{Scenario's van CGP}

In november 1982 presenteerde het CGP 'Quelques scenarios d'éwolution d mopen terme $e^{*}$ ten behoeve van de consultatieprocedure voor het opstellen van de doeleinden van het Negende Plan. Het CGP had voor de periode tot en met 1988 diverse scenarios opgesteld en door het INSEE laten simuleren op basis van het DMS-model (CGP 1982c) [13].

Scenario's zijn geen voorspellingen, maar tonen mogelijke ontwikkelingen bij een specifieke veronderstelde constellatie van interne en externe factoren. Zij laten zien welke problemen zich mogelijkerwijs kunnen voordoen en hoe effectief specifieke combinaties van instrumenten zouden kunnen zijn. Wat de internationale factoren betreft werden hypothesen opgesteld met betrekking tot de ontwikkeling van de olieprijs, de economische groei van de zes belangrijkste handelspartners (met name de economische groei in de VS nam een belangrijke plaats in), de ontwikkeling van de inflatie bij de belangrijkste handelspartners en de ontwikkeling van de importen van de OECD landen, de olieproducerende landen, de ontwikkelingslanden en van de Oostbloklanden. De resultaten voor de jaren 1983-1984 ('Plan Intérimair') en de jaren 1984-1988 (Negende Plan) zijn samengevat in tabel 5.7. 
Tabel 5.7 Scenario's van het Negende plan

COMPARAISON DES DIFFERENTS SCENARIOS INTERNATIONAUX $Z_{*} Y_{1} X$

\begin{tabular}{|c|c|c|c|c|c|c|}
\hline \multirow{2}{*}{$\begin{array}{l}\text { TAUX D'EVOLUTION ANNUEL } \\
\text { MOYEN EN \% }\end{array}$} & \multicolumn{3}{|c|}{ ANNEE $1982 \cdot 1983$} & \multicolumn{3}{|c|}{ IXe PLAN (1984-1988) } \\
\hline & $z$ & $\mathrm{Y}$ & $\mathrm{x}$ & $\mathbf{z}$ & $\mathrm{Y}^{\prime}$ & $x$ \\
\hline Prix réel du pétrole & -4.5 & -7.1 & -4.5 & +4.0 & 0.3 & +4.0 \\
\hline $\begin{array}{l}\text { Evolution du PIB des } 6 \text { principaux } \\
\text { partenaires de la France } \\
\text { dont: }\end{array}$ & +1.8 & +0.6 & +1.4 & +2.7 & +1.5 & +28 \\
\hline Evolution du PIB des Etats Unis & +0.6 & -1.0 & +0.9 & +3.1 & +2.1 & +3.9 \\
\hline $\begin{array}{l}\text { Evolution des prix des } 6 \text { principaux } \\
\text { partenaires de la France } \\
\text { dont: }\end{array}$ & +7.8 & +6.5 & +6.9 & +7.1 & +5.3 & +4.5 \\
\hline Evolution des prix aux Etats-Unis & +7.0 & +5.2 & $* 6.2$ & +6.9 & +5.1 & +4.3 \\
\hline $\begin{array}{l}\text { Evolution de la demande d'importa } \\
\text { des pays hors OCDE } \\
\text { dont: }\end{array}$ & +2.7 & +1.41 & +2.7 & *. 5.8 & $+3.1^{1}$ & +6.4 \\
\hline Demande de POPEP & +5.0 & +3.0 & +5.0 & +7.8 & +3.4 & +8.3 \\
\hline $\begin{array}{l}\text { Demande des pays en voie de } \\
\text { développement }\end{array}$ & +2.2 & +0.7 & +2.2 & +5.6 & +3.2 & +6.4 \\
\hline Demande des pays de l'Est & +0.8 & +0.5 & +0.8 & +2.3 & +2.0 & +2.3 \\
\hline
\end{tabular}

1 La demande adressée à la France est supposée croitre d'un point de moins, soit respectivement 0.4 $\%$ pour la période $1982-1983$ et $2.1 \%$ pour la période du IXème Plan.

Bron: CGP (1982c, 9)

Drie scenario's werden onderscheiden:

- scenario $\mathrm{Z}$, dat een langzaam herstel veronderstelde van de wereldeconomie op het niveau van $1975-1980$;

- scenario $Y$, dat een voorzetting van de recessie van 1979 veronderstelde met een deflatoire en protectionistische tendens;

- scenario X, dat een verdere toename van de economische groei in de VS en Japan Met betrekking tot de economische en sociale ontwikkeling in het binnenland werden hypothesen opgesteld, die leidden tot zeven combinaties, waarin het scenario "E" centraal stond. Daarin werd uitgegaan van een voortgaande stijging van de overheidsuitgaven (de investeringen van de 'administrations' stijgen met $2.3 \%$ per jaar gemiddeld en hun consumptie met 3\%; het aantal werknemers neemt met $1.1 \%$ toe). De investeringen van de publieke ondernemingen stijgen fors met $10 \%$ per jaar in volume ('rôle moteur') en om de sociale kassen in evenwicht te brengen neemt in scenario ' $E$ ' de belasting op de toegevoegde waarde toe. De wrerkweek zal eind 1985 nog 35 uur bedragen. De koopkracht van het gemiddelde salaris per hoofd stijgt met $0.5 \%$ per jaar, waarbij rekening wordt gehouden met een stijging van het salaris bij 
de laagste inkomensgroepen. De inkomens van de ondernemers maken eenzelfde bescheiden ontwikkeling door.

De andere scenario's wijken op een of meerdere punten van het centrale scenario ' $E$ ' af. Zo gaat scenario 'A' vit van een grotere stijging van de koopkracht (1.5\% in plaats wan $0.5 \%$ ), en wordt in scenario ' $B$ ' van een grotere beperking op de overheidsuitgaven en een bescheidener groei van de koopkracht van de sociale uitkeringen (2.5\%) uitgegaan, terwijl het evenwicht wan de socialle fondsen hersteld moet worden door middel van belastingverhoging op alcohol, tabak en benzine. Scenario ' $F$ ' kent een verhoogde investeringsinspanning van de publieke ondernemingen $(+4.5 \%)$ met het doel het produktieapparaat sneller te moderniseren. In scenario ' $G$ ' subsidieert de overheid de arbeidstijdverkorting, welke verondersteld wordt minder snel te verlopen dan in scenario ' $E$ '. Verder zijn de scenario's ' $C$ ' en 'D' identiek aan $F$ en $G$ met dien verstande, dat de koopkracht sneller stijgt. Door de scenario's ' $A$ ' tot en met ' $G$ ' te combineren met die Wan ' $\mathrm{X}$ ', ' $\mathrm{Y}$ ' en ' $\mathrm{Z}$ ' ontstaan 21 scenario's.

\section{Beperkingen van de scenariomethode}

De beperkingen van de scenariomethode vloeien enerzijds voort uit de onzekerheid met betrekking tot de externe en interne factoren en anderzijds uit beperkingen inherent aan het hanteren van econometrische modellen als het DSM-model. Eén van de centrale problemen betreft het feit, dat het model is gebaseerd op gedragsvergelijkingen, die wellicht relevant waren in de economische orde in de periode 19591980, maar waarin geen rekening wordt gehouden met de in 1981 doorgevoerde veranderingen:

"(...) il ne prend donc pas en compte les modifications de comportements et de structures qui doivent résulter des réformes récentes: nationalisations, décentralisation, droits nouveaux des travailleurs dans l'entreprise, planification contractuelle, etc...." (CGP 1982c, 3).

Er wordt door het CGP op gewezen, dat het model beter de effecten registreert van conjuncturbeleid gericht op de vraagzijde, dan van structuurbeleid gericht op de aanbodzijde van de economie. De positieve effecten van beleid gericht op de modernisering van het produktieapparaat, of van het verhogen van de uitgaven voor Onderzoek en Ontwikkeling komen op basis van het model niet goed tot uiting.

"Par ailleurs les modèles traitent mieux les effets de la politique économique sur la demande globale que sur l'offre: c'est ainsi qu'ils ne retracent ni les effets favorables recherche-développement, ni l'atténuation des propentions à importer qui devrait résulter d"une meilleure intégration du tissu industriel et de la constitution de filières cohérentes" (CGP 1982c,3).

\section{Belangrijkste resultaten van de scenariomethode}

In tabel 5.8 zijn de belangrijkste resultaten samengevat. Naast de centrale scenario's EZ, EY en EX zijn nog enkele politiek interessante varianten van het meest waarschijnlijk geachte Z-scenario weergegeven. 
Tabel 5.8 Vergelijking van verschillende senario's gedurende de planperiode

EZ : EY: EX:"AZ: $B Z$ : FZ: GZ:

PIB étranger

(en \%)

$\begin{array}{lllllll}2,7 & 1,5 & 2,8 & 2,7 & 2,7 & 2,7 & 2,7\end{array}$

Prix du PIB étranger

(en \%)

$\begin{array}{lllllll}7,1 & 5,4 & 4,5 & 7,1 & 7,1 & 7,1 & 7,1\end{array}$

PIB marchand

(en \%)

$\begin{array}{lllllll}2,5 & 2,1 & 2,4 & 2,9 & 2,5 & 2,7 & 2,8\end{array}$

Volume de la consommation des ménages (en \%)

$\begin{array}{lllllll}1,8 & 1,6 & 1,8 & 2,6 & 2,0 & 2,0 & 2,0\end{array}$

Volume de l'unvestissement des entreprises (en \%)

Prix à la consommation (en \%)

$\begin{array}{rrrrrrr}5,5 & 5,1 & 5,7 & 4,9 & 5,3 & 5,5 & 6,2 \\ 8,9 & 6,5 & 6,3 & 10,7 & 5,8 & 8,8 & 4,9 \\ 0,5 & 0,1 & 0,4 & 1,5 & 1,5 & 0,6 & 0,4\end{array}$

Pouvoir d'achat du salaire net par tête (en \%)

Pouvoir d'achat du revenu disponible des ménages (en $\%$ )

$\begin{array}{rrrrrrr}1,8 & 1,4 & 1,7 & 2,4 & 1,7 & 1,8 & 1,8 \\ +289 & +64 & +195 & +447 & +95 & +36 & +194\end{array}$

Taux de chồmage au sens du BIt en 1988 (\% de la population active)

$\begin{array}{lllllll}9,5 & 10,1 & 9,8 & 9,2 & 9,9 & 9,3 & 9,8\end{array}$

Variation du taux des prélèvement obligatoires au cours du IXème Plan $+1,9+1,7+1,6+2,2+0,4 \quad+1,8+1,2$

Capacité de financement des administrations en 1988

$\begin{array}{lllllll}-2,0 & -2,8 & -2,1 & -2,6 & -1,4 & -1,5 & -1,9\end{array}$

Bron: CGP (1982c)

\section{Groel en betalingsbalans}

De scenario's maken duidelijk, dat een macro economisch stimuleringsbeleid voor Frankrijk niet effectief is: een snellere groei dan de partners van bijw. 0,2\% per jaar vertaalt zich in een betalingsbalanstekort (AZ) en woor een terugkeer naar evenwicht is een lagere groei van 0.2 nodig (EZ en BZ) met gevolgen voor de werkgelegenheid. Scenario $\mathrm{FZ}$ zou een uitweg kunnen bieden door de hogere investeringen, waardoor op korte termijn weliswaar de betalingsbalans verslechtert als gevolg van de vergrote import van investeringsgoederen, maar op langere termijn de autonomie kan worden 
vergroot door versterking van de concurrentiekracht. Ook versterking van de grondstoffenbasis kan dergelijke positieve gevolgen hebben. Uit de scenario's wordt de kwetsbaarheid duidelijk van de Franse economie met betrekking tot internationale ontwikkelingen. Een vermindering van de groei bij de belangrijkste handelspartners van bijy. $1.2 \%$ (verschil scenario $\mathrm{Z}$ en $\mathrm{Y}$ ), leidt tot een daling van de economische groei in Frankrijk van $0.5 \%$ over de periode van het Negende Plan.

\begin{abstract}
"Pour faire face à de tels risques, il est donc indispensable d'élargï les marges d'autonomie par des actions résolues tant vis à vis de l'extérieur (en particulier par la recherche d'une stratégie commune avec nos partenaires européens et le renforcement de la coopération avec le Tiers-Monde) que dans le domaine intérieur (en poursuivant de pair le partage du trałail et les efforts destinés à obtenir un différentiel de croissance, ce qui suppose notamment une diminution significative de notre rythme d'inflation et la rénovation en profondeur de notre appareil de production"' (CGP 1982c, 5).
\end{abstract}

\title{
Arbeidsverdeling en werkgelegenheid
}

De regering zette in haar 'Document d'Orientation' uiteen, dat voor de bestrijding van de werkloosheid niet kan worden volstaan met een conjunctureel en structureel groeibeleid; door de toetreding van 725.000 personen op de arbeidsmarkt gedurende de planperiode is arbeidstijdverkorting een onmisbaar supplement. De scenario's maken een aantal randvoorwaarden voor de effectiviteit van dat instrument duidelijk:

- de produktiekosten mogen niet stijgen

- de bedrijfstijd mag niet verminderen, op straffe van inflatoire spanningen en importstimulering

- scenario GZ toont, dat langzame invoering van ATV minder effectief is, maar dat snelle invoering gepaard gaat met kostenstijging, die overigens door de overheid gedragen zol moeten worden, opdat de ondernemingen van lastenstijging gevrijwaard blijven.

Gesteld wordt, dat door middel van een decentrale invulling op contractuele basis het beste aansluiting zal worden gevonden bij de specifieke omstandigheden op microniveau en daarom de voorkeur verdient ('Contrat de solidarité').

\section{Inflatiebestrijding}

Inflatiebestrijding is een essentiele voorwaarde ter verbetering van de concurrentiekracht van de ondernemingen, ter stimulering van de werkgelegenheid en ter vermijding van voortdurende devaluaties van de franc. De scenario's maken duidelijk dat drie factoren wan belang zijn:

- matiging van alle inkomens is noodzakelijk (vergelijk AZ en EZ)

- vermindering van de overheidsuitgaven en overdrachtuitgaven (vergelijk $A Z$ en $\mathrm{BZ}$ ). Met name de financieringsmethode van de sociale uitkeringen is van groot belang; wordt gekozen voor het verhogen van de BTW en werkgeverspremies, of worden de lasten van de consumptiehuishoudens verhoogd?

- vermindering van investeringen, of verlenging van bedrijfstijd leidt tot het in gebruik stellen van oude jaargangen machines, waardoor inflatoire spanningen kunnen ontstaan. 
De meer structurele oorzaken van de inflatie, zoals het bestaan van rigiditeiten en allerlei privileges van beroepsgroepen zijn niet in de scenario's opgenomen, omdat simulatie van structurele factoren met de DSM-model niet goed mogelijk is.

\section{Modernisering van het produktieapparaat}

Scenario $\mathrm{FZ}$ toont het belang van een grote investeringsinspanning en scenario $\mathrm{GZ}$ laat de effecten zien van zo'n verhoging van de investeringen gecombineerd met arbeidstijdverkorting. Echter, de inspanning is onvoldoende om een duidelijk verschil in de groei tot stand te brengen, hetgeen erop duidt dat een nog grotere investeringsinspanning nodig is, dan in de scenario's $F Z$ en $G Z$ wordt verondersteld.

De beoogde coherentie van de industriële structuur en verwevenheid van de industriële activiteiten moet ook langs andere wegen dan het opvoeren van de investeringen gestalte krijgen. Genoemd worden een beleid gericht op het verminderen van de import van investeringsgoederen (herovering van de binnenlandse markt), het verhogen van de uitgaven voor $R$ en $D$, het verbeteren van de opleidingen en het verbeteren van de relaties in de onderneming tussen de werknemers en de managers. Zoals eerder opgemerkt tonen de scenario's niet de gevolgen voor de produktiviteit van deze meer structurele maatregelen; daartoe is onderzoek buiten het model om nodig.

\section{Overheidsuitgaven en de financiering van sociale voorzieningen}

Als het conjunctuurbeleid een vermindering van de overheidsuitgaven vereist mogen deze niet het structuurbeleid betreffen. De middelen ter versterking van de aanpassing van de industrièle structuur dienen te allen tijde te worden gevrijwaard van conjuncturele schommelingen.

Snellere groei van de koopkracht van de sociale uitkeringen dan het BNP leidt volgens de scenario's tot budgettaire problemen, evenals financiering, door middel van lastenverzwaring van de ondernemingen. Anderzijds blijkt een verzwaring van de lasten van de huishoudens een negatief effect op de vraag te hebben.

De scenario's maken duidelijk, dat de regering in 1984 over zeer weinig manoeuvreerruimte beschikt; de 'constraints externes' doen zich in alle hevigheid voelen, terwijl de noodzaak van structurele aanpassing van het industriële produktieapparaat algemeen wordt onderkend. Welk plan is binnen die smalle marges tot stand gekomen?

\subsubsection{De Eerste Wet op het Plan: de doeleinden}

In de Eerste Wet werd expliciet gekozen woor een open Frankrijk [14], dat initiatieven tot coördinatie van economisch beleid in de EG en de OECD diende te nemen en steun diende te verlenen aan de landen van de Derde Wereld. De uitgaven voor de ontwikkelingshulp dienden te worden verhoogd tot $0.7 \%$ van het BNP in 1988. In het binnenland moest de nationale solidariteit worden bevorderd door vermindering van de ongelijkheden en verbetering van de levensomstandigheden van achtergestelde bevolkingsgroepen (inkomensgelijkheid, milieu en ruimtelijke ordening, renovatie van oude steden etc.).

In het 9de Plan staat de modernisering van de industrie centraal 
(...) c'est un esprit volontariste qui anime le coeur de la stratégie du IXe Plan. Les efforts internes doivent être mobilisés pour développer nos capacité de production compétitives. C'est la clé pour desserrer durablement la contrainte extérieure et pour retrouwer progressivement un différentiel positif de croissance compatible avec le maintien de l'équilibre extérieur retrouvé" (Catinat en Maurice 1984, 1019).

Daartoe dienen de investeringen als percentage van het BNP op het niveau van 1973 te worden gebracht, de uitgaven voor onderzoek sterk toe te nemen en bovenal het onderwijs beter te worden afgestemd op de eisen van een moderne industrie. Ten behoeve van een snelle modernisering is een 'revolution culturelle" nodig, waardoor de Fransen ontvankelijker worden voor nieuwe produkten en produktietechnieken. Een ieder moet bij het veranderingsproces orden betrokken, waartoe democratisering van de beslluitvorming binnen de ondernemingen en decentralisatie van de besluitvorming naar de regio's noodzakelijk zijn [15].

De investeringsinspanning moet niet met buitenlandse leningen worden gefinancierd, maar met binnenlandse besparingen. Het structuurbeleid moet worden ondersteund met een conjunctuurbeleid gericht op een evenwichtige betalingsbalans en verlaging van de inflatie. Als doel wordt evenwicht op de betalingsbalans in begin 1985 gesteld en een inflatie, die overeenkomt met de ontwikkelingen bij de belangrijkste handelspartners. De doeleinden met betrekking tot de betalingsbalans en de inflatie worden 'objectifs de sauvegarde' genoemd.

Overigens dient het evenwicht op de betalingsbalans niet op basis van devaluaties of protectionisme te worden gerealiseerd, maar langs de weg van de 'rigueur'; een 'rigueur', die in de structurele ontwikkeling van de economie is ingebed [16]. De strategie van het Negende Plan is in schema 5.1 schematisch weergegewen.

De modernisering, de doelstellingen met betrekking tot de betalingsbalans, de inflatie en de economische groei zijn alle gericht op een verbetering van de werkgelegenheid. Gesteld wordt, dat Frankrijk qua werkgelegenheid de beste ontwikkeling van de EG moet realiseren, waaraan een arbeidstijdverkorting naar een 35-urige werkweek een belangrijke bijdrage dient te leveren.

In de Eerste Wet op het Plan werd ook vastgelegd, dat voor de gehele planperiode financiele middelen gereserveerd dienden te worden voor een aantal 'Programmes d'execution prioritaires' (PPE), opdat conjuncturele schommelingen niet van invloed zouden zijn op de realisatie van structurele plandoeleinden (zie 5.6.4).

Het wetsontwerp werd van een advies voorzien door de CES en de 'Conseil d'Etar', waarna de ministerraad op 15-03-1983 haar goedkeuring verleende. Het parlement volgde op 30-06-1983, waarna de Eerste Wet op het Plan een feit was.

\section{Consistentie van doeleinden getoetst}

Ter voorbereiding van de Tweede Wet op het Plan, werd onderzocht of de 'grands objectifs' konden worden gerealiseerd op een financieel verantwoorde wijze, rekening houdend met de macro-economische randvoorwaarden.

Door middel van een optimalisatiemethode werd met het DSM-model nagegaan onder welke voorwaarden de doeleinden van de Eerste Wet op het Plan gerealiseerd konden worden. 
Schema 5.1 De strategie van het $9^{\text {de }}$ Plan

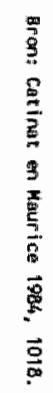

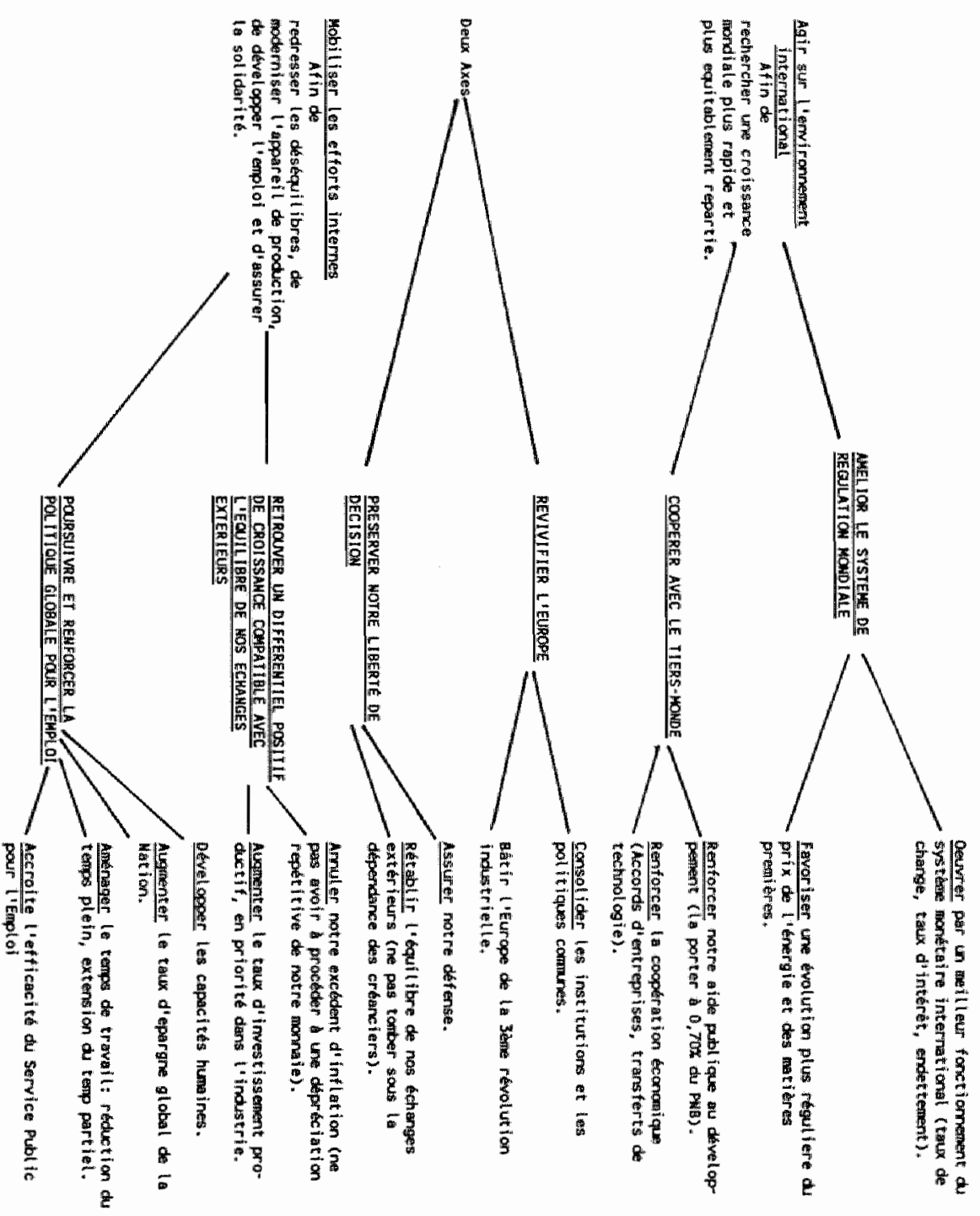


De gebruikelijke methode in de macromodellen is simulatie. De endogene variabelen

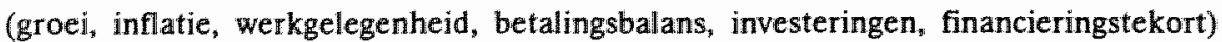
worden berekend op basis wan hypothesen met betrekking tot de internationale ontwikkeling en binnenlandse economisch-sociale politiek. Optimalisatie impliceert echter maximalisatie van een doel onder een reeks van randwoorwaarden met inzet van instrumentvariabelen. Daartoe werden de kwantitatieve doeleinden van de Eerste Wet gesplitst in een 'objectif au sense technique du terme' en in een aantal "constraints" (Catinat en Maurice schema 5.1

1984). Als doel werd de maximalisatie van de gemiddelde werkgelegenheid in de jaren 1984-1988 gekozen.

De randvoorwaarden waren:

- een evenwichtige betalingsbalans in begin 1984;

- een inflatie, die convergeert naar die van de belangrijkste handelspartners;

- een investeringsniveau, dat als percentage van BNP eind 1988 gelijk is aan het niveau van 1973 ;

- een groei van het BNP van $1 \%$ boven het OECD-gemiddelde.

Voor de exercitie werden twee scenario's opgesteld: een optimistische (Y) en een pessimistische $(Z)$, waarin een aantal endogene variabelen uit het analytische model doelstellingsvariabele werden [17].

De twee scenario's met betrekking tot de internationale ontwikkelingen waren:

- scenario Z (positief): de groei van de VS en Japan zet door en wordt vanaf 1984 ook door de andere industrielanden overgenomen. De groei in de OECD zall in 1988 gemiddeld $2.8 \%$ bedragen en de inflatie $4.3 \%$. De prijs van een vat olie bedraagt op korte termijn $\$ 29$ en loopt op tot $\$ 35.5$ in 1988 (prijzen 1983). Ook werden veronderstellingen gemaakt met betrekking tot groei in de olieproducerende- en ontwikkelingslanden;

- scenario $Y$ schetste een pessimistischer beeld van de internationale ontwikkelingen. Uit de optimalisatiemethode bleek, dat de doeleinden zeer ambitieus waren: voor herstel van het betalingsevenwicht tegen eind 1984 was een 'politique de rigueur' noodzakelijk, die echter leidde tot een afname van de economische groei. In de periode 1986-1988 kon de groei zich evenwel stabilieren als aan de volgende voorwaarden werd voldaan:

- behoud van de concurrentie door middel van een zogenaamd neutrale wissellkoers; als de inflatie relatief stijgt worden binnen het Europese Monetaire Systeem de wisselkoersen aangepast, zodat uit dien hoofde geen concurrentieverlies optreedt;

- de produktiecapaciteit moet worden afgestemd op vraagontwikkelingen en concurrerend worden, zoals verondersteld in de scenarios PZ en PY. Een extra investeringsinspanning boven de 'spontane investeringen' is nodig van $7.5 \%$ bij het positieve scenario.

De simulatie van het CGP wees echter uit, dat elke verhoging van de investeringen leidde tot een oplopen van de import van investeringsgoederen. De verslechterende betalingsbalans kon echter een tussenfase zijn, waarna door de versterking van de concurrentiekracht betere tijden konden aanbreken [18]. Overigens werd er in elke analyse de nadruk opgelegd, dat een koopkrachtstijging slechts op termijn mogelijk zal 
zijn en dat zulks niet tot een toename van de consumptie diende te leiden, maar tot een vergroting van de besparingen, die voor de modernisering van de industrie moeten worden aangewend.

\subsubsection{De Tweede Wet op het Plan: de middelen}

Malkin (1986) brengt de middelen van het Negende Plan onder in drie categorieèn: de 'Programmes Prioritaires d'Execution' (PPE), de 'plans sectoriels/filieres' en de 'contrats de plan'.

\section{Programmes Prioritaires d'exécution (PPE)}

In het verleden werden de lange termijn doelstellingen van het Plan voortdurend doorkruist door het korte termijn conjunctuurbeleid gericht op inflatiebestrijding, of het terugdringen van het betalingsbalanstekort. In het verleden zijn pogingen ondernomen de overheid te binden aan het uitvoeren van specifieke onderdelen van het plan; zo kende het Vijfde Plan de 'enveloppes d'équipements collectifs', het Zesde Plan de 'programmes finalisés' en het Zevende en Achtste Plan de 'Programmes d'Action Prioritaires'. De PPE onderscheiden zich niet alleen van genoemde voorgangers doordat zij op basis van een intensief consultatieproces tot stand zijn gekomen,

"(...) mais aussi par leur définition, leur portée et leur contenu" (Regard sur l'actualité 1984, 15).

De PPE zijn namelijk nauwkeurig in de Wet op het Plan omschreven, waarin het budget gedurende de gehele planperiode is vastgelegd. De overheid verplicht zich deze harde kern van het plan te realiseren, ongeacht de conjuncturele ontwikkelingen van het moment [19]. Voor het eerst in de geschiedenis van de Franse indicatieve planning zijn wettelijk de lange termijn prioriteiten budgettair veilig gesteld. Overigens is geen sprake van een 'force obligatoire', maar van een 'engagement morale', zij het, dat die morele plicht aanzienlijk is aangescherpt (Quinet en Touzery 1986, 67; Bauchet 1986, 105) $[20]$.

De procedure van het vaststellen van de PPE verliep langs twee lijnen: enerzijds via de regio's en de CNP en anderzijds via de ministeries (vergelijk schema 5.2). Vanaf februari 1983 werd met de diverse ministeries overlegd over de PPE ("schemas directeurs"), omdat op elk van de begrotingen posten moesten worden aangewezen, die tesamen het budget woor een PPE zouden vormen. Door deze procedure werden de PPE vanuit diverse invalshoeken benaderd: regio's, sociale partners en de ministeries. Daardoor konden sleutelprojecten en complementariteiten zichtbaar worden gemaakt. Twaalf zogenaamde 'Groupes Administratifs de Programmes' (GAP), waarin vertegenwoordigers van het Ministerie van Financièn, Budget en de technisch betrokken ministeries zitting hadden, verbijzonderden de PPE naar zogeheten "sous-programmes". In de GAP werd woor elk onderdeel van de PPE een post op de begroting aangewezen, opdat de PPE reeds in de 'loi de finances 1984' konden worden opgenomen. In juli 1983 maakte de Premier in een brief duidelijk welk 'plafond' voor elk ministerie gold met betrekking tot elke PPE. Tevens werd in de GAP voor de gehele planperiode de groei van het budget per PPE vastgesteld. Het prioriteitskarakter blijkt duidelijk uit de groei van de PPE van $16 \%$ tegen een groei van $6.3 \%$ voor de rest van de begroting. 
Het beslag op de budgettaire middelen voor planperiode blijkt uit tabel 5.10 : prioriteit kregen onderwijs (91 Mdf) en onderzoek (65 Mdf).

\section{Plan sectoriels - plans de filières}

Naast de PPE's kent de Tweede Wet wan het Negende Plan als tweede categorie van middelen de 'Plans sectoriels et filières". In hoofdstuk 3 is uiteengezet welke betekenis aan het concept wan de 'filière' kan worden gehecht; in hoofdstuk 6 zad worden besproken hoe de overheid na 1981 aan het 'filière'-beleid inhoud heeft gegeven, terwijl in hoofdstuk 7 de aandacht zich in het bijzonder zal richten op het 'Plan d'Action Filière Electronique" (PAFE).

Tabel 5.10 De budgetten voor de PPE

\begin{tabular}{|c|c|c|}
\hline Les PPE & $\begin{array}{l}\text { Projet de } \\
\text { loi de } \\
\text { finances } \\
1984\end{array}$ & $\begin{array}{l}\text { Enveloppe } \\
\text { IXe Plan }\end{array}$ \\
\hline $\begin{array}{l}\text { 1. Moderniser l'industrie grâce aux } \\
\text { nouvelles technologies et à un effort } \\
\text { d'épargne }\end{array}$ & 3183 & 19900 \\
\hline $\begin{array}{l}\text { 2. Poursuivre la rénovation du système } \\
\text { d"éducation et de formation des jeunes }\end{array}$ & 16610 & 91531 \\
\hline 3. Favoriser la recherche et l'innovation & 10650 & 64194 \\
\hline $\begin{array}{l}\text { 4. Développer les industries de } \\
\text { communication }\end{array}$ & 3594 & 21190 \\
\hline 5. Réduire la dépendance énergétique & 2767 & 15462 \\
\hline 6. Agir pour l'emploi & 5356 & 36278 \\
\hline 7. Vendre mieux en France et à l'étranger & 4686 & 27707 \\
\hline $\begin{array}{l}\text { 8. Assurer un environment favorable à la } \\
\text { famille et a la natalité }\end{array}$ & 225 & 1305 \\
\hline 9. Réussir la décentralisation & 3299 & 21047 \\
\hline 10. Mieux vivre dans la ville & 2588 & 15147 \\
\hline $\begin{array}{l}\text { 11. Moderniser et mieux gérer la système } \\
\text { de santé }\end{array}$ & 5114 & 28693 \\
\hline 12. Améliorer la justice et la sécurite & 1339 & 8095 \\
\hline TOTAL & 59411 & 350549 \\
\hline
\end{tabular}

Bron: Ministère de I'Industrie et de Recherche, Paris, Lettre 101, no. 194, avril 1984. 
Schema 5.2 De tot standkoming van het Negende Plan

\section{Calendrier de préparation du $9^{\circ}$ Plan}
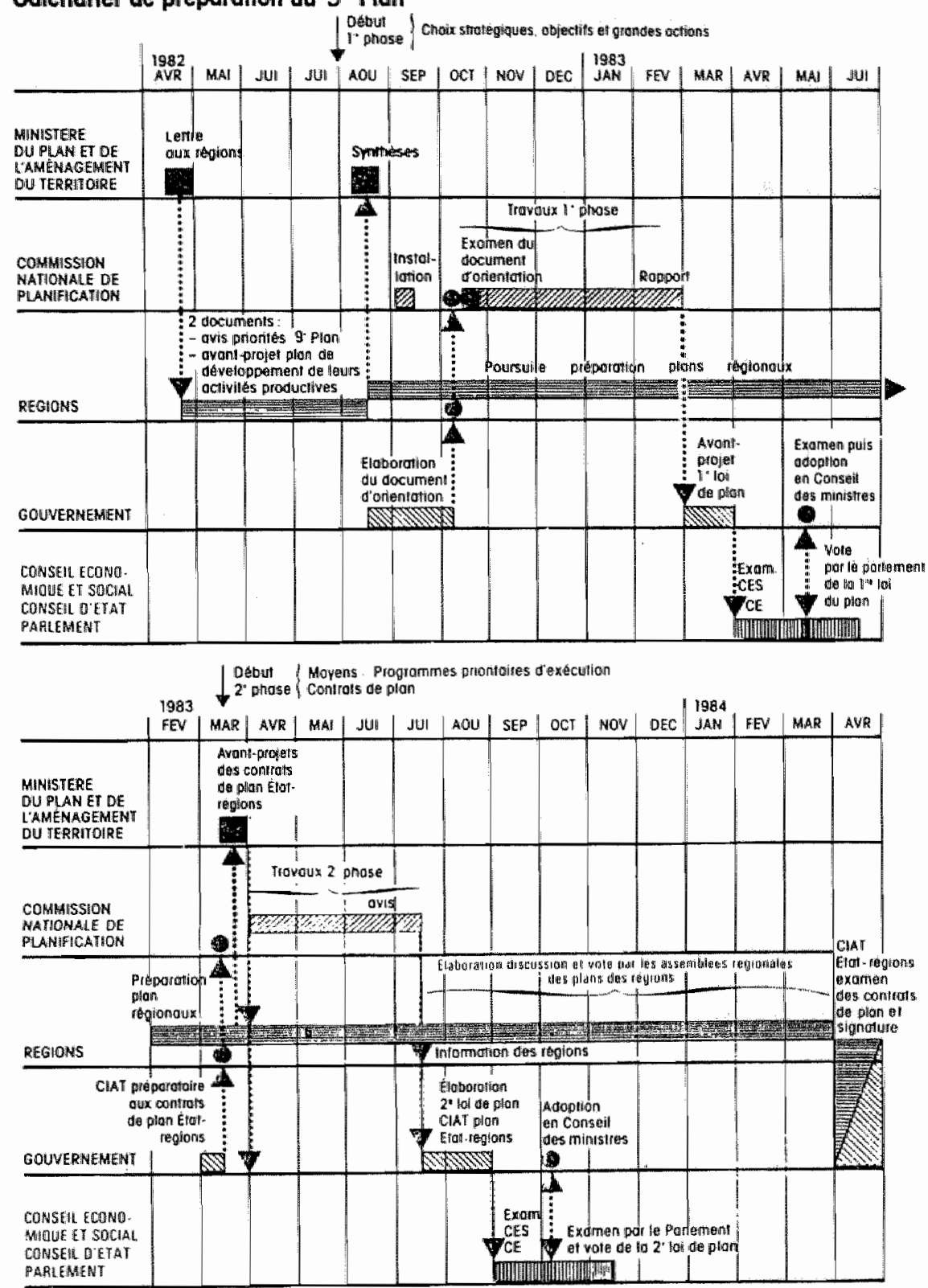

Bron: lettre du giéme Plan no. 1 
Op deze plaats wordt de relatie tussen het Negende Plan en sectorale en 'filiere"plannen uiteengezet.

Het Negende Plan zelf bevat geen expliciete 'filière'-plannen. Sommige plannen met betrekking tot specifieke 'filières' waren al geruime tijd in de vitwoeringsfase toen het Negende Plan op 1 januari 1984 van start ging, terwijl andere 'filière'-plannen in het Negende Plan werden aangekondigd. Dat is conform de opvatting, dat het planningsproces een continue aangelegenheid is, waarin PPE's in de loop van de planperiode worden bijgesteld en worden geconcretiseerd in verticale sector- of 'filière'-plannen. Het Negende Plan bevat geen coherent geheel van sectorplannen, die tesamen leiden tot de realisatie van de doeleinden aan het eind wan de planningsperiode; het Negende Plan verschaft het kader, waarbinnen verticale en horizontale plannen gestalte kunnen krijgen, een kader dat overigens zelf voor bijstelling tijdens het planningsproces in aanmerking kan komen.

De continuilteit van het planningsproces werd na de start van het Negende Plan in januari 1984 institutioneel vorm gegeven door voor de realisatie van de industriepolitieke doeleinden de 'Commission Nationale sur l'Tndustrie' (CNI) in te stellen. Deze breed samengestelde commissie kende een twaalftal verticale en horizontale 'Groupes Stratégiques Industrielles', die de ontwikkeling van een aantal specifieke sectoren moesten volgen en adviezen moesten uitbrengen (vergelijk hoofdstuk 6). Met betrekking tot het industriebeleid staat PPE 1 centraal, terwijl ook de PPE's 2, 3 en 4 van belang zijn. PPE 1 kent een viertal sub-programma's, die zijn weergegewen in tabel 5.11 .

Tabel 5.11: De sub-programma's van PPE no. 1

\begin{tabular}{|c|c|c|c|c|}
\hline \multirow{2}{*}{ Sous-programmes } & \multicolumn{2}{|c|}{$\begin{array}{l}\text { Base } 1984 \\
\text { (projet de loi finances) }\end{array}$} & \multicolumn{2}{|c|}{ Envelloppo 1984-1988: } \\
\hline & $\begin{array}{l}\text { Dépenses: } \\
\text { ondinalres }\end{array}$ & $\begin{array}{l}\text { Autorisations } \\
\text { de programmes }\end{array}$ & $\begin{array}{l}\text { Dépenses } \\
\text { ordinaires }\end{array}$ & $\begin{array}{l}\text { Autorisations } \\
\text { de programmes }\end{array}$ \\
\hline $\begin{array}{l}1 \text { Enclourager la diffusion } \\
\text { des nouvelles technologies } \\
\text { dans les indusittries } \\
\text { manufacturiares et } \\
\text { l'artisianat }\end{array}$ & 334,25 & 755.5 & $2.363,2$ & $4.930,3$ \\
\hline $\begin{array}{l}2 \text { Favoriser l'emergence } \\
\text { d'une offre competitive pour } \\
\text { les biens d'equigement } \\
\text { avances }\end{array}$ & 34,8 & $1.155,4$ & 205,6 & 6.814 .4 \\
\hline $\begin{array}{l}3 \text { Maitriser les techniques } \\
\text { nouvellas dans la sectieur } \\
\text { agroalimentaire }\end{array}$ & 34,1 & 661.2 & 383,2 & 3.508 .95 \\
\hline $\begin{array}{l}4 \text { Diffuser les nouvelles } \\
\text { technologies dans le BTP }\end{array}$ & 95.7 & 105.25 & 919.7 & 755,25 \\
\hline Totalal & 498.95 & $2.677,35$ & 3.871 .7 & $16.008,9$ \\
\hline
\end{tabular}


De "sous-programmes" betreffen de stimulering van de vraag en het aanbod in de sector van de geavanceerde investeringsgoederen, de technologische ontwikkeling in de landbouw, de voedingsmiddelenindustrie en in de BTP ("Batiment Travaux Public"). In andere PPE's worden andere sectoren en 'filieres' genoemd: electronica en communicatieindustrie (PPE 4); machinebouw, chemie en scheepsbouw (PPE 1); biotechnologie (PPE 5) en de energie in een apart hoofdstuk. Benadrukt dient te worden dat het 9de Plan zelf, met uitzondering van de energie en transportsector, geen specificaties met betrekking tot de genoemde sectoren bevat [21].

Ten behoeve van de controle op de realisatie van de PPE's worden een aantal indicatoren ontwikkeld zoals:

- elk jaar neemt het aantal werknemers in de "productique" toe met een factor 9 ,

- het aantal in Frankrijk gebouwde robots moet stijgen met een factor 3,5,

- voor 50.000 ha landbouwgrond worden irrigatiesystemen aangelegd,

- in 1988 verbruiken nieuwe Franse auto's niet meer dan 6 liter benzine per $100 \mathrm{~km}$.,

- meer dan 3 miljoen werknemers moeten onder een 'contrat de solidarite' (ATV) vallen,

- in elke stad boven de 35.000 inwoners komt een agentschap van de 'Agence Nationale pour l'Emploi',

- renovatie van 700.000 woningen in de categorie van de sociale woningbouw,

- uitgaven van Onderzoek zullen toenemen tot $2.5 \%$ van het BNP, waarvan $45 \%$ door het bedrijfsleven wordt gefinancierd,

- in de sfeer van Onderzoek en Ontwikkeling moet het aantal samenwerkingsverbanden verdubbelen,

- 15 wetenschappelijke-technische centra worden opgericht,

- het aantal ingenieurs moet verdrievoudigen.

Naast de PPE's wordt de 'noyau dur" van het Negende Plan gevormd door twee wetten, die betrekking hebben op de militaire uitgaven en het onderzoek. Voor die terreinen zijn speciale wetten aangenomen, opdat budgetten voor een langere periode dan eén jaar konden worden gegarandeerd. Conform artikel 5 van de Hervormingswet werden die twee wetten in de Tweede Wet op het Plan geïntegreerd [22].

\section{Contrat de Plan}

De derde categorie van middelen ter realisatie van de plandoeleinden werd gevormd door de planningsovereenkomsten ('contrats de plan'), die moesten worden afgesloten tussen de overheid en de regio's enerzijds en tussen de overheid en de ondernemingen anderzijds. Het was de bedoeling met de planningsovereenkomsten een compromis te vinden tussen het behoud van de autonomie van de actoren en de wens hun strategische beslissingen af te stemmen op de doeleinden van het Nationale Plan. Voor een gedetailleerde bespreking van de mogelijkheden en beperkingen van de planningsovereenkomsten wordt verwezen naar de hoofdstukken 6 en 7.

Met betrekking tot de Tweede Wet op het Plan werd dezelfde procedure gevolgd als voor de Eerste Wet: rapporten van de CNP en de GAP werden voorgelegd aan de ministerraad, die op 10-10-1983 het wetsontwerp opstelde. Na advies van de CES en de 'Conseil d'Etat' keurde het parlement de wet goed op 12-12-1983, waarna hij op 2412-1983 van kracht werd. 


\subsubsection{Conclusies}

Het hoofdstuk over de Franse indicatieve planning overziende, lijkt het Plan in Frankrijk voor alles een 'animateur' geweest van de discussie met betrekking tot het macro-economische beleid, tevens heeft het Plan een psychologische rol gespeeld bij het doordringen van de werkgevers en de vakbonden van de noodzaak tot modernisering van de Franse industrie. Wat de concrete invulling van het industriebeleid op sector- en regionaal niveau betreft, heeft het Plan tot 1981 geen rol van betekenis gespeeld. Voor 1981 kreeg het industriebeleid grotendeels vorm buiten het Plan om:

"Tout cela donne le sentiment d'une planification fondée sur une aide sélective à des entreprises - ou groupements d'entreprises comme le Groupement des industries sidérurgiques (GIS) - plus que d'une politique de développement à long terme d'activités rarement explicitée dans les plans" (Bauchet 1986, 70). [23]

De opzet met betrekking tot het Negende Plan was anders: hoewel het Plan qua procedure en inhoud grote verwantschap vertoonde met de voorgaande plannen, pretendeerde het Negende Plan door haar decentrale en contractuele benadering het industriebeleid in de loop van de planperiode nader vorm te geven in met name de "Plans de filieres"; het industriebeleid zou zo een integraal onderdeel van het planningsproces moeten worden en een geïntegreerd geheel van mesosystemen moeten betreffen.

Dat het Negende Plan niet, of maar zeer ten dele aan die verwachtingen beantwoordde, bleek reeds tijdens de bespreking van het wetsonderwerp van de Eerste Wet op het Plan [24]. De vraagtekens werden door de afgevaardigden enerzijds geplaatst bij de 'médiocrité de la concertation' [25] en anderzijds bij de mate van specificatie en coherentie van het Plan.

Wat de consultatie betreft, werd door de toenmalige Secrétaire d'Etat chargé du Plan, M. Jean Le Garrec, de onbevredigende gang van zaken in de CNP bevestigd [26]; Le Garrec beklaagde zich over het feit, dat de vertegenwoordigers van werkgevers en werknemers met name in de 'Commission Nationale de la planification' hun verplichte stokpaardjes bereden zonder een poging te doen tot afstemming van de visies te komen [27].

Wat de functie van het Plan als richtinggevend kader voor de economische agenten betreft spitste de kritiek zich toe op de afwezigheid van gekwantificeerde doeleinden in het Plan [28]. Zoals eerder opgemerkt is het overigens de vraag, of in een open complexe economie, waarvan de ondernemingen opereren op een turbulente wereldmarkt tot een nadere kwantificering van de doeleinden kan en moet worden overgegaan. Jospin van de PS schetste in het Parlement duidelijk het dilemma, waarvoor een volontaristische overheid in de jaren tachtig staat: enerzijds zou kwantificering van de doeleinden het verplichtende karakter van het $\mathbb{P l a n}$ ten goede komen, anderzijds is het risico groot, dat de doeleinden door interne en externe factoren niet worden gerealiseerd, waardoor het Plan gemakkelijk zijn geloofwaardigheid zou kunnen verliezen. Een Plan met te vage en algemene doeleinden wordt dan snel een 'simple dissertation' [29].

"La recherche du juste milieu (...) sera un exercice difficile. Pour exister, le planification devra s'appuyer sur le secteur public et la décentralisation" (Jospin in Le Monde 16-6-1983). 
Zoals uiteengezet door Estrin en Holmes (zie hoofdstuk 2), dient het indicatieve Plan in een moderne, open economie voor alles informatie te verschaffen, algemene informatie over mogelijke ontwikkelingen van macro- en mesovariabelen ${ }_{*}$ informatie over overheidsbeleid (premie- en belastingdruk, monetair beleid, industriepolitiek); informatie over prioriteiten van overheidsbeleid, zoals de PPE's, enz., informatie over specifieke technologische ontwikkelingen, verwachtingen met betrekking tot diverse wereldmarkten etc.

Belangrijk is, dat het Plan 'démocratique, continue et contractuelle' is. Zoals uiteengezet moet het planningsproces een voortdurend proces zijn, waarin algemene doelstellingen worden verbijzonderd en aangepast aan veranderende omstandigheden. $\mathrm{Zo}$ als Jospin opmerkte, moet er sprake zijn van een gedecentraliseerd informatieuitwisselingsproces, moeten prioriteiten worden gesteld voor de publieke sector en moeten de rechten en plichten van de regio's en de publieke ondernemingen in contracten worden vastgelegd. De decentralisatie via de regio's werd in het Negende Plan met voortvarendheid ter hand genomen, de prioriteiten werden in de PPE's vastgelegd en de 'contrats de plan' moesten de rechten en plichten voor de regio's en de publieke ondernemingen regelen. Daarvan kwam niet veel terecht.

Groot probleem bij het ontwikkelen en concretiseren van lange termijn doelstellingen en prioriteiten vormde het 'rigueur'-beleid vanaf maart 1983, waardoor de maatregelen ter bestrijding van de korte termijn problemen (en daardoor het Ministerie van Financiën) in het centrum van de belangstelling kwamen te staan. François Simon schrijft in Le Monde dd. 18-4-1986 onder de titel ' $I$ était une fois le Plan":

"C'est en catastrophe que le IXe Plan sera élaboré, juste après le 23 mars 1983, c'est a dire dans la foulée de la nouvelle politique de rigueur, qu'il ne fera que confirmer".

Onder druk van de politieke ommezwaai van maart 1983 moest binnen drie weken het wetsontwerp van de Eerste Wet op het Plan opgesteld worden. Naast Jean le Garrec (secrétaire d'Etat) en Hubert Prévot (Commissair au Plan), waren daarbij twee architecten van de 'rigueur' nauw betrokken te weten: François-Xavier Stasse (lid van het secretariaat van de President) en Henri-Guillaume (lid van het kabinet van de Premier).

Hoe de lange termijn doelstellingen met betrekking tot de ontwikkeling van de industriële structuur (wast te leggen in de 'loi sur l'industrie') en de rol van de publlieke ondernemingen onder de druk van de korte termijn problemen bezweken, wordt in het volgende hoofdstuk besproken. 


\section{Bijlage 5.1 De essenties van het model Fifi}

De openheid van de Franse economie plaatste het te gebruiken macromodel voor de taak zichtbaar te maken, welke gevolgen op middellange termijn te verwachten zouden zijn van de internationale concurrentie. Vervolgens moest het model duidelijk maken wat de effecten zouden zijn van verschillende belleidsinstrumenten. De openheid van de economie eiste inzicht in inkomens- en prijsontwikkellingen en daartoe moest de planning in fysieke grootheden plaats maken voor een planning in waarden.

Courbis (1970) legde in zijn theorie van de "économie concurrencée een verband tussen de mogelijkheden van economische groei en het concurrentievermogen van de groep van sectoren, die aan de internationale concurrentie waren blootgesteld. Courbis maakte onderscheid tussen een 'secteur concurrencé' en een 'secteur abrité'. Uitgaande wan een vaste wisselkoers en een perfecte substitutie tussen de produkten van de binnenlandse en buitenlandse producenten, is de prijs van de buitenlandse concurrenten een 'constraint' voor de binnenlandse producenten. Voorts neemt in de theorie van Courbis het door de ondernemers gewenste niveau van interne financiering van de investeringen en de zogenaamde Phillips-relatie tussen een procentuele verandering tussen de lonen, prijzen en werkgelegenheid een belangrijke plaats in. De prijzen voor de concurrerende sector worden gezet door de buitenlandse ondernemingen en afhankelijk van de kosten (met name de loonkosten) van de binnenlandse producenten resulteert voor hen een bron voor interne financiering. Is de winst gering dan wordt weinig geïnvesteerd, waardoor de concurrentiepositie verder wordt aangetast. Evenwicht tussen aangeboden en gevraagde hoeveelheid ontstaat in de 'secteur concurrencé door toe- of afname van de importen.

In tegenstelling tot de Keynesiaanse vraagmodellen, waarin de import afhankelijk is van de binnenlandse produktie en de prijzen endogeen zijn, is bij Courbis de exogene prijs van de importgoederen bepalend.

In de 'secteur arbité' is geen sprake van concurrentie: de binnenlandse ondernemers kunnen een prijs zetten, die de gewenste winst oplevert met het oog op het gewenste niveau van interne financiering van de investeringen.

De binnenlandse produktie en werkgelegenheid zijn in het model afhankelijk van het concurrentievermogen ten opzichte van de buitenlandse ondernemingen. Als kostencomponenten zoals belastingen, grondstoffen en dergelijke niet op korte termijn omlaag zijn te brengen, dan zijn de loonkosten bepalend voor het concurrentievermogen, aldus Courbis. Zijn de lonen relatief hoog, dan zal de winst relatief laag zijn met het gevolg dat investeringen nagenoeg uitblijven, waardoor het concurrentievermogen verder verzwakt. Ondernemers worden dan gedwongen werknemers te ontslaan, waardoor een druk op de lonen ontstaat. De concurrentiepositie verbetert, de winsten stijgen en de weg omhoog ligt open.

De wijze, waarop de macromechanismen werken in thet Fifi-model, heeft grote gevolgen voor het beoordelen van diverse vormen van overheidsbeleid. Een algemene vraagstimulering zal afhankelijk van de concurrentiepositie leiden tot een toename van de binnenlandse produktie, of tot een toename van de importen. Varianten die direkt de produktiekosten voor de ondernemers drukken hebben een positief effect op de winsten en daarmede op het investeringsniveau. Verbetering van de concurrentie- 
positie en werkgelegenheid zijn het gevolg. Bij de berekening van de varianten voor het Zesde Plan wordt de aandacht vooral gevestigd op het effect van veranderende produktiekosten op de ontwikkelingen in de "secteur concurrencé". Wordt bijvoorbeeld de vraag gestimuleerd in de 'secteur abrité' dan zall op korte termijn de produktie toenemen. Echter, door de toename van de vraag naar arbeid ontstaat een opwaartse druk op de lonen, hetgeen negatieve gevolgen heeft voor de 'secteur concurrence'. Het is zeer wel mogelijk, dat in het positieve effect van vraagstimulering in de beschermde sector resulteert in de groter negatief effect voor de concurrerende sector.

Afgezien van de gebruikelijke problemen, die zich met macromodellen voordoen, richt de kritiek op Fifi zich vooral op het Phillipsmechanisme en op het beperken van de concurrentieconcept tot de prijsconcurrentie. Vooral toen na de devaluatie van de franc in 1969 de positieve resultaten uitbleven werd de twijfel alan de macrorelaties in Fifi groter. Kritiek werd vanuit diverse richtingen geuit:

- de "verwachtingen school" redeneerde, dat de relatie tussen lonen en werkgelegenheid op korte termijn wel kan werken, maar dat op middellange termijn sprake is van een 'natuurlijk' niveau van werkgelegenheid bepaald door de technologische ontwikkelling en bevolkingsgroei;

- de vakbonden hadden stevige kritiek op Fifi, die vooral de ideologische grondslagen van het model betrof.

"This structure of the model, reproducing the operations of the capitalist economy, makes its use in the medium-term very doubtfull. It boils down in effect to a justification of the capitalist system, and considers capitalism as the only possible form of economic organisation. In this sense, FIFI is not a neutral tool ...." (Liggins 1975, 154).

- een derde belangrijke bron van kritiek betrof het feit, dat ontwikkelingen in arbeid en kapitaal wordt geëndogeniseerd. In het model is dat niet het geval. Verder wordt erop gewezen, dat de mogelijkheden van de 'secteur concurrencé' groter zijn dan Fifi verondersteld, omdat in de concurrentiestrijd andere parameters dan de prijs relevant zijn. 
Bijlage 5.2 Het planningsproces voor 1981

parlement
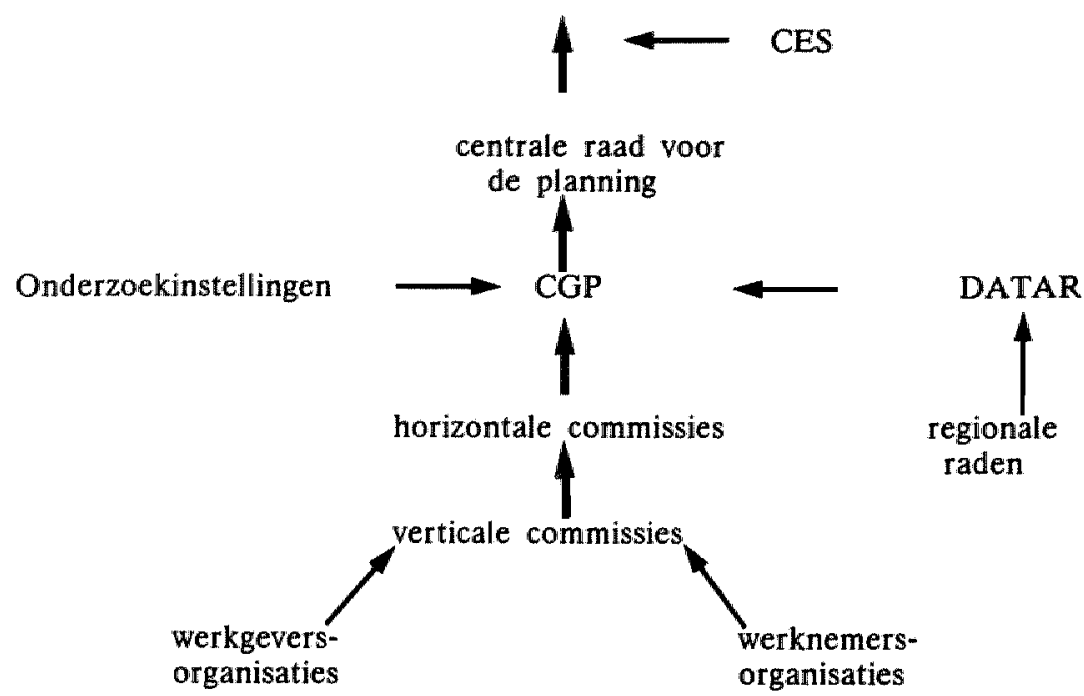


\section{Bijlage 5.3}

Tabel 5.1 Samenstelling van de toegevoegde waarde van de ondernemingen (m.u.v. de GEN) in de periode 1974-1982 (in \%an de toegevoegde waarde)

\begin{tabular}{lrrrrrrrrr}
\hline & 1974 & 1975 & 1976 & 1977 & 1978 & 1979 & 1980 & 1981 & 1982 \\
\hline Rémunération des & & & & & & & & & \\
salariés, dont: & 66,0 & 68,5 & 69,1 & 68,8 & 68,9 & 68,5 & 69,7 & 71,2 & 71,1 \\
- Salaires bruts & 50,9 & 51,7 & 52,0 & 51,5 & 51,4 & 50,6 & 51,4 & 52,5 & 52,0 \\
- Cotisations sociales & 15,1 & 16,8 & 17,1 & 17,3 & 17,5 & 17,9 & 18,3 & 18,7 & 19,1 \\
Excédent brut d'exploil- & & & & & & & & & \\
tation dont: & 10,1 & 10,1 & 10,3 & 10,2 & 11,0 & 11,4 & 9,8 & 8,2 & 7,8 \\
- Epargne brute & 6,9 & 6,2 & 5,7 & 5,6 & 5,1 & 4,8 & 5,5 & 6,2 & 6,3 \\
- Intérêts nets versé & 1,6 & 3,1 & 3,7 & 4,1 & 3,4 & 3,6 & 3,9 & 3,8 & 3,7 \\
Impots & 4,1 & 4,0 & 3,7 & 3,7 & 3,6 & 3,8 & 3,9 & 3,6 & 3,4 \\
Dividendes versés & & & & & & & & & \\
\hline
\end{tabular}

Bron: Comptes de la Nation - 1982, Soulage (1983)。

Zoals uit tabel 5.2 blijkt zijn in Frankrijk de salarissen gestegen, terwijl de produktiviteitsontwikkeling dat eigenlijk niet toeliet. Voor Japan en de BRD zijn tegengestelde ontwikkelingen waarneembaar (vergelijk Balassa 1981).

Tabel 5.2 De ontwikkeling van de salarissen en de produktiviteit in enkele geïndustrialiseerde landen tussen 1975-1981

\begin{tabular}{lcccccc}
\hline & \multicolumn{5}{c}{$\begin{array}{c}\text { Productivité } \\
\text { Salaires réels }\end{array}$} & $\begin{array}{l}\text { apparente du travail } \\
\text { Ecart }\end{array}$ \\
\hline & $1975-1979$ & $1980-1981$ & $1975-1979$ & $1980-1981$ & $1975-1979$ & $1980-1981$ \\
\hline R.F.A. & 2,4 & 0,4 & 3,2 & 0,4 & $-0,8$ & 0 \\
Japon & 2,9 & 0,7 & 3,8 & 2,4 & 0,9 & 1,7 \\
U.S.A. & 1,1 & 0,8 & 0,9 & $-0,1$ & $-0,2$ & 0,9 \\
France & 4,4 & 1,8 & 2,7 & 0,7 & $-1,7$ & $-1,1$ \\
Italie & 2,8 & 0,6 & 1,3 & 1,1 & $-1,5$ & $+0,5$ \\
\hline
\end{tabular}

Bron: Soulage (1983).

Van de toegevoegde waarde bleef in Frankrijk in de jaren zeventig onvoldoende ruimte voor investeringen en onderzoek, waardoor het produktieapparaat sterk verouderde (tabel 5.3). 
Tabel 5.3 Gemiddelde leeftijd van de kapitaalgoederenvoorraad in de Franse industrie

\begin{tabular}{lccc}
\hline & 1963 & 1973 & 1980 \\
\hline Biens intermédiaires & 6,9 & 6,7 & 8,2 \\
Biens d'équipement & 6,4 & 5,6 & 5,9 \\
Biens de consommation & 7,6 & 7,2 & 8,9 \\
TOTAL industrie & 6,4 & 6,1 & 7,1 \\
\hline
\end{tabular}

Bron: INSEE - Les comptes de l'industrie - 1981; Soulage (1983).

Deze ontwikkelingen vonden hun weerslag in de betalingsbalans.

Frankrijk exporteerde relatief weinig naar de andere OECD-landen en exporteerde relatief weinig hoogwaardige industriële produkten, met uitzondering van wapens. (vergelijk tabellen 5.4 en 5.5 en 5.6 ).

Tabel 5.4 Handelsbalans per zone in MF van 1981-1982

\begin{tabular}{|c|c|c|c|c|c|c|}
\hline & & Monde & CEE & $\begin{array}{l}\text { OCDE } \\
\text { hors } \mathrm{CEE}\end{array}$ & $\begin{array}{l}\text { Etranger } \\
\text { hors } \mathrm{OCDE}\end{array}$ & Zone franc \\
\hline \multirow[t]{2}{*}{ Biens intermédiaires } & 1981 & 1711 & -14796 & -4334 & -18697 & 2144 \\
\hline & 1982 & -2552 & -18281 & -6277 & 18523 & 3488 \\
\hline \multirow{2}{*}{$\begin{array}{l}\text { Biens d'équipement } \\
\text { professionnel }\end{array}$} & 1981 & 36614 & -16152 & -13003 & 57794 & 7974 \\
\hline & 1982 & 33096 & -28573 & -19864 & 72357 & 9176 \\
\hline \multirow{2}{*}{$\begin{array}{l}\text { Bìens d"équipement } \\
\text { ménager }\end{array}$} & 1981 & -7417 & -3840 & -4008 & -393 & 324 \\
\hline & 1982 & -10080 & -4099 & -5729 & -653 & 398 \\
\hline \multirow[t]{2}{*}{ Automobile } & 1981 & 27073 & 3858 & 2305 & 17773 & 3137 \\
\hline & 1982 & 20333 & -1014 & 3064 & 14650 & 3633 \\
\hline \multirow{2}{*}{$\begin{array}{l}\text { Biens de consomma- } \\
\text { thon courante }\end{array}$} & 1981 & -4388 & -7883 & 567 & -700 & 4762 \\
\hline & 1982 & -12428 & -15157 & -898 & -1931 & 5558 \\
\hline \multirow{2}{*}{$\begin{array}{l}\text { Ensemble de l'indus- } \\
\text { trie }\end{array}$} & 1981 & 53593 & -38313 & -19606 & 93171 & 18341 \\
\hline & 1982 & 28369 & -67124 & -2970 & 1102946 & 22248 \\
\hline
\end{tabular}

Bron: comptes de la Nation 
Tabel 5.5 De penetratiegraad* Van industriẻle produkten in de periode 1970 -1983

$\begin{array}{llllllllll}1970 & 1973 & 1978 & 1979 & 1980 & 1981 & 1982 & 1983 & \begin{array}{l}\text { Variation } \\ 1973-1978\end{array} & \begin{array}{l}\text { Variation } \\ 1978-1983\end{array}\end{array}$

\begin{tabular}{|c|c|c|c|c|c|c|c|c|c|c|}
\hline $\begin{array}{l}\text { Biens intermé- } \\
\text { diaines }\end{array}$ & 21,3 & 23,1 & 25,8 & 27,3 & 27,9 & 27,8 & 28,3 & 28,5 & 2.7 & 2,7 \\
\hline $\begin{array}{l}\text { Biens d'equipe- } \\
\text { ment professionel }\end{array}$ & 25,3 & 27,7 & 30,5 & 32,6 & 33,0 & 35,3 & 37,1 & 37,5 & 2,8 & 7,0 \\
\hline $\begin{array}{l}\text { Biens d'équipement } \\
\text { ménager }\end{array}$ & 28,4 & 33,6 & 41,2 & 42,7 & 43,6 & 49,2 & 49,5 & 51,2 & 7,6 & 10,0 \\
\hline $\begin{array}{l}\text { Automobiles, trans- } \\
\text { port terrestre }\end{array}$ & 17,5 & 20,6 & 24.7 & 25,8 & 26,1 & 29,2 & 31,2 & 30,9 & 4,1 & 6.2 \\
\hline $\begin{array}{l}\text { Biens de consom- } \\
\text { mation courante }\end{array}$ & 11,2 & 13,6 & 18,9 & 21,0 & 21,5 & 21,9 & 22,9 & 23,1 & 5,3 & 4,2 \\
\hline Total industrie & 19,3 & 21,6 & 25,2 & 26,9 & 27,5 & 28,6 & 29,7 & 29,8 & 3,6 & 4,6 \\
\hline
\end{tabular}

* Import (produktie van de branche + import - export)

Bron: INSEE

Tabel 5.6 Exportgraad* van industriêle produkten in de periode 1970-1983

\begin{tabular}{|c|c|c|c|c|c|c|c|c|c|c|}
\hline & 1970 & 1973 & 1978 & 1979 & 1980 & 1981 & 1982 & 1983 & $\begin{array}{l}\text { Variation } \\
1973-1978\end{array}$ & $\begin{array}{l}\text { Variation } \\
1978-1983\end{array}$ \\
\hline $\begin{array}{l}\text { Bitens intermé- } \\
\text { diaires }\end{array}$ & 18,2 & 19,6 & 25,5 & 26,0 & 25,8 & 27,9 & 27,6 & 28,8 & 5,9 & 3,3 \\
\hline $\begin{array}{l}\text { Biens d'equipement } \\
\text { purofessionnel }\end{array}$ & 25,6 & 29,0 & $43_{4} 3$ & 45,2 & 42,3 & 47,0 & 46,3 & 50,0 & 14,3 & 6,7 \\
\hline $\begin{array}{l}\text { Biens d'équipé- } \\
\text { ment ménager }\end{array}$ & 15,1 & 17,2 & 21,9 & 22,2 & 21,5 & 21,7 & 19,9 & $24_{n} 1$ & 4,7 & 2,2 \\
\hline $\begin{array}{l}\text { Automobiles, trans- } \\
\text { port terrestre }\end{array}$ & 37,7 & 38,9 & 47,9 & 49,8 & 44,5 & 46,0 & 40,5 & 40,6 & 9,0 & $.7,3$ \\
\hline $\begin{array}{l}\text { Btems de consom- } \\
\text { mation courante }\end{array}$ & 15,0 & 16,8 & 18,0 & 18,3 & 18,4 & 19,3 & 18,5 & 19,7 & 1,2 & 1,7 \\
\hline Total Industrie & 20,6 & 22,6 & 29,7 & 30,4 & 29,4 & 31,7 & 30,7 & 32,4 & 7,1 & 2,7 \\
\hline
\end{tabular}

* Export (produktie van de branche - import - export)

Bron: INSEE 
[1] Vergelijk de idee van de "pure" indicatieve planning besproken in hoofdstuk 2.3.1.

[2] Massé sprak van het 'Plan de la Nation', daarmee aangevend dat het plan een zaak van alle groepen in de samenleving was en dat consultatie zou leiden tot een 'contract social".

[3] "Le Plan est un instrument pour réaliser les objectifs de domination des monopoles contre la classe ouvrière et les masses populaires" (uitspraak van een CGT voorman, geciteerd naar Cohen 1969).

[4] "(...) le plan dont la technique comptable s'affine présente de facon marquée lors du IIlème plan un cadre cohérent de perspectives sectorielles à moyen terme qui servent de cadre de référence aux entreprises dans leur propre programmation" (Petit 1983, 7).

"(...) the literature attests that the planners continued to be influential in encouraging the cumulative structural changes over the period, which resulted in industrialists moving into export markets and expanding the domestic production of traditionally imported goods" (Estrin en Holmes 1983a, 65).

[5] "Si le 4ème plan marque l'apogée d'une forme de planification indicative c'est surtout par les engagements qu'a pris à son égard le gouvernement. Le plan est soumis pour la première fois au Parlement et le gouvernement s'engage sur les programmes d'équipements collectifs alors que dans les Ilème et IIIème plans les recommendations des commissions en la matière n'engageaient pas les administrations concernées" (Ullmo 1970, 14).

[6] "Jusquau IVe Plan inclus, les résultats des projections par branche qui ressortaient de l'étude de marché généralisée étaient baptisés "objectifs indicatifs". Ceci évidemment présupposait une intervention potentielle de l'Etat dans toutes les branches, puisque les prévisions qui ressortaient d'une demande intérieure protégée de la concurrence internationale étaient baptisées "objectifs" et que, dans ces conditions, il n'y avait aucune raison que l'Etat n'aide pas les entreprises à atteindre ces objectifs" (Ullmo 1970, 345).

[7] "(...) le Plan gagne en exhausivité et en précision: il fixe pour chaque branche d'activité industrielle un taux de croissance cohérente avec la croissance globale" (Quinet en Touzery 1986, 50).

[8] Lutz $(1969,14)$ citeert in dat verband het Vijfde Plan:

"The projection is based on an evaluation of the productive possibilities of the economy during the plan: labour, productive equipment, technical progress. There is worked out correspondingly an image of "final demand" or of what is expected to be demanded, in the terminal year for purposes of consumption, various types of investment, and export, account being taken of the social objectives of the plan. Given this image of demand, and assuming internal and external equilibrium, a detailed table of supply, i.e. of production and imports, is drawn up. To these tables of demand and supply are added tables which describe the way in which incomes are distributed and used, and in which saving pass from savers to investors".

[9] Drie sectoren werden in dat verband als prioriteit aangewezen:

"gros matériel d'équipement, construction aéronautique, électronique" (Quinet en Touzery 1986,52 ).

Vermeldenswaard is het feit, dat wel de 'Commissair au Plan' bij die keuze werd 
betrokken, maar dat geen sprake was van consultatie in de moderniseringscommissies over de keuze van de prioriteiten en dat evenmin de industriële programma's van de prioriteiten gepubliceerd werden (vergelijk Bonnaud 1975, 98 en 99).

[10] Ullmo $(1970,350)$ concludeert: "De sorte que, au total, le texte même du VIe Plan ne va pas au bout de cette volonté de sélectivité."

Bonnaud stelt: "Thus, in practice, the notion of industrial priorities was abandoned."

Estrin en Holmes (1983a, 184): "Whatever actually transpired, the existence of ambiguity in the record as to whether certain sectors were given preferential treatment would make it hard for an investor, ex ante, to know what to expect When he heard that a particular industry was to be given priority".

[11] Refererend aan het zich terugtrekken van de vakbeweging wit het overleg schrijft Seibel $(1975,168)$ : "But now is has become clear that the rules of the game are contested at the root by some of the social groups which are part of the planning machinery. Inevitably, this altered the significance of the Plan itself, for its choices and targets increasingly became those of the government".

[12] Zie voor een uitgebreide bespreking van de regionalisering: Turpin (1983), Délébeque (1984) en Keating en Hainsworth (1986).

[13] Zie voor een bespreking van het DMS-model (Dynamique Multi Sectorial): Service des Programmes de l'INSEE, Une représentation de l'économie française: le modèle DMS, in: Revue Economique, 31, nr. 5, septembre 1980 , pp. 930-982.

[14] "Le maintien de l'ouverture de ses frontières est, pour la France, une donnée fondamentale de son action internationale" (Commissariat Général du Plan, 1983, Rapport du IXe Plan).

[15] Zie voor een bespreking van de 'planification démocratique': Beaud 1985, 47-51.

[16] "La politique de court terme est mise au service d'un projet a plus long terme: celui du Plan" (Taddei 1984, 1255). Voor kritiek zie de conclusies in 5.6.5.

[17] "Il fallait donc faire fonctionner les modèles "à l'envers", les utiliser pour déterminer les conditions selon lesquelles les objectifs de la première loi de Plan pourraient être atteints. L'utilisation des modèles en mode d'optimisation s"avérait appropriée" (Catinat en Maurice 1984, 1023, 1024).

[18] In het rapport van de CES (zie ook Eisner 1983) wordt ook gewezen op het effect van een versterking van de industriële structuur met betrekking tot importsubstitutie en exportverhoging.

[19] Het was de bedoeling dat het Ministerie van Financiën van alle overheidsuit* gaven en -inkomsten driejaren projecties zou gaan publiceren. Pierre Bérégovoy, de Minister van Financiën in 1985, komt die afspraak niet na voor de periode '86-'87 (vergelijk LNE dd. 15-3-1985).

[20] "Les enveloppes budgétaires des PPE figurent dans le dispositif de la loi et non seulement dans le texte du rapport annexé, comme ce fut le cas pour les PAP du 7e Plan. Sans doute la présence de ces crédits dans le positif ne leur confère-telle aucune force obligatoire - l'ordannance organique du 2 janvier 1959 relative aux lois de finances l'interdirait -, mais le caractère d'engagement moral de l'exécutif comme du législatif s'en trouve considérablement renforcé" (Regard sur l'actualité 1984). 
[21] "Au fil des plans, l'Etat a progressivement renoncé à préciser le contenu d'une politique sectorielle a moyen terme sauf dans l'energie et les transport" (Bauchet $1986,103)$.

[22] 'La loi de programmation militaire' (dd. 08-07-"83), waarin voor de planperiode $830 \mathrm{Mdf}$ (in lopende prijzen) is gereserveerd voor de militaire uitgaven, waarin met name de 'force de frappe' prioriteit geniet.

'La loi d'orientation et la programmation de la recherce' (LOP) met het doel de onderzoekuitgaven op te voeren tot $2.5 \%$ van het BNP in 1986 (vergelijk hoofdstuk 6).

In de Tweede Wet op het Plan werden verder de doeleinden opgenomen met betrekking tot het verhogen van de hulp aan de ontwikkelingslanden tot $0.7 \%$ van het BNP in 1988 en het bereiken van een energieafhankelijkheid van $50 \%$ in 1990 (was 35\% in 1982).

[23] In LNE dd 25-4-1983 merkt Claude-Alain Sarre van de CNPF op: "Toutes les disscussion lourdes ont été prises "hors Plan", hetgeen volgens Claude Gruson oud-directeur van INSEE zijn oorzaak vindt in gebrek aan kennis: "Comment voulez-vous faire une politique industrielle quand vous ne savez pas ce qui se passe dans l'industrie? Au bout de compte, ce sont les idées prétendues géniales du directeur général de l'Industrie qui dominant".

[24] Zie Le Monde dd. 16-6-1983: Le débat sur le IXe Plan à l'assemblée Nationale; "Majorité et opposition se réjoignent dans la critique".

[25] M. Merchais van de PCF.

[26] Zie Le Monde dd. 30-7-1983, pp. 18.

[27] Van veel zijden wordt benadrukt dat het Plan een ontmoetingsplaats is alwaar ideëen kunnen worden uitgewisseld. De tijd van 'concertation' is voor bij: (zie Claude Alain Sarre in LNE dd. 25-4-1983, of H. Guillaume, commissair au Plan, in de Daily Telegraph dd. 21-2-1983, of $\mathrm{H}$. de Charette in Le Monde dd. 18-41986).

[28] M. Planchon van de PS: "Le développement, tel qu'il est aujourd'hui présenté, n'est pas suffisamment précis et cohérent pour servir avec efficacité de cadre de référence aux agents economiques" (Le Monde dd. 16-6-1983).

Op die kritiek volgt de zgn. 'lettre rectificative', waarin de min of meer gekwantificeerde doeleinden met betrekking tot de economische groei, de inflatie, de betalingsbalans en de ontwikkelingshulp voorkwamen (zie 5.6.3 en 5.6.4).

[29] Le Monde dd. 16-6-1983. 


\section{HET FRANSE INDUSTRIEBELEID}

\subsection{Inleiding}

De beschrijving en verklaring van het industriebeleid is een centraal element van onze probleemstelling. Het industriebeleid, dat in het kader van het indicatieve plan gestalte kreeg is in hoofdstuk 5 aan de orde gesteld. Aan het slot van het vorige hoofdstuk werd gesignaleerd, dat in Frankrijk veel belangrijke beslissingen met betrekking tot de industriële ontwikkeling worden genomen buiten de officięle planning. om in kleine kring van technocraten en topambtenaren. In dit hoofdstuk wordt na een korte schets van de historisch-culturele context het na-oorlogse industriebeleid besproken, zoals dat onder de presidenten De Gaulle, Pompidou, Giscard d'Estaing en Mitterrand gestalte kreeg.

In een aparte paragraaf zal de publieke onderneming als instrument van industriepolitiek aan de orde komen (6.2). Het in dit hoofdstuk gepresenteerde chronologische overzicht zal in hoofdstuk 7 worden uitgewerkt aan de hand van een casestudie van de "filière électronique".

\subsection{Het industriebeleid in de Vijfde Republiek}

\subsubsection{Inleiding}

In de relatie tussen de overheid en het bedrijfsleven speelden na 1945 de kartels en de branche-organisaties een belangrijke rol. De branche-organisaties gaven voor 1958 (toetreding tot de EEG) vorm aan de Franse "anti-markt-traditie' (zie Intermezzo II) door in overleg met 'hun' afdeling op het Ministerie van Industrie een plan voor de sector op te stellen. Voor de ondernemers en hun branche-organisaties

"(...) the state was not considered an alien force to be limited, but an instrument for protecting against the unknown and guarding what one had already gained" (Zysman 1977, 55).

De overheid beschermde de duizenden kartels, die in de eerste jaren na de oorlog ongeveer 85\% van de produktie beheersten (McArthur en Scott 1969). De afspraken, die het bedrijfsleven met de overheid maakte varieerden van de 'gentlemen's agreement" tot het vaststellen van quota, die tussen de producenten tegen marktprijzen werden verhandeld. De kartels werden meestal in samenwerking met de overheid beheerd door de branche-organisatie, die veelal ook de financiering van de investeringen regelde, waardoor in feite de produktiecapaciteit van elk van de leden werd beheerst [1]. 
Na de politieke chaos wan de Vierde Republiek (1944-1958) breekt met de terugkeer van De Gaulle in 1958 een periode van politieke stabiliteit aan: stabiliteit is éen van de voorwaarden om aan de 'Etat dêveloppeur' op consistente wijze inhoud te kunnen geven; lange termijn doeleinden kunnen worden ontwikkeld, een adequate institutionele structuur kan worden opgezet en een coherent geheel van instrumenten kan worden ontworpen (vergelijk hoofdstuk 3). Over de will van de Franse overheid om aan de industriële ontwikkeling richting te geven, behoeft geen twijfel te bestaan. Uitgangspunt van De Gaulle en de andere presidenten van de Vijfde Republiek is steeds het streven naar politieke onafhankelijkheid geweest, hetgeen zijn vertaling vond en windt in het streven naar 'francisation' van strategische technologieẽn en strategische 'filières de production'.

Met betrekking tot de aanpassing van de industriële structuur aan veranderende comparatieve voordlelen werd door alle presidenten en regeringen van de Vijfde Republiek een grote verantwoordelijkheid bij de overheid gelegd. Zo sprak De Gaulle (vergelijlk 6.2.1):

"Pour que notre pays repétrisse ses structures et rajeunisse sa figure, mon gouvernement, fort de l'équilibre maintenant rétabli, va engager de multiples et vigoureuses interventions" (geciteerd naar Bauer en Cohen 1985, 255).

Met de presidenten Pompidou en Giscard d'Estaing werd de toonzetting weliswaar liberaler, maar door middel van generiek en specifiek industriebeleid werd in feite gepoogd grote invloed uit te oefenen op de strategische beslissingen wan de ondernemingen (zie 6.1.2 en 6.1.3).

Mitterrand daarentegen presenteerde de overheid expliciet als de initiator en organisator van de aanpassing van de industriële structuren, waarbij 'Le Plan' en de "secteur nationalisé élargi" de centrale instrumenten vormden. Bauer en Cohen (1985, 257) vatten de visie van Mitterrand als volgt samen:

"Le Plan se voyait reconnaitre un rôle central dans l'orientation de l'économie. Expression de l'intérêt général et de la volonté nationale, il devait suppléer aux faillites du marché, soumettre les intérêts particuliers au bien public, porter l'effort national dans les domaines qui commandaient l'avenir. L'Etat, enfin, réformé, renforcé et démocratisé devait intervenir partout où les tâches de la modernisation et le projet de justice sociale l'exigeaient. En un mot, l'Etat devait arracher la France à son sous-développement relatif, il devait réveiller une France assoupie et vieillie, il devait moderniser et conduire la société."

Blijken zal dat het industriebeleid in de Vijfde Republiek een grote mate van continuilteit vertoonde: de interventies van liberale presidenten waren talrijker en specifieker dan op basis van hun retoriek zou mogen worden verwacht, terwijl Mitterrand grote tegenkrachten ontmoette, waardoor zijn voluntaristische aanpak in belangrijke mate moest worden bijgesteld.

\subsection{1 'La politique industrielle Gaullienne' (1958-1969)}

Na de Tweede Wereldoorlog verkeerde het Franse produktieapparaat in een 'piètre étar". L'Insee (1951) portretteerde de situatie qua sectorale opbouw, produktietechnologie en regionale spreiding (Cahiers Français no. 211, 1983, 4 en 8). In het kader van het Plan werd aanvankelijk een zeer selectief en dirigistisch beleid gevoerd, waar- 
na in het Tweede en Derde Plan voor een meer integrale benadering werd gekozen (vergelijk hoofdstuk 5). Met de creatie van de EEG signaleerde het bedrijfsleven het gevaar van de buitenlandse concurrentie; familiebedrijven, waarin vrijwel elke vorm van strategische planning ontbrak riepen de hulp van de overheid in. Deze koos enerzijds voor generiek beleid, waarbij langs macroeconomische weg voor een beter concurrentieklimaat moest worden gezorgd (Plan Rueff) en anderzijds voor specifiek beleid, waarbij de organisatie van de industriële structuur op meso- en microniveau ter hand werd genomen. De specifieke overheidsinterventies waren enerzijds gericht op het creëren van grote ondernemingen, die als 'Champion National' de strijd met andere giganten op de wereldmarkt moesten aankunnen en anderzijds op het realiseren van specifieke lange termijn projekten, die Frankrijk onafhankelijk moesten maken met betrekking tot produktie van wapens, energie en dergelijke (Grands Pro. grammes).

Ook kende het specifieke industriebeleid in de Vijfde Republiek de zogeheten 'Plans sectoriels": omdat het ondernemingsinitiatief met name in de innovatie- en stagnatiefase uitbleef, nam de overheid de organisatie van strategisch geachte sectoren voor haar rekening.

\section{Generiek beleid; Plan Rueff}

De politiek was de mening toegedaan, dat de opening van de grenzen een fundamentele reorganisatie van de Franse economie vereiste. Protectie, subsidies en loon- en prijsindexaties dienden plaats te maken voor kostenmatiging en inflatiebestrijding, waardoor voor de ondernemingen voldoende financiële ruimte zou ontstaan ter financiering van de investeringen nodig voor de modernisering van het produktieapparaat (Sautter 1982). Het Plan Rueff (1958) beoogde de inflatie (15\%) en het tekort op de handelsbalans terug te dringen door het afschaffen van de koppelingen tussen lonen en prijzen, het verlagen van de sociale uitkeringen, het verminderen van de subsidies voor de publieke ondernemingen en een devaluatie van $17.5 \%$.

Het Plan Rueff stond model voor diverse plannen van de Vijfde Republiek gericht op de stabilisatie van de conjuncturele ontwikkeling (Plan de Stabilisation, Plan-Barre, Plan-Delors). Zoals in hoofdstuk 5 is uiteengezet noodzaakten de korte termijn inflatie- en betalingsbalansproblemen tot conjuncturele ingrepen, die de lange termijn doeleinden van het Plan doorkruisten en de positie van het Ministerie van Financiën versterkten. Dat neemt niet weg, dat de overheid in de periode-De Gaulle ook de structuurpolitiek vorm heeft gegeven met name door het opzetten van de zogeheten "Grands Programmes".

\section{Grands Programmes}

Vanuit de politieke wens van nationale onafhankelijkheid gingen onder president De Gaulle de 'Grands Programmes' van start. Soms worden zij aangekondigd in het Nationale Plan, maar zoals in hoofdstuk 5 is besproken, wond de realisatie van deze programma's niet of nauwelijks in het kader van de Nationale planning plaats.

In het algemeen kan een 'Grand Programme' als volgt worden gekenmerkt:

- de politiek selecteert een programma met het doel de onafhankelijkheid van van 
Frankrijk te waarborgen (bijv. energie, wapensystemen, electronica);

- het onderzoek in partikuliere en publieke organisaties wordt gecentraliseerd;

- de produktie wordt geconcentreerd bif een 'Champion National", die veelal fuseert. Bestaat geen partikuliere onderneming, dan wordt een publieke onderneming in he leven geroepen. Ook het netwerk van toeleveringsbedrijen wordt door de overheld rond de sleutelonderneming georganiseerd;

- de binnenlandse markt wordt afgeschermd, opdat de Nationale Kampioen lange termijn plannen kan ontwikkelen. Met name van een gegarandeerde overheidsvaag kan een stabiliserende werking uitgaan;

- heeft de binnenlandse sector voldoende concurrentiekracht ontwikkeld, dan worden de grenzen geopend en de export ondersteund met een krachtige 'diplomatie industrielle".

\section{Sectorplannen}

Naast de "Grands Programmes" voert de overheid in de Vijfde Republiek een specifiek industriebeleid met betrekking tot sectoren, die van strategisch belang worden geacht, maar waarin de ondernemingen onvoldoende initiatief tot investeren en reorganiseren nemen. De machinebouw, jzer en staal, de chemie zijn sectoren, die van elke regering in de Vijfde Republiek de aandacht vroegen en kregen. Aangezien het sectorbeleid eigenijk vanaf het begin van de jaren zeventig een belangrijke rol gaat spelen, worden de 'Plans sectoriels' niet op deze plaats, maar in 6.1.3.3 nader belicht.

\subsection{2 'Limperatif industrlel' (politique industrlelle Pompldolienne) (1969-1974)}

\subsubsection{Inleiding}

Tussen 1965 en 1970 verschenen in Frankrijk enkele invloedrijke boeken en rapporten [2], die allen de 'L'exigence de compétivité benadrukten. Met name het bevorderen van het ontstaan van grote industriele groepen (6.1.2.1) en het ontwikkelen van nieuwe 'Grands Programmes' (6.1.2.2) kwamen in het industriebeleid centraal te staan.

\subsubsection{Concentratie: de Industriële groep}

De opening van de grenzen betekende niet dat de coördinatie van de economische handelingen aan het marktmechanisme werd overgelaten. Wel trad een verandering op in het overheidsbeleid:

"The state is no longer satisfied to guard a static balance in the economy, but is carefully and selectively prodding business to adopt competitive policies of growth" (Zysman 1977, 61).

Zo stimuleerde de overheid vanaf het midden van de jaren zestig het ontstaan van grote industriele groepen, die zich op basis van schaalvoordelen een sterke concurrentiepositie moesten verwerven.

"(...) il apparait aux pouvoirs publics que le marché européen et mondial ne peut être pénétré valablement que par des secteurs industriels de pointe et des groupes industriels sollides et de très grande taille dont ils vont donc susciter la création" (Gongeon en Ponson 1983, 53). 
Tabel 6.1 Het ontstaan van de industriële groepen in Frankrijk van 1965 tot 1974.

\begin{tabular}{|c|c|c|c|}
\hline AnnGe & $\begin{array}{l}\text { Entreprises } \\
\text { se regroupant }\end{array}$ & Secteur d'activitú & Groupe final \\
\hline 1965 & $\begin{array}{l}\text { Ugine } \ldots \ldots \ldots \ldots \ldots \ldots \ldots \ldots \\
\text { Kuhimann } \ldots \ldots \ldots \ldots \ldots \ldots \ldots \ldots \\
\text { BRP, RAP } \ldots \ldots \ldots \ldots \ldots \ldots\end{array}$ & $\begin{array}{l}\text { Transf. metaux } \\
\text { Chimie } \\
\text { Pétrole (État) }\end{array}$ & $\begin{array}{l}\text { Ugine Kuhlmann } \\
\text { ERAP }\end{array}$ \\
\hline 1966 & 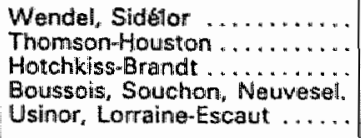 & $\begin{array}{l}\text { Siderurgie } \\
\text { Electroménager } \\
\text { Equipement militaire } \\
\text { Verre } \\
\text { Sidenurgie }\end{array}$ & $\begin{array}{l}\text { Wondel-Siddélor } \\
\text { Thomson-Brandt } \\
\text { BSN } \\
\text { Usinor-DNEL. }\end{array}$ \\
\hline 1967 & 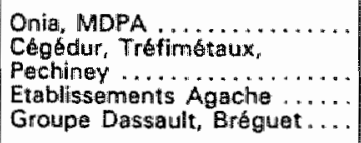 & $\begin{array}{l}\text { Chimie (Etat) } \\
\text { Métaux } \\
\text { Textile } \\
\text { Áronautique }\end{array}$ & $\begin{array}{l}\text { EMC } \\
\text { Pechiney tabsorptiony } \\
\text { Agache-Willot } \\
\text { Dassault }\end{array}$ \\
\hline 1968 & Thomson-Brandt, CGTSF .... & Électrique & $\begin{array}{l}\text { Thomson-CSF } \\
\text { (apports d'actifs) }\end{array}$ \\
\hline 1969 & Agache-Willot, Saint-Freres & Textilie & $\begin{array}{l}\text { Agache-Willot } \\
\text { [absorption] }\end{array}$ \\
\hline 1970 & 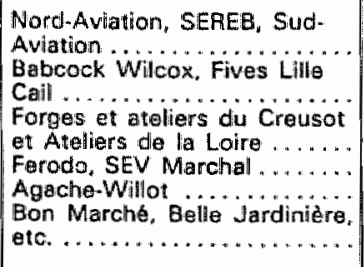 & $\begin{array}{l}\text { Aéronautique } \\
\text { Équipement } \\
\text { Siderurgie } \\
\text { Equipement auto } \\
\text { Textile } \\
\text { Négoce }\end{array}$ & $\begin{array}{l}\text { SNIAS } \\
\text { Babcok-Fives } \\
\text { Creusot-Loire } \\
\text { Ferodo (absorption) } \\
\text { Agache-Willot }\end{array}$ \\
\hline-1971 & 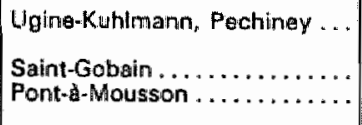 & $\begin{array}{l}\text { Chingie et métaux } \\
\text { non ferreux } \\
\text { Verre } \\
\text { Fonderie }\end{array}$ & $\begin{array}{l}\text { PUK } \\
\text { SGPM }\end{array}$ \\
\hline $\begin{array}{l}1961 \text { - } \\
1972\end{array}$ & $\begin{array}{l}\text { Constitution progressive du } \\
\text { groupe DMC } \ldots \ldots \ldots \ldots \ldots \ldots \ldots \\
\text { Bgghin, Say } \ldots \ldots \ldots \ldots \ldots \ldots \\
\text { Empain, Schneider } \ldots \ldots \ldots \ldots\end{array}$ & $\begin{array}{l}\text { Textile } \\
\text { Sucre } \\
\text { Equipement }\end{array}$ & $\begin{array}{l}\text { DMC } \\
\text { Beghin-Say } \\
\text { Empairn-Schneider }\end{array}$ \\
\hline 1973 & $\begin{array}{l}\text { BSN } \\
\text { Genvis-Danone } \ldots \ldots \ldots \ldots \ldots \ldots \\
\text { LOntal } \ldots \ldots \ldots \ldots \ldots \ldots \\
\text { Synthalabo } \ldots \ldots \ldots \ldots \ldots \ldots \ldots\end{array}$ & $\begin{array}{l}\text { Varre } \\
\text { Alimentalira } \\
\text { Parfumarie } \\
\text { Phatimacio }\end{array}$ & $\begin{array}{l}\text { BSN-Genvais-Danono } \\
\text { L'Oreal (absorption) }\end{array}$ \\
\hline 1974 & $\begin{array}{l}\text { Mokta, Penarroya, Le Nickel. } \\
\text { Pemod, Alicard: ............... }\end{array}$ & $\begin{array}{l}\text { Metaux non forroux } \\
\text { Alimentaira }\end{array}$ & $\begin{array}{l}\text { Imótal } \\
\text { Pernod-Alicard }\end{array}$ \\
\hline
\end{tabular}

Bron: Congeon en Ponson (1983, 54).

Om haar specifieke industriebeleid in het kader van de 'Grands Programmes' en de sectorplannen effectief gestalte te kunnen geven streefde de Franse overheid naar het ontstaan van één of twee 'Champions Nationales' per sector. Stoléru (1969) toonde zich een groot voorstander van het Champion-beleid, waarbij door het bestaan van de verbindingen via de "corps d'état" een goede mogelijkheid aanwezig zou zijn de strategie van de onderneming af te stemmen op de doeleinden van de overheid.

De concentratie werd door de Franse overheid niet alleen gestimuleerd door middel van fiscale maatregelen, maar ook door direkte interventies. Hoewel met de nationalisaties van 1945 ondernemingen ontstonden als Renault, CdF en SNCF, die reeds enige kenmerken van een industriẻle groep vertoonden en ook in de jaren vijftig 
ondernemingen als $\mathrm{CGE}_{*}$ Rhóne-Poulenc, Lafarge, Air Liquide en Mïchelin een sterke groei doormaakten,is het fenomeen van de industrięle groep in Frankrijk pas na 1965 sterk opgekomen.

In de periode van 1966 tot 1973 werden de industriele en financiële groepen gecreèerd, die ook hedentendage de Franse industriële structuur domineren (zie tabel 6.1).

Om een sterke internationale concurrentiepositie te verkrijgen dienden de industriẻle groepen te internationaliseren; de Franse groepen dienden hun activiteiten uit te breiden tot over de grenzen, niet alleen om te profiteren van lage lonen, vermindering van transportkosten, het omzeilen van importbelemmeringen, of voor het opzetten van een buitenlands commercieel netwerk, maar ook om de beschikking te krijgen over belangrijke grondstoffen, zoals olie en ijzererts.

Karpik (1987) zet uiteen, dat de "large enterprise à la françailse' eneraijds wordt gekenmerkt door een strategie, waarvan de symbiose met de staat, de nadruk op technologische creaties en het vermijden van concurrentie, de belangrijkste elementen vormen en anderzijds door een specifieke organisatievorm, waarin een elite de skepter zwaait, sprake is van strakke hiërarchische verhoudingen, het strategisch en uitvoerend management sterk zijn gescheiden en waarin het 'compartimentsdenken" (sterk gescheiden organisatorische eenheden) overheerst. De elite van het strategisch management is afgesloten van de dagelijkse managementproblemen; één van haar belangrijkste taken is het onderhouden van de nauwe banden met het politiek-bestuurlijke circuit, dat woor een groot deel voor de vulling van de orderportefeuille zorgt.

De verklaring voor het ontstaan, de ontwikkeling en de strategie van de grote Franse industriële groepen dient niet alleen, of juist maar zeer ten dele te worden gezocht in technisch-economische factoren zoals schaalvoordelen. Ook de prioriteiten, die de Franse overheid stelde met haar 'Grands Programmes', die veelall werden opgebouwd rond één 'Champion Nationale" vormen geen afdoende verklaring voor de organisatievorm en de strategie van de groepen, omdat in een aantal gevallen het management een beleid tegengesteld aan de overheidsdoelstellingen ontwikkelde (vergelijk bijv. de strategie van Thomson en CGE ten opzichte van CII in het kader van het Plan Calcul, zie hoofdstuk 7).

De verklaring van de vormgeving en de strategie van een groot aantal van de Franse industriele groepen blijkt vooral gezocht te moeten worden in de typische sociopolitieke structuur met de 'corps d'état' en daarmee verbonden karakteristieken van de markt, waarop de groepen opereren. Nagenoeg alle in tabel 6.1 genoemde groepen zetten hun produkten af op markten, waarop de overheid een zeer belangrijk deel van de vraag woor haar rekening neemt. Veelal betreft het (delen van) langlopende indu* striẻle projekten, die in nauw over $\|$ eg tussen de ambtenaren, politici en managers van eenzelfde 'corps" tot stand zijn gekomen. Zysman (1977) zet uiteen, dat een hiërarchische organisatiestructuur, die parallellen vertoont met de structuur van het overheidsapparaat, voor de industriële groepen een efficiënte structuur is voor het binnenhalen van de overheidsorders en het afstemmen van het produkt op de politieke normen en de plannen van de andere actoren in het netwerk van een 'Grand Program$m e$ '. In tegenstelling tot Chandler's 'structure follows strategy" is ten aanzien van de Franse ìndustriële groepen van het omgekeerde sprake: de hiërarchische structuur met 
een ellite in de top, die nauwe banden heeft met de politieke en ambtelijke top en opereert op een markt, die wordt gedomineerd door langlopende overheidsprojekten, is bepalend voor de strategie van de groep. De groep richt zich op door de overheid afgeschermde dan wel door haar vraag gedomineerde markten, investeert veel in het ontwikkelen van een produkt, dat aan de technische eisen van de vrager moet voldoen en bekommert zich niet om commercialisering en de concurrentie op de wereldmarkt. De daarbij passende hiërarchische structuur is niet geschikt voor alert handelen op turbulente markten waar een hevige concurrentiestrijd woedt. Dan is een flexibele structuur van bijv. de ' $M$-form' en ringen van 'sub-contractors' gewenst.

In het verleden hebben de grote Franse groepen de concurrentiemarkten vermeden, omdat de interne coherentie van die groepen het betreden van markten, die een andere organisatiestructuur vergen, verbood (Karpik 1987, 6) [3]. De industriële groepen, die deel uitmaken van het circuit van de 'Grands corps" worden gekenmerkt door een hiërarchische structuur en een strategie, waarbij de onderneming zich via het sociopolitieke circuit richt op de overheidsvraag, waardoor op haar beurt de hiẻrarchische structuur weer wordt versterkt (zie schema 6.1) [4].

Schema 6.1 Faktoren van invloed op de ondernemingsstructuur

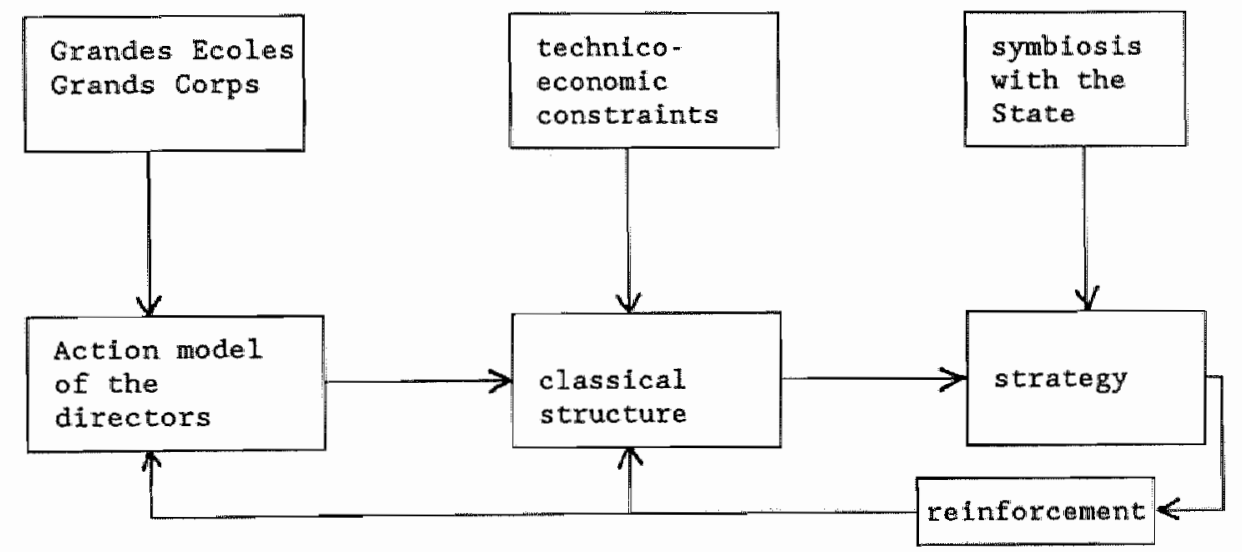

Bron: Karpik 1987, 13.

\subsubsection{2 'Grands Programmes': speerpunten}

Van de 'Grands Programmes' onder Pompidou maakten vooral de telecommunicatie en de nucleaire energie een sterke ontwikkeling door. Omdat de Franse binnenlandse markt te beperkt was en de benodigde financiële middelen de Franse macht te boven gingen, werd voor een aantal 'Grands Programmes' samenwerking gezocht met Europese partners. Die ontwikkeling werd in de jaren zeventig en tachtig sterker en mondde onder Mitterrand uit in het Eureka-initiatief [5]. De achterliggende filosofie is, dat coute que coûte afhankelijkheid van Amerikaanse technologie moet worden vermeden. De Europese oriëntatie van de 'Grands Programmes' ten tijde van 
Pompidou blijkt uit het beleid van Aerospatial (Concorde en Airbus), CNES (Ariane welke na tien jaar van onderhandeling in 1973 voor de eerste maal wordt gelanceerd), CII (Unidataprojekt, waarin werd samengewerkt met Siemens en Philips) en EDF (Europees verrijkingsprogramma Tricastin in 1973).

Geconcludeerd kan worden, dat in de periode Pompidou werd gezocht naar een combinatie van generiek beleid, gericht op het scheppen van een investeringsvriendelijk ondernemingsklimaat en een specifiek beleid, gericht op het creëren van industriële groepen en het realiseren van ambitieuze 'Grands Programmes".

\subsection{3 'La politique industrielle Giscardienne' (1974-1981)}

\subsubsection{Inleiding}

Het industriebeleid van Valếry Giscard d'Estaing (VGE) was gebaseerd op 'devx jambes' (Morvan 1983): conform de neo-liberale filosofie van VGE en zeker van zijn eerste minister Raymond Barre (1976-1981), werd de markt geliberaliseerd en thet initiatief aan de ondernemers gelaten; tegelijkertijd werd echter niet geschroomd sectoren van overheidswege te reorganiseren en individuele ondernemingen te steunen (6.2.3.11). Het devies 'n'intervenir que pour fortifier' $\mathrm{kreeg}$ institutioneel vorm in een viertal interdepartementale commissies, die met betrekking tot het industriebeleid vergaande bevoegdheden hadden (6.2.3.2). Het neoliberale industriebeleid resulteerde in een relatief kwetsbare industriële structuur met een beperkt aantal sterke, maar geïsoleerde sectoren (6.2.3.3).

\subsubsection{1 'Redéploiement industriel': deux jambes}

VGE poogde de concurrentiepositie van het bedrijfsleven te versterken door een 'redéploiement industriel', welke een terugtreden van de overheid en het centraal stellen van de onderneming en het marktmechanisme voorstond.

"Contrairement à l'ỉée recue, le redéploiement industriel ne doit donc pas être synonyme d'extension de l'emprise de l'Etat sur l'économie: il commande, au contraire, de rationaliser et de diminuer les interventions: la responsabilité de l'adaptation de l'appareil productif francais incombe aux chefs d'entreprise euxmêmes"' (de Combret 1978, 9).

Tevens kondigde de regering aan, dat naast haar beleid gericht op het versterken van de grote industriële groepen de aandacht vooral zou uitgaan naar de 'Petits et Moyens entreprises' (PME) en met name naar de 'Petits et Moyens Entreprises Industriels' (PMI),

De 'liberale' benadering kreeg zijn ware vorm toen door Raymond Barre na 1979 het generieke industriebeleid een centrale plaats kreeg toegewezen, het mededingingsbeleid nieuw leven werd ingeblazen, de prijscontroles werden opgeheven, de beperkingen ten aanzien van buitenlandse investeringen werden verruimd, de kapitaalmarkt werd geliberaliseerd (Loi Monory in 1978) en een monetair belleid werd gevoerd, dat was gericht op een versterking van de internationale positie van de franc.

Hoewel de regering in de presentatie van haar beleid er minder nadruk op legde, was ook onder Giscard d'Estaing sprake van een specifiek interveniërende overheid. Aanvankelijk was de aandacht gericht op de 'bande des quatres' [6], welke later werd 
uitgebreid tot een zevental speerpuntsectoren. De overheid selecteerde in de desbetreffendle sector een sleutelonderneming, waarmee een contract werd afgesloten met het doel aan de steunverlening specifieke voorwaarden te verbinden met betrekking tot reorganisatie, investeringen en dergelijke. Green (1983a, 169) schrijft over die zogenaamde 'Strategic Reinforcement Approach' van 1980:

"Paradoxically, the application of a pragmatic market- orientated attitude to finance supply resulted in a more detailed and direct involvement of the state in the pace and direction of industrial development. Dirigism was not abandoned but simply transformed into 'liberal direction"."

\subsubsection{De institutionele vormgeving; interdepartementale commissies; contracteconomie}

De coördinatie van het industriebeleid, lag in de eerste jaren na de Tweede Wereldoorlog in handen van 'Le Plan'. Die taak verdween geheel toen VGE de moderniseringscommissies van het Plan verving door een 'Consell Central de La Planification'.
"Valéry Giscard d'Estaing ne brise pas, au niveau du discours, avec l'ardente obligation du général de Gaulle. Il prétend même le rendre plus opérationnel. Voilla ce qu'il faut faire, jour après jour, pour maintenir l'emploi et en même temps pour transformer les structures de l'économie française dans le cadre d'un programme d'ensemble dont le conseil central de planification que j'ai créé arrêtera les grandes lignes" (Bauer en Cohen, 1985, 255).

De coördinatie van het beleid met betrekking tot de aanpassing van de structuur berustte bij de nieuwe Centrale Raad, maar zoals in hoofdstuk 5 is besproken bleek die raad zich niet tot een centrale coördinerende instantie met betrekking tot het structuurbeleid te ontwikkelen.

Die rol wist het Ministerie van Industrie zich evenmin toe te eigenen. De wil daartoe was reeds onder De Gaulle bij diverse achtereenvolgende Ministers van Industrie aanwezig, temeer daar het Ministerie van Financiën het ontwikkelen van een voluntaristisch industriebeleid niet ambieerde [7].

Ortoli stelde bij zijn benoeming in 1969 als 'Ministre du Développement Industriel et Scientifique,, dat zijn ministerie belangrijke coördinerende taken had met betrekking tot de financiering van de industriële ontwikkeling (IDI) en de regionale spreiding (DATAR). Een 'Comité interministériel de politique industrielle' moest voor de coördinatie van het industriebeleid zorgdragen. Toen Ortoli in 1972 zijn ministerie aan Rue de Grenelle verliet schreef Le Monde (25-7-1972): "Beaucoup d'interventions, pas de stratégie", waarmee werd aangegeven dat van een gecoördineerdle strategie, gericht op expliciete lange termijn doeleinden geen sprake was. Toen de opvolger van Ortoli, Jean Charbonnel, het ministerie verliet schreef Le Monde:

"Le pouvoir était ailleurs, sur l"affaïre Lip, sur l'affaire Berliet ou face à la CGE. Le ministre n'a pu ni faire prévaloir son point de vue face aux industriels, ni mème être soutenu par le gouvernement auquel il appartenail" (geciteerd naar Bauer en Cohen 1985, 269).

Met andere woorden: de coördinerende taak met betrekking tot enerzijds de ministeries en anderzijds de industriële groepen werd door het Ministerie van Industrie 
keer op keer niet waargemaakt. Dat weerhield Minister d'Ornano er in 1974 niet van te verklaren:

"Je crois indispensable l'existence en France d'un ministère chargé de coordonner le développement industriel et scientifique du pays, pour ma part j'ai l'intention de m"employer à cette tâche et $(. .$.$) , je prendrai les mesures$ nécessaires tant en ce qui concerne la répartition des attributions que la cooperation interministérielle (...)"

Het ontbreken van een deskundig en krachtig coördinerend ministerie heeft in de loop der jaren tot een verbrokkeling van het beleid en een 'maquis de mésures' geleid (Hough 1979; Petit 1983). Met name door de directe verbindingen tussen de afdelingen van het Ministerie van Industrie met hun "eigen" branches en ondernemingen werd een gecoỏrdineerde aanpak problematisch. In de loop van de jaren zeventig vond met betrekking tot de coördinatie van het industriebeleid een belangwekkende ontwikkeling plaats: de coördinatie van het beleid ten aanzien van de stagnerende sectoren, het stimuleren van nieuwe ondernemingen, de regionale spreiding van industriële activiteiten en de veelbelovende 'sunrise'-sectoren werd gedelegeerd aan vier kleine inderdepartamentale commissies. In die kleine slagvaardige commissies participeren ministers van de desbetreffende departementen, die worden bijgestaan door een deskundige staf van topambtenaren van de 'Trésor'. Green (1983a, 175) spreekt van een organisatorische innowatie:

"The interministerial committees are at the heart of French efforts to manage industrial crises. Ostensibly, they constitute an imaginative and highly appropriate innovation within a tradition of state responsibility for industrial success"'.

\section{CIASI (Comité Interministériel pour l'Amênagement des Structures Industrielles)}

In 1974 werd de CIASI ingesteld met het doel steun te verlenen aan ondernemingen in stagnerende sectoren, die in potentie de concurrentie aankonden, maar tijdelijk in financiële problemen verkeerden. De CIASI werd opgevat als een externe organisatievorm ter compensatie van een falende kapitaalmarkt. De overheid stelde financiële middelen beschikbaar op voorwaarde, dat de onderneming ook zelf een belangrijk

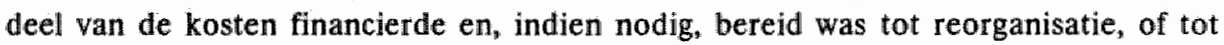
vervanging van het management. Daarbij ontstond overigens het gevaar, dat een goed lopende onderneming werd 'verzocht' een slecht geleide onderneming over te nemen met het risiko mee gesleurd te worden in het dal (Curzon Prize 1981).

De CIASI vergaderde eénmaal per week en bleek in staat op basis van de rapporten van de 'Trésor' tot snelle beslissingen te komen. Tot 1981 werden via de CLASI ongeveer 900 ondernemingen gesteund, waarmee een bedrag was gemoeid van 2.8 MdF. De steun werd vooral verleend aan ondernemingen in de stagnatiefase (staal, textiel, scheepsbouw), maar a priori waren geen sectoren van steunverlening uitgesloten [8].

\section{FSAI (Fonds Spécial d'Adaptation Industrielle)}

Deze interdepartementale commissie coördineerde het regionale industriebeleid. 
Ondernemingen in nieuwe veelbelovende sectoren werden gestimulleerd zich te vestigen in regio's met relatief veel werklozen. Investeringen werden tot $50 \%$ door de FSAI gefinancierd met behulp van de zogeheten 'prêts participatifs' (lange termijn leningen tegen een lage rente, die een deel van het eigen vermogen worden als de onderneming winst maakt en de overheid zich terugtrekt) [9].

CIDISE (Comité interministériel pour le Développement des Investissements et le Soutien de l'Emploi)

Deze interdepartementale commissie selecteerde kleine veelbelovende ondernemingen, voorzag hen van risicodragend kapitaal onder voorwaarde, dat hun investeringsprogramma's een bijdrage leverden aan de export, importsubstitutie, of aan produkten procesinnovaties. Gelijk de CIASI werd door de CIDISE op joint venture basis deelgenomen.

\section{CODIS (Comité de Développement des Industries Stratégiques)}

In 1978 werd de CODIS opgericht. Bedoeld als een 'mini-MITr' stond de commissie voor de taak een beperkt aantal strategische sectoren te selecteren (robotica, biotechnologie, kantoorautomatisering, energiebesparing, off-shore) en binnen elke sector een sleutelonderneming uit te kiezen, waarmee een 'Contrat de développement' moest worden afgesloten, waarin de voorwaarden van de financiële steunverlening werden vastgelegd. Hoewel de CODIS niet over eigen financiële middelen beschikte Iuidt het oordeel van Green (1983a, 181):

"Indeed, despite the limitation of its jurisdiction, the launch of the CODIS procedure gave the government the possibility of pursuing systematic and detailed industrial planning of a type never before seen in France".

\section{Contracteconomie}

Vanaf het midden van de jaren zestig heeft de Franse overheid een voorkeur aan de dag gelegd voor het afsluiten van contracten met branche-organisaties en individuele partikuliere en publieke ondernemingen. Met recht kan van een 'contracteconomie' (Vermaat 1980) worden gesproken (vergelijk Lutz 1969, 30 en 45; Green 1982; Hough 1979) "De contracten tussen de overheid en het bedrijfsleven werden enerzijds afgesloten in het kader van de inflatiebestrijding en anderzijds in het kader van het industriebeleid.

Zo werden in 1966 de zogeheten 'contrats de stabilité' afgesloten. De strikte prijsbeheersing werd opgeheven en in plaats daarvan werden ter beteugeling van de inflatie contracten afgesloten: de prijs van een produkt mocht worden verhoogd, als die van een ander produkt navenant werd verlaagd.

In de 'contrats anti-hausse' van 1971 werd vastgelegd, dat de prijzen in een periode van zes maanden met slechts $1.5 \%$ mochten stijgen en dat in de dienstensector in het geheel geen prijsstijging mocht plaatsvinden. In de 'Programmation annuelle' van 1972 voor de PME gold, dat prijsstijgingen alleen waren toegestaan als de prijzen van de grondstoffen waren gestegen. In de "Accord de programmation annuelle accordée" (1974) werd vastgelegd, dat elke verlaging van de grondstoffenprijs onmiddellijk in 
een prijsdaling moest worden doorgegeven. Elke winststijging werd voor $100 \%$ wegbelast.

In de 'contrats de progrès' met de publieke ondernemingen werd vastgelegd, dat de loonontwikkeling de prijsstijging mocht overstijgen voor zover er een produktiviteitsstijging tegenover stond.

Wat het industriebeleid betreft zijn de 'Programmes d'Action concentée' vermeldenswaard: daarin werden tussen de overheid en de ondernemingen van een sector voorwaarden van de reorganisatie vastgelegd. In 1966 werden dergelijke 'programmes" afgesloten met de ijzer- en staalsector, de electronica (Plan Calcul) en later ook met de meubel- en speelgoedindustrie. Opgemerkt dient te worden, dat de 'Programmes' globaal van karakter waren en meer een morele aansporing impliceerden, dan dat sprake was van harde juridische sancties (Green 1982).

De 'contrats de développement' in het kader van de CODIS pasten in de Franse contract-traditie.

Voor een 'Etat développeur' biedt het contract de mogelijkheid zekerheid te krijgen over de strategische beslissingen van de onderneming, terwijl de onderneming zich gevrijwaard weet van ad hoc interventies. De contracten, afgesloten in het kader van de CODIS, impliceerden een verschuiving van een min of meer globaal sectorbeleid naar een meer ondernemingsspecifiek beleid. Green (1982) acht de contracten afgesloten met de particuliere ondernemingen een effectief instrument, omdat in geval van het niet nakomen van de verplichtingen, de overheid haar financiële steun kan intrekken met een mogelijk faillissement van de onderneming als gevolg. Dat is een sterke sanctie van de overheid. Zo werd bijw. in de electronische sector met een aantal ondernemingen een 'contrat de croissance' afgesloten, waarin werd bepaald dat $12 \%$ van de investeringen met een 'zachte' lening zou worden gefinancierd onder voorwaarde, dat de lening tegen normalle rentetarieven zou worden terugbetaald als de investeringsdoeleinden miet zouden worden gehaald.

Zoals in 6.2 uiteengezet zall worden, verkeerde de overheid ten aanzien van de publieke ondernemingen in een andere positie, waardoor haar sancties zwakker waren en zij niet zo'n duidelijk standpunt kon innemen als tegenover de partikuliere ondernemingen.

\subsubsection{De balans van een neo-liberaal industriebeleid}

Wat zijn de gevolgen van 'la politique industrielle Giscardienne' voor de ontwikkeling van de industriele structuur? Het oordeel is niet onverdeeld positief:

- Ondanks pogingen het industriebeleid te coördineren in een viertal interdepartementale commissies, moet worden geconstateerd dat in het begin van de jaren tachtig nog steeds sprake is van een 'maquis de mésures' (Morvan 1983).

- Ondanks de intentieverklaring van de regering het accent van het beleid te verschuiven van de grote industriële groepen naar het $P M E$, blijkt achteraf toch, dat de grote ondernemingen vooral van de steunverlening te hebben geprofiteerd. Door de steun te richten op een beperkt aantal grote industriële groepen ontstond een industriële structuur met enkele sterk concurrerende speerpuntondernemingen, die echter geen verbinding hadden met de andere elementen van de industriële structuur ( het zgn. 'crénequxt'-beleid). 
- Ondanks de intentieverklaring het accent te verschuiven van een defensieve naar een offensieve aanpak stromen in het begin wan de jaren tachtig nog altijd grote sommen geld naar de traditionele probleemsectioren.

- Ondanks het in standhouden van 'Le Plan' en het instellen van een 'Conseil Ceritral de la Planification' vindt de besluitvorming met betrekking tot het industriebeleid niet plaats op basis van een breed consultatieproces, maar in kleine kring van topambtenaren en managers van grote industriële groepen. (Thierry en Soulage 1983 spreken van een beleid 'ératiste et centraliste').

In het navolgende wordt op elk van de genoemde punten nader ingegaan.

\section{Maquis de mésures}

Schema 6.2 Instanties betrokken bij het industriebeleid in 1981.

\begin{tabular}{|c|c|c|}
\hline Orgamismas & Bul to l'intervenition & Modafites des canceurs \\
\hline 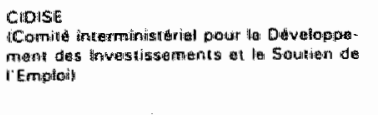 & 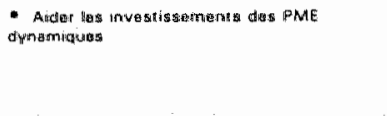 & 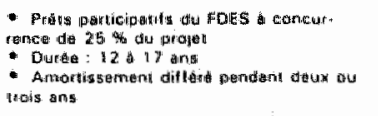 \\
\hline 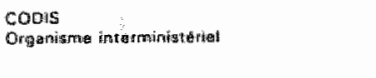 & 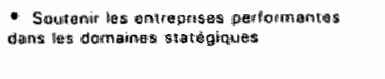 & 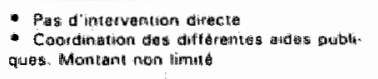 \\
\hline 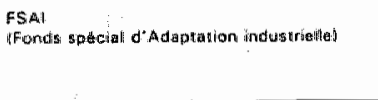 & 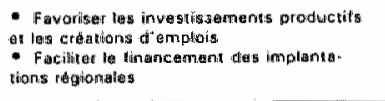 & 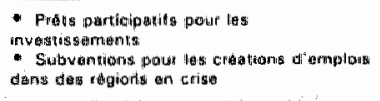 \\
\hline 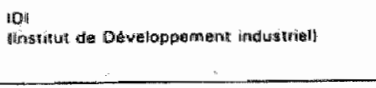 & 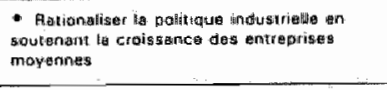 & 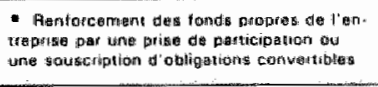 \\
\hline 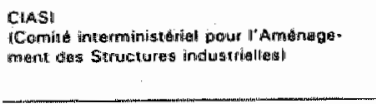 & 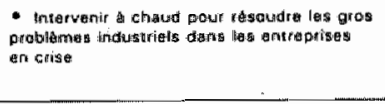 & 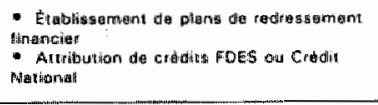 \\
\hline 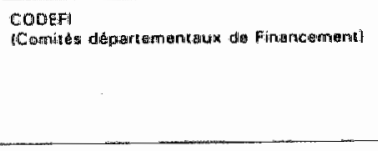 & 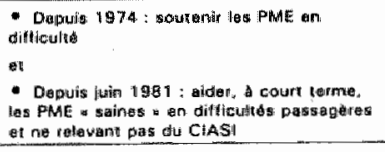 & 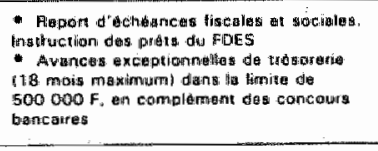 \\
\hline 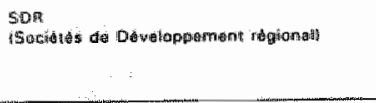 & 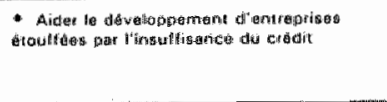 & 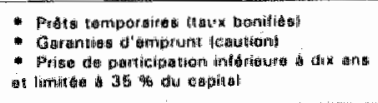 \\
\hline 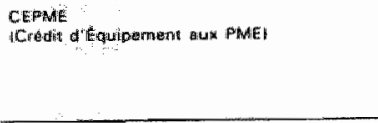 & 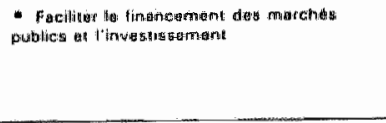 & 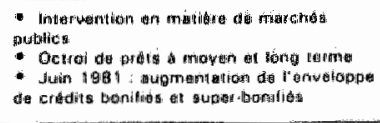 \\
\hline Crebdit Netlomel & 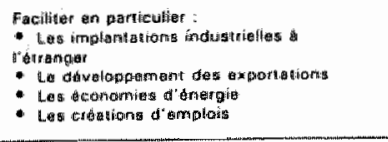 & 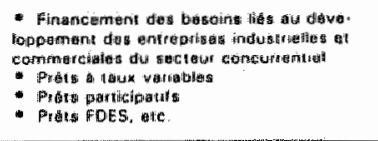 \\
\hline 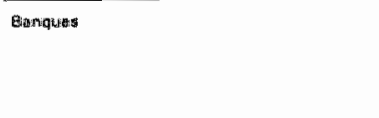 & 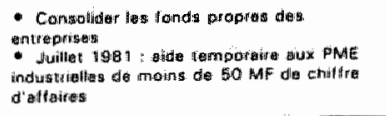 & 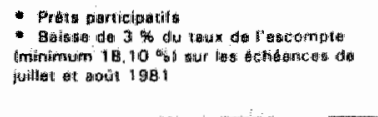 \\
\hline
\end{tabular}

Bron: CF no. $212(1983,12)$. 
Uit schema 6.2 blijkt welke instanties bij de financiering van het industriebeleid waren betrokken. Tal van ministeries hadden vanuit hun eigen optiek bemoeienis met de industriêle ontwikkeling: Ministerie van Industrie, Energie, Transport, Defensie, Posten Telecommunicatie, Buitenlandse Handel, Technologie, Ruimtelijke Ordening en last but not least het Ministerie van Financiên.

De regelingen zijn door de bemoeienis vanuit diverse invalshoeken een 'maquis' geworden.

"Ce système d'aides, constitué par strates successives sans harmonisation globale, forme un maquis touffu, fait d'un ensemble complexe de prêts, de subventions, de garanties, de marchés publics, de bonifications, et apparait comme un ensemble mal maitrisé, trop centralisé, cloisonné en de multiples guichets gerés par des administrations jalouses de leur pouvoir, reconduites sans toujours de visions stratégiques clairement explicites" (Stoffaès 1983b, 13).

\section{La polltique de créneaux}

Van 1945-1973 heeft een snelle industrialisatie plaats gevonden. Weliswaar werden vanaf het midden van de jaren zestig regio's in het noorden en oosten met ernstige problemen geconfronteerd, maar de groeieuforie bleef overheersen. De crisis van 1973 toonde de rellatieve zwakte van de Franse industrie, ondanks de sterke positie in enkele 'créneaux'. Het beeld is per sector verschillend en daarbinnen weer per onderneming. In zijn algemeenheid (zie Messeca 1983a) blijkt de zware industrie (ijzer en staal, scheepsbouw, ijzergieterij, basischemie, raffinaderijen, hout-papier) in ernstige problemen te verkeren. Andere basissectoren, zoals glas, cement en aluminium zijn wel concurrerend. De consumptiegoederen 'en repli', zoals textiel, leder, speelgoed, meubels en schoenen worden met een stagnerende markt en toenemende concurrentie geconfronteerd. Ook de industrie van de huishoudelijke apparaten kent een hoge penetratiegraad, niet alleen van de $B R D$, maar ook van Itallië. De 'filière'-landbouwvoedingsmiddelen behoudt zijn sterke positie op de Europese markt, maar de toeleverende industrie van de landbouwmachines is zwak, evenals de kunstmestindustrie. In het algemeen is ook sprake van onvoldoende realisatie van toegevoegde waarde stroomafwaarts in de bedrijfskolom.

De 'poles de compétivité' van de Franse industrie anno 1973 zijn de automobielindustrie, de sector van het spoorwegmateriaal en de investeringsgoederen, die vanaf 1973 een verbetering van de handelsbalans te zien geven, omdat met name de export naar de Oostbloklanden en de OPEC is toegenomen, dankzij de 'diplomarique industrielle'.

De industrièle structuur in 1973 is een 'tissu poreux' met enkele geîsoleerde speerpunten en een groot aantal zwalke plekken. De sterke speerpunten zijn vooral met gevolg van het 'Grands Programme'-beleid:

"Beaucoup de nos grandes réalisations techniques et de nos pôles de compétitive sont dus aux relations értroites qui se sont développées entre les administrations techniques et leurs fournisseurs autour de grands programmes d'équipement et d"infrastructure" (Stoffaès 1983b, 13). 
Schema 6.3 Overheidssteun aan de Franse industrie in 1981

\begin{tabular}{|c|c|c|}
\hline 1. Grands projets publics & Em MafF & \\
\hline 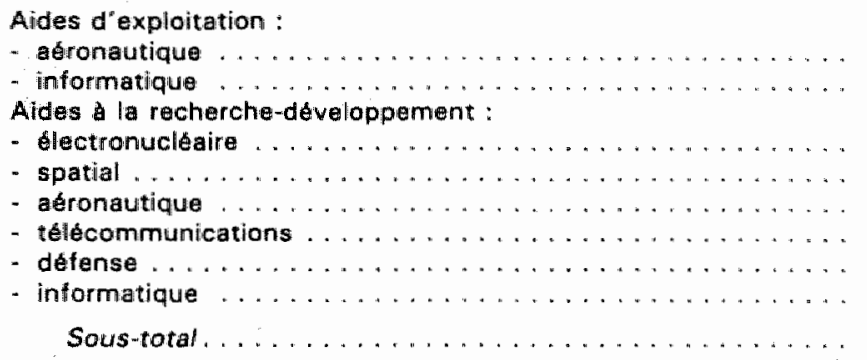 & $\begin{array}{r}2.1 \\
0.3 \\
0.6 \\
1.0 \\
1.3 \\
2.0 \\
8.5 \\
0.5 \\
16.3\end{array}$ & 16.3 \\
\hline \multicolumn{3}{|l|}{ II. Secteurs en reconversion } \\
\hline 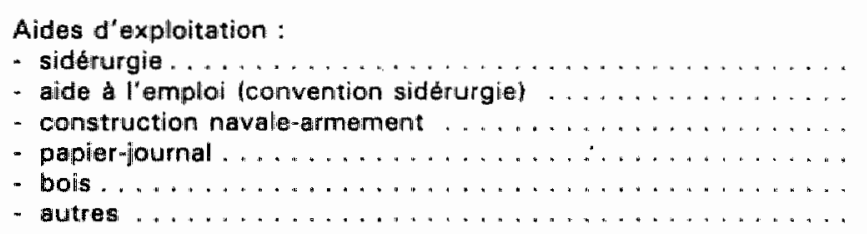 & $\begin{array}{l}1,3 \\
1,1 \\
2,2 \\
0,3 \\
0,1 \\
0,6\end{array}$ & \\
\hline 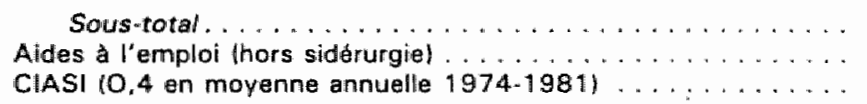 & $\begin{array}{l}5,6 \\
1.7 \\
0.8\end{array}$ & 5.6 \\
\hline Sous-total $\ldots \ldots \ldots \ldots \ldots \ldots \ldots \ldots \ldots \ldots$ & $\overline{2.5}$ & 2,5 \\
\hline \multicolumn{3}{|l|}{ 1II. Industries nouvelles } \\
\hline$\ldots \ldots \ldots \ldots \ldots \ldots \ldots \ldots \ldots \ldots$ & 0.7 & 0.7 \\
\hline \multicolumn{3}{|l|}{ N. Aides a l'exportation } \\
\hline $\begin{array}{l}\text { Aides a la grande exportation } \ldots \ldots \ldots \\
\text { Autres aides } \ldots \ldots \ldots \ldots \ldots\end{array}$ & $\begin{array}{r}17,1 \\
1,7 \\
\end{array}$ & \\
\hline Sous-total . . . . . . . . . . . . . . . . . . & $18 \overline{8}$ & 18.8 \\
\hline \multicolumn{3}{|l|}{ V. Autres aides } \\
\hline 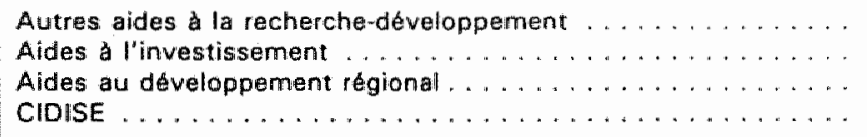 & $\begin{array}{l}0.5 \\
6.5 \\
1.0 \\
0.7\end{array}$ & \\
\hline Sous-total . . . . . . . . . . . . . . . . . . & 8,7 & 8.7 \\
\hline Total & & 52,6 \\
\hline
\end{tabular}

Bron: C.F. no. $212(1983,15)$. 
Toch leidde de fundamentele zwakte van de industrielle structuur ma 1973 nog niet direkt tot grote problemen op de handelsbalans, omdat de export naar de "Pays en Voie de Développement' (PVD) en naar de OPEC-landen kan worden opgevoerd. Uit de ontwikkeling van de penetratiegraden van de technologisch geavanceerde produkten op de Franse markt en de problemen, die Franse ondernemingen ondervonden op de markten van andere OECD-landen, bleek dat er fundamenteel iets mis was met de Franse industrie (vergelijk hoofdstuk 5) [10]. Na 1979 kwamen die problemen duidelijk aan het licht.

In tal van studies wordt de conclusie getrokken, dat het neo-liberale industriebeleid heeft geleid tot een industrięle structuur met enkele 'créneaux performantes', maar dat anno 1981 geen sprake is van een 'tissu industriel': de 'Grands Programmes' zijn nach onderling verbonden, noch zijn vanuit de 'Grands Programmes' bewust netwerken van afnemers en toeleveranciers opgebouwd [11]. Het neo-liberale industriebeleid was niet expliciet gericht op het organiseren en ontwikkelen van economische mesosystemen; het beleid richtte zich op specifieke sectoren en ondernemingen, zonder daarbij expliciet de relaties met de toeleverende en afnemende sectoren en ondernemingen in acht te nemen.

Een en ander blijkt ook uit de verdeling van de industriële overheidssteun over de sectoren en ondernemingen. In schema 6.3 wordt een overzicht gegeven van de steun aan de industrie in 1981. De helft van die steun kwam terecht bij een zestal industriële groepen: Thomson-CSF, Dassault, SNIAS, CII-HB, CGE en Creusot-Loire. De steun was gelijkelijk verdeeld over de grote exportcontracten (wapens, energiecentrales, 'usines clés en main'), de speerpuntindustrieèn (lucht- en ruimtevaart, electronica, nucleaire energie, telecommunicatie) en de stagnerende sectoren (ijzer en staal, zware chemie, textiel, scheepsbouw).

\section{Etatiste et centraliste}

In het voorgaande is diverse malen gewezen op het grote aantal afdelingen van diverse ministeries en andere publieke en semi-publieke instanties, dat met het industriebeleid van doen had.

\footnotetext{
"Tous ces partages institutionels, "joints au caractère improvisé et conjuncturel des décisions', n"ont pas été favorables à la mise en place d'une politique cohérente: les entreprises ont souvent été écartées entre divers ministères de tutelle (cf entreprises nationalisées); les institutions de base de la politique industrielle ont été étatiste, centralisées ... mais souvent sans centre, trop souvent tournées vers les seules groupes. Tout cela a encouragé la négociation au 'coup par coup' des grands programmes brülant, directement entre quelques grands fonctionnaires et quelques grands dirigants, et donc nui à la concertation générale" (Morvan 1983, 33).
}

Noch het Ministerie van Industrie, noch het 'Plan' (zie Soulage en Thiery 1983, 83), hebben zich tot een centraal coördinerende instantie kunnen ontwikkelen. Voorzover van coördinatie sprake was geschiedde zulks vanuit het Ministerie van Financiën, dat echter het lange termijn structuurbeleid niet in zijn portefeuille had.

Niet alleen in wetenschappelijke kringen, maar ook in het bedrijfsleven en de politiek kunnen afkeurende geluiden over 'la politique industrielle Giscardienne' worden ge- 
hoord. De organisatie van de werkgevers, CNPF, is voorstander van een flexibel op de omgeving van de onderneming gericht beleid, waartoe met name de hoogte van de belasting- en premiedruk moet worden gerekend. Volgens Lepas (1983) is de stijging van olieprijzen in 1973 afgewenteld op de ondernemingen (vergelijk Balassa 1979 en Cotta 1978) en zijn de salarissen voortdurend gestegen, waardoor de financięle marges van de ondernemingen onder druk zijn komen te staan (zie CF 212,63).

De vakbeweging is daarentegen in het algemeen een voorstander van een meer planmatig industriebeleid al zijn tussen de vakverenigingen belangrijke verschillen te constateren. In een enqueête van het CGP in het kader van het werk voor de CNP zetten de vijf grote vakcentrales hun visie op het industriebeleid uiteen.

De 'Conféderation Générale du Cadres' (CGC) constateerde, dat het industriebeleid was versnipperd over tal van ministeries en instellingen, maar 'Dans la masse de ces interlocuteurs il n'y a qu'un absent: le Plan' (zie CF 212). Daarin diende volgens de CGC verandering te komen: het 'Plan' diende met betrekking tot het industriebeleid niet alleen de organisatie van de consultatie voor haar rekening te nemen, maar ook als tegenspeler op te treden van de ministeries, met name van 'Le Budget'. De CGC was voorstander van een flexibel plan, dat op demokratische wijze tot stand kwam en in een wet werd vastgelegd, opdat van het 'Plan' ook enige daadkracht kan uitgaan. Ook de CFDT ('Conféderation Français Démocratique du Travaill') was een groot voorstander van gedecentraliseerde demokratische planning, waarbij de doelleinden van het 'Plan' zouden worden gerealiseerd door middel van contracten met de actoren. Meer dan de andere vakverenigingen was de CFDT voorstander van de "autogestion", welke gestalte zou moeten krijgen door een daadwerkelijke democratisering van de besluitvorming binnen de onderneming.

De meer behoudende 'Force Ouvrière' (CGT-FO) benadrukte het belang van de consultatie in het kader van het 'Plan', maar was van mening, dat de vakbeweging op geen enkele manier medeverantwoordelijkheid voor het Plan moest dragen: het 'Plan' is een 'Plan Gouvernement' en geen 'Plan Nation' (vergelijk CF no. 212 (1983, 74). De CGT ('Conféderation Géneral du Travail') keurde het industriebeleid van Giscard sterk af. Zij stond een zeer planmatige aanpak voor, hetgeen bleek uit de antwoorden op een enquete, die in 1983 door de CNP werd gehouden. De CGT benadrukte de rol van 'Le Plan' en de publieke ondernemingen. Na een "dispositif transitoire' (1982-1983) zouden in het Negende Plan op 1-1-1984 en de daarin geïntegreerde 'loi sur le développement industriel de la France" naar de mening van de CGT de doeleinden met betrekking tot de industriêle ontwikkeling moeten worden vastgelegd op basis waarvan de 'contrats de plan' met de genationaliseerde ondernemingen konden worden heronderhandeld (vergelijk 6.2).

"L'année 1983 marquera l'entrée dans une phase normale de fonctionnement de la procédure: les travaux préparatoires au IXe Plan connaîtront leur terme dans le vote de la seconde loi de Plan (qui intégrera la loi sur le développement industriel de la France). Cette loi définira les orientations économiques nationales pour lla période 1984-1988; elle servira de cadre de référence pour la définition des plans stratégiques des groupes nationalisés" (CF 212, 1983, 77).

Het Negende Plan, de sector- en 'filière'-plannen, alsmede de contracten met de ondernemingen dienden naar de mening van de CGT in 1984 een coherent geheel te vormen. Of die wens werd vervuld wordt onderzocht in 6.1.4.2. 


\subsection{4 'Les Trois Mitterrandismes' (1981-1986)}

\subsubsection{Inleiding}

Zowel met betrekking tot het economisch beleid in het algemeen als met betrekking tot het industriebeleid in het bijzonder was maart 1983 een keerpunt. In maart 1983 maakte Mitterrand de expliciete keuze voor een beleid van bezuinigingen ('riguew'), een beleid gericht op de wereldmarkt en voor het behoud van de franc in het Europese Monetaire Systeem (EMS). Die beslissingen hadden niet alleen grote gevolgen voor het macro-economische beleid, maar ook voor het economische structuurbeleid: het interventionisme van J.P. Chevènement, die poogde maximale inhoud te geven aan de 'Etat développeur', werd gevolgd door een neo-liberale aanpak van Laurent Fabius en Edith Cresson. Aan de periode van Chevènement was de periode van de voorzichtig opererende Pierre Dreyfus vooraf gegaan, zodat well wordt gesproken van "les trois Mitterrandismes" met betrekking tot het industriebeleid.

In 6.1.4.1 worden de uitgangspunten van de 'Parti Socialiste' (PS) ten aanzien van de inrichting van de 'Etat développeur' besproken: hoe zouden de doeleinden met betrekking tot de ontwikkeling van de industriële structuur moeten worden geformuleerd, welk instrumentarium moest worden ontworpen en welke institutionele vormgeving paste daarbij? In 6.1.3.2 worden de 'trois Mitterrandismes' besproken, waarna in 6.1.4.3 de balans wordt opgemaakt.

\subsubsection{1 'L'Etat développeur socialiste Française'}

Zoalls in hoofdstuk 3 is uiteengezet kan ideaaltypisch onderscheid worden gemakt tussen de 'Etat régulateur' en de 'Etat développeur'. Het industriebeleid 'régulatrice' bestaat uit macro-economisch omgevingsbeleid (Keynesiaans vraagbeleid, kostenmatïgings- en mededingingsbeleid). Die vorm van industriebeleid is generiek en indirekt; zij vindt haar uitwerking in een verandering van de relatieve prijzen, of in een verandering van de marktstructuur. Het is overigens de vraag of daarvoor het begrip 'industriebeleid' wel adequaat is: Petit (1983) geeft er de voorkeur aan te spreken vam een 'politique d'offre' en reserveert het begrip 'politique industrielle" voor de direkte interventies van de 'Etat développeur' in het marktproces (vergelijk De Jong 1987). De beschrijving van het ideaaltype uit hoofdstuk 3 volgend, blijkt de 'Etar développeur socialiste Française" er als volgt uit te zien:

- de doeleinden met betrekking tot de ontwikkeling van de industriële structuur worden vastgelegd in een indicatief plan, i.c. in 'la loi sur l'Industrie" als onderdeel van het Negende Plan.

Zoals in hoofdstuk 3 is uiteengezet dienen die doeleinden zodanig geformuleerd te zijn, dat concretisering, bijstelling of vervanging tijdems het planproces in overleg met de betrokkenen kan plaatsvinden. Het planproces dient daartoe een continu en democratisch karakter te dragen. De doelleinden dienen een consistent geheel te zijn van macrodoeleinden (zoals economische groei, export en werkgelegenheid), van meso-doeleinden (sectoren, 'filieres', regio's) en micro-doeleinden (publieke ondernemingen).

- een intensief en breed consultatieproces op micro-, meso- en macro-niveau is een eerste vereiste voor het genereren van voldoende informatie en voor het op elkaar 
afstemmen van de belangen van de verschillende groepen (legitimatie en identificatie met de doeleinden);

De consultatie kan de 'pressions socio-politiques' omzetten in de noodzakelijke 'adhésion' (De Bandt 1983a). De consultatie dient zich niet alleen op macroniveau af te spelen tussen politici en vertegenwoordigers van overkoepelende belangenorganisaties, maar juist ook het mesoniveau van de regio en de 'filiere' te betreffen, alsmede het microniveau van de onderneming. Een fundamentele herziening van de politieke besluitvorming (decentralisatie) en van de participatie van de werknemers in de ondernemingen behoren tot de belangrijkste hervormingen, die de socialisten na hun verkiezing willen doorvoeren;

- om de specifieke doeleinden met betrekking tot de ontwikkeling van de industriêle structuur te kunnen realiseren moet de 'Etat développeur" over een adequaat instrumentarium beschikken: 'Gérer le système' impliceert het kunnen reguleren van de 'critères de décisions, de gestion' (De Bandt 1983a). Met name 'Le Plan' en de 'entreprise publique' moeten het instrumentarium worden. van de 'Etat développeur socialiste Française'. Want alleen beheersing van de strategische beslissingen van de structuurbepalende industriële en financiële groepen biedt de overheid de mogelijkheid mesosystemen te reorganiseren conform de doeleinden van het Plan. De Bandt (1987):

"Beside the ideological motives, which were quite strong, the objective of the extension of the public sector, in 1981/1982, was mainly, from the standpoint of industrial policy, to integrate some of the big firms into a consistent planrational approach for the redeployment and further development of the french industrial system, through the crisis. The nationalized firms were to be both restructuring and growth poles within the industrial system and tools for the management of the entire system" (vergelijk Bellon 1983, 427 en 431). [12)

De socialisten benadrukten, dat de selectieve nationalisatie een marktconform instrument is: de autonomie met betrekking tot de strategische beslissingen blijft in handen van het management; op basis van onderhandeling zal tussen de overheid en de onderneming een overeenkomst ("contrat de plan') worden gesloten met het doel de ondernemingsstrategie af te stemmen op de plandoeleinden;

- van groot belang is de coördinatie van het industriebeleid vanuit eén centraal ministerie, waar ook de informatie en expertise aanwezig is om industriele ontwikkelingen en strategieên te kunnen beoordelen: 'une expertise autonome' (De Bandt 1983, 50). Zo'n coördinerend ministerie staat voor een zware taak: enerzijds moet het beleid van de diverse ministeries op elkaar worden afgestemd (naast de coördinatie van het korte termijn conjunctuurbeleid van het Ministerie van Financiën op de lange termijn doeleinden van het Plan, dient ook het beleid van de diverse afdelingen van het Ministerie van Industrie op elkaar te worden afgestemd), anderzijds moet de coördinerende instantie de strategische beslissingen van de structuurbepalende ondernemingen op de plandoeleinden afstemmen [13].

\subsubsection{Les trois Mitterrandismes}

In deze paragraaf wordt besproken hoe het industriebeleid gestalte kreeg onder Pierre Dreyfus, Jean-Pierre Chevenement, Laurent Fabius en Edith Cresson. 


\section{Dreyfus, voorzichtig op afstand}

Na een korte overgangsperiode met Pierre Joxe als Minister van Industrie werd Pierre Dreyfus in juni 1981 aangezocht als Minister van Industrie, omdat hij als oud PDG van Renault het wantrouwen van de ondernemers tegen de socialistische regering mogelijk enigszins zou kunnen wegnemen. Dreyfus vervulde die rol uitstekend door met grote nadruk op de autonomie van de publieke ondernemingen te wijzen en voor de 'contrat de plan' het 'modèle Renault' als voorbeeld te gebruiken (vergelijk Commissariat Général du Plan, 1982e).

Onder Dreyfus werden de nationalisaties gerealiseerd (zie 6.2). Dat proces werd met grote voortvarendheid aangepakt, omdat Dreyfus zich als geen ander realiseerde, welk een verlammende invloed wan een onzekere overgangsperiode kan uitgaan op het nemen van strategische beslissingen. Dreyfus verdedigde de nationallisaties door te wijzen op de slechte financièle positie van een groot aantal structuurbepalende ondernemingen; de kapitaalmarkt verschafte hen niet voldoende risicodragend kapitaal, waardoor de noodzakelijke investeringen uitbleven. De overheid zou daarentegen haar taak als aandeelhouder wel naar behoren vervullen door de ondernemingen van de benodigde financiële middelen te voorzien. De vrees voor een 'étatisation' en voor ad hoc interventies was volgens Dreyfus ongegrond, omdat de autonomie van het management zou worden gewaarborgd in de 'contrats du plan'. In zijn 'Lettre de Mission' aan de nieuwe PDG's van de publieke ondernemingen stelde Dreyfus nadrukkelijk:

"Votre autonomie sera entière et vous mettra en mésure de prendre les initiatives nécessaires au bon développement de votre Groupe (....)

Vous recherchez d'abord l'efficacité économique, par une amélioration continue de la compétitivité toute carence d'efficacité affecterait, en effet l'ensemble de l'économie française. Les critères habituels de gestion des entreprises industrielles s'appliqueront intégralement à votre Groupe (....)

L'importance de la dimension internationale dans les activités de votre groupe est liée à l'ouverture, nécessaire et souhaitable, de l'industrie française, sur l'extérieur. Vous veillerez donc à préserver et développer cette dimension internationale comme condition essentielle de la compétitivité et du progrès technique. Dans ce domaine également, les critères habituels de gestion et de concurrence des entreprises industrielles s'appliqueront intégralement à votre groupe dans ses activités hors de France" (Lettre de Mission in Dreyfus, 1983).

Tegelijkertijd benadrukte Dreyfus, dat de publieke onderneming een specifieke verantwoordelijkheid heeft:

"Votre capacite d'entreprendre s'inscrira dans le respect des grandes orientations fixées par l'Etat".

en dat de onderneming met betrekking tot het creëren van arbeidsplaatsen zorg moet dragen voor

"(...) d'organiser les relations du Groupe avec les autres entreprises et les soustraitants afin de preserver leur identité et leurs capacités".

Ook diende de publieke onderneming een voorbeeldfunctie te vervullen ten aanzien van het sociaal beleid en de informatieuitwisseling en dialoog met de werknemers. Dreyfus besloot zijn brief aan de PDG's met de opdracht op korte termijn een 'Plan 
d'Entreprise: voor te leggen, op basis waarvan zou worden onderhandeld met het 'Ministère de turelle' over een 'convention pluri-annuelle entre L'Etat et votre groupe'. Wat die ondernemingsplannen betreft is Dreyfus van mening, dat de inhoud algemeen van aard moest zijn, welke voortdurend aan nieuwe ontwikkelingen kon worden aangepast. Die 'plans glissants' zouden moeten worden geschreven met 'un crayon a la main, une gomme dans l'autre' (LNE 8-3-1982, 41). In dat verband werd veelvuldig gesproken over het 'Modele Renault; een model waarover overigens niet veel bekend is (Commissariat Général du Plan, 1982e). Dubus en Lemaître [14] beschreven de relatie tussen Renault en de overheid als 'pragmatisch'. Toen in 1962 de eerste overheidssteun aan Renault werd gegeven voor het financieren van een omvangrijk investeringsprogramma, stelde Renault een vijfjaren plan op, dat elke jaar werd geactualiseerd. Het ondernemingsplan werd door een selecte groep onder strikte geheimhouding opgesteld en voorgelegd aan de Minister van Industrie en de verantwoordelijken van de "Trésor". Het Plan van Renault besloeg slechts enkele pagina"s en beschreef globaal de investeringsplannen en de financiële middelen, die de 'Etatactionnaire zou moeten verschaffen. De overheid heeft Renault op een enkele uitzondering na (15) Jaltijd een zeer grote mate van autonomie verleend.

"La Régie est au contraire toujours restée maitresse de sa gamme et de sa stratégie. Le plan d'entreprise définit les objectifs et les investissements. Il n'entre pas dans le détail des produits. C'est un document clair mais simple. Cela ne nous a pas empêchés de nous soumettre aux grands objectifs du Plan: notamment dans le domaine de l'exportation et de l'aménagement du territoire" (Barraux 1982a, 43 citeert een woordvoerder van Renault).

Dreyfus hanteerde bij het ontwerpen van de relatie tussen de overheid en de publieke ondernemingen het 'Modele Renault' als uitgangspunt en bepaalde, dat de publieke ondernemingen slechts één 'Ministère de tutelle' zouden hebben: het Ministerie van Industrie voor de industriële groepen en het Ministerie van Financiën voor de financiele groepen.

Overigens was in begin 1982 de discussie over de vorm en inhoud van de relatie tussen de overheid en de publieke onderneming nog volop gaande: Christian Goux, voorzitter van de 'Commission centrale de réforme de la Planification', is met Michel Rocard, 'Ministre du Plan', voorstander van een zwaar opgetuigd 'Comité des Contrats de $P l a n^{*}$, waarvan diverse ministers lid zouden zijn, waarvan het voorzitterschap en secretariaat zouden worden bekleed door respectievelijk de premier en de "commissair au Plan". Volgens die gedachtengang bespreken de publieke ondernemingen en het 'Ministère de tutelle' de inhoud van het 'Contrat de Plan', dat vervolgens ter toetsing aan de nationale plandoeleinden wordt voorgelegd an het 'Comité des contrats de Plan'. In het Plan Intérimair was in die procedure voorzien, maar Dreyfus geeft daar een eigen afgezwakte interpretatie aan, waarbij alles door éen ministerie wordt afgehandeld.

Van meet af aan was een kernvraag wat moest gebeuren in geval van een fundamenteel verschil van mening tussen het ministerie en het management van de onderneming? Dreyfus was daarover in een interview met $\mathbb{L N E}$ (8-3-1982) niet duidelijk. Enerzijds diende de PDG conflicten te vermijden, anderzijds was de macht van de overheid afhankelijk van de mate, waarin de industriële groep financieel op de overheild steunde [16]. 
In dat verband wees Dreyfus erop, dat de bemoeienis van de overheid met de strategie van de groep niet in elke sector en niet met betrekking tot alle publieke ondernemingen even groot kan en zal zijn. Daar waar de problemen groot zijn en de financiële behoeften navenant, zall de overheid 'très présente' zijn (ijzer en staal, zware chemie enz.). Betreft het een sector, die een grote diversiteit vertoont en met zeer open grenzen te maken heeft (electronica), dan zal slechts een 'minimum de coordination entre les programmes de développement' kunnen worden verlangd.

Voor de sectoren, die in mei 1981 in grote problemen verkeerden en waarin de toekomstige publieke ondernemingen geen centrale rol zouden vervullen, werden door Dreyfus 'Plans sectoriels' opgesteld: machinebouw, textiel/kleding, leer/schoenen, speelgoed en de meubelindustrie. Deze 'Plans sectoriels' betroffen de stagnerende sectoren met overwegend PME/PMI, die ten tijde van VGE in het industriebeleid geen belangrijke plaats innamen.

In 6.2 .3 is beschreven, dat tot mei 1981 een onderneming, die voor overheidssteun in aanmerking willde komen, aan drie criteria moest voldoen: de onderneming moest groot zijn, tot de 'bande des quatres' behoren (nucleair, electronica, telecommunicatie, wapensystemen) en betrokken zijn bij grote exportcontracten. Dit sectorbeleid werd door Dreyfus doorbroken:

"Il n'y a pas de secteur technologiquement condammé où il ne soit possible d'obtenir des gains de productivité. A condition que la modernisation d'une entreprise traditionnelle tienne bien compte de ce qui se fait en amont - pour les matériaux et pour les machines - et en aval, dans la distribution. Car nous ne raisonnons pas en termes de secteurs, mais d'entreprise et de fillière" (Dreyfus 1983, CF 212, 29).

Dreyfus beoogde de plannen te realiseren door middel van het afsluiten van contracten met branche-organisaties en individuele ondernemingen. Naast de genoemde 'plans sectoriels' werden onder Dreyfus ook voor de ijzer en staal (september 1982; Lettre 101, 15-06-1982) de chemie (Lettre 101, 18-1982) en de micro-electronica (Lettre 101, 12-03, 1982) plannen opgesteld. Deze werden door Chevènement aangepast en in uitvoering genomen.

De periode van Dreyfus (mei 1981-juni 1982) overziende lijkt hij met betrekking tot de sturende roll van de overheid en met name met betrekking tot het gebruik van de publieke onderneming als instrument van het industriebeleid, de kant van de gematigde zogeheten 'industriels' te hebben gekozen [17].

Met de vormgeving van de relatie tussen de overheid en de publieke onderneming volgens het modele Renault, had Dreyfus ongetwijfeld de toon gezet. Dat neemt niet weg, dat de "planificateurs" de strijd om een meer dirigistische rol van de owerheid nog niet als verloren beschouwden.

In tegenstelling tot de 'industriels' stonden zij een 'Etat' voor, die de ontwikkeling van de industriële structuur bepalde [18].

Onder Chevènement kregen de 'planificateurs' meer mogelijkheden de rol van de overheid met betrekking tot de industriele ontwikkeling en het gebruik van de publieke ondernemingen varm en inhoud te geven. 
In juni 1982 werd Dreyfus opgevolgd door Chevenement, voorman van de CERES [19] binnen de PS en als zodanig bekend als een groot voorstander van de "Etat développeur'. Onder Chevènement werden het Ministerie van Technologie en het Ministerie van Industrie samengevoegd tot het Ministere de la Recherche et de L'Industrie' (MRI), zodat het industriebeleid met betrekking tot de traditionele sectoren en het beleid ten aanzien van de nieuwe technologieën in eén hand werden verenigd.

In navolging van Dreyfus nam Chevènement afstand van de 'créneaux'- benadering:

"Il $n^{\prime} y$ a pas de secteur condammé, il n'y a que de technologies dépassées. C'est pourquoi il faut moderniser les industries traditionelles, diffuser en leur sein les technologies de l'avenir et non pas se résigner a les laisser disparaïtre; et, simultanément, développer les activités nouvelles qui sont susceptibles, dans les prochaines années, de créer des emplois, de rétablir l'équilibre extérieur, de maintenir la France au premier rang des puissances technologiques et industrielles et d'assurer ainsi son indépendance" (Chevènement 1983, 31).

Chevènement kondigde op 'Les Joumées de Travail sur la Politique Industrielle' (15-16 november 1982) een brede maatschappelijke discussie over de mogelijke en gewenste ontwikkeling van de industriële structuur aan. De resultaten van dat consultatieproces zouden worden vastgelegd in 'La loi de Plan sur L'Industrie', dat onderdeel zou uitmaken van het Negende Plan.

Op de 'Joumées de Travail' werd in 'la maison de la Chimie' in Parijs met een zestal colloquia het startschot gegeven voor zeven maanden van discussiebijeenkomsten en consultatieronden. De resultaten zouden worden gespresenteerd op 'Les Assises Nationales', die waren gepland op 27-27 juni 1983. Chevènement ontvouwde op de eerste dag van de 'Journées' een visie op het industriebeleid, dat in principe alle sectoren en 'filières' van de Franse economie betrof (Chevènement 1983).

\section{Industries de base; logique de planification}

De basissectoren, zoals de ijzer en staal en de zware chemie zijn enerzijds van essentiële betekenis voor de macro-economische ontwikkeling van het land (werkgelegenheid, handelsbalans) en zijn anderzijds van groot belang als toeleverancier van de verwerkende industrie. Hoewel vrijwel alle basissectoren in 1981 verlies maakten, kon een industrieland als Frankrijk zich volgens Chevènement niet permitteren de verliesgevende sectoren af te stoten en voor die produkten geheel afhankelijk te worden van buitenlandse leveranciers. Het industriebeleid van de overheid moest worden gericht op het behoud en de modernisering van de basisindustrieën, opdat zij weer concurrerend zouden worden en de Franse afnemers van hoogwaardige relatief goedkope produkten zouden kunnen woorzien. De plannen van Chevènement betroffen enerzijds het financieren en richten van de investeringen van de publieke ondernemingen en anderzijds het reorganiseren van de economische activiteiten rondom de publieke sleutelondernemingen. Voor de ijzer en staalindustrie was reeds onder Dreyfus een saneringsplan in werking gezet, terwijl voor de kunstmestindustrie en de zware chemje onderhandelingen waren gestart in het kader van het afsluiten van de "Contrats de 
Plan'. Voornemens bestonden om ook voor de petrochemische industrie en voor de hout- en papiersector met de betrokken ondernemingen herstructureringsplannen op te zetten.

De nationalisaties in de basisindustrieẽn boden volgens Chevènement een goede mogelijkheid om tot een efficiênte herstructurering te komen.

"L'extension du secteur public, désormais largement présent dans les industries de base, modifie profondément les conditions de définition et de mise en oeuvre d"une politique de modernisation et de rationalisation des structures; elle suscite un nouveau type de comportement industriel intégrant mieux les préoccupations du long terme alors qu'en même temps le poids des investissements et lle rôle de l'Etat induisent une logique de planification; la conclusion de contrats de plan avec les entreprises nationales et leur articulation avec le $9 \mathrm{e}$ Plan devraient concrétiser l'émergence de cette logique" (Ministère de l'Industrie, Lettre 101, no. 181, 3).

\section{Industries de transformation; logique de marché}

Het industriebeleid van het MRI richtte zich met betrekking tot de verwerkende industrie op de omgeving van de ondernemingen. Zoals eerder opgemerkt beschikte het MRI niet over het instrumentarium het beleid met betrekking tot de omgevingsfactoren van de onderneming vanuit één industriepolitieke invalshoek te coördineren [20]. Chevènement wilde de coördinerende rol van het MRI aanzienlijk versterken. Hij kondigde aan, dat op het DGI een speciale afdeling zall worden belast met het opstellen van een overzicht van de gecumuleerde effecten van alle overheidsmaatregelen voor specifieke sectoren en ondernemingen. Ook de afstemming van het belleid van het Ministerie van Onderwijs op de behoeften van het bedrijfsleven zall vanuit het MRI beter worden gecoördineerd; in het kader van het 'Plan d'Action Filière Electronique' werd daartoe een eerste aanzet gegeven (vergelijk hoofdstuk 7). In het kader van de 'Loi d'Orientation et de Programmation pour la Recherche et le Développement Technologique' (LOP) zal het MRI de technologiediffusie door middel van de zogeheten 'Programmes Mobilisateurs' coördineren (zie verderop). De omgeving van de verwerkende industrie zal vanuit het $M R I$ worden beïnvloed door voor met name de PMI de mogelijkheden te verrumen zich in te passen in een 'tissu industriel dense et dynamique'. Van groot belang daarbij zijn het referentiekader, dat de 'Loi de Plan sur l'Industrie' zal moeten bieden en de 'code de la sous-traitance" in het kader van de 'contrat de plan' met de publieke ondernemingen (zie 6.2).

Het beleid van het MRI zal in toenemende mate worden gedecentraliseerd door sectorale en regionale afdelingen van nationale instituten op te zetten, waardoor concrete overheidsmaatregelen beter kunnen worden afgestemd op de behoeften op meso- en microniveau.

Ook werd vanuit het MRI voor de verwerkende industrie een groot automatiseringsprogramma gestart in thet kader van 'Le Plan Machine-outil', dat onder Chevènement wordt verruimd tot het 'Plan Productique".

Naast dat horizontale pllan werd voor de verwerkende industrie ook een aantal vertikale plannem gelanceerd of aangekondigd:

- in de sector van de 'biens d'équipements" werden naast de machinebouw ook landbouwmachines: 
- in de consumptiegoederensector werden de plannen van Dreyfus voortgezet (textiel, - meubelen, speelgoed) en werd een specifiek plan aangekondigd voor de automobielsector (Ministère de I'Industrie, Lettre 101, 24-11-1982).

Tot slot werden met betrekking tot de verwerkende industrie de zogeheten 'appels d'offres d'initiarive industrielle' gestart: voor markten waar geen Franse ondernemingen opereerden deed het MRI een gerichte oproep aan ondernemingen zich te melden met een ondernemingsplan, dat na goedkeuring met steun van de overheid zou kunnen worden gerealliseerd [21].

Naast de basis- en de verwerkende industrieèn vormden de speerpuntindustrieën het derde aandachtsgebied wan Chevènement.

\section{Activités de pointe; logique de programmation et de filière}

Conform de beproefde formule van de 'Grands Programmes' werden een aantal grote projecten gestart, waarvan de 'Programmes Mobilisateurs' (zie verderop) en het PAFE (zie hoofdstuk 7), het meest in het oog sprongen.

Over alle genoemde plannen moest van november 1982 tot eind juni 1983 een diepgaande discussie plaatshebben met alle betrokkenen. De conclusies zouden worden vastgelegd in

"La loi de Plan sur l'Industrie" (...). Elle constituera la cadre de cohérence de la politique industrielle des années 1984-1988. Elle devra à la fois profiler le développement industriel des prochaines années, en préciser le rythme et en prévoir les moyens juridiques et financiers (Ministère de l'Industrie, Lettre 101, no. 181,8$)$.

Juist in een tijd van relatief grote onzekerheden zou zo'n beeld van de mogelijke en gewenste ontwikkeling van de industriële structuur voor de strategische ondernemingsbeslissingen een goed referentiekader kunnen bieden. Niet dat de overheid tot in detail de industriële ontwikkeling conform de wet zou kunnen sturen, maar dankzij de planningsovereenkomsten met de publieke ondernemingen zou zij volgens Chevènement wel de grote lijnen kunnen vaststellen.

\section{Publieke ondernemingen}

De publieke ondernemingen hebben in 1982 grote verliezen gemaakt (zie 6.2), waardoor nagenoeg geen middelen beschikbaar waren voor het financieren van kostbare investeringsprogramma"s. Gezien de financële problemen van de centrale overheid in de periode 1982-1983 (vergelijk hoofdstuk S) stelde Chevènement een "gestion equilibrée' voor de publieke ondernemingen als voorwaarde voor steunverlening [22]. Wat de relatie tussen de overheid en de publieke ondernemingen betreft, zette Chevènement in woorden de lijn van Dreyfus voort (LNE 06-09-1982), maar aarzelde in werkelijkheid niet in de basissectoren en de "filière électronlque" zeer ingrijpende reorganisaties door te voeren ('jeu de meccano'). In begin 1983 werd de relatie met de publieke ondernemingen opnieuw ter discussie gesteld; voor het rechtse kamp vormden de grote verliezen daartoe aanleiding, voor het linkse kamp het uitblijven van planningscontracten met een werkelijke sturende inhoud (zie 6.2). De discussie betrof met name de vraag bij welke instantie de verantwoordelijkheid met betrekking tot de publieke ondernemingen lag: 
- conform de wet op de nationalisatie was een 'Haut Conseil du Secteur Public' ingesteld, maar haar funktie beperkte zich tot informatieverschaffing en consultatie (zie 6.2);

- Lit het organisatieschema van het MRI blijkt, dat het ministerie een aparte 'Service des Entreprises Nationales' had ingesteld. Van daaruit werden de onderhandelingen met de ondernemingen over de planningsovereenkomsten gevoerd. De contracten, die met het ministerie zouden wordlen opgesteld moesten door een interdepartementale commissie, onder voorzitterschap van de premier of de Minister van het Plan, worden getoetst (LNE 24-01-1983);

- de controle a posteriori geschiedde door de Rekenkamer, waarbij de vraag kan worden gesteld, of die instantie met 240 'magistrats' en 600 medewerkers in staat moest worden geacht naast haar lopende werkzaamheden ook de gang van zaken bij de internationaal opererende industriële groepen te kunnen controleren. Barreaux (1983a) heeft zo zijn bedenkingen:

"(...) ni les contrôlleurs d'Etat, ni les commissaires de gouvernement, ni les conseillers a la Cour des Comptes et encore moins le Parlement ne sont actuellement armés pour juger de la gestion de groupes de plus en plus diversifiés et engagés sur des marchés concurrentiels" (vergelijk hoofdstuk 7).

Voor Chevenement werd vanaf november 1982 het oplopend verlies van de publieke ondernemingen een zeer groot probleem; voor een aantal sectoren moesten direkt beslissingen worden genomen en kon het resultaat van de consultatieronden op de 'Assises' in juni 1983 niet worden afgewacht. Chevènement ging over tot het forceren van reorganisaties ('jeu de meccano'), hetgeen grote weerstand bij de PDG's van de ondernemingen opriep (zie "affaire-Gandois" in Le Monde).

Binnen het kabinet werd vanaf begin 1983 de tweedeling tussen 'les industrielles' en 'les planificateurs' steeds duidelijker zichtbaar: aan de ene kant de ministers Rocard en Delors, die de inflatiebestrijding en bezuinigingen hoog in het vaandel hadden staan en aan de andere kant Chevenement, die van mening was, dat Frankrijk met betrekking tot een aantal strategische 'filières' een eigen koers moest varen, desnoods met uittreding uit de EG als gevolg.

Tegen de politiek van Chevenement waren een aantal invloedrijke groeperingen gekant: de PDG's van de publieke ondernemingen, de leden van het 'corps des mines', die voortdurend hun gevestigde orde verstoord zagen en de invloedrijke Minister van Financiën Delors.

Toen in maart 1983 met de EG-landen onderhandeld moest worden over de derde devaluatie van de franc, werd Mitterrand voor de keus gesteld binnen de EMS te blijven en het spel 'd la Européenne' te spelen, of Frankrijk te isoleren van de internationale economie. De druk vanuit het bedrijfsleven, met name ook van het management van de publieke ondernemingen, was inmiddels zo groot geworden, dat Mitterrand koos voor een open en op de EG georiënteerd Frankrijk en Chevènement ontslloeg als Minister van Onderzoek en Industrie. Daarbij zou de druk vanuit het 'corps des mines', dat het Ministerie van Industrie beheerst, van grote betekenis zijn geweest [23].

De in hoofdstuk 5 beschreven ommezwaai in het macro-economische beleid vond zijn evenbeeld in het industriebeleid, zoals dat vorm kreeg onder Fabius en Cresson. 
Het economisch beleid tot maart 1983 had geleid tot een aanzienlijke lastenverzwaring van het bedrijfsleven als gevolg van de invoering van de vijfde vakantieweek, de arbeidstijdverkorting tot 39 uur en de verhoging van het minimumloon en de sociale lasten (Balassa 1985). Daarbij kwam de psychologische "last" van de nationalisatie, de herinvoering van de indicatieve planning en de democratisering van de interne besluitvorming in de onderneming. Tevens was een prijsstop van kracht geworden, waardoor per saldo de winsten van de ondernemingen onder druk kwamen te staan. Zo stegen bijvoorbeeld de kosten in de automobielsector in 1982 met $10 \%$, terwijl de prijzen aan banden werden gelegd. In de stagnerende sectoren (kolen, scheepsbouw, ijzer en staal) golden kostbare afvloeiingsregelingen ('congés de conversion'). De publieke ondernemingen werden voor de taak gesteld de produktie op te voeren, hetgeen tesamen met de stijgende kosten leidde tot verliezen, die met leningen moesten worden gedekt: de schuldenlast steeg sterk en de subsidies per werknemer namen gigantische vormen aan: 140.000 Fr in de kolen, 115.000 Fr in de staal en 175.000 tot 200.000 Fr in de scheepsbouw bij een gemiddeld loon van $110.000 \mathrm{Fr}$. De financiële situatie van de publieke ondernemingen was van dien aard geworden, dat in het kader van het 'rigueur'-beleid van maart 1983 nog maar éen doel heilig was: in 1985 moesten alle publieke ondernemingen weer winst maken met uitzondering van Usinor en Sacilor (ijzer en staal).

Fabius, een protégé van Mitterrand, werd de nieuwe Minister van Industrie.Hij onderschreef de bezuinigingsfilosofie van het nieuwe kabinet-Mauroy; hij herstelde de verbinding tussen het 'Elysée' en 'Rue de Grenelle', die onder Chevènement in het ongerede was geraakt [24]. Fabius sprak zich niet uit voor een expliciet 'filière'-beleid (Fabius 1983, 37 en 39) en de 'rôle développeur' van de overheid maakte plaats voor een 'rôle catalyseur'. De overheid moest vooral door middel van het creëren van een gunstige omgeving voor de ondernemingen een bijdrage leveren aan de gewenste ontwikkeling van de industriële structuur.

"Mais, de grâce, évitons le "meccano". Le Ministère de l'Industrie a un rôle d'impullsion et d'arbitrage" (Fabüus 1983, 39).

De publieke ondernemingen zullen daarbij een belangrijke rol kunnen spelen

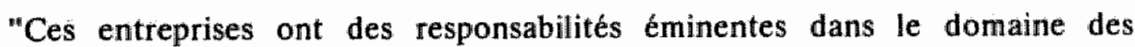
nouveaux droits des travailleurs, et de la formation, de la recherche, de l"equilibre du commerce extérieur, du soutien à l'investissement et a l'emploi. Les réformes juridiques étant réalisées, il s'agit pour ces entreprises, qui sont des organismes vivants, d"aller clairement de l'avant et de jouer leur rốle de pôles décisifs de développement".

Maar financiële gezondheid is daarbij een eerste voorwaarde:

"Les entreprises nationales, immergées dans l'économie de marché et la concurrence internationale, ne pourraient longtemps vivre si elles s'excluaient de contraintes de la gestion. L'Etat doit donc remplir à leur égard son rôle d'actionnaire. Un actionnaire qui demande à ces entreprises d'avoir dans un délai raisonnable des comptes au moins équilibrés" (Fabius 1983, 37).

Met de komst van Fabius op het MRI werd definitief gekozen voor de lijn van de 
'industriels': de consultaties gericht op het opstellen van 'la loi sur l'industrie" werden opgeschort en "les Assises' werden geannuleerd. Een omvattend kader van de mogelijke en gewenste industriêle ontwikkeling kwam niet tot stand, waardoor het ook niet goed mogelijk was de strategie van de publieke groepen door middel van de planningsovereenkomsten te richten op specifieke doeleinden. De doeleinden werden niet in het kader van het Plan geformuleerd en voorzover ad hoc voor een sector of 'filiere" doeleinden werden gesteld, waren deze te algemeen van aard om een strategie van een individuele groep op te kunnen richten (vergelijk hoofdstuk 7).

Dat neemt niet weg, dat tijdens het ministerschap van Fabius belangwekkende maatregelen werden genomen, zoals de instelling van het 'Fonds Industriel de Modernisation' (FIM) en de formele vormgeving van de consultatie over het industriebeleid in de zogenaamde "Commission Nationale sur l'Industrie".

\section{Fonds Industriel de Modernisation (FIM)}

Op de ministerraad van 29-04-1983 werd besloten tot de instelling van een investeringsfonds, dat beoogde investeringen te financieren door middel van een laagrentende lening, of een lening van een hypotheekbank (zie supplement Lettre 101, no. 195). In principe zijn ook op maat gesneden kortlopende leningen mogelijk. De FIM financiert bij voorkeur projekten in de sfeer van de hoogwaardige technologie, de kantoorautomatisering en 'carte à mémoire", de biotechnologie, het uitrusten van opleidingen met microcomputers en het realiseren van zuiniger auto's. Ondanks deze prioriteiten is a priori geen enkele investering van de FIM uitgesloten. De aanvragen moeten worden ingediend bij de ANVAR, die woor het bereiken van de PMI gedecentraliseerd te werk gaat. In gevall van projekten onder de vijf miljoen francs kan de regionale afdeling van de ANVAR zelf beslissen; voor grotere projekten is toestemming van het Ministerie van Industrie modig. Snelle besluitvorming is gewaarborgd (binnen twee maanden) en in principe is ook een $100 \%$ financiering van projekten mogelijk. De FIM wordt gevoed door de CODEVI ('Comptes pour le Développement Industriel'), warop partikuliere spaarders gelden kunnen deponeren tegen een aantrekkelijke belastingvrije rente (livret A) met een maximum van 10.000 francs (per fiscaal huishouden zijn twee rekeningen mogelijk).

Vanaf september 1983 ging de FIM van start. In december 1985 werd door het Ministerie van Industrie verslag gedaan: met tevredenheid werd geconstateerd, dat de gemiddelde daling van de investeringen in de periode van 1973 tot 1984 van $2 \%$ per jaar in 1984 en 1985 is omgebogen in een positieve ontwikkeling.

"Après avoir analysé les composantes de cette reprise, (stijging van de investeringen J.G.) le ministre a souligné la contribution apportée par le Fonds industriel de modernisation, mis en place à la fin de 1983, (...) (Ministère de I'Industrie, Lettre 101, no. 210, 2).

De FIM heeft in de jaren 1983 en $198419 \mathrm{MdF}$ uitgezet en in $1985 \mathrm{zal} 13.5 \mathrm{MdF}$ via de FIM lopen, hetgeen neerkomt op $12 \%$ van de industriële investeringen. Voor 1986 werd $9 \mathrm{MdF}$ gedoteerd. De selectieprocedure verliep naar wens: het PME (minder dan 500 personen) nam $80 \%$ van het aantal leningen en $43 \%$ van het totale bedrag voor haar rekening (Lettre 211, supplément). Ook werd met tevredenheid geconstateerd, 
dat $2 / 3$ van de investeringen Franse produkten betroffen; met name de hypotheekbanken sloten in het kader van de FIM samenwerkingscontracten met Franse producenten af (Ministère de l'Industrie, Lettre 101, no. 210),

\section{De consultatie: Commission Nationale sur l'Industrie}

Op 11-10-1983 werd door Fabius het eerste (1) debat in het parlement over het industriebeleid geïnitieerd met een rede, walin de modernisering van het industrièle produktieapparaat nog eens als de prioriteit nummer één van het Negende Plan werd gepresenteerd met de 'filière électronique' als centrale spil (Ministère de I'Industrie, Lettre 101, no. 190). In het parlementaire debat, dat overigens weinig nieuws opleverde, kondigde Fabius de instelling van een 'Commission Nationale sur L'Industrie' (CNI) aan, die moest dienen als consultatieplatform voor de sociale partners met betrekking tot industriepolitieke vraagstukken. Vlak na het van start gaan wan het Negende Plan werd op 17-02-1984 door Fabius en Le Garrec (Plan) de CNI geïnstalleerd onder voorzitterschap van Dalle (PDG van L'Oréal) en met Gallois (DGII), Prévot, Prager en Soulage (CGP) als rapporteurs. De commissie moest een platform zijn voor reflexie, informatieuitwisseling en advisering (Lettre 193, 2). Daartoe werden binnen de CNI een aantal 'Groupes Stratégie Industrielles' (GSI) ingesteld, zoals die ook in het kader van de voorbereiding van het Negende Plan werkzaam waren geweest [25].

Naast de drie vertikale GSI (chemie, landbouw-voedingsmiddelen en BTP) werden er acht horizontale ingesteld, die de hoofdthema's van het Negende Plan betroffen:

- 'Technologies diffusantes': de basistechnologieën, zoals de 'filière électronique', biotechnologie en de nieuwe materialen;

- modernisering van de ondernemingen in de verwerkende industrie: technische, financiële en sociale aspecten van het moderniseringsproces;

- financieringsvraagstukken;

- opleidingen;

- commercie, kwaliteit en distributie op de Franse markt;

- dienstverlening aan de ondernemingen, met name aan de PME/PMI;

- exportbevordering en internationalisering van het bedrijfsleven;

- vernieuwing van de industriële structuur met name door het creèren van nieuwe ondernemingen.

Hoewel volgens ingewijden [26] de werkelijke consultatie uitbleef, lieten Prévot (CGP) en Gallois (DGI) geen gelegenheid onbenut het belang van de 'concertation' te benadrukken. Zo trekken zij bij de presentatie van het synthese-rapport van de GSI met betrekking tot het functioneren van de CNI de vergelijking met de moderniseringscommissies van Monnet:

"(...) les GSI ne sont pas sans nous rappeler les commissions de modernisation, mises en place par Jean Monnet, dont on se souvient de l'impact sur la construction de la France moderne. L'accord quasi général sur les diagnostics et constats, la progression commune et convergente sur les mesures à prendre ont été la règle de presque tous les GSI. Dans tous les cas, les points de vue ont pu se confronter et s'affiner dans un grand respect réciproque" (Ministère de I'Industrie, Lettre 101, no. 196, 10). 
Madame Edith Cresson volgt in juli 1984 Fabius op; het technologiebeleid werd in een apart 'Ministère de la Technologie' ondergebracht, dat onder leiding kwam van Hubert Curien en het Ministerie van Industrie krijgt ook de verantwoordelijkheid over de buitenlandse handel, waardoor de naam veranderde in "Ministèré de Redéploiement Industriel et du Commerce Extérieur' (MRICE).

Als Hubert Curien het zelfstandig geworden 'Ministère de la Techmologie" gaat leiden in juli 1984 is de periode; waarop de LOP [27) Jbetrekking had voor een belangrijk deel verstreken (zie verderop): een jaar na zijn aantreden werd de opvolger van de LOP, 'Le Plan Triennal' (1986-1988) door het parlement goedgekeurd. Alvorens op dat Plan nader in te gaan onderwerpen wij eerst het socialistische technologiebeleid vanaf 1981 aan een nadere beschouwing (vergellijk OECD 1986).

\section{Het sociallistische technologiebeleid}

Op 13-01-1982 presenteerde Mitterrand in het Palais de Congrès een aantal ideeën met betrekking tot het technologiebeleid. Een 'Loi d'orientation et de programmation pour la recherche et le développement technologique de la France' (LOP) moest worden geintegreerd in het Negende Plan. Van oktober 1981 tot januari 1982 had een consultatieproces plaats, waarbij op 32 regionale bijeenkomsten en een tiental sectorale studiedagen zo'n 30.000 personen ideeën over het te voeren technologiebeleid uitwisselden. Daaruit werd duidelijk, dat de budgetten voor $R$ en $D$ niet alleen moesten worden verhoogd, maar dat deze ook over een langere periode dan één jaar moesten worden beschermd tegen conjuncturele ingrepen: in een speciale wet dienden de middelen voor een langere periode te worden gegarandeerd, zoals dat al jaren met betrekking tot de militaire uitgaven het geval was. Ook bleek uit de consultaties, dat de modernisering van de industrie alleen kon slagen als diverse belanghebbenden nauw werden betrokken bij het vaststellen van de richting van het onderzoek en bij de toepassing en de diffusie van de resultaten. De onderzoekzoekcentra moesten uit hun geïsoleerde positie worden gehaald. De budgettering van het onderzoek over meerdere jaren en de organisatie van het onderzoek moesten vorm worden gegeven in de LOP, waarover Mitterrand in het Palais de Congrès zegt:

"Cette loi programmera pour les prochaines années les grandes masses de l'effort financier de recherche et donnera à cette activité le cadre dont elle a besoin: elle consacrera le rôle et la fonction sociale des métiers de la recherche, elle rénovera et amplifiera les moyens de la formation aux métiers scientifique et techniques, elle adaptera l'organisation nationale et régionale aux impératifs de la décentralisation. Je souhaite la voir inspirée très profondément par la volonté (...) de placer la recherche là où elle doit aujourd'hui être situé: non dans un isolement qui confinerait les chercheurs dans leurs contres ou leurs laboratoires mais au carrefour de tous les grands problèmes de la société".

De LOP, die in juli 1982 door het parlement werd aangenomen, stelde een verhoging van de $\mathrm{R}$ en $\mathrm{D}$ uitgaven tot $2.5 \%$ van het PIB in 1985 als doel (in 1980 werd $1.8 \%$ aan $R$ en $\mathbf{D}$ uitgegeven).Ook werd als voorwaarde voor het realiseren van de ambitieuze doeleinden een toename van het aantal werknemers in de onderzoeksector met $4.5 \%$ gesteld. Daartoe moesten de middelen van de opleidingsinstituten worden verdubbeld en dienden ondernemingen te worden gestimuleerd afgestudeerden een onderzoek- 
plaats aan te bieden, opdat zij zich verder zouden kunnen specialiseren [28]. Om de consultatie binnen de onderzoekinstellingen te verbeteren, kondigde de LOP een nieuw statuut voor het personeel aan, waarin de mobiliteit van de onderzoekers centraal stond. De onderzoekinstellingen moesten worden ontsloten, omdat de feitelijke ontwikkelingen allerlei dwarswerbanden tussen de traditionele disciplines hadden aangebracht.

Naast het onderzoek in de publieke instellingen, betrof de LOP ook de stimulering van het onderzoek in het partikuliere bedrijfsleven, dat wan de geplande stijging van de $\mathbb{R}$ en D-uitgaven zo'n 60\% voor haar rekening moest nemen. De maatregelen, die in dat verband in de jaren 1983-1984 werden genomen betroffen het verhogen van subsidies, het bieden van belastingfaciliteiten en het teweeg brengen van synergieeffecten door het organiseren van dwarsverbanden tussen publieke en partikuliere onderzoekinstellingen, universiteiten en ondernemingen.

In de $\mathbb{L O P}$ werd het technologiebeleid langs vier lijnen gestalte gegeven: 'programmes mobilisateurs", fundamenteel onderzoek, toegepast onderzoek en de "programmes de développement technologiqué.

\section{Programmes mobilisateurs}

De 'Programmes mobilisateurs' werden in de LOP aangekondigd als een middel om de fondsen, die over diverse instellingen waren verspreid te concentreren op een beperkt aantal specifjeke programma's en tegelijkertijd de plannen van de diverse actoren (onderzoekinstellingen, opleidingsinstituten, publieke en partikuliere ondernemingen) op het betreffende terrein te coördineren. In een annexe stelde de LOP zeven programes mobilisateurs vast [29].

In de LOP werd ook gewezen op het belang van de 'très grands équipements' (bijv. de cyclotron) en werd per sector een lijst van projekten opgesteld, die tot 1985 specifieke aandacht behoefden (zie Ministère de la Recherche, Lettre RT no. 2-3, pag. 8).

\section{Fundamenteel onderzoek, toegepast onderzoek en 'Grands Programmes"}

In het verleden werd het fundamentele onderzoek regelmatig slachtoffer van het bezuinigingsbelleid. De LOP voorzag in een jaarlijkse volumestijging van de fundamentele onderzoekuitgaven van $13 \%$. Vermeldenswaard is de prioriteitsverschuiving ten gunste van de sociale wetenschappen met het oog op het belang van het herstel van de dialoog tussen wetenschap en samenleving. Fundamenteel onderzoek in het kader van de 'Programmes mobilisateurs' no. 4, 5 en 6 moest het inzicht in die problematiek verdiepen.

De LOP wees ook op het belang van het toegepaste onderzoek op gebieden als de gezondheidszorg, nieuwe materialen, soft-ware, landbouw en voedingsmiddelen en de 'productique'. Nieuwe organisatievormen moesten zorgdragen voor een adequate informatieuitwisseling tussen de behoeften van maatschappelijke groeperingen en de onderzoekcentra.

Van drie "Grands Programmes' werd in de LOP expliciet melding gemaakt: nucleaire energie, lucht- en ruimtevaart en aceanologisch onderzoek. Vastgesteld werd, dat deze programmes van strategisch belang waren voor de Franse economie en dat de finan- 
ciering en organisatie deelname van de overheid vereiste, waarbij een steeds grotere samenwerking op Europees niveau noodzakelijk was.

\section{Nieuwe organilsatiestructuur}

Naast de toename van de middelen werd door de LOP in een aantal nieuwe instituties voorzien, die een verandering van de organisatie van het onderzoek beoogden met het doel de dialoog tussen wetenschap en samenleving te verbeteren.

- 'Consell Supérieur de la Recherche et de la Technologie' (CSRT) werd gevormd naar gelijkenis van de CNP en werd geconsulteerd met betrekking tot alle belangrijke technologievraagstukken.

- De LOP voorzag in de creatie van de 'Etablissements publics d caractère scientifique et technologique' (EPST); een nieuwe juridische structuur voor onderzoekinstellingen, waardoor zij flexibeler op veranderingen konden reageren dan de onder de hiërarchie van ministers vallende instellingen. In de bestuursorganen van een EPST is ook het personeel vertegenwoordigd. De ontwikkeling van toepassingen van de onderzoekresultaten en de diffusie van de technologische kennis werden expliciet tot de taak van een EPST gerekend.

- In het kader van de regionalisering en het bereiken van de PME/PMI werden 'Délegués Régionaux à la Recherche et à la Technologie" ingesteld. De regionale raden kregen 'comités consultatifs régionaux de la Recherche et du développement technologique", die breed waren samengesteld met belanghebbenden uit de desbetreffende regio. Met betrekking tot technologische vraagstukken moesten die comités door de regionale Raad worden geconsulteerd. Verder werd voorzien in de regionalisering van tal van nationale organisaties, zoals bijv. ANVAR.

Tevens werden in het kader van de regionalisering de 'Centre régional d'innovation et de transfert de technologie' (CRITT) ingesteld.

Deze centra moesten het informatieaanbod naar de ondernemingen in de regio vertalen en samenwerkingsverbanden tussen onderzoekcentra, ondernemingen en opleidingsinstituten organiseren. Op den duur dienden de CRITT zelffinancierend te worden; aanvankelijk namen de departementen en gemeenten de financiering van de CRITT voor hun rekening, maar na verloop vän tijd moesten de belanghebbende ondernemingen door middel van contracten met de CRITT voor de financiën zorgen in ruil voor 'technologieinformatie op maat' (zie Lettre 101, no. 194, 11). Tot slot is in de LOP voorzien in de creatie van zogeheten 'Groupements d'Interêt Public' (GIP), die werden ingesteld voor een gelimiteerde periode en waren samengesteld uit vertegenwoordigers van diverse publieke en partikuliere organisaties. Doel van de GIP was het opzetten van gezamenlijke onderzoekprojekten.

In de opvolger van de LOP, 'Le Plan Triennel' (1986-1988) werden de lijnen van de LOP voortgezet, omdat die aanpak over het algemeen als een succes werd beschouwd (zie Ministère de la Recherche, Lettre RT no. 1).

\section{Terug naar het industriebeleid}

Zoals gezegd beheerde Edith Cresson vanaf juli 1984 het nieuwe MRICE. Het beleid van Fabius werd voortgezet: 
- over het sector- en 'filière'-beleid werd weinig meer vernomen,

- in het kader van het bezuinigingsbeleid werd in de begroting van MRICE voor de steun aan de publieke ondernemingen slechts $8.3 \mathrm{MdF}$ beschikbaar gesteld, terwijl dat in $1985 \mathrm{nog} 11.86 \mathrm{MdF}$ betrof. De kredieten woor het industriebeleid werden eveneens enigszins verminderd, hetgeen volgens Cresson niet de doelstellingen van het beleid in gevaar zou brengen, omdat in de publieke ondernemingen inmiddels financieel orde op zaken was gesteld en de grote herstructureringen in de stagnatiesectoren nagenoeg waren voltooid (Lettre 101, no. 209, 1).

Cresson verdedigde het "beleid op afstand" met betrekking tot de publieke ondernemingen door te wijzen op de goede resultaten, die daarmee onder Fabius waren geboekt: in de ministerraad van 28 maart 1985 bracht Cresson verslag uit van de 'contribution essentielle au développement industriel, technologique et social du pays' van de publieke ondernemingen (zie Lettre 101, no. 203, 3):

- financieel evenwicht; de vijf in 1982 genationaliseerde groepen (CGE, Saint in 1984 een positief financieel resultaat van $3 \mathrm{MdF}$, terwijl daar in 1983 een verlies van 0,6 MdF en in 1981 een verlies van 1,4 MdF tegenover stond

- de investeringsuitgaven van de publieke ondernemingen waren in 1984 met $13 \%$ gestegen ten opzichte van 1983

- de handelsbalans van de ondernemingen vertoonde in 1984 een verbetering van $18 \mathrm{MdF}$. Ook de steun van de publieke ondernemingen aan de PME leverde een belangrijke bijdrage aan het herstel van de handelsbalans.

Cresson sprak in dat verband van 'le partenaniat' en van 'l"exportation Kangourou', hetgeen betekende dat de grote ondernemingen en met name de publieke industriële groepen hun exportkanalen ten dienste stelden aan PME/PMI. Zo exporteerde Rhône Poulenc in 1984 voor 470 MF voor diverse PMI en Péchiney voor $350 \mathrm{MF}$ (Lettre 101, no. 201, 4).

- de uitgaven van $R$ en $D$ van de publieke ondernemingen makten inclusief het defensieonderzoek ongeveer $1 / 3$ uit van de totale $R$ en $D$-uitgaven

- de publieke ondernemingen leverden een bijdrage aan de versterking van de industriële structuur door het afsluiten van de 'conventions de stabilité', (in het kader van de contrat de plan werden ongeveer 1000 van dergelijke "conventions" afgesloten; zie Lettre 101 , no. $208,5-7$ en paragraaf 6.2 )

- met betrekking tot de werkgelegenheid hadden de publieke ondernemingen een grote krachtsinspanning geleverd door arbeidsplaatsen te behouden, of werknemers elders aan werk te helpen (sociétes de réconversion; vergelijk paragraaf 6.2).

Van de officiële zijde van het MRICE werd dus een zeer positief beeld geschetst van de bijdrage van de publieke ondernemingen aan het realiseren van de overheidsdoelstellingen. In de volgende paragraaf wordt die rol aan een nadere beschouwing onderworpen. 


\subsection{De rol wan de publieke onderneming in het Franse industrielbeleid}

\subsubsection{Inleiding}

In het voorgaande is het industriebeleid in Frankrijk vanaf 1945 geschetst. In deze paragraaf wordt dieper ingegaan op de rol van de publieke ondernemingen in die periode, waardoor de nationalisaties van 1982 in een historische context worden geplaatst (6.2.1). De yorm, inhoud en de doeleinden van de nationalisaties van 1982 komen in 6.2 .2 aan de orde, waarna in 6.2 .3 nader wordt ingegaan op de vraag, of en zo ja hoe de overheid na 1981 in staat is geweest de strategische beslissingen van de publieke ondernemingen af te stemmen op de plandoeleinden.

\subsubsection{De publieke onderneming in historisch perspectief}

De 'Manufactures Royales' van Colbert worden in het algemeen beschouwd als de eerste publieke ondernemingen in Frankrijk (Hafsi 1985). In de speerpuntsectoren van de 17 de eeuw, zoals de glas-, textiel- en aardewerkindustrie werden overheidsbedrijwen gesticht met ook nu nog klinkende namen als Saint-Gobain, Gobelins en Sèvres. Vanzelfsprekend was ook de wapenindustrie een publieke aangelegenheid (Manufacture d'armes de Saint-Etienne). In de 19e eeuw werden een aantal activiteiten onder staatsbeheer gebracht vanwege het publieke karakter: bijv. de uitgave van de staatscourant (Journal Officiel), de 'Banque de France' en de 'Caisse des Dépots"; ook. de tabaksindustrie is in Frankrijk van oudsher (1816) een staatsaangelegenheid. In de twintigste eeuw vonden vier nationalisatiegolven plaats. $\mathrm{Na}$ de Eerste Wereldoorlog werden in het Verdrag van Versailles een aantal Duitse bezittingen toegedeeld aar Franse publieke ondernemingen, terwijl voor de wederopbouw van Frankrijk een aantal specifieke financiële instellingen werden opgericht. Op die manier werd de publieke sector uitgebreid met de kalimijnen in de Elzas (1921), het 'Office National de l'Azote' (1924), de 'Compagnie Française des Pétroles' (1924), aan wie de Duitse bezittingen in Turkije toevielen en in de kolensector (Mines de la Sarre) werden 'société d'économie mixte' opgericht. Om de wederopbouw te stimuleren en te coôrdineren werden de 'Crédit National" (1919), "la Caisse Nationale de Crédit Agricole' (1920), 'la Banque Française du Commerce Extérieur (1920), "la Caisse Centrale du Crédit Hôtelier' (1923) en de 'Compagnie Nationale du Rhône' opgericht (vergelijk CF 214, 3-7).

De economische crisis van de jaren dertig was aanleiding tot een tweede golf van nationalisaties: een aantal in financiële moeilijkheden verkerende ondernemingen werden door de overheid overgenomen en gehergroepeerd. Zo werden uit een aantal ondernemingen in 1933 de 'Compagnie Générale Transatlantique" en de "Messageries Maritimes' gevormd en in 1935 werd uit enkelle ondernemingen de luchtvaartmaatschappij 'Air France' samengesteld.

De linkse regering van Léon Blum, die aan het eind van de jaren dertig korte tijd aan het bewind was (het 'Front Populair') ging niet op grote schaal tot nationalisatie over; de meningen in het linkse kamp over de publieke onderneming als instrument tegen de economische crisis waren namelijk zeer verdeeld. De CGiT was voorstander van nationalisatie, omdat het een effectief instrument zou zijn in de strijd tegen de crisis (investeringen in grote publieke projekten zoals spoorwegen, mijnen, electriciteit en 
hoogovens en beheersing van de prijzen van de basisgoederen). De Radikalen en Communisten vonden de tijd voor nationalisatie op grote schaal nog niet gekomen. Zij waren geen voorstander van nationalisaties, die tot doel hadden de kapitalistische machine weer op gang te brengen. Blum behoorde tot die laatste groep. Op bescheiden schaal werd de overheidsdeelname in de 'Banque de France' en de wapenindustrie vergroot. In 1937 werd na de val van Blum door de radikaal Chautemps de SNCF opgericht als een 'société d'économie mixte' met een overheidsdeelname van $51 \%$.

De derde uitbreiding van de sector van de publieke ondernemingen vond plaats direkt na afloop van de Tweede Wereldoorlog. De van oudsher sterke anti-markthouding was versterkt door de crisis van de jaren dertig en de collaboratie van veel ondernemers met de Duitse bezetter. Er was een politieke meerderheid, die nationalisatie van strategische ondernemingen noodzakelijk achtte voor een efficięnte wederopbouw van de Franse economie. Door middel van 'ordonnances' werden tussen december 1944 en juni 1945 de kolenmijnen in 'Nord' en 'Pas de Calais', alsmede de 'Rëgie Nationale des Usines Renault' [30] genationaliseerd; de Franse overheid nam een meerderheidsbelang in de koopvaardijwloot en vier fabrieken werden hergroepeerd tot SNECMA (Société Nationale d'Etude et de Construction de Moteurs d'Aviation). Bovendien kwam Air France geheel in overheidshanden terecht. Via de wet werden in 1945 de "Banque de France" en vier 'Banques de dépots" (Crédit Lyonais, Sociétế Générale, BNCI, Comptoir National d'Escompte) genationaliseerd.

In 1946 werden de staatsondernemingen EDF (Electricité de France), GdF (Gaz de France) en $\mathrm{CdF}$ (Charbonnage de France) opgericht, terwijl tevens 34 verzekeringsmaatschappijen in overheidshanden kwamen. De derde nationalisatiegolf werd in 1948 afgesloten met een meerderheidsbelang in de 'Compagnie Générale Transatlantique' en in de 'Messageries Maritimes'.

In de periode van 1948-1982 vonden geen schoksgewijze uitbreidingen of inkrimpingen van de sector van de publieke ondernemingen plaats. Wel werden naast de nationalisatie van de 'L'Energie électrique des départements d'outremer', een aantal publieke onderzoekinstituten opgericht, die het lange termijn onderzoek in strategisch geachte sectoren voor hun rekening namen; CEA (Commissariat à l'Energie Atomique, 1945), Bureau de la Recherche Pëtrolière (BRP), CNES (Centre Nationale d'Etudes Spatiale, 1961) en het Centre National pour l'exploitation des Oceans (1967). Ook vonden er in die periode enkele belangwekkende reorganisaties plaats, waaruit: 'l'Office Narional d'Etudes et de Recherches Aeronautique' (ONERA 1963) en de 'l'Entreprise de Recherches et d'Activités Petrolières' (ERAP) ontstonden. Naast die publieke onderzoekinstituten werden enkele 'sociétés d'économie muxxté opgericht voor de aanleg van de 'autoroutes' en de tunnel door de Mont Blanc (1957). In 1967 werd de 'Entreprise Minière et Chimique' (EMC) gevormd uit 'l'Office National de l'Azote et les Potasse d'Alsace'. Een jaar later werden 32 verzekeringsmaatschappijen hergroepeerd tot l'U.A.P., GAN en AGF. In 1970 werd de 'Société Nationale Industrielle Aerospatiale' (SNLAS) gevormd uit Nord Aviation, Sud Aviation en SEREB, tevens wordt in dat jaar de CEA gereorganiseerd.

Ook tijdens het neo-liberale bewind van VGE breidde de overheid haar deelnemingen in partikuliere ondernemingen uit: zo werden in 1978 de leningen aan de "Société 
Aeronawtique Dassault' omgezet in een minderheidsbelang en werden de schuiden van de staatsondernemingen omgezet in 'prêts participatifs'. De facto is sprake van nationalisatie wan de ijzer en staalindustrie, ondat de 'Caisse d'Amortissement pour 'Acier' (CAPA), die met overheidsgelden werd gefinancierd, zich volledig garant stelde voor de schulden van de staalondernemingen. In de drie nieuwe financieringsmaatschappijen, die over de staalondernemingen het beheer voerden, nam de overheid voor $55 \%$ deel via de 'Caisse Dépots' en 'Crédit National'. De nationalisatie van de staalindustrie in 1982 door de socialisten was dan ook niets meer dan een bekrachtiging van een feitelijke situatie.

Tot slot kan worden opgemerkt, dat in de jaren zestig en zeventig ook een zogenaamde sluipende nationalisatie ('nationalisations rampantes') plaats vond, doordat de publieke ondernemingen vertikaal integreerden, diversificeerden en internationaliseerden (vergelijk Andreff 1984).

In hoofdstuk 2 van Haut Conseil (1984) zijn tabellen opgenomen, die een beeld geven van de publieke onderneming in Frankrijk voor de vierde nationalisatiegolf van 1982 . Daaruit blijkt dat:

- voor de nationalisaties van 1982 het aandeel van de publieke ondernemingen in de Franse economie qua investeringen, werkgelegenheid, toegevoegde waarde niet significant verschilde van de positie van de publieke ondernemingen in andere WestEuropese landen

- de publieke ondernemingen activiteiten in een groot aantal sectoren ontplooiden - 1974 een keerpunt betekende in die zin, dat daarvoor de produktie en de investeringen in de publieke sector minder snel toenamen dan in de partikuliere sector en dat na 1974 de situatie omgekeerd was. Overigens werden de investeringen niet uit winsten gefinancierd: door de druk op de tarieven is de 'taux d'autofinancement' in de jaren zeventig sterk gedaald, waardoor de investeringen met behulp van leningen en subsidies moesten worden gefinancierd. Zo steeg de behoefte aan financiële middelen van $19 \mathrm{MdF}$ in 1975 tot $60.4 \mathrm{MdF}$ in 1982; de 'subventions d'exploitation' stegen van 8.7 MdF in 1975 tot $24.7 \mathrm{MdF}$ in 1982 . De slechte financiële positie van veel publieke ondernemingen in 1981 was het gevolg van lage tarieven en hoge investeringen, waardoor wel de produktiviteit steeg, maar het woordeel werd doorgegeven aan de afnemers. Uit Haut Conseil (1984, vol. 1, hoofdstuk 3) blijkt, dat de publieke onderneming niet achter bleef qua arbeidsproduktiviteit, noch dat haar slechte financiële situatie te wijten zou zijn aan hoge salarissen.

\subsubsection{De nationalisatie in $\mathbf{1 9 8 2}$}

\subsubsection{Het nationalisatieproces}

Nationalisatie als instrument van industriebeleid is binnen de communistische partij (PCF) en de socialistische partij (PS) lange tijd punt van discussie geweest. Voor de Tweede Wereldoorlog beschouwden de communisten nationalisatie als een verwerpelijke politiek, dat het kapitalistische systeem juist in stand hield. Na 1945 werd de publieke onderneming echter steeds meer beschouwd als een breekijzer, waarmee de socialistische en later communistische samenleving vorm gegeven zou kunnen worden. De socialisten in Frankrijk werden pas in 1972 bij het opstellen van het 'Programme 
Commun' met de communisten voorstander van selectieve nationalisatie. Terwijil voor de communisten de 'rupture avec le systeme capitaliste' voorop stond, waren de socialisten veel pragmatischer ingesteld en beschouwden zij de publieke onderneming als een instrument, waarmee de strategie van kapitalistische ondernemingen zou kunnen worden bijgestuurd. Voor de socialistische voormannen Mitterrand en Rocard, moesten publieke ondernemingen, die op de wereldmarkt concurreren (Entreprises Public Industriel Concurrencée: EPIC) in de eerste plaats onderworpen blijven aan de wetten van het marktmechanisme, hetgeen een grote mate van autonomie impliceerde. De meningsverschillen met de PCF ten aanzien van het aantal te nationaliseren ondernemingen, de wraag of ook de dochterondernemingen moesten worden genationaliseerd en op welke wijze de controle van de overheid vorm moest krijgen, leidden in 1977 tot een breuk in het linkse kamp (vergelijk Blanc 1984). Voor de presidentsverkiezingen van 1981 werden de handen weer ineengeslagen en werd de selectieve nationalisatie no. 21 van Mitterrand's '110 propositions': de publieke onderneming werd gepresenteerd als een instrument, waarmee de economische crisis het hoofd zou kunnen worden geboden. Hoe één en ander concreet gestalte moest krijgen werd pas na de verkiezingsoverwinning duidelijk.

De regering had de mationalisaties kunnen realiseren door middel van 'ordonnances" met een minimale schadeloosstelling voor de partikuliere aandeelhouders. Gekozen werd echter voor de langere weg van het parlementaire debat en voor een ruime schadeloosstelling met het doel de weerstand tegen de nationalisatie niet onnodig aan te wakkeren Beaud 1985, 70). Het verloop van het juridische steekspel, dat van september 1981 tot 13 februari 1982 plaatsvond tussen de oppositie en de regeringscoalitie is weergegeven in (Beaud 1985, hoofdstuk 5). Het eerste wetsontwerp, dat op 23 september 1981 bij het parlement werd ingediend, werd fel bekritiseerd:

- principiële bezwaren werden gemaakt op grond van art. 2 van de Grondwet (nationalisaties zouden van Frankrijk een socialistische staat maken) en op grond van de Verklaring van de Rechten van de Mens (de noodzaak, dat de in het wetsontwerp genoemde ondernemingen een publiek karakter moesten krijgen was niet voor alle ondernemingen en hun dochterondernemingen onderzocht)

- principièle bezwaren werden ook gemaakt tegen het maken van een uitzondering voor de buitenlandse banken en de 'banques mutuelles', alsmede tegen het hanteren van een arbitraire grens van $1 \mathrm{MdF}$ aan deposito's (de banken die minder deposito's hadden vielen buiten de nationalisatie).

- tot sllot betroffen de principiële bezwaren het 'l'effet d'extraterritorialitê": de Franse staat kreeg door de nationalisatie van Franse moedermaatschappijen controle over buitenlandse dochterondernemingen, terwijl zij in principe geen zeggenschap had op buitenlands grondgebied. In verband daarmee speelde de vraag, of het management van de publieke industriële groep autonoom beslissingen kon nemen over het aankopen en afstoten van filialen (zogeheten 'respiration'), of dat daarvoor toestemming van het parlement nodig was (zie verderop)

- de hoogte van de schadeloosstelling aan de aandeelhouders werd aangevochten (vergellijk Haut Conseil 1984, Vol. I, 261).

De 'Conseil Constitutionnel' erkende de problematiek rond de uitzondering van de 'banques mutuelles', de relaties met de filialen en de schadeloosstelling. De regering 
besloot een nieuw wetsontwerp in te dienen, dat wederom de weg van Tweede Kamer, Senaat en Raad van State moest doorlopen. In het aangepaste wetsontwerp bleven de uitzondering voor de coöperatieve en buitenlandse banken, alsmede de grens van 1 MdF gehandhaafd, bij de berekening van de schadeloosstelling van de aandeelhouders werd echter ook het dividend over 1981 in acht genomen (vergelijk Blanc en Brulé 1982, 84-85) en werd met betrekking tot de 'respiration' een wetsontwerp in het vooruitzicht gesteld. Op 13 februari 1982 werd de Wet op de Nationalisatie gepubliceerd.

De wet regelde de volgende nationalisaties:

- vijf industriële groepen werden voor $100 \%$ genationaliseerd:

La Compagnie Générale d'Electricité (CGE), la Compagnie Saint-Gobain, Pechïney. Ugine-Kuhlman (PUK), Rhône-Poulenc en Thomson-Brandt

- twee financiẻle groepen werden voor $100 \%$ genationaliseerd:

'La Compagnie financière de Paris et des Pays Bas' en 'la Compagnie financière de Suez"

- 39 banken werden genationaliseerd, waarvan overigens drie coöperatieve banken later bij de wet van 17-05-1982 worden uitgezonderd.

In oktober 1981 had de Franse overheid zich reeds een meerderheidsbelang verworven in "la Société Aéronautique Marcel Dassault" en was zij met Matra overeengekomen de 'defensiepoot' af te zonderen van de 'mediapoot', waarvoor de aandeelhouders een schadeloosstelling zouden krijgen, die na tussenkomst van de 'Conseil Constitutionnel' op 1880 Ffrs. werd vastgesteld.

In november 1981 zijn de staalgroepen Usinor en Sacilor door de uitbreiding van hun kapitaal en de omzetting van de leningen van de $\mathrm{FDES}$ in aandelen voor $95 \%$ in overheidshanden terecht gekomen.

Wat enkele buitenlandse ondernemingen betreft wordt:

- op 22 februari 1982 een accoord bereikt met Hoechst over de uitbreiding van het Franse overheidsbelang in Roussel Uclaf

- op 21 april 1982 het belang van de Franse overheid in CII-HB uitgebreid tot $84 \%$ en daalt de deelname van Honeywell Information Systems van $47 \%$ tot $16 \%$

- op 14 oktober 1982 door de Franse overheid van ITT 'la Compagnie Générale de Construction Téléphonique' (CGCT) en 'le Laboratoire Central de Télécommunica-

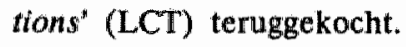

Met de nationalisaties is een totalbedrag gemoeid van $47 \mathrm{MdF}$.

De omvang van de nationalisaties in termen van omzet, winst en verlies en aantallen werknemers blijkt uit bijlage 6.10 .

Wat de sectorale verdeling betreft blijken de genationaliseerde ondernemingen zich te bevinden in:

- de basissectoren: ijzer en staal en metallurgie (Usinor, Sacilor en PUK, terwijl de publieke ondernemingen Entreprise Minière et Chimique (EMC) en Charbonnage de France (CdF) daarin al grote belangen hadden), de bouw- en constructiematerialen (Saint Gobain) en de electro-mechanische industrie (CGE en Thomson).

- de consumptiegoederensectoren, de pharmacie (Roussel-Uclaf, Rhoône- Poulenc), de huishoudelijke apparaten (Thomson) en de consumentenelectronica (Thomson)

- sectoren, die in het centrum van de technologische ontwikkelingen staan: metallur- 
gie en nieuwe materialen, (PUK, Saint-Gobain), de electronica en informatica (CII$\mathbb{H B}, \mathrm{CGE}$, Thomson, Matra), de vliegtuigbouw (Dassault- Breguet) en de bouw en publieke werken (CGE, Saint-Gobain).

De overheid kreeg door de nationalisaties van 1982 enerzijds een groot belang in de basissectoren, die veelal in grote problemen verkeerden en anderzijds in de speerpuntsectoren, die voor de modernisering van de industrie van essentiële betekenis waren.

"Sauvegarder et consolider les bases héritées du passé; renforcer et promouvoir les activités d'avenir. La gauche francaise de 1982 reste, la, dans la lignée du Conseil national de la résistance et de De Gaulle, et, au-dela, des saint-simoniens et de Colbert" (Beaud 1985, 78).

De banken, die in 1982 werden genationaliseerd zijn opgenomen in Haut Conseil (1984, vol. 1, hoofdstuk 2), waarmee het overheidsaandeel in de 'banques incrites' steeg tot $92 \%$ van de deposito's (was $60 \%$ ). Wordt echter het gehele financiële systeem in aanmerking genomen, dan blijken de nationalisaties van 1982 slechts $1 / 10$ van de totale deposito"s uit te maken en 1/8 van de kredieten, waardoor het aandeel in de deposito's steeg tot $74 \%$ en in de kredieten tot $69 \%$.

De twee financięle groepen Paribas en Suez beschikken over sleutelposities in de financieel-industriële wereld van Frankrijk (Bellon 1980). Paribas is actief in de bankwereld (Banque de Paris et des Pays-Bas, Crédit du Nord, Compagnie bancaire en een aantal buitenlandse banken), in de verzekeringen en neemt deel in tal van industriële ondernemingen. Suez heeft ook een belangrijke bancaire divisie (Indosuez, Crédit industriell et commercial, Monod francaise de banque), participeert in de verzekeringsen financiële wereld, maar ook in industrielle groepen, zoals Saint-Gobain. De verbindingen worden versterkt door

"(...) de relations personnelles structurantes; elles constituaient le lieu - à la fois aboutissement et moyen d'action - d'alliances de familles et de groupes" (Beaud $1985,81)$.

\subsubsection{1 'Contrats de Plan' (CdP)}

De specifieke taken van de publieke onderneming dienden vastgelegd te worden in een overeenkomst met de overheid. Om over de strategie te kunnen onderhandelen moest de onderneming een 'Plan d'Entreprise' opstellen, waarin zij haar lange termijn plannen met betrekking tot de omvang en richting van de investeringen en de organisatie van de markt uiteen zette. Tevens gaf zij aan, welke de gevolgen van haar beleid zijn op sociaal- en regionaal gebied. Het was de bedoeling, dat het ondernemingsplan eerst in de onderneming werd bediscussieerd, alvorens het aan het ministerie zou worden voorgelegd; de ondernemingsleiding zou op die manier gedwongen worden een gedegen lange termijn plan te ontwikkelen, dat de toets der kritiek kon doorstaan, terwijl de werknemers een beter inzicht kregen in de mogelijkheden en beperkingen wan de onderneming een autonoom economisch en sociaal beleid te voeren. Confrontatie van het ondernemingsplan met de doeleinden van het Nationale Plan zou zonodig leiden tot onderhandelingen over de bijstelling van de ondernemingsstrategie, waarbij eventuele extra kosten voor rekening van de overheid zouden komen: de wederzijds rechten en plichten moesten worden vastgellegd in een planningsovereenkomst ('contrat de plan', CdP). 
De onderhandeling met de publieke onderneming werd van groot belang geacht voor het concretiseren en bijstellen van de doelstellingen van het Nationale Plan. Tijdens de onderhandelingen zou namelijk informatie kunnen vrijkomen, die voor de overheid onontbeerlijk is voor het opstellen van realistische plandoeleinden. Omgekeerd zou tijdens het opstellen van het CdP een informatieuitwisseling kunnen plaatsvinden op grond waarvan het microniveau de uiteindelijke plandoeleinden, bijwoorbeeld met betrekking tot de herstructurering van de sector, als legitiem zou kunnen ervaren, hetgeen voor de realisatie van onschatbare waarde is.

Alleen een institutioneel kader, dat de mogelijkheid schept voortdurend informatie uit te wisselen van micro, wia meso naar macroniveau en omgekeerd, schept de condities waarbinnen een effectief planningproces kan plaatswinden (vergelijk hoofdstuk 3).

\section{De Inhoud van het 'Contrat de Plan'}

Hoewel de inhoud van de CdP geheim is, blijkt uit diverse bronnen [31], dat de CdP, die werden afgesloten tijdens die voorbereidingsperiode van het Negende Plan zeer algemeen en globaal van aard zijn. De gedachte leefde toen, dat de afstemming van de ondernemingsstrategie op de doeleinden van het nationale plan zich nog in een overgangsfase bevond, omdat de doeleinden van het Negende Plan pas per 1 januari 1984 zouden worden vastgesteld. In de $\mathrm{CdP}_{\text {, }}$, die in de loop van 1983 werden afgesloten blijken de volgende afspraken te zijn gemaakt (zie noot 31 ).

Speciale afdelingen van het ministerie lichten het 'plan d'entreprise' door op de conformiteit met de LOP. Behalve Thomson, Péchiney en CdF-Chimie gaven alle andere publieke ondernemingen een stijging van de $R$ en $D$-uitgaven te zien. De stijging van 10\%, die werd voorzien in de LOP werd echter niet gehaald (Haut Conseil 1984, 213). Wat de investeringen betreft, blijkt wel de omvang, maar niet de richting van de investeringen te zijn vastgelegd in de 'contrat de plan' [32].

Vrijwel alle 'contrats de plan' bevatten passages over om- en bijscholingen en over arbeidstijdverkorting (Haut Conseil 215, 21). Wat de meer ondermemingsspecifieke doeleinden met betrekking tot bijwoorbeeld de ontwikkeling van de rentabiliteit betreft, blijkt dat daarover richtlijnen zijn afgesproken met uitzondering van Thomson en CGE.

Wat de bijdrage van de onderneming aan de handelsbalans betreft, werd in de 'contrat de plan' afgesproken, dat vanaf juli 1983 periodiek de balans van elke onderneming afzonderlijk op het ministerie wordt besproken.

Wat het sociale beleid betreft werd met enkele ondernemingen een stabilisatie van de werkgelegenheid overeengekomen (Haut Conseil 1984, 215) en met anderen werden spelregels van de herstructurering vastgesteld.

In de loop van de tijd zouden de CdP worden geactualiseerd, totdat eind 1983 de doeleinden van het Negende Plan bekend zouden zijn. Echter, zoals uiteengezet werd vanaf maart 1983 de concretisering van de industriepolitieke doeleinden in 'la loi sur I'industrie' op een laag pitje gezet, waardoor ook na de invoering van het Negende Plan een concreet referentiepunt voor het opstellen van de CdP ontbrak. Weliswaar werd in het Negende Plan voor de publieke ondernemingen een belangrijke rol weggelegd met betrekking tot de realisatie van de Programmes Prioritaires d'Exécution (vergelijk 5.6.4) nrs. 1, 4, 5 en 7, maar het bleek niet goed mogelijk die algemeen 
geformuleerde doeleinden te concretiseren naar ondernemingsniveau (Haut Conseil 1984, 225-226). Greffe (1983) schrijft:

"Il est vrai que, même s'ils sont peu nombreux et sélectifs, les objectifs affichés par le Plan sont rarement transposables et opératoires au niveau de la gestion des firmes".

Zoals viteengezet werd vanaf maart 1983 onder Fabius en Cresson het industriebeleid met uitzondering van het PAFE steeds meer horizontaal van aard, waardoor de concretisering van sectorale- en 'filière'doeleinden steeds meer op de achtergrond geraakte. Tegelijkertijd kreeg de publieke onderneming in het kader van de bezuinigingen minder middelen toegewezen en werd het management voor de taak gesteld voor januari 1986 uit de rode cijfers te komen. De publieke onderneming kreeg daartoe een grote mate van autonomie met betrekking tot ontslagmogelijkheden, reorganisaties, herstructurering van activiteiten, beroep doen op de kapitaalmarkt, de aan- en verkoop van filialen etc.

Het beeld dringt zich op van een conjunctureel 'rigueur'-beleid', dat het voluntaristische industriebeleid met de publieke onderneming als 'fer de lance' terzijde schuift, gelijk dat met het nationale indicatieve plan was gebeurd.

De inhoud van de bijstellingen en aanhangsels van de CdP werd na januari 1984 zo mogelijk nog algemener en globaler van aard dan de CdP al waren, hetgeen sterk in de hand werd gewerkt door het uitblijven van een meerjaren financieringsplan voor de publieke ondernemingen. Het Ministerie van Financièn weigerde de afspraken in de CdP voor een langere periode dan éen jaar financieel te bevestigen. Slechts voor de periode van één jaar werden middelen toegezegd, hetgeen de afstemming van de CdP op de meerjaren PPE's doorkruiste.

Het uitblijven van een financiele meerjarenplanning in het kader van de CdP noodzaakte partijen tot het maken van globale afspraken op lange termijn. Anders gezegd: het management van publieke ondernemingen, dat graag de handen vrij wille houden werd zo de mogelijkheid geboden zich contractueel niet voor een langere periode dan één jaar vast te leggen. Daarmee werd de idee van het verlengen van de planningshorizon van de ondernemers en het afstemmen van hun strategie op lange termijn doelen ernstig doorkruist.

Dat de publieke onderneming na maart 1983 nagenoeg volledige autonomie genoot, bleek onder andere uit haar mogelijkheden op de kapitaalmarkt te opereren ("prêt participatif $)_{*}$ alsmede uit het uitblijven van de wet, die het parlement controlemogelijkheden moest bieden op de aan* en verkoop van dochterondernemingen door het management van de publieke onderneming ('loi de respiration').

\subsubsection{2 'Prêt participatif' en 'lol de respiration'}

Wat het aantrekken van risikodragend kapitaal betreft werd voor de publieke onderneming de zogeheten 'prêt participatif' (PP) in het leven geroepen (zie annexe Haut Conseil 1984, 258 en 259). De PP is een lening zonder stemrecht, die de kenmerken van een aandeel en een obligatie in zich verenigt; er vindt geen aflossing plats en de rente is woor een deel vast en voor een deel aan de winst gekoppeld. De gegarandeerde rente ligt boven het gangbare dividend; de PP kan op de beurs worden ver- 
handeld. Omdat geen sprake is van een aflossingsverplichting verschijnt de lening niet als schuld op de balans, maar als aandelenkapitaal [33].

De grotere autonomie, die na maart 1983 aan de publieke ondernemingen werd gegeven, bleek niet alleen uit de grotere vrijheid, die werd geboden met betrekking tot het aantrekken van risicodragend kapitaal, maar ook uit het niet strak regelen van de toestemming woor het aan- en verkopen wan filialen via een zogeheten 'loi de respiration du secteur public'.

Artikel 34 van de Grondwet stelt, dat de wetgever een regeling moet treffen met betrekking tot het overdragen van eigendom van de publieke naar de partikuliere sector. Publieke ondernemingen kunnen filialen kopen en afstoten ('respiration'), waardoor in feite sprake is van 'nationalisations rampantes" of van "dénationalisation". Voor die handelingen moest een wettelijke regeling worden getroffen. In 1978 werd het vraagstuk van de 'respiration' actueel: de 'Conseil d'Etat' moest een uitspraak doen over het stichten van Cogema en over de bijdrage van de overheid aan SNEA [34]. Er werd een liberale interpretatie gegeven van artikel 34, waarbij op de keper beschouwt het parlement elke 'respiration' apart zou moeten beoordelen.

"En effet la position du Conseil d'Etat peut résumer ainsi: en l'absence d'un texte de loi fixant lles règles de transferts de propriêté, seul le Parlement est compétent pour approuver les cessions d'entreprises du secteur public vers le secteur privé. Cette nouvelle orientation a constitué dès le départ un enjeu considérable pour la gestion du secteur public. Dorénavant tout transfert d'entreprises publiques vers le secteur privé, qu'il s'agisse certes d'entreprises publiques de premier rang, mais qu'il s'agisse également de filiales ou de sousfiliales (quel que soit le rang d'affiliation au secteur public de premier rang) doit théoriquement faire l'objet d'une autorisation législative" (Haut Conseil 1984, 178).

Door de uitbreiding van de publieke sector met een groot aantal ondernemingen, waarvoor de 'respiration' een wezenlijk onderdeel van de strategie is [35] werd de noodzaak van een duidelijke wettelijke regeling algemeen gevoeld.

In maart 1983 werd aan de 'Haut Conseil du Secteur Public' ter beoordeling een wetsontwerp woorgelegd, waarin werd voorgesteld het parlement alleen controle te laten uitoefenemen over de publieke ondernemingen wan de zogenaande 'premier rang' [36]. Uit het wetsontwerp werd niet duidelijk, of die controle alleen de holding betrof, of dat ook een lijst van zogeheten 'strategische filialen' moest worden opgesteld, die eveneens aan de parlementaire controle onderworpen zouden zijn (Haut Conseil 1984, 176). Groot probleem daarbij is het formuleren van de criteria op grond waarvan sprake is van een "strategisch filiaal' (omzet, aantal werknemers?). Op grond van artikel 34 is het overigens niet noodzakelijk, dat het parlement de controle zelf uitoefent; zij kan die bevoegdheid delegeren aan een specifieke instantie, of aan de ondernemingsleiding zelf overlaten.

Het wetsontwerp liet veel vragen onbeantwoord. In haar commentaar stelde de 'Haut Consell', dat een 'loi de respiration du secteur public' de volgende elementen zou moeten bevatten:

- de aan- en verkoop van filialen door ondernemingen van de 'premier rang' moet door het parlement worden gecontroleerd

- het is onmogelijk alle voornemens daartoe vooraf ter goedkeuring aan het parle- 
ment voor te leggen: het aantal zal onhandelbar worden, de snelheid en geheimhouding van de besluitworming zouden in gevaar komen. De controle moet worden gedelegeerd aan een 'pouvoir réglementaire', of aan de ondernemingsleiding

- een uitgebreid informatiesysteem met betrekking tot alle 'respiration-handelingen' moet controle achteraf mogelijk maken.

Wat het vraagstuk van de 'strategische filialen' betreft merkt de 'Haut Conseil' op, dat óf een poging kan worden gedaan een lijst met filialen op te stellen, waarbij onvermijdelijk arbitraire keuzen zullen moeten worden gemaakt, of voor een pragmatische oplossing kan worden gekozen, waarbij de publieke ondernemingen vrij zijn aandelen te kopen en te verkopen, zolang maar geen meerderheidsbelangen in het geding zijn. Na het commentaar van de 'Haut Consell' is het wetsontwerp niet meer in het parlement ingediend, vanwege de grote politieke voetangels en klemmen en de wens het management zo min mogelijk in haar strategische beslissingen te belemmeren. Dat neemt niet weg, dat het vraagstuk van de respiration wel actueel was (Andreff 1984, 246):

- Saint Gobain kocht Compagnie Général d'Eaux (Haut Conseil 1984, 180)

- Saint Gobain verkocht 1/3 van Saint Gobain Emballage (Monson 1984, 40)

- Péchiney verkocht winstgevende onderdelen van haar Amerikaanse dochter, 'Howmet Aluminium Corp'

- Saint Gobain, Péchiney, Elf-Aquitaine, Renault en een groot aantal banken sloten samenwerkingsverbanden af met buitenlandse ondernemingen.

Het niet nationaliseren in 1982 van alle filialen van de industriële en financiële groepen en het handhaven van de autonomie van de publieke ondernemingen om in andere ondernemingen deel te nemen, delen van de onderneming te verkopen en met andere partikuliere ondernemingen diverse samenwerkingsovereenkomsten af te sluiten, leidde ertoe, dat de grenzen tussen de publieke en de partikuliere ondernemingen vervagen (vergelijk Haut Conseil 1984, 290-291 en 286; Andreff 1984, 250 en Annexe 3).

"Le résultat de ce mouvement de concentration est la formation de véritables groupes publics articulés autour d"une "entreprise publique mère", intégrant éventuellement quelques sociétés "privées" (d'économie mixte, en fait), localisées en France ou à l'étranger" (Andreff 1984, 246).

De relatie tussen de overheid (i.c. het Ministerie van Financiën) en de genationaliseerde financiêle groepen

In de relatie tussen de industriële groepen en het Ministerie van Industrie is een ontwikkeling te signaleren naar een grotere mate van autonomie; in de relatie tussen het Ministerie van Financiën en de banken is van meet af aan sprake geweest van een maximale autonomie van het management [37].

In een interview met de 'Haut Conseil' bevestigde Jean-Maxime Lévêque, PDG van 'Crédit Commercial de France', dat de nationalisatie geen verandering van betekenis voor het management van de bank was.

"A ce niveau d'appréciation générale, on peut considérer qu'a la suite de son changement d'actionnaires, la marche de la banque et son développement se sont poursuivis normalement" (Haut Conseil 1985, 288). 
Dat neemt niet weg, dat de socialisten aanvankelijk wel degelijk een taak zagen weggelegd voor de genationaliseerde bancaire sector: kredietverlening conform de prioriteiten van het Plan, actieve participatie in ondernemingen, die in moeilijkheden verkeerden, verlenen van advies en direkte steun aan de PMI bij nieuwe investeringen, opzetten van exportkanalien en het investeren in het buitenland [38].

Deze activiteiten zouden in de $\mathrm{CdP}$ moeten worden vastgelegd, maar die werden tussen het Ministerie van Financiẻn en de banken niet afgesloten. Omdat veel van de bankactiviteiten verband hielden met het conjunctuurbeleid, zouden de banken zich minder goed lenen voor het afsluiten van CdP, waarin in principe meerjarenafspraken worden gemaakt. Delors, de toenmalige minister van Financiën, zet voor de 'Haut Conseil' uiteen, dat de bespreking van het 'plan d'entreprise' van drie banken, die extra steun hadden gekregen (Crédit de Nord, Marseillaise de Crédit en Bordelaise de Crédit) zouden kunnen uitmonden in een CdP. Het kwam er niet van. Integendeel: het Ministerie van Financiẻn toonde geen enkele ambitie haar greep op de financiële wereld te versterken. Het nieuwe wettelijke kader voor de genationaliseerde banken [39] is eerder gericht op een liberalisering (décloisement) van de kapitaalmarkt, dan op een verdergaande afscherming en regulering. Ook met betrekking tot de verzekeringsmarkt bestaan dergelijke liberaliserende opvattingen.

Uit het bovenstaande blijkt het zeer globale karakter van de CdP. Betekent dat nu dat de publieke ondernemingen in het geheel geen bijdrage hebben geleverd aan de realisatie van de doeleinden van het Negende Plan? In het navolgende wordt nader op de vraag ingegaan. Onderscheid wordt gemaakt naar de publieke onderneming als instrument van conjunctuur-, structuur- en sociaal beleid.

\subsubsection{De publieke onderneming en het conjunctuurbeleid}

De publieke onderneming kan instrument zijn van conjunctuurbeleid door variatie van de omvang van de investeringen, de hoogte van de tarieven of prijzen, en door variatie van de hoogte van de lonen. Door de investeringen op te voeren kan de publieke onderneming de vraag in de economie aanjagen, door de tarieven laag te houden remt de onderneming de inflatie en versterkt zij tevens een concurrentiepositie van haar afnemers en door de lonen te varièren zouden de publieke ondernemingen de bestedingen kunnen remmen of stimuleren en wordt de 'cost-push-inflatie' geremd of aangewakkerd.

De socialisten waren in principe geen voorstander van het gebruik van de publieke onderneming voor conjuncturele doeleinden: lonen van werknemers moesten worden bepaald door de (georganiseerde) arbeidsmarkt, terwijl de investeringen niet zozeer van belang zijn qua omvang, als wel qua richting, omdat daardoor de ontwikkeling van de industriële structuur wordt bepaald.

Voor onderzoek naar de mogelijkheden van het hanteren van de tarieven van de publieke ondermeming als instrument van conjunctuurbeleid werd in het kader van het Negende Plan een speciale werkgroep ingesteld, die tot de volgende aanbevelingen kwam [40].

De tariefstelling moet worden gerekend tot de autonomie van de publieke onderneming; variaties dienen het gevolg te zijn van kostenontwikkelingen en concurrentiekracht. 
Een overheidsbeleid van tariefstabilisatie of -verlaging gecombineerd met een contracyclische verhoging van de investeringen, leidt tot verliezen bij de publieke onderneming. Dat heeft twee negatieve gevolgen:

- de autonomie van een onderneming, die financieel afhankelijk is van de overheid wordt snel tot een wassen neus (vergelijk Dreyfus 1973)

- een verlieslijdende publieke onderneming schept onzekerheid met betrekking tot de ontwikkeling van het tarief in de toekomst: potentiële afnemers worden afgeschrikt, omdat de vrees bestaat, dat de onderneming haar tarieven in de toekomst relatief sterk zal moeten verhogen om de tekorten te kunnen dekken.

De hoogte van de tarieven moet niet in de 'contrat de plan' worden opgenomen, omdat korte termijn aanpassingen daardoor worden bemoeilijkt; wel is het zinvol de methodiek van de berekening van het tarief in de contracten vast te leggen. Als door grote tariefstijgingen problemen ontstaan voor sociaal zwakkeren (prijzen van energie en openbaar vervoer) dient via subsidies corrigerend te worden inge- grepen en niet via de vaststelling van de tarieven door hogerhand.

De bedoelingen met betrekking tot het gebruik van de publieke onderneming als instrument van conjunctuurbeleid zijn bescheiden [41], maar hoe verging het de publieke onderneming in werkelijkheid?

De regering hanteerde na mei 1981 de publieke onderneming slechts in beperkte mate als een instrument van conjunctuurbeleid: het stimuleringsbeleid van de 'relance' (mei 1981-juni 1982) werd na een overgangsperiode (juni 1982-maart 1983) veranderd in een beleid van 'rigueur', hetgeen ook zijn weerslag had op het beleid ten aanzien van de publieke ondernemingen. Tot maart 1983 namen de investeringen toe (weliswaar minder sterk dan gepland( (Andreff 1984, 205), en de lonen stegen [42].

Vanaf juni 1982, als de eerste bezuinigingsplannen worden aangekondigd, droeg de publieke onderneming via de algemene prijsstop en de loonmatiging niet meer bij dan de partikuliere ondernemingen, zij het dat de controle scherper was. Na de ommezwaai in maart 1983 waren de publieke ondernemingen in het geheel geen instrument van het conjunctuurbeleid meer: de ondernemingen werden vrij gelaten zelf orde op zaken te stellen door middel van verhoging van de tarieven en ontslag van personeel [43].

\subsubsection{De publieke onderneming en het structuurbeleld}

In het "Plan Intérimaire" is uiteengezet welke rol de publieke onderneming als speerpunt, als herstructureringspool, als motor voor de PMI en als instrument van regionaal beleid zou moeten spelen.

Daartoe zou de publieke onderneming van ruime financięle middelen moeten worden voorzien, waarmee de investeringen in specifieke richtingen zouden kunnen worden opgevoerd. Tegelijkertijd zou de publieke onderneming de spil worden, waaromheen de herstructureringen in zowel de stagnerende als de speerpuntsectoren zouden worden georganiseerd. De voortrekkersrol ten opzichte van het PMI zou gestalte krijgen door middel van de 'conventions de stabilités', waaruit een belangrijke versterking van het industriële netwerk zou kunnen resulteren. De rol in het regionale beleid zou in contracten tussen de publieke onderneming en de regionale instanties nader geconcretiseerd moeten worden. 
Wat de investeringen betreft is reeds opgemerkt, dat in de CdP geen afspraken ten aanzien van de richting van investering werden gemaakt, terwijl ook met betrekking tot de herstructureringen slechts globaal werd aangegeven op welk 'métier" de betreffende groep zich zou moeten toeleggen. Wel blijkt uit onderzoek wan de 'Haut Conseil' (1984) andere bronnen [44] dat van de nationalisatie een versnellende invloed op een aantal reorganisaties is uitgegaan (Stoffaès 1983). Wanneer in een sector produktiecapaciteit moet worden gereduceerd, dan zal jeder van de actoren pogen zijn eigen produktiecapaciteit in stand te houden en anderen voor de overcapaciteit te laten opdraaien. Er onstaat een situatie, die lijkt op het 'prisoners dilemma' (vergelijk Driehuis en Van den Doel 1979), die alleen doorbroken kan worden als een externe instantie met grote bevoegdheden de reorganisatie op zich neemt. Als het 'ministère de tutelle" in deze zijn rol als katalysatoren en organisator van mesosystemen beter met publieke dan met particuliere ondernemingen kan vervullen, dan zouden de nationalisaties in dat opzicht zin hebben gehad. Hoewel het niet goed mogelijk is een volledig helder beeld te krijgen van de invloed van het ministerie op het gedrag van de publieke onderneming, zijn zowel ambtenaren als managers van mening, dat de institutionalisering van het contact tussen de overheid en de ondernemingsleiding in het kader van de onderhandelingen over het $\mathrm{CdP}$ beter inzicht verschafte in de dilemma's van de ondernemingen en de wensen van de overheid. Algemeen is de opvatting dat het 'ministère de tutelle' op basis van die verbeterde informatieuitwisseling herstructureringsprocessen heeft kunnen versnellen. Dat will niet zeggen, dat de overheid herstructureringen kon doorvoeren, die tegen de strategie van de ondernemingsleiding van de publieke onderneming ingingen. Anders gezegd: de individuele ondernemingen hadden met betrekking tot de herstructurering van hun sector een aantal opties, maar de "markt" bracht de herstructurering niet tot stand; na de nationalisatie was er in het 'ministère de tutelle' als het ware een platform ontstaan, een makelaar, die geblokkeerde situaties kon doorbreken binnen de door de ondernemingen voorgestelde opties (vergellijk de herstructurering van Thomson en CGE in hoofdstuk 7).

Wat de 'conventions de stabilité' betreft is reeds in 6.2 opgemerkt, dat diverse publieke ondernemingen wat dat betreft actief zijn, maar ook nu geldt dat die 'conventions' wellicht slechts een strategie hebben versneld. Wat was namelijk met de 'conventions de stabilite' aan de hand?

Publieke ondernemingen moesten met de toeleverende industrie contracten afsluiten voor lange termijn leveringen, overdracht van technologische kennis, het bieden van management- en financiële ondersteuning, het beschikbaar stellen van haar buitenlandse afzetkanalen, etc. Rond de publieke ondernemingen zouden op die manier netwerken van binnenlandse toeleverende ondernemingen kunnen ontstaan. Het MRICE presenteerde de positieve ontwikkelingen op dat terrein als het resultaat van de nationalisaties. Bij die visie dient echter een kanttekening te worden geplaatst. Zoals in hoofdstuk 3 is uiteengezet, doet het proces van 'récentrage', dat wil zeggen van terugkeer naar de kernactiviteiten van de onderneming, zich vanaf het begin van de jaren tachtig in zeer veel grote ondernemingen in alle markteconomieèn voor. Toegenomen onzekerheden nopen ondernemingen tot het afstoten van ondernemingsvreemde nevenactiviteiten en zich te concentreren op hun 'mêtier' alwaar hun comparatieve voordelen liggen. Omdat de specifiek op de 'core business' afgestemde comple- 
mentaire activiteiten veelal alleen tegen relatief hoge kosten via de markt kunnen worden georganiseerd (asset specificity) creëert de onderneming 'gowemance structures' ter coördinatie van de complementaire activiteiten. In navolging van de netwerkrelaties in de Japanse industriële groepen [45] werden in West-Europa en de V.S. ook economische organisatievormen ontwikkeld, die tegen relatief lage transactiekosten de activiteiten van de toeleverancier afstemmen op die van de grote onderneming (bijv. het 'co-makership').

Het 'contrat de stabilité' paste uitstekend in die ontwikkeling; de publieke ondernemingen sloten dergelijke contracten af gelijk partikuliere ondernemingen dat deden. Nergens is uit gebleken, dat het management van de publieke onderneming zich in deze anders gedroeg dan hun collegae van de partikuliere ondernemingen en extra gunstige voorwaarden voor het toelewerende Midden- en Kleinbedrijf zouden hebben gehanteerd.

Wat het regionale beleid betreft, blijkt uit onderzoek [46], dat de publieke onderneming noch betrokken is geweest bij het overleg over de CdP tussen de regio en de nationale owerheid, noch dat tussen de regio en de publieke onderneming apart contracten werden afgesloten. Wel zijn een aantal ad hoc gevallen bekend, waarin de regering poogde een publieke onderneming te bewegen zich te vestigen in regio's met een hoge werkloosheid [47]. Er vond op grond van die pogingen veelal een langdurig moeizaam proces van touwtrekken tussen de ondernemingsleiding en de ambtenaren van het betreffende ministerie plaats, dat meestal resulteerde in een inefficiënt compromis (vergelijk hoofdstuk zeven).

Wat de "bijdrage" van de publieke ondernemingen aan de realisatie van de regionale doelstellingen betreft, is uit het onderzoek geen verschil gebleken ten opzichte van de "bijdrage" van partikuliere ondernemingen; de overheid bleek wat dat betreft onvoldoende greep te hebben op het beleid van het management van de publieke onderneming.

\subsubsection{De publieke onderneming en het sociale beleid}

Een belangrijk onderdeel van het sociale beleid van de socialistische regering vormde de vergroting van de participatie van de werknemers. Daaraan werd vorm gegeven door de 'Lois Auroux' [48] en de 'loi sur la démocratisation du secteur public'. In de wetten werd geregeld hoe de informatievoorziening over de beleidsplannen van het management naar de werknemers vorm moest worden gegeven en over welke onderdelen van de strategie de werknemers de gelegenheid kregen met de ondernemingsleiding van gedachten te wisselen ('droit d'expression'). Verbetering van de relatie tussen de werknemers en de ondernemingsleiding werd van groot belang geacht; in tal van rapporten werd benadrukt, dat in Frankrijk, in tegenstelling tot Japan en de BRD, geen sprake is van een 'cogestion', waarbij 'arbeid' en 'kapitaal' zich inzetten voor het belang van de onderneming, maar van hoge scheidingswanden tussen de werknemers en het management. De 'lois Auroux' die op de partikuliere sector van toepassing zijn, hadden tot doel een informatieuitwisseling tussen de belangengroepen op gang te brengen, waaruit een consultatie en participatie kon wolgen. De Haut Conseil (1984, 383) merkt op: 
"Les lois Auroux ont eu le mérite d'amener les partenaires à se rencontrer en dehors de tout conflit".

De wetten hebben niet zozeer tot doel tot een 'cogestion' te komen, als wel

"(...) permettre aux salariés de s'exprimer, de s'informer, la décision restant aux PDG et aux conseils d"administration".

Om die informatieuitwisseling en discussie vorm te geven werden zogeheten 'conseils d'atelier' en 'conseils de bureau' ingesteld (zie Haut Conseil 1984, 378).

Met betrekking tot de publieke ondernemingen werd een verdergaande bevoegdheid aan de werknemers toegedacht, die werd vastgelegd in de 'loi de démocratisation du secteur public' (loi DSP). In de 'Consell d'Administration' zijn de diverse belangengroepen vertegenwoordigd en dat is de plaats

"(...) où sont déterminées par les administrateurs agissant collégialement les orientations stratégiques où sont suivis et contrôlés les résultats" (Haut Conseil 1984, 370).

In artikel 7 van de Loi DSP is het belang van de 'Conseil d'Administration' vastgelegd:

"Aucune décision relative aux grandes orientations stratégiques, économiques, financières ou technologique de l'entreprise [...] ne peut intervenir sans que le conseil d'administration en ait préalablement délibéré" (vergelijk Haut Conseil 1984, 331-335) [49].

Over de wijze, waarop de demokratisering formeel vorm is gegeven was de vakbeweging tevreden en was de werkgeversorganisatie niet ontevreden. Over de uitvoering van de wetten lopen de meningen uiteen. Wat de gang van zaken bij de publieke ondernemingen betreft, bleek de informatieverschaffing naar de leden van de 'Conseil d'Administration' over het 'plan d'entreprise', de resultaten van de onderhandelingen met het ministerie, alsmede over ingrijpende beslissingen, die in de 'contrat de plan' werden vastgelegd, veelal achteraf plaats te vinden. Voor zover ex ante informatie aan de 'Consell d'Administration' werd verstrekt was deze zeer globaal van aard en inzicht in de strategie en de financiering werd niet gegeven. De vakbeweging en het Ministerie van Industrie waren dan ook zeer kritisch over de resultaten van het democratiseringsproces [50].

Op grond van haar onderzoek kon de 'Haut Conseil' niet anders dan tot een kritisch oordeel over het funktioneren van de 'Conseil d'Administration' komen:

"En premier lieu, il faut noter les difficultés à prendre en compte, par les conseils d"administration actuellement en place, les dispositions (dans la lettre et dans l'esprit) de l'article 7 de la loi de démocratisation qui leur confèrent des. prérogatives étendues sur lla définition de la stratégie économique financière ou technologique de l'entreprise. Comme cela a été relevé ci-dessus la plupart des décisions capitales pour l'avenir des groupes qui ont été prises dans la periode n'ont donné lieu à aucun débat approfondi dans les conseils et parfois même ont été connues de ceux-ci après qu'elles alient été arrêtées et diffusées par la presse $^{* *}$ (Haut Conseil 1984, 316).

Samenvattend kunnen wij concluderen, dat de publieke onderneming als instrument ter verbetering van de democratisering binnen de onderneming heeft gefaald: de besluitvorming over het 'plan d'entreprise' en het "contrat de plan' voltrok zich buiten 
de werknemers om en van besluiten, die niet in de planningsovereenkomst terecht kwamen werden zij achteraf (via de pers) op de hoogte gesteld.

\subsubsection{Conclusies}

In dit hoofdstuk is onderzocht hoe het industriebeleid in Frankrijk gestalte kreeg. De aandacht is daarbij in het bijzonder uitgegaan naar het beleid met betrekking tot de creatie van de industriële groepen en de organisatie van de 'Grands Programmes' onder de presidenten De Gaulle, Pompidou, Giscard d'Estaing en Mitterrand. Met betrekking tot de laatstgenoemde werden drie 'Mitterrandismen' onderscheiden: het voorzichtige beleid van Dreyfus, het interveniërende beleid van Chevenement en het liberale beleid van Fabius.

Uiteengezet werd, dat de 'loi sur l'industrie', waarin de overheid de mogelijke en gewenste ontwikkeling van de 'filières' zou aangeven, niet tot stand kwam en dat het socialistische industriebelleid steeds grotere overeenkomsten ging vertonen met dat van haar voorgangers. Die voorgangers bleken in het initiëren en organiseren van een aantal mesosystemen zeer succesvol te zijn geweest: de 'Grands Programmes" van de olieindustrie, de nucleaire energie, de lucht- en ruimtevaart en de transportmiddelenindustrie zijn alom bekend. Uit het onderzoek bleek, dat 'l'Etat' in staat was complexe sub-systemen te organiseren en in hun ontwikkeling te sturen, mits de overheid de vraagzijde van de binnenlandse markt beheerste, dan wel die markt kon afschermen, de grondstoffenvoorziening of het fundamentele onderzoek via haar kanalen liepen en zij een krachtig coördinerend overheidsorgaan in het leven kon roepen, dat beschikte over toegang tot de financiële middelen, over voldoende informatie en expertise en via de kanalen van een 'corps d"état' een goede verbinding had met het bedrijfsleven, de bureaucratie en de politiek. De mogelijkheid de strategie van ondernemingen af te stemmen op doeleinden van industriebeleid werd in belangrijke mate door de bovengenoemde factoren bepaald. Dat gold zowel voor partikuliere als publieke ondernemingen.

Uiteengezet is, dat het 'créneaux'-beleid resullteerde in een aantal geỉsoleerde successen (en mislukkingen), waaruit geen sterke geïntegreerde industriële structuur ontstond. Met name de diffusie van de informatie en kennis vanuit de 'Grands Programmes' naar de andere sectoren en 'filieres" bleef uit (vergelijk Ergas 1987). De socialisten beoogden met een voluntaristisch industriebeleid tot een geîntegreerde aanpak te komen, waarbij de publieke ondernemingen een centralle rol moesten vervullen. De relatie tussen 'Entreprises Publics' Industriels Concurrencée' (EPIC) en de overheid werd vorm gegeven in het 'contrat de plan'. Echter, de planningsovereenkomsten konden niet aan de verwachtingen beantwoorden:

- de overheid bleek niet goed in staat duidelijke doeleinden te ontwikkelen op macroen mesoniveau op grond waarvan op microniveau over de inhoud wan de CdP kon worden onderhandeld;

- De inhoud van het CdP is conform het 'modele Renault' algemeen van aard [51].

- de autonomie van de publieke onderneming was niet op voldoende coherente wijze geregeld: zo werd bijv. de bevoegdheid over de 'respiration' niet bij wet geregeld;

- het ontbreken van een financiële meerjarenplanning ondermijnde de effectiviteit van de CdP [52]. 
- het ontbreken van een CdP voor de banken en Paribas en Suez plaatste deze financiele sector nagenoeg buiten elke overheidscontrole;

- de informatievoorzlening naar en de raadpleging van de "Conseil d'Administration" met betrekking tot de strategie van de groep bleef in de meeste gevallen uit [53]. Uit onderzoek blijkt (zie noot 44), dat het management en de top van het ministère de tutelle de onderhandelingen over de CdP vanuit een oogpunt van informatieuitwisseling positief beoordeelden, hetgeen in een aantal gevallen een positieve uitwerking op de snelheid van het proces wan herstructurering van sectoren en investeren van ondernemingen tot gevolg kan hebben gehad [54].

Een geïntegreerd industriebeleid, dat een overall-beeld wan de industriële structuur creëert, meso-systemen in hun ontwikkelling beheerst door middel van de publieke ondernemingen en aan elkaar verbindt door een centraal overheidsorgaan, kwam niet tot stand. Noch 'le Plan', noch het 'Ministère de l'Industrie' en evenmin het 'Ministère de la Planification et de l'Aménagement de Territoire', bleken in staat de rol van centrale actor naar zich toe te trekken. Integendeel, door de dominantie van de korte termijn problemen van de inflatie en de betallingsbalans bleef het Ministerie van Financiën haar centrale rol behouden.

Resumerend kunnen wij vaststellen, dat de publieke onderneming in principe een instrument van structuur- en sociaal beleid zou kunnen zijn (vergelijk 4.2). Uit dit hoofdstuk is echter gebleken, dat de publieke onderneming in Frankrijk in de periode 1981-1986 als zodanig faalde.

\section{Noten behorend bij hoofdstuk 6}

[1] Over de jaren zestig schrijven McArthur en Scott (1969) in dat verband: "It would appear that the state not only tolerated, but in some cases encouraged seller concentration and that a number of cartels were under state supervision at the time of our research."

[2] De bekendste: Jean Jacques Servan Schreiber, Le Defi Americain, 1967 en Lionel Stoléru, L'impératif industriel, Seuil, 1969.

[3] Vergelijk de strategie van Thomson en CGE met betrekking tot de computermarkt in de jaren zeventig; zie hoofdstuk 7 .

[4] Volledigheidshalve merken wij op dat het bovenstaande niet van toepassing is op de groepen, die niet tot het 'grands corps' circuit behoren en niet op een door de overheidsvraag gedomineerde markt opereren (BSN, L'Oréal bijvoorbeeld).

[5] Zie Beije et al. (1987).

[6] Nucléaire sector, electronica, telecommunicatie en wapensystemen.

[7] In maart 1968 wees Charpentier, de Directeur-Generaal van de Industrie, in een interview met l'Express op de zwakte van het toenmalige Ministerie van Financiën met betrekking tot het industriebeleid.

"Lorsqu'ils ont un problème à régler, les industriels francais s'adressent au ministere des Finances. A plus long terme, le Plan trace une politique industrielle pour la France. Mails personne n'est chargé de définir en permanence une politique pour nos industries et de s'assurer que les innombrables décisions de I'Etat vont dans le sens de cette politique et ne l'entravent pas" (geciteerd naar Bauer en Cohen 1985, 269). 
[8] '(...) il n'y pas de branches condamnee' (Combret, Le Monde 1978), een slogan die na 1981 overigens veelvuldig door de socialisten zal worden gebezigd.

[9] Zie Haut Conseil du secteur public (1984, 258 en 259).

[10] "En se concentrant trop sur quelques créneaux privilégiés (on peut estimer qu'en 1981 au moins $66 \%$ du total des aides à l'industrie ếtaient destinés, soit au soutien des grands projets publics, soit à la grande exportation) et en n'adoptant pas une attitude plus offensive dans les autres domaines, la France est demeurée technologiquement dominée dans ses ếchanges extérieurs malgré dés réussites brillantes dans certains domaines" (CF 212, 17).

[11] Een uitzondering vormt de filière nucléaire.

[12] De Bandt zet uiteen, dat het generieke industriebeleid, dat met name via belasting- en subsidiemaatregelen gestalte kreeg (zogenaamde "transfer industrial policy"), weinig effectief is gebleken "(...) for that reason, developmental industrial policies are needed and justified" (De Bandt 1987, 56).

[13] Bij het aantreden van de eerste regering Mauroy in 1981 is niet dujdelijk of het CGP, het Ministerie van Industrie of het nieuwe 'Ministère de la Planification et de l'Aménagement du Territoire', de 'expertise autonome' zal worden.

[14] Interview met Dubus in 1983 en Lemaitre in 1984.

[15] Zo werd Renault "verzocht" de vrachtwagenproduktie van Berliet over te nemen, hetgeen resulteerde in Renault-VHI.

[16] 'S'il souhaite se maintenir à son poste, un PDG d'entreprise nationalisée n'entre pas en conflit avec les Pouvoirs publics. Il s'explique et tente de convaincre .... Cela dit, je ne me choquerai pas des manifestations d'égoïsme d'entreprise. Notre démarche se veut pragmatique. Nous avons choisi des hommes de charactère comme PDG. Il faut s'attendre à des rapports parfois difficiles" (...) "Les groupes accepteront ou non nos suggestions. Notre force de persuasion dépendre de l'aisance financière des groupes".

[17] Alain Minc (LNE 08-03-1982) beschouwde de 'industriels' in tegenstelling tot de zogeheten 'planificateurs' als 'les nouveaux saint-simoniens', die

"Passionnés d'industrie, formés à l'ombre des grands corps de l'Etat, [ils] croient aux vertus du modèle français de nationalisation".

Deze nieuwe 'saint-simoniens' van de publieke ondernemingen werden door Dreyfus een grote mate van autonomie gelaten. De benadering van de 'industriels' paste in de traditie, waarin Pierre Lefaucheux en Pierre Dreyfus 'la Régie Renault' uitbouwden en Pierre Guillaumat en André Giraud Elf-Erap respectievelijk het $\mathrm{CEA}$ voor hun rekening namen. De 'indusiriels' beogen volgens Minc (LNE 08-03-1982):

"La nationalisation à la française [consiste à ] alleger la contrainte financière qui pèse sur les groupes pour mieux libérer la capacité offensive des équipes dirigeantes. Les hommes comptent plus que les plans".

[18] Goux (LNE 08-03-1982): "L'Etat est le seul capable de prendre en compte les équilibres macro-économiques dans les choix des investissements. Lui seul peut coordonner les restructurations industrielles".

[19] CERES is de groepering binnen de socialistische partij, die een zeer planmatige sturing van de economische ontwikkeling voorstond.

[20] "Le Ministère de l'Industrie n'êtait pas doté jusqu’à présent des structures luii permettant d'intervenir sur les questions touchant à l'environnement de l'entreprises" (Ministère de l'Industrie, Lettre 101, no. 181, 3). 
[21] Die procedure was niet nieuw, maar werd ook reeds in het kader van de CODIS gehanteerd. (In Ministère de l'Industrie, Lettre 101, no. 184 en volgende verschijnen regelmatig dergelijke "appels d'offres").

[22] "L'Etat n'est pas un collectionneur d'ardoises (...)"

"Il n'y a pas d'autonomie de gestion qui puisse survivre a l'accumulation des deficits" (LNE 06-09-1982).

[23] De Bandt lichtte die rol van het 'corps des mines' toe op éên van de preliminaire sessles van het congres "Toward a competitive future for Europe", Studium Generale EUR, november 1985.

[24] Elysée staat voor de president met zijn staf en "Rue de Grenelle' voor het Ministerie van Industrie.

[25] De GSI kregen een dubbele taak: met betrekking tot de prioriteiten, die in het Negende Plan waren vermeld moest de CNI

"(...) suivi de la milse en oeuvre du Plan et, si besoin est, propositions d'inflexions et de mesures nouvelles;

met betrekking tot andere terreinen zou de CNI overgaan tot een

"(...) exploration de l'avenir et conclusions à tirer en ce qui concerne l'action de l'Etat et des partenaires sociaux" (Ministère de l'Industrie, Lettre 101, 195, 8).

[26] Interview met Soulage op het CGP in december 1984.

[27] Lol d'orientation et de programmation pour la recherche et le développement technologique de la France.

[28] Daartoe werden de 'Conventions Industrielles de Formation pour la Recherche' (CIFRE) ingesteld.

[29] -production et utilisation rationelle de l'énergie et diversification énergétique, -essor des biotechnologies,

-maitrise du développement de la filière électronique,

-recherche scientifique et innovation technologique au service du développement du Tiers Monde,

-recherche sur l'emploi et l'amélioration des conditions de travail,

-promotion du français langue scientifique, et diffusion de la culture scientifique et technique,

-développement technologique du tissu industriel"

(Ministère de la Recherche, Lettre RT, no. 2/3, 7).

[30] De nationalisatie van Renault vond zijn oorzaak in de collaboratie van Louis Renault met de Duitse bezetter.

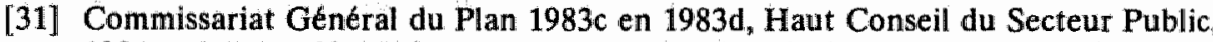
1984, vol. I, hoofdlstuk 3. Interviews met Stoffaës (adjunct-hoofd DIELI), Dubus (Renault), Ranque (Thomson), Lemettre (CGE) (zie ook Daube (1983), Pesant (1983), Le Monde dd. 24-2-1983, Notice 7 in Cahiers Français no. 212.

[32] De effecten van de overeengekomen investeringsstijgingen op meso- en macroniveau zijn overigens niet alleen moeilijk vast te stellen door het ontbreken van informatie over de richting van de investeringen, maar ook door het probleem, dat niet alle ondernemingen de investeringen tot dezelfde meso- en macrocategorie rekenen (Haut Conseil 1984, 212).

[33] Saint-Gobain gaf 150 miljoen ECU aan PP's uit, die overigens na 10 jaar voor minimaal 960 ECU (uitgifteprijs 1000 ECU) verkocht kunnen worden aan éen van de vier banken, die zich met de uitgifte belastten. Daarna bestaat die mogelijkheid steeds met intervallen van 5 jaar. 
[34] Vergelijk Haut Conseil du Secteur Public (1984, 76 en 77) en Haut Conseil du Secteur Public (1988, 44).

[35] Saint Gobain verrichtte in 1982 alleen al 200 respiration- handelingen.

[36] Voor een opsomming van de Entreprises public du premier rang zie Haut Conseil du Secteur Public (1984, vol. II, Annexe 2, blz. 476 e.w.).

[37] "Il ne faut pas que les banques nationales soient des appendices de l'Administration. Leur autonomie de décision et d"action doit être totale", aldus Mitterrand op de ministerraad dd. 17 februari 1982 (geciteerd naar de Haut Conseil 1984, 360).

[38] Zie Haut Conseil 1984, 366 voor enkele positieve resultaten op dat terrein.

[39] Loi bancaire, la modernisation des caisses d'épargne, la loi sur le développement des investissements et la protection de l'épargne (vergelijk Haut Conseil vol. $\mathrm{II}_{\text {, }}$ 362).

[40] Zie Commissariat Général du Plan (1983a).

[41] Dat de verleiding erg groot is om de tarieven te gebruiken als instrument in de strijd tegen de inflatie was onder andere gebleken uit de periode-Barre, toen de publieke onderneming een belangrijke rol in de 'politique d'austérité' speelde door geen tariefverhogingen toe te staan, door aan andere sectoren lage tarieven in rekening te brengen en door de lonen te bewriezen.

[42] Dat alles echter op zo'n schaal, dat Andreff $(1984,206)$ concludeert: "Au total, les entreprises publiques n'ont que modérément servi la politique de relance (comme en 1975-1976) tout en absorbant ses effets (déficits)".

[43] "Notons qu'ainsi le secteur public élargi a participé, plus ou moins directement, à la baisse de la part des salaires dans la valeur ajoutée depuis 1982 , au freinage de la croissance de la consommation (depuis 1983) et à la "rationalisation" des effectifs employés" (Andreff 1984, 207).

[44] Zie interviews met o.a. Le Floch-Prigent (Rhône-Poulenc) en Delors (toenmalig minister van Financiën) en Fabius (toenmalig minister van Industrie) in Haut Conseil du Secteur Public 1984, vol. II, deel 2, hoofdstuk 3. Die opvattingen werden bevestigd in diverse gesprekken met Chr. Stoffaës, die toentertijd adjunct-directeur van DIELI was en zeer nauw betrokken was bij de reorganisatie tussen Thomson en CGE.

[45] De keiretsu is de opvolger van de zaibatsu, waarin een aantal industriële ondernemingen met toeleveranciers, een handelshuis (sogo shosja) en een bank een hecht industrieel-financieel netwerk vormen.

[46] Zie Déllébeque (1984).

[47] Bijp. het geval wan de videofabriek van Thomson in Tonnerre.

[48] Zie bijv. Haut Conseil du Secteur Public (1988, 234-273).

[49] Met andere woorden: "Dans le secteur public, la codécision s'exerce au sein du conseil d'administration qui intervient sur les grandes orientations; la gestion quotidienne rellève de l'exercice normal de la direction" (Haut Conseil 1984, 383).

[50] De CGT verklaarde in een interview met de 'Haut Conseil':

"Dans ces conditions, l'expression des travailleurs sur la vie de leur entreprise et sur sa gestion ne peut être que limitée, l'essentiel des éléments leur échappant" (Haut Conseil, 1984, 314). 
De CFDT stelde:

"Certes les plans d'entreprise et les contrats de plan ont été le plus souvent présentés et discutés, mails dans des conditions quil ne permettent pas véritablement de changer les choses. Les banques, d"ailleurs, restent en marge des contrats de plan, ce qui ne se justifie pas" (Haut Conseil 1984, 326).

Maar ook het Ministerie van Industrie was niet onverdeeld positief over de inschakeling van de Conseil d"Administration in de besluitvorming over de strategie van de groep:-

"D'une manière générale, la qualité des informations fournies est insuffisante et la transparence de la gestion encore faible" (aldus een rapport van het MRI september 1983, geciteerd naar de Haut Conseil 1985, 122).

[51] Zoals in hoofdstuk 7 nader zal worden geadstrueerd kunnen ondernemingen, die hun handen vrij willen houden met succes een beroep doen op de toegezegde autonomie. Blijken zal dat het niet mogelijk is met de EPIC a priori in het CdP de strategie over een aantal jaren vast te leggen: de onzekerheden zijn voor op de wereldmarkt opererende ondernemingen zo groot, dat het opnemen van een reeks specifieke ontbindende voorwaarden met betrekking tot mogelijke ontwikkelingen op de markt, of in de omgeving zou leiden tot prohibitieve contractkosten.

Bovendien is de informatie vrijwel altijd ongelijk verdeeld in het voordeel van de publieke onderneming, waardoor de ambtenaren van het 'Ministère de tutelle' in een afhankelijke positie verkeren.

[52] "Les contrats de plan sont en panne. Pour une entreprise industrielle, il n'est pas possible de définir sa politique, ou de l'insérer dans un concept national planifié, si elle ne sait si les financements sont possibles, et comment ils s'organiseront. La puissance publique, quant à elle, répugne, semble-t-il, à s'engager dans un programme pluriannel de financement. Comment concilier deux différences de comportement antinomiques. Jusqu' à présent, cela n'est pas fait" (Haut Conseil 1984, 352).

[53] "Manifestement, ces contrats (Contrat de Plan JG) sont surtout discuté entre le PD-G et les instances ministèrielles" (Haut Conseil 1984, 341).

[54] Twee kanttekeningen moeten hierbij worden geplaatst:

- de vertegenwoordigers in de 'conseil d'administration' die afkomstig zijn van diverse afdelingen van verschillende ministeries moesten op één lijn worden gebracht, hetgeen veelal een moeizaam, langdurig proces was (Haut Conseil 1984, 408);

- de vertegenwoordigers van de vakbeweging in de 'conseil d'administration" beschouwden het functioneren van de raad als een mislukking, hetgeen impliceert dat de consultatie binnen de publieke onderneming niet van de grond is gekomen en dat het overleg over de strategische beslissingen zich in de vertrouwde kleine kring van managers en topambtenaren is blijwen afspelen. 


\section{DE 'FILIERE ELECTRONIQUE'}

\subsection{Inleiding}

De in de hoofdstukken ến tot en met vier besproken theorieën verschaffen een algemeen inzicht in de wijze, waarop een 'Etat développeur' op consistente wijze vorm dient te geven aan een economische orde, waarin het indicatieve plan, een anticiperend industriebeleid en de publieke onderneming een centrale rol spelen. De twee intermezzo's, alsmede de hoofdstukken vijf tot en met zeven hebben inzicht verschaft in de specifieke condities van de Franse economische orde in verleden en heden. In dit hoofdstuk zal aan de hand van een case-studie worden nagegaan hoe ' $L$ 'Erat développeur' de economische orde vorm heeft gegeven op het specifieke niveau van de 'filière' en de industriële groep. De case-studie van de 'filière électronique' vormt derhalve een nadere adstructie van hetgeen in hoofdstuk 6 in zijn algemeenheid is opgemerkt over het industriebeleid en de rol van de publieke ondernemingen. Gekozen is voor de 'filière électronique', omdat deze de harde kern was van het industriebeleid in de periode 1981-1986. De 'filière électronique' werd door de socialisten beschouwd als een strategische 'filière', die in de toekomst een grote economische groei te zien zou geven en voor de vernieuwing van de produkten en produktieprocessen van andere branches en "filieres" van essentiële betekenis zou zijn.

${ }^{m}$ La grande affaire industrielle d'ici à la fin de ce siècle, à coté du redéploiement energétique, est l'électronique non seulement parce qu'il s'agit d'un secteur essentiel en terme de croissance d"emploi ou d"exportation, mais aussi parce qu"il est au centre de toute modernisation de l"ensemble de notre industrie. L'électronique constituera la priorité industrielle du IXe Plan"' (Mitterrand 1982, 417).

De beheersing van de electronische 'filière" werd niet alleen vanuit economisch gezichtspunt een belangrijke rol toegedacht, maar de 'francisation de la filière électronique" werd ook noodzakelijk geacht vanuit militair-politiek en cultureel oogpunt [1].

De analyse in dit hoofdstuk is gericht op het achterhalen van de effectiviteit van het beleid met betrekking tot de 'filière électronique'; heeft het beleid invloed gehad op de strategische beslissingen van de actoren, zijn de doeleinden van de overheid met betrekking tot de ontwikkeling binnen en van het netwerk gerealiseerd? Zoals eerder opgemerkt (zie 1.1) is het uitermate moeilijk de effecten van overheidsbeleid te isoleren van de gevolgen wan andere interne en externe factoren. Desalniettemin zou een gedetailleerd micro-onderzoek mogelijk enig inzicht kunnen verschaffen in de gevolgen van de verandering van de machtsbasis van de verschillende actoren, zoals die zich met de nationalisaties in $\mathbf{1 9 8 2}$ heeft voltrokken. Nagegaan zal worden, of en in welke mate de overheidsdoeleinden met betrekking tot de diverse branches van de 
'filière électronique' ten aanzien van de investeringen, $\mathrm{R} \& \mathrm{D}$, samenwerking tussen grote en kleine ondernemingen etc. zijn gerealiseerd en in hoeverte in dat verband de strategie van de publieke ondernemingen vanuit de overheid is beinvloed.

Analyse van de branches in hun economische, maar ook socio-politieke context, kan inzicht verschaffen in de wijze, waarop de Franse overheid heeft gepoogd de ontwikkelingen in de strategische "filière électronique' te beheersen.

De 'fillère électronique' zall derhalve volgens de systematiek van de netwerkbenadering worden geanalyseerd:

- welke zijn de actoren: ondernemingen, branche-organisaties, onderzoekinstellingen, politieke partijen en (afdelingen van) ministeries;

- wat is de machtsbasis van de actoren: welke kennis en informatie is van essentieel belang en wie beschikt daarover; wie beheerst de vraag- of aanbodzijde van de markt; welk transactieketen is van strategisch belang, is sprake van patenten, verboden of vergunningen?

- welke zijn de doeleinden, instrumenten en strategieën van de actoren; heeft de overheid ten aanzien van de ontwikkeling van het netwerk specifieke doeleinden, welke instrumenten staan haar ter beschikking, welke strategieën ontwikkelen de andere actoren?

- aan de historie van de relaties in het netwerk en die met haar omgeving dient in de case-studie ook aandacht te worden besteed, omdat alleen dan de strategie van de actoren goed kan worden begrepen.

In 7.1 worden de diverse branches van de 'filière électronique' gepresenteerd, waarna in 7.2 nader op de telecommunicatie en de computerindustrie wordt ingegaan. In 7.2 .1 wordt de ontwikkeling van de telecommunicatieindustrie tot 1981 geanalyseerd; na een beschrijving van de rol van de diverse actoren (7.2.1.0), wordt in 7.2.1.1 aandacht besteed aan de industrielle groepen Thomson en CGE. De machtsverhoudingen in de telecommunicatieindustrie rond 1981 komen in 7.2.1.2 aan de orde.

De ontwikkelingen in de computerindustrie passeren in 7.2.2. de revue. De rol van de diverse actoren wordt in 7.2.2.0 beschreven. In 7.2.2.1 wordt de balans van 1974 (begin van de periode van president Giscard d'Estaing) opgemaakt, waarna in 7.2 .2 .2 de strategie van de industriẻle groepen vanaf 1974 aan bod komt. In 7.2.2.3 wordt het beleid van Giscard d'Estaing met betrekking tot de computerindustrie besproken. De balans van de 'filiere electronique' in 1981 wordt in 7.2.2.4 opgemaakt.

In 7.3 wordt het beleid van na 1981 geanalyseerd: de nationalisaties komen in 7.3.0 aan bod en het 'Plan d'Action Filière Electronique' in 7.3.1. Aan de pogingen de centralle actor in de telecommunicatieindustrie, (Direction Générale des Télécommunication) weer onder overheidscontrole te brengen, wordt paragraaf 7.3 .2 gewijd. Het beleid ten aanzien van de publieke ondernemingen komt in 7.3 .3 aan bod: de inhoud van de 'contrats de plan' in 7.3.3.0 en het 'Yalta de la Télécommunication' in 7.3.3.1. De herstructureringen in enkele andere branches van de 'filière électronique' worden in 7.3.3.2 beschreven.

In paragraaf 7.3 .4 worden de ontwikkelingen vanaf 1981 nogmaals geanalyseerd, maar nu vanuit het perspectief van de industriële groepen: Thomson (7.3.4.1), Bull 7.3.4.2), CGE (7.3.4.3) en Matra (7.3.4.4). Conclusies volgen in 7.4 . 


\subsection{De branches van de 'filière électronique'}

De 'fullère électronique' bestaat uit een grote variëteit van branches: telecommunicatie, computers, massaconsumptiegoederen, etc. Verwarring over de samenstelling van de 'filière électronique" kan gemakkelijk ontstaan, omdat onderzoekers en overheidsinstanties niet dezelfde indeling hanteren. Zo worden in de nomenclatuur van de 'Direction des Industries Electroniques et de l'Informatique' (DIELI) van het Ministerie van Industrie elf branches tot de 'filière' gerekend, zulks in tegenstelling tot de nomenclatuur van de 'Féderation des Industries Electrique et Electronique' (FIEE), die slechts zeven branches kent (Truel 1983, 41; Gougeon, Ponson, Tinard 1984, 24)). Zoals in hoofdstuk 3 is aangegeven behoeft het geen verbazing te wekken, dat het Ministerie van Industrie een andere indeling hanteert dan een brancheorganisatie, omdat vanuit de optiek van de beleidsdoelstellingen van de overheid andere branches relevant kunnen zijn dan vanuit de optiek van een werkgeversorganisatie. Omdat in het navolgende de analyse van de rol van de overheid centraal staat wordt uitgegaan van de indeling van de DIELI (zie schema 7.1, vergelijk Zarader 1983, 244).

\subsection{De branches van de telecommunicatie en computers tot 1981 nader bekeken}

\subsubsection{Inleiding}

Wij richten onze aandacht in dit hoofdstuk in het bijzonder op de branche van de telecommunicatie en van de computers. Blijken zal, dat de overheid in de eerstgenoemde branche haar 'rôle développeur' uitstekend heeft weten waar te maken, maar dat zij in de computerbranche niet in staat bleek de ontwikkelingen ook maar enigszins richting te geven.

\subsubsection{De telecommunicatieindustrie voor 1981}

Halverwege de jaren zeventig werd het politieke besluit genomen het telefoonnet in Frankrijk drastisch te moderniseren: in het Zevende Plan werd de telecommunicatie één van de PAP [2] (126 MdF van de in totaal $200 \mathrm{MdF}$, dat voor 25 PAP beschikbaar was voor de periode 1977-1981 viel aan de telecommunicatie toe, zie 5.5). De Franse overheid heeft als een ware 'Etat Développeur' vorm gegeven aan de ontwikkeling van de branche door middel van een gerichte financiering, reorganisatie van ondernemingen, protektie van de markt, organisatie van het onderzoek en de creatie van een centrale coördinerende organisatie.

\subsubsection{De actoren in historisch perspectief}

In de jaren twintig had ITT zich een sterke positie op de Franse telecommunicatiemarkt verworven. Door middel van haar 'switching companies', Compagnie Général de Constructions Téléphoniques (CGCT) en Le Matériel Téléphonique (LMT), voorzag ITT onder het toeziend oog van de PTT de lokale markten van telefooncentrales. In ruil voor een groot marktaandeel was. ITT bereïd aan de lokale overheden centrales te leveren, die op hun specifieke behoeften waren toegesneden met als resultaat, dat voor Frankrijk als geheel geen goed geintegreerd telefoonnet ontstond. De situatie 


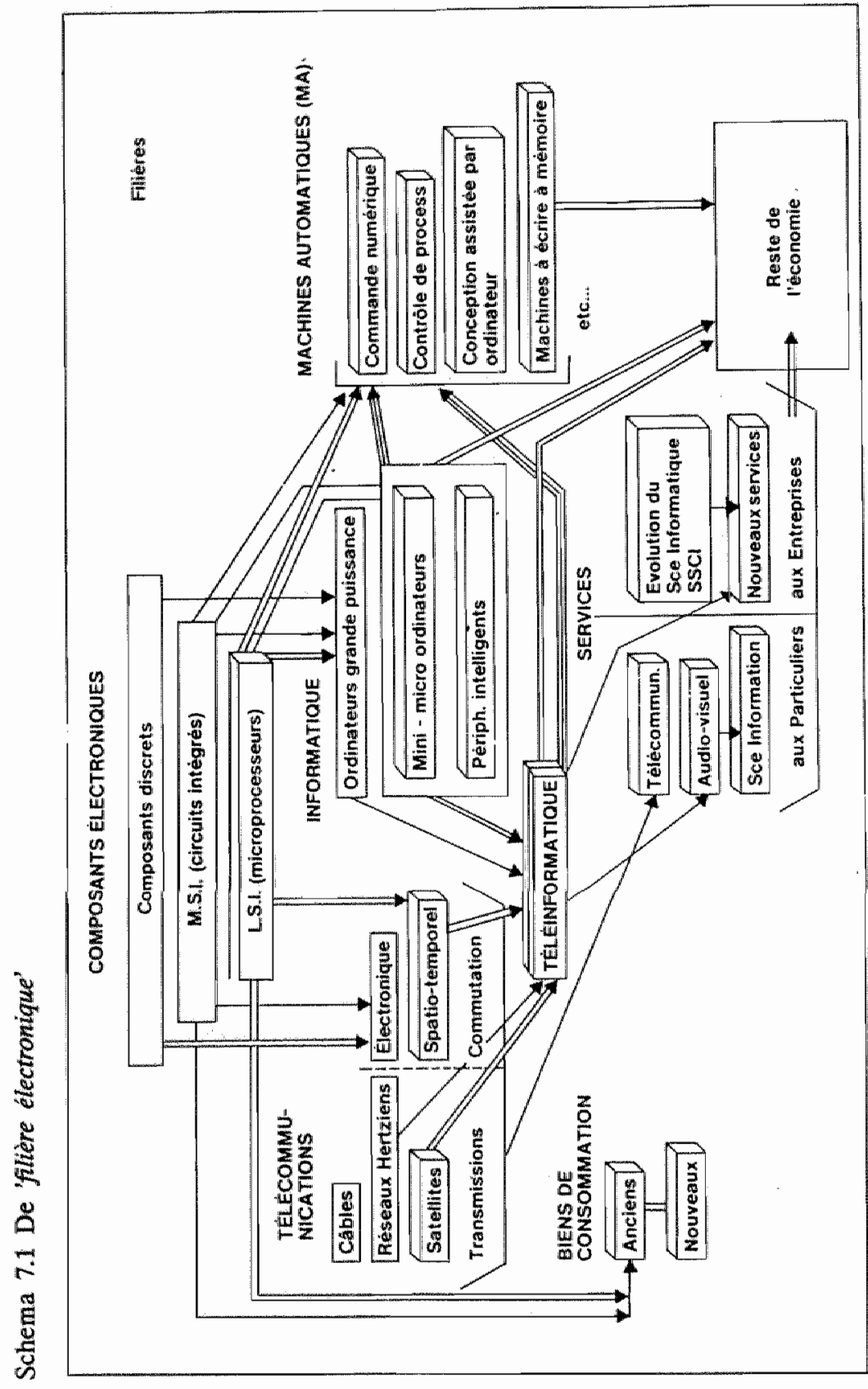

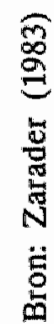


was in het begin van de jaren zestig zo slecht, dat de NATO de Franse verbindingssystemen als een gevaar voor de verdediging van het Westen beschouwde (Cawson, Holmes en Stevens 1985, 18).

Naast CGCT en LMT van ITT opereerden op de Franse markt CIT van CGE en Ericsson-France, maar die namen tot ongeveer 1975 een bescheiden positie op de markt in. De grote electronica-groep Thomson was tot het midden van de jaren zeventig de grote afwezige op de Franse markt; in 1926 had zij haar belangen aan ITT verkocht en in 1967 was met CGE de afspraak gemaakt, dat zij zich niet op die markt zou begeven ('Yalta de l'électronique') [3].

De markt werd onder de zittende ondernemingen verdeeld in de zogeheten 'Club des Télécommunications". Twee "sociétés d'économie mixte' (Socotel en Soletec) organiseerden en verdeelden de markt. Aanvankelijk was Socotel opgericht om onder de hoede van het 'Centre National des Etudes des Télécommunication" (CNET zie verderop) de technische samenwerking tussen de ondernemingen te coördineren; in werkelijkheid ontwikkelde Socotel zich tot een organisatie, die de verdeling van de markt regelde: LMT en CGCT (groep ITT) kregen $42.5 \%$ van de markt van telefooncentrales, CIT (groep CGE) 29\%, La Société des Téléphone Ericsson (STE, groep Ericsson) $18 \%$ en l'AOIP $10.5 \%$. De organisatie Sotelec speelde dezelfde rol met betrekking tot de transmissie: Alcatell en Cables de Lyon (groep CGE) hadden $40 \%$ in handen, G3S 30\%, LTT (groep ITT) 20\%, TRT (groep Philips) $6 \%$ en het restant was verdeeld over enkele kleine ondernemingen (Barreau en Mouline 1987, 41).

Naast de ondernemingen is in de telecommunicatiebranche een belangrijke rol weggelegd voor het CNET en de 'Direction Général des Télécommunications' (DGT) van het Ministerie van de PTT.

Toen de CNET in 1944 werd opgericht, was het alleen een onderzoekcentrum , dat werd beheerst door het 'Corps des Ingénieurs de l'Ecole Supérieur des Telecommunications' en 'Ecole Polytechnique'. Later toen de telecommunicatie een speerpuntsector werd, kreeg het CNET ook andere taken toegedeeld: met name moest hij zorgdragen voor de 'francisation' van de communicatietechnologie met het doel van de dominantie van ITT af te komen. De CNET had een grote macht, die voor een belangrijk deel was gebaseerd op zijn taak de technische standaarden vast te stellen. In de loop der jaren had het CNET ook de taak van financieel controlleorgaan gekregen van het Ministerie van PTT: in 1954 werd de "Service Central du Controle des Prix' gecreëerd, dat onder de verantwoordelijkheid van de direkteur van het CNET werd geplaatst. De prijzen van de telecommunicatiematerialen werden door het CNET vastgesteld op basis van de kosten van de leveranciers, hetgeen impliceerde dat het CNET de winstmarges bepaalde. Gevolg van deze controle was een prijsdaling van de telecommunicatiematerialen in de periode 1967-1973. Ook werd het CNET vertegenwoordiger van de producenten ten overstaan van Socotel en Sotelec. Door die taken was het CNET tot ongeveer 1974 de belangrijkste verbindingsschakel in de Franse telecommunicatieindustrie. Vanuit zijn spilpositie was hij in staat door middel van patentpooling en marktverdelingsafspraken de Franse ondernemingen te bevoordelen ten opzichte van ITT. Tegelijkertijd werd gepoogd de dominantie van ITT te doorbreken door haar alleen toestemming te verlenen het Pentacontasysteem op het platteland te installeren en aan Ericsson-France de centrales in de grote steden te gunnen (CP400 systeem). 
De verdeel- en heerspolitiek ten opzichte van de buitenlandse ondernemingen werd gevolgd in afwachting wan de ontwikkeling van een eigen Franse centrale, hetgeen door het CNET en de CGE ter hand was genomen (de E10).

Het prijs- en marktverdelingsbeleid van het CNET, dat buiten zijn oorspronkelijke onderzoektaak omging, doorkruiste in toenemende mate de steeds belangrijker wordende DGT, waarmee in 1974 een groot conflict ontstond.

In 1941 was de 'Direction des Télếcommunications' (DT) gecreëerd, die het overheidsbeleid ten aanzien van de radio, telefoon en telegrafie onder haar hoede $\mathrm{kreeg}$. De DT was onderdeel van het Ministerie van PTT. Onderdeel zijn van een zware bureaucratie leverde echter in toenemende mate problemen op: het aantrekken van hooggekwalificeerd personeel werd belemmerd door de starheid in de salarissen, investeringsbeslissingen konden niet autonoom worden genomen en er bestonden geen mogelijkheden buiten het budget om extra financiële middelen aan te trekken. Omdat de telecommunicatie in het Zevende Plan een prioriteit was geworden en een flexibele aanpak gewenst was, stelde Minister Giscard d'Estaing in 1967 voor de telefonie los te koppelen van het Ministerie van PTT en een zelfstandige 'Compagnie de Téléphone' te creëren. Zo'n verzelfstandiging werd later (1974) ook aanbevolen door de 'Cormmission Parlementaire de Contrôle de Gestion du Service Public du Téléphone', alsmede door de 'l'Association des Ingénieurs des Télécommunications'. In 1978 werd een afscheiding van de telefonie uit het Ministerie van de PTT ook voorgesteld in het rapport Nora-Minc. Al die voorstellen vielen niet in goede aarde. Door de sterke oppositie van de vakbonden, die "een ontmanteling van het publieke goed" vreesden en niet wilden, dat hun leden de ambtelijke status zouden verliezen, koos de regering. niet voor een verzelfstandiging van de DGT [4], maar voor een compromis, waarbij de DGT onderdeel van het overheidsapparaat bleef, maar volop de gelegenheid kreeg zich als een particuliere onderneming te gedragen.

De reorganisatie van het Ministerie van PTT in 1971 was een eerste stap op weg naar de feitelijke verzelfstandiging van de DGT. Binnen de PTT ontstonden toen twee aparte direkties: de DGT en de 'Direction Générale des Postes et des Services Financiers'. Elk van de directies was autonoom met betrekking tot de besteding van het budget en het personeelsbeleid en de DGT slaagde erin door middel van een premiestelsel hoog gekwalificeerde ingenieurs aan te trekken.

De DGT wilde als dominante vrager op de Franse telecommunicatiemarkt niet meer afhankelijk zijn van buitenlandse producenten en uitte vanaf het begin van de jaren zeventig in toenemende mate kritiek op het beleid van het CNET toen een snelle modernisering van het Franse telecommunicatienetwerk onder leiding van de dominante Franse onderneming CGE uit bleef.De DGT weet dat aan laksheid en onvoldoende financiële steun van het CNET. In 1974 werd de Franse markt nog steeds door buitenllandse ondernemingen gedomineerd: ITT nam $40 \%$ voor haar rekening en Ericsson $16 \%$. Ondanks de inspanningen in het kader van het Zesde Plan had de telecommunicatie in Frankrijk toch een achterstand opgelopen: in 1975 was de telefoondichtheid in Frankrijk de helft van die in Duitsland en 1/4 van die in Zweden; de omzet in de telecommunicatie industrie beliep in Frankrijk 1\% van het 'Produit Intérieur Brut' (PIB) tegen bijvoorbeeld $1.5 \%$ in Duitsland en $2.2 \%$ in Zweden [5]. In 1974 ontstond tussen de DGT en het CNET een scherp conflict over de wederzijdse 
competenties, waaruit de DGT als overwinnaar te voorschijn kwam. In het Zevende Plan werd de DGT de grootste investeerder in Frankrijk (120 MdF in de periode 1975-1979). Om die plannen te kunnen waarmaken wilde de DGT over eigen finan* cieringsmogelijkheden beschikken en tevens werd het noodzakelijk geacht haar organisatiestructuur toe te snijden op haar 'rôle développeur'.

De DGT kreeg de mogelijkheid zelfstandig financiële middelen aan te trekken, waardoor zij onafhankelijk werd van het Ministerie van Financiën. Naast de interne financiering uit de opbrengsten van haar telecommunicatiediensten en de leningen wan de "sociétếs de financement' (financièringsmaatschappijen, zoals Finextel, Codetel, Agritel en Creditel), was haar belangrijkste financieringsbron de 'Caissé Nationale des Télécommunications' (CNT). De CNT zette leningen uit, sloot bankkredieten af en nam deel in de financieringsmaatschappijen. Van 1974 tot 1978 dekte de CNT $78 \%$ van de financieringsbehoefte van de DGT. Zij werd daarmee én van de grootste Franse leners op de Eurodollarmarkt. Critici wezen er overigens op, dat het afsluiten van leningen in het buitenland relatief duur was en dat een grote afhankelijkheid van het buitenland ontstond (Barreau en Mouline 1987, 113). Daar stond tegenover, dat haar financiêle onafhankelijkheid de DGT in staat stelde als een ware 'l'Etat développeur' vorm te geven aan haar voluntaristische industriebeleid in de telecommunicatie.

Wat de aanpassing van de organisatiestructuur van de DGT betreft, is het decreet van 16-10-1974 van belang. Binnen de DGT werden drie direkties opgezet [6]:

- de 'Direction de la Production' (DPR) verving de 'Direction de l'Equipment et des Marchés'. De nieuwe directie omvatte ook de ingenieursdiensten, die voorheen onder het CNET vielen;

- de 'Direction des Affaires Commerciales' (DAC);

- de 'Direction des Affaires Industrielles' (DAI), welke de centrale instantie zou worden voor het industriebeleid in de telecommunicatiesector. De DAI ontwikkelde het beleid, verzorgde de technische controle en beheerste de prijsontwikkelling van de dienstverlening. De twee laatstgenoemde taken werden van het CNET overgenomen. Het CNET zelf werd sterk afhankelijk van de DAI, omdat deze ook de onderzoekgelden beheerde.

Aan het hoofd van de DGT en de DAI werden sterke persoonlijkheden benoemd: $G$. Théry (polytechnicien, corps des télécommunications) en J.P. Souviron (polytechnicien, corps des mines) [7].

In 1976 werd het domein van de DAI uitgebreid tot DAII: 'Direction des Affaires Industrielles et Internationales' en in 1980 werd de DAC de 'Direction des Affaires Commerciales et Télématiques', waardoor zij verantwoordelijk werd voor de commercilalisering van alle produkten van de telecommunicatieindustrie. Ook kreeg de DGT een eigen 'Service d̀ la Prospective et des Erudes Economiques' (SPES); waar lange termijn ontwikkelingen op technisch, economisch en sociaal-politiek terrein voor de telecommunicatie industrie werden geanalyseerd.

"Au terme de ces réformes, la DAII concentre tous les moyens de la politique industrielle des télécommunications depuis la recherche (tutelle sur le CNET) jusqu' à la commercialisation (aide à l'exportation et à l'investissement à

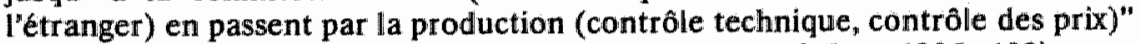
(Barreau en Mouline 1987, 110) (zie ook Bauer en Cohen 1985, 192). 
Het CNET was door de DGT duidelijk naar de achtergrond gedrongen en richtte zijn aandacht vooral op de technologische ontwikkelingen en stelde de "Nommes d'Exploitation et de Fonctionnement' (NEF) vast.

\subsubsection{De industriêle groepen}

Zoals in 6.1 .2 is uiteengezet stimuleerde de Franse overheid in de jaren zestig en zeventig het ontstaan van industriele groepen; in de electronische industrie vond de concentratie plaats door middel van externe groei. Conform de opties van het Vijfde Plan ontstonden aan het eind van de jaren zestig twee industriele groepen in de electronische sector: CGE en Thomson (vergelijk Barreau en Mouline 1987, 37-42). De ontwikkelingen tot het begin van de jaren zeventig zijn weergegeven in schema 7.2 .

\section{CGE}

In 1952 nam CGE een minderheidsaandeel in CSF, hetwelk zij in 1957 met diezelfde onderneming ruilde voor een deelname in CIT. In 1958 nam zij een onderneming in de automatisering over (CEGEA) en deed zij haar aandeel in de "Compagnie des Lampes ${ }^{*}$ over aan Thomson. In 1965 nam CGE een producent van consumptiegoederen (CEPEM) over. Tevens werd een overeenkomst met CSF gesloten over CITEC ('Compagnie pour l'Informatique et les Techniques Electronique de Contrôle'), die op haar beurt over diverse filialen beschikte. In 1966 nam CIT de volgende ondernemingen over:het 'Atelier des Montage Electrique", de 'Compagnie Industrielle de Distribution Automatique", 'Quarz Electrique' en de 'Société Lannionnaise d'Electronique'. Ook werd in 1966 door CGE een overeenkomst gesloten met 'Hispano Alsacienne' op het gebied van de telecommunicatie, hetgeen de aanzet vormde voor de fusie CIT-Alcatel in 1969.

De ontwikkeling van de omzet en het personeelsbestand geven een indicatie van de groei van CGE: van 1959 tot 1972 steeg de omzet van 2.150 MF tot $12.606 \mathrm{MF}$ (in francs van 1972) en het aantal werknemers steeg van 15.000 in 1960 tot 100.000 in 1969.

\section{Thomson}

De 'Compagnie Francaise Thomson Houston' (CFTH) werd in 1959 de nummer één in Frankrijk op het gebied van de radio en televisie door een overeenkomst met Pathe Marconi. In 1962 nam zij het 'Etablissement Bonnet' over. Thomson breidde haar activiteiten in de medische sector uit in Duitsland (1963), België (1965), Italië (1967) en Spanje (1968). In 1966 werd 'Hotchkiss-Brandt' (wapens, automobiel, huishoudelijke apparaten) overgenomen, waardoor de groep Thomson-Brandt ontstond, die in 1967 SOGEME (gespecialiseerd in de postautomatisering) overnam.

In de consumptiegoederensector versterkte Thomson haar positie door de overname van Claret in 1968, terwijl in 1968 ook het belangrijke concern 'Compagnie Générale de Télégraphie Sans Fil' (CSF) in de halfgeleiders en de computers binnen de groep werd gehaald.

De externe groei blijkt uit de toename van de omzet van $1305.5 \mathrm{MF}$ in 1959 tot 7.673 in 1972 (in francs van 1972) en uit de toename van het personeelsbestand van 12.005 in 1959 tot 88.700 in 1969. 


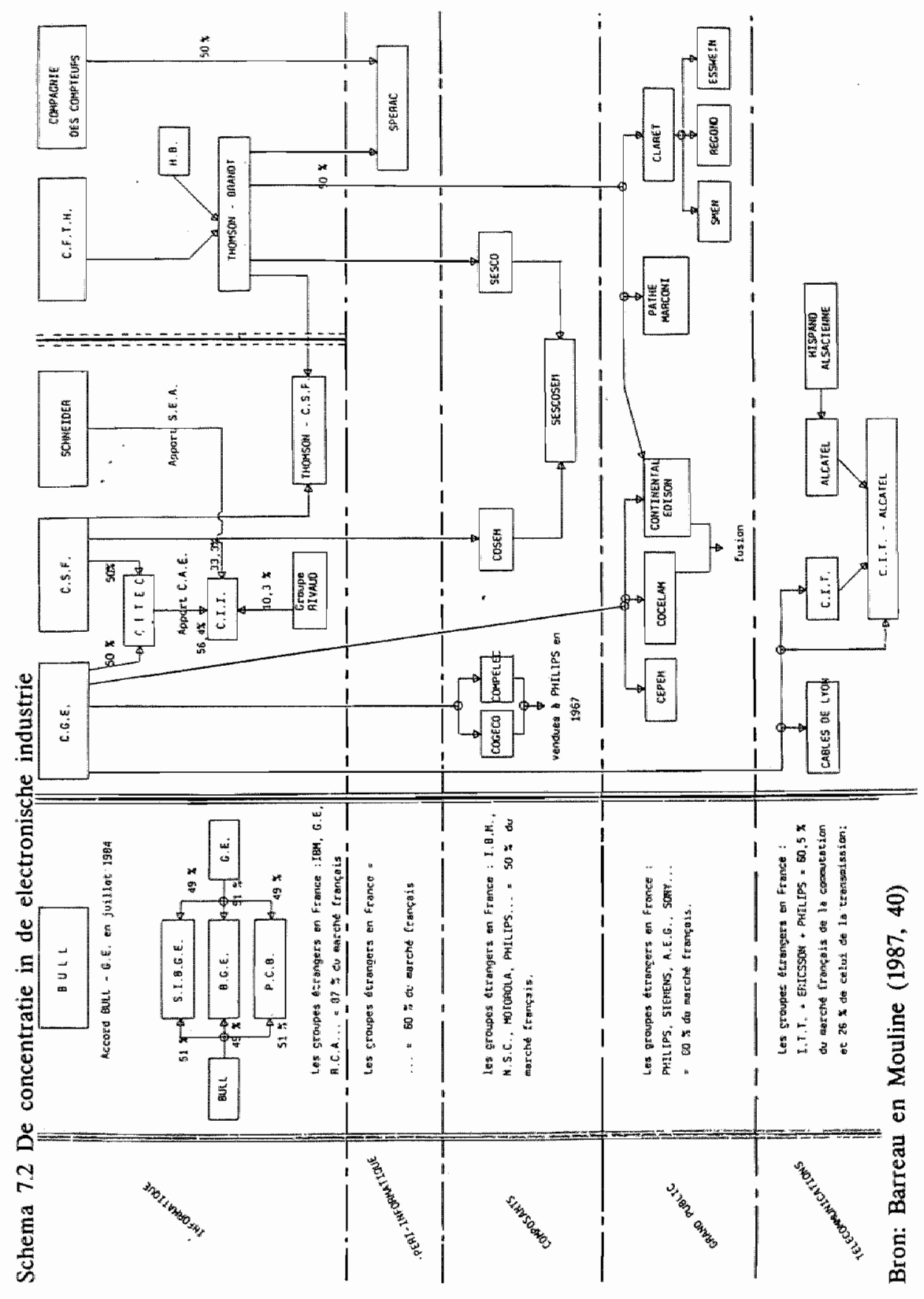


Het in 6.1 .2 geschetste algemene beeld van de strategie van de Franse industriêle groepen in de jaren zestig wordt door CGE en Thomson bevestigd (Barreau en Mouline 1987,41$)$. De positie, die de groepen door middel van de externe groei verkregen hadden, poogden zij te consolideren door middel van marktverdelingsafspraken, alsmede door de creatie van gemeenschappelijke dochterondernemingen. De groepen voerden een 'politique de moindre risque' in plaats van een 'stratégie offensive*. Biellon $(1980,89)$ merkt in dat verband op, dat het scheppen van gemeenschappelijke ondernemingen gericht was op het creêren van een 'alliance conflictuelle d'attente'.

De terughoudende opstelling van de twee Franse electronische groepen blijkt ook uit hun schuchtere internationalisatiebeleid. In 1969 realiseerde de electronische divisie van CGE ternauwernood $10 \%$ van de omzet in het buitenland en bezat zij slechts vier buitenlandse filialen: CITCOM (USA), Brasitel (Brazilië), CEGECIT (Venezuela) en Telmo (Marokko).

Thomson was iets sterker op het buitenland georiënteerd; zij realiseerde in $196935 \%$ van haar electronische activiteiten in het buitenland (Barreau en Mouline $(1987,42)$, Internationalisering betekende voor de Franse groepen in de jaren zestig op de eerste plaats export naar de Derde wereld en de Oostbloklanden, die grote publieke markten kenden, waarop de Franse diplomatie goede toegangen had.

Ook het in 6.1 .2 geschetste beeld van de starre verouderde interne organisatie van de Franse industriële groepen in de jaren zestig wordt door CGE en met name Thomson bevestigd. Uiteengezet is (3.1.2.5) dat een industriële groep alleen een efficiënt beleid kan ontwikkelen als het management goed is geinformeerd over ontwikkelingen binnen de groep, over de marktsituatie en over haar socio-politieke omgeving. Diverse auteurs (Stoleru 1969, McArthur en Scott 1969, Zysman 1977) hebben erop gewezen, dat de Franse ondernemingen in de jaren zestig in vergelijking met bijv. hun Amerikaanse concurrenten niet over een efficiënt informatiesysteem beschikten: onderzoek van o.a. McArthur en Scott (1969) heeft uitgewezen, dat het merendeel van de managers toentertijd bijw. niet op de hoogte was van de winsten en verliezen van de diverse onderdelen van de groep. Dat gold ook voor de electronische groepen. Barreau en Mouline $(1987,43)$ constateren in dat verband:

"Peu informés sur eux-memes, les entreprises et groupes de l'électronique ignorent presque tout de leurs concurrents et des potentialités des marchés. La fonction commerciale qui devrait fournit ce type de renseignements est en effet complletement negligée $[8]$.

Gezien het gebrek aan informatie over interne en externe ontwikkelingen behoeft het geen verbazing te wekken, dat het ontwikkelen van middellange en lange termijn plannen in de twee electronische groepen niet tot de gangbare managementpraktijken behoorde. Op grond van het ontbreken van lange termijn inzichten werden door de ondernemingen onjuiste strategische beslissingen genomen, zoals het afstoten van de halfgeleiders-industrie door Thomson en het verminderen van de participatie in CII (zie verderop).

Uiteengezet is (3.1.2.5), dat een industriële groep alleen goede resultaten kan boeken als de organisate van de groep voortdurend wordt aangepast aan veranderingen in de 
strategie, of in de omgeving. Zo is voor een gediversifiseerde onderneming een multidivisionele structuur een efficiènte organisatievorm (vergelijk McArthur en Scott 1969). Echter, Thomson paste haar structuur na de overnamen in de jaren zestig in het geheel miet $\mathrm{aan}_{*}$ terwijl CGE onder leiding van $\mathrm{A}$. Roux wel tot een andere structuur over ging, maar ook daar bleven de hiërarchische gezagslijnen domineren. Giscard d'Estaing vas mening, dat een toename van de concurrentie de Franse ondernemingen zou dwingen tot een efficiëntere organisatie, verbetering van hun informatiesystemen, het opzetten van lange termijn plannen etc. (vergelijk 6.1.3.1). In dat verband werd in 1972 het 'Yalta de l'électromique' open gebroken en traden Thomson en SAT toe tot de telecommunicatiemarkt. In 1975 kondigde A AchilleFould (secrétaire d'Etar) aan, dat het quota-systeem voor de telecommunicatiemarkt geleidelijk zou worden afgeschaft (Barreau en Mouline 1987, 117). Ook werd in die tijd de keuze van de technologie van de centrales belangrijk: doorgaan met de technisch achterhaalde "spatial', of de voorkeur geven aan de 'communication temporelle", waarin de E10 van CGE een sterke positie innam [9]. Probleem was op dat moment echter de beperkte capaciteit van de E10 in vergelijking met de meer traditionelle systemen van de concurrenten van CGE. De DGT achtte daarom in 1975 verdere invoering van de verouderde 'communication spatiale' noodzakelijk. Zij lanceerde daartoe een 'appel d'offre', waarop echter alle Franse ondernemingen reageerden met voorstellen centrales te bouwen met buitenlandse technologie. Omdat de DGT juist een 'francisation' van de technologie beoogde, werd in mei 1976 besloten prioriteit te geven aan de ontwikkeling van een electronische centrale met een grote capaciteit. CIT-Alcatel moest de E10 perfectioneren en samen met het CNET de opvolger (E12) ontwikkelen. Een dergelijke geheel electronische centrale zou tegen lagere kosten kunnen worden geproduceerd, terwijl de toepassingsmogelijkheden voor allerlei diensten naast de telefoon enorm groot waren. Snelle bestellingen van de E10 door de DGT zou het exportimago van CGE gunstig beïnvloeden (LNE 9-8-1982, 34), aangezien de DGT internationaal in hoog aanzien stond. In 1977 kondigde Théry aan, dat Frankrijk binnen vier jaar 'tout électronique'zou zijn, hetgeen grote gevolgen zou hebben op industrieel en sociaal terrein. Zo werden Thomson en CGCT gedwongen ook digitale centralles te ontwikkelen, hetgeen enorme investeringen vergde, die Thomson later zouden opbreken. Op sociaal terrein dreigde werklloosheid te ontstaan, omdat het aantal benodigde ingenieurs en technici voor de produktie van een digitale centrale vier maal minder was dan voor een analoge centrale. De E10 werd een groot succes.

Pébereau, PDG van CIT-Alcatel, verklaardle in Le Nouvel Economist dd. 9-8-1982:

"Aujourd'hui trois centraux E10 sortent chaque semaine de nos usines. Cela n"a pas d"équivalent dans le monde".

Terug naar 1975. In afwachting van het ontwikkelen van een digitale centrale met een grotere capaciteit werden na het 'appel d'offre' van 1975 de Metaconta van LMT en AXE van Ericsson geinstalleerd, maar de DGT wenste minder afhankelijk te worden van de buitenlandse producenten. Naast de 'francisation' van de technologie achtte de DGT ook een "francisation" van de industriële structuur gewenst. Een afhankelijkheid wan ongeveer $60 \%$ van buitenlandse leveranciers achtte zij niet gewenst, hetgeen in 1976 leidde tot de overname van LMT (ITT) en STE (Ericsson) door Thomson [10]. 


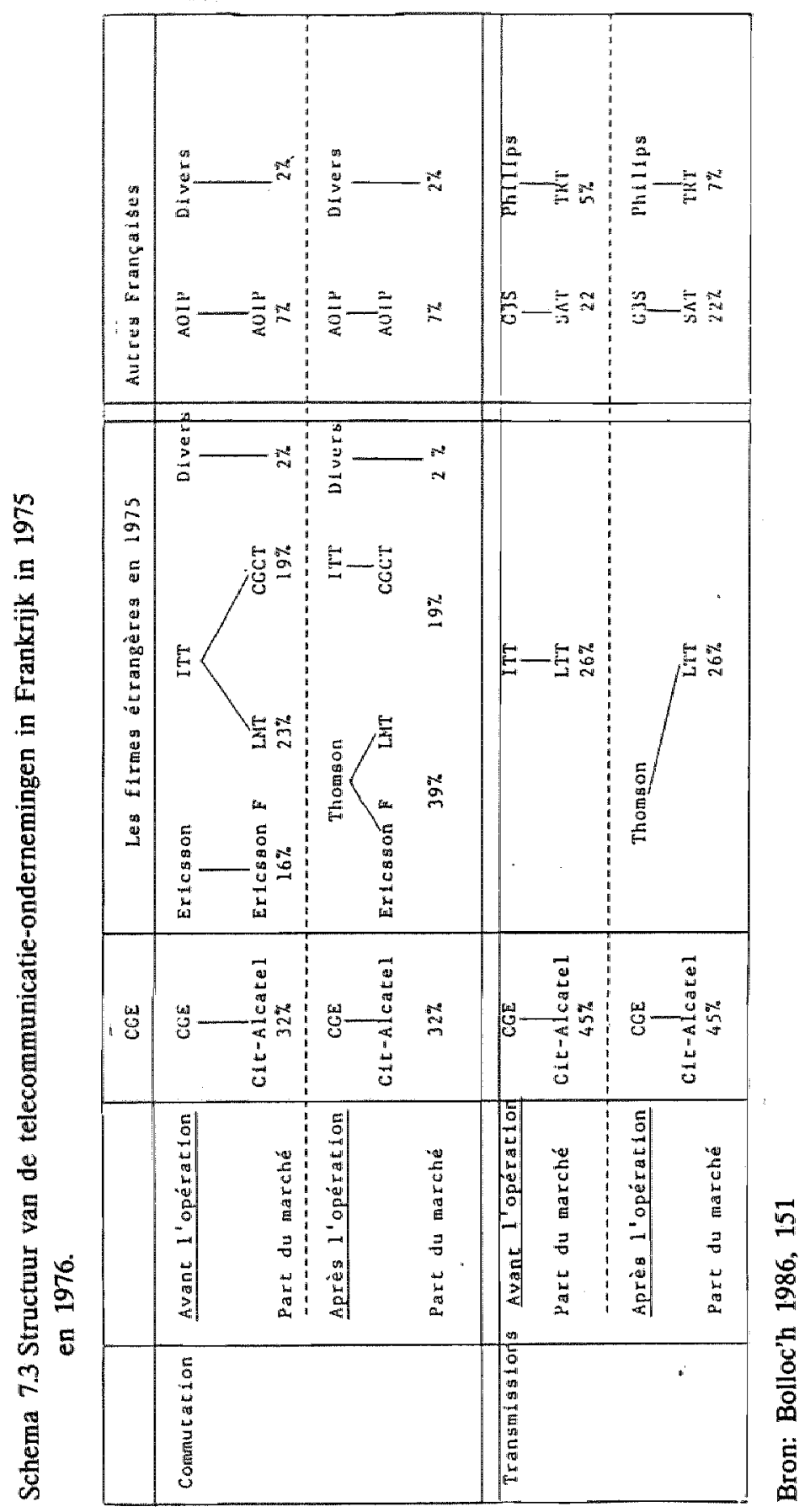


Na die operatie was de markt min of meer evenredig verdeeld tussen Thomson-CSF en CIT-Alcatel, terwijl voor CGCT $16 \%$ overbleef.

Omdat in de toekomst alleen nog de electronische centrale door de DGT zou worden afgenomen nam Thomson het ontwerp van zo'n centrale van LMT (MT20) verder in ontwikkeling, hetgeen haar echter duur kwam te staan. Vanaf 1976 produceerden LMT en STE binnen Thomson-CSF-Téléphone twee electromechanische systemen, waaraan in 1977 een digitaal systeem werd toegevoegd. In de periode 1977 tot 1982 voerde Thomson het grootste assortiment centrales ter wereld, hetgeen zeer inefficiënt bleek te zijn, zowel qua onderzoek en produktie als qua marketing (vergelijk LNE dd. 9-8-1982, 36). Grote reorganisaties bleken noodzakelijk: tussen 1977 en 1982 werden er van de 12000 arbeidsplaatsen 4000 geschrapt of omgeschoold. De introduktie van de digitale centrale (MT 20) ging met grote vertragingen gepaard, hetgeen te wijten was aan het onderschatten van de problemen, die voortvloeienden uit de integratie van de diverse onderzoekafdelingen. Thomson-CSF-Téléphone kwam in grote financiële problemen; de onzet daalde van $2 \mathrm{MdF}$ in 1979 tot $1.9 \mathrm{MdF}$ in 1980 en 1981, terwijl juist een stijging tot $2.5 \mathrm{MdF}$ noodzakelijk werd geacht (ter vergelijking: CIT-Alcatel had een omzet van bijna $3 \mathrm{MdF}$ in 1981).

Om de krachten op de buitenlandse markt te bundelen werd tussen CIT- Alcatel en Thomson een samenwerkingsovereenkomst afgesloten. De DGT beoogde met die operatie tevens de concurrentie in het binnenland te vergroten, waardoor zij als monopsonist de producenten tegen elkaar uit zou kunnen spelen.

Inmiddels had ITT met CGCT gepoogd ook een deel van de Franse telecommunicatiemarkt te veroveren: op de regering werd druk uitgeoefend naast de El0 en de MT20 ook de S12 van ITT af te nemen. Toen orders uitbleven haalde ITT de produktie bij CGCT weg, zodat alleen nog een onderzoekafdeling overbleef, die door ITT met sluiting werd bedreigd. President Giscard d'Estaing en Premier Barre weigerden aan de druk van ITT toe te geven en stelden beslissingen uit tot na de verkiezingen van mei 1981.

\subsubsection{De machtsverhoudingen in de telecommunicatiesector rond 1981}

CGE, Thomson en CGCT zijn op het moment van de nationalisaties voor wat de afzet in Frankrijk van de centrales betreft geheel afhankelijk van de DGT, die zich had ontwilkkeld tot een autonome organisatie binnen het overheidsapparaat en die in staat bleek het netwerk van de telecommunicatieindustrie, volkomen te beheersen. De macht van de DGT was gebaseerd op:

- de beheersing van de vraagkant van de markt, waardoor zij in de positie verkeerde herstructureringen en samenwerkingsverbanden tot stand te brengen [11]. Zij was in de positie prijzen te zetten en zij kon specifieke ondernemingen of groepen bevoordelen onder de voorwaarde, dat zij hun strategieèn afstemden op de wensen van de DGT. Als groot afnemer van halfgeleiders participeerde zij actief in thet 'Plan Composants' (zie 7.2.2).

- de beschikking over de technische kennis. De DGT werd de mogelijkheid geboden hooggekwalificeerd personeel aan te trekken en overvleugelde het CNET, waardoor zij ook van het aldaar aanwezige kennispotentieel gebruik kon maken (sterke verbindingen via het 'corps des ingénieurs des télécommunications') [12]. 
- de toegang tot eigen financiële middelen, waardoor de DGT niet afhankelijk was van de jaarlijkse begrotingsperikelen.

- het beheer van de fondsen voor marktstudies en exportbeoordeling, waarmee de DGT de aandacht van de ondernemers kon richten op onderbelichte marktsegmenten.

- de diversificatie vanuit de telecommunicatie naar de 'télématique, monétique et fibres optiques' (zie verderop, vergelijk Bolloch 1986, 194).

- de creatie van fillalen, die buiten de controle van de Rekenkamer vielen (zie verderop, vergelijk Bauer en Cohen 1985, 219).

De DGT werd in toenemende mate geleid als een partikuliere onderneming: tal van rentabiliteitscriteria werden gehanteerd, terwijl in de organisatie het topmanagement zich gelijk een partikuliere onderneming met de lange termijn strategie bezighield en de directies met de uitwoering.

Conform de cyclus van Hafsi (1984; zie 4.5.2) heeft de DGT zich ontwikkeld tot een autonome organisatie, die het netwerk van de telecommunicatie volledig beheerste.

"Le directeur des Télecommunications est en passe de devenir l"homme le plus puissant de France, en raison des moyens financiers et des pouvoirs dont il dispose",

aldus R.A. Viven, de voorzitter van de Financièle Commissie van het parlement in 1980 (geciteerd naar Bolloc'h 1986, 257) [13].

\subsubsection{De computerindustrie voor 1981}

De 'l'informatique' neemt in de 'filière électronique' een bellangrijke plaats in; met name in het ontwikkelen van moderne defensiesystemen en het besturen van kerncentrales neemt de computer een strategische positie in. De Franse overheid heeft gepoogd door middel van een drietal versies van het 'Plan Calcul' de beheersing over de computerindustrie te krijgen. In tegenstelling tot de DGT in de telecommunicatie kreeg de overheid in de computerbranche geen voet aan de grond.

\subsubsection{De actoren in historisch perspectief}

Een centrale actor aan ondernemerszijde is de "Compagnie Machines Bull' (CMB). Bull bewoog zich in 1933 in de papiersector en breidde haar activiteiten uit naar de informatica (geperforeerde kaarten). $\mathrm{CMB}$ was toentertijd de tweede onderneming in Europa, die samen met IBM de markt beheerste. Problemen ontstonden door een gebrek aan nieuwe produkten en door de oplopende kosten als gevolg van het leasingsysteem (stijgende rente, hoge afschrijvingen). Om de problemen het hoofd te bieden ging Bull over tot het rationaliseren van haar leasing-activiteiten, tot het opzetten van gezamenlijk onderzoek met de 'Compagnie Générale de Télégraphie Sans Fil' (CSF) en ook stelde zij woor, dat het Amerikaanse General Electric (GE) 20\% van de aandelen zou overnemen à $\$ 40$ miljoen. De Gaulle blokkeerde het laatstgenoemde beleidsvoornemen; er moest een "Franse oplossing" komen.

Bull kwam definitief in de problemen door het mislukken van de verkoop van de grote computer Gamma 60. McArthur en Scott (1969) wijzen erop, dat Bull volledig ver- 
zuimde de ontwikkeling van de Gamma 60 te baseren op deugdelijk marktonderzoek. $\mathrm{CMB}$ was succesvol geweest met de kleine Gamma 10 en in plaats van zich toe te leggen op het uitbouwen van dat marktsegment, lanceerde Bull een totaal ander model, dat geenszins aansloot bij de wensen van de afnemers en zonder begeleidende commerciële activiteiten op de markt werd gebracht. Bull verzuimde ook de software in voldoende mate te ontwikkelen, terwijl voor de opleiding van de potentiële gebruikers geen faciliteiten werden gecreëerd (Barreau en Mouline 1987, 34).

De toenmalige Minister van Financiën, Giscard d'Estaing, wilde Bull redden door middel van een "Franse oplossing", zodat Frankrijk voor de computer als essentièle schakel in de technologie voor de nucleaire energie en de defensie niet afhankelijk zou worden van het buitenland, i.c. Amerika. Op initiatief van de overheid werd een groep opgezet, waarin CGE, CSF, Bull en de 'Caisse Dépots' deelnamen. Door de onderlinge belangentegenstellingen en het gebrek bij de overheid aan adequate informatie en voldoende financiële middelen, liep de 'Franse oplossing' op niets uit (McArthur en Scott 1969, 469). Intussen voerde Callies, PDG van Bull, wederom onderhandelingen met het Amerikaanse General Electric, maar nu was de situatie veranderd ten gunste van GE: door de onzekerheid bij Bull was goed geschoold personeel vertrokken, terwijl GE bezig was andere bruggehoofden in Europa te slaan, waardoor zij minder in Bull was geinteresseerd dan voorheen. Toen Bull wederom verzocht of GE aandelen wilde overnemen stelde GE hogere eisen, die resulteerden in een belang van $49 \%$ a $\$$ 43 miljoen. Op 8 april 1964 gaf de overheid noodgedwongen haar goedkeuring aan de kapitaaloverdracht en ontstond Bull-GE.

Op 18 juli 1966 vond een gedenkwaardige ministerraadvergadering plaats: de Amerikaanse onderneming 'Control Data Corporation' weigerde aan CEA een grote computer te leveren, hetgeen voor De Gaulle aanleiding was een plan te ontwikkelen, gericht op het realiseren van totale onafhankelijkheid van Frankrijk op het gebied van de informatica. Het "Plan Calcul" werd gelanceerd, waarin de creatie van een sterke concurrerende Franse onderneming als doel werd gesteld. De Nationale Kampioen moest het onderzoek, de produktie en de marketing van een breed scala computers beheersen. De activiteiten van de onderneming moesten zich concentreren op de 'Grosse Informatique', dat will zeggen de 'électronique professionelle' voor de industriële- en de overheidsmarkt.

Uit de filialen van CSF, CGE, Schneider en de Groupe Rivaud ontstond de 'Compagnie de I'Informatique Internationale (CII) (zie schema 7.4).

Met de creatie van CII ging in december 1966 het eerste 'Plan Calcul' van start. Op het Ministerie van Industrie bestond de idee, dat CII onder overheidsparaplu een eigen Franse technologie zou ontwikkelen en dat Bull-GE de Amerikaanse technologie zou importeren en 'franciseren'.

De "Délégation à l'Informatique" werd de overheidsorganisatie, die de ontwikkelingen in de computerindustrie vorm en richting moest geven: de 'Délégation' moest het algemene beleid ontwikkelen, het onderzoek coördineren, de overheidsaankopen op de Franse produktie afstemmen en dle ontwikkelingen (met name die van CII) evalueren. Aanvankelijk werd de 'Délégation' aan de Premier toegevoegd, hetgeen haar interdepartementale coördinatietalak benadrukte. Echter, onder druk van het Ministerie van Financiën werd zij spoedig naar het Ministerie van Industrie overgeheveld, 
hetgeen haar bevoegdheden aanzienlijk beperkte.

Parallel aan het "Plan Calcul' liep het 'Plan Composants", dat gericht was op "francisation' van de grondstof van de informatica: de halfgeleiders [14]. De overheid nam initiatief tot het behoud voor Frankrijk van de produktie van de halfgeleiders. CGE had namelijk haar filiaal aan Philips verkocht en toen ook Thomson zich uit de halfgeleiders wilde terugtrekken, dreigde die strategische industrie geheel uit Frankrijk te verdwijnen. Thomson werd "verzocht" voor een subsidie van $100 \mathrm{MF}$ over 5 jaar ('convention composants') haar filiaal (Cosem) te fuseren met SESCO, een andere producent van componenten. In 1968 was Sescosem een feit. Thomson bleek echter niet werkelijk geïnteresseerd in de creatie van een dynamisch efficiënt Sescosem. $\mathrm{Zij}$ beschouwde de produktie van halfgeleiders als een 'service' voor haar eindprodukten; Sescosem was slechts een toeleverancier, waarvan de produkten gemakkelijk door die van een concurrent konden worden vervangen. Door gebrek aan investeringen, waardoor geen nieuwe groeipolen van de markt betreden konden worden, verloor Sescosem in de periode 1968-1974 7\% van haar marktaandeel (van $23 \%$ naar $16 \%$ ). In 1976 maakte de onderneming $100 \mathrm{MF}$ verlies.

Schema 7.4 Aandeelhouders van CII eind 1966

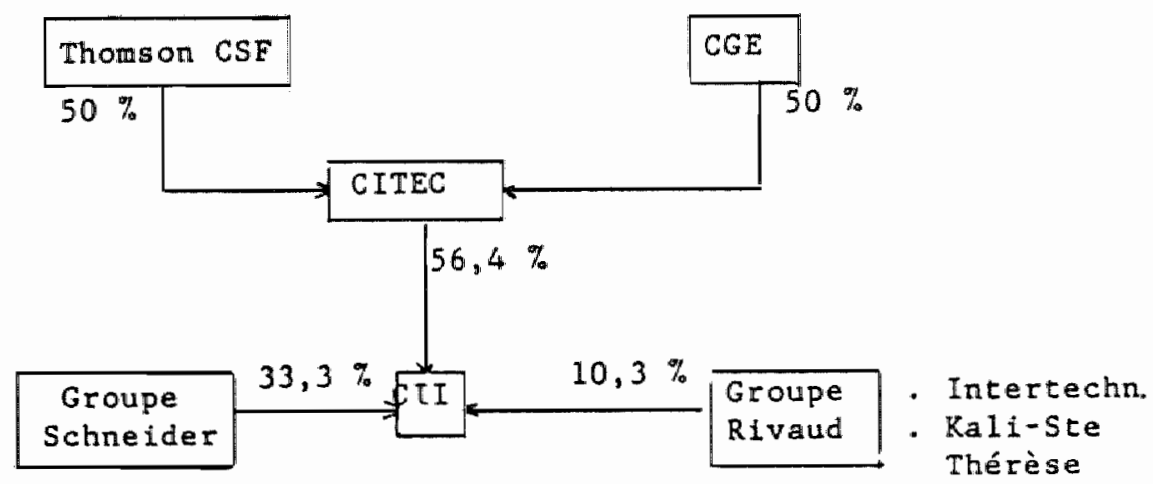

Bron: Bolloc'h $(1986,32)$

Met het 'Plan Calcul' ging het niet naar wens. Zoals gezegd lag de organisatorische verantwoordelijkheid voor het 'Plan Calcul'; evenals dat voor het 'Plan Composants', bij de 'Délégation d l'informatique' van het Ministerie van Industrie. Deze instantie had officieel de taak de ontwikkelingen van CII te monitoren, maar omdat CGE en Thomson niet in CII investeerden en haar in tegendeel alleen voor hun eigen doeleinden gebruikten, ging de 'Délégation' zich in toenemende mate met de directe gang van zaken bij CII bezighouden. Paul Richard, PDG van Thomson beschreef de situatie als volgt:

"On sauvegardait l'apparence de capitalisme libéral et, en toile de fonds, il y avait une autorité totale de l'Etat. La Délégation (Délégation à l'informatique JG) intervenait a tous les échelons de facon quotidienne" (geciteerd naar Bolloc'h 1986, 58). 
In het netwerk van overheid naar CII beheersten de 'hauts fonctionnaires' de sleutelposities.

\begin{abstract}
"Whatever the wisdom of the decision to create a French computer firm, it certainly appears that once again the government bureaucrats chose to do what they knew best - wield the power of the state and manipulate the web of school and social ties between the top-echelon businessmen and government officials * to create operating companies, direct capital flows, and establish guaranteed markets" (Zysman 1977, 75).
\end{abstract}

Twee problemen deden zich echter daarbij voor: enerzijds betrof de 'l'informatique' een turbulente markt met snelle technologische veranderingen, waarvan de vraag niet in alle segmenten door de overheid kon worden beheerst [15], anderzijds moest de Nationale Kampioen de beschermde nationale markt verlaten om de noodzakelijke schaalvoordelen te kunnen realiseren, waarbij zij op de wereldmarkt de strijd moest aanbinden met het dominante IBM.

Uit de hieronder beschreven geschiedenis van het 'Plan Calcul' zal blijken, dat de Franse overheid geen mogelijkheden had de strategie van de betrokken ondernemingen (CGE, Thomson-CSF, CII en Bull-GE) te coördineren en af te stemmen op haar nationale doeleinden. De individuele ondernemingen bleken in hun onderlinge concurrentiestrijd voortdurend het overheidsbeleid te doorkruisen. Daarom werd CII geen sterke Nationale Kampioen, maar een speelbal in handen van de twee rivalen Thomson en CGE.

Door de fusie tussen Thomson en CSF in 1968 was Thomson naast CGE een belangrijke partner in $\mathrm{CII}$ geworden. Thomson en $\mathrm{CGE}$ waren grote rivalen met alls gevolg, dat in hun onderlinge concurrentiestrijd het belang van CII, i.c. het industriebeleid van de overheid, volledig ondergeschikt werd gemaakt aan de deelbelangen van Thomson-CSF en CGE.

"En outre, un climat de guerre froide régnail entre eux deux (Thomson-CSF en CGE JG). Et cet état de tension permanente a certainement beaucoup nui à l'action industrielle"' (Bolloc'h 1986, 36).

Ook op Bull kreeg de Franse overheid geen greep. In 1968 werd onder leiding van GE in Shangri-la (V.S.) besloten, dat Bull de ontwikkeling van de kleine computer aan Olivetti zou overlaten en haar middelgrote 64-systeem in GE zou inbrengen, waardoor voor Bull niet veel meer dan de rol van toeleverancier over bleef. Toen GE rond 1970 besloot de strijd met IBM niet aan te gaan en haar activiteiten overdroeg aan Honeywell, was dat voor Bull aanleiding bij de Franse overheid een fusie met CII te bepleiten, waaruit een sterke Franse onderneming zou kunnen ontstaan.

De problematiek in 1970 rond de herstructurering van de informatica-activiteiten van GE wordt wel de 'seconde affaire Bull' genoemd. Toen GE besloot haar computeractiviteiten over te dragen aan Honeywell Information Systems (H.I.S., waarin Honeywell deelnam voor $81.5 \%$ en GE voor $18.5 \%$ ), had de Franse overheid kunnen besluiten de activiteiten van Bull niet in Honeywell te integreren en een fusie CII-Bull van de grond te tillen. CII zelf was echter niet zo happig op zo'n fusie, omdat zij Bull eerder als een rival dan als een ideale partner beschouwde. terwijl CGE en Thomson in een combinatie van Bull en $\mathrm{CII}$ een bedreiging voor hun eigen marktpositie zagen. De "Franse oplossing" ging niet door en Bull werd bij HIS gevoegd. 
Wel werd 'A l'ombre de l'Etat' het 'Yalta de l'électronique' gesloten met het doel door middel van een herverdeling van de activiteiten tussen Thomson en CGE de spanningen in CII te verminderen. Thomson kreeg een meerderheidsbelang in $\mathrm{CII}$ en trok zich als tegenprestatie terug uit de telecommunicatie, dat aan CGE toeviel.

Uit schema 7.5 blijkt, dat via de 'Compagnie Française pour le Financement de l'Informatique" (FININFOR) CII werd beheerst door Thomson (A. Danzin, vice president van Thomson werd directeur van FININFOR). Ook blijkt dat Schneider haar belang in de informatica sterk verminderde.

Schema 7.5 Aandeelhouders van CII na het "Yalta de l'électronique"

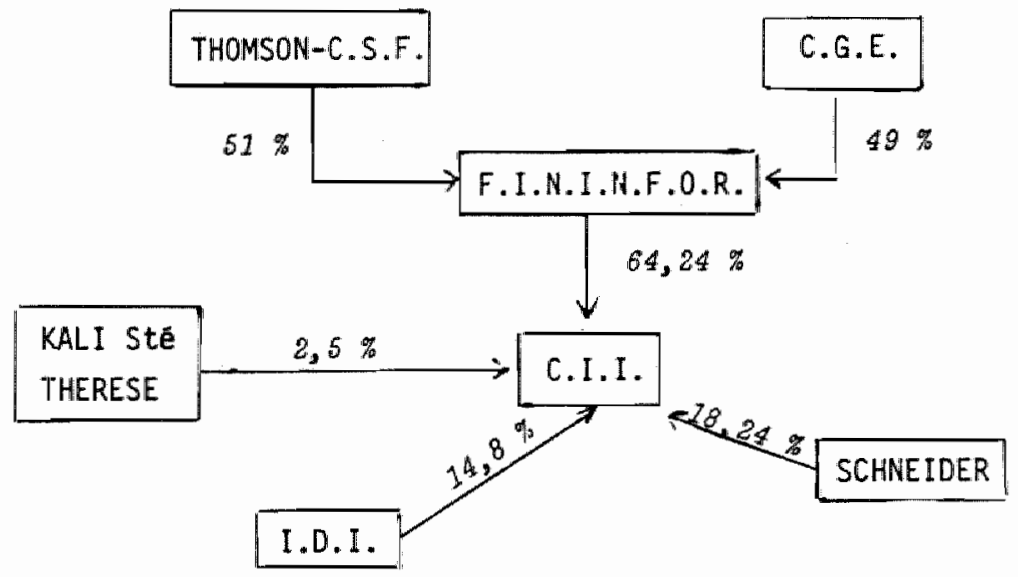

Bron: Barreau en Mouline $(1987,67)$ (vergelijk Bolloc'h 1986, 36).

Tegelijkertijd werden de activiteiten in de mini-informatique in CII geconcentreerd: de 'Compagnie des Compteurs' verkocht haar aandelen SPERAC aan CGE, die ze op haar beurt met steun van de overheid overdeed aan CII. Thomson was de andere aandeelhouder van SPERAC.

De problemen werden voor $\mathrm{CII}$ met de reorganisatie echter niet opgelost: CII beheerste niet de technologie van de halfgeleiders en had evenmin een sterke positie op het gebied van de software. Met name de achterstand met betrekking tot halfgeleiders, waardoor zij gedwongen was deze van buitenlandse ondernemingen te kopen, leidde tot een algehele technologische achterstand, omdat de 'composants' de kern van het computersysteem vormen.

Ondanks de overheidssteun in de periode 1967-1971 (zie tabel 7.1) zijn de resultaten van met name de Nationale Kampioen niet indrukwekkend: in 1970 komt CII op de wereldmarkt van computers niet verder dan $0.3 \%$ en op de Franse markt van de 'Grosse Informatique' neemt zij] slechts $9.5 \%$ voor haar rekening (IBM $58 \%$ en Honeywell-Bull 18.5\%). Zoals gezegd was het ook met de "strategische grondstof" van de 'filiere électronique', de 'composants', slecht gesteld. 
Tabel 7.1 Steunverlening aan de Franse electronische industrie in de periode 1967-1971

\begin{tabular}{|c|c|c|}
\hline Branche & Firmes bénéficiaires & Période 1967-1971 \\
\hline Grosse informatique & C.I.I. & $\begin{array}{l}400 \text { millions de franes } \\
\text { pour frais et marchés } \\
\text { d'étude, } 125 \text { millions de } \\
\text { francs de prets }+10 \text { mil- } \\
\text { lions de francs (1) }\end{array}$ \\
\hline Péri-informatique & S.P.E.R.A.C. & $\begin{array}{l}100 \text { millions de francs } \\
\text { (marchés d"étude et crédits } \\
\text { de développement) (2) }\end{array}$ \\
\hline Composants & Sescosem & $\begin{array}{l}100 \text { millions de francs sub- } \\
\text { ventions }(2)\end{array}$ \\
\hline Télécommunicatiuns & $\begin{array}{c}\text { C.I.T.Alcatel, câbles de } \\
\text { Lyon (groupe C.G.E.) } \\
\text { G.3.S., A.O.I.P., } \\
\text { L.M.T., L.T.T." } \\
\text { C.G.C.T. (groupe I.T.T.) } \\
\text { Ericsson }\end{array}$ & $\begin{array}{l}12 \text { milliards entre } 1954 \text { et } \\
1965 \text { (2e } 3^{e} \text { et } 4 \text { plans) } \\
4 \text { milliards par plan } \\
12 \text { milliards pendant le } \\
5 \text { elan }(1966-1970)(3)\end{array}$ \\
\hline
\end{tabular}

Bron: Barreau en Mouline (1987, 48)

$\mathrm{Na}$ afloop van het eerste 'Plan Calcul' werd in 1971 de steun aan CII voor 5 jaar verlengd ( $870 \mathrm{MF}$ ), terwijl ook Sescosem opnieuw steun kreeg toegewezen. Daarmee ging het tweede "Plan Calcul" van start.

Voor de periode 1971-1975 werd 1.315 MF in de sector gestoken, waarvoor naast CII ook de ondernemingen Intertechnique en Logobax in aanmerking kwamen [16].

Voor CII was in het begin van de jaren zeventig de tijd aangebroken om strategische keuzen te maken, terwijl ook Honeywell-Bull met een nieuwe situatie te maken had, omdat de besluiten van Shangri-La niet door Honeywell werden bekrachtigd. Honeywell wilde zich namelijk zowel op de grote als de kleine computersystemen concentreren, terwijl Bull door moest gaan met de ontwikkeling van de '64'. CII besloot de Europese kaart te spelen met het doel een sterk Europees samenwerkingsverband te creëren, dat zou zijn opgewassen tegen de Amerikaanse druk. De omstandigheden voor een Europese aanpak leken gunstig.

De Amerikaanse onderneming RCA was uit de informatica gestapt, waardoor Siemens, dat daarmee een samenwerkingsverband had, alleen was komen te staan. In januari 1972 sloten Siemens en CII een overeenkomst, waarbij CII de technische leiding kreeg over de ontwikkeling van een nieuwe serie produkten, die compatibel waren met IBM. Met een andere Europese partner, Philips, werd in september 1972 een accoord gesloten. Het enthousiasme voor een Europees samenwerkings verband, 
UNIDATA geheten, was groot. Doel: verovering van $6 \%$ van de wereldmarkt en van $20 \%$ van de Europese markt.

CGE was echter minder gelukkig met de gang van zaken: zij vreesde vooral Philips voor haar 'mini-informatique' en bewerkte de Franse overheid om geen goedkeuring aan Unidata te geven. De vlam sloeg echt in de pan toen de Franse minister van de PTT in december 1972 verklaarde, dat de telecommunicatie voor Thomson geen verboden terrein meer was, waardoor het 'Yalta de l'électronique' werd opengebroken (vergelijk 7.2.1.0) en de strijd tussen CGE en Thomson op alle fronten losbarstte. Omdat Thomson via CII eigenlijk leiding gaf aan de totstandkoming van Unidata, legde CGE tegenvoorstellen op het bureau van de Minister van Industrie, die door het Ministerie van Financiën en door Honeywell-Bull werden ondersteund. In die voorstellen zinspeelde Ambroise Roux van CGE op een mogelijke fusie wan HB met CII, waardoor weer een Franse oplossing in het vizier kwam. Dat viel op het Ministerie van Industrie echter in verkeerde aarde: als moest worden gekozen voor een Europese oplossing, of voor een Franse met een Amerikaans randje, dan had de eerste duidelijk de voorkeur: op 12 februari 1974 werd het Unidata accoord ondertekend.

\subsubsection{De balans van de 'filière électronique" in 1974}

Het overschot op de handelsbalanswan de 'filière électronique' in 1974 van 53 MF bleek met name te steunen op de professionele electronica, dat wil zeggen: op produkten voor de industrie en defensie, terwijl de halfgeleiders, medische electronica, consumptiegoederen, computers en de telecommunicatie een tekort vertoonden. De penetratiegraad in de zwakke branches nam sterk toe (Barreau en Mouline 1987, 71). De overheidssteun ging vooral naar de computerindustrie en de telecommunicatie. De steun aan CII was gemeten als percentage van de omzet $26.5 \%$, hetgeen in vergelijking met bijv. het Engelse ICL (6.3\%) relatief groot was. Desalniettemin waren de resultaten mager: het aandeel van CII in het 'parc public national' was in $197427 \%$, terwijl bijv. de Duitse industrie $43.5 \%$ en de Engelse $56 \%$ wan hun nationale markt bedienden. De interne financiering van CII was $8.4 \%$ in de periode 1971-1974 tegen $17 \%$ voor ICL en $21.8 \%$ voor IBM. De penetratie was in Frankrijk $83.5 \%$ in 1974 tegen $60.5 \%$ in Engeland.

Verbetering in de handelsbalans moest worden gerealiseerd door enerzijds een verandering van de strategieèn van de industriële groepen en anderzijds door het ontwikkelen van een effectief overheidsbeleid.

\subsubsection{De strategie van de industriële groepen 1974-1981}

CII bleef de speelbal tussen Thomson, CGE en later ook Saint-Gobain (zie verderop). Wat Thomson betreft bleef de strategie vooral defensief van aard (externe groei, traditionele organisatiestructuur, beschermde markten). CGE paste daarentegen haar organisatiestructuur aan, maar bleef zich terughoudend opstellen wat de internationalisering betreft. 


\section{Thomson}

De overnamen van Thomson in de consumentenelectronica ("Electronique Grand Public': EGP) waren gericht op het creëren van afzetkanalen en niet op het ontwikkelen van nieuwe produkten, of het invoeren van geavanceerde produktiecapaciteit. Haar beleid bleef erop gericht onderdelen, of eindprodukten in Japan en de V.S. te kopen en haar eigen rol te beperken tot die van handelaar. Thomson-Brandt (EGP) zette in 1974 Thomson Espanola op, in 1975 ESE in Singapore, nam in 1977 Telefunken over en in 1979 Rohren S.A. (van SABA), alsmede Videon S.A. in 1980. Thomson-CSF, voor $40 \%$ in handen van Thomson-Brandt, bewoog zich op de beschermde markten van de professionele electronica, de medische electronica en de telecommunicatie en in geringe mate ook op de computer- en halfgeleidersmarkt. In 1980 werd $80 \%$ van de produktie op beschermde markten afgezet (PTT, Ministerie van Defensie, ORTF, luchthavens en ziekenhuizen), terwijl van de export $90 \%$ naar slechts tien afnemers ging. Drie produktgroepen waren voor Thomson-CSF belangrijk: - de professionele electronica betrof $41 \%$ van haar activiteiten, $60 \%$ van haar export en $55 \%$ van haar onderzoekbudget;

- de telecommunicatie leverde Thomson, ondanks de problemen met de MT 20 toch opdrachten op door haar goede relaties met de overheid;

- radiologie: CGR had in 1979 18\% van de wereldmarkt in handen en $65 \%$ van de Franse markt.

De branches van de 'informatique' en de 'composants' werden door Thomson niet van strategisch belang geacht, maar slechts van ondersteundende waarde.

In het begin van de jaren tachtig boden de 'télêmatique' [17] en de kantoor automatisering ('bureaucratique') Thomson-CSF goede mogelijkheden, maar Thomson aarzelde en liet kansen liggen.

De defensieve opstelling van Thomson blijkt ook uit het handhaven van de traditionele organisatiestructuur in veranderende tijden. Thomson bleef per markt georganiseerd, waardoor dwarsverbindingen tussen afdelingen, die verschillende markten bedienden, niet werden gelegd. Door de grote autonomie van Thomson-Brandt (EGP) en Thomson-CSF (telecommunicatie, professionele electronica), die overigens haar strategie geheel afstemde op de DGA van het Ministerie van Defensie [18], vindt tussen de afdelingen van verschillende produkten geen informatieoverdracht en coördinatie van activiteiten plaats. Mogelijkheden op het gebied van de toepassing van vindingen uit bijv. de professionele electronica in de EGP bleven daardoor wit. Zo werd de 'video disque' ontwikkeld door het 'département informatique" van ThomsonCSF, maar moest worden geproduceerd door het 'département transmission' en zou moeten worden verkocht door het 'département commutation privé", hetgeen onmogelijk bleek. Concurrentie op open markten vereist snelle communicatielijnen tussen onderzoek-, produktie- en marketingafdelingen, die dwars door traditionele markten heen kunnen lopen.

\section{CGE}

CGE veranderde na 1974 wel haar organisatiestructuur en internationalisatiebeleid. Toen zij in de nucleaire sector werd geconfronteerd met de toewijzing van de 
'Superphenix' aan Creusot-Loire en in de telecommunicatie met de komst van Thomson, vond CGE de tijd rijp zich te verwijderen uit de beschermde publieke markten. Besloten werd tot het ontwikkelen van een eigen 'métier' door het stimuleren van eigen onderzoek, tot een politiek van diversificatie en tot een aanpassing van de organisatiestructuur (Barreau en Mouline 1987, 94).

De diversificatie qua afnemers van partikuliere telefoonaansluitingen realiseerde CGE in Frankrijk door de creatie in 1974 van Electrobail en SLET en van GST in 1976. Door een participatie in Locatel in 1979 werd de markt wan de grote afnemers betreden.

De geografische diversificatie naar Noord Amerika werd gerealiseerd door de overname in 1974 van de Amerikanen RPRC (partikuliere communicatie) en van Friden Mailing Equipment (frankeermachines) in 1979, door de creatie van het filiaal TSS (publieke communicatie) in 1979 en door de overname van Alta Technology (betalingsterminals) in 1980. De Europese markt werd bestreken đoor de overname van de Engelse onderneming Roneo Vickers in 1980 (Télématique bureaucratique), terwijl haar filiaal GSI diverse overnamen in de 'Service informatique' realiseerde.

De diversificatie van activiteiten kreeg gestalte door de penetratie op de markt van de energiebesparing en van nieuwe energiebronnen, alsmede door toetreding op de markt van de 'télémarique' en de kantoorautomatisering.

CIT-Alcatel stelde haar technologische kennis veilig door de overname van de leveranciers van halfgeleiders (aankoop van de communicatiedivisie van $\mathrm{CII}-\mathrm{HB}$ in 1977 en van Semi Process Inc. in 1980). In tegenstelling tot Thomson betekende voor CIT-Alcatel het aankopen van buitenlandse technologie niet, dat zij zich daardoor in een afhankelijkheidspositie manoevreerde; op basis van de aangekochte technologie bleek bijv. het filiaal Transac in staat een geheel nieuw produkt te ontwikkelen (automatische bankkluis), waarmee een offensief beleid werd gevoerd. In 1980 bleek CGE zich ontwikkeld te hebben tot een holding, die diverse industriële en commerciële ondernemingen onder zich had. Zij verminderde in toenemende mate haar directe deelnemingen in ondernemingen en ging steeds meer over tot het creëren van gespecialiseerde holdings, die in een bepaalde activiteit waren gespecialiseerd (Barreau en Mouline 1987, 95). De aangekochte ondernemingen werden gereorganiseerd in het kader van het 'métier' van CGE, waarna de Jeiding werd toevertrouwd aan een autonome holding. Zo creêerde CIT-Alcatel in 1980 bijv. een holding (Alcatel électronique), die alle activiteiten op het terrein van de 'télématique' en 'bureaucratique" onder haar hoede nam. De centrale holding van CGE was door dat beleid relatief klein (370 personen in 1980).

\subsubsection{La politique industrielle Giscardienne met betrekking tot de computerindustrie}

In de periode 1974-1981 vonden in het belleid met betrekking tot 'l'informatique' een aantall belangrijke ontwikkelingen plaats:

- het opheffen van de 'Délégation d̀ l'Informatique', het opzeggen van Unidata en de fusie CII-HB (het zogenaamde Derde 'Plan Calcul');

- veranderingen in het kader van het 'Plan Composants': toetreding van Matra en Saint-Gobain tot de halfgeleiders-branche; 
- het afsiuiten van 'Contrats de croissance' en 'Contrats de développement';

- het beleid met betrekking tot CII

\section{Het Derde Plan Calcul}

Met de komst in 1974 van Giscard d'Estaing als president en van Chirac als Premier werd met betrekking tot Unidata een ander beleid gevoerd. De 'Delégation a l'Informatique', welke een groot voorstander van Unidata was, werd opgeheven en vervangen door de 'Direction des Industries Electrique et Electronique' (DIELI). In tegenstelling tot de 'Délégation' is DIELI, i.c. de nieuwe Minister van Industrie, M. d'Ornano, geen voorstander van Unidata. Daarentegen werd een fusie CII-HB op het Ministerie beschouwd als een sterke bundeling van de Franse krachten en de creatie van een goede toegangspoort naar de Amerikaanse markt [19]. Ook de andere actoren waren tegen Unidata:

- CGE vreesde de concurrentie van Philips (mini- en péri-informatique) en die van Siemens (nucleaire energie, telecommunicatie, computers);

- Honeywell was in een hevige concurrentiestrijd met IBM gewikkeld en duldde geen sterke Europese concurrent naast zich;

- Thomson scheen tevreden met een situatie, waarin zij zich kon bevrijden van de (financiële) last van $\mathrm{CII}$;

- tot slot was de overheid geporteerd voor een Amerikaanse oplossing, omdat die ertoe zou kunnen leiden, dat de vicieuze subsidiecirkel met CII doorbroken zow kunnen worden.

Inmiddels ging de strijd tussen Thomson en CGE door: omdat het 'Yalta van de l'electronique' was opengebroken, was volgens CGE ook de grond van een dominante positie van Thomson binnen CII weggevallen. CGE was van mening, dat Thomson uit CII diende te vertrekken. Na arbitrage van Huvelin (voorzitter CNPF) werd CGE in het gelijk gesteld en Thomson trok zich uit CII terug.

Wederom kwam de PDG van CGE, Ambroise Roux, met zijn voorstel CII te fuseren met HB. De overheid aarzelde tussen het versterken van Unidata en de fusie CII-HB, maar door de bovengenoemde tegenstand koos VGE in mei 1975 voor de fusie CIIHB. Formeel bleven de Fransen overigens een meerderheid behouden [20].

Honeywell domineerde de combinatie CII-HB op twee manieren: in technologisch opzicht waren de Fransen van de Amerikanen afhankelijk, terwijl Honeywell tevens een 'actionnaire privilegié' was, die over belangrijke beslissingen haar veto kon uitspreken. Daarbij ging het om besiluiten met betrekking tot het aanstellen van de PDG, investeringen boven de $30 \mathrm{MF}$ en het overnemen van ondernemingen [21]. De overeenkomst tussen CII en HB, ook wel het derde Plan Calcul genoemd, was voor de Franse overheid een kostbare aangelegenheid:

- $1200 \mathrm{MF}$ subsidie over een periode van vier jaar;

- $130 \mathrm{MF}$ voor de aankoop van de aandelen van Honeywell;

- $630 \mathrm{MF}$ om de rekeningen van CII over 1976 te vereffenen;

- 135 MF ter compensantie van de verliezen van CII tot de datum van de feitelijke overdracht;

- 35 MF als bijdrage aan de vergroting van het eigen vermogen van CII-HB in 1978. Vervolgens werden contracten afgesloten met de 'Caisse Nationale des Marchés de 
l'Etat" (CNME), die CII-HB een afzet garandeerden van 4.05 MdF in de periode 19761980.

Schema 7.6 De fusie CH-HB in 1975

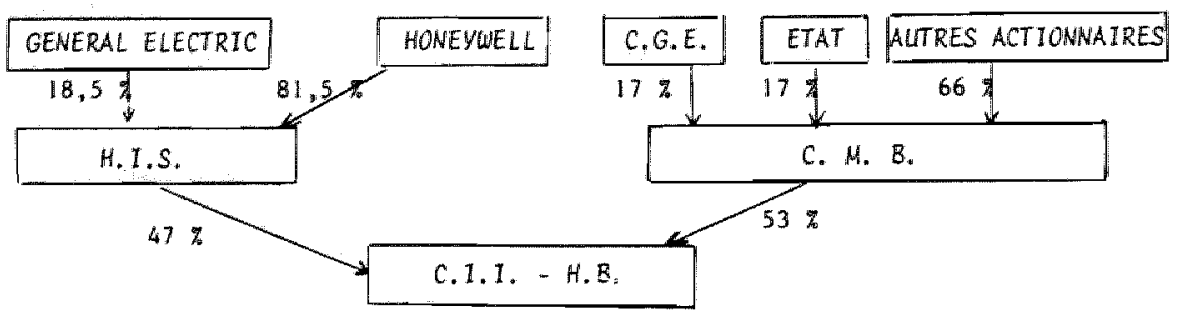

Bron: Barreau en Mouline (1987, 96) [22]

CII-HB sloot met HIS overeenkomsten met betrekking tot de coördinatie van de technologieën, de distributie en de uitwisseling van licenties. Een en ander moest ertoe leiden, dat CII-HB in 1980 uit de rode cijfers zou zijn.

De beslissing CII te fuseren met HB bracht veel politieke deining teweeg: 'links' vocht de veramerikanisering van de Franse electronica- industrie aan en toonde zich voorstander van nationalisatie, waardoor de strategie van de ondernemingen wel op de doelleinden van het 'Plan Calcul' zouden kunnen worden afgestemd, 'rechts' was furieus, omdat de autonomie van Frankrijk verloren was gegaan.

\section{Le Plan Composant, de entrée van Matra en Saint-Gobain}

In 1974 ging het met Sescosem slecht: de produktie van halfgeleiders daalde in Frankrijk van $24 \%$ in 1968 naar $16.3 \%$ in 1974 en voor 1976 werd een verlies van 100 MF voorzien. De penetratie op de Franse markt van 'composants' was groot; Sescosem en EFCIS (CEA) namen in $197816 \%$ van de markt voor hun rekening, terwijl RTC (Philips) en de Franse filialen van Texas Instruments en Motorola $45 \%$ van de Franse markt bedienden. De grote afhankelijkheid van het buitenland werd, met name door DIELI en de DGT als een bedreiging voor de 'filière électronique' beschouwd. Zij beidlen ontwikkelden het 'Plan Composants' en bewerkstelligden de entrée in de branche van twee dynamische ondernemingen: Matra wilde toetreden om haar afhankelijkheid wan de militaire opdrachten te verminderen, terwijl Saint-Gobain wilde diversificeren.

Matra was reeds actief in de 'télématique' (Barreau en Mouline 1987, 100), "communication" en de electronica voor de automobielindustrie en werkte samen met de Amerikaanse ondernemingen Harris en Intel.

Saint-Gobain bewoog zich vooral op verzadigde markten en stond aan het eind van de jaren zeventig voor de beslissing in welke 'secteur de l'avenir' zij zou diversificeren. Het 'Plan Composants' was voor haar aanleiding voor de electronica te kiezen. In 1978 richtte zij met de Amerikaanse onderneming National Semi Conductor (NSC) het filiaal Eurotechnique op. Saint-Gobain bracht $90 \mathrm{MF}$ in, de Franse overheid $100 \mathrm{MF}$ over een periode van vijf jaar en NSC de technologie. 
$\mathrm{Na}$ een anallyse van een werkgroep van het Ministerie van Industrie, waarin een somber beeld van de 'péri-informatique' werd geschetst, lanceerde de overheid in 1977 een plan met doeleinden voor de groeli van de omzet, export, rentabiliteit en de herstructurering van de sector. Op basis daarvan werden 'contrats de croissance' (zie 6.1.3) getekend met SEMS (Thomson), Transac en Sintra (CGE), Benson, Logobax, Intertechnique en Pyrel (Rhone-Poulenc). Van de zeven gesteunde ondernemingen behoorden er vier tot grote industriële groepen. Over een periode van vier jaar werd. $100 \mathrm{MF}$ subsidie verleend, waaruit een stijging van de omzet van $1.3 \mathrm{MdF}$ en een reductie van de buitenlandse penetratiegraad van $70 \%$ naar $50 \%$ moesten voortvloeien (Barreau en Mouline 1987, 98). DIELI onderhandelde met de ondernemingen over de geplande groei, export etc. en coördineerde de steun van de diverse betrokken instanties (FDES, ANVAR, DGRST, DATAR). Naar rato van het niet realiseren van de doeleinden dienden de ondernemingen de subsidie terug te betalen.

\section{Contrats de développements; de CODIS}

Om de tekorten op de handelsbalans weg te werken werden er in het kader van de CODIS voor de EGP en de kantoorautomatisering, 'contrats de développement' (zie 6.1.3) afgesloten. Deze contracten beoogden niet de strategie van de industriële groepen te beînvloeden, maar betroffen alleen de commerciële activiteiten. De DGI van het Ministerie van Industrie verzorgde de dossiers van de ondernemingen en de CODIS, die zelf niet over financiële middelen beschikte, vervulde de rol van intermediair tussen de diverse afdelingen van de betrokken ministeries. Aangezien de dossiers en contracten geheim zijn, is over de steunverlening via de CODIS niet veel bekend (Barreau en Mouline 1987, 104 en 137). Van de 8 a $13 \mathrm{MdF}$ (!) die in het kader van de CODIS zou zijn overgedragen, wordt het aandeel voor de EGP door Barreau en Mouline (1987) verwaarloosbaar geacht. In 1979 werden 'contrats de developpement' afgesloten in de kantoorautomatisering, waarvan vooral Saint-Gobain schijnt te hebben geprofiteerd (Barreau en Mouline 1987, 105).

\section{CII: een Nationale Kamploen?}

In de periode na 1975 werd CII niet door CGE gesteund; integendeel CGE duldde geen sterk CII-HB naast zich en verbood CII elke activiteit op het terrein van de minicomputers en kantoorautomatisering. Ingeklemd tussen CGE en Honeywell wist CII echter wel de weg naar de Franse overheid te vinden voor het binnenslepen van lucratieve orders.

In dle jaren 1979-1980 bewoog CII-HB zich in toenemende mate op de markt van de kantoorautomatiseringen en "péri-informatique". In dat verband werd in $198060 \%$ van de Franse onderneming R2E overgenomen. Ook toen werd de combinatie CII-HB dwarsgezeten in haar strategie door één van haar aandeelhouders. CGE vreesde namelijk de concurrentie van CII-HB op die markten en weigerde mee te werken aan een financieringsplan voor CII-HB, terwijl ook de overname van de Duitse specialist in schrijfmachines, Olympia-Werke, werd verboden. Brulé, PDG van CII, wilde ook Transac (dochter van $\mathrm{CGE}$ ) overnemen. HB had daar aanvankelijk geen bezwaar 
tegen, maar na een 'bewerking' door CGE werd Brulé deze strategie verboden. Brulé en Roux raakten in een hevig conflict gewikkeld, dat bij President Giscard d'Estaing werd uitgevochten. Hij hakte de knoop door en gaf geen van de kemphanen zijn zin: Brulé bleef PDG van CII, maar in plaats van CGE werd in september 1979 SaintGobain de nieuwe hoofdaandeelhouder. Voor Saint-Gobain betekende de electronica een welkome diversificatie (zie schema 7.7).

In 1980 en 1981 verwierf Saint-Gobain $30 \%$ van Oliwetti met het doel een Europese onderneming te creëren op het gebied van de computers en de automatisering. SaintGiobain beoogde in 1985 40\% van haar omzet in de electronische sector te realiseren. Zij creërde met haar aankopen een consistent geheel van activiteiten op de markt van de computers en kantoorautomatisering, maar was erg afhankelijk van buitenlandse technologie van NSC voor de halfgeleiders, van Honeywell voor de computers, van Olivetti voor de kantoorautomatisering en van Corning Glass woor de glasvezelkabells (Barreau en Mouline 1987, 102).

Schema 7.7 Deelname van Saint-Gobain in CII

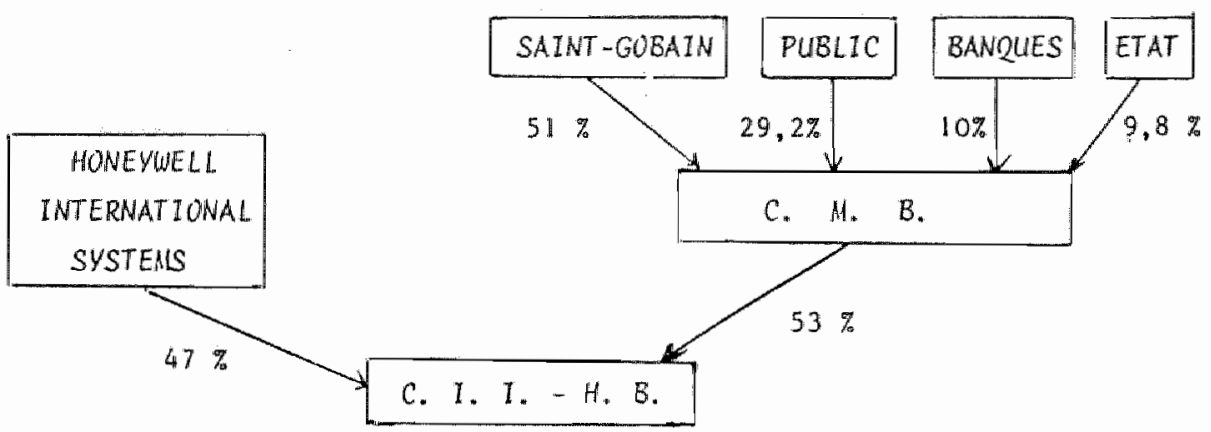

Bron: Barreau en Mouline (1987, 97)

Brulé beoogde CII tot de Franse kampioen van de kantoorautomatisering te maken en was dan ook zeer in zijn wiek geschoten toen Farnoux, de PDG van Saint Gobain, met Olivetti een samenwerkingsverband aanging, waardoor CII niet meer het Franse rijk alleen had. In tegenstelling tot de verwachtingen van Brulé bleek Saint-Gobaïn geen 'slapende' aandeelhouder te zijn, maar een eigen strategie te ontwikkelen, gericht op het veroveren van een leidinggevende positie in Europa op het gebied van de 'informatique' en de 'bureautique".

Brule opende de tegenaanval: de CODIS werd in een rapport voorgespiegeld hoe met het CII-concept voor de 'bureautique' de handelsbalans en werkgelegenheid kon worden verbeterd. Brule drong met zijn voorstellen door tot het bureau van Giscard d'Estaing, waarmee voor Saint Gobain het startschot voor de tegenaanval was gegeven. Tot mei 1981 bleef deze politiek gevoelige materie echter op het bureau van de president liggen. 


\subsubsection{De balans in 1981}

Hieronder wordt eerst kort de situatie per branche belicht, waarna wordt ingegaan op de relatie tussen de overheid en de industriele groepen.

\section{De branches}

Volgens het Rapport Farnoux (zie verderop) bedroeg de produktie in de 'filiere électronique" in $198195 \mathrm{MdF}$, hetgeen overeenkwam met 3\% van het PIB. Er waren in de filière 300.000 personen werkzaam. De handelsbalans vertoonde een tekort van 2.6 MdF. Ongeveer 50\% van de Franse markt werd door het buitenland bediend via importen en de afzet van vestigingen van buitenlandse ondernemingen in Frankrijk. Positieve resultaten werden geboekt in de telecommunicatie, professionele electronica en de dienstverlening (SSCI). Met betrekking tot de andere branches van de 'filière électronique" (l'informatique, composants, électronique médicale) zijn de resultaten minder gunstig.

\section{Professionele electronica}

Met een omzet van 18.891 MF in 1981 nam de Franse industrie de tweede plaats in achter de V.S. De handelsbalans vertoonde een overschot van $8078.8 \mathrm{MF}$, hetgeen een stijging van $9 \%$ ten opzichte van 1980 betekende. $51 \%$ van de omzet werd in het buitenland gerealiseerd (in 1977 was dat $46 \%$ ). Relatief de meeste werkgelegenheid werd in de professionele electronica gerealiseerd (ongeveer 2000 arbeidsplaatsen per jaar).

\section{Telecommunicatie}

De handelsbalans van de telecomminicatie vertonde ook een overschot: $1235 \mathrm{MF}$ in 1981 tegen $930 \mathrm{MF}$ in 1980 . Na de reorganisaties in de sector was de dominantie van buitenlandse ondernemingen (60.5\% in 1974) omgezet in een aandeel van $84 \%$ voor de Franse ondernemingen. Probleem bleef echter het relatief grote aandeel van de Derde wereldlanden in de export.

\section{SSCI}

De Franse ondernemingen zijn succesvol; CISI, GSI en Cap Gemini Sogeti zijn de drie belangrijkste ondernemingen in Europa. Hoewel de overheid indirect aandeelhouder is (Barreau en Mouline 1987, 106) intervenieerde zij niet. Wel is de steun van de DGT in de vorm van marktonderzoek van belang.

Tussen 1975 en 1981 nam de omzet toe met een factor 3.7. De handelsbalans is positief en de penetratiegraad laag (nauwelijks 10\%).

\section{Computerindustrie}

Hoewel CII-HB in 1980 een stijging van de omzet van $22 \%$, een stijging van de resultaten met $60 \%$ en de creatie van 1213 arbeidsplaatsen te zien gaf, is de balans van het Derde Plan Calcul toch negatief: 
- CII-HB bracht geen samenwerking met de Europeanen Siemens en Philips tot stand, terwijl dergelijke verbindingen alom noodzakelijk werden geacht;

- zij slaagde er niet in, conform de doelstellingen, de helft van de Franse markt te veroveren $(27 \%$ in 1980 en een penetratiegraad van buitenlandse ondermemingen van $70 \%$ op de Franse markt van computers);

- haar afhankelijkheid van HIS nam toe (zie verderop);

- CII-HB bleef niet de grootste Europese computergroep, maar moest die plaats afstaan aan ICL.

Ook buiten CII-HB waren de resultaten in de computerindustrie mager:

- de situatie in de mini-informatique was slecht: SEMS leed verlies en de Franse ondernemingen verloren terrein: hun omzet steeg $20 \%$ in 1980 , terwijl de markt met $30 \%$ groeide;

- de 'contrats de croissance' in de 'peri-informatique' hadden niet de verwachte resultaten opgeleverd. Met name het terugdringen van de penetratie van $70 \%$ naar $50 \%$ bleef steken op $64 \%$. Er resulteerde in 1981 een tekort op de handelsbalans van $1726 \mathrm{MF}$;

- de steun van de CODIS is niet voldoende gebleken voor een verbetering van de handelsbalans van de kantoorautomatisering en de 'EGP'. Integendeel: de tekorten namen toe: 4537 MF in 1980 werd 5920 in 1981 voor de 'EGP'; 2197 MF voor de kantoorautomatisering in 1979 werd $2881 \mathrm{MF}$ in 1981 . In 1981 werd $96 \%$ van markten voor de kantoorautomatisering en $86 \%$ van die van de 'EGP' door buitenlandse ondernemingen bediend.

\section{Composants}

De branche van de 'composants' vertoonde een tekort van $882.6 \mathrm{MF}$ in 1980 en een penetratiegraad in 1981 van $83 \%$ voor de zgn. 'actifs' en $50 \%$ voor de zgn. 'passifs'.

\section{Medische electronica}

Het tekort op de handelsbalans in 1981 was 221.9 MF en de penetratiegraad bedroeg $68 \%$, maar deze branche realiseerde wel een stijging van de omzet in het buitenland $(90 \%$ in 1981$)$.

\section{De relatie overheid-industriële groepen}

De DGT was de centrale actor in de 'filière électronique' geworden. Haar machtsbasis lag in de telecommunicatie en van daaruit sloeg de DGT haar vleugels uit naar de halfgeleiders, dienstverlening en consumptiegoederen. Wat de telecommunicatie betreft, bleef de produktie in het buitenland echter slecht ontwikkeld $(0.8 \%$ van de omzet van CIT-Alcatel en Thomson werd in het buitenland gerealiseerd), terwijl ook de export van ondergeschikt belang bleef (16\% van de omzet voor CIT-Alcatel en Thomson, terwijl door de overheid $30 \%$ was gepland).

Ondanks de financiële steun en de bereidheid van de overheid diepgaand te interveniëren waren de resultaten van het industriebeleid in de computerindustrie niet indrukwekkend. Uit bovenstaande analyse blijkt, dat een belangrijke oorzaak was gelegen in het ontbreken van een krachtige overheidsorganisatie, die de strategie van 
de industriële groepen op een consistente wijze in een specifieke richting kon sturen. Toen in 1966 de weg van de 'Etat développeur' werd ingeslagen, had daarbij ook een adequate organisatie moeten worden gecreëerd. Enerzijds had binnen de overheidsorganisatie een krachtige coördinerende instantie opgezet moeten worden en anderzijds had de Nationale Kampioen geen rivaliserende aandeelhouders mogen hebben. In plaats daarvan was de 'Délégation à l'Informatique' bij het relatief zwakke Ministerie van Industrie ondergebracht, waardoor van interdepartementale coördinatie nauwelijks sprake kon zijn. Door het ontbreken van een krachtige 'tutelle', trad de overheid in de computerindustrie niet initiërend en doelbewust op, maar juist onzeker en aarzelend ('l'affaire Bull, Unidata, strijd binnen CII, strijd tussen CII en SaintGobain). Kernpunt van dat aarzelende beleid blijkt enerzijds het gebrek aan informatie bij de overheidsinstanties met betrekking tot de strategie van de ondernemingen en anderzijds de onbeheersbare marktsituaties. Zo wijzen McArthur en Scott $(1969,320)$ er op, dat de overheid in geval van de 'l'affaire Bull' in principe wel over de instrumenten beschikte om het electronische subsysteem te besturen, maar dat de juiste informatie ontbrak om tijdig te kunnen ingrijpen (vergelijk Barreau en Mouline 1987, 51).

Als de overheid onder dergelijke omstandigheden van ongelijke informatieverdeling toch doeleinden en/of instrumenten ontwikkelt, die indruisen tegen de strategieën van de ondernemingen, dan is het beleid gedoemd te mislukken. Dat blijkt o.a. duidelijk wit de gang van zaken rond CII en Sescosem. Als van overheidswege geen expliciete doeleinden op meso- of microniveau worden ontwikkeld dan zijn de ondernemingen in een goede positie de doeleinden van beleid (mede) vorm te geven [23]. Door dle 'déplanification' en het neo-liberale industriebeleid van na 1974 was daarvan in toenemende mate sprake. Als met andere woorden tegenover het management van een industriële groep geen krachtige overheidsorganisatie staat, zoals bijv. de DGT in de telecommunicatie, dan worden de financiële middelen niet verdeeld op grond van objectieve criteria en afgestemd op de realisatie van expliciete doeleinden, maar vloeien de gelden naar de ondernemingen met de sterkste lobby en wordlen die gelden aangewend conform de belangen van het management [24].

Opvallend is in dit verband het aanhoudend grote aandeel van de steunverlening, dat aan de grote groepen toeviel. Ondanks herhaalde uitlatingen van de ministers, dat de fondsen juist voor het Midden- en Kleinbedrijf bestemd zijn, blijken juist de grote industrièle groepen ervan te profiteren (vergelijk 6.1.3.3).

Het gemis van een expliciet voluntaristisch industriebeleid, vorm gegeven door een sterk overheidsorgaan enerzijds en het bestaan van een informatievoordeel en goede verbindingen met het overheidsapparaat gebaseerd op persoonlijke relaties anderzijds, worden duidelijk zichtbaar in de gang van zaken rond Thomson. Hoewel Thomson haar positie in de medische- en halfgeleidlerssector had versterkt, was haar strategie op de eerste plaats gericht op het handhaven van haar comfortabele positie op de beschermende markt van militaire produken, waar zij onder leiding van de DGA (zie noot 18) veel investeerde in $R$ en $D$. Zulks in tegenstelling tot haar beleid in de computer-, halfgeleiders en de electronische consumptiegoederenindustrie, waarin Thomson een zeer afwachtende houding aannam. In plaats van het ontwikkelen van een eigen 'métier' prefereerde zij de produktie van buitenlandse produkten in licentie, 
of fungeerde zij louter als afzetkanaal woor de buitenlandse producenten.

Ook aan de wensen van de overheid met betrekking tot de internationalisatie, reorganisatie van activiteiten en organisatiestructuur, alsmede met betrekking tot de steun aan het Midden- en Kleinbedrijf, werd alleen door de industriëlle groepen gehoor gegeven als een en ander paste in hun eigen strategische plannen.

De vraag ligt nu voor, of het socialistische industriebeleid in de periode 1981-1986 daarin wezenlijk verandering heeft gebracht. Waren de doeleinden het 'Plan d'Action Filière Electronique' voldoende geẽxpliciteerd? Verkreeg de overheid in het kader van het 'contrat de plan' na de nationalisatie wel tijdig de juiste informatie met betrekking tot de strategieën van de industriële groepen? Beschikte het 'Ministère de tutelle" over effectieve instrumenten om, indien nodig, het beleid van het management bij te sturen?

\subsection{De 'filière électronique" na 1981.}

\subsubsection{De Nationalisaties}

Met de nationalisaties van CGE, Saint-Gobain, Thomson, CII-HB, Matra en ITT beoogde de Franse overheid zodanige veranderingen in de machtsverhoudingen in de 'filière électronique" aan te brengen, dat ziji wezenlijke invloed zou kunnen uitoefenen op de strategische beslissingen van het management. Op basis van het 'filiere'-concept moest een geïntegreerde benadering van de diverse branches tot stand komen, waarbij herstructurering van de activiteiten van de ondernemingen moest leiden tot industrièle groepen, die zich tot hun 'métier' beperkten ('récentrage'), zonder dat in de branches monopolieposities zouden ontstaan. De Franse ondernemingen dienden ten opzichte van de buitenlandse concurrenten de strategische branches van de 'filière' the beheersen.

Het management van de particuliere industriële groepen had volgens de socialisten verzuimd voldoende te investeren in $\mathbb{R}$ en $D$, in nieuwe produkten en in delen van de 'filière", die vanuit het systeem gezien van strategisch belang waren.

Zoals in hoofdstuk 6 is uiteengezet houdt die ondernemingsstrategie nauw verband met de typisch Franse socio-politieke context, waarvan de 'corps d'état' een essentieel onderdeel vormen. Het is dan ook de vraag, of Farnoux een goed beeld schetste van het effect van de nationalisaties toen hij opmerkte:

"La grande nouveauté résultant de la nationalisation, c'est la découverte que l'on a un actionnaire. Dans la forme française du capitalisme, les grands groupes n'avaient pas ou peu d'actionnaires très présents, contrairement à ce qui se passe aux Etats-Unis ou l'actionnariat a encore un roôle très actif. Queque I'on ait dit de la disparité entre les partenaires, les exigences de l'Etat aujourd'hui sous la forme du contrat de Plan me paraissent correspondre à ce qu'un banquier allemand ou un Conseil d'Administration américain exige de l'industriel qui est chargé de faire fructifier les actifs quil lui sont confiés". Bron: CF 1984 (Bolloc'h (1986, 341).

Met andere woorden: zouden door de nationalisaties de feitelijke machtswerhoudingen zodanig veranderen, dat de overheid als aandeelhouder het management zou kunnen sturen en zou kunnen dwingen in haar strategie rekening te houden met de belangen van de 'filiere' als geheel en van de overheid? 
Formeel kwam met de nationalisaties een belangrijke wijziging in de machtsverhoudingen tot stand: de staat werd eigenaar van $93 \%$ van de computerindustrie, van $94 \%$ van de halfgeleiders, van $78 \%$ van de telecommunicatieindustrie, van $78 \%$ van de professionele electronica en van $75 \%$ van de ondernemingen, die in de consumentenelectronica opereerden [25]. Bolloc'h $(1986,293 \mathrm{e.v}$ ) is van mening, dat door de nationalisaties de socio-politieke context in de "filière électronique" grondig werd gewijzigd: de overheid gaf de electronica eerste prioriteit en maakte expliciet duidelijk, dat zij in de "filière" zou interveniêren met het doel specifieke doeleinden, (neergelegd in het 'Plan d'Action Filière Electronique': PAFE) te realiseren. De nationalisatie van de sleutelondernemingen in de 'filière' zou de mogelijkheid bieden de activiteiten van de ondernemingen te herstructureren en gerichte (financięle) steun te verlenen aan de branches, die vanuit een oogpunt van 'filière'-belang van strategische waarde werden geacht.

De belangrijkste electronische groepen werden in 1982 genationaliseerd: $C G \mathbb{E}$, Thomson, Saint-Gobain, CII-HB, ITT en Matra. De aandelen werden met uitzondering van Matra niet voor $51 \%$, maar voor $100 \%$ door de staat overgenomen, zodat de overheid-aandeelhouder zich volledig op de lange termijn strategieën kon concentreren zonder rekening te hoeven houden met de korte termijn rentabiliteitseisen van de 'gewone' aandeelhouders [26].

Matra nam een uitzonderingspositie in:

- nationalisatie van deze onderneming vond plaats vanwege haar bellang voor de defensieindustrie; haar 'Ministère de tutelle' werd niet het Ministerie van Industrie, maar dat van Defensie;

- door de sterke oppositie van de PDG en het personeel tegen een nationalisatie van $100 \%$ en de dreiging 'en masse' op te stappen, werd voor Matra een uitzonderingspositie gemaakt. Slechts $51 \%$ van de aandelen ging naar de staat over en voor het waarborgen van haar autonomie werd een speciaal statuut opgesteld (Bolloc'h 1986, 304).

Ter toelichting op de nationalisatie van de dochterondernemingen van de buitenlandse ondernemingen het volgende:

- de dochters van ITT waren in 1971 in het 'Programme Commun' op de lijst van te nationalliseren ondernemingen gezet, omdat ITT toentertijd een groot aandeel had in strategisch belangrijk electronische industrieĕn en de telecommunicatie. Hoewel ITT in 1981 alleen nog over CGCT beschikte werd de nationalisatie toch doorgezet met name vanwege

"l'image extrêmement négative de la maisonmère, qui avait montré qu"elle n'hésitait pas à utiliser sa puissance industrielle à des fins politiques, et qu"elle pouvait constituer un véritable danger pour les Etats" (Bolloc'h 1986).

Gedoeld werd op de veronderstelde rol van ITT bij de val van President Allende in Chili.

- Om zeggenschap te krijgen over CII-HB had de Franse overheid kunnen volstaan met de nationalisatie van Saint-Gobain, dat via Bull een meerderheidsbelang in CIIHB had. 


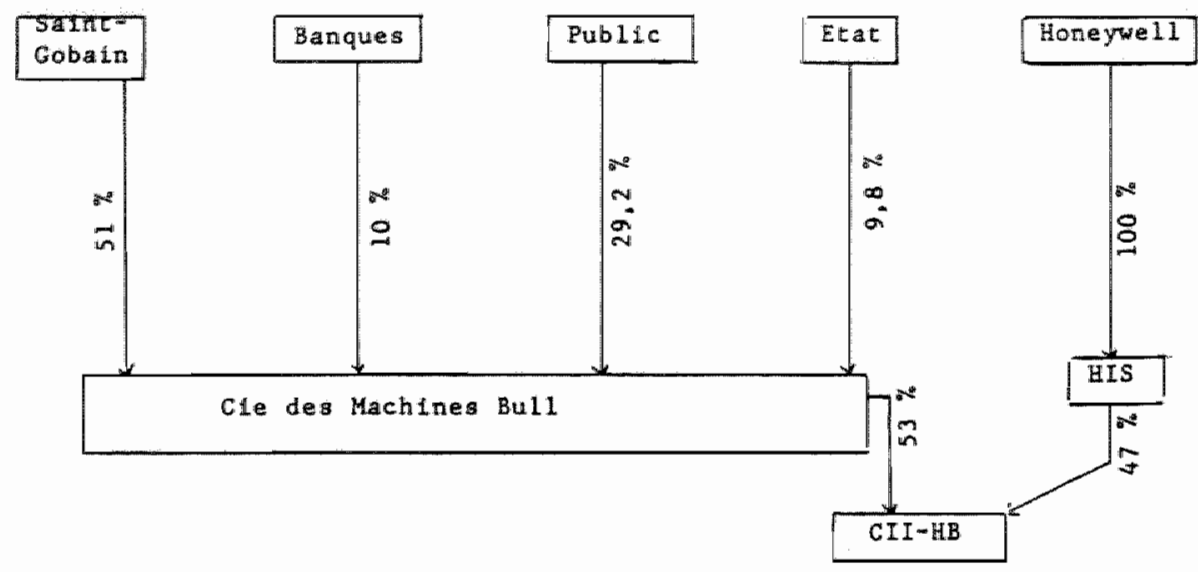

Bron: Bolloc'h (1986, 300)

Toch werd besloten met Honeywell te onderhandelen over de overname vam haar belang, omdat de wens leefde de machtsverhoudingen ten opzichte van de Amerkaanse partner fundamenteel te wijzigen. Zoals uit schema 7.8 blijkt, was voor de nationalisatie $47 \%$ van CII-HB in het bezit van Honeywell Information Systems (HIS), waarmee de schijn van Amerikaanse dominantie werd tegengegaan.

In werkelijkheid domineerde Honeywell echter vanwege haar superieure kennis. Bovendien was contractueel vastgelegd, dat de produktstrategie door een paritair samengestelde commissie zou worden bepaald, waarin echter de stem van de PDG, die altijd door de grootste onderneming (en dat was Honeywell) zou worden geleverd, de doorslag zou geven. Zo werd CII genoodzaakt van haar systeem uit de Unidataperiode (dat IBM-compatible was), over te stappen op het systeem van Honeywell met het doel voor Honeywell een afzetkanaal in Europa te worden. Formeel had Honeywell een minderheidsaandeel in CIl-HB, maar materieel bleek Honeywell na enige tijd zowell het produktassortiment, het onderzoek, als de aanstelling van het kaderpersoneel te domineren (Bolloc'h 1986, 303). Omdat CII-HB zo nauw met Honeywell was verbonden, leek het verstandig ook na de nationalisatie een formele relatie met het Amerikaanse bedrijf in stand te houden: Honeywell behield een aandeel van $16 \%$.

Met de nationalisatie van CII-HB kreeg de Franse overheid weer volledig zeggenschap over de onderneming, die vanaf het eerste 'Plan Calcul' het symbool was geweest van de wil van de Franse overheid tot een "francisation' van de computerindustrie te komen. Door het ter zijde schuiven van de hun eigen belang nastrevende rivalen Thomson en CGE, beoogde de overheid een situatie te creëren, waarin voor CII-HB een coherente lange termijn strategie zou kunnen worden uitgezet [27]. 


\subsubsection{Plan d'Action Filière Electronique}

De situatie in de 'filière électronique' werd onderzocht door de 'Mission filière électronique", die op 19 augustus 1981 door het 'Ministère de la Rechenche et de la Technolagie' werd geïnstalleerd (voorzitter was A. Farnoux). Naast de twaalf permanente leden waren ook vertegenwoordigers van het Ministerie van Industrie, de DGRST, de DGA en de CNRS aanwezig. In maart 1982 presenteerde de commissie haar rapport over de situatie in de 'filière électronique'. Haar aanbevelingen werden door de regering grotendeels overgenomen en zijn terug te vinden in het 'Plan d'Action Filiere Electronique' van juli 1982 [28].

In het rapport-Farnoux werd een 'Secrétariat d'Etat d'Electronique" voorgesteld, dat het beleid met betrekking tot de 'filière électronique' zou moeten coördineren. De commissie benadrukte het belang van zo"n centraal coördinatieorgaan voor het ontwikkelen van een effectief industriebeleid (vergelijk hoofdstuk 3 over de karakteristieken van L'Etat développeur). Die aanbeveling werd niet in het PAFE overgenomen. In het PAFE werd melding gemaakt van een programma van vijf jaar (1983-1987), waarin $140 \mathrm{MdF}$ (waarvan $55 \mathrm{MdF}$ door de overheid) in de 'filière électronique' werd gestoken, hetgeen moest leiden tot:

- de creatie van 80.000 arbeidsplaatsen;

- everwicht op de handelsbalans; in 1987 diende de 'filière' een overschot van $14 \mathrm{MdF}$ te vertonen, terwijl zonder specifiek beleid door de directeur van DIELI een tekort van $19 \mathrm{MdF}$ werd verwacht;

- beheersing van de technologie van de 'filière';

- een stijging van de groei van de produktie met 3 à $9 \%$ per jaar.

De acties richtten zich op vier terreinen:

- onderzoek: acht grote projekten werden gestart, waarin publieke en private onderzoeklaboratoria samenwerkten (in september 1983 werden de projekten gemeld op de ministerraad);

- de opleiding van ingenieurs en technici;

- toepassingen werden gestimuleerd door bijv. het 'plan productique' (zie verderop);

- de industriële structuur, welke in september 1982 werd toegelicht door de direkteur van DIELI: $40 \%$ van de uitgaven zouden worden besteed aan het versterken van de "points forts" (professionele electronica, telecommunicatie) en $43 \%$ aan het ontwikkelen van strategische branches, waarin Frankrijk geen sterke concurrentiepositie innam (halfgelleiders, consumentenelectronica, computers). In specifieke plannen voor elk van de branches werd één en ander nader uitgewerkt.

\section{Onderzoek}

Zoals in 6.1.4 is uiteengezet werd in het kader van de LOP de onderzoekinspanning sterk opgevoerd met het doel de uitgaven van $\mathrm{R} \& \mathrm{D}$ op te laten lopen tot $2.5 \%$ van het PIB in 1985. Het 'programme mobilisateur' voor de electronica behelsde acht nationale projekten, waarvan er vanaf juli 1982 zes door een commissie met vertegenwoordigers uit het CNET, DIELI, DGA, ADI werden geëvalueerd (Barreau en Mouline 1987, 173). Het projekt 'Electronique Grand Public' liep slecht door het geringe aantal onderzoekspecialisten op dat terrein. In september 1983 werden acht nationale projekten gestart met de 'EGP' als grote afwezige. 


\section{Opileidingen}

De ADI is het orgaan, dat zich bezighoudt met de opleidingen in de informatica. Vermeldenswaard is het VFI-projekt, dat in de zomer van 1983 werd gestart (VFI staat voor 'Volontaires pour la Formation à l'Infonmatique'): militaire dienstplichtigen, die een opleiding in de informatica hadden genoten konden op vrijwillige basis projekten starten voor de opleiding van werkloze jongeren. In 1984 werden op die wijze 11.000 jongeren bereikt.

Ook vermeldenswalard is het in januari 1985 door premier Fabius gelanceerde 'Plan informatique pour tous' met het doel de middelbare scholen en universiteiten van microcomputers te voorzien en jongeren op te leiden in de informatica. De financiering liep voor 300 a $400 \mathrm{MF}$ via l'ANVAR, voor $400 \mathrm{MF}$ via het Ministerie van Onderwijs en voor $1.2 \mathrm{MdF}$ via het budget voor de 'filière électronique".

Het programme mobilisateur 'filière électronique kende centrale betekenis toe aan de opleiding van ingenieurs en technici. Een plan voor de opleiding in de micro-electronica werd operationeel in 1983: 15 MF werd gefinancierd door ADI, 2.5 MF door het Ministerie van Onderwijs en 3 MF door het MRI. In vier plaatsen (Parijs, Grenoble, Toulouse en Rennes) moesten per jaar 300 specialisten worden opgeleid. Ook het 'Plan Productique' (zie verderop) voorzag in de opleiding van ingenieurs en technici voor de 'productique'.

Tot slot stimuleerde het Ministerie van Onderwijs het aantal studenten in de informatica: het aantal afgestudeerde ingenieurs in die sector steeg van 170 in 1980 tot 2650 in 1985.

\section{Specifieke 'plans sectoriels' (vergelijk Barreau en Mouline 1987, 170 e.v.)}

Een nieuw 'Plan Composants' werd in september 1981 aangekondigd door president Mitterrand. Na moeizaam overleg in de interdepartementale commissie voor de geïntegreerde schakelingen (GICI) werd de industrie gereorganiseerd, hetgeen resulteerde in de overname van Eurotechnique (Saint-Gobain) door Thomson (zie verderop).

\section{Le pllan micro-électronique}

In dat plan (1983-1985) werd met name de ontwikkeling gestimuleerd van geîntegreerde schakelingen, die een belangrijke rol spelen in de EGP (circuits integrếs lineaires). Er werd $2.550 \mathrm{MF}$ bechikbaar gesteld voor onderzoek en ontwikkeling en $1925 \mathrm{MF}$ over de periode 1983-1986 voor stimulering van de investeringen.

\section{Le plan composants passifs (1983-1986)}

Een bedrag van $800 \mathrm{MF}$ werd beschikbaar gesteld voor onderzoek en ontwikkeling. In de branche verschaffen ongeveer 400 PMI werk aan 35.000 personen. De ondernemingen, die een onderzoekcontract met de overheid tekenden, dienden zelf een gelijkwaardige financielle bijdrage te leveren.

Le plan Image (eind 1982) richtte zich op het gebied van de 'communication visuelle". Rond vijf regionale polen (Rennes, Grenoble, Toulouse, Est, Région Parisienne) werd 
het onderzoek geconcentreerd. De financiële bijdrage was beperkt: 200 MF over een periode van drie jaar.

\section{Le plan mini-informatque}

In januari 1982 werd door DIELI een plan gelanceerd, gericht op onderzoek en ontwikkeling van de 'briques de base" in de mini- informatique, waarvan de resultaten door diverse constructeurs konden worden toegepast. $\mathrm{Er}$ werd $600 \mathrm{MF}$ beschikbaar gesteld en SEMS kreeg een centrale roll toegewezen. In maart 1982 werd aangekondigd, dat de overheid de steun aan de ontwikkeling van de chips voor de microelectronica zal voortzetten ( $480 \mathrm{MF}$ voor onderzoek en ontwikkeling en $340 \mathrm{MF}$ voor stimulering van de investeringen.

\section{Le programme MARISIS}

Dat programma was gericht op de ontwikkeling van een 'supercalculateur' ten behoeve van de nucleaire sector, de luchtvaart en de meteorologie. Daartoe diende in de periode 1981-1987 765.3 MF beschikbaar te komen, waarvan 50\% afkomstig zou zijn van het Ministerie van Defensie en $50 \%$ van de Ministeries van Onderzoek en PTT. De realisatie werd toevertrouwd aan Bull en Sintra in samenwerking met de publieke laboratoria INRIA en CNET en de universiteiten van Rennes en Nice. Verwacht werd dat Frankrijk in 1988 nog ongeveer drie jaar zou achterliggen bij de Japanners (Fujitsu, Hitachi en NEC) en de Amerikanen (Cray, Control Data).

\section{Le plan productique}

Het 'plan productique' werd in juli 1982 door J.P. Chevènement gelanceerd; zijn opvolger, L. Fabius, vulde in maart 1983 de grote lijnen in. Doel van het plan betrof de modernisering van de 'industries manufacturières' (ongeveer 20.000 ondernemingen met 2 miljoen arbeidsplaatsen en een omzet van $520 \mathrm{MdF}$ ).

In het plan werden enerzijds maatregelen getroffen gericht op het stimuleren van de vraag naar nieuwe produktiemethoden (fiscale faciliteiten, verlaging van de saciale premies, privileges bij de FIM), anderzijds werd het aanbod van moderne produktietechnieken gereorganiseerd rond drie polen: Renault, Matra en CGE.

Het plan betrof een periode van drie jaar en voorzag in een steunverlening voor het

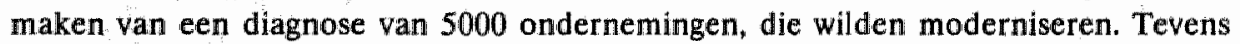
werden 250 'projets pilotes" opgezet, waarin afnemende PMI en producenten van moderne produktiemethoden participeren. De aanbieders van geavanceerde produktietechnieken konden via een 'contrat de développement" extra steun krijgen.

\section{Le programme PUCE}

Dat programma beoogde de integratie van Franse componenten - en met name van Franse geïntegreerde schakelingen - in industriële produkten. Daartoe werden afnemende ondernemingen gesteund in het ontwikkelen van nieuwe produkten, waarin die nieuwe technologieën konden worden toegepast. Het MRI verleende steun voor 'l'êtudes de faisabilité', die meestal werden uitgevoerd door een onderneming 'de 
service et de conseil en micro-électronique" (Barreau en Mouline 1987, 175). De ondernemingen richtten zich tot de DRIR (Direction Régionale de l'Industrie et de la Recherche). In begin 1985 hadden ongeveer zestig ondernemingen van het programma gebruik gemaakt, waarmee $6 \mathrm{MF}$ was gemoeid. DIELI had zich ten doel gesteld in de periode 1986-1988 500 a 600 ondernemingen te steunen.

Tot slot is de oprichting van twee nieuwe centra vermeldenswaard.

Om de verspreiding van technologische kennis en de toepassingen te stimuleren werden nieuwe centra opgericht, zoals het 'Centre Mondial de Micro-Informatique' (februari 1982), dat tot taak kreeg een compacte multi-funktionele personal computer te ontwikkelen, die ook afgezet zou kunnen worden gebruikt in Derde Wereldlanden en door alle leeftijdscategorieën. Het centrum moest ook zorgdragen voor het ontvankelijk maken van het grote publiek voor een dergelijke PC.

Ook werd het 'Centre d'Erudes des Systèmes et Technologies Avancées' (CESTA) in februari 1982 opgericht. Het werkterrein van het CESTA ging verder dan de 'fulière électronique' en betrof ook onderzoek, opleiding en assistentie bij de keuze van nieuwe technologieën in het algemeen en stimulering van diffusie van kennis in een breed scala van sectoren.

\subsubsection{Veranderingen in de machtsverhoudingen binnen l'Etat développeur}

Wat het beleid binnen de 'filière électronique' betreft, zijn twee overheidsorganen van belang: de DGT en de DIELI. In de periode 1981-1986 vonden een aantal ontwikkelingen plaats, die van invloed waren op de machtsbasis wan deze twee actoren. Met name de positie van de DGT als "staat in een staat" werd in toenemende mate ter discussie gesteld. Vanuit diverse ministeries werden pogingen ondernomen de machtspositie van de DGT te ondergraven; het Ministerie van Industrie, Defensie, van de PTT, van Financiën en dat van Cultuur waren alle van mening, dat de DGT zich een te autonome positie had verworven [29].

Geprobeerd werd de partikulliere fillialen uit de DGT te verwijderen en de inkomsten van de DGT naar het ministerie van Financiën te leiden. Die ingrijpende veranderingen gingen uiteindelijk niet door, omdat betrokkenen begrepen, dat het succes in de telecommunicatie juist te danken was aan de autonomie van de DGT. Wel werden enkele kleüne wijzigingen aangebracht: zo kreeg de minister van de PTT meer bevoegdheden met betrekking tot het uitstippelen van de lange termijn beleidslijnen, waardoor de verhouding met de DGT iets evenwichtiger werd. Ook werd de greep van de DGT op CNET verminderd: het CNET nam taken van de DAII over, waardoor het een iets krachtiger tegenspeler van de DGT zou kunnen worden (vergelijk Bolloc'h 1986, 657).

Omdat de DGT een onderdeel van het overheidsapparaat was, kon ter afstemming van haar gedrag op de overheidsdoeleinden bezwaarlijk een 'contrat de plan" worden opgesteld. Ter regeling van de rechten en plichten van de DGT werd in 1983 een 'charte de gestion" opgesteld. Vastgelegd werd, dat de DGT de exploitatie van het telecommunicatienet naar eigen inzichten kon regelen binnen de grenzen, die expliciet in de 'missions' werden vastgesteld (bijv. met betrekking tot het aantal te realiseren telefoonlijnen en met betrekking tot de tarieven). Tegelijkertijd verplichtte de overheid 
zich tot een financiële injectie van $27 \mathrm{MdF}$ voor de periode 1982-1985. Bij nader inzien bleek het 'charte de gestion' eerder een formalisering van de autonomie van de DGT te zijn, dan een geslaagde poging de DGT onder controle van het Ministerie van PTT, of van Industrie te brengen. Door een herverdeling van taken tussen het Ministerie van Industrie en de DGT in maart 1983, werd de positie van de DGT juist nog aanmerkelijk versterkt. Van oudsher was het Ministerie van Industrie namelijk het 'organe principal de tutelle de l'électronique'; alleen de militaire electronica was een aangelegenheid van het Ministerie van Defensie en de telecommunicatie viel onder het 'Secrétariat aux PTT', i.c. de DGT. In die taakverdeling werd in 1983 een verandering aangebracht ten gunste van de DGT. In verband met technologisch-industriêle ontwikkelingen, waardoor een vervlechting was opgetreden tussen de telecommunicatie, de computerbranche en de kantoorautomatisering, werd in maart 1983 het Ministerie van de PTT omgedoopt tot een 'Secrétariat d'Etat aux PTT' en (inclusief de DGT) ondergebracht bij het Ministerie van Industrie. In de zomer van 1984 werd de vervolgstap gezet: het beleid met betrekking tot de 'informatique' en de 'bureautique' werden ondergebracht bij de DGT, die daarmee ook verantwoordelijk werd voor de publieke ondernemingen in die sectoren, alsmede voor de onderzoekcentra (INRIA, ADI, CESIA). Deze reorganisatie, die een betere coördinatie beoogde tussen het beleid ten aanzien van de telecommunicatie, de telematica, de computerbranche en de kantoorautomatisering, had een breuk in de "filière êlectronique" tot gevolg: de DGT coorrdineerde het beleid met betrekking tot de 'télécommunication, l'informatique et la bureautique', terwijl de DIELI zich bezighield met de 'composants, audiovisuelle, service Conseil en Informatique, médicale électronique et l'électronique industriel.

De positie van de DGT was in de loop der jaren veranderd. Voor 1981 onderhandelde Thery als een gelijke met het Ministerie van Financiën [30] De omgeving van de DGT was toentertijd relatief stabiel: de nationale markten waren gesloten en de vraag naar telecommunicatiediensten was betrekkelijk homogeen. De levering van de telecommunicatiediensten was een betrekkelijk eenvoudige bestuurlijke aangelegenheid [31]. De DGT poogde na 1983 haar onafhankelijkheid te vergroten door haar diversificatiestrategie uit te bouwen en via haar filialen een 'DGT bis" te construeren, dat onafhankelijker zou zijn van het Ministerie van Financiën [32]. Bekend zijn in dat verband het minitel-programma, het 'plan câble' en de 'carte d mémoire'.

In het kader van het 'plan télématique' waren in december 1984530.000 minitels in gebruik, hetgeen werd opgevoerd tot 1.115 .000 in 1985 en tot 5.000 .000 in 1987 [33]. In het kader van het 'plan cable', dat door de DGT in 1982 werd aangekondigd werd de bekabeling van Frankrijk ter hand genomen [34]. De DGT werd daarin gesteund door het Ministerie van PTT, dat de sateliettelevisie gaarne op de kabel wilde, alsmede door het Ministerie van Cultuur, dat in het kabelnet een goede mogelijkheid zag een vooraanstaande plaats van de Franse cultuur op de televisie te waarborgen. Op het terrein van de 'carte à mémoire' had de Franse industrie een voorsprong op haar concurrenten [35]. Probleem was echter de produktie van de terminals, die niet door Franse ondernemingen werd beheerst, hetgeen leidde tot een handelstekort van $700 \mathrm{MF}$. De DGT poogde dat stuk van de filiere te ontwikkelen door met enkele banken het initiatief te nemen het gebruik van de "carte d mémoire" te stimuleren (loketten, telefooncellen, winkels) en door het verlenen van onderzoekcontracten aan 
Temco (terminals), ESD (électronique Serge Dassault) en Olivetti-Logobax. DGT zette de bestellingen van de "cartes d̀ mémoüres" in 1985 en 1986 door.

Hoewel door de reorganisatie binnen het Ministerie van Industrie de DGT verantwoordelijk was geworden woor de integratie van het beleid met betrekking tot telecommunicatie, kantoorautomatisering en de computerindustrie, was zij niet onverdeell gelukkig met de gang van zaken:

- De investeringen in de telecommunicatie werden gestabiliseerd op $27 \mathrm{MdF}$ (in francs van 1982, vastgelegd in het 'charte de gestion' van februari 1983). De schuld van de DGT was sterk opgelopen en de financieringsmogelijkheden via de speciale maatschappijen waren ingeperkt. Het instrument van de vraag was daardoor minder krachtig geworden.

- De DGT kreeg geen controle over de halfgeleiders- en dienstenbranche; het was haar met de creatie van Secimos niet gelukt en het lukte haar met de reorganisatie in 1983 wederom niet (DIELI bleef de 'tutelle' over de halfgeleiders behouden). Dat zat de DGT dwars, omdat het Ministerie van Industrie met betrekking tot die strategische branche van de componenten geen 'róle développeur' vervulde. Op het Ministerie van Industrie heerste vanouds een liberale geest, waarin de korte periode van Chevenement geen wezenlijke verandering had kunnen brengen. De DGT daarentegen was een ware 'L'Etat développeur', die initiatief nam, netwerken organiseerde en in hun ontwikkeling stuurde. Het beleid met betrekking tot de voor haar beleidsterrein zo belangrijke halfgeleiders-industrie wenste de DGT niet in handen van het Ministerie van Industrie te laten.

- De DGT en de PTT waren een groot tegenstander van het vertrek van Thomson uit de telecommunicatie, waardoor CGE een monopolistische positie zall krijgen (zie 7.3.3.1). L. Mexandeaux, minister van de PTT, bracht dat standpunt duidelijk naar voren (zie Barreau en Mouline 1987, 176). Het Ministerie van Industrie (i.c. de DIELI) was echter een groot voorstander van de reorganisatie en van de versterking van Thomson, zij was bereid daarvoor de overheveling van de telecommunicatieactiviteiten naar CGE goed te keuren. Toen de DGT bij het Ministerie van Industrie was ondergebracht moest zij zich in die situatie schikken.

Ook was voor de DGT de situatie op de markt, alsmede de wijzé van financiering. drastisch gewijzigd. Rond 1984 was $90 \%$ van de huishoudens was voorzien van een telefoonaansluiting en de verkopersmarkt was omgeslagen in een kopersmarkt.

"Il faut demarcher, convaincre, vendre les nouveaux services sans pouvoir statut oblige - motiver les commerciaux avec des primes ou appâter les clients avec des tarifs degressifs en fonction de la consommation" (L'Expansion, 201).

Met name voor de grote ondernemingen was de dienstverlening van het telecommuni-

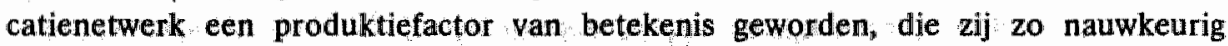
mogelijk op hun specifieke wensen afgestemd willden zien.

Juist op het moment, dat de omgeving turbullenter werd en de markt een grote mate van flexibiliteit wereiste, ondernam de overheid pogingen de handelsvrijheid van de DGT aan banden te leggen [36].

Wat de financiering betreft was besloten, dat de DGT de investeringen in de branches van de telecommunicatie, computers en kantoorautomatisering uit eigen midelen moest bekostigen. Er wordt in dat verband gewezen op het gevaar, dat de DGT 
genoodzaakt zou zijn de tarieven van de 'télémarique' te verhogen, hetgeen haar beleid, gericht op een snelle penetratie van de markt, gemakkelijk kon doorkruisen [37].

Dat alles nam niet weg, dat de DGT met name door de uitbreiding van haar verantwoordelijkheden over de computers en de kantoorautomatisering ook in de periode 1981-1986 over een zeer grote macht beschikte. De politiek wist met die 'staat in de staat' niet goed raad. Om voor de parlementsverkiezingen van maart 1986 een krachtige politieke daad te stellen, waaruit de kiezer zou moeten afleiden, dat de socialistische regering geen 'staat in een staat' duldde, werd in januari 1986 de DGT "ontmanteld" en de coördinatie van het beleid met betrekking tot de branches van de 'filière électronique' overgedragen aan de nieuw gecreëerde 'Délégation à la Strategié" (DGS). De PTT werd gereorganiseerd: naast de bestaande direkties van de telecommunicatie en de post, werden twee nieuwe gecreëerd: de 'Direction des Affaires Communes, Personnel et Affaires Sociales, Budget et Complabilité' en de 'Délégation Générale d la Stratégie' (DGS). De DGS moest voorstellen doen met betrekking tot de strategie van de PTT, coördineerde de vertegenwoordiging van de PTT in nationale en internationale instanties, stemde de strategie van de fillialen af op de algemene beleidslijnen van de PTT en voerde samen met het Ministerie van Industrie de "tutelle" over de telecommunicatie, computerbranche en kantoorautomatisering. De creatie van de DGS opende de mogelijkheid het beleid met betrekking tot de 'filiere' weer in eén hand te brengen; toen Hirel (oud-directeur van DIELI) werd benoemd tot hoofd van de DGS lag het in de lijn van de verwachtingen, dat de branches van DIELI in de DGS zouden worden geîntegreerd. Echter, de wisseling van de politieke wacht in maart 1986 voorkwam zo'n reorganisatie (vergelijk Groenewegen 1989b).

\subsubsection{Het beleid met betrekking tot de publieke ondernemingen na de nationallisaties}

\subsubsection{De "contrats de plan"}

Zoals in 6.2.2.1 is uiteengezet, vormde het 'contrat de plan' (CdP) het instrument bij uitstek van de 'Etat développeur socialiste Française'. De scepsis, die in die paragraaf werd geuit, wordt bevestigd door de resultaten wan de CdP, die met de electronische groepen werden afgesloten: in de CdP werden met de electronische groepen geen gedetailleerde afspraken gemaakt. Hoewel de CdP geheim zijn, is uit het geringe aantal publikaties en interviews met ingewiijden (Haut Conseil 1984; Cahiers Français no. 212 , notice 7 ; Stoffaès van DIELI) op te maken, dat de omvang van de contracten slechts enkele bladzijden betrof, waarin afspraken werden gemaakt in zeer algemene termen.

De CdP met de electronische groepen betroffen vijf onderdelen van het ondernemingsbeleid.

\section{Investeringen}

In alle $\mathrm{CdP}$ werden doeleinden met betrekking tot de investeringen opgenomen. Echter over die afspraken zijn slechts summiere cijfers bekend (Haut Conseil 1984, 211). In Cahiers Francais no. 212 (notice 7 ) is sprake van een verhoging van de investeringen van CGE voor 1984 met $2,9 \mathrm{MdF}$. 


\section{R en D}

De interne financiering van de $R$ en $D$ door de publieke ondernemingen moest aanvankelijk met $10 \%$ per jaar stijgen in de periode 1983-1985. Dat percentage werd echter niet gehandhaafd: gemiddeld lag de beoogde stijging in 1983 rond de $4 \%$ (Haut Conseil 1984, 212-213) en op $10 \%$ woor CGE. Voor Thomson werd zo'n stijging in het geheel niet owereengekomen.

\section{Bijdrage an de handelsbalans}

Het CdP van 1984 met CGE kondigde een verdubbeling van de export aan voor de jaren 1981-1987, ook met. Thomson werden afspraken gemaakt, maar geen enkel cijfer kan worden gepreciseerd (Haut Consell 1984; 62).

\section{Ondersteuning van het Midden- en Kleinbedrijf}

De publieke groepen werden gestimuleerd meer aandacht aan het Midden- en Kleinbedrijf te besteden 0. . door het aanstellen van een vertegenwoordiger van de toeleveranciers in de 'Conseil d'Administration' (Haut Conseil 1984, 323); in mei-juni 1982 werden de 'conventions de stabilité' opgesteld met het doel de risicoverdeling tussen de afnemers en de toeleveranciers evenwichtiger te maken [38].

\section{Behoud en creatle van werkgelegenheid}

Niet alle groepen hebben daaromtrent doeleinden in de CdP opgenomen (Matra, Bull, $\mathrm{CGE}$ en Thomson wel). Alle groepen maakten afspraken met betrekking tot het nemen van allerlei maatregelen, alvorens tot ontslag over te gaan (herplaatsen binnen de groep, omscholing, arbeidstijdverkorting).

Om antwoord te kunnen geven op de vraag, of de overheid, i.c. de DIELI, in staat is geweest het beleid van het management af te stemmen op haar beleidsdoeleinden laten wij in het navolgende een aantal interventies de revue passeren en vragen ons af wie initiatief nam, wie daadwerkelijk de beslissingen nam, welke eventuele veranderingen in de machtsverhoudingen optraden en welke de gevolgen waren voor de dynamiek van de individuele ondernemingen en voor de dynamiek van de 'filière électronique' als geheel.

\subsubsection{Yalta de la télécommunication}

In 1983 werd besloten de activiteiten van CGE en Thomson te reorganiseren: CGE zou zich specialiseren in de telecommunicatie (communication publique, transmission, fils et cables, téléphonie privée, services en informatique) en Thomson in de 'électronique professionelle, EGP et composants'.

In schema 7.9 is de reorganisatie samengevat.

De intentieverklaring met betrekking tot de reorganisatie werd eind augustus 1983 door Gomez en Pébereau getekend. In het dertig pagina's tellende stuk [39] werd vastgelegd welke activiteiten Thomson in de nieuw op te richten onderneming (Thomson Télécommunication:TT) zou inbrengen: 
- Thomson-CSF en de filialen Ferrer-Auran, Vega, Cimest, TIT, Somartel, Sote, Saci en Thomson-CSF Inc. USA;

- de divisies in de 'faisceaux hertziens', ruimtevaart, de $50 \%$ in Telspau, de onderneming LTT en de activiteiten in de kantoorautomatisering;

- Thomson-CSF-informatique (met uitzondering van Cimsa, Cameca en Saphymo), Ausware, TITN, AEA en Syseca.

De waarde van de inbreng van Thomson in TT werd op 751 MF vastgesteld. Tevens werd door Thomson en CIT-Alcatel hun aandeel van $34 \%$ in Locatel ingebracht.

Schema 7.9 Reorganisatie Thomson en CGE: eerste fase

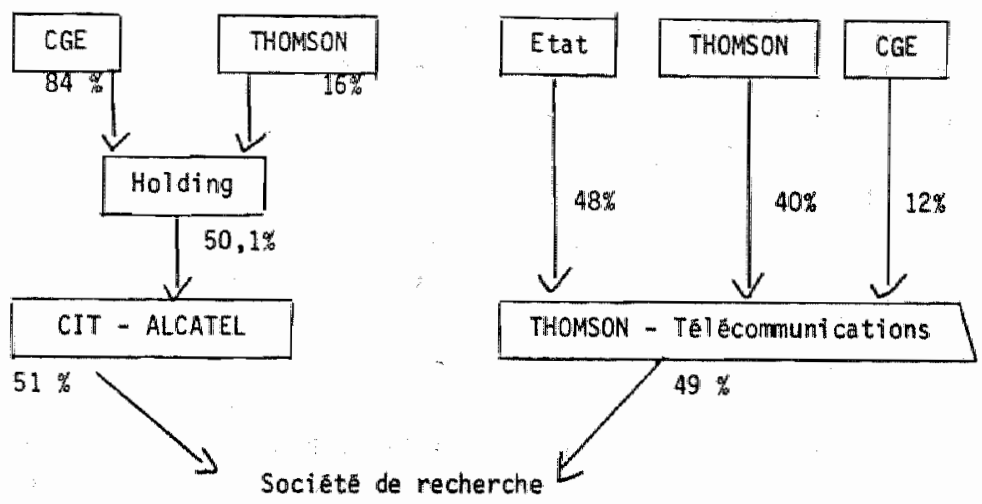

Bron: Le Monde (22-9-1983, 41)

De bijdrage van de overheid bestond uit een kapitaalinjectie van $720 \mathrm{MF}$, waardoor de verdeling binnen TT als volgt was samengesteld: de overheid $48 \%$, Thomson $40 \%$ en CGE $12 \%$ (zie schema 7.9). Tevens werd een 'prêt participatif' verleend van $250 \mathrm{MF}$. CGE creërde op haar beurt een holding, waarin zij $50.1 \%$ van haar aandeel in CITAlcatel inbracht. De holding werd voor $84 \%$ van CGE en voor $16 \%$ van Thomson (zie schema 7.9). Op die manier werd de $12 \%$ deelname van CGE in TT betaald door de $16 \%$ deelname van Thomson in de nieuwe holding [40].

Afgesproken werd door de fusie CIT-Thomson-Telecommunications uiterlijk 1 januari 1987 een feit zou zijn. Thomson kon haar deelname in CIT-TT opvoeren tot maximaal 40\%. Wat de leiding over TT betreft werd afgesproken, dat CGE van Thomson en de overheid het mandaat kreeg de strategische beslissingen te nemen; in de vergaderingen zou de vertegenwoordiging van Thomson met die van CGE meestemmen.

Naast de reorganisaties in het kader van de creatie van CIT-TT vonden tussen CGE en Thomson nog de volgende overdrachten plaats:

- CGE deed aan Thomson haar deelname van $72 \%$ in Sintra over met uitzondering wan de telecommunicatieactiviteiten;

- in de consumentensfeer werd CEPEM (keukens) overgedragen;

- CGE nam de activiteiten in de postsortering (Hotchkiss-Brand-Soge^me) over en 
- de kabels van Thomson-Jeumont

- de activiteiten in de halfgeleiders trok Thomson naar zich toe.

Een zeer opvallend gevolg van het 'Yalta de la Télécommunication' betrof de monopoliepositie van CGE: na het verdwijnen van Thomson was naast CGE weliswaar CGCT nog actief, maar dat was geen volwaardige concurrent meer, omdat zij produceerde in licentie van Thomson. Er was tussen de DGT en CGE een bilateraal monopolie ontstaan; CIT-Alcatel was voor $2 / 3$ van haar omzet afhankelijk van de DGT, maar deze kon op har beurt de prijzen niet te ver naar beneden drukken, omdat CIT-Alcatel dan twee van haar zeven fabrieken zou moeten sluiten [41]. Om een beter beeld te krijgen van de positie van CIT- Alcatel heeft de DGT door een leger controleurs de afzetmarkten van CIT-Alcatel laten onderzoeken en in afwachting van de resultaten werd vanaf 1 jamuari 1984 geen enkele centrale meer besteld. Het was duidelijk dat de DGT niet gelukkig was met de monopoliepositie van CIT-Alcatel en zij zocht vanaf eind 1983 dan ook naarstig naar wegen om haar afhankelijkheid te verminderen. Buiten de telecommunicatie werd een groter marktaandeel gegund aan Matra, SAT, SAGEM en TRT, terwijl voor de toelevering wan telefooncentrales werd gezocht naar een tweede leverancier. Mexandeau, Minister wan PTT, had direct na het 'Yalta de la Télécommunication' gewezen op de noodzaak voor CGE om Europese samenwerkingsverbanden aan te gaan [42]. De idee was, dat een sterke Europese onderneming de geliberaliseerde Amerikaanse markt zou kunnen betreden. De bundeling van Europese krachten werd echter steeds door de strategie van met name de Amerikaanse ondernemingen doorkruist: op 30-7-1984 sloot ATT een overeenkomst om in Spanje 250 miljoen dollar te investeren in een fabriek voor halfgeleiders, BT en IBM maakten afspraken om met betrekking tot de 'télématique "un de UK, terwijl ITT interesse toonde in ICL. Dat Amerikaanse "driemanschap" opende een offensief op de Europese markt van de telecommunicatie en de computers, wararbij de Europese ondernemingen geïnteresserde partners bleken. De DGT zou haar pogingen naast CIT-Alcatel een tweede leverancier aan te stellen doorzetten, hetgeen uiteindelijk resulteerde in het samengaan van CIT-Alcatel met ITT.

Bij nadere beschouwing blijkt, het 'Yalta de la Télécommunication' een goed voorbeeld te zijn van een geval, waarbij de overheid met succes een makelaarsrol vervulde:

"Il revient à l'Etat le mérite d'avoir joué son rôle; celui d'entériner (tout en l'assortissant de certaines conditions) l'accord entre deux chefs d'entreprise responsables dépositaires de son patrimoine, Ce faisant, il tord le cou au concept - dépassé - d'une politique industrielle concue dans les profondeurs de l'administration; il donne tout son sens a l'autonomie de gestion du secteur public; et il retire leurs dernieres illusions aux nostalgiques qui pensaient encore que l'on peut - et même que l'on doit - gérer une entreprise nationalisée selon des critères différents de ceux du secteur privé. Pour un actionnaire socialiste, ce n'est pas si mal'" (L'Expansion, 123),

De overheid kon met succes als catalysator fungeren, omdat de belangen van de diverse partijen in elkaars verlengde lagen. Op het eerste gezicht zou de indruk kunnen ontstaan, dat de overheid erin was geslaagd de strategie van twee publieke ondernemingen volledig naar haar hand te zetten. Immers, in 'Le Sacialisme Industriel' (Boublil 1977) werd precies alangekondigd welk lot Thomson en CGE na de nationalisatie beschoren zou zijn [43]. 
De concentratie van telecommunicatieactiviteiten bij CGE was echter ook in de jaren 1981-1982 door de betrokken ondernemingen zelf woorgesteld. Toentertijd stuitte het ontstaan van een monopoliepositie van CGE echter af op hevig verzet van de DGT. In 1983 lag de situatie anders: de DGT was bij het Ministerie van Industrie ondergebracht en de DIELI had duidelijk belang bij een grondige reorganisatie van Thomson, waarvan de overdracht van de telecommunicatie een essentieel onderdeel vormie.

Bij nadere beschouwing blijkt, dat ook de strategie van Gomez van Thomson zeer well paste in de reorganisatie, die uiteindelijk door het 'Yalta de la Télécommunication' werd bewerkstelligd. Immers, Gomez was van meet af aan bezig het mosaique van veelsoortige activiteiten terug te brengen tot enkele 'mëtiers'. Omdat Thomson financieel zwak was, DIELI beslist wilde dat Thomson zich niet uit de halfgeleiders en de medische electronica zou terugtrekken, de telecommunicatie enorme investeringen vergde en in Frankrijk eén onderneming moest ontstaan met voldoende produktieschaal [44] (i.c. CIT-Alcatel), lag het voor de hand dat Gomez na de mededeling van Fabius, dat alle publieke ondernemingen per 1 januari 1985 uit de rode cijfers moesten zijn, ervoor koos de telecommunicatie over te dragen aan CGE.

CGE kreeg op haar beurt een uitstekende gelegenheid met financièle steun van de overheid een monopoliepositie te verwerven. Algemeen was dan ook de indruk dat Pebereau van CGE als beste uit de reorganisatie naar voren was gekomen [45].

Het 'Yalta de la Télécommunication' is tot stand gekomen, omdat beide rivalen begrepen, dat doorgaan van de concurrentiestrijd voor beide desatreus zou zijn. DIELI heeft op subtiele wijze de zwakke positie van Thomson gebruikt om eisen te stellen, die uiteindelijk ook voor Thomson in een perspectiefvolle reorganisatie uitmondden. De overheid diende het spel voorzichtig (mee) te spelen: enerzijds kon de socialistische regering met haar denkbeelden over de stimulerende rol van publieke ondernemingen zich niet permitteren de afspraken van Gomez en Pebereau slechts te ratificeren, anderzijds moest zij ook zorgvuldig de autonomie van het management in acht nemen. Die beperkte manoeuvreerruimte bleek bijw. uit de brief van Fabius aan Gomez en Pebereau, die opende met "Vous m'avez fait part de votre souhait d'engager les procédures nécessaires à une redéfinition (...)", maar waarin ook expliciete voorwaarden aan de operatie werden gesteld met betrekking tot het voortbestaan van het produktassortiment van Thomson, het respecteren van de afspraken tussen CGCT en Thomson en de samenwerking op het gebied van de halfgeleiders [46].

Overigens kan uit de gang van zaken met betrekking tot het tot standkomen van het 'Yalta de la Télécommunication' worden opgemaakt, dat van het idee van democratisering van de besluitworming in de vorm van in het betrekken van alle belanghebbenden in een breed consultatieproces hetwelk uitmondt in een CdP, niets is terechtgekomen.

"Pour la méthode, on retiendra que, comme par le passé, tout s'est décidé entre quelques hommes. Le 'secret des affaires' aidant, la démocratie industrielle reste pour la gauche comme pour la droite un slogan" (Le Monde 22$9-1983,41)[47]$. 


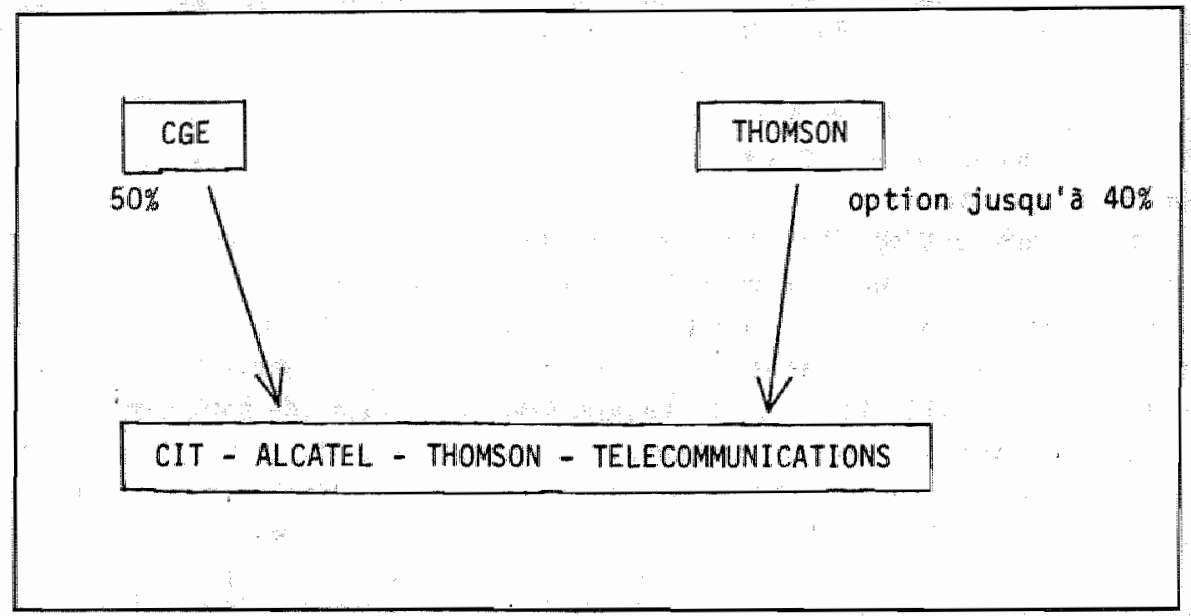

Bron: Barreau en Mouline $(1987,184)$.

7.3.3.2 Herstructureringen in de halfgeleiders en de computerindustrie, in de kantoorautomatisering en in de 'productique".

\section{Halfgeleiders}

De 'polle composants' werd rond Matra en Thomson gevormd. De overheid oordeelde het niet juist door de steun voor de "circuits M.O.S." te spreiden over EFCIS (Thomson), MHS (Matra-Harris) en Eurotechnique (NSC-Saint Gobain). Door de nationalisaties kreeg de overheid een belang in de drie ondernemingen. Toen tussen hen een fusie niet mogelijk bleek, opteerde de overheid voor samengaan van EFCIS en Eurotechnique. In het kader van het tweede 'plan composants' nam Thomson in 1983 Eurotechnique over (zie Haut Conseil 1984, 80).

Thomson en Matra werden tot samenwerking "uitgenodigd" bijv. op het terrein van de microlitografie, waaruit Thomson zich aanvankelijk wilde terugtrekken. Uit de reorganisaties rond de halfgeleiders blijkt, dat DIELI het financieel zwakke Thomson naar haar hand kon zetten, maar dat Matra duidelijk haar eigen weg ging.

\section{Computerindustrie en Kantoorautomatisering}

De activiteiten in de computerbranche en de kantoorautomatisering werden georganiseerd rond de nieuwe Nationale Kampioen "Bull", die na de nationalisatie uit CII-HB was ontstaan.

In 1983 werden vijf filialen onder de moedermaatschappij (Compagnie des Machines Bull) gebracht: 
- Bull Systèmes (het oude CII-HB) : computers

- Bull-SEMS (oude SEMS)

: mini-computers

- Bull-Transac (van CGE)

- Bull-Peripheriques

: Kantoorautomatisering

: randapparatuur en (inclusief Cynthia en $\mathrm{R} 2 \mathrm{E}$ ): micro-computers

- cartes à memoires' [48]

Bull werd door de overname van SEMS en Transac de centrale onderneming in de computerbranche en de kantoorautomatisering. Echter, twee jaar na het ontstaan van Bull deed zich een probleem voor, toen de combinatie Matra-Norsk Data zich op de markt van de 'informatique scientific' wilde presenteren. Hoewel opsplitsing van de publieke markt van mini-computers niet in de ideeèn van DIELI paste, werd de nieuwe pool geen haar breed in de weggelegd [49]. Blijkbaar was de overheid niet goed in staat de publieke markt voor Bull te reserveren.

Wat de kantoorautomatisering betreft was Bull na de reorganisatie de Nationale Kampioen geworden. CGE voelde zich echter ook aangetrokken tot die snel groeiende markt en was niet van plan een afwachtende rol te spelen, hetgeen bleek uit haar samenwerking met Olivetti. Ook combineerden Telic-Alcatel van CGE en de Amerikaanse groep Wang hun competenties, waardoor een sterke combinatie ontstond. Ook Thomson en Hewlett-Packard tekenden in 1984 een overeenkomst van dien aard. Blijkbaar was de overheid niet goed in staat de 'bureaucratique' voor Bull te reserveren en de activiteiten van de publieke groepen onder controle te houden.

\section{Productique}

In oktober 1983 presenteerde Fabius een "plan productique' voor de ontwikkeling van de fabriek van de toekomst. CGE, Matra en Renault werden de 'póles productiques'. CGE had filialen in de robotica (ACB, CGMS, SCEMI) en in de beheersing van produktieprocessen. Om de activiteiten te hergroeperen, creëerde CGE in 1984 uit CGMS de 'Compagnie Générale de Productique' (CGP), welke voor $60 \%$ door CGE werd beheerd en voor $40 \%$ door Althom-Atlantique (groep CGE). Doel: het veroweren van de eerste plaats in Europa en van $4 \%$ van de wereldmarkt in de 'productique*. In het aanhangsel van het CdP werden die doeleinden opgenomen.

Matra hergroepeerde ook haar activiteiten in de "robotique". Zij werkte nauw samen met Renault: in 1984 kwam een samenwerkingsverband tot stand tussen RenaultAutomation en Matra-Datavision (Hant Conseil 1984, 95),

\subsubsection{De ontwikkelingen buf Thomson, Bull, CGE en Matra nader bekeken}

\subsubsection{Inleiding}

Hoewel niet vlekkeloos kwamen door de reorganisaties binnen de publieke groepen toch duidelijk 'récentrage-polen' tot stand.

"Ainsi, avec la CGE pour les communications civiles, Bull pour l'informatique" et la bureaucratique. Thomson pour l'electronique professionnelle, l'électronique -grand public, Matra en Thomson pour les composants, Matra (et Renault) et la COE pour la productique, les pôles d'activité semblent clairement definis (...)" (Barreau en Mouline 1987, 185). 
De herstructureringen in de 'filière électronique' overziendie, kan worden geconcludeerd, dat DIELI in het ene geval initiatief kon nemen en reorganisaties kon doorvoeren (Thomson en Bull), maar in het andere geval bleek DIELI slechts in staat de reeds uitgestippelde ondernemingsstrategie te ratificeren (Matra, CGE). Dat beeld wordt bevestigd als de gang wan zaken rond Thomson, Bull, CGE en Matra in de periode 1981-1986 nog eens nader wordt bezien.

\subsubsection{Thomson}

Thomson leed in 1982 een verlies van $2.2 \mathrm{MdF}$, had haar strategie met betrekking tot het activiteitenpakket niet aangepast aan de internationale concurrentieverhoudingen en had geen enkele poging ondernomen haar organisatiestructuur te wijzigen. $\mathrm{Na}$ de verandering van de leiding heeft DIELI met voortvarendheid de reorganisaties bij Thomson mede vorm gegeven. Daarbij stond DIELI het dienen van twee belangen voor ogen: enerzjjds moest Thomson weer winstgevend worden, anderzijds moest Thomson activiteiten ontplooien, die vanuit nationaal belang van strategische waarde werden geacht. DIELI had de mogelijkheden de ondernemingsstrategie te beïnvloeden, omdat Thomson in belangrijke mate afhankelijk was van haar financiële steun en van de overheidsorders.

Ten tijde van de nationalisatie was Thomson aanwezig in een twintigtal branches met de hoofdactiviteit in de militaire electronica, $\mathbb{E G P}$, medische electronica, halfgeleiders en de tellecommunicatie. Door de slechte financiêle resultaten was een "récentrage" nodig, waarop DIELI duidelijk invloed heeft uitgeoefend [50]. Het management stelde een vermindering van activiteiten voor in de verliesgevende sectoren van de medische technologie, de halfgeleiders en de telecommunicatie. Echter, DIELI was van mening, dat Thomson juist in de eerste twee eerstgenoemde sectoren een strategische plaats. diende te veroveren. In dat verband was DIELI een tegenstander van de overeenkomst tussen Thomson-CGR en de Amerikaan Technicare (Haut Conseil 1984, 63), hetgeen op een mogelijk terugtrekken van Thomson uit de medische sector vooruit liep. DIELI dwong Thomson CGR te behouden en met behulp van overheidssteun werd het onderzoek in enkele medische speerpuntentechnologieẽn uitgebreid. Ook met betrekking tot de halfgeleidersindustrie drukte DIELI een duidelijk stempel op de strategle van Thomson. Zoals uiteengezet beschouwde Thomson de halfgeleiders (Sescosem) van ondergeschikt belang. Onder druk van DIELI werd de 'composants' binnen Thomson een kernactiviteit en dankzij de stimulering van de investeringen en de overheidsorders werden zelfs enige bescheiden successen geboekt. Door de initiatieven van J. Noels (PDG Thomson-Composants) en het "plan microélectronique' van 1983, ging Thomson over tot de produktie van halfgeleiders in zeer grote series en bond zij de strijd aan met de Japanse concurrentie. Thomson kocht Mostek, waarmee zij toegang kreeg tot de Amerikaanse markt. Een groot deel van de kapitaalinjecties (3.5 MdF van augustus 1982 tot december 1985) werd aan investerimgen in de halfgeleiders besteed. Resultaat: de afzet nam in 1985 met $14 \%$ toe ondanks een inzinking van de markt.

Wat de telecommunicatie betreft, is hierboven uiteengezet hoe Thomson in het kader van het 'Yalta de la Télécommunication' haar activiteiten overdeed aan CGE; een reorganisatie waarin de begeleidende hand van DIELI zichtbaar was. 
Wat de produktie van micro-computers betreft, tekende SEMS van Thomson in september 1981 een overeenkomst met SEL (Amerikaanse groep Gould). DIELI sprak daarover haar veto uit en wenste een samenwerking tussen SEMS en Bull. In de micro-computers boekte Thomson later successen mede dankzij de stimulering van de vraag door de overheid. Thomson kende met de MOS (T.O. 7-70 en T.O. 9) in de 'micro-informatique" een groot succes en had in $198530 \%$ van de Franse markt in handen (opleidingen in het kader van het 'plan informatique pour tous' creèerde een markt van 100.000 micro-computers).

Wat de consumentenelectronica betreft, doet zich rond de samenwerking tussen het Japanse JVC, enkele Europese ondernemingen en Thomson een vermeldenswaardig steekspel voor, walarbij DIELI uiteindelijk aan het kortste eind trok [51]. De zogenaamde 'affaire $J 3 T$ ' begon toen Thomson $75.5 \%$ van de aandelen van Max Grundig wilde kopen. Philips had de andere $24.5 \%$ in handen. Grundig was bereid met Thomson in zee te gaan onder voorwaarde, dat zij het V2000-systeem voor videorecorders zou kunnen blijven produceren. Thomson en Philips hadden echter een zeer verschillende visie op een aantal technische ontwikkelingen (toekomst V2000 en de $8 \mathrm{~mm}$ videostandaard), waardoor geen hechte Europese samenwerking tot stand kon komen. Gomez, PDG van Thomson, had sterke woorkeur voor samenwerking met het Japanse JVC, maar moest onder druk van DIELI formeel de Europese kaart blijven spelen. De afkeuring van het Duitse 'Kartelamt' van de geplande overname van Grundig door Thomson kwam Gomez zeer goed uit: er werd tegen het besluit van het 'Kartelamt' geen beroep aangetekend, want Gomez zag een mogelijkheid zich van het Europese toneel te verwijderen, zonder dat DIELI daardoor groot gezichtsverlies leed.

Thomson sloot met JVC een samenwerkingsowereenkomst. Philips ontfermde zich over Grundig en Thomson nam Telefunken over. De oriëntering van Thomson op Japan werd in 1985 doorgezet door een contract met Nakamichi met betrekking tot de produktie van compact disks. Door de aard van de markt van de consumentenelectronica kon DIELI onvoldoende druk op Thomson uitoefenen: zij kon geen afzetperspectieven bieden in geval van een Europese samenwerking, de vraag werd op geen enkele manier door de Franse overheid beheerst en de dominantie van Philips bood DIELI en. Thomson geen manoeuyreerruimte. Als de ondernemingsleiding in zo'n geval een eigen strategie ontwikkelt (geen vertrouwen in V2000 en wel in samenwerking met JVC), blijkt het voor de overheid niet mogelijk die strategie om te buigen: de specifieke kennis over de ontwikkelingen op dergelijke markten is in handen van de onderneming, waardoor het voor een overheidsinstantie, die geen controle heeft over de vraag, uitermate hachelijk wordt haar wil door te drukken. Bovendien had ook het onderzoek in de consumentenelectronica geen plaats meer in de 'programmes mobilisateur", zodat DIELI langs die weg ook geen invloed kon uitoefenen.

De professionele electronica is en blijft de grote kracht van Thomson: in 1986 groeit de omzet mede door de installatie van defensie-systemen in Saoedi Arabiê en het contract over de levering van het geavanceerde communicatiesysteem RITA aan het Amerikaanse ministerie van Defensie [52].

De reorganisatie van activiteiten heeft gevolgen voor de organisatiestructuur.

A. Gomez was van meet af aan bezig met de aanpassing van de organisatie van 
Thomson, welke ongeveer twee jaar in beslag zou nemen. De herstructurering vond plaats rond vier polen (EGP, composants; armément, équipments médicaux) en was: gericht op het creëren van fillialen per produkt, zodat autonome 'profit centers' ontstonden en de verantwoordelijkheden voor de gehele gang van zaken met betrekking tot ến produktgroep bij een đuidelijk aanwijsbaar managementteam kwam te liggen. Tevens bood zo'n organisatiestructuur duidelijk inzicht in de financiële situatie en prestaties van de diverse produkten.

Onder de moedermaatschappij (Thomson-S.A.) werden de grote filialen gebracht (Brandt, Armément, Thomson-Informatiques Services, Thomson-CGR) en holdings zoals Thomson-Grand-Public. Als gevolg van de reorganisaties daalde het aantal werknemers bij de centrale diensten van 1800 tot 300 .

Een scherpere taakverdeling tussen de moedermaatschappij en dle filialen kwam tot stand, waarbij de centrale zich concentreerde op de strategische planning, de internationale strategie en de sociale aangelegenheden, terwijl de filiallen zich op de operationale taken richtten.

Een ander gevolg van de reorganisatie was het doorbreken van de traditioneel gegroeide relaties met afdelingen en personen van departementen. Thomson maakte zich minder afhankelijk van beschermde gepriviligeerde markten en stemde haar organisatiestructuur af op de eisen, die de internationale concurrentiestrijd stelde.

\subsubsection{Bull}

Het verlies in 1983 (1MdF) werd in 1985 omgebogen in een bescheiden winst, dankzij een totaal nieuwe strategie. DIELI speelde ook bij de beleidsombuigingen van Bull een grote rol:

- herstructurering van de computer- en de kantoorautomatiseringsactiviteiten in vijf afdelingen: Bull Systèmes, Bull-SEMS, Bull-Transac, Bull-Phéripheriques en 'Cartes d Memoires'.

- reorganisatie van produktiemethoden en de ontwikkeling van een groot investeringsprogramma, gefinancierd met forse kapitaalinjecties van de overheid (1.5 MdF in 1983). In 1984 werd een uitzonderlijk CdP getekend, omdat de financiele toezeggingen van de overheid een meerjarenperiode (1984-1986) betroffen (1 MdF). Ook gaf Bull 'prêts participatifs' uit (1.15 MdF in de periode 1982-1985) en kreeg zij leningen van het FIM (200 MdF in 1985).

Tevens voerde de Franse overheid haar steun ten behoeve van de $R$ en $D$ op: van 20 MF in 1981 voor CII-HB tot 288 MF voor Bull in 1984.

- Bull ontwikkelde een strategie gericht op het aanbieden van een total pakket: de produkten bestreken het hele spectrum van "Informatique Grosse" tot de micro computers, de "péripheriques", advisering, opleiding etc.

Om deze strategie te kunnen realiseren dienden samenwerkingsovereenkomsten te worden afgesloten; de kosten van $\mathrm{R}$ en $\mathrm{D}$ voor alle systemen zijn immers niet door én individuele onderneming te dragen. De voornaamste partners werden Honeywell, dat Bull toegang tot de Amerikaanse markt verleende en Nippon Electric Cy. (NEC), dat het brede spectrum van computers bestreek. Bull zette een internationaal netwerk op "pour l'acquisition de matériel et de technologies" met 
Amerikaanse groepen als Convergent Technology (terminal bancaire), Ridge (minscientific). Tolerant Systems (logiciel Unix), Microsoft (logiciel) en met Olivetti en de CNET. Ten behoeve van de distributie werden overeenkomsten getekend met INI (Spanje), ABL (Brazilie), Cortelonne Noblex (Argentinië), ECIL (India) en AST Research (USA). Op het gebied van de halfgeleiders worden met Matra, Thomson en Honeywell verbindingen aangegaan. Met Siemens en ICL werd een gezamenlijk onderzoekcentrum in Munchen opgezet ten behoeve van het onderzoek op het gebied van de kunstmatige intelligentie (operationeel in 1986). Met JeumontSchneider werd in 1985 een onderzoekonderneming gestart.

In november 1985 vond een interne reorganisatie plaats: Bull-SEMS en Bull-Transac werden divisies van Bull S.A.

"Grâce à une gestion plus rigoreuse, à un interêt soutenu de son actionnaire public, Bull a retrouvé l'équilibre financier des 1985" (Barreau en Mouline 1987, 194).

\subsubsection{CGE}

Zoals gezegd stelde DIELI zich ten opzichte van CGE en Matra terughoudender op dan ten opzichte van Thomson en Bull; enerzijds omdat zij financieel niet afhankelijk waren van de overheid, anderzijds omdat de strategie van beide ondernemingen goed paste in de overheidsdoelstellingen.

CGE was voor de nationalisatie een collage van autonome ondernemingen geweest, gecoördineerd door een relatief kleine holding van zo'n 300 personen. Elk filiaal werd bestuurd door een 'baron'; zij kwamen maandelijks bijeen om informatie over de verschillende filialen van de groep uit te wisselen. CGE zelf had geen enkele internationale bekendheid in tegenstelling tot haar filialen Alcatel, Alsthom Atlantique en les Câbles de Lyon.

Zoals gezegd bewoog CGE zich in tegenstelling tot Thomson in toenemende mate op internationale concurrentiemarkten, hetgeen ook een verandering van haar organisatiestructuur noodzakelijk maakte. Die noodzaak werd door de nationalisaties aangescherpt. Na de nationalisatie ontwikkelde de moedermaatschappij zich in verband met het opstellen van het CdP van de gehele groep tot de intermediair tussen het Ministerie van Industrie en de filialen. Evenzo werden de relaties binnen de groep versterkt door de verplichting in de 'lois Auroux' een 'directeur des affaires sociales' en 'un comité du groupe' in te stellen: de directeur coördineerde de verkiezingen in de verschillende filialen en het comité versoepelde de contacten tussen de werknemerswertegenwoordigers uit de verschillende filialen.

CGE ontwikkelde een strategie ter verovering van de Amerikanse telecommunicatiemarkt. Zij veranderde haar image van financiële comglomeraat in dat wan een industriẻle groep met een duidelijk 'métier' (Barreau en Mouline 1987, 191). De 'récentrage" van de groep kwam tot uiting in de specialisatie in twee polen: enerzijds de activiteiten in de energie en het transport en anderzijds de telecommunicatie geconcentreerd in CIT-Alcatel. In 1982 maakten die activiteiten nog 2/3 van het totaal uit; in 1984 was dat toegenomen tot $9 / 10$. Tegelijkertijd werd de internationalisatie ferm ter hand genomen. G. Pebereau (PDG van CIT-Alcatel en vanaf juni 1984 van CGE) maakte in juni 1983 duidelijk wat de ambities van CIT-Alcatel waren: over de periode 1983-1987 
moesit de onderneming met $20 \%$ per jaar groejen, het marktaandeel moest van $3 \%$ stijgen tot $9 \%$ en de activiteiten in Amerika moesten drastisch worden uitgebreid. Met de herschikking van de activiteiten in het kader van het 'Yalta de la Télécommunication", ontving CGE $1.2 \mathrm{MdF}$ steun voor Thomson-Telecommunications (1984-1985) en kreeg zij de garantie van orders en kredieten voor onderzoekdoeleinden van de DGT over de periode 1984-1987. In het rapport Bonnefous et al. (1982) wordt melding gemaakt van een bedrag van $36 \mathrm{MdF}$ aan orders over een periode van drie jaar dankzij versnelde modernisering van de centrales: Door de reorganisaties werd Alcatel de vijfde onderneming op de wereldranglijst met een omvang, die voldoende werd geacht voor de concurrentiestrijd op de internationale markten.

De integratie van de telecommunicatieactiviteiten van Thomson in CGE vereiste een integratie van alle daarmee verbonden activiteiten uit de verschillende filialen. De wil om synergieen tussen de filialen tot stand te brengen leidde tot de aanstelling van een toegevoegd directeur voor de coördinatie van alle nationale industriële activiteiten en het ontwikkelen van een industriebeleid voor de groep [53].

Om voet op de Amerikaanse markt te zetten had CGE deelnemingen in en overeenkomsten met diverse Amerikaanse ondernemingen (Lynch Corporation, Sonitral Corporation, Communication Corporation of America, Fairchild Industries, Celware Technologies Corporation). De plannen van CGE in oktober 1985 met ATT een samenwerkingsovereenkomst te sluiten waren bedoeld om een stevige positie op de Amerikaanse markt te veroveren.

\subsubsection{Matra}

DIELI had op Matra weinig greep, hetgeen reeds bleek uit de nationalisatie van $51 \%$, het aanblijven van PDG Lagardère en uit de mogelijkheden van Matra op de kapitaalmarkt leningen af te sluiten. Ook wat de reorganisatie van de activiteiten betreft, bleek DIELI het initiatief, behoudens de uitzondering van de verkoop van de divisie 'presse el audiovisuel', geheel aan Matra te laten (Barreau en Mouline 1987, 192). Matra bleef aanvankelijk haar sterk gediversificeerde structuur behouden. Pas in juni 1985 kondigde Lagardère een 'récentrage' aan op de militaire produkten, ruimtevaart, halfgeleiders en de telecommunicatie (Barreau en Mouline 1987, 192). Drie ondernemingen in de 'productique' werden in juli 1985 afgestoten (Robotronics, Manucentre Automatic en Sormel). In augustus van dat jaar werd $49 \%$ van haar filiaal Comelin (cincuits imprimes') aan een Amerikaanse onderneming overgedaan. In januari 1986 nam Matra een deelneming in het filial 'Télécommuntcations Privees' van CGCT. In februari 1986 onderhandelde Matra met Fiat over de verkoop van haar filialen Jaeger en Solex ("automobiel electronica') en in juni 1986 doet zij haar "horlogerie over aan Seiko.

\subsection{Conclusies}

De analyse in dit hoofdstuk was gericht op het achterhalen wan de effectiviteit wan het industriebeleid met betrekking tot het realiseren van de doeleinden ten aanzien van de 'filière electronique' en het gebruik van de publieke ondernemingen dienaangaande. Is de overheid in staat geweest de strategieèn van de industriële groepen te beinvloeden 
en af te stemmen op haar doeleinden?

Uit het voorgaande kan worden afgeleid, dat de owerheid de ambitie had met betrekking tot de 'filiere électronique' een 'rôle dêweloppeur' te spelen. Zij maakte die ambitie op diverse manieren waar:

- in vergelijking met voorgaande regeringen was na 1981 met betrekking tot de "filiere electronique sprake van een snelle besluitvorming: na de rapportage in juli 1982 kwam snel het PAFE tot stand gevolgd door een groot aantal sectorplannen;

- de overheidssteun voor de 'filière électronique' was na 1981 beduidend; met name de steun voor $R$ en $D$ was belangrijk (opdrachten voor marktonderzoek via de $D G T$ en DGA en subsidies via ANVAR): $5 \mathrm{MdF}$ in 1982, 6,7 MdF in 1983, $8 \mathrm{MdF}$ in $1984 \mathrm{en}$ 8.9 MdF in 1985 (Barreau en Mouline 1987, 214).

Ook kwam de 'Etat-actionnaire' haar verplichtingen na door het verschaffen wan risicodragend kapitaal:

- 1982: $1.85 \mathrm{MdF}$

- 1983: 4 MdF

- 1984: $3 \mathrm{MdF}$

- 1985: $2.75 \mathrm{MDF}$

- 1986: 2.1 MdF

(Bron: Barreau en Mouline 1987, 215)

In dit hoofdstuk is de aandacht met name uitgegaan naar de telecommunicatie- en de computerindustrie. De doeleinden van het beleid met betrekking tot produktiegroei, handelsbalans, investeringen, $R \& D$, opleidingen etc. waren - voor zover bekend - in het PAFE niet nauwkeurig, maar in nogal algemene bewoordingen geformuleerd. Toetsing van de effectiviteit van het overheidsbeleid aan de realisatie van dergelijke algemene doeleinden kan gemakkelijk tot gunstige oordelen leiden. Zo rapporteerde de Minister van Industrie, op de ministerraad dd. 21-11- 1984 dat:

- de groei van de produktie in 1984 steeg van $3 \%$ naar $8 \%$

- de irvesteringen sterk waren toegenomen

- het tekort op de handelsbalans was verminderd van $13 \mathrm{MdF}$ in 1982 tot $6 \mathrm{MdF}$ in 1984 (zie schema 7.11 voor een overzicht per branche)

- de doeleinden met betrekking tot de opleiding van ingenieurs en technici waren gerealiseerd.

Fabius had als Minister van Industrie de eis gesteld, dat de publieke ondernemingen per 1-1-1985 uit de rode cijfers zouden zijn. Die doelleinden werden gerealiseerd; ook de zwakke ondernemingen Thomson en Bull lieten positieve resultaten zien. Thomson ging van een tekort van $2.2 \mathrm{MdF}$ in 1982 maar overschot van $583 \mathrm{MF}$ in 1985 en Bull van een tekort van $1.3 \mathrm{MdF}$ in 1982 naar overschot van $110 \mathrm{MF}$ in 1985 . CGE en Matra realiseerden in 19851.185 MF resp. $113 \mathrm{MF}$ winst.

Zoals eerder op diverse plaatsen is opgemerkt, kunnen de resultaten in de 'filiêre électronique' in het algemeen, of van de publieke ondernemingen in het bijzonder niet rechtstreeks met het beleid van de overheid in verband worden gebracht. Tal van factoren zijn op het resultaat van invloed, waarvan het overheidsbeleid er eten is. Gedetailleerde analyse van de feitelijke gang van zaken kan mogelijkerwijs wel uitsluitsel omtrent het effectiviteitvraagstuk geven. Barreau en Mouline zijn van mening, 
dat de overheid door de verbeterde informatievoorziening over de strategieen van de ondernemingen en door het scala van instrumenten, dat haar ter beschikking stond in staat is gebleken wel degelijk invloed uit te oefemien op de strategie van bepaalde industriele groepen (Barreau en Mouline 1987, 221).

Des objectifs clairement définis, des groupes plus offensifs et mieux gérés, de nouveaux instruments d'intervention étatique et de nouveaux moyems d'information, des délais de réaction moindres, des relations Etat-groupes plus equilibrées, tous ces facteurs lailssent augurer une réussite de la politique électronique de la gauche et le retour a l'équilibre financier des groupes de l'électronique semble l'attester (Barreau en Mouline 1987).

De onderhandelingen over de CdP en de directe interventies

"(...) ont provoqué une modification des stratégies des groupes électroniques (Thomson et Bull essentiellement), de défensives, elles deviennent offensives" (Barreau en Mouline 1987, 219).

Schema 7.11 Positieve en negatieve resultaten in de 'filière électronique' in 1986

\begin{tabular}{lllll}
\hline & 1982 & 1983 & 1984 & 1985 \\
\hline $\begin{array}{l}\text { croissance en volume } \\
\text { de la production }\end{array}$ & $5,9 \%$ & $8,4 \%$ & $10,5 \%$ & $6,7 \%$ \\
\hline
\end{tabular}

taux de couverture :

— ensemble filière électronique $\begin{array}{rrrrrrr}75 & 7 \% & 86,5 \% & 88,3 & \% & 90 & \%\end{array}$ dont :

\begin{tabular}{lcccccccc}
$*$ composants & $80,4 \%$ & $86,6 \%$ & 90,7 & $\%$ & 103 & $\%$ \\
\hline$*$ télécommunications & 298 & $\%$ & 482,5 & $\%$ & 501 & $\%$ & 483 & $\%$ \\
\hline$*$ électronique professionnelle & 510,6 & $\%$ & 700 & $\%$ & 645 & $\% \%$ & 504 & $\%$ \\
\hline$*$ S.S.I.I. & 127 & $\%$ & 132 & $\%$ & 142,5 & $\%$ & 140 & $\%$ \\
\hline
\end{tabular}

et des moins bons

\begin{tabular}{lllll} 
croissance de l'emploi & nc $\quad$ nc $\quad 2 \%$ & $1 \%$ \\
\hline
\end{tabular}

taux de couverture :

\begin{tabular}{lllllll}
\hline bureautique & $19,5 \%$ & $21,3 \%$ & $26,2 \%$ & 36 & $\%$ \\
\hline * électronique grand public & $16,6 \%$ & $24,2 \%$ & $30,7 \%$ & $35,6 \%$ \\
\hline * électronique médicale & $65,3 \%$ & $70,7 \%$ & 61 & $\% \%$ & $66,8 \%$ \\
\hline *instrumentation scientifique & $37,5 \%$ & $26,2 \%$ & $28,3 \%$ & $27,4 \%$ \\
\hline *informatique & $65,6 \%$ & $71,6 \%$ & $74,6 \%$ & $69,7 \%$ \\
\hline
\end{tabular}

Bron: Barreau en Mouline $(1987,218)$. 
Thomson verlegde haar arbeidsterrein naar concurrentiele markten, de halfgeleiders werden niet meer alleen als een ondersteunende sector gezien, maar als een strategische, terwijl de consumentenelectronica niet meer alleen vanuit een korte termijn commercieel gezichtspunt werd benaderd. Bull ontwikkelde zich tot een 'constructeur global' en diversificeerde in de software en dienstverlening. Alle groepen internationaliseerden en gingen diverse (Europese) samenwerkingsverbanden aan.

De veranderingen in de strategieën en omgeving leidden tot aanpassingen van de organisatiestructuur: CGE beoogde synergieën tussen filialen tot stand te brengen; Thomson poogde autonome winstcentra te ontwikkelen, waardoor een structuur tot stand kwam, waarmee effectiever de concurrentiestrijd kon worden aangegaan.

De positieve conclusies, die door o,a, Barreau en Mouline worden getrokken, behoeven ons inziens nuancering omdat gebleken is, dat de DIELI op bepaalde ondernemingen geen greep bleek te hebben (CGE en Matra) en zeker niet altijd in staat bleek de markt af te schermen voor de Nationale Kampioen (bijv. de toetreding Matra op de computermarkt). Ook is gebleken, dat de positieve resultaten met betrekking tot bijv. de herstructureringen rond het 'Yalta de la télécommunication' veeleer een bevestiging van reeds geplande ondernemingsstrategieën waren, dan dat van een daadwerkelijke beïnvloeding, laat staan van een ombuiging, sprake was (vergelijk blz. 398). Conform de conclusies uit hoofdstuk zes, blijkt uit de analyse in hoofdstuk zeven, dat de overheid met betrekking tot de publieke ondernemingen de ene keer succesvol de rol van initiator en organisator (bijv. de DGT met betrekking tot de telecommunicatie), of van makelaar en katalysator (bijv. het Ministerie van Industrie in het Yalta de la télécommunication) kan vervullen, maar de andere keer totaal geen greep heeft op de ondernemingsstrategieën (bijv in de computerindustrie met betrekking tot de ontwikkelingen in CII).

Die beperking van de effectiviteit van het beleid houdt enerzijds verband met algemene factoren als de aard van het produkt en de positie van de ondernemingen op de markt en anderzijds met het in gebreke blijven van de overheid wat betreft het aanpassen van haar organisatiestructuur aan haar ambitieuze rol als 'Etat développeur'. In hoofdstuk 8 worden deze twee factoren nader bezien.

\section{Noten behorend bij hoofdstuk 7}

[1] "La maîtrise de lla filière électronique est une condition du maintien de l'indépendance économique de la France, voire de son identité culturelle" (Gongeon, Ponson en Tinard 1984, 23).

[2] Vergelijk de bespreking van de 'Programmes d'Action Prioritaires' (PAP) van het Zevende Plan in 5.5 .

[3] Belangrijke marktverdelingsafspraken worden in Frankrijk veelal met het begrip 'Yalta' aangeduid, zie ook het 'Yalta de la télécommunication' (7.3.3.1).

[4] In het kader van de realisatie van de PAP werd in 1968 de DT omgevormd tot de DGT: Direction Général des Télécommunication. 
[5] Deze gegevens zijn ontleend aan Barreau en Mouline (1987).

In 1973 waren in Frankrijk 5 miljoen lijnen aangesloten, waardoor zij qua lijnen per inwoner de 19 de plaats innam op de wereldranglijst achter bijw. Griekenland.

[6] Naast die nieuwe directies werden binnen de DGT in 1974 ook twee nieuwe diensten opgezet: 'Service du Personnel' (SPEL) en de SPAF ('Service des Programmes et des Affaires Financières').

[7] Stoffaes, een vooraanstaande "haut fonctionair van het Ministerie van Industrie, bevestigde in een persoonlijk onderhoud, dat het opvallend is dat Souviron als lid van het 'corps des mines' een belangrijke positie binnen de DGT innam, omdat de DGT het domein van het 'corps des ingénieurs des télécommunication' is. Na 1981 volgt hij zelfs. Théry op. Wellicht werd langs die weg gepoogd een goede verbinding met het Ministerie van Industrie te bewerkstelligen, alwaar het 'corps des mines' domineert.

[8] Eén en ander blijkt bijw vit de introduktie van de Gamma 60 door Bull (zie verderop).

[9] De overgang van de analoge, electro-mechanische centrales naar de volledig electronische, digitale centrale, was in Frankrijk volledig afhankelijk van de ideeên van de DGT. CGE had samen met het CNET met de E10 een eigen technologie voor de digitale centrale ontwikkeld (zgn. 'communication temporelle").

[10]. De macht van de DGT om dergelijke herstructureringen door te voeren wordt door Durand (1988) herleidt tot de autonomie ten aanzien van de techniekkeuze van de DGT: "Même si le choix de la technologie temporelle française ne date que de 1977 , le développement technologique autonome permet la francisation des constructeurs qui, jusqu' a cette date, travaillaient, sous licence étrangère (Durand 1988, 430).

[11] De telecommunicatieindustrie heeft overigens een grote produktieschaal kunnen bereiken dankzij het vaststellen van internationale standaarden. Belangrijk zijn in dat verband organisaties als de CEPT ('Conférence Européenne des Postes et Télécommunication') en de CCITT ('Comilé Consultatif International Télégraphique et Téléphonique"), alsmede de CCIR ("Comité Consultatif International des Radiocommunication'), dat op wereldniveau de standaarden en normen vaststelt. De ingenieurs van het CNET participeerden actief in die organisaties.

[12] Na de schermutselingen in 1974 werd het CNET beheerst door de DGT (zie V'Expansion 21-9-1984, 199 en 205).

[13] "Ce quil, finalement, conduit a soulever la question de fond: la DGT, c'est quoi au juste? Une vache a lait de l'Etat, prenant le relais de 1'automobile? Un poseur de câbles? Une société de services? Un tribunal veillant au respect du monopole de l'Etat sur les télécommunications? Un actionnaire de l'électronique nationa* Iise? Le plús gros investisseur civil de l'Etat? La plus belle coloníe de l'Ecole polytechnique? Tout cela un peu, et beaucoup d'autres choses encore" (L'Expansion, dd. 21-9-1984 p. 197).

Of volgens Thery: "En fait, c'est une chauve-souris. Je suis oiseau regardez mes ailes! Je suis souris, yoyez mes pattes"' (L'expansion dd. 21-9-1984, 199).

[14] Naast de 'convention composants' werd in 1967 ook een 'convention péri-informatique' (betreft de produktie van beeldschermen, diskettes etc.) getekend door Thomson en de Compagnie des Compteur. 
[15] In de zgn. professionele ellectronica waren de ondernemingen sterk afhankelijk van de overheidsvraag (zie 7.2.2.2), maar in de consumentenelectronica, de kantoorautomatisering e.d. speelde de vraag van de overheid geen rol van betekenis.

[16] Ook de "Secteur des Service en Informatique" maakte deel uit van het Tweede 'Plan Calcul", maar de financiele steun voor die branche behoefde echter niet groot te zijn, omdat de Franse ondernemingen het uitstekend deden. Wel intervenieerde de overheid in het overnamebeleid door te verbieden, dat de Amerikaanse onderneming LEASO de Franse nummer één SEMA overnam.

[17] Télématique is de branche van nieuwe activiteiten nauw verbonden met de informatica, de overdracht (telecommunication) en de presentatie op beeldscherm.

[18] De Délégation Générale pour l'Amément is de intermediair tussen de 'EtatsMajors des armées' en de ondernemingen (vergelijk Barreau en Mouline 1987, 89 en 90).

[19] d'Ornamo, Minister van Industrie, had het idee dat CII-HB sterk genoeg zou zijn om de strijd aan te binden met IBM, Burroughs en NCR; een uitgekiend complementair produktenpakket en een kostenbesparende arbeidsverdeling zouden de sleutels voor CII-HB zijn in de strijd op de wereldmarkt. Gezamenlijk onderzoek, uitwisseling van licenties en verkoop van elkaars produkten, zouden beide partijen ten goede komen (LNE 28-6-1982, 44).

[20] Honeywell had specifieke voorzorgsmaatregelen getroffen: zo was bepaald, dat in geval van nationalisatie van CII-HB het Amerikaanse bedrijf haar participatie aan andere aandeelhouders mocht verkopen voor een forfaitair bedrag van 200 miljoen dollar. Door de nationalisatie in 1982 van Saint-Gobain, dat via CMB $53 \%$ van de aandelen van CII-HB bezat, kon Honeywell van de gemaakte clausule gebruik maken. $\mathrm{Zo}^{\prime} \mathrm{n}$ besluit zou de volledige terugtrekking van Honeywell hebben betekend en de doodsteek voor CII-HB, dat in technologisch opzicht erg afhankelijk was van Honeywell (LNE dd. 28-6-1982, 44). Het pakte met de nationalisatie overigens anders uit (zie 7.3.0).

[21] Vergelijk J. Barreau, en J. le Nay (1982).

[22] Omdat HIS bepaalde activiteiten van CII niet wille voortzetten (fabrieken in Toulouse en Andelys) werd in 1976 een holding opgericht (Compagnie Générale d'Informatique et de Systemes: GOGIS), waarin Thomson voor $55 \%$ deelnam, CGE voor $29 \%$ en Schneider voor $14 \%$. Die holding nam de fabrieken in Toulouse en Andelys over, alsmede SEMS (Société Européene de mint-informatique et de Systemes), die op haar beurt de activiteiten in de mini-informatique van 'Télémecanique Electrique' had overgenomen. Thomson werd op die manier de leider in de mini-informatique op de Franse markt (45\% in 1976) en kwam in aanmerking voor veel overheidssteun: $130 \mathrm{MF}$ voor de reconstructie van de fabriek in Toulouse, die grote computers bouwde, alsmede $55 \mathrm{MF}$ subsidie en 65 MF lening van de DGRST ten behoeve van de ontwikkeling van de technologie voor de mini-informatique.

[23] Barreau en Mouline (1987, 51) merken in dat verband op:

"En fin de periode (1958-1969) cependant les dirigeants de groupes auront des contact plus faciles avec les membres des cabinets ministériels (finances notamment) auxquels ils s'adressent directement car ils pourront se prévaloir d'une formation commune ("X" et ENA)". 
Als duidelijke doeleinden en instrumenten ontbreken worden de relaties aangewend om de strategieën van de industriële groepen te realiseren.

[24] "Les liens personnels (voire familiaux) entre les principaux dirigeants du groupe et les hommes politique au pouvoir ont probablement joué un rôle; mais les fonctionnaires de DIELI ont également fait preuve d'une méconnaissance profonde de la strategie d'un groupe qui n'a jamais manifeste d"ambitions vis-ăvis des marches concurrentiel (composants par exemple) (....) Barreau en Mouline 1987, 141).

[25] Na de nationalisatie werd $49 \%$ van de produktie in de electronische industrie verzorgd door de Franse publieke ondermemingen, $33 \%$ door de buitenlandse ondernemingen (waarvan $13 \%$ IBM, $7 \%$ Philips) en $18 \%$ door de partikuliere Franse ondernemingen (zie LNE dd. 24-5-1982, 72).

[26] Stern, PDG van Bull, merkte in dat verband op:

"L'appartenance de mon entreprise au secteur public m'autorise des choix stratégiques plus vastes puisque je puis planifier à long terme, alors que si elle était privée je serais condamné à une stratégie à court terme dont les conséquences à long terme seraient peut être extrêmement désastreuses. Ce sont des éléments extrêmement importants qui modifient profondément le comportement" (geciteerd naar Bolloc'h 1986).

[27] Bolloc'h (1986) wees erop, dat de nationalisatie van CII-HB ook een symbolische waarde had:

"Sa création avait été le produit de la volonté de l'Etat Gaullien, et l'Etat était resté par la suite très impliqué dans cette firme, surtout parce que les deux groupes qu'il avait sollicité de prendre en charge CII ne s'y investissaient pas vraiment en réalité".

[28] Zie Le Monde 14-5-1982 en LNE 24-5-1982, p. 72-73.

[29] Zo verklaarde in augustus 1981 de staatssecretaris van de PTT:

"La DGT ne devra plus se comporter comme une entité indépendante, mais comme partie intégrante des PTT" (geciteerd naar Bolloc'h (1986, 657)).

[30] "Fort de l'appui de l'Elysée, Gérard Théry pouvait négocier d'égal à égal avec les Finances, et donc garder ses milliards de bénéfices pour lui et les réinvestir là où bon lui semblait" (L'Expansion 21-9-84, p. 201).

[31] "Commercialement, la solution allait de soi. Il fallait créer un réseau d'agences, mettre en place les procédures de raccordement pour une production de masse, mais c'était un problème purement administratif" (L'Expansion, dd. 21-9-84, p. 201).

[32] Vergelijk l'Expansion 21-9-1984, 207.

[33]. Vergelijk Epstein (1986).

[34] Experiment van de DGT met de bekabeling in Biarritz.

[35] l'Expansion 11/24 mei 1984, p. 27 e.v.

[36] Op de eerste plaats speelde de decentralisatiewet de DGT parten, omdat haar eigen indeling in negen regio's werd doorkruist. De lokale afdelingen van de DGT werden onderworpen aan de regionale raden en de 'Commissair de la République'.

Op de tweede plaats dreigde de Wet-Le Pors de DGT en met name het CNET de mogelijkheid te ontnemen ingénieurs aan te stellen zonder deze de (lage) 
ambtelijke rang (en salariëring) te moeten verlenen. Om de concurrentie met het bedrijfsleven aan te kunnen werd woor het CNET een uitzondering op de WetLe Pors bedongen (L'expansion 21-9-84, p. 203).

[37] Vergelijk Le Monde 8-7-83 en I'Expansion 21-9-84.

[38] De "conventions d'évolution' leken op de "conventions stabilitét, maar kennen aan de toeleveranciers een grotere rol toe (vergelijk 6.2.2.1 en Barreau en Mouline 1987, 190).

[39] Le Monde 22-9-1983, 41.

[40] Le Monde 22-9-1983, 41.

[41] L'Expansion 21-10/3-11-1983, 122.

[42] Le Monde 23-9-1983, 32.

[43] "L'ossature de la politique de commutation repose, dans l'esprit des pouvoirs publics, sur le groupe qui a la plus faible expérience téléphonique et surtout qui n'a pas l'assise financiere suffisante pour assurer un potentiel de recherche assez puissant, à savoir Thomson. La logique industrielle commande au contraire de concentrer l'ensemble des moyens en commutation sous l'égide de la CGE" (L'Expansion, 121, 122).

[44] Vergelijk Roobeek (1988b) wat betreft benodigde efficiènte produktieschaal in de telecommunicatieindustrie.

[45] "M. Georges Pebereau est un virtuose. Il réalise aujourd'hui avec au gouvernement socialiste ce que son ancien patron M. Ambroise Roux, n'avait jamais ose esperrer" (Le Monde 22-9- 1983, 41).

[46] Le Monde 22-9-1983; 41.

[47] In zijn kritiek op de gang van zaken bepleitte Charzat, secretaris van de PS, alsnog voor een brede consultatie met de vakbeweging (Le Monde 23-9-1983, 32).

[48] Voor een uiteenzetting over de 'carte d puce* zie I'Expansion 11 en 24-5-1984, pp. $27-29$

[49] Toen CNES haar computerpark moest vervangen heeft zij niet bij de Nationale Kampioen Bull, maar bij de concurrent Matra-Norsk Data een grote bestelling geplaatst.

[50] Die rol van DIELI werd in interviews met Christian Stoffaès duidelijk bevestigd (Stoffaess was toentertijd de tweede man van DIELI en voerde de onderhandelingen met Thomson).

[51] Zie LNE 14-3-1983 en 21-3-1983.

[52] RITA (Réseau Intégré de Transwissions automatiques) was het paradepaardje van Thomson, waarmee zij in de slag ging met Plessey om de grootste order, die het Pentagon ooit aan een buitenlandse onderneming had gegund. Ondanks de nauwe banden tussen Thatcher en Reagan ging toch Thomson met de eer strijken (zie Le Point no. 686, 11-11-1985, pp. 109-110).

[53】 CGE bevond zich in 1986 met de reorganisatie tussen twee structuren in: de holding met zeer zelfstandige filialen aan de ene kant en sterk geintegreerde groepen, zoals bijv. IBM aan de andere kant. 
"De paradox van het economisch vak is, dat wij slechts door vereenvoudiging van de werkelijkheid algemene samenhangen kunnen demonstreren en dat wif andenijds moeten doen zien wat de werkelikheid doet"

H.W. Lambers geciteerd naar De Jong (1981, p. 1268).

\section{CONCLUSIES}

\subsection{Inleiding}

Onze probleemstelling betrof op de eerste plats de vraag, hoe de Franse overheid in de periode 1981-1986 het industriebeleid vorm heeft gegeven in het kader van het Negende Plan en met de publieke onderneming als centraal instrument, op de tweede plaats zochten wij naar een antwoord op de vraag, waarom het beleid deze specifieke vorm kreeg en op de derde plaats wilden wij een oordeel geven over de effectiviteit van het gevoerde beleid.

In paragraaf 1.1 is uiteengezet, dat zo'n probleemstelling een ordevraagstuk is, dat als een 'série d l'américaine' bestudeerd dient te worden. Ordevraagstukken zijn uit de aard der zaak multi-disciplinair en voor de verklaring dienen dergelijke vraagstukken op 'het snijvlak van diverse disciplines geplaatst te worden' (vergelijk Zuidema 1982). Onderzocht moet worden welk complex van interdependente variabelen verklarend is. Daarbij kunnen algemene concepten uit diverse disciplines bruikbaar zijn, welke vervolgens met specifieke condities van plaats en tijd moeten worden ingevuld. In een onderzoek, dat als een 'série à l'américaine" ter hand wordt genomen, worden bestaande theoretische classificaties en verbanden uit diverse disciplines in de werkelijkheid toegepast; blijken kan, dat het gebruik van de theorieèn in een nieuwe situatie uitbreiding, of aanscherping van de theoretische concepten vergt. Zo gezien is sprake van een 'open pattern model', dat voortdurend op basis van nieuwe inzichten en empirische gegevens wordt aangepast (vergelijk Wilber en Harrison 1978).

In hoofdstuk 2 zijn de theoretische inzichten met betrekking tot de indicatieve planning besproken, de ondernemingsstrategieen en het specifieke industriebeleid kwamen in hoofdstuk 3 aan de orde en met de theorie van de publieke ondermeming werd het overzicht van theorieen in hoofdstuk 4 afgesloten. In dit afsluitende hoofdstuk worden de conclusies van het onderzoek samengevat; deze betreffen enerzijds het antwoord op de probleemstelling en anderzijds een oordeel over de bruikbaarheid van de in hoofdstuk twee tot en met vier besproken theoretische inzichten. In 8.1 wordt voor de 
Indicatieve planning, in 8.2 voor het industriebeleid en in 8.3 voor de publieke onderneming aangegeven wat de socialistische regering met haar beleid beoogde en hoe het beleid vorm werd gegeven; tevens wordt een verklaring gegeven voor de specifieke ontwikkelingen in Frankrijk in de periode 1981-1986. Gepoogd zal worden de analyse boven het niveau van de beschrijving uit te tillen en tot een formulering te komen van meer algemene voorwaarden met betrekking tot de effectiviteit van indicatieve planning, industriebeleid en het gebruik van publieke ondernemingen in een markteconomie. Een oordeel over de effectiviteit van het beleid in Frankrijk in de periode 1981-1986 komt in 8.4 aan de orde.

In 8.5 wordt de wraag naar de bruikbaarheid van de bestaande theoretische concepten aan de orde gesteld; welke concepten en classificaties zijn bruikbaar gebleken, welke behoeven aanscherping, of aanvulling en op welke wijze zouden dergelijke verbeteringen tot stand kunnen worden gebracht?

\subsection{Indicatieve planning}

De Franse overheid beoogde met de revitalisering van het Plan niet alleen de produktie en verspreiding van informatie op basis van een breed consultatieproces te bevorderen, maar ook pretendeerde zij met het Plan een duidelijk richtinggevend kader te bieden, waar de marktpartijen hun strategie op zouden kunnen afstemmen (zie 6.1.4.1).

De socialisten in Frankrijk waren van mening, dat de economische crisis, die zich vanaf het eind van de zestiger jaren had ingezet, te wijten was aan het uitblijven van voldoende investeringen in de juiste richting, waardoor een adequate aanpassing van de industriële structuur niet tot stand was gekomen (zie 6.1.3.3). Zij waren van mening, dat de beslissingen omtrent investeringen, die de structurele ontwikkeling van de economie bepalen, niet langer aan het partikuliere bedrijfsleven (de "anarchie van de markt") mochten worden overgelaten. Toen vanaf het Vierde Plan, met name onder thet presidentschap van Valéry Giscard d'Estaing, het indicatieve plan op de achtergrond raakte, hebben de socialisten en communisten er steeds krachtig voor gepleit, dat juist in tijden van relatief grote onzekerheden de ondernemers gebaat zijn bij een richtinggevend indicatief plan. Een indicatief plan, tot stand gekomen op basis van een intensief consultatieproces, diende de marktpartijen van complementaire informatie te voorzien, waardoor markt- en omgevingsonzekerheid zou worden gereduceerd. Het undicatieve plan moest de marktpartijen een coherent toekomstbeeld bieden, waarop zij hun investeringsbeslissingen zouden kunnen afstemmen.

Toen de socialisten in 1981 samen met de communisten de regering vormden, hebben zij met grote voortvarendheid gepoogd de klassieke funkties van de 'planification à la française' in ere te herstellen. Ten behoeve van een breed intensief consultatieproces werd een indrukwekkende organisatiestructuur opgezet, terwill in de hervormingswet werd vastgelegd, dat de doeleinden en de middelen van het Plan in een aparte wet zouden worden vastgelegd, zodat cenieder de besluiten van het parlement ook zol moeten respecteren (vergelijk 5.6).

Uit het onderzoek is gebleken, dat het Negende Plan, zowel qua richtinggevend kader als qua consultatieforum ernstig te kort is geschoten. 
Wat het richtinggevend kader betreft, was de deceptie bij de voorstanders van het herstel van de traditionele planning zeer groot toen bleek, dat kwantitatieve doeleinden in de Wet op het Plan niet, of nauwelijks aanwezig waren (vergelijk 5.6.3). Wat dat betreft was er nawwelijks enig verschil te ontdekken tussen het Achtste en het Negende Plan.

De verklaring voor die ontwiklkeling kan worden gevonden in de theoretische inzichten van Estrin en Holmes (1983b), in de bevindingen met de voorgaande acht plannen in Frankrijk en in de specifieke ommezwaal van het economisch beleid in maart 1983.

Zowel uit de theorieen van indicatieve planning, als uit de ervaringen met de Franse plannen vanaf ongeveer 1960 , kan worden afgeleid, dat een kwantificering van macroeconomische doeleinden in het Plan weimig nut heeft, als de interne en externe factoren niet door de nationale overheid in voldoende mate kunnen worden beheerst [11. Naarmate de economie opener en complexer wordt, neemt de beheersbaarheid voor de nationale overheid af. Zoals uit het onderzoek is gebleken, heeft de socialistische regering daarin met de uitbreiding van haar instrumentarium van het specifieke industriebeleid en de publieke ondernemingen geen verandering kunnen brengen. Daarentegen heeft zij met de ommezwaai in haar conjuncturele economüsche beleid in maart 1983 de besluitvorming rond de lange termijn doeleinden van het Negende Plan volledig doorkruist en werd het Plan tot een rechtvaardiging en uitwerking wan haar conjuncturele bezuinigingsbeleid. Uit het onderzoek is gebleken, dat de coördinatie van het conjuncturele en structurele beleid de Franse Plannen van meet af aan parten heeft gespeeld, hetgeen voor een belangrijk deel kan worden verklaard uit het ontbreken van een krachtig planningsorgaan bijw. in de vorm van een Ministerie van Planning [2] . Ook na 1981 bleken het nieuwe 'Ministère du Plan et de l'Aménagement du Territoire' en het in ere herstelde 'Commissariat General du Plan' niet in staat zich tot zo'n krachtig cob̉rdinatieorgaan te kunnen ontwikkelen. Integendeel: tussen het Ministerie en het Planbureau bestond grote onduidelijkheid omtrent de taakverdeling, waardoor de andere ministeries in de gelegenheid waren op de oude voet voort te gaan. Met name het Ministerie van Financiën kon de korte termijn scepter blijven zwaaien.

Wat het consultatieproces in het kader van het Negende Plan betreft, is uit het onderzoek gebleken, dat de organisatorische opzet strookte met de theoretische inzichten omtrent de indicatieve planning in een moderne markteconomie ("democratique, continue et contractuelle"). Echter, uit het onderzoek kwam ook naar voren, dat de werkzaamheden in de formele commissies meer een ritueel, dan een inhoudelijk karakter hadden, geljik dat overigens vanaf ongeveer 1960 het geval was geweest in de Franse planning. Het uitblijven van een daadwerkelijke consultatie heeft o.i. te maken met het feit, dat in Frankrijk de feitelijke besluitvorming plaats vindt in kleine kring van technocraten en topmanagers, waarbij de achtergrond van een gemeenschappelijk 'corps d'etat' een belangrijke rol speelt. Het neo-corporatisme met overleg tussen de sociale partners en het aanvaarden van gemeenschapplijke verantwoordelijkheid, is in Frankrijk niet sterk ontwikkeld (vergelijk Intermezzo II). Het behoeft geen verbazing te wekken, dat het opzetten van een formele overlegstructuur aan de feitelijke consultatie en besluitvorming niet veel verandert. 
Samengevat kan worden gesteld, dat het Negende Plan geen kwantitatieve richtinggevende doeleinden bevatte, maar kwalitatieve doeleinden met betrekking tot de groei van het BNP, verbetering van de betalingsbalans, versterking van de concurrentiepositie etc. De scenario"s van het Negende Plan (vergelijk 5.6.2) zouden voor de marktpartijen waardevolle informatie kunnen bevatten als op basis van die scenario's een consultatie van de belanghebbenden plaatsvindt, waardoor lange termijn afspraken met betrekking tot loon- en prijsontwikkelingen, belastingen, investeringen ed. kunnen worden gemaakt. Zoals uiteengezet vervulden de scenario's die rol niet en bleef een ware consultatie uit, waardoor het Negende Plan net als zijn voorgangers een 'Plan de Governement' werd in plaats van een 'Plan de Nation'.

In een poging de beschrijving van de Franse indicatieve planning op een algemener niveau van analyse te brengen, zouden wij onderscheid willen maken tussen vier typen van indicatieve planning. Tussen de twee uitersten van het integrale- en het informa* tieplan kunnen die van het katalysator- en sturende plan worden onderscheiden. In het "ex ante integralle coherente plan" worden macro-economische doeleinden verbijzonderd naar het mesoniveau van de regio en de sector en naar het microniveau van de publieke onderneming. Door middel van het afschermen van markten, gerichte financiering, import van technologie, selectieve nationalisatie e.d. poogt de overheid de doeleinden van het integrale plan te realiseren. In het informatieplan daarentegen beperkt de rol van de overheid zich tot die van producent en verspreider van informatie, welke relevant wordt geacht voor het nemen van strategische beslissingen op microniveau, maar die elders in het systeem niet wordt geproduceerd.

Tussen de twee extremen van het integrale- en het informatieplan kan de overheid door middel van het indicatieve plan ook de rol van katalysator en makelaar vervullen. Zij kan het indicatieve plan gebruiken als consultatieplatform, waar partijen elkaar niet alleen ontmoeten om informatie uit te wisselen, maar waar zij ook tot samenwerkingsverbanden komen en mogelijk tot een coördinatie van hun toekomstplannen. De rol van de overheid kan nog een stapje verder gaan en de organisatie en besturing van economische sub-systemen behelzen, waarbij zij gebruik maakt van specifieke instrumenten, zoals bijv. een dominante positie als vrager op de desbetreffende markt (vergelijk bijv. de telecommunicatie).

De vraag, of indicatieve planning in een open, complexe markteconomie effectief kan zijn, dient verbijzonderd te worden naar de diverse typen van planning. Het ligt voor de hand, dat de voorwaarden woor het welslagen van een integrale planning beduidend stringenter zijn, dan voor het realiseren van een effectief informatieplan. Algemeen gesteld betreffen de voorwaarden van de effectiviteit van het indicatieve plan enerzijds de mate van beheersbaarheid van interne en externe factoren door de betreffende overheid en anderzijds de organisatorische vormgeving van de planning.

Hoe werken die algemeen geformuleerde voorwaarden uit voor de vier onderscheiden vormen van planning?

In een integraal indicatief plan worden doeleinden op macro-, meso- en microniveau geformuleerd. Een essentieel onderdeel vormt het sectorstructuurplan, waarin de toekomstige ontwikkeling met betrekking tot het geheel van sectoren op een coherente wijze zichtbaar wordt gemaakt. Van grote betekenis in het integrale indicatieve plan is het instrumentarium, waarmee het centrale coordinatieorgaan het beleid van de minis- 
teries en de ondernemingen kan coördineren en kan afstemmen op de doeleinden wan het plan.

Het doel van het integrale indicatieve plan betreft niet alleen het realiseren van onzekerheidsreductie door middel van de produktie en verspreiding van informatie, maar ook het realiseren van een gewenste ontwikkeling in de sectorstructurur door middel van het beinvloeden van het gedrag van verschillende ministeries, ondernemingen en vakbeweging. Wanneer kan het integrale indicatieve plan die doeleinden realiseren? Onder welke voorwaarden kan zo'n plan effectief zijn?

Kwantitatieve doeleinden zijn alleen te formuleren als voldoende informatie over de ontwikkeling van de interne en externe factoren voor handen is. Wat de externe factoren, zoals bijv. de situatie op de wereldmarkt, technologische ontwikkelingen, grondstoffenprijzen ed. betreft, kan door gespecialiseerde onderzoekinstellingen systematisch onderzoek worden verricht [3] en door internationale organisaties, zoals de OECD kan een belangrijke coördinerende taak worden vervuld. Echter, de snelheid, omvang en onvoorspelbaarheid van de veranderingen kunnen van dien aard zijn, dat het formuleren van kwantitatieve doeleinden problematisch is (vergelijk 5.6).

Ook de produktie van informatie over de ontwikkeling van interne factoren, zoals bijw. de binnenlandse loon- en prijsontwikkeling, of de hoogte van het financieringstekort, stuit niet alleen op grote problemen, omdat die binnenlandse ontwikkelingen in belangrijke mate door de genoemde externe factoren worden beïnloed, maar ook omdat het vereiste consultatieplatform kan ontbreken. Lange termijn afspraken tussen overheid en bedrijfsleven zijn een onmisbaar element in een effectief integraal plan, maar naarmate de interne en externe ontwikkelingen turbulenter worden, is het moeilijker dergelijke afspraken te maken.

Stappen wij over van het macroniveau naar het mesoniveau van de sectorstructuur, dan dient in een integraal plan het planningsproces zodanig georganiseerd te zijn, dat het centrale coördinatieorgaan van de marktpartijen voldoende informatie krijgt met betrekking tot de bestaande, de te verwachten en de gewenste structurele ontwikkeling van de economie. Wat de informatie over de gewenste ontwikkeling betreft is informatie over veranderende comparatieve voordelen nodig, hetgeen inzicht in bovengenoemde externe factoren vergt. Wat de bestaande en de te verwachten structuur betreft, is informatie nodig over bijv. bestaande netwerken en de strategie van de ondernemingen dienaangaande (vergelijk 3.2.1.4). Dergelijke informatie kan alleen worden geproduceerd als een adequat consultatieplatform bestaat en als partijen een belang hebben daarin gemotiveerd te participeren.

Dat belang en die motivatie kunnen door de overheid worden beinvloed, hetgeen ons op het vraagstuk van het instrumentarium brengt. Een integraal indicatief plan kan alleen effectief zijn als de overheid over voldoende instrumenten beschikt om de doeleinden van het plan te kunnen realiseren; alleen dan kan het formuleren van doeleinden voor de marktpartijen een onzekerheidsreducerende betekenis hebben (vergelijk 2.3.1). Zoals bij de bespreking van de 'development state' is uiteengezet, kan dat instrumentarium een breed scala van subsidies, import- en exportregelingen, het beheersen van publieke onderzoekcentra en het selectief nationaliseren van industriële groepen betreffen. Als het centrale coördinatieorgaan in staat is de markt- en de socio-politieke omgeving van de microactoren te beheersen, doordat zij bijw. de 
vraagzijde van de markt, of de produktie van de technologie controlleert, dan kan zij in principe de strategieèn van de ondernemingen afstemmen op de mesodoeleinden [4]. Daarbij kan de publieke onderneming in principe een effectief instrument zijn als aan een reeks van voorwaarden met betrekking tot informatievoorziening en beheersbaarheid van haar omgeving is voldaan (vergelijk 4.5). Als in zo'n situatie lange termijn doeleinden met betrekking tot de omvang en richting van de investeringen, de organisatie van de markt, de netwerkrelaties (met name met betrekking tot het Midden- en Kleinbedrijf) expliciet in een planningsovereenkomst kunnen worden vastgelegd en als de overheid van haar kant financiële verplichtingen over een aantal jaren aangaat, dan zijn de ingrediënten voor een effectief gebruik van de publieke onderneming in het kader van een integraal indicatief plan aanwezig.

Als de omgeving turbulenter wordt (technologische ontwikelingen, toetreding van nieuwe industrielanden, prijsbewegingen), de ontwikkelingen van de interne factoren minder voorspelbaar (vakbeweging en werkgevers komen niet tot meerjaren-afspraken), de economie opener (de overheid kan door middel van bijv. importrestricties markten miet meer afsluiten), de economische structuur complexer (interdependenties zijn niet meer te doorzien, laat staan te beheersen), de financiele kracht van de ondernemingen sterker (het financiële instrumentarium van de overheid wordt dan minder effectief) en de concurrentie een 'globalization' ondergaat (de overheid kan de strategie van (publieke) ondernemingen niet meer binden), dan kan een integraal indicatief plan geen effectief instrument van owerheidsbeleid meer zijn.

Zoals gezegd stellen de andere vormen van indicatieve planning minder hoge eisen aan de beheersbaarheid van de ontwikkeling van interne en externe factoren en de kwaliteiten van het coördinerende orgaan.

Wat het indicatieve plan, dat sturend optreedt ten aanzien van specifieke sectoren betreft, gelden dezelfde eisen van informatieproduktie en beheersbaarheid, als hierboven geformuleerd, maar dan alleen voor de desbetreffende sector. Uit onderzoek is gebleken [5], dat in sectoren, die in de innovatie- en rijpheidsfase verkeren zulk interveniërend specifiek beleid effectief kan zijn in tegenstelling tot sturing van sectoren in de expansiefase. Een en ander houdt verband met de grotere afhankelijkheid van ondernemingen van overheidsinitiatieven en subsidies: voor het opzetten van kostbare onderzoekprojecten kan een gedeeltelijke overheidsfinanciering van grote betekenis $z_{i j n_{y}}$ evenalls dat voor de financiering wan een "geordende terugtocht" uit stagnerende sectoren het geval kam zijn.

Wat het indicatieve plan van het katalysatortype betreft, staat als voorwaarde van effectiviteit niet de voorspelbaarheid en beheersbaarheid van externe, respectievelijk interne ontwikkelingen op de voorgrond, mar de kwaliteit van het consultatieproces. Als de ondernemingen vanwege "geblokkeerde" situaties [6] niet zelf tot informatieuitwisseling en samenwerking komen, maar daarvan well het belang inzien, dan kan een katalysatorplan een effectief instrument zijn om partijen bij elkaar te brengen.

Wat het informatieplan betreft, verschillen de voorwaarden van effectiviteit naar de soort van informatie, dat het plan bevat. Gaat het om informatie over het beleid van (buitenlandse) overheden, of over ontwikkelingen op de wereldmarkt, dan is de bereidheid van marktpartijen mee te werken niet aan specifieke voorwaarden gehouden. Partijen moeten er alleen van overtuigd zijn, dat de moeite, die zij zich ge- 
troosten opwegen tegen de baten van de beschikbaarheid van dergelijke informatie in een indicatief plan. Gaat het daarentegen om informatie over sectorale ontwikkelingen, specifieke technologische ontwikkelingen, concurrentieverhoudingen, samenwerkingsverbanden en dergelijke, dan betreft zulks informatie, die vanuit een oogpunt van de concurrentiepositie van strategische waarde is. Partijen produceren die informatie bij voorkeur zelf en zijn zeker niet bereid deze aan derden ter beschikking te stellen, tenzij] in het kader van een katalysator- of specifiek interveniërend plan het coordinatieorgaan initiatieven ontwikkelt, die voor hen van belang zouden kunnen zijn. Samengevat kunnen wij stellen, dat aan de effectiviteitseisen van een integraal indicatief plan, waarin de publieke ondernemingen een cemtrale rol vervullen, in een moderne markteconomie niet kan worden voldaan. Voor een specifiek interveniërend plan zal dat in uitzonderingsgevallen het geval kunnen zijn namelijk als interne en externe factoren beheerst kunnen worden en partijen een direct belang hebben.

Het indicatieve plan in een complexe, open markteconomie zal wel effectief de rol van katalysator- en makelaarplatform kunnen vervullen op voorwaarde, dat een adequate organisatiestructuur voor de consultatie en concertatie wordt opgezet. Het indicatieve plan als informatieplan kan in een moderne markteconomie op effectieve wijze een nuttige rol vervullen als informatiebron voor de marktpartijen (zie 2.3.3) op voorwaarde, dat vanuit de overheid de informatievergaring en distributie, in nauw overleg met de afnemers, op een consistente wijze wordt georganiseerd. Voor het welslagen van zowel het katalysator- als het informatieplan geldt, dat de marktpartijen zelf het nut ervan moeten inzien. De nationale plannen boeten overigens aan effectiviteit in, naarmate de concurrentie en samenwerking tussen de ondernemingen internationaler wordt.

\subsection{Het industriebeleid}

De socialistische regering van 1981 was van mening, dat de economische crisis in Frankrijk in de eerste plaats een industriële crisis was. Het beleid van de regering Giscard-Barre had zich geconcentreerd op enkele speerpuntsectoren ('créneawx'), waardoor een "poreuze" industriële structuur was ontstaan. De concurrentiekracht van de Franse industrie moest volgens de socialisten worden versterkt door een voluntaristisch specifiek industriebeleid, waarin de ontwikkeling van strategische 'filiteres' zou worden afgestemd op de doeleinden van een alle sectoren omvattend sectorstructuurplan. Een en ander moest als onderdeel van het Negende Plan gestalte krijgen in de "loi sur l'industrie".

Uit het onderzoek is gebjeken, dat door het Ministerie van Industrie weliswaar een aantal sector- en 'filiere' -plannen zijin ontwikkeld, maar dat deze niet werden ingepast in een "wet op de toekomstige industriele structuur". Gebleken is, dat het socialistische industriebeleid een grote continuiteit vertoonde met dat van zijn voorgangers: successen in sectoren, waarin ook de voorgangers succesvol waren en mislukkingen in de sectoren, waarop de Franse overheid al vanaf 1945 geen greep heeft kunnen krijgen.

De verklaring voor die continuilteit moet worden gezocht in ontwikkelingen in de omgeving van de nationale overheid, die grote beperkingen opleggen aan de sturings- 
mogelijkheden van een nationale overheid, aan het zwak ontwikkelde conceptuele kader en de wankele empirische basis van een specifiek industriebeleid en tot slot aan het uitblijven van een effectieve overheidsorganisatie, die enig tegenwicht kon biedien aan de industriële groepen. Wij bezien elk van die factoren wat nader.

Het gebrek aan beheersbaarheid van interne en externe factoren speelde de indicatieve planning parten en is ook de oorzaak van het mislukken van het specifieke industriebeleid, waarmee de Franse overheid niet alleen de ontwikkeling van specifieke 'filières" wilde beheersen, maar als een ware 'Etar dêloppeur' greep wilde krijgen op de ontwikkeling van het gehele industrièle systeem (vergelijk 6.1.4.1). De gang van zaken rond de diverse "filière"-plannen roept de vraag op, of een "Etat développeur" voldoende informatie over het microniveau kan verzamelen, waardoor een juiste analyse van de marktstructuur en sociopolitieke structuur van de sector en/of 'filieres' kan worden gemaakt, de juiste aangrijpingspunten voor het beleid kunnen worden geïdentificeerd en het adequate instrumentarium kan worden ontwikkeld.

De theoretische concepten voor het in kaart brengen van de bestaande, te verwachten en de gewenste industriële structuur zijn zwak ontwikkeld, terwijl een voldoende empirische basis ontbreekt. Zoals in 3.2.1.4 is uiteengezet, staat de integratie van de statistische en de monografische 'filière' nog in de kinderschoenen, terwijl voor de invulling van die concepten de overheid inzicht behoeft in de strategie van de ondernemingen. Op beide problemen komen wij in het navolgende terug.

Ook is uit het onderzoek gebleken, dat de vereiste organisatorische structuur voor het ontwikkelen van een specifiek industriebeleid weliswaar formeel van de grond kwam in de vorm van de 'Commission Nationale sur l'Industrie' en de 'Groupes Stratégiques Industrielles', maar gebleken is, dat die overlegstructuren in werkelijkheid niet meer om het lijf hadden dan de andere rituele consultatiefora van het CGP. Gepoogd werd het Ministerie van Industrie een centrale coördinerende rol toe te delen, maar zoals uiteengezet is dat ministerie van Industrie altijd "un ministere faible et diminuée" geweest. Daarin kwam in de periode 1981-1986 geen verandering. Weliswaar is het Ministerie van Industrie door diverse regeringen in woorden als een centrale coobrinator naar voren geschoven, (1954-1955; 1959-1960; 1979-1981; 1981-1983), maar in daden heeft 'Rue de Grenelle' nooit greep op de industriele ontwikkelingen gekregen. Daar waar de overheid grote invloed als afnemer kon doen gelden, moest het beleid aan de betrokken ministeries worden overgelaten (Ministerie van Defensie, van Transport, van Energie) aan unstanties als de DGT, of aan de betrokken industriele groepen (vergelijk hoofdstuk 7).

Ook in de periode $1981-1986 \mathrm{kreeg}$ het Ministerie van Industrie niet de kans zich te ontwikkelen tot de centrale coördinator, die richting geeft aan het industriebeleid: in de betreffende periode wisselde de politieke top van het ministerie maar liefst vijf maal en veranderde de portefeuille van activiteiten drie maal: Dat is geen situatie, waarin een consistent lange termijn beleid kan worden ontwikkeld en de macht van het Ministerie van Financiën zou kunnen worden aangetast.

Zijn er meer algemene verklaringen te geven voor de continuîteit van het Franse industriebeleid. en voor de successen in de ene sector en de mislukkingen in de andere?

Worden diverse case-studies vergeleken, dan blijkt de overheid in Frankrijk geen 
greep te krijgen op bijv de computersector, de consumentenelectronica en de machinebouw, terwijl uil de cases van de telecommunicatie en de energiesector blijkt, dat de overheid wel in staat is de ontwikkelingen in een subsysteem te sturen (Groenewegen 1989a). Echter, ook die successen thebben een zwart randje: na verloop van tijd blijkt de centrale coördinerende instantie zo autonoom te kunnen worden, dat sprake wordt van een staat in een staat (vergelijk de positie van de DGT, ERAP en EDF).

Uit de case-studies zijn algemene voorwaarden te formuleren, waaronder LEtat développeur' succesvol economische subsystemen richting kan geven: die voorwaarden betreffen enerzijds de alard van het produkt en de markt en anderzijds de wijze, waarop de interventie institutioneel vorm wordt gegeven.

De overheid blijkt een economische subsysteem richting te kunnen geven als zij de vraagzijde wan de markt beheerst, een dominante afnemer is, of als zij de binnenlandse markt effectief kan afsluiten. Is tevens sprake van een produktieproces met een verzekerde aanvoer van grondstoffen, wan een beheersing van het technologische onderzoek in de publieke laboratoria en van grootschalige investeringen, dan is in principe organisatie van de sector, of "filiere" door de centrale overheid mogelijk (vergelijk Hafsi 1984).

Vergelijken wij de ontwikkelingen in de olie-, telecommunicatie- en nucleaire industrie met die in de informatica, consumentenelectronica en de machinebouw, dan blijkt een markt, die wordt gekenmerkt door snelle technologische veranderingen, een grote diversiteit van produkten, een groot aantal ongelijkssoortige vragers en aanbieders en het ontbreken van een af te schermen thuismarkt, door de nationale overheid niet beheersbaar (vergelijk OECD 1986). Poogt de overheid in zo'n sector richting te geven aan de structurele ontwikkelingen, dan wordt zij geconfronteerd met ondernemingen, die in een hevige concurrentiestrijd zijn gewikkeld en van waaruit voortdurend krachten werkzaam zijn, die het overheidsbeleid doorkruisen (vergelijk Plan Calcul, Unidata en de ervaringen in de consumentenellectronica met Thomson, JVC en Grundig).

Als bovengenoemde ingrediënten voor een succesvolle beheersing door de overheid aanwezig zijn, dan is het zaak het beleid vanuit één centraal punt vorm te geven. Van essentieel belang is een organisatiestructuur met goede verbindingen naar de andere overheidsinstanties en naar de betrokken industriele en financiële groepen. Wat dat betreft is uit de case-studies gebleken, dat in Frankrijk met succes grote industriele projekten vanuit de overheid zijn georganiseerd, als het desbetreffende subsysteem tot het domein van eén van de 'corps d'état' kon worden verklaard, van waaruit de contacten met het bedriffsleven, de bureaucratie en de politiek werden gelegd.

De rol van een sterk centraal coördinerend orgaan is van essentiële betekenis: -om te vermijden, dat gevestigde belangen het overheidsbeleid naar hun hand zetten. 'L'Etat développeur' moet het desbetreffende subsysteem organiseren buiten de gevestigde belangen om.

Dat kan vorm worden gegeven door de creatie van een publieke onderneming naast de bestaande partikuliere ondernemingen, of door het organiseren van een fusie tussen bestaande partikuliere ondernemingen, die gecoördineerd worden vanuit één centraal punt;

- om te vermijden, dat de gevestigde belangen binnen het bureaucratische apparaat 
het beleid naar hun hand zetten. Daartoe dient de organisatie van het subsysteem buiten de bestaande overheidsorganisaties te worden geplatatst (vergelijk de DGT);

- om te vermijden, dat politieke korte termijn belangen invloed op het te organiseren subsysteem kunnen uitoefenen. Daartoe dient het projekt van de politiek te worden afgeschermd. Van groot belang in deze is het ontwikkelen van expliciete lange termijn doeleinden voor de desbetreffende organisatie, waaruit duidelijke criteria voor de beoordeling van de effectiviteit kumnen worden afgeleid. Als de leiding van de desbetreffende organisatie conform de industriels Saint-Simoniens ${ }^{*}$ de autonomie wordt gelaten naar eigen inzichten haar doeleinden te realiseren (zie de olie-, nucleaire- en telecommunicatieindustrie), dan zal zij niet gemalkkelijk een speelbal van korte termijn politieke belangen worden. Belangrijk daarbij is het garanderen van de financiële middellen over een lange periode.

De overheid in een markteconomie heeft niet alleen problemen een voluntaristisch specifiek industriebeleid te realiseren, vanwege de onbeheersbaarheid van interne en externe factoren, vanwege de moeilijkheden rond het invullen van de bestaande, te verwachten en de gewenste industriële structuur, of vanwege het opzetten van een adequate organisatiestructuur, maar ook vanwege de kracht van haar tegenspeler: de industriële groep.

Bauer en Cohen $(1984 ; 1985)$ zetten uiteen, hoe de industriële groepen zich ontwikkelen tot zogenaamde 'governements privés l'appareil indiustrielles' (vergelijk 3.1.2.5 en 6.1.2.1). Deze groepen worden geleid door een selecte groep van managers, die verbonden met de diverse beslissingscentra via de netwerken van een 'corps d'état', een grote autonomie hebben met betrekking tot het vaststellen van de doeleinden van de organisatie. Zij beschikken over een zodanig arsenaal van financiële, intellectuele en politieke middelen, dat zij er veelal in slagen grote invloed uit te oefenen op de markten de socio-politieke structuur. De autonomie van het 'appareil' vindt zijn basis in de expertise en de informatieongelijkheid. Vanuit die basis wordt een organisatie opgebouwd, die in velerlei opzicht sterker staat dan haar tegenspelers op het ministerie:

- het 'appareil' is stabieler, omdat het met minder frequente wisselingen aan de top wordt geconfronteerd dan het politieke systeem,

- het 'appareil' hanteert een lange termijn horizon en opereert op wereldniveau in tegenstelling tot de korte termijn nationale politiek,

- het "apparell" kent een hierarchisch opgebouwde structuur volgens het principe van het democratische centralisme in tegenstelling tot de structuur van (gelijkwaardige) rivaliserende (afdelingen van) ministeries.

De vraag, of het nationaliseren van de 'govemements privés de l'appareil' een mogelijkheid is om de machtsverhoudingen te veranderen ten gunste van dle overheid, komt in de volgende paragraaf aan de orde.

\subsection{Publieke ondernemingen}

De publieke onderneming moest een sleutelrol vervullen in het structuurbeleid als speerpunt voor nieuwe technologische ontwikkelingen, als herstructureringspool en als motor voor het Midden-en Kleinbedrijf. Ook zou de publieke onderneming instrument van regionaal beleid zijn en tot slot zou de publieke onderneming een belang- 
rijke rol moeten spelen in het sociale beleid met name met betrekking tot de democratisering van de interne besluitvorming [7].

Een en ander moest in de planningsovereenkomsten gestalte krijgen.

Uit het onderzoek is gebleken, dat de publieke industriele groepien ter financiering van hun investeringen extra financiële middelen kregen toegewezen, maar dat de overheid door middel van de planningsovereenkomsten nauwelijks greep op de strategieên van de groepen had.

Gebleken is, dat de planningsovereenkomsten geen doeleinden met betrekking tot de richting van de investeringen bevatten, en met betrekking tot de herstructureringen geen expliciete afspraken kenden. Ook is duidelijk geworden, dat de publieke ondernemingen met de 'conventions de stabilité met het Midden- en Kleinbedrijf geen andere strategie volgden dan de partikuliere ondernemingen.

Wat de bijdrage van de publieke onderneming aan het regionale beleid betreft, is gebleken dat de ondernemingen op geen enkele manier betrokken zijn geweest bij het opstellen van de 'contrats de plan' tussen de regio's en de centrale overheid, laat staan dat tussen de regio's en de publieke ondernemingen planningsovereenkomsten zijn afgesloten. Wel heeft de overheid ad hoc gepoogd publieke ondernemingen te bewegen tot investeringen in specifieke regio's met een hoge werkloosheid, gelijk zij dat ook ten aanzien van de partikuliere ondernemingen heeft gedaan. Geconcludeerd kan worden, dat de publieke onderneming zeker geen instrument van regional beleid was, dat op consistente wijze in thet kader van regionale plannen werd toegepast.

Wat de democratisering van de publieke onderneming betreft, kan worden geconstateerd, dat de 'Lois Auroux' en de 'loi sur la démocratisation du secteur public' in principe voorzagen in een een grotere participatie van de werknemers in het besluitvormingsproces van de onderneming. Uit het onderzoek is echter naar voren gekomen, dat de informatievoorziening en beraadslaging over het 'plan d'entreprise' en het 'contrat de plan' weinig om het lijf hadden, terwijl de 'Conseil d'Administration' bij ingrijpende beslissingen, die buiten het 'contrat de plan' om gingen, pas achteraf op de hoogte werd gesteld (vergelijk bijv. het 'Yalta de la télécommunication').

Uit de theoretische inzichten is naar voren gekomen, dat de publieke onderneming alleen een effectief instrument kan zijn als aan een aantal voorwaarden is voldaan. Die voorwaarden betreffen de specificatie van de doeleinden, de formulering van indicatoren en criteria van effectiviteit en efficiëntie [8], de creatie van een centraal coördinatieorgaan, het afschermen van de onderneming van budgettaire korte termijn perikelen en het creëren van een consultatieforum voor overheid en onderneming (vergelijk 4.5).

Theorieën over de strategie van industriële ondernemingen maken duidelijk; dat zowel partikuliere als publieke ondernemingen voortdurend hun autonomie willen versterken, zowel ten opzichte van hun concurrenten, toeleveranciers en afnemers, als ten opzichte van branche-organisaties, vakbonden en overheid. Daartoe wordt gepoogd de markt- en de socio-politieke omgeving beheersbaar te maken. Dat is voor publieke ondernemingen niet anders dan voor partikuliere. De relatie tussen de overheid en de publieke onderneming is er een van voortdurende strijd, van veranderende machtsverhoudingen en strategieën. In zijn algemeenheid kan worden gesteld, dat de positie van de onderneming sterker is, naarmate haar activiteiten van grotere economische of 
politieke strategische waarde zijn, zij een monopoliepositie inneemt tegenover veel afnemers en als sprake is van idlosyncratische kennis, die niet snel tegen geringe kosten is te vervangen. In zijn algemeenheid blijkt ook de financièle onafhankelijkheid en de vrijheid met betrekking tot het samenstellen van het management van belang. De overheid is minder goed in staat op de strategie van de onderneming invloed uit te oefenen als deze in turbulente markten opereert, sterk gediversificeerd is en participeert in complexe netwerken van verschillende 'governance structures". Zoals eerder opgemerkt is de positie van de overheid sterker als zij de produktieketen stroomopwaarts beheerst door bijv. de technologische kennis van een publieke organisatie, zoals de CNES, CNET, of CEA en als zij een dominante afnemer is en/of in staat is de binnenlandse markt af te schermen.

Ook de in 1982 genationaliseerde groepen vertoonden de kenmerken van een 'appareil". Of de onderneming van partikuliere dan wel van publieke aard is makt zo gezien geen verschil. Door het ontbreken van een 'loi sur l'industrie' en een plannings. overeenkomst met specifieke doeleinden en financiële meerjarenafspraken ontbrak het richttinggewende kader en vanuit de overheid kreeg de publieke onderneming alle gelegenheid zijn informatievoordeel uit te buiten om binnen twee jaar de weg naar grotere autonomie in te slaan. Verzuimd werd aan overheidszijde een deskundig ministerie te creẻren, dat de publieke groepen een waarlijk tegenwicht kon bieden. Het uitblijven van een centraal coördinatiepunt bood de publieke groepen alle gelegenheid de diverse afdelingen van de verschillende ministeries tegen elkaar uit te spelen en tevens bleek het management in staat slim op de publieke opinie in te kunnen spelen als het ging om de "bedreiging van hun autonomie" (vergelijk Affaire Gandois) [9].

Tot slot moet worden opgemerkt, dat de socialistische hervormers onvoldoende rekening hebben gehouden met de bestaande socio-politieke structuren, zoals het 'corps des mines", dat in een aantal industriële sectoren en netwerken domineert [10]. Selectieve nationalisatie kan in principe effectief zijn vanuit een oogpunt van verbetering van de informatieuitwisseling tussen de overheid en het management van de industriële groep, of vanuit een oogpunt van versnelling van reorganisaties tussen industriële groepen. Echter, als het beleid indruist tegen de belangen van dominante netwerken, dan verandert selectieve nationalisatie niets aan de informatiestromen en besluitvormingsstructuren. Als situaties ontstaan, zoals ten tijde van Chevenement, waarin de politieke top (minister plus enkele adviseurs) het moest opnemen tegen het management van een onderneming, dat zich gesteund wist door het netwerk van het 'corps des mines' op het ministerie en in andere belangrijke organisaties, dan is het onmogelijk tegen de will van het heersende sociopolitieke systeem in een ander beleild tot stand te brengen [11].

Samenvattend kan worden geconcludeerd, dat de Franse overheid niet in staat is geweest de indicatieve planning te revitaliseren tot de 'planification à la française' van Massé, niet in staat is geweest een voluntaristisch industriebeleid te realiseren, dat niet alleen geïsoleerde 'Grands Programmes' betrof, maar ook de ontwikkeling van gekoppelde mesosystemen beheerste, en evenmin in staat is geweest de publieke onderneming tot een effectief instrument van structuur-en sociaal beleid te maken. De verkllaring voor die gang van zaken moet niet alleen worden gezocht in een 
complex yan specifieke economische en politieke omstandigheden, die leidden tot de ommezwaai in het beleid in maart 1983, maar ook zijn meer algemenere verklaringen te geven, die de aard van de markt, de positie van de industriële groepen en de organisatie van het overheidsapparaat betreffen.

\subsection{Een oordeel over de effectiviteit}

Zoals uit de bespreking in paragraaf 4.3 is gebleken, moet woor het beoordelen van de effectiviteit van het overheidsbeleid nauwkeurig kunnen worden vastgesteld welke doeleinden moesten worden gerealiseerd. Er is op gewezen, dat het uitermate moeilijk is na te gaan, of het (gedeeltelijk) realiseren wan de doeleinden (geheel) het resultaat van het beleid is geweest, of dat andere verklarende variabelen een rol speelden. Met betrekking tot het waststellen van de effectiviteit van de publieke onderneming is uiteengezet, dat de onderzoeker idealiter de beschikking zou moeten hebben over een sociale welvaartsfunctie met de verschillende factoren en bijbehorende coëfficiënten. Omdat zo"n functie ontbreekt is in het onderzoek gekozen voor een beschrijvende analyse, waarin zo systematisch mogelijk is nagegaan, welke doeleinden de beleidsmakers voor ogen stonden en of zij in staat zijn geweest het gedrag en de strategie van de actoren zodanig te beînvloeden, dat daardoor de beoogde doeleinden werden gerealiseerd.

De theoretische inzichten, die de voorwaarden blootleggen, waaronder indicatieve planning, specifiek industriebeleid en de publieke onderneming effectief kunnen zijn, blijken bij het uiteindelijke oordeel van groot nut.

Uit de analyse in de voorgaande paragrafen kan worden geconcludeerd, dat in Frankrijk in de periode 1981-1986 niet kon worden voldaan aan de voorwaarden, die worden gesteld aan een effectief integraal indicatief plan met een specifiek sectorstructuurbeleid en de publieke onderneming als centraal instrument. De externe en interne factoren konden in onvoldoende mate worden beheerst, de vereiste organisatiestructuur kwam niet van de grond en het consultatieproces kwam niet verder dan een formeel ritueel. De doelejnden bleken niet kwantificeerbar en te vertalen naar microniveau, het ontbrak de beleidsmakers aan voldoende informatie met betrekking tot de industriële structuur, en tot slot bleek ook het instrumentarium niet adequaat voor het beinvloeden van de strategie van de industriële groepen. In de planningsovereenkomsten met de publieke ondernemingen bleken de doeleinden van het structuur- en sociaal beleid niet voldoende nawweurig te kunnen worden vastgelegd; de planningsovereenkomst is een relationeel contract, maar na korte tijd bleek de publieke onderneming de weg naar volledige autonomie te hebben afgelegd, waardoor de vage formuleringen van het 'contrat de plan' niet verder werden aangescherpt. De specifieke interveniërende planning is effectief gebleken in de sectoren, waarin Frankrijk wanaf de jaren vijftig succesvol was; na 1981 was sprake van mislukkingen in sectoren, waarin ook voorafgaande regeringen niet succesvol waren. Het 'socialisme industriel' heeft daaraan niets kunnen veranderen. Wat het gebruik van de publieke onderneming in het specifieke sectorbeleid betreft, is gebleken dat op de richting van de investeringen geen grotere invloed dan voorheen kon worden uitgeoefend, terwijl omvangrijke herstructureringen als die tussen Thomson en CGE eerder een bekrachti- 
ging van het ondernemingsbeleid waren, dan dat sprake was van beinnloeding van de strategie door de overheid. Hetzelfde geldt voor het gebruik van de publieke onderneming als spil in strategische netwerken van waaruit specifieke relaties met het Midden- en Kleinbedrijf waren opgebouwd; de publieke ondernemingen gedroegen zich met de "conventions de stabilite" niet anders dan de partikuliere ondernemingen, die de strategie van de 'récentrage' toepasten en van daaruit allerlei relaties met toeleveranciers, co-makers etc. opbouwden.

Wat de beoordeling van de effectiviteit van het Negende Plan en de rol van de publieke ondernemingen vanuit een oogpunt van informatieproduktie betreft; is uit het onderzoek gebleken, dat in het kader van het Negende Plan een uitgebreide formele consultatiestructuur is opgezet, maar dat de feitelijke informatiestromen langs de vertrouwde kanalen van de topambtenaren en topmanagers liepen. Wat de rol van de publieke onderneming in deze betreft, is uit het onderzoek naar voren gekomen, dat in officiële rapporten en verslagen van interviews (zie bijv. Haut Conseal 1984) benadrukt wordt, dat de informatieuitwisseling tussen overheid en onderneming aanmerkelijk was verbeterd. Wij menen, dat hierbij een kanttekening op zijn plaats is. Als partijen in de planningsovereenkomsten geen expliciete afspraken maken met betrekking tot de richting van de investeringen, de financiering op de lange termijn, de samenwerkingsovereenkomsten. de herstructureringen etc. en als later blijkt, dat de grote beslissingen buiten het kader van de planningsovereenkomst (en de Conseil d'Administration) om zijn genomen [12], dan kan toch bezwaarlijk worden geconcludeerd, dat de nationalisaties hebben bijgedragen tot een verbetering van de informatieuittwisseling?

\subsection{Een oordeel over de besproken theoretische concepten}

\subsubsection{Inleidding}

Een oordeel vellen over het nut van theoretische concepten is geen eenvoudige zaak. Groudsblom (1974, 17 e.v.) heeft vier invalshoeken onderscheiden, van waaruit theorieën kunnen worden beoordeeld: de empirische precisie, de theoretische systematiek, de reilkwijdte en de maatschappelijke relevantie.

Het criterium van de empirische precisie betreft de nauwkeurigheid, waarmee sociale wetenschappers gelijk de natuurwetenschappers de werkelijkheid weergeven; komen de voorstellingen van de wetenschappers overeen met de werkelijkheid? Wij hebben in dat verband gesproken van theoretische concepten, die met specifieke condities van plaats en tijd moeten kunnen worden ingevuld (zie 1.1).

Het criterium van de theoretische systematiek betreft de stap, die in de wetenschap van de empirie moet worden gemaakt naar verbanden op algemener niveau. In termen van Lammers $(1983,426 / 427)$ :

"(...) wetenschappelijke kennis moet zowel 'kloppen', alls ook een logisch samenhangend geheel van begrippen, stellingen en theorieën te zien geven".

Wij hebben in dat verband gesproken van de economiebeoefening als een 'série a l'américaine': uit het empirisch material, hetwelk verzameld is in een theoretisch geconnoteerde werkelijkheid, moet de wetenschapper pogen te komen tot typologieên, 
classificaties en theoretische verbanden. Vervolgens kunnen nieuwe inzichten en data leiden tot bijstelling van de theoretische verbanden, zodat sprake is van een voortdurende wisselwerking tussen specifiek en algemeen niveau (vergelijk 1.1).

Het criterium van de reikwijdte betreft de geldigheid, de actieradius van een theorie. Deze eerste drie criteria betreffen volgens Goudsblom de "intrinsieke kenmerken van kennis": hoe precies zijn de gegevens, hoe sluiten de onderdelen op elkaar en hoe groot is het terrein, dat zij bestrijken? Het vierde criterium van de maatschappelijke relevantie is wan een andere orde: wat is het nut van de theorie voor het oplossen van maatschappelijke problemen?

Goudsblom wijst erop, dat niet tegelijkertijd aan alle criteria voldaan kan worden. Er bestaat een spanningsweld tussen bijv. precisie enerzijds en reikwijdte anderzijds. Dat spanningsveld is in hoofdstuk drie ter sprake gekomen toen werd uiteengezet, dat de neoklassieke theorie in zeer grote mate voldoet aan de eis van theoretische systematiek, maar voor ons soort probleemstellingen minder relevant is, omdat de concepten zich niet voor "empirische precisie" lenen. Omgekeerd: de netwerkbenadering is adequaat voor een nauwkeurige beschrijving van de empirie, maar betaalt daarvoor een prijs in termen van theoretische systematiek. Geconcludeerd kan worden, dat voor het vaststellen van het nut van theoretische concepten diverse criteria kunnen worden gehanteerd. Welk criterium relevant is, hangt in de eerste plaats af van de probleemstelling van de onderzoeker, hetgeen in ons geval betekent, dat het criterium van de "empirische precisie" van groot belang is [13]. Daarnaast is het van essentiële betekenis vanuit de empirie tot een theoretische systematiek te komen en deze in wisselwerking met nieuw empirisch materiaal aan te passen en op een hoger algemeen niveau te brengen, waardoor de reikwijdte van de theoretische verbanden wordt vergroot. Het criterium van de maatschappelijke relevantie speelt in ons onderzoek zeker ook een rol, omdat overheden indicatieve plannen ontwerpen en industriebeleid voeren met het doel maatschappelijke problemen van werkloosheid, inkomensverdeling e.d. op te lossen. Als de theorie bijdraagt tot een beter begrip van de werking van economische processen en tot het formuleren van voorwaarden van effectief overheidsbelleid, dan is zo'n theorie maatschappelijk relevant te noemen.

Welk oordleel kan nu over de theoriee̊n, die zijn besproken in de hoofdstukken twee $\mathrm{t} / \mathrm{m}$ vier, worden uitgesproken?

Gebleken is, dat diverse theorieèn bruikbare concepten voor de analyse van de specifieke Franse situatie hebben geleverd. Problematisch was echter, dat elke theorie slechts een aspect van de complexe werkelijkheid betrof. Voor de beantwoording van onze probleemstelling bleek een geïntegreerde benadering noodzakelijk, waarin naast economische, ook sociologische, politicologische en culturele factoren een plaats kunnen krijgen, terwijl de dynamiek van die multi-dimensionele relaties in een historisch kader moest worden geplaatst. Daarvoor werd op basis van de denkbeelden omtrent het 'mésosystème" en de 'filiere' uit de 'Ecole frangaise de l'économie industrielle' het concept van de netwerkbenadering geintroduceerd, waarin de diverse in hoofdstuk twee $t / m$ vier afzonderlijk besproken concepten in principe een plaats konden krijgen. In het navolgende zullen wij de bruikbaarheid van de bouwstenen van een voor onze probleemstelling relevant geachte invulling van de netwerkbenadering bespreken, 
waarna wij zullen afsluiten met een voorstel tot verdere systematisering van die benadering.

\subsubsection{Theorieên met betrekking tot de indilcatieve planning}

Aan de hand van Hayek (1937) en Richardson (1960) is duidelijk geworden, welk een centralle rol de informatieproduktie en -verspreiding in een markteconomie speelt. Aan de hand van het volledige stelsel van toekomstmarkten van Arrow en Debreu bleek, onder welke stringente voorwaarden het prijsmechanisme het coördinatievraagstuk van Hayek kan oplossen, terwijl Meade (1971) toont, welk een complex stelsell van indicatieve planning nodig is om tot dezelfde oplossingen als het marktmechanisme te kunnen komen. Zijn theoretische constructie is zeer bruikbaar gebleken voor de beschrijving van de "ex ante integrale coherente planning"', welke in Frankrijk tot en met het Vierde Plan nagestreefd werd. De 'aggregate indicative planning' van Harrod (1973) leverde inzicht in het belang van de beïnvloeding van de verwachtingen via de plandoeleinden (centraal idee in het Vijfde en Zesde Plan), terwijl de 'altemative justification' van Estrin en Holmes (1983) duidelijk maakte, dat planning in de betekenis van doelgerichte realisatie van kwantitatieve macrodoeleinden in een open, complexe economie niet meer mogelijk is. Het indicatieve plan in een moderne markteconomie is in de eerste plaats een kader, waarbinnen informatie kan worden geproduceerd en verspreid. Estrin en Holmes zetten uiteen, dat die informatie zowel het macro- als het mesoniveau kan betreffen, maar bieden onvoldoende aanknopingspunten voor het antwoord op de vraag, hoe onderzocht zou moeten worden welke concrete informatie voor welke beslissingen ontbreekt, en hoe die informatie geproduceerd en verspreid zou moeten worden. Estrin en Holmes wijzen op het belang van de consultatie van alle belanghebbenden, maar geven onvoldoende houvast voor concreet onderzoek in die richting.

Voor een goed begrip van de ontwikkeling van de Franse indicatieve plannen bleek het niet mogelijk te volstaan met de concepten uit de besproken theorieèn van indicatieve planning. Inzicht in de historische rol van L'Etat is noodzakelijk om te kunnen begrijpen, waarom ten tijde van het debâcle van het Zevende Plan door de regering toch de formele planningsstructuur in stand werd gehouden, terwijll dat inzicht ook duidelijk maakt waarom de socialisten in 1981 het Negende Plan revitaliteerden langs de lijnen van de 'Commission Nationale de la Planification' en de doeleinden en middelen willen vastleggen in een Wet op het Plan.

Een goed begrip van de historisch gegroeide machtsverhoudingen tussen het CGP en het Ministerie van Financiën is noodzakelijk om te kunnen begrijpen waarom het CGP, of het Ministerie van Planning na 1981 geen werkelijke vuist konden maken en het korte termijn beleid van het Ministerie van Financiën voortdurend in staat was de lange termijn doelstellingen van het Plan te doorkruisen.

Samengevat kan worden gesteld, dat de besproken theorieën van indicatieve planning een theoretische systematiek leveren, waarmee de empirie van Franse indicatieve planning kan worden gestructureerd, maar dat de feitelijke gang van zaken alleen goed begrepen kan worden als de specifieke historische context in de analyse wordt betrokken. 


\subsubsection{Theorieën met betrekking tot ondernemingsstrategleën}

Wat het vraagstuk van de verklaring van de vormgeving en de effectiviteit van het industriebeleid betreft is kennis van de strategie van de ondernemingen onontbeerlijk. Wat dat betreft lijken voor onze probleemstelling de theorieên van neoklassieke aard weinig houvast te bieden: enerzijds doet zich het probleem voor, dat de complexe werkelijkheid wordt vereenvoudigd tot 'single-exit-situations', anderzijds kunnen theoretische constructies worden aangetroffen, die zo complex zijn, dat zij voor de analyse van concrete problemen niet relevant meer zi [n [14].

De transactiekostentheorie levert als centraal leerstuk van de nieuwe institutionele theorie, voor onze probleemstelling wel zeer bruikbare concepten als 'asset specificity', opportunistisch gedrag, informatieongelijkheid e.d. De relevantie van die concepten is o.a. gebleken uit de analyse van Estrin en Holmes betreffende het informatievraagstuk in het kader van de indicatieve planning. Voor de toepassing op onze probleemstelling bracht de transactiekostenbenadering echter een aantal bezwaren met zich mee, die o.a. verband houden met de methodologische individualistische grondslag, waardoor andere verklaringen dan het maximaliserende, of minimaliserende gedrag van de actoren buiten beschouwing blijven. De bestudering van ordevraagstukken als een 'séríe à l'américaine' vereist, dat juist wordt onderzocht welk complex van interdependente variabelen relevant is. Gebleken is, dat de concepten uit de transactiekostentheorie daarbij een belangrijke heuristische waarde kunnen vervullen, maar dat zij moeten worden ingebracht in het bredere kader van de zogenaamde netwerkbenadering.

Een ander probleem met de transactiekostentheorie betreft haar beperkte dynamische karakter. Hoewel door de zogenaamde 'fundamental transition' een dynamisch element wordt geintroduceerd, blijft de theorie in hoofdzaak comparatief statisch van aard, omdat het proces van de verandering van de 'governance structures' geen expliciet onderwerp van analyse is.

Wat de analyse van de dynamiek van economische organisatievormen betreft biedt de Dynamische Markttheorie meer houvast, omdat zij naast inzicht in de invloed van het ondernemingsgedrag op de marktstructuur ook de krachten achter de marktontwikkeling blootlegt. Daarmee wordt niet alleen inzicht verschaft in de ontwikkeling van de "condities waarbinnen de marktpartijen marktstructuren kunnen vormen en omvormen", maar ook kan uit de theoretische inzichten worden afgeleid in welke fasen van de produkt-levens-cyclus industriebeleid van de overheid effectief zou kunnen zijn. Zoals elke theorie heeft ook de Dynamische Markttheorie haar beperkingen; de scheiding tussen endogeen en exogeen wordt zo getrokken, dat bijv. de ontwikkeling in de relatie tussen de onderneming en de overheid buiten het gezichtsveld blijft. Een verdere verruiming van het conceptuele kader wordt geboden door benaderingen, zoals die van Porter (1980) en in het verlengde daarvan door de netwerkbenadering. Was bij de structuralistische versie van het 'Structure-Conduct-Performance'-paradigma sprake van een eênrichtingverkeer tussen gedrag en structuur en in de 'updated version' van Scherer (1970) van een wisselwerking (vergelijk Porter 1981), in de netwerkbenadering worden ook de 'basic conditions', zoals de technologische ontwikkeling en de socio-politieke structuur in de wisselwerking betrokken.

Gebleken is, dat de netwerkbenadering (mésosystème- of 'filière'-benadering in de 
Théorie Economie Industrielle) bruikbare inzichten levert met betrekking tot de analyse van de dynamiek van economische subsystemen. Voor de analyse van het specifieke industriebeleid, waarmee de Franse overheid de pretentie had mesosystemen in hun ontwikkeling te sturen door middel van publieke ondernemingen op sleutelposities, is het netwerkconcept van grote betekenis gebleken. Het heeft ons enerzijds een aantal relevante vraagstellingen geboden met betrekking tot de diversiteit van de actoren, de multi-dimensionaliteit van de relaties, de (veranderende) machtsbasis van de actoren en het bellang van inzicht in de historie en anderzijds heeft de netwerkbenadering laten zien hoe de theoretische concepten uit de verschillende onderdelen wan de economie en andere disciplines geïntegreerd zouden kunnen worden tot én theoretisch kader voor de analyse van economische organisatievormen (vergelijk Barney en Ouchi 1986).

\subsubsection{Theorieên met betrekking tot de rol van de overheid}

Zoals in hoofdstuk 3 is uiteengezet, dient voor een verklaring en een beoordeling van het industriebeleid niet alleen inzicht te bestaan in de strategieën wan ondernemingen, maar ook in de organisatie en de rol van de overheid. Voor dat onderzoek zijn in het kader van onze probleemstelling theorieën, die de diversiteit van actoren op micro- en mesoniveau niet zichtbaar maken, minder relevant gebleken (vergelijk de "public choice' theorieën in 3.2.1.5). Daarentegen leverden typologieën van neocorporatistische beleidsnetwerken well bruikbare inzichten in de omstandigheden, waaronder het overheidsorgaan in een netwerk sterk staat tegenover een industriële groep en omgekeerd (vergelijk schema 3.14).

Voor de beoordeling van de organisatorische opzet van de interveniërende overheid na 1981, bleek het concept van L'Etat développeur een zeer bruikbaar referentiekader te bieden, waartegen de feitelijke ontwikkelingen konden worden afgezet.

Samengevat kan worden gesteld, dat voor de analyse van de ondernemingsstrategieèn enerzijds, en de rol van de overheid anderzijds, door de diverse economische, sociologische en politicologische theorieèn bruikbare concepten worden geleverd, die in een geintegreerde netwerkbenadering kunnen worden ingebracht.

\subsubsection{Theorieën met betrekking tot de publieke onderneming}

Een belangrijk onderdeel van onze probleemstelling betreft de effectiviteit van de publieke onderneming. Omdat de effectiviteit niet op basis van een objectieve maatstaf kan worden vastgesteld (vergelijk 4.3 ), moet in een gedetailleerde micro-analyse worden nagegaan, hoe de relatie tussen de publieke onderneming en de overheid vorm heeft gekregen en in hoeverre het ministerie in staat is geweest de strategie van de onderncmingen daadwerkelijk te beïnvloeden. De theoretische verhandelingen over de publieke onderneming in een centraal geleid stelsel hebben de ogen geopend voor de informatie- en motivatieproblematiek tussen principaal en agent. De inzichten in de relatie tussen de publieke onderneming en de overheid in een markteconomie zijn relevant gebleken voor de analyse van de gang van zaken in Frankrijk na 1981, omdat zij duidelijk aangeven onder welke omstandigheden de weg naar autonomie snell kan worden afgelegd (vergelijk Hafsi 1984). In verband daarmee heeft ook het concept van het rellationele contract zijn bruikbaarheid bewezen. 


\subsubsection{Slot}

Het geheel overziende kumnen wij stellen, dat alle besproken theorieën voor de beantwoording van onze probleemstelling tekortkomingen vertoonden, hetgeen geen verbazing behoeft te wekken, omdat ellke theorie vanuit haar specifieke invalshoek de werkelijkheid ordent en opdeelt in endogene en exogene variabelen.

Voor de beantwoording van ordevraagstukken is een geîntegreerde benadering noodzakelijk; voor de beantwoording van onze probleemstelling bleek inzicht in de historie van het land, de rol van de overheid, het ontstaan van de industriële groepen, de relaties tussen de bureaucratie en het topmanagement e.d. onmisbaar noor het begrijpen van de vormgeving en de effectiviteit van het socialistische industriebeleid na 1981 .

Om te kunnen verklaren waarom in bepaalde sectoren het beleid succesvol was en in andere niet en om een uitspraak te kunnen doen over de mate van beïnvloeding van de strategie van de publieke ondernemingen door het betreffende ministerie, moest de rol van de overheid worden geplaatst in het netwerk van diverse actoren met multidimensionele relaties. Economische, sociologische, of wat voor soort van theorieern schieten per definitie te kort voor de analyse van dat soort netwerken. Netwerken zijn multi-disciplinair van aard en derhallve is alleen een zogenaamde geintegreerde theorie van economische organisatievormen "bruikbaar", dat wil zeggen geschikt om tot grote empirische precisie te komen. In principe zou de netwerkanalyse de gesignaleerde tekortkomingen, in bijv. de theorie van indicatieve planning van Estrin en Holmes, in de transactiekostentheorie, of met betrekking tot de integratie van de statistische en monografische 'filiere', kunnen oplossen, maar uit hoofdstuk 6 en vooral 7 is gebleken, dat zo'n analyse gemakkelijk blijft steken in een gedetailleerde beschrijving van casestudies. De empirische precisie kan dan groot zijn, maar de theoretische systematiek en reikwijdte kunnen volledig ontbreken. In principe biedt de netwerkbenadering een 'grille d'analyse' (Durand 1988), waarmee op systematische wijze de complexe multidimensionele relaties tussen actoren en de dynamiek van het meso-systeem in kaart kunnen worden gebracht, maar die systematiek is nog niet sterk ontwikkeld, waardoor beschrijwingen snel een overdaad aan gegevens bevatten, waaruit moeilijk conclusies van algemenere aard kunnen worden getrokken.

Samenvattend kan worden gesteld, dat een groot aantal van de theoretische concepten bruikbaar is gebleken in de zin, dat zij de mogelijkheid van "empirische precisie" boden. Daarentegen is het met de "theoretische systematiek"' van een geïntegreerde theorie van economische organisatievormen nog slecht gesteld, terwijl ook de "reikwijdte" nog kwestieus is. Wat de maatschappelijke relevantie betreft zouden wij willen opmerken, dat de besproken theorieën en ideaaltypen, zoals bijv. de cyclus van Hafsi (1984) en die van 'L'Etat développeur' de voorwaarden blootleggen, waaronder planning in een markteconomie effectief kan zijn. Voor het oplossen van maatschappelijke vraagstukken kunnen dergelijke inzichten zeer relevant zijn.

Voor de behandeling van ordevraagstukken lijkt de netwerkbenadering een handvat te bieden, waarmee de complexe werkelijkheid tegemoet kan worden getreden. Op basis van case-studies kunnen classificaties en typologieën worden ontwikkeld, die in volgende case-studies kunnen worden gebruikt en naar bevind van zaken kunnen worden 
aangepast. Ook kunnen hypothesen geformuleerd worden in de trant van de generalisaties, die in dit hoofdstuk zijn gepresenteerd, welke in nieuwe case-studies aan een nadere toetsing kunnen worden onderworpen. De netwerkbenadering zou wellicht tot scherpere hypothesen kunnen komen en tot data, waarmee tot kwantitatieve toetsing kan worden overgegaan, als in aansluiting met de concepten uit de transactiekostentheorie de verschillende relaties, die de actoren met hun omgeving opbouwen, zouden kunnen worden gekoppeld aan empirische gegevens omtrent relatie-specifieke investeringen, frequentie van de transacties, duur van de relaties, graad van vertrouwen in de relatie, etc [15].

Zulk onderzoek is multi-disciplinair van aard en behelst de analyse van een groot aantal case-studies, waaruit data beschikbaar zouden kunnen komen, die voor een systematische toetsing in aanmerking komen.

Het onderzoek naar het hoe, waarom en de effectiviteit van het Franse industriebeleid in het algemeen, en naar de rol van de publieke onderneming in het bijzonder, heeft ons duidelijk gemaakt hoe gecompliceerd zo'n multi-disciplinaire benadering kan zijn en hoe groot de behoefte is aan structurerende conceptuele kaders. Als verdere systematisering van de netwerkanalyse daaraan een bijdrage zou kunnen leveren, dan zou het bestuderen van ordevraagstukken een stuk verder op weg zijn geholpen.

\section{Noten behorend bij hoofdstuk 8}

[1] Voorbeelden van interne factoren zijn de loon- en prijsontwikkelingen; voorbeelden van externe factoren zijn de ontwikkelingen op de wereldmarkt, de toetreding van nieuwe industrielanden e.d.

[2] Niet dat zo'n nationaal orgaan internationale conjuncturele ontwikkelingen zou kunnen beheersen, maar wel in de zin dat het nationale conjuncturele antwoord op de externe ontwikkelingen zou kunnen worden ingepast in het structuurbeleid.

[3] Bijv. door het CEPII, DP, CGP.

[4] Van die situatie was bijw. sprake in Japan tot ongeveer 1965, toen Miti de markten socio-politieke omgeving van de ondernemingen volledig beheerste (vergelijk Johnson 1982).

[5] Vergelijk bijv.Kikkawa (1983); Bertsch en Stam (1986).

[6] Bijvoorbeeld het 'prisoners dilemma' in geval van de afbouw van produktiecapaciteit (vergelijk Van den Doel en Driehuis 1979), of samenwerking tussen concurrenten in de pre-competitieve fase.

[7] In 6.2 is ook de rol van de publieke onderneming als instrument van conjunctuurbeleid besproken. Uiteengezet is, dat de publieke onderneming na de nationalisering van 1982 die rol niet kreeg toebedeeld, waardoor wij er in deze paragraaf ook niet nader op ingaan.

[8] Wat de efficiëntie van de publieke onderneming betreft is in 1983 door de Minister van Industrie, Laurent Fabius, gesteld, dat alle publieke ondernemingen per 1 januari 1986 uit de rode cijfers moesten zijn, maar zoals in 4.3 .2 is uiteengezet, zijn aan het hanteren van dergelijke criteria voor publieke ondernemingen grote bezwaren verbonden. 
[9] Gandiois was de PDG van Rhône-Poulenc, die na de nationalisatie niet werd vervangen. $\mathrm{Na}$ een jaar stapte hij onder veel publiciteit op met als reden, dat onder de socialisten van de autonomie niets meer over bleef.

[10] Discussie op de preliminaire sessie over het Franse industrie beleid van het congres 'A Competitive Future for Europe' gehouden in mei 1985 aan de Erasmus Universiteit te Rotterdam met J. de Bandt, adviseur van de Minister van Industrie, J.P Chevènement.

[11] Bestudering van de strategie van Thomson wijst uit, dat zij voortdurend in staat was afdelingen van diverse ministeries tegen elkaar uit te spelen en dat op het Ministerie van Industrie de strategie van Thomson door de leden van het 'corps des mines* niet alleen werd verdedigd ten opzichte van de politieke top van het ministerie, maar tot in Brussel toe.

Cawson, Stevens en Holmes (1985) wijzen er in dat verband op, dat het hoofd van DIELI tevens lid was van de 'Conseil d'Administration' van Thomson, waardoor de opvallende constructie ontstond, dat het hoofd van de overheidsafdeling, dat het beleid ontwikkelde, tevens lid was van het hoogste bestuursorgaan van de onderneming, die vanuit het ministerie gestuurd moest worden. De leden van het 'corps des mines' hadden voldoende gelegenheid de informatie van Thomson naar de ministeriële top naar eigen voorkeur "in te klleuren", waardoor de organisatie van het industriebeleid snel de kenmerken van een "captured network" kreeg, waarin het Ministerie van Industrie de strategie van Thomson tot haar eigen beleid maakte (vergelijk 3.2.1.5).

[12] Vergelijik het 'Yalta de la télécommunication".

[13] Als wij in het navolgende spreken over de "bruikbaarheid" van theoretische concepten, dan wordt daarmee gedoeld op de empirische precisie, die met die concepten kan worden bereikt.

[14] Vergelijk bijwoorbeeld het citaat van Arrow op blz. 56.

[15] Onderzoek als dat van bijv. Daems (1982) vormt daartoe een aanzet; de volgende stappen zouden een scherpere classificatie van de 'governance structures" en het verzamelen van nieuwe data betreffende de transactie-specifieke-investeringen en de diversiteit van de rellaties in netwerken kunnen betreffen. 


\section{SAMENVATTING}

In deze studie wordt onderzocht, hoe de Franse overheid in de periode 1981-1986 gestalte heeft gegeven aan haar industriebeleid, waarom het beleid die vorm kreeg en of de economische organisatievormen effectief zijn geweest. Drie elementen staan daarbij centraal: de indicatieve planning, het specifieke industriebeleid gericht op de 'filière' en de publieke onderneming.

De studie betreft de vraag naar het ontstaan en de ontwikkeling van economische organisatievormen en een beoordeling van hun effectiviteit.

In het eerste hoofdstuk wordt van dergelijke ordevraagstukken gesteld, dat die bestudeerd dienen te worden met behulp van zowel algemene als specifieke theorieen.n. De algemene theoriee̊n uit diverse disciplines leveren algemene concepten, waarmee de werkelijkheid kan worden gestructureerd; voor de analyse van concrete ordevraagstukken dienen die algemene concepten te worden ingevuld met specifieke condities van plaats en tijd, hetgeen zogeheten specifieke theorieën oplevert. Welke algemene concepten voor de verklaring en beoordeling van economische organisatievormen relevant zijn kan niet a priori worden vastgesteld, maar dient onderwerp van onderzoek te zijn.

Uiteengezet wordt, dat het onderzoek naar ordevraagstukken uit de aard der zaak multidisciplinair is. In beginsel kunnen naast economische variabelen ook sociologische, politicologische, alsmede historisch-culturele variabelen van belang blijken te zjjn. De theorie van economische organisatievormen bestaat derhalve uit een samenstel van theorieën uit economische en andere disciplines, waarop afhankelijk van de aard van de te verklaren economische organisatievorm een beroep kan worden gedaan. Betoogd wordt, dat de zogeheten 'filière'- of netwerkbenadering een methode van onderzoek is, waarin op voorhand geen potentiële verklarende variabelen worden buiten gesloten, maar waarbij al onderzoekend wordt nagegaan welk complex van verklarende interdlependente variabelen relevant is.

Uit het onderzoek naar de vormgeving en effectiviteit wan het Franse beleid in de periode 1981-1986 blijkt, dat voor de verklaring van concrete economische organisatievormen zeker niet met economische variabelen kan worden volstaan. Naast economische factoren, zoals schaaleffecten en verlaging van de transactiekosten blijken ook sociologische ('corps d'état'), politicologische (organisatie van de 'Grands Programmes') en historische (rol 'L'Etat') variabelen in de verklaring niet te kunnen worden gemist.

Wij hebben in deze studie derhalve een beroep moeten doen op theoretische concepten en verbanden uit diverse disciplines.

In de hoofdstukken twee tot en met vier worden diverse algemene theoretische 
concepten besproken volgens een indeling, die aansluit bij de empirie van de Franse situatie: in hoofdstuk twee komen concepten uit de theorieên van indicatieve planning aan de orde, in hoofdstuk drie uit de theorieèn van de ondernemingsstrategieen en de rol van de overheid in een markteconomie, en in hoofdstuk vier concepten uit de theorieên van de publieke onderneming.

In hoofdstuk twee wordt uiteengezet, dat aan de theorieën van indicatieve planning het marktfalen ten grondslag ligt. Het falen betreft de produktie en verspreiding van informatie ter reductie van markt- en omgevingsonzekerheid. Die informatieproblematiek kan theoretisch worden opgelost met behulp van het model van indicatieve planning van J.E. Meade, dat is gebaseerd op de inzichten van Arrow en Debreu, of met behulp van het model van R.F. Harrod, dat is gebaseerd op Keynesiaanse groeimodellen, maar ook met behulp van minder algemene theoretische concepten uit de wereld van de transactiekostentheorie. Op basis van concepten als beperkte rationaliteit, opportunistisch gedrag, onzekerheid en complexiteit van de omgeving van oligopolistische marktstructuren, kennen Estrin en Holmes het indicatieve plan in een moderne markteconomie een belangrijke onzekerheidsreducerende rol toe. Het belang is enerzijds gelegen in de rol van consultatieplatform en anderzijds in de produktie en verspreiding van informatie.

In hoofdstuk drie wordt uiteengezet, dat industriebeleid gericht is op het beinvloeden van ondernemingsgedrag. Theoretische concepten, die inzicht kunnen verschaffen in de strategie van ondernemingen met betrekking tot de omvang en de richting van investeringen en met betrekking tot de organisatie van de markt, kunnen worden aangetroffen in het brede scala van de theorieën van de industriële organisatie, de Nieuw Institutionele Theorie, de Dynamische Markttheorie, alsmede in meer bedrijfskundige benaderingen. In vergelijking met de Angelsaxische benadering, ligt het accent in de Franse theorieën van de industriële organisatie en ondernemingsstrategie meer op de multi-disciplinaire benadering. In de bespreking van de ' $L$ 'Ecole Française de l'Economie Industrielle' wordt met name aandacht besteed aan het fenomeen van de industriële groep en aan de concepten van de 'filière' en het 'mésosystème'. Een theoretische analyse van de strategie van industriële groepen in hun mesosystemen is voor de onderhavige studie van belang, omdat het industriebeleid in Frankrijk in de periode 1981-1986 was gericht op het realiseren van specifieke doeleinden op mesoniveau door middel van het beinvloeden van de strategie van genationaliseerde industriele groepen.

Nadat is uiteengezet waarom naast de revitalisering van de indicatieve planning ook een (decentraal) specifiek industriebeleid noodzakelijk kan worden geacht, wordt in het tweede deel van hoofdstuk drie thet wraagstuk van de gewenste inrichting van het overheidsapparat besproken aan de hand van theoretische concepten uit de politicologie. De typologie van 'L'Etat Régulateur' en 'L'Etat Développeur' biedt inzicht in đe vereiste organisatie en expertise van een overheid, die een specifiek industriebeleid wenst te voeren.

In hoofdstuk vier wordt uiteengezet, warom het instrumentarium van 'L'Etat Développeur' kan worden uitgebreid met de publieke onderneming. Centraal in dit hoofdstuk staat de vraag, hoe het behoud van de autonomie van het management van 
de genationaliseerde onderneming kan worden verenigd met het instrumentele karakter van de publieke onderneming. Theorieên van juridische (relationele contract) en van sociologisch-politicologische aard (cyclus van samenwerking via confrontatie tot autonomie) leveren bruikbare algemene concepten.

Nadat in intermezzo I en II respectievelijk conclusies uit de besproken theoretische inzichten zijn getrokken en de specifieke kenmerken van de Franse historisch-culturele context zijn besproken (rol van 'L'Etat' en van de "corps d'état"), worden in hoofdstuk vijf de Franse indicatieve plannen besproken. De aandacht gaat specifiek uit naar het industriebeleid, zoals dat in het kader van de Plannen gestalte kreeg. Met betrekking tot het Negende Plan (1984-1988) wordt nader ingegaan op de macroeconomische context, op het planningsproces, op de organisatorische vormgeving van dat proces en op de inhoud van het Plan. Uit het onderzoek blijkt, dat formeelorganisatorisch de indicatieve planning door de socialistische regering is gerevitaliseerd en aangepast aan de eisen van een open en complexe economie. Feitelijk bleek het echter niet mogelijk het Plan opnieuw te wortelen in de Franse samenleving, zoals dat ten tijde van Monnet en Massé het geval was geweest. Dat werd duidelijk toen Mitterrand in maart 1983 zijn economische koers 180 graden draaide in de richting van de 'rigueur', waardoor het Ministerie van Financiën weer het korte termijn heft in handen nam.

Omdat een belangrijk deel van het industriebeleid buiten de officiële planning om gestalte kreeg (creatie van grote industriële groepen en organisatie van de zogeheten 'Grand Programmes') wordt in hoofdstuk zes geanalyseerd, hoe dat industriebeleid' vorm kreeg onder de presidenten De Gaulle, Pompidou, Giscard d'Estaing en Mitterrand. Met betrekking tot de laatstgenoemde worden drie 'Mitterrandismen' onderscheiden: het voorzichtige beleid van Dreyfus, het interveniërende beleid van Chevènement en het liberale beleid van Fabius en Cresson.

Uiteengezet wordt, dat de 'loi sur l'industrie', waarin 'L'Etat développeur' de mogelijke en gewenste ontwikkeling van de 'filières' zou aangeven, niet tot stand komt en dat het socialistische industriebeleid steeds grotere overeenkomsten gaat vertonen met dat van haar voorgangers. Die voorgangers blijken in het initiëren en organiseren van een aantal mesosystemen zeer succeswol te zijn geweest: de 'Grands Programmes' van de olieindustrie, de nucleaire energie, de lucht- en ruimtevaart en de transportmiddelenindustrie zijn alom bekend. Uit het onderzoek blijkt, dat ' $L$ 'Etat' in staat is complexe subsystemen te organiseren en in hun ontwikkeling te sturen, mits de overheid de vraagzijde van de markt beheerst, de grondstoffenvoorziening of het fundamentele onderzoek via haar kanalen lopen en zij een krachtig coördinerend orgaan in het leven kan roepen, dat beschikt over toegang tot de financiële middelen, over voldoende informatie en expertise en dat via de kanalen van een 'corps d'état' een goede verbinding heeft met het bedrijfsleven, de bureaucratie en de politiek. De mogelijkheid de strategie van ondernemingen af te stemmen op doeleinden van industriebeleid wordt in belangrijke mate door de bovengenoemde factoren bepaald. Dat geldt zowel voor partikuliere als publieke ondernemingen.

Uit de analyse blijkt, dat het socialistische industriebeleid steeds grotere overeenkomsten met dat van haar voorgangers gaat vertonen. De 'Grands Programmes' 
worden woortgezet, maar een geîntegreerd beleid, zoals de socialistische 'L'Etat Développeur", dat met betrekking tot de 'filières'voor ogen stond komt niet tot stand. Noch 'le Plan', noch het 'Ministère de l'Industrie' en evenmin het 'Mimistère de la Planification et de l'Aménagement de Territoire', blijken zich een centrale coördinerende rol te kunnen toeëigenen. Integendeel, door de dominantie van de korte termijn problemen van de inflatie en de betalingsbalans bleef het Ministerie van Financiën haar centralle rol behouden.

Uit de analyse van de 'contrats de plan' tussen het 'Ministère de futelle' en de publieke onderneming blijkt, dat deze organisatievorm weliswaar theoretisch de mogelijkheid biedt de autonomie te verzoenen met de afstemming van de ondernemingstrategie op de overheidsdoeleinden, maar dat in werkelijkheid de onderneming tal van mogelijkheden heeft zo'n relationeel contract in haar voordeel om te zetten, aangezien de industriele groep een informatievoordeel heeft en haar organisatiestructuur is afgestemd op het realiseren van lange termijn doeleinden.

De algemene bevindingen uit hoofdstuk zes worden in hoofdstuk zeven nader bezien aan de hand van een case-studie van de kern van het socialistische industriebeleid: de 'filière électronique'. Twee branches staan centraal: de telecommunicatie en de computerindustrie. De ontwikkelingen voor 1981 worden vergeleken met die na de nationalisaties, waarbij de gang van zaken in vier ondernemingen specifieke aandacht krijgen: Thomson, Bull, CGE en Matra.

Tot slot worden in hoofdstuk acht enkele conclusies getrokken met betrekking tot de effectiviteit van het Franse industriebeleid in de periode 1981-1986 en wordt een oordeel gegeven over de bruikbaarheid van de besproken theoretische concepten voor de bestudering van concrete ordevraagstukken. 


\section{SUMMARY}

This research analyzes how the French government formulated her industrial policy in the period 1981-1986, why that particular type of economic organization was chosen and whether the instruments and organizations have been effective.

The research concerns the question of the emergence and development of economic organizations and an assessment of their effectiveness.

Chapter one explains that problems of economic organization have to be studlied with the use of general and specific theories. General theories, from different disciplines, supply general concepts. These then enable the researcher to structure the complex reality. For the analysis of concrete problems of economic organization those general concepts have to be complimented by specific conditions of place and time, which results in so-called specific theories. Which concepts are relevant for the problem at hand cannot be decided upon beforehand, but must be object of the research itself. Problems of economic organization are multidisciplinary by nature, this implicitly indicates the implies the relevancy of theoretical concepts from different disciplines. The theory of economic organizations consists of a collection of theories derived largely from economics, but also from other disciplines. Researchers call upon the concepts from different theories depending on the nature of the problem at hand. It is argued that the "filiere"- or network approach does not exclude potential explanatory variables beforehand, but opens the possibillty to find out, during the research, what complex of interdependent variables is relevant.

From the research into the formalisation and the effectiveness of the French policy in the period 1981-1986 it follows that one cannot limit the analysis to purely economic variables, but must also include sociological ("corps d'état"), political (organisation of the "Grands Programmes') and historical variables. In this study we have had to call upon theoretical concepts and relations from different disciplines. In the chapters two, three and four different theoretical concepts are discussed following a subdivision which corresponds with the French empirical situation: the theories of indicative planning are explained in chapter two, the theoretical underpinnings of industrial policy and the strategies of industrial groups are subject of chapter three, whereas the theory of the public enterprise is central in chapter four.

In chapter two we explain that market failure is the theoretical foundation for indicative planning; of central importance is the underproduction of information due to specific characteristics of information as an economic good. Underproduction of information leaves the economic actors with market and environmental uncertainty, a problem that is solved in the model of indicative planning of J.E. Meade. This model is 
based on the full set of contingency claims markets of Arrow and Debreu. A second theory of indicative planning is developed by R.F. Harrod, who based his ideas on Keynesian growth models. A third contribution worth mentioning is the theory of Estrin and Holmes, who use bounded rationality, opportunistic behaviour, complexity and uncertainty from the transaction cost theory in order to point out what role an indicative plan could play in a modern, open market economy. The importance of the plan lies in its role as platform of consultation on the one hand and as producer and disseminator of information, which is not produced elsewhere in the economic system on the otherhand.

Chapter three explaines that industrial policy aims at influencing the strategies of the enterprises in respect to the volume and direction of the investments on the one hand and the organization of the market on the other. Theoretical concepts relevant for the description and analysis of the entrepreneurial strategies can be found in the large spectrum of theories of industrial organization, new institutional economics, dynamic market theory and in theories of strategic management. In comparison with the Anglo-saxon school the French theories of industrial organization and strategic management favour a more multi-disciplinary approach. In the review of the ' $L$ 'Ecole Française de l'Economie Industrielle' we pay special attention to the concepts of the industrial group and the 'filiere" or 'mésosystème' (networking), because the industrial policy of the French government in the periode 1981-1986 aimed at the realization of specific objectives at the mesolevel of the "filiere" by influencing the strategies of the nationalized industrial groups.

In the second part of chapter three the organization of a intervening government (L'Etat Développeur") is discussed by using concepts from the political science. The typology of the so-called 'Regulatory' and 'Developmental State' show how the central government should organize an economic system in order to realize an effective industrial policy.

In chapter four we explain why the 'Etat Développeur' should want to enlarge her instruments with the nationalization of industrial and financial groups. A central issue in this chapter concerns the question how the autonomy of the management of the public enterprises, which operate in open competitive markets can be combined with the instrumental use of the enterprise for the realisation of the objectives of the industrial pollicy of the national government. Juridical theories (like the relational contract) and theories of sociological and political nature (for example the cycle of cooperation, confrontation and autonomy) could supply useful concepts for the description and analysis of the public enterprises in market economies.

After having summurized the probable usefulness of the theories discussed in the first chapters and after having presented the most outstanding characteristics of the French system in the intermezzo's I and II, we analyse the French indicative Plans in chapter five. The attention is focused on the industrial policy as it was formulated within the framework of the Plans. With respect to the Ninth Plan (1984-1988) the macroeconomic context, the planning process, the institutional setting and the contents are discussed in detail. The research shows how the government adjusted the formal organization of the planning to the requirements of an open and complex economy 
like France in the eighties. However, in reality it turned out to be impossible to establish the Plan in the French society, which became clear when president Mitterrand completely changed his economic policy in march 1983; as a consequence the Ministery of Finance, with its short term policies was in full control of the situation again. Long run structural planning was pushed into the background again.

In chapter six the industrial policies of the governments, after 1945 , is analyzed. In addition to the industrial policy, which was formulated and implemented in the framework of the national Plan, an important part of French industriall policy was realized outside the official plan. Well-known are the so-called 'Grands Programmes', which were begun under President De Gaulle and continued under the presidency of Pompidou, Giscard d'Estaing and Mitterrand. In this chapter special attention is paid to the three forms of 'Mitterrandism": the careful policy of Dreyfus, the 'meccano' interventions of Chevenement and the liberal policies of Fabius and Cresson. It is explained why the "loi sur l'industrie" (Industrial Planning Act), in which the Developmental State should outline a picture of the possible and desirable industrial structure ('filières") was not realized after all. After march 1983 not only the conjunctural policy' of the French government changed fundamentally, also her industrial policy was transformed from a voluntaristic one into a liberal policy and did not further deviate from the policies of the former presidents. Also the successes and the failures were similar. From the sixties onwards the French government was succesful in sectors like the telecommunication, the oil industry, the nucleair energy, the transportation sector and in the aircraft and space industries as well as in the military sectors. 'L 'Etat' had shown itself to be able to initiate the emergence and to control the development of complete economic sub-systems. From this research it becomes clear that a Development State can be effective given it is in control of the demand side of the market, the supply of technological knowledge or basic materials. When there exists a central pilot organization which is able to orchestrate the policies of the departments of the ministeries as well as the strategies of the industrial groups and, of crucial importance, is the possession of knowledge and information as well as the existence of a good relation between the civil servants, politicians and managers. Industrial policy can be effective when the government or the public agent is able to influence the strategies of the enterprises, which depends largely on the conditions mentioned above. This applies to priwate as well as to the public enterprises.

After a short revival of the system of indicative planning and a voluntaristic industrial policy the socialist government soon had to follow the footsteps of their predecessors: the 'Grands Programmes" were continued and an integrated 'filière" policy was not realized. Neither 'Le Plan', nor 'Le Ministère de L'Industrie' or 'Le Ministere de la Planification et l"Aménagement du Territoire" turned out to be able to play the role of pilot organization. The lack of such central actor enabled the Ministery of Finance to place the short run conjunctural policies in the centre of attention and to push long term structural pollicies backstage.

The relationship between the government and the public enterprise was organized in a 'Contrat de Plan' (planning-agreement). The result of negotiations between the civil servants of the Ministery of Industry and the management of the enterprise was 
formulated in termes of rights and obligations in a contract between these two autonomous parties. However, the contract turned out to be of limited value: the objectives of the national plan were very vague and the Act on the Industrial Structure was never realized; therefore it was extremely difficult to formulate concrete objectives for the firms which fitted into the plans at meso and macrolevel. Because of the vagueness of the objectives at macro and mesolevel and because of the superiority in knowledge and information about concrete markets the managers could take advantage of the planning agreements.

The general conclusions of chapter five and six are illustrated in chapter seven by means of a case study of the electronic industry ('filière électronique'). Two sectors are analyzed in detail: in the telecommunication and the computer industry the developments before 1981 are compared with the situation after the nationalizations. In chapter seven the attention is focused on the results of four firms: Thomson, CGE, Bull and Matra.

Finally, in chapter eight, conclusions are drawn on the one hand in respect to the effectiveness of French industrial policy and on the other hand about the usefulness of theoretical concepts in studying questions of economic organization and industrial policy. 


\section{RESUME}

Dans la présente étude l'on étudie comment les pouvoirs publics français ont formulé leur politique industrielle pendant la période 1981- 1986, pourquoi cette politique fut formulé ainsi, et si les formes d'organisation économique ont été effectives. Trois éléments sont centraux: la planification indicative, la politique industrielle spécifique des 'filières', et l'entreprise publique.

L'étude concerne la question de savoir comment naissent et se développent des formes d'organisation économique, et quelle en est l'effectivité. Dans un premier chapitre l'on pose que ces questions d'organisation économique doivent être étudiées simultanément à l'aide de théories générales et spécifiques. Les théories gënérales de différentes disciplines livrent des aspects généraux qui permettent de structurer la réalité; pour l'analyse de problèmes concrets ces concepts doivent être nourris de conditions spécifiques de lieu et de temps, ce qui formait des théories appelées spécifiques. Quells concepts généraux pour l'explication et le jugement de formes d'organisation économique sont pertinents ne peut pas être fixé à l'avance, mais doit être l'objet de la recherche elle-même.

L'on expose que la recherche en matiére de formes d'organisation est essentiellement multidisciplinaire. En principe des variables sociologiques, politologiques, mais aussi des variables historico- culturelles peuvent apparaître comme importantes à côté de variables purement économiques. La théorie des formes d'organisation économique consiste donc en un ensemble de théories empruntées à l'économie et à d'autres disciplines, qu'on peut appeler à la rescousse en fonction de la nature de la forme d'organisation économique à expliquer. L'on argue que l'approche dite par 'filières' ou réseaux est une méthode de recherche qui n'exclut pas à l'avance des variables explica. tives potentielles, mais où, pendant la recherche, l'on vérifie quel complexe de variables explicatives interdependantes est pertinent.

De la recherche concernant la formalisation et l'éfficacité de la politique française pendant la période 1981-1986, il apparaît que pour l'explication des formes concrètes d'organisation économique, les variables économiques ne suffisent certainement pas. A côté de facteurs économiques, comme des effets d'échelle et la reduction de conts de transaction, des variables sociologiques ('corps d'état'), politiques (organisation de 'Grands Programmes') et historiques (rôle de "l'Etat") ne peuvent être laissées à l'écart. L'on a dès lors, dans l'étude, dû faire appel à des concepts théoriques et des relations empruntées à différentes disciplines.

Dans les chapitres deux, trois et quatre l'on discute différents concepts theoriques selon une subdivision qui cadre avec la situation française empirique: dans le chapitre deux l'on retrouve des concepts des théories de la planification indicative, dans le 
chapitre trois des concepts des théories des stratégies d'entreprise et du rôle des pouvoir publics dans une économie de marché, et dans le chapitre quatre des concepts de la thếrie de l'entreprise publique.

Dans le chapitre deux l'on expose que les théories de la planification indicative reposent sur les imperfections de fonctionnement du marché. Ces imperfections concernent la production et la diffusion de l'information réduisant les incertitudes de marché et d'enviromnement. Cette problématique de l'information peut être résolue à l'aide du modèle de la planification indicative de J.E. Meade, modèle basé sur les vues de Arrow et Debreu, ou avec le modèle de R.F. Harrod, basé sur les modèles de croissance keynésiens, mais également à l'aide de concepts théoriques moins généraux empruntés au monde de la théorie des coüts de transaction. Sur la base de concepts comme ceux de la rationalité limitée, de comportement opportuniste, de l'incertitude et de la complexite de l'environnement de structures monopolistiques, des auteurs comme Estrin et Holmes attribuent au plan indicatif dans un économie de marché moderne un rôle important dans la réduction de l'incertitude. L'importance réside d'une part dans le rôle d'une plateforme de consultation, de l'autre dans la production et la diffusion de l'information.

Dans le chapitre trois l'on expose que la politique industrielle vise à influencer le comportement d'entreprise. Des concepts théoriques quil permettent de comprendre la stratégie d'entreprise par rapport au volume et à la direction de leurs investissements, et par rapport à l'organisation du marché, peuvent être trouvés dans le large spectre des théories de l'organisation industrielle, de la Nouvelle Théorie Institutionelle, de la Théorie Dynamique du Marché, ainsi que dans des approches plus axées sur le fonctionnement des entreprises. En comparaison avec l'approche anglo-saxonne, l'accent dans les théories françaises de l'organisation industrielle et de la stratégie d'entreprises repose plus sur l'approche multidisciplinaire. Dans la discussion de l'Ecole française de l'économie industrielle" l'on s'attache notamment au phénomène du groupe industriel et aux concepts de 'filière" et de "mésosystème". Un analyse théorique de la stratégie des groupes industriels' dans leur mésosystème est importante dans le cadre de la présente étude, parce que la politique industrielle de la France pendant la période 1981-1986 était axée sur la réalisation d'objectifs spécifiques au niveau 'méso', par l'influence que l'on exerce sur la stratégie de groupes industriels nationalisés.

Après avoir exposé pourquoi à côte de la révitalisation de la planification industrielle l'on observe la nécessité d'un politique industrielle spécifique (décentralisée), l'on discute dans la deuxième partie du chapitre trois le problème du l'organisation souhaitable de l'appareill public, à l'aide de concepts théoriques de la politologie. Le typologie de 'l'Etat régulateur' et de 'l'Etat développeur' éclaire l'organisation et l'expertise requises pour un pouvoir public quil souhaite mener un politique industrielle spécifique.

Dans le chapitre quatre l'on expose pourquoi la panoplie d'instruments de 'l'état développeur' peut être étendue par l'entreprise publique. La question centrale est celle de savoir comment l'on peut reunir le maintien de l'autonomie de direction de l'entreprise nationalisée et le caractère instrumental de l'entreprise publique. Des theories des nature juridique (contrat relationnel) et socio-politique (cycle collabo- 
ration-confrontation-autonomie) fournissent des concepts généraux utilisables. Après avoir tiré, dans des intermezzos I et II, les conclusions, d'une part des visions théoriques discutées, de l"autre des caractéristiques spécifiques du contexte historicoculturel français (rôle de 'I"état" et des 'corps d'état'), l'on discute dans le chapitre cinq les plans indicatifs français. L'attention se dirige specifiquement vers la politique industrielle, ainsi qu'elle fut développée dans le cadre des Plans. Par rapport au Neuvième Plan (1984-1988) l'on entre dans plus de detalls en ce qui concerne le contexte macro-économique, la procédure de planification, la structuration organisationnelle et le contenu du plan. La recherche apprend que la planification indicative a été, dans un sens d'organisation formelle, révitalisée par le gouvernement socialiste et adaptée aux urgences d'une économie ouverte et complexe. En fait il n'apparaissait pas possible d'enraciner de nouveau le plan dans la société française, comme c'était le cas du temps de Monnet et de Massé. Cela devenait clair lorsque Mitterrand changeait, en 1983, sa course de 180 degrès dans la direction de la "rigueur", ce qui eut comme conséquence que le Ministère des Finances reprenait la barre à court terme.

Parce qu'une partie importante de la politique industrielle prenait corps en dehors de la planification officielle (création de grands groupes industriels et organisation des 'Grands Programmes', comme on les appelait) le chapitre six analyse comment la politique industrielle se formait sous les présidents De Gaulle, Pompidou, Giscard d'Estaing et Mitterrand. Par rapport à ce dernier l'on distigne trois 'Mitterrandismes': la politique prudente de Dreyfus, la politique d'intervention de Chevènement, et la politique libérale de Fabius et Cresson. L'on expose que la "loi sur l'industrie', dans laquelle 'l'Etat développeur' indiquait le développement possible et souhaité des 'filières', ne prends pas corps, et que la politique industrielle socialiste va montrer des ressemblances de plus en plus grandes avec celle de ses prédécesseurs. Ces prédécesseurs semblent avoir marqué de grands succès dans l'initiation et l'organisation d'un nombre de mésosystemes: les 'Grands Programmes' de l'industrie pétrolière, de l'énergie nucléaire, de l'aéronautique et du spatial sont universellement connus. La recherche apprend que 'l'Etat' est à même d'organiser des sous-systèmes complexes et de diriger leur évolution, à condition que les pouvoirs publics dominent le côté demande du marché, que l'approvisionnement en matières premières ou la recherche fondamentale passent par ses canaux, et qu'elle fonde un organisme de coordination puissant qui ait accès à des moyens financiers, une information et une expertise suffisantes, et qu'à travers les canaux des 'corps d'état' il ait un bon contact avec la vie des affaires; la bureaucratie et la politique. La possibilité d'harmoniser la stratégie d'entreprises avec les objectifs de la politique industrielle est déterminée de façon importante par les facteurs qui viennent d'être nommés; ceci vaut aussi bien pour les entreprises particulières que pour les entreprises publiques.

L'analyse apprend que la politique industrielle socialiste va ressembler de plus en plus à celle de ses prédecesseurs. L'on continue les "Grands Programmes", mais une politique intégrée, comme celle de 'I'Etat Développeur' socialiste, que l'on avait en vue par rapport aux filières, ne naît pas. Ni 'le Pلan', ni le "Mìnistère de l'Industrie", ni le 'Ministère de la Planification et de l'Aménagement du Territoire' ne semblent pouvoir s'attendre un rôle central coordinateur; au contraire, par la dominance de problèmes du court terme (inflation, balance des paiements) le Ministère de Finances 
retenait un rôle centrall.

L'analyse des 'contrats de plan' entre le 'Ministère de tutelle' et l'analyse publique apprend que cette forme d'organisation quoique donnant la possibilité de concillier l'autonomie avec l'harmonisation de la stratégie d'entreprise et les objectifs publics, donne en fait à l'entreprise de nombreuses possibilités de transformer un tel contrat relationnel à son avantage, vu que le groupe industriel a un avantage d'information et que sa structure organisationnelle est axée sur la réalisation d'objectifs à long terme. Les résultats généraux du chapitre six sont analysés plưs en détail au chapitre sept, à l'aide d'une étude de cas du noyau de la politique industrielle socialiste: la 'filière élecronique'. Deux branches se trouvent être concernées: la télécommunication et l'industrie des ordinateurs. Les développements avant 1981 sont comparés avec ceux qui suivent les nationalisations, l'évolution de quatre entreprises spécifiques étant particulièrement prise sous la loupe: Thomsom, Bull, CGE en Matra.

Finalement, dans le chapitre huit, l'on tire quelques conclusions concernant l'éffectivité de la politique industrielle française pendant la période 1981-1986, et l'on porte un jugement sur le caractère utilisable des concepts théoriques discutés pour l'étude de problèmes concrèts d'organisation. 


\section{DANKWOORD}

Het schrijven van een proefschrift heeft jets van het maken van een lange reis, waarop het gezegdle "eenzaam, maar niet alleen" van toepassing is.

Tot het maken van een lange reis wordt men geinspireerd. In mijn geval kwam de aansporing in eerste instantie van Prof. dr. H.W. Lambers, die in zijn werkkolleges en later als voorzitter wan de vakgroep mijn belangstelling voor de institutionele economische theorieën opwekte. Prof. drs. Jan Zuidema heeft met zijn artikelen en in tal van gesprekken getoond welke beperkingen de econoom parten spelen en welke moeilijkheden hem wachten als hij over de grenzen van de traditionele discipline heen wil kijken.

Toen besloten was de tocht door de Franse economie aan te vangen was een van de eerste, die mij letterlijk en figuurlijk vergezelde Pierre Lebelle. Hij was niet alleen zeer behulpzaam bij het opstellen van de eerste. Franse brieven, maar toonde mij ook welk een volharding nodig is om tot de kern van de Franse bureaucratie door te dringen. Een andere belangrijke reisgezel was Paul Beije. Met hem heb ik een onvergetelijke reis langs een groot aantal Franse universiteiten gemaakt met het doel de beginselen van de "Théorie Economie Industrielle' eigen te maken.

Een derde belangrijke steunpilaar was Prof. dr. Jean Pealinck, die niet alleen altijd bereid was tot het leggen van een contact, of het vertalen van een stuk, maar ook bij het organiseren van een" aantal internationale congressen zijn gewicht in goud meer dan waard bleek.

Met inspirators en metgezellen alleen kom je er niet: er zijn ook personen nodig, die de route bespreken, controleren of het pad wordt gevolgd en uiteindelijk beoordelen of het doel is bereikt. Veel dank ben ik verschuldigd aan de promotoren Prof. dr. Wil Albeda en Prof. dr. Hein Schreuder, alsmede aan de leden van de beoordelingscommissie. De promotoren hebben mij de vrijheid gelaten de route en vervoermiddelen te kiezen en hebben het resultaat nauwgezet beoordeeld. De leden van de beoordelingscommissie hebben het lijvige manuscript snel en accuraat gelezen. Hun verlossend jawoord klinkt nog steeds als muziek in mijn oren.

Goed, een reîs wordt uitgestippeld, gemaakt en beoordeeld. Maar hoe belangrijk zijn niet degenen, die zorgen voor het proviand en voor de verwerking van de 'hieroglyfen' en het 'spijkerschrift" tot een leesbaar reisverslag? Eenieder, die mijn tocht van nabij heeft meegemaakt weet van welk een onschatbare waarde Wilma Speijer in deze voor mij is geweest.

Reizen moet je mogelijk gemaakt worden; in dat verband wil ik op deze plaats mijn ouders gedenken en Marga bedanken. Zij boden mij elk op hun eigen wijze de ruimte, zonder welke ik aan het eind van de straat al weer zou zijn teruggekeerd.

Ik heb van mijn tocht door de Franse economie genoten, ik hoop dat zulks ook voor de llezer gellt. 


\section{REFERENTIES}

Adams, W.J., en Chr., (1986), "French Industrial Policy", Washington D.C.: the Brookings Institution".

ADEFI (1983), Economie Industrielle, Paris: Economica.

Admiraal, P.H., (1979), "Mesopotamiè; Land tussen Markt en Plan?". Economische Statistische Berichten, 24-10-1979, pp. 1110-1115.

Admiraal, P.H., (1987), "Economische Orde", in: Admiraal en Blom (red).

Admiraal, P.H., en H.W. Blom, (red), (1987), "Van alle Markten Thuis", Opstellen aangeboden aan J.R. Zuidema ter gelegenheid van zijn afscheid als hoogleraar aan de Erasmus Universiteit Rotterdam, "s-Gravenhage: Universitaire Pers Rotterdam.

Aglietta M., A. Orléan en G. Oudiz (1981), "Des adaptions différenciées aux contraintes internationales", Revue Economique, pp. 660-712.

Aglietta, M., en R. Boyer, (1982), "Une Industrie Compétitive en France et dans le monde", Journées de Travail sur la Politique Industrielle de la France, Ministère de la Recherche et de l'Industrie, Paris.

Albeda, W. (1971), Sociaal-Economisch beleid en economische orde, Rotterdam: Universitaire Pers

Albeda, W., (1977a), "Participatie in Planning; de Franse Ervaring"', ESB, 30-11-1977, pp. 1180-1183.

Albeda, W. en P. Vos, (1977b), "De Overlegstructurur in de Economische Orde", in: Economische Orde, Pre-adviezen van de Vereniging voor Staathuishoudkunde, Leiden: Stenfert Kroese.

Albeda, W. (1986a), "The Future of the Welfare State", Maastricht: Presses Interuniversitaires Européennes.

Albeda, W. en J. Wemelsfelder, (1986b), "De verzorgingsstaat, slopen of renoveren"? Assen: Van Gorcum.

Albeda, W. en M.D. ten Hove, (1986c), "Neocorporatisme: evolutie van een gedachte, verandering van een patroon", Kampen: Kok.

Albin, S.J., (1971), "Uncertainty, Information Exchange and the Theory of Indicative Planning", the Economic Journal, march, pp. 61-90.

Alchian, A.A , $_{n}$ en H. Demsetz, (1972), "Production, Information Costs, and Economic Organization", American Economic Review, pp. 777-795.

Anastossopoulos, J.P., (1979), "Les voies de l'autonomie", Dossier l'entreprise puplique en guestion I, Revue française de Gestion, mars-awril.

Anastossopoulos, J.P., (1980), "La Stratégie des Entreprises Publiques", Paris, Dalloz Gestion.

Anastossopoulos, J.P. en B. Stora (1982), "Pour une nouvelle relation état-entreprise publique" "Revue française de gestion, no. 36, juin-juillet-aout, pp. 23-26.

Anastossopoulos, J.P., G. Blanc and P. Dussaugé, (1985), "Les Multinationals Publiques", "Paris, PUF.

Andreff, V., (1984), "Les Entreprises Publiques, Cours d'U.V, en Lisence", Fascicule I et II, Université des Sciences Sociales de Grenoble.

Andrews, W.G. en S. Hoffman (ed), (1981), The Fifth Republic at Twenty, Albany: State University of New York Press.

Arena, R., (1983), "Mésoanalyse et Théorie de l'Economie Industrielle", in: ADEFI.

Arena, R., M. Rainelli en A. Torre, (1984), "Du Concept à l'Analyse de Filière: une Tentative d'Eclaircissement Theorique", LATAPSES, Université de Nice. 
Armour, H.O. en D.J. Teece, (1978), Organizational structure and economic performanice: A test of the multidivisional hypothesis, Bell Journal of Economics, 9. pp. 106-122.

Armour, H.O., en D.J. Teece, (1980), Vertical integration and Technologicall Innovation, Review of Economics and Statistics, LXII, no. 3, august, pp. 490-494.

Arrous, J., (1982), La Coordination entre les Firmes et à l"Intërieur des Firmes: vers une (re) définition de I'Economie Industrielle", in: ADEFI.

Arrow, KJ., (1962), Economic Wellfare and the Allocation of Resources for Invention, in: The Rate and Direction of Incentive activity, Economic and Social factors, National Bureau of Economic Research, pp. 609-626, Princeton: Princeton University Press.

Arrow, K.J., (1969), The organization of Economic Activity: Issues Pertinent to the Choice of Market versus Non-market Allocation, in: The Analysis and Evaluation of Public Expenditure: the PPB System, vol. 1, US Joint Economic Committee, Washington DC: US Government Printing Office.

Arrow, K.J., (1974), "The Limits of Organization", New York: Norton.

Arrow, K.J., (1985), The Economics of Agency, in Pratt. W en R Zeckhauser eds.

Artus, P., C. Bismut en M. Debonneuil, (1981), "La Pénétration Etrangère sur le Marché Francais: vingt années plus une", Economie et Statistique, pp. 3-39.

Atreize, (1976), "La Planification Française en Pratique", Paris: Editions Ouvrières. Aujac, (1960), "La Hierarchie des Industries dans un Tableau des Echanges Interindustriels", Revue Economique, vol.11, no. 2, mars, pp. 169-238.

Bain, J.S., (1956), "Industrial Organization"" New York: Wiley.

Balassa, B. (1979), "L'Economie Française sous la Cinquième République 1958-1978", Revue Economique no. 6, pp. 939-973.

Ballassa, B." (1981), "The French Economy Under The Fifth Republic 1958-1978", in: W.G. Andrews en S. Hoffmann (eds).

Balassa, B., (1985), "French Industrial Policy under the Socialist Government", American Economic Review, may 1985, pp. 315-319

Bandt, J. de, (1983a), "La Politique Industrielle: Réponse de l'Etat-Nation a la Crise?", Revue d"Economie Industrielle no. 23, 1er Trimestre, pp. 36-56.

Bandt, J. de, (1983b), "Les Nationalisations: la Gestion du Secteur Public et du Système Productif", Revue d'Economie Politique, no. 5, pp. 704-713.

Bandt, J. de, (1983c), "Vous avez dit 'fillière'?" in: La politique industrielle, Cahiers français no. 212 , p. 34.

Bandt, J. de, (1985), "La Filière de Production Comme Catégorie de la MésoDynamique Industrielle", Cahiers du CERNEA, no. 16, juin.

Bandt, J. de (1987), "French Industrial Politics, Successes and Failures", in: A Competitive Future for Europe, Beije, Groenewegen, Kostoulas, Paelinck, Van Paridon (eds).

Barney, J.B., en W.G. Ouchi (eds) (1986), "Organizational Economics", California, San Francisco: Jossey-Bass Publishers.

Barraux, J., (1982a), "La Rentrée des Nationalisés", Le Nouvel Economiste, no. 352, pp. $44-45$.

Barraux, J., (1982b), "Industrie; Le Programme Chevènement", Le Nouvel Economiste, no. 363, 22-11-1982, pp. 34-35.

Barraux, J., (1982c), "L'Etat et ses 4000 Entreprises", le Nouvel Economiste no. 327, 8-3-1982, pp: $38-44$.

Barraux, $J_{n,}$ (1983), "Quelle Politique pour I'Industrie", Le Nouvel Economiste, no. $370,10-1-1983$, pp. 34-39.

Barreau, J. en A. Mouline, (1987), L'Industrie électronique française: 29 ans de relations Etat-groupes industriels (1958-1986), Paris: LGDJ.

Barreau, J., en J. le Nay, (1982), "Les restructurations des groupes français de l'électronique 1974-1981", Revue d’économie industrielle, no. 21, 3e trimestre. 
Barré, R., (1986), "Science and Technology Policy in France", Futures, voll. 18, no. 2, april, pp. 298-308.

Bauchet, P., (1966), "La Planification Française", Paris: Editions de Seuil.

Bauchet, P., (1986), "Le Plan dans I'Economique Française", Paris: Economica.

Bauer M, en E. Cohen, (1981), "Qui Gouverne les Groupes Industriels? Essai sur I'Excercice du Pouvoir et dans le Groupe Industriel", Paris, Editions du Seuil.

Bauer, M., en E. Cohen, (1983), "The Invisibility of Power in Economics; Beyond Markets and Hierarchies", in: A. Francis, J. Turk en P. Willman (eds).

Bauer, M., en E. Cohen, (1985), "Les grandes Manoeuvres Industrielles"; Paris: Belfond.

Baumol, W.J. (1980), "'Public and Private Enterprise in a Mixed Economy", London: McMillan.

Baumol, W.J., J. Panzar en R. Willig, (1982), "Contestable Markets and the Theory of Industrial Structure", New York: Harcourt Brace Jovanovich Inc.

Beaud, M., (1985), "La Politique Economique de la Gauche", Tome II, Le grand écart, Paris: Syros.

Begeer, W., L.H. Klaassen en J.R. Zuidema (red) (1973), "Economie dezer Dagen", Rotterdam: Universitaire Pers Rotterdam.

Behrens, P., (1985), "The firm as a complex institution", Journal of Institutional and Theoretical Economics, pp. 62-75.

Behrens, P., (1986), "Industrial Policy and the Nature of the Firm, Comment", Journal of Institutional and Theoreticall Economics, 142, pp. 109-113.

Bellon, B., (1980), "Le pouvoir Financier et I'Industrie en France", Paris: Editions de Seuil.

Bellon, B. en J.M. Chevalier, (1983), (eds) "L'Industrie en France", Paris: Flammarion.

Bellon, B., (1983), "Cinq Préalables pour une Pollitique Industrielle", in: Bellon and Chevalier (eds).

Bellon, B., en J.M. Chevalier, (1983), "Les Nouveaux Enjeux de la Compétivité", in: Bellon and Chevalier (eds).

Benson, J.K., (1975), "The organizational network as a political economy", Administrative Science Quarterly, june, pp. 229-249.

Bertsch, B. en J.A. Stam (1986), "Industriebeleid in Japan nader bezien, De electronische industrie", Economische Statistische Berichten, pp. 86-92.

Beije, P.R., J. Groenewegen, I. Kostoulas, C. van Paridon en J. Paelinck, (red) (1987), "A Competitive Future for Europe?, Towards a New European Industrial Policy", London: Croom Helm.

Beije, P.R. en J. Groenewegen (1989a), "The French Communication Industry: Defined and Analyzed through the Sociall Fabric Matrix and Network Analysis, paper voor de 31ste Annual Conference of the Western Social Science Assocation, april, Albuquerque, New Mexico, USA.

Bidault, F., (1984), "Strategic Management and the Resources of Industrial Organization", Ecole Supérieur de Commerce de Lyon.

Bienayme, A., (1984), "Les choix économiques du IXe Plan", Revue economique; vol. 35 , no. 6, novembre, pp. $1261-1288$.

Bishop, M., en J. Kay, (1988), "The impact of privatisation on the performance of the UK public sector", paper presented at the 15th annual conference of EARIE in Rotterdam.

Bizaquet, A., (1983), "L'Importance des Entreprises Publiques dans I'Economie Française et Europeenne", Revue Economique, mai, pp. 434-465.

Black, J., (1968), "The Theory of Indicative Planning"', Oxford Economic Papers, 20, november, pp. 301-319.

Blanc, J., en C. Brule, (1982), "Les Nationalisations Françaises en 1982", Notes et Etudes Documentaires, Paris: La Documentation Française. 
Blaug, M., (1976), "Paradigms versus Research Programmes", in: S.J. Latsis (ed). Blaug, M., (1980), "The Methodology of Economics", Cambridge: Cambridge University Press.

Bloch-Lainée, F., (1959), "A la Recherche d'une Economie Concertếe" "Paris: Editions de l'Europe.

Bloch-Lainée, F., (1981), La France en Mai 1981, Paris, La Documentation Française. Blondel, Marc, (1983a), "Des Bases Conflictuelles pour la 1er Loi du Plan", FOHebdo no. $1741,16-2-1983$.

Blondel, Marc, (1983b), "IXe Plan: la Reconversion?" FO-Hebdo no. 1749, 20-4-1983. Blondel, Marc, (ongedateerd), "La CGT - Force Ouvrière et la Planification", Paris. Boekemia, F., en D.J. Kamann (red), (te verschijnen in 1989) "Netwerken", Groningen: Wolters Noordhoff.

Boland, L.A., (1978), "Time in Economics v.s. Economics in Time: the "Hayek Problem"', Canadian Journal of Economics, XI, no. 2, pp. 240-261.

Bolland, L.A., en G. Newman, (1979), "On the Role of Knowledge in Economic Theory", Australian Economic Papers, pp. 71-80.

Boland, L.A., (1979), "Knowledge and the Role of Institutions in Economic Theory", Journal of Economic Issues, vol. XIII, no. 4.

Bolloc'h, Le Ch., (1986), "La Politique Industrielle Française en Matière d'Electronique 1974-1985", Thèse de Doctorat de I'Université Paris-Nord.

Boltho, A., (1982), ed, "The European Economy; Growth and Crisis", Oxford: Oxford University Press.

Bonnaud, J.J., (1970), "Les Instruments d'Execution du Plan Utilisés par I'Etat à l'Egard des Entreprises", Revue Economique, juillet, pp. 554-596.

Bonnaud, J.J., (1975), "Planning and Industry in France" in: Hayward and Watson (1975) (eds).

Bonnefous, E., M. Blin, J. Moinet, R. Tomasini, H. Torre, (1982), Rapport d'information au nom de la Commission des. Finances, du Contrôle budgêtaire et des Comptes économiques de la Nation sur le contrôle des Entreprises Publiques: Sociétés industrielles nationalisées par la loi no. 82-155 du 11 février 1982, Sénat no. 179.

Boogerman, E., (1986), "Frankrijk 1981-1986", Amsterdam: Thomas Rap.

Boot, P., (1987), "Overheidsondernemingen; de mogelijkheden en misverstanden", Tijuschrift voor politieke Economie, jaargang 9, no. 1, pp. 55-73

Booij, $H_{*},(1977)$ "Theorieen over de ontwikkelingen in de economische orde", Preadviezen van de Vereniging van de Staathuishoudkunde, pp. 1-23.

Booij, H.s, (1987), "Nieuwe Institutionele Economie", in: P.H. Admiraal en H.W. Blom (red).

Borcherding, T.E., W. Pommerekne en F. Schneider, (1982), "Comparing the Efficiency of Private and Public Production:" the Evidence from five Countries", Zeitschrift für Nationalökonomie suppl. 2.: pp.127-156.

Bornstein, M., (1975), "Economic Planning East and West", Cambridge (Mass): Ballinger Pub. Co.

Boublil, A., (1977), "Le Socialisme Industriel", Paris: PUF.

Boublil, A., (1980), "Filières Industrielles et Politique Economique", Annalles des Mines, janvier, pp; 53-58.

Boublil, A., (1981), "Nationalisations: les Conditions du Succès", Revue Française d'Administration Publique, No. 20, oct.-dec., pp. 7-13.

Brouwer, M., (1985); "Ontwikkelingen in de Theorie van de Industriële Organisatie (I), Statische Theorieën", Economische Statistische Berichten, 28-8-1985, pp. 851856.

Brouwer, M., (1986), "Ontwikkelingen in de Theorie van de Industriële Organisatie II, Dynamische Theorieên", Economische Statistische Berichten, 30-7-1986, pp. 749756. 
Brown, CJ., (1980), "Industrial Policy and Economic Planning in Japan and France", National Institute Economic Review no. 93, august, pp. 59-75.

Bruggeman, $F_{n},(1985)$, "Industrie de Biens d'Investissement et Crise:Reflexions à Propos de l'Echec du Plan Machine-Outil", Revue d'Economic Industrielle no. 31, 1er Trimestre, pp. 222-236.

Brus, W., (1965), "Some General Problems of Decentralization in a Socialist Economy, in: Brus (1975), The Economics and Politics of Socialism, London: Routledge and Kegan Paul.

Buck, T., (1982), "Comparative Industrial Systems; industry under capitalism, central pllanning and self-management", London: McMillan.

Burink, F., en J. Groenewegen (1983), "Industriebeleid à la Française", Economische Statistische Berichten, 13-7-1983, pp. 622-627.

Butler, RJ., (1983), "Control through Markets, Hierarchies and Communes: a Transactional Approach to Organizational Analysis", in: A. Francis, J. Turk en P. Willman (eds).

Cahiers Français Les, (1977), "No Spécial sur la Planification", mai-juin.

Calori, R., en R. Noël, (1986), "Successful Strategies in French High Technology Companies", Long Range Planming, vol. 19, no. 6, pp. 54-65.

Carassus, J., (1978), "The Budget and the Plan", in: J.Hayward en O. Narkiewicz, (eds), London: Croom Helm.

Carré, J.J., P. Dubois, en E. Malinvaud, (1972) "La Croissance Française", Paris". Editions du Seuil.

Catinat, M. en J. Maurice, (1984), "Analyse quantitative de la Stratégie Macro-Economique du IXe Plan", Revue Economique, décembre, pp. 1007-1090.

Cave, $M_{*}$ en $P_{*}$ Hare, (1981), "Alternative Approaches to Economic Planning", London: MacMillan.

Cawson, A., (1982), "Corporatism and welfare. Social policy and State intervention in Britain", London: Heinemann

Cawson, A., P. Holmes, en A. Stevens, (1985), "The Interaction between Firms and the State in France; the Telecommunications and Consumer Electronics Sectors", Cambridge.

CF (Cahiers Français), điverse nummers, Parijs: La Documentation Française.

CFDT (1982)," "Nationalisations: la voie francaise", Colloque Parti Socialiste, 11-12 décembre.

CFDT, (1983), "Pour un Développement Régional Démocratique", Paris.

CFDT, (1984), "Aujourd'hui", Revue du Changement Social, no: 65, La Planification en question.

CFDT, (1984), "Les Acquis du IXe Plan", Paris.

CGT, (1982), "Nationalisations: la voie française", Colloque Parti Socialiste, 11-12 décembre.

Chandler, A.D., (1982), "The M-Form: Industrial Groups, American Style", European Economic Review 19 , pp. 3-23.

Chapuy, J., and J. Virole, (1982), "Le Secteur Public Industriel des Communautés Européennes", Revue d'Economie Politique, septembre-decembre, vol, 92, 5/6, pp. 945-963.

Chevalier, J., (1977), "L'Economie Industrielle en Question", Paris: Calmann-Lévy.

Chevènement, J.P., (1982a), "Allocution d'Ouverture, une Politique Industrielle pour la France", in: Ministère de la Recherche et de l'Industrie. Actes des Journés de Travail des 15-16 novembre 1982, La Documentation Française.

Chevènement, J., (1982b), "Entreprises nationales et politique industrielles", discours prononcé devant les PDG des entreprises nationales du secteur industriel et des organismes public de recherche, 31 augustus.

Chevènement, J.P. (1983), "La Cohérence d'une Politique Industrielle", Les Cahiers Frangais, no. 212, juillet-septembre 1983. 
Coase, R.H., (1937), "The Nature of the Firm", Economica, pp. 386-405.

Coase, R.H., (1984), "The New Institutional Economics", Journal of Institutional and Theoretical Economics, 140, pp. 229-231.

Coenen-Huther, J., (1979), "Planning in Frankrijk", Rijswijk: Sociaal Centraal Planbureau.

Cohen, S.S., (1969), "Modern Capitalist Planning: The French Model", Berkeley California: University of California Press.

Cohen, S., and Gourevitch (eds), (1982), "France in the Troubled World Economy", London: Butterworth.

Combret de, F., (1983), "Le Redéploiement Industriel", Les Cahiers Français, no. 212, juillet-septembre 1983, pp. 8-14.

Commissariat Général du Plan, (1978), "Rapport sur l'Adaptation du VIIe Plan", Paris.

Commissariat Général du Plan, (1979), "Rapports sur les Options du VIIle Plan", Paris.

Commissariat Général du Plan, (1981), "Le Plan Intêrimaire, Stratégie pour deux ans 1982-1983", novembre.

Commissariat Général du Plan, (1982a), "Commission Chargée de Suivre l'Exécution du Plan Intérimaire (1982-1983)", Dossier de Presse.

Commissariat Général du Plan, (1982b), "Groupes Long Terme Mis en Place pour la Préparation du IXe Plan", Communique de Presse.

Commissariat Général du Plan, (1982c), "Quelques Scenarios d'Evolution à Moyen Terme", novembre.

Commissariat Général du Plan, (1982d), "Economie Industrielle", Paris.

Commissariat Génêral du Plan, (1982e), "Les Entreprises Publiques du Sectéur Concurrentiel; Décisions Stratégiques", Modes de Fonctionnement et Relations avec l'Etat, Paris: Telesis.

Commissariat Général du Plan, (1982f), "Aides à l'Industrie", Parïs.

Commissariat Général du Plan, (1983a), "La Tarification Publique, quelques Réflexions pour le IXe Plan", Paris: La Documentation Française.

Commissariat Général du Plan, (1983b), "La Lettre du 9e Plan", no. 1-7.

Commissariat Général du Plan, (1983c), "Analyse des Contrats du Plan par Firm", Notice no. 7, Les Cahiers Français, no. 212.

Commissariat Général du Plan, (1983d), "Politique Industrielle et Contrats de Plan en 1984"* Notice no. 8, Les Cahiers Français, no. 212, juillet-septembre 1983.

Commissariat Général du Plan, (1983e), "La Diffusion de la Recherche et de l'Innovation dans I'Industrie", GSI no. 4, Paris: Cahiers des Groupes de Stratégie Industrielle no. 14.

Commissariat Général du Plan, (1983f), " Rapport Annexé à la Première loi de Plan, Tome 2, La Strategie et les Grandes Actions", Paris: La Documentation Française.

Commissariat Général du Plan, (1983g), "Rapport Annexé à la Deuxième loi de Plan, les Moyens d'executions du 9e Plan", Paris: La Documentation Française.

Commissariat Genéral du Plan, (1983h), "Rapport Annexé à la Première loi de Plan, Tome 1, Les choix du 9e Plan", Paris: La Documentation Française.

Commissariat Général du Plan (1985), "Faire Gagner Le France", Paris: une rapport du Plan sur l'Horizon 2000.

Commission du Bilan (1981), (Président Francois Bloch Lainé La France en Mai 1981: Forces et Faiblesses", Paris: La Documentation Française.

Commission Nationale de Planification, (1982), "Développement des Activites Productive", Commission de Travaill, no. 2.

Commons, J., (1934), "Institutional Economics", Madison: The University of Wisconsin Press. 
Conn, D., (1978), "Economic Theory Comparative Economic Systems: a Literature Survey". Journal of Comparative Economics 2, pp. 355-381:

Cotta, A.s (1977), "Reffexion sur la Politique Industrielle de la France", Le Redéploiement Industriel, Etude de Politique Industrielle, no. 17. Ministère de l'Industrie.

Cotta, A., (1978), "La France et l'Impératief mondial", Paris: PUF.

Cotta, A., (1983), "L'Entreprise Publique Aujourd'hui Réalité Economique ou Réalité Politique?" Revue Commentaire, décembre.

Courbis, R., (1970), "The Fifi Model Used in the Preparation of the French Plan", Economics of Planning, vol. 12, pp. 37-78.

Cowling, K., (1987), "An industrial strategy for Britain: the nature and role of planning", International Review of Applied Economics, vol. 1, nr. 1, pp. 1-22.

Cox, A., (1982), "Politics, Policy and the European Recession", London: MacMillan.

CREI, (1981-1983), "La filière électronique", Document travail, no. 109, Paris,

CREI, (1984), "La filière électronique", Document travail, no. 111, Paris.

CREI (ongedateerd), Readings d'Economie Industrielle, vol. VI Filière, Paris.

Crozier, M., en E. Friedberg, (1977), "L'Acteur et le système; les contraintes de l"action collective", Paris: Seuil.

Curzon Price, V., (1981), "Industrial Politics in the European Community", London: MacMillan.

Cyert, R.M. en J.G. March, (1963), "A Behavioral Theory of the Firm", Englewood Cliffs N.J.: Prentice-Hall.

Daems, H., (1982), "Inter-Industry Differences in Forward Vertical Integration by Ownership", Working Paper 82-1.

Daems, H. en S. Douma, (1984), "Concurrentie: analyse en strategie", Deventer: Kluwer.

Dahlman, C.J., (1979), "The problem of externality", Journall of Law and Economics, 22 , pp. 141-162.

Dahrendorf, R., (1982), ed, "Europe"s Economy in Crisis", London: Weidenfelld and Nicolson.

Dannebaum U., W. Fach en G. Simonis, (1984), "Das 'modell' Frankreich, Politik und Oekonomie in Etatistischem System"; Politische Vierteljahreschrift, april.

Daube, M., (1983), "Les contrats de plan des entreprises publiques", Economique et Politique, avril, pp. 16-21.

Davies, D., en P. Brucato Jr., (1987), "Property rights and transaction costs" theory and evidence of privately-owned and government-owned entreprises", Journal of Institutional and Theoretical Economics, vol. 143, no. 1, pp. 722.

Dekker, P., (1989), "Overheidsplanning in West-Europa", Rijswijk: Sociaal Cultureel Planbureau.

Delauney, Q. (1984), "Kind van Marx en Thatcher: de Franse nationalisaties", Tijdschrift voor politieke Ekonomie, februari.

Delapierre, M. en J. Zimmermann, (1984), "Les multinationales de l'électronique: des stratégies différences" "Revue d'economique industrielle, no. 28 , pp. 9-35.

Délébeque, B., (1984), "Le IXème Plan et la Réforme de la Planification Régionale", paper gepresenteerd in Jelenia-Gora Congres, 10-12 october.

Delion, A.G., (1981), "Les Entreprises Publiques et le Concept d'Efficacité", Revue Française d'Administration Publique, no. 20, octobre-decembre, pp. 13-31.

Delion, A.G., en M. Durupty, (1982), "Les Nationalisations 1982" "Paris: Economica.

Delion, A., en M. Durupty, (1983), "Chronique des entreprises publiques", Revue française d'Administration publique, diverse nrs.

Delion, A., (1984), "Le Controle des Entreprises Publiques", Cahiers Française 214, janvier-fevrier, $\mathrm{pp} \cdot 42-44$.

Delion, A., (1984), "L'évolution du contrôle des entreprises publiques en France", Revue française d'Administration publique, no. 32, octobre-décembre, pp. 688- 
Delors, J., (1978), "The Decline of French Planning", in: S. Holland (ed): Beyond Capitalist Planning, Basil Blackwell.

Delors, J., (1982), "France: between Reform and Counter-Reform", in: R. Dahrendorf (ed)

Demsetz, H., (1967), "Towards a Theory of Property Rights", American Economic Review, proceedings, may, pp. 347-359.

Demsetz, H., (1969), "Information and Efficiency: Another Viewpoint", Journal of Law and Economics, april, pp. 7-22.

Dercksen, W.J., (1986), "Industrialisatiepolitiek Rondom de Jaren Vijftig: een sociologische beleidsstudie", Assen: Van Gorcum.

Dorn, J.A. (1986), "Industrial Policy and the Nature of the Firm", Comment, Journal of Institutional and Theoretical Economics, 142, pp. 101-108.

Douma, S.W., (1987), "Competitive Strategies and Economic Theories of Organization", Paper, Madrid: 14th EARIE-conference.

Dow, G.K., (1987). The function of authority in transaction cost economics, Journal of Economic Behaviour and Organization 8, pp. 13-38.

Dreesman, A.C.R., (1979), "Limperg Leer der Externe Oganisatie", in: Limperg Instituut (red), Reflecties op Limperg, Deventer: Kluwer.

Dreyfus, P., (1980), "The Efficiency of Public Enterprise: Lessons of the French Experience", in: Baumol, (ed).

Dreyfus, P., (1982), "Tutelle Unique et Plan Glissant", Interview, le Nouvel Economiste, no. $327,8-3-1982$, pp. $40-41$.

Dreyfus, P., (1983), "Ma Politique Industrielle", Les Cahiers Français, no ${ }^{212}$, juilletseptembre 1983 , pp. 28-31.

Driehuis, W., en J. v.d. Doel, (1979), "Werkloosheid en Economische Orde", in: Werkgelegenheid: recht of beleid?, Geschriften voor de Vereniging van Arbeidsrecht, Alphen aan de Rijn: Samson

Dugger, W.M., (1983), "The Transactions Cost Analysis of Oliver E. Williamson: a New Synthesis?" Journal of Economic Issues, vol. XVII, no. 1, pp. 95-114.

Duprat, H., (1983), "Problèmes Posés par les Nomenclatures et l'Agrégation", in: ADEFI.

Durand, M., (1988), "Les rapports Etat-industrie, un cadre d'analyse* le cycle du produit", no. 3, pp. 419-441.

Durupty, M., (1983), "l'Entreprise publique comme instrument de la politique de l"Etat" Communication XIXème congrès international des sciences administratives, Tokyo.

Durupty, M., (1984), "Les relations entre l'Etat et les entreprises publiques en Europe occidentale", Revue Française d'Administration publique, no. 32, octobredecembre, pp. 675-688.

Dutailly, J.C., (1981), "La Crise du système productif", Economie et Statistique, novembre, pp. 3-20.

Dyas, G., en H. Thanheiser, (1976), "The Emerging European Enterprise, Strategy and Structure in French and German Industry", London: MacMillan.

Dyson, K, en S. Wilks (1983), eds, "Industrial crisis: a comparative study of the State amnd Industry"', Oxford: Robertson.

Eisner, R., (1983), "The Ninth Plan: a Review and Evaluation of the Preparatory Phase", 3-3-1983, Paris.

Elliasson, G., (1984), "The Micro-Foundations of Industrial Policies", in: Jacquemin, A. (ed)

Elster, (1983), "Explaining technical change", Cambridge: Cambridge University Press.

Encaoua, D., en A. Jacquemin, (1982), "Organizational Efficiency and Monopoly Power", European Economic Review 19 (1982), pp. 25-51.

Epstein, N., "Et voilà! Le Minitel", Intermediair, jrg. 22, nr. 33, pp. 7-11.

Ergas, E., (1984), "Corporate Stratégies in Transition", in: Jacquemin, A. (ed) (1984). 
Escambert, B., (1983), "La Priorité Industrielle", Les Cahiers Françaiss, no. 212, juilletseptembre 1983 , pp. 3-8.

Estrin, S., en P . Holmes, (1980), "The Performance of French Planning 1952-1978*", Economics of Planning, vol. 16, no. 1, pp. 1-19.

Estrin $_{*}$ S., en P. Holmes, (1983a), "French Planning in Theory and Practice", London: Allen and Unwin.

Estrin, S., en P. Holmes, (1983b), "How Far is Mitterrand from Barre?" "Challenge, november/december, pp. 46-50.

Estrin, S., en V. Perotin, (1986), "Nationalisation and Privatisation; a Survey", London School of Economics, draft paper.

Eijk, C.J. van, (1980), "De modelmatige achtergrond van het WRR-rapport, Plaats en toekomst van de Nederlandse industrie", Economische Statistische Berichten, dd. 10-9-1980, pp. 1006-1009.

Fabius, L., (1983), "Priorité à la Modernisation de l'Industrie", Les Cahiers Français, no. 212 , juillet-septembre 1983 , pp. 36-40.

Faire, (1976), "A quoi sert le 7e Plan?", Paris: Graphiti, pp. 49-55.

Fama, E., en M. Jensen, (1983), "Separation of Ownership and Control", Journal of Law and Economics, 26, pp. 301-325.

Fama, E., en M. Jensen, (1983), "Agency Problems and Residual Claims", Journal of Law and Economics, 26, pp. 327-350.

Foray, D., (1985), "Questions à 'I'Industrial Organization' et Constitution de l'Industrie en tant que'object d'Analyse", paper voor de Journées d'Etude Franco-Britannique, Rennes.

Francis, A., J. Turk en P. Willman, (1983). "Power, Efficiency and Institutions, A Critical Appraisal of the "Markets and Hierarchies Paradigm"', London: Heinemann.

Friedberg, E., (1979), "Staat und Industrie in Frankreich", International Institute of Management, Berlin.

Furuboth, E.G., en S. Pejovich, (1974), (eds), "The Economics of property rights", Cambridge Mass.

Galbraith, J.K., (1967), "The New Industrial State", Penguin books, Middlesex, England.

Galbraith, J.K., (1973), "Economics and the public purpose", Boston: Houghton Mifflin.

Gamby, B., en J.P. Balladur, (1981), "Les Institutions Economiques", in: J.P. Page.

Gascuel A., (1962), "Aspects du quatrième Plan", Paris: Berger-Levrault.

Gauron, A., en J. Maurice, (1980), "Des Politiques Economiques pour le VIIIe Plan", Revue Economique, septembre, vol. 31, nir. 5, pp. 894-929.

Gilessen van, M. (1983), "Twee jaar Mitterrand: een Tussenbalans", Internationalle Spectator", november, pp. 721-729.

Gillard, L., (1975), "Premier Bilan d'une Recherche Economique sur la MésoAnalyse", Revue Economique, no. 3, pp. 478-516

Gilly, J.P., en F. Morin, (1981), "Les Grands Groupes Industriels en France", Paris: La Documentation Française.

Godfroy, A., (1981), "Netwerken van organisaties: strategieën, spellen, structuren", s-Gravenhage: VUGA.

Godfroy, A., (1987), "The useful powerlessness of policy-networks", paper gepresenteerd op het $8^{\text {ste }}$ EGOS-congres; Antwerpen.

Gomez, A., en M. Sauzay, (1982), "Le rôle moteur du secteur public", Ministère de la Recherche et de l'Industrie.

Gongeon, P., B. Ponson en Y. Pinard, (1984), "La Filière Electronique, Regards sur l'actualité", avril, nr. 100, Paris: La Documentation Française, pp. 23-40.

Gougeon, $P_{* *}$ en B. Ponson, (1983), "Concentration et Groupes Industriels", Cahiers Français 211, mai-juin, pp. 53-61. 
Goto, A., (1982), "Business Groups in a Market Economy", European Economic Review, pp. 53-70.

Goudard, D., (1984), "Tarifs et equilibre financier des entreprises publiques", Revue économique, IXième Plan, vol. 35 , no. 6 , pp. 1213-1238.

Goudzwaard, B. (1970), "Ongeprijsde schaarste", Den Haag: v. Stockum en Zoon.

Goux, Chr, en X. Greffe, (1982), "Mobiliser l'Ensemble des Forces de la Nation", Le Monde 17-3-1982.

Granovetter, M., (1985), "Economic Action and Social Structure: The Problem of Embeddedness", American Journal of Sociology, 3, nowember, pp. 481-450.

Gray. J.. (1984), "Hayek on Liberty", Oxford: Oxford University Press.

Gray. J., (1987), "The Economic Approach to Human Behaviour; its Prospects and Limitations" in: Radnitzky en Bernholz (eds).

Green, D., (1982), "Government and Industry in France: A Contractual Approach". Public Money, septembre, pp. 27-31.

Green, D., (1983a), "Strategic Management and the State: France", in: Dyson K. en S. Wilks (eds)

Green, D., (1983b), "The French Institute of Industrial Developpement", in: Hindley, B. (ed).

Green, D., (1983c), "Giscardisme-Industrial Policy", in: Wright, V. (ed).

Green, D.* (1984), "Mitterrand: From Socialism to Realism", Economic Affairs, apriljume, pp. 23-26.

Greffe, X, (1983), "Les Entreprises Publiques dans la Politique de l'Etat", Revue Economique, no. 3 , mai, pp. 496-534.

Groenewegen, J., (1982), "The discretionary economy", boekbespreking van Marc Tool (1979), in Intermediair 5-3-1982.

Groenewegen, J. en F. Burink (1983), "Industriebeleid à la française", Economische Statistische Berichten, dd. 13-7-1983, pp. 622-627.

Groenewegen, J., (1984), "Review of Estrin and Holmes" in:" the Journal of Economic Issues, septembre 1984, pp. 914-918.

Groenewegen, J., (1985), "Industriebeleid in Frankrijk", Maandschrift Economie, jrg. 49. pp. 226-240.

Groenewegen, J., (1987a), "About Government Policies, Industrial Systems and Strategies of (public) enterprises", The case of the "Filière électronique", paper gepresenteerd op het $8 \mathrm{e}$ EGOS-congres, Antwerpen.

Groenewegen, $J_{.,}(1987 \mathrm{~b})$, "Macro and industrial politics in a market economy: the Dutch case", paper gepresenteerd op het seminar "Economic policy-industrial policy - the missing link", Institut for Samfundsøkonomi og Planlagning, Roskilde, Denmark.

Groenewegen, J., (1987c), "L'Etat développeur: de Franse weg", in: H. Schenk (1987).

Groenewegen, J., (1987d), "La Série à l'Américaine, Transactiekostentheorie nader bezien", in: Admiraal en Blom (red).

Groenewegen, J.* (1988b), "Reforms in a centrally planned economy; constraints and possibilities, the case of the Soviet Union", Paper gepresenteerd op het $15 \mathrm{de}$ EARIE-congres, Rotterdam.

Groenewegen; J." (1988c), "Recent developments in the EEC and possible consequences for ASEAN", paper gepresenteerd op het seminar EEC-ASEAN, Institute for South-East Asian Studies, Singapore.

Groenewegen J., en P.R. Beije (1989a), "The French Communication Industry: Defined and Analyzed through the Social Fabric Matrix and Network Analysis", paper voor de 31ste Annual Conference of the Western Social Science Assocation, april, Albuquerque, New Mexcico, USA.

Groenewegen, J., (1989b), "Successen en mislukkingen in het Franse industriebeleid, de cases van de telecommunicatie, computerindustrie, olieindustrie en de machinebouw vergeleken", Research Memorandum Vakgroep Economische 
Organisatievormen EUR.

Groenewegen, J., $(1989 \mathrm{c})$, "Theorieën van economische organisatievormen", in: Boekema en Kamann (red) (te verschijnen in 1989).

Grossman, J., en J.E. Stiglitz, (1976), "Information and Competitive Price Systems", American Economic Review, vol. 66 , no. 2, pp. 246-253.

Groves, T., (1973), "Incentives in Teams", Econometrica, vol. 41, pp. 617-663.

Gruchy, A.G. (1972), "Contemporary Economic Thought, the contribution of Neoinstitutional Economics", London: MacMillan.

Gruchy, A.G., (1982), "Planning in Contemporary Institutional Thought", Journal of Economic Issues, vol. XVI, no. 2, june, pp. 371-379.

Gruchy, A.G., (1984), "Uncertainty, Indicative Planning and Industrial Policy", Journal of Economic Issues, vol. XVIII, no. 1, march, pp. 159-180.

Haan, P. de, en R. Fernhout, "Economische Planning en Wetgeving", Socialisme en Democratie, no. 7/8, julv/augustus 1982 , pp. 363-373.

Habbernay van, G., (1984), "Frankrijk na twee jaar Mitterrand", Tijdschrift woor Politieke Economie, februari, pp. 28-47.

Hafsi, T., (1984), "Entreprise Publique et Politique Industrielle", Paris: McGraw-Hill.

Hagedoorn, (1984), "Some Notes on the Theory of the Firm", Centre for Technology and Policy Studies, Apeldoorn: TNO.

Hahn, F., (1980), "General Equilibrium, Public Interest", Special Issue: "The Crisis in Economic Theory, pp. 123-138.

Hakansson, H. (ed), (1986), "Industrial Technological Developments", A Network Approach, London: Croom Helm.

Hare, P., (1985), "Planning the British Economy", New York: St. Martin's Press.

Harrod, R.F., (1939), "Dynamic Theory", in: Sen (1970).

Harrod, R.F., (1973), "Economic Dymamics", London: MacMillan.

Haut Conseil du Secteur Public, (1984), "L'extension du secteur public: les objectifs et les réalisations", Rapport 1984 (volume 1) et volume 2: la gestion du secteur public: le suivi des activités. Paris: La Documentation Française.

Haut Conseil du Secteur Public, (1988), Rapport 1986, "Evolution et gestion du secteur public", Paris: La Documentation Française.

Hayek, F.A., von, (1937), "Economics and Knowledge", Economica, pp. 33-54.

Hayek, F.A., von (1945), "The Use of Knowledge in Society", American Economic Review 35, pp. 519-530.

Hayward, J., en M. Watson, (1975), "Planning Politics and Public Pollicy", Cambridge: Cambridge University Press.

Hayward, $J_{n,}$ (1978), "Planning in Europe", London: Croom Helm.

Hayward, J., (1982), "France: the Strategic Management of Impending Collective Impoverishment", in Cox (ed).

Hayward, J., (1986). "The State and the Market Economy, Industrial Patriotism and Economic Intervention in France", Brighton: Wheatsheaf Books Ltd.

Hayward, J., en O. Narkiewicz, (1978), eds, "Planning in Europe", London: Croom Helm.

Hendrikse, G., en H. Schreuder, (1987), "Economische Organisatietheorieën"', ESB 29-1987, pp. 810-815.

Hervouët F., (1983), "L'Etatisation, Enfant Naturel de la Nationalisation, Chronique Administrative", Revue d"Administration Publique, pp. 1319-1334.

Herzog, Ph., (1983), "Faire du Renouveau de la Production pour I"Emploi l'Axe du XIe Plan", Economie et Politique, avril 1983, pp. 12-15.

Heijdra, B.J., A.D. Lowenberg, en R.J. Mallick, (1988), "Marxism, Methodological individualism and the New Institutional Economics", Journal of Institutional and Theoretical economics, 144, pp. 296-317.

Hindley, B, (1983), ed. "State Investment Companies in Western Europe", London: MacMillan. 
Hirschleifer $\mathbb{J}_{*,}$ "Where are we in the Theory of Information?" American Economic Review, may 1973, pp. 31-39.

Hodgson, G.M., (1988a), "Economics and Institutions", Oxford: Polity Press.

Hodgson, G.M, (1988b), "Institutional economic theory "the old versus the new", paper for the presentation at the European-North American workshop on Institutional Economics, 26-29 june 1988, London.

Holland, S., (1975), "The Socialist Challenge", London: Quartet Books.

Holman, O., en K. Poot, "Europese monetaire Integratie, Struktuurpolitiek en bezuinigingsbeleid in Frankrijk", Tijdschrift voor Politieke Economie, 6e jaargang; $\mathrm{nr}$., pp. $57-83$.

Holmes, P., (1985), Nationalisation/dênationalisation: la part des Mythes", Economie et Humanisme, no. 284 , juillet-aout, pp. $79-81$.

Hoogstraten, H.J, (1982), "Investeringsgedrag van ondernemingen": een analyse van strategische posities, strategievorming en ondernemingsresultaten, dissertatie THTwente.

Hough, J.R., (1979), "Government Intervention in the Economy of France", in: P. Maunder (ed).

Hough, J., (1982), "The French Economy", London: Croom Helm.

Hutchison, T.W., (1984), "Institutional Economics Old and New", Journal of Institutional and Theoretical Economics, 140, pp. 20-29.

Hutchison, T.W., (1986), "Industrial Policy: a Note on the History of Ideas", Journal of Institutional and Theoretical Economics, vol. 142, no. 1, march, pp. 238.

Imai, K., en H. Itami, (1984), "Interpenetration of organization and market", International Journal of Industrial Organization, 2, pp. 285-310.

Ingen Housz, A., (1982), "De reorganisatie van de Franse economie", ESB, dd. 20-11982.

Ingen Housz, A., (1982), "Frankrijk: de tweede fase", ESB dd. 20-10-1982.

Insee, (1951), "La France industrielle de 1946", Paris: La Documentation Française.

Insee, (1981), "La Crise du Système Productif", Paris: La Documentation Française.

Jacquemin, A. en E. de Ghellinck, (1980), "Family Control, Size and Performance in the Largest French Firms", European Economic Review 13, (1980), pp. 81-91.

Jacquemin, A. (ed), (1984), "European Industry: Public Policy and Corporate Strategy", Oxford: Clarendon Press.

Jacquemin, A. en M. Rainelli, (1984), "Filières de la Nation, fillières d'Enterprises", Revue Economique, march, pp. 379-392.

Jacquemin, A., (1986), "Selectiemechanismen een marktmacht in de industriële organisatie", Cabay: Louvairn Le Neuve.

Jarillo, J.C., (1988), "On Strategic Networks", Strategic Management Journal, vol. 9, no. 1 , pp. 31-41.

Jensen, M. en M. McMeckling, (1976), "Theory of the Firm: Managerial Behavior Agency Costs and Ownership Structure", Journal of Financial Economiics, 3, pp. 305-360.

Johannisson, B., (1987), "Beyond Process and Structure: Social Exchange Networks", International Studies of Management and Organization, Vol. XVII, no. 1., pp. 323.

Johanson, J. en L.G. Mattson, (1987), "Interorganizational Relations in Industrial Systems: A Network Approach Compared with the Transaction - Cost Approach", International Studies of Management and Organization, vol. XVII, no. 1, pp. 3448.

Johnson, Ch. (1982), "MITI and The Japanese Miracle", Stanford, Cal. : Stanford University Press.

Johnson, T. en I. Hägg, (1987), "Extrapreneurs - Between Markets and Hierarchies", International Studies of Management and Organization, vol. XVII, no. 1, pp. 6474. 
Join-Lambert, M.T. (1984), "La Planification Sociale dans le IXe Plan", Revue Economique, no. 6, novembre, pp. 1147-1172.

Jones, G., (1983), "Transaction costs, property rights and organizal culture: an exchange perspective", Administrative Science Quarterly, 28, pp. 454-467.

Jong, H.W. de, (1980), "Het Nederlandse structuurbeleid: "De zichtbare vinger aan de onzichtbare hand", Sectorstructuurbeleid: mogelijkheden en beperkingen, Preadviezen bij het WRR-rapport Plaats en toekomst van de Nederlandse Industrie, Den Haag, 1980, pp, 21-53.

Jong, H.W. de, (1981a), "Marktorganisatie, Mededinging en Prijsworming", Economisch Statistische Berichten 23/30-12-1981, pp. 1268-1280.

Jong, H.W. de, (1981b), "Dynamische Markttheorie", Leiden: Stenfert Kroese.

Jong, H.W. de (1982), "De Maatschappij voor Industriële Projecten; Voortrekker van Industrieel Herstel", Economische Statistische Berichten, 14-7-1982, pp. 708-712. Jong, H.W. de, (1985), "Industriepolitiek: een lege Doos"', Economische Statistische Berichten, 27-2-1985, pp. 192-197.

Jong, H.W. de, (1986), "European Organization: entrepreneurial economics in an organizational setting", in: H.W. de Jong en W.G. Shepherd (eds) 1986.

Jong, H.W. de, en W.G. Shepherd, (eds), (1986), "Mainstreams in Industrial Organization", Book I and II, Dordrecht: Kluwer.

Jong, H.W. de, (1987), "Externe Organisatie en Industriepolitiek", in: H. Schenk (red).

Jong, H.W. de, (ed), (1988), "The structure of European Industry", Studies in Industrial Organization, Vol. 1, Den Haag: Martinus Nijhoff Publishers.

Kapp, K., (1968), "In Defence of Institutional Economics", The Swedish Journal of Economics, vol. LXX, no. 1, pp. 1-15.

Karpik, L., (1972), "Les politiques et les logiques d'action de la grande entreprise industrielle", Sociologie du Travail, 13, pp. 82-105.

Karpik, L., (1987), "Success and Limits of French Corporations: Industrial Elite, Structure and Strategy, ISA Conference, july 1987.

Kay, J.A., and Z.A. Silberstone, (1984), "The New Industrial Policy-Privatisation and Competition", Midland Bank Review, spring, pp. 8-16.

Kay, J.A., and D.J. Thompson, (1986), "Privatisation: a Policy in Search of a Rationale", Economic Journal 96, pp. 18-32.

Keating, M. en P. Hainsworth, (1986), Decentralisation and Change in Contemmporary, France: Aldershot.

Keizer, P.K., en J. Soeters (red) (1987), "Economie, Sociologie en Psychologie: Visies op integratie", Assen/Maastricht: Van Gorcum.

Keizer, P.K. en J. Soeters, (1987), "Economie als gedrags- en maatschappijweten* schap: een integratieprobleem" in: P. Keizer en J. Soeters (red).

Keyser, W. en R. Windle, (1978), (eds) "Public enterprise in the EEC", Part IV France, Alphen aan de Rijn, Sijthoff en Noordhoff.

Kikkawa, M., (1983), "Shipbuilding, Motor cars and Semiconductors"' the Diminishing Pole of Industrial Policy in Japan", in: G. Shepherd, F. Duchene en Ch. Sanders (eds).

Kirzner, I.M., (ed), (1982), "Method, Process and Austrian Economics", Washington DC: Heath and Company.

Kirzner, I.M., (1982), "Uncertainty, Discovery and Human Action: a Study of the Entrepreneurial Profile in the Missesian System" in: Kirzner (ed) 1982.

Klein, B., R.G. Crawford en A. Alchian, (1978), "Vertical Integration, Appropriable Rents, and the Competitive Contracting Process", Journal of Law and Economics, 21, pp. 297-326.

Knoke, D. en J. Kuklinski, (1982), Network analysis, London: Sage.

Kornai, J., (1971), "Anti-Equilibrium", Amsterdam.

Kornai, J., (1980), "The Dilemmes of a socialist economy: the Hungarian experience", 
Cambridge Journal of Economics, 4, pp. 147-157.

Kreukels, A.M.J., (1980), "Planning en Planningproces. Een Verkenning van SociaalWetenschappellike Theorievorming op Basis wan Ruimtelijke Planning", "sGravenhage: VUGA Boekerij.

Kuisel, R.F., (1981), "Capitalism and the State in Modern France", renovation and economic management in the twentieth century, Cambridge: Cambridge University Press.

Lachmann, L.M., (1976), "From Mises to Shackle: An Essay on Austrian Economics and the Kaleidic Society", Journal of Economic Literature, vol. 14, pp. 54-62.

Lafay, G., (1981), "La Dynamique de spécialisation des Pays Européens", Revue Economique.

Laganier, J., (1985), "Représentation du système productif et politique industrielle", in: Les Politiques Industrielles, ADEFI, Paris: Economica.

Lambers, H.W., (1958), "Over de Institutionele Markt", De Economist, pp. 753-775.

Lambers, H.W., (1967), "Over het Ondernemingsdoel", TVVS no. 10/11. pp. 207-213.

Lammers, C.J., (1983), "Organisaties Vergelijkenderwijs, Ontwikkeling en Relevantie van het Sociologisch Denken over Organisatie", Utrecht: Spectrum.

Lange en Taylor, (1970), "On the Economic Theory of Socialism", in: Lippincott (ed)

Langlois, R., (1986), "Economics as a Process: Essays in the New Institutional Economics", New York: Cambridge University Press.

Latsis, S., (1972), (ed), "Method and Appraisal in Economics", Cambridge: Cambridge University Press.

Laurent, P., (1986), "Contribution pour l'Etude des Relations de Pouvoir par l'Analyse de Filière, Mêmoire pour le Dîplome d'Etudes Approfondies sciences de gestion", Ecole Supérieure de Commerce de Lyon.

Laurencin, J.P. en J.Ch. Monateri, (1984), "L'Industrie Française dans L'Europe", Revue d'Economie Industrielle no. 27, pp. 42-56.

Lecomber, R., (1970), "Government Planning with and without the Cooperation of Industry", Reflections on the British Experience, Economics of Planning, 10, 1-2, pp. 53-87.

Leibenstein, H., (1966), "Allocative Efficiency vs. "X"-Efficiency", American Economic Review, 56, pp. 392-415.

Lehmbruch, G., (1982), "Neo-corporatism in comparative perspective", in: Lehmbruch en Schmitter, 1982.

Lehmbruch, G., en Ph.C. Schmitter (eds) (1982), "Patterns of corporatist policymaking", London" Sage.

Lemettre, J.F., (1983), "Pour une politique du système industriel", Revue d'économie industrielle, no. $23, \mathrm{pp} .66-78$.

Lemettre J.F., (1984), "Gérer la Contradiction", Cahiers Française 214, janvier-fevrier, pp. 44-47.

Leuthy, H., (1955), "The State of France, New York: Praeger.

Lepas, A., (1983), "La Politique Industrielle vue par le Patronat, les Cahiers Français no. 212 , juillet-septèmbre 1983 , pp. 60-67.

Leray, C., (1983a), "Efficacité Economique des Nationalisations Industrielles de 1982", Paris: Thèse.

Leray, C., (1983b), "L'Appréhension de l'Efficacité dans les Entreprises Publiques Industrielles et Commerciales", Revue Economique, mai, pp. 612-654.

Liggins, D., (1975), "National Economic Planning in France", Hampshire: Saxon House.

Lindbeck, A., (1981), "Industrial Policy as an issue in the economic environment", The World Economy, pp. 391-405.

Lindenberg, S., en H. de Vos, (1985), "The Limits of Solidarity: Relational Contracting in Perspective and Some Criticism of Traditional Sociology", Journal of Institutional and Theoretical Economics, 141, pp. 558-569. 
Lindsay, C., (1980), "Is there a Theory of Public Organisations"? In Clarkson and Martin (eds).

Lippincott, B.E., (ed) (1970), "On the Economic Theory of Socialism" New York: Augustus M. Kelley.

Littlechild, S.C., (1982), "Equilibrium and market forces" in: Kirtzner (ed).

Loasby, B.J.; (1982), "Economics of Dispersed and Incomplete Information" in: Kirzner (ed).

Lowe, A., (1977), "On Economic Knowledge: Toward a Science of Political Economics", New York: Harper and Row.

Lowe, A., (1980), "What is Evolutionary Economics", Journal of Economic Issues vol. XIV no. 2, pp. 247-254.

Luca, C., (1983), "La Deuxième Loi du XI\{e\} Plan, Problèmes de Coherences et Points d"Appui", Economic et Politique, novembre, pp. 31-35.

Luethy, H., (1957), "French Against Herself", New York: Meridian Books.

Lutz, V., (1969), "Central Planning in a Market Economy", London: Longmans.

Machin, H. en V. Wright (eds), (1985), "Economic Policy and Policy-Making under The Mitterrand Presidency 1951-1984", London.

Machlup, F., (1967), "Theories of the Firm: Marginalist, Behavioral, Managerial", The American Economic Review, pp. 1-33.

MacNeil, I., (1987), "Relational Contract Theory as Sociology: A Reply to Professors Lindenberg and de Vos" Journal of Institutional and Theoretical Economics, 143, pp. 272-290.

Malkin, D. (1984), "Mutation Industrielle et IX\{e\} Plan", Revue Economique, pp. 1091-1147.

Malkin, D, (1986), "IXth French Plan", Futures vol. 18, no. 2, april, pp. 295-315.

Malsot, J., (1980), "Fillieres et Effects de Dominations dans le Système Productif", Annales de Mines, janvier, pp. 29-40.

Marchesnay, M., en Y. Morvan, (1982), "Micro, Macro, Meso"', Revue d'Economie Industrielle, no. 8, pp. 99-103.

Marchesnay, M., (1982), "Où en est la Mésoanalyse?" in: ADEFI.

Marchesnay, M., (1984), "Recueil d"articles et travaux récents (1982-1984)", Montpellier: Travaux de L'ERFI.

Marchesnay, M., (1985), "La compléxité du système industriel: clarifier pour réguler", Communication aux rencontres Franco-Brittaniques du CNRS, 30-31 mai, Rennes.

Marger, P.L., (1982), "Le Dialoque Social, Democratie Industrielle et Nouvelle Productivité", in: Ministère de la Recherche et de l'Industrie (1982b).

Massé, P., (1965a), "Le Plan ou l'Auti-Hasard", Paris, Editions Gallimard.

Masse, P., (1965b), "The French Plan and Economic Theory", Econometrica, vol. 33, pp. $265-276$.

Massé, P., (1980), "Repenser du Plan", Revue Economique, septembre 1980, pp. 813814.

Massé, P., (1986), "Une Lettre de M. Pierre Massé", Le Monde 13-5-1986.

Maunder, P., (1979) (ed), "Government Intervention in de Developed Economy", London: Croom Helm.

Mazier, J., en C. Stoffaës; (1983), "Les secteurs Industriels face à la crise (1974-1981)" in: Le tissu industriel, Cahiers Français 211, mai-juin, pp. 19-28.

Mazzolini, R., (1979) "Government controlled Enterprises", New York: Wiley and Sons.

McArthur, J: H. en B. R. Scott, (1969), "Industrial Planning in France", Cambridge (Mass.): Harvard University Press.

Meade, J.E., (1971), "The Controlled Economy", London: Allen and Urwin.

Meijknecht, P.A.M., (1979), "Planverbintenissen: vormgeving aan privaatrechtelijke verbintenissen, in het bijzonder ten dienste van het economisch beleid mede 
bezien tegen de achtergrond van het Poolse recht", Zwolle: Tjeenk Willink. Mescheriakoff, A.S., (1985), "L'Autonomie des Entreprises Publiques, Eléments pour une Théorie", Revue du Droit Public, pp. 1575-1623.

Messeca, E., (1983a), "Forces et faiblesses de l'industrie actuellement" in: Le tissu industriel, Cahiers Français no. 211, mai-juin, pp. 65-71.

Messeca, E., (1983b), "Analyse Sectorielle du Tissu Industriel" in: Le tissu industriel, Cahiers Français 211, mai-juin, pp. 37-48.

Mikus, R., (1976), "Die Theorie der Indikativen Planung unter besonderer Berücksichtigung des Problems unvollkommener Information", Berlin: Duncker und Homblot.

Miller, D. en H. Mintzberg, (1983), "The case for configuration"', in Morgan (ed).

Miller, J.B. (1979), "Meade on Indicative Planning: A Review of Informational Problems", Journal of Comparative Economics, 1979, pp. 27-40.

Millward, et. al, (1983), Public Sector Economics, London: Longman.

Millward, R., and D.M. Parker, (1983), "Public and Private Enterprise: Comparative Behaviour and Relative Efficiency", in: Millward et al., (eds).

Ministère de l'Economie et des Finances, (1982), "Le Project du Reforme de Planification", les Notes bleues, 21 juin 1982, no. 76.

Ministère de la Recherche et de l'Industrie, (1982a), "Conventions de Stabilité", Etudes de Politique Industrielle, no. 33, mai, Paris: La Documentation Française".

Ministère de la Recherche et de l'Industrie, (1982b), "Une Politique Industrielle pour la France", Actes des Journées de Travail des 15 et 16 novembre 1982, Paris: La Documentation Française.

Ministère de l'Industrie, Lettre 101, diverse jaargangen, Paris.

Ministère de la Recherche, (diverse jaargangen) Lettre RT, Paris.

Ministère du Plan et de l'Aménagement du Territoire, (1982a), "Project de Calendrier de la Préparation du IXe Plan", Communique du Presse.

Ministère du Plan et de l'Aménagement du Territoire, (1982b), "Communique du Presse: sur I'Installation de la Commission Nationale du Planification: sur les Groupes Tripartites du Strategie Industrielle" (GSI).

Mintzberg, H.,(1987a) . The strategy concept I: Five P's for strategy, California Mangement Review, vol. 30, nr. 1, fall, pp. 11-22.

The Strategy concept II, Another look at why organizations need strategies, California Management Review, vol. 30, fall 1987, pp. 25-32.

Mintzberg, H., (1987b), The Design School, Reconsideration of the Basic Premises of Strategic Management, september 1987, unpublished paper.

Mistral, J., (1980), "Fillères et Compétivité: Enjeux de Politique Industrielle", Anales des Mines, janvier, pp. 41-52.

Mitterrand, F., (1982), "Discours", zonder titel, Ministère de la Recherche et de l'Industrie (1982b).

Molitor, B., (1980), "Politique Industrielle et Planification en France", Revue Economique, septembre, vol. 31 , nr. 5 , pp. $837-852$.

Monsen, R., (1984) "French Socialists March to the Right", Challenge septemberoktober, pp. $37-42$.

Monteverde, $\mathrm{K}$. en D. Teece, (1982), "Appropriable rents and quasi-vertical integration", Journal of Law and Economics 25 , pp. 321-328.

Montfort, J., (1983), "A la Recherche des Filières de Production" "Economique et Statistique, no. 151, pp. 3-12.

Montfort, M.J. en J.C. Dutailly, (1983), Les Filières de Production", INSEE, Paris: Archives et Documents no. 67.

Montfort, J. (1985), L'analyse des filières de production, ADEFI, Paris: Economica. Montmorillon, de B., (1986), "Les Groupes Industriels", Paris: Economica.

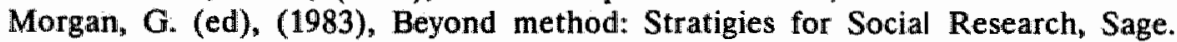


Morvan. Y", (1983), "La Politique Industrielle Depuis la Fin de la Seconde Guerre Mondialle", Revue d'Economie Industrielle, $1^{\text {er }}$ Trimestre, pp. 19-35.

Morvan, Y., (1985), "L'economie industrielle et la filière", in: l'analyse de fullière, ADEFI, Paris: Economica.

Murrell, $P_{\text {., }}(1979)$, "Planning and Coordination of Economic Policy in Market Economies", Journal of Comparative Economics 3, pp, 145-166.

Muysken, J., en H. Schreuder, (1985), (red), Economische Wetenschappen: eenheid in verscheidenheid?, Assen/Maastricht: van Gorcum.

NEDO, (1976), "Control of Public Enterprises in France", London.

Nelson, R., en S. Winter, (1982), "An evolutionary theory of economic change", Cambridge, (Mass.): Harvard University Press.

Newman, G., (1976), "An Institutional Perspective on Information", International Social Science Journal, vol. 28 , no. 3, pp. $466-492$.

Nizard, L., (1973), "La Planification et Societé, Colloque d'Uriage, Grenoble: Presses Universitaires de Grenoble.

Noorderhaven, N., (1987), Contractual relations and the interorganizational quest for control, Paper presented at the 8th EGOS colloquium, Antwerp, 22-24 july, 1987.

Noorderhaven, N.G., (1988), "Agency theory as a framework for organizational studies", Researchmemorandum nr. RR 1988-01, Faculteit Bedrijfskunde, Universiteit Groningen.

North, D.C., (1978), "Structure and Performance: the Task of Economic History", Journal of Economic Literature, vol. XVI, september; pp. 963-978.

North, D.C., (1981), "Structure and Change in Economic History", New York.

North, D.C., (1986), "The New Institutional Economics", Journal of Institutional and Theoretical Economics, vol. 142, no. 1, march, pp. 230-238.

Odagiri, H., (1986), "Industrial Policy in Theory and Practice", in: H.W. de Jong en W.G. Shepherd (eds).

OECD, (1981-1986), "Economic Surveys: France", Paris.

OECD, (1986), "La Politique d"Innovation en France", Paris: Economica.

Ouchi, W., (1980), "Markets, Bureaucracies and Clans", Administrative Science Quarterly, 25, pp. 129-141.

Ouchi, W., en O.E. Williamson, (1981), "The Markets and Hierarchies Program of Research: Origins, Implications, Prospects", in: A. van de Ven en W. Joyce (eds).

Ozenda, M. en O. Senhaji, (1984), "Le 9e Plan pour 1984-1988", Regards sur l'Actualité, no. 98, Paris: La Documentation Française.

Pagé, J.P., (1981), "Profil Economique de la France au Seuil des Années quatre-vingt, Paris: La Documentation Française.

Parti socialiste, "Les organes de controle du secteur public", Annex II, Congrès: La Voie Française, décembre 1981.

Pelkmans, J., (1985), "The Functions of Public Sector Enterptises in the European Community", Maastricht: European Institute of Public Administration.

Peltzman, S., (1976), "Towards a more general theory of regulation", Journal of Law and Economics, 19 ,pp. 211-240.

Pennings, J.M., (ed), (1985), "Organizational strategy and change", London: JosseyBass.

Perez, R. (1983), "Introduction méthodologique sur l'articulation filières - Stratégies", in: ADEFI, 1983, Economica.

Perotin, V. and S. Estrin, (1986), "'Does Ownership Matter"? Draft Paper for CNRSESRC-project.

Perroux, F., (1955), Note sur la notion pôle de croissance, Economie Appliqué, Série D, voll. 8.

Perroux, F., (1962), "Le Quatrième Plan Francais", Paris: PUF Collection, 'Que saisje?'.

Perrow, C., (1981), "Markets, Hierarchies and Hegenomy", in: A. van de Ven en W. 
Joyce (eds).

Perrow, C. (1979), "Complex Organizations, Gilenview, Illinois: Scott, Foresman en Company.

Pesant, Chr., (1983), "Les entreprises publiques à l'heure des contrats de plan", Economie et Politique, mars, pp. 45-48.

Petit, $P_{n}$ (1983), Origine et Originalité de la Planification Française", Paris: Cepremap, no. 8314.

Pferrer, J., en J. Salancik, (1978), "The External Control of Organizations, a Resource Dependence Perspective", New York: Harper and Row:

Podevin, G. (1985), "Tentative d'Evaluation du Plan Français de Développement de la Machine-outil. (1982-1985)"'. Communication, Colloque Franco-Britannique, Rennes: GESI, novembre 14 en 15.

Podevin, G., (1985), "I'Industrie Francaise des Machines-outils à Métaux: un Déclin Décisif"? Revue d'Economie Indastrielle no. 31, 1 er trimestre 1985, pp. 236-246.

Popper, K.R., (1961), "The Poverty of Historicism", London: Routledge and Kegan Paul.

Popper, K.R., (1973), "The Open Society and its ennemies, vol. I and II, London: Routledge and Kegan Paul.

Porter, M.E. (1980), "Competitive Strategy, Techniques for Analyzing Industries and Competitors", New York: The Free Press.

Porter, M.E., (1981), "The contribution of industrial organization to strategic management" Academy of Management Review, jrg. 6, pp. 609-620.

Porter, M.E., en V.E. Millar, (1985), "How Information Gives You Competitive Advantage", Harvard Business Review, august, pp. 149-160.

Porter, M.E., (1985), Competitive Advantage: Creating and Sustaining Superior Performance, New York: The Free Press.

Porter, P.K., G. Scully en D. Slottje, (1986), "Industrial Policy and the Nature of the Firm", Journal of Institutional and Theoretical Economics, voll. 142, no. 1, march, pp. 79-101.

Posner, R.A. (1977), "Economic Analysis of Law", Boston.

Postma, J.K.T., (1977), "Het Zevende Franse Plan", ESB, 4-5-1977, pp. 408-413.

Pratt, W. en R., Zeckhauser (eds), (1985), Principals and Agents: the Structure of Business, Boston: Harvard Business School.

Pryke, R., (1981), "The Nationalized Industries", Policies and Performance Since 1968, Oxford: Martin Robertson.

Putterman, L., (1987), "Corporate governance, Risk-bearing and Economic Power: A Comment on Recent Work by Oliver Williamson", Journal of Institutional and Theoretical Economics (JITE), 143, pp. 422-434.

Quinet, E. en L. Touzery, (1986), "Le Plan Français, Mythe ou Nécessité", Paris: Economica.

Radnitzky, G., en P. Bernholz (1987), (eds), "Economic Imperialism", New York.

Rainelli, M, (1977), "A Propos des Découpages de l'Industrie", Revue d'Economie Industrielle, no. 1 , pp. 57-79.

Rainelli, M., (1979), "Sur les Découpages de l'Industrie", Revue d'Economie Industrielle, no. 8, pp. 104-109.

Rainelli, M., (1983), "La Construction du Niveau Intermediaire" in: ADEFI.

Rapp, L., (1986), "Les Groupes d'Entreprises Publiques", "Que sais-je', Paris: PUF

Redwood, J., en J. Hatch, (1982), "Controlling Public Industries", Oxford: Basil Blackwell.

Rees, R., (1984), "Public Entreprise Economics", London: Weichenfeld and Nicolson Ltd.

Regards sur l'Actualité, (1982), "La Nouvelle Planification", Paris: La Documentation Françalise.

Regards sur l'Actualité, (1984), no. 98, "Le 9e Plan pour 1984-1988", Paris: La 
Documentation Française.

Reynaud-Cressent, B., (1982), "Les Contenus Théoriques du Concept de Branche dans une Problématique de Définition de la Branche d'Edition de Livres"', in: ADEFI.

Reynolds, L., (1981), "Foundations of an Institutional Theory of Regulation", Journal of Economic Issues, vol. XV, no. 3, september, pp. 641-656.

Richardson, G.B., (1959), "Equilibrium, Expectations and Information", The Economic Journal, june, pp. 223-237.

Richardson, G.B., (1960), "Information and Investment", Oxford: Oxford University Press.

Richardson, G.B., (1972), "The Organization of Industry", The Economic Journal, 82, pp. $883-896$.

Richonnier, M, (1984), "Les Hésitations Offensives, le Cas de I'Electronique", Revue d'Economie Industrielle no. 27, pp. 91-108.

Robins, J.A., (1987), "Organizational Economics: Notes on the Use of Transaction Cost Theory in the Study of Organizations, Administrative Science Quarterly, 4

Robinson, J., (1980), "Time in Economic Theory", Kyklos, vol. 33, pp. 219-229.

Rocard, M., en J. Attali, (1977), "Socialisme en Ekonomische Politiek", Economische Notities no. 2, Amsterdam: Wiardi Beckman Stichting.

Racard, M., (1982), "Les Enjeux de la Decennie 80, Discours d"Installation de la Commission Nationale de Planification", Communique de Presse, 8 septembre 1982.

Roehl, Th., (1983), "A transactions cost approach to international trading structures: the case of the Japanese General Trading Companies, Hitotsubashi Journal of Economics, 24, pp. 119-135.

Roelandt, Th., (1986), "Vervlechtingsconglomeraten en sectorstructuurbeleid", Researchmemorandum, vakgroep Economische Organisatievormen, EUR.

Romme, S., (1987), "Organizational and Economic Approaches to Firm Strategy: a Behavioral Perspective", Paper for 8th EGOS-Colloquium, Antwerp.

Roobeek, J.M., (1988a), "Een race zonder finish; de rol van de overhell in de technologie wedloop", Amsterdam: VU-uitgeverij.

Roobeek, J.M., (1988b), "Telecommunications, an industry in transition", in: H.W. de Jong (ed).

Ross, S.A., (1973), The Economic Theory of Agency: "The Principal's Problem, American Economic Review, mei, pp. 134-139.

Rotheim, R.J., "Contingent Contracts and Uncertain Economics", Journal of Post Keynesian Economics, pp. 637-639.

Roy le, Th. (1984), "Les Contrats de Plan",in: 'Nationalisations", Cahiers Français 214, janvier-fevrier, pp. 47-51.

Ru de, H., (1981), "Staatsbedrijven en Staatsdeelnemingen, Juridische Aspecten en de Gevolgen daarvan over het Economische Beleid", dissertatie Nijmegen.

Ru de, H., (1982), "The Public Enterprise as an Instrument of State Politics; the Netherlands, unpublished paper.

Sautter, Chr. (1982), "France" in: Boltho A. (ed).

Sauzey, M., (1982), "Le Rôle Moteur du Secteur Public", in: Ministère de la Recherche et de l'Industrie (1982b).

Savary, J., (1984), "French Multinationals", London: Pinter.

Schenk, H., en J. Korpel, (1985a), "Complementariteit en Samenwerking, Beschouwingen rond het Thema Technologie en Industriële Structuur", (rapport in opdracht van $E Z / S o z a w e / O$ en $W$ ), Groningen.

Schenk, H., (1985b), "Industriepolitiek: een 'common sense'- benadering", Maandschrift Economie, 49, (3), pp. 192-213.

Schenk, H., (red), (1987), "Industrie- en Technologiebeleid", Groningen: WoltersNoordhoff. 
Schenk, H., en D.J. Kamann, (1987), "Naar een Ruimtelijk Georiënteerd Specifiek Technologiebeleid", in: Schenk (red).

Scherer, FM., (1970), "Industrial Market Structure and Economic Performance", Chicago: Rane McNelly.

Scherer, F.M., (1980), "Industrial Market Structure and Economic Performance", 2nd ed., Chicago: Rand McNally College Publishing Company.

Scherer, F.M., (1986), "On the Current State of Knowledge in Industrial Organization" in: De Jong en Shepherd (eds).

Schotman, H., (1984), "Investeringsgedrag van Ondernemers", Eindhoven: Koba.

Schreuder, H., (1981), "Maatschappelijke verantwoordelijkheid en maatschappelijke berichtgeving van ondernemingen", Leiden: Stenfert Kroese.

Schreuder, H., (1985a), "Economie (en) bedrijven"; over de bedrijfseconomie als discutabel, spannend en een eigenaardig onderdeel van de economische wetenschappen, Oratie verschenen in Muysken en Schreuder (red).

Schreuder, H., (1985b), "Economic Theories of Organization: An Overview and Assessment of Some Recent Developments" "Research Memorandum, RM 85007, Faculteit der Economische Wetenschappen, Rijksuniversiteit Limburg.

Schreuder, $\mathrm{H}_{\text {, }}$ (1987a), "Economie en psychologie onder één lappendeken", in: $\mathrm{P}$. Keizer en J. Soeters (red).

Schreuder, H., en H. Hendrikx (1987b), "Economische Organisatietheorieën", Economische Statistische Berichten, dd. 2-9-87, pp. 214-299.

Seibel, C., (1975), "Planning in France", in: M. Borstein (ed).

Sen, A, (1970), "Growth Economics", Harmondsworth: Penquin.

Senalt, "Loi Portant Réforme de la Planification", 7 juillet 1982.

Servan-Schreiber, J.J., (1967), "Le Défi Américain", Paris: Editions Denoêl.

Shackle, G.L.S., (1973), "Epistemics and Economics, a Critique of Economic Doctrines", Cambridge: Cambridge University Press.

Shaffer, S., (1984), "Production and Contingent Contracts: Comment", Journal of Post Keynesian Economics, pp. 634-636.

Shepherd, G., F. Duchène en Ch. Saunders, (1983), (eds), Europe's Industries; Public and Private Strategies for Change, London: Pinter.

Shepherd, W., (1976), "Public Enterprise", Lexington (Mass.): Lexington Books.

Shepherd, W., (1985), "The Economics of Industrial Organization", New Jersey: Prentice Hall Inc.

Shonfield, A., (1965), "Modern Capitalism: the Changing Balance of Public and Private Power", London: Oxford University Press.

Simon, F., (1983), "Le préparation du IXe Plan", Le Monde 22-4-1983.

Simon; F., (1986a), "Il était une fois le Pllan", Le Monde 18-4-1986.

Simon, F., (1986b), "Le Plan en question, tout cela mérite débat", Le Monde, 4-111986.

Simon, H, (1959), "Theories of Decision Making in Economic and Behavioral Science", American Economic Review, 49, pp. 253-283.

Simon, H., (1961), "Administrative Behaviour", New York: MacMillan.

Simon, H.A., (1976), "'From Substantive to Procedural Rationality", in: S. Latsis (ed).

Simon, $\mathbb{H}_{\text {, }}(1979)$, "Rational Decision Making in Business Organizations", American Economic Review, 69, pp. 493-513.

Soulage, B., (1983), "La Politique Industrielle dans le 9eme Plan Français", Working Paper, Commissariat Général du Plan.

Soulage, B., (1984), "Etat et Sociètés Nationalisées", in: 'Nationalisations", Cahiers Français no. 214, janvier-février, pp. 36-42.

Soulie, D, (1980), "Filière de Production et Integration Verticale, Annales des Mines", janvier, pp. 21-28.

Spierings, R.C., (1988), "Agency-theorie", Economische Statistische Berichten, 3-81988 , pp. $716-719$. 
Stam, J.A., en B. Bertsch (1986), "Industriebeleid in Japan nader bezien, De electronische industrie", Economische Statistische Berichten, pp. 86-92.

Steen, R. van der, (1988), "Een analysekader voor specifiek industriebeleid", Researchmemorandum, 1988-4, Vakgroep Economische organisatievormen, EUR.

Stein, B.A., (1976), "Collective Ownership, Property Rights and Control of the Corporation", Journal of Economic Issues 10, pp. 298-313.

Stigler, G.J., (1971), "The Theory of Economic Regulation", Bell Journal of Economics and Management Science, pp. 3-21.

Stoffaès, Chr., (1980), "Introduction: filières et stratégies industrielles", Annales des Mines, janvier, pp. 9-20.

Stoffaès, Chr., (1983a), "Objectifs êconomiques et critères de gestion du secteur public industriel", Revue Economique, mai, pp. 656-683.

Stoffaës, Chr, en J. Mazier (1983b), "L"industrie: mal aimée des Français", in Le Tissu industriel, Les Cahiers Français no. 211, Paris: La Documentation Française, pp. 2-3.

Stoffaès, Chr., (1984a), "Le contexte historique", in "Nationalisations industrielles et bancaires", Les Cahiers Français no. 214, Paris: La Documentation Française, p. 3-7.

Stoffaęs, C., (1984b), "Les Restructurations depuis 1982", Cahiers Français 214, janvier-fevrier, pp. 56-60.

Stoffaës, C., (1984), "French Industrial Strategy in Sunrise Sectors", in: A. Jacquemin, (1984).

Stolêru, L., (1969), "L'Impératif Industriel", Paris: Seuil.

Suleiman, E.N., (1974), "Politics, Power and Bureaucracy in France: the Administration Elite" , Princeton, N.J.: Princeton University Press.

Suleiman, E.N., (1979), "Les Elites en France", Paris: Editions le Seuil.

Taddei, D., (1984), "Le IXe Plan: de la rigueur à une politique de l'offre, Revue économique, vol. 35,6 , pp. 1239-1261.

Teece, D., (1980), "Economics of Scope and the Scope of the Enterprise", Journal of Economic Behavior and Organization, no. 1, pp. 223-245

Teece, D., (1984), "Analysis and Strategic Management", California Management Review, spring, vol. XXVI, no. 3, p0p-, 87-110.

Thierry, S.P. en B. Soulage (1983), "Quelles institutions pour une nouvelle politique industrielle", Revue d'économie industrielle, no. 23 , pp. $79-92$.

Thirwall, A.P., (1982), "De-Industrialisation in the United Kingdom, Lloyds Bank Review, vol. 144, pp. 22-37.

Thorelli, H., (1986), "Network: between markets and hierarchies", Strategic Management Journal, vol. 7, pp. 37-51.

Tichy, N., M. Tushman en Ch. Fombrun, (1979), "Social network analysis for organizations"i", Academy of Management Review, vol. 4, no. 4, pp. 507-519.

Tittmus, R.M., (1971), "The Gift Relationship: from Human Blood to Sociall Policy", New York: Pantheon Books Inc.

Toledano, J., (1978), "A Propos des Filières Industrielles", Rubrique Récensions, Revue d'Economie Industrielle no. 6, pp. 149-158.

Tool, M.R., (1979), "'The Discretionary Economy, A normative theory of Political Economy", Santa Monica, California: Goodyear Publishing Co.

Torre, A., (1983), "Contribution de la Théorie de l'Influence Economique à l'Analyse des Filières du Production", LATAPSES, Université de Nice.

Torre A, (1985), "Influence Productive et Structure Industrielles" (une Application a l'Etude du Secteur Public Industriel), Thèse, Université de Nice.

Torre, A., (1985), L'impact du secteur public industriel sur l'économie Françailse: Mésures et critères d'evaluation, Communication au colloque Franco. Britannique, Rennes. 
Truêl, I.L. (1983), "L'Exemple: la Filière Electronique", in: La politique industrielle, Les Cahiers Français, no. 212.

Turpin, E, (1983), "Le tissu industriell régional entre 1954-1975", in: Le Tissu Industriel, Cahiers Français, no. 211, pp. 12-19.

Uitermark, P.J., (1982). "Sectorstructuurbeleid: Industriepolitiek op zoek naar een theorie (I)". Maandschrift Economie, jrg. 46, pp. 67-134.

Ullmo, Y., (1970), "La Planification en France", Paris: Dalloz.

Ullmo, Y., (1975), "France" in: Hayward en Watson (eds).

Van Cayseele, P. en H. Schreuder, (1988), "De economische inbreng in de strategiebepalingen van ondernemingen": een overzicht, paper Vakgroep Bedrijfseconomie, Sectie Organisiatie, Faculteit der Economische Wetenschappen, Rijksuniversiteit Limburg.

Vassille, L., (1982), "Nationalisations, le Secteur Public s'expose à la concurrence", Economique et Statistique, no. 150, décembre.

Vassille, L, (1983), "Une Puissante Logique Industrielle Relie les Activités des Groupes", Economique et Statistique, décembre, pp. 4-28.

Ven, A. v.d., A.J. Liston en G. Walker, (1979), "Coordination patterns within an interorganizational network", Human relations, vol. 32 , no. 1, pp. 19-36.

Ven, A. van de, en W. Joyce, (1981), eds., "Perspectives on Organizational Design and Behaviour, New York: Wiley

Vermaat, A.J.y (1980), "Frictie of Koppeling, Besluitvormingsproblemen in een Gemengde Economie", ESB, 15-10-1980, pp. 1158-1166.

Vermeend, W., (1983), "Fiscale investeringsfaciliteiten", Arnhem: Gouda Quint.

Victorri, J., (1979), Le rôle du secteur public dans la politique économique", Revue economique, no. 1 , pp. $72-87$.

Vigezzi, M., (1983), "L'Utilité du Concept de Système Productif pour la Définition d'une Politique Industrielle", Grenoble: Université de Grenoble.

Villesèche, J., (1984), "Le Plan Câble", Economie et Stratistique, juillet-aout, pp. 2634.

Virole, J., (1984), "L'entreprise publique et le droit des communantés Européennes", Revue Française d'Administration publique, no. 32, pp. 727-738.

Virole, $J_{\text {., }}$ (1978), "France", in: Keyser en Windle (eds).

Vrolijk, $\mathrm{H}_{*,}$ (1982), "Wat is Struktuurbeleid?", in: H. Vrolijk en R. Hengeveld (red).

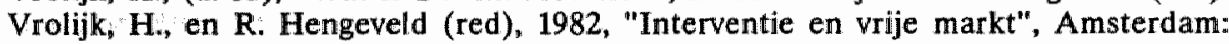
SUA.

Wagener, H.J., (1980), "Economische systemen", Alphen a/d Rijn: Samson.

Wassenberg, A., (red), (1980), "Netwerken: organisatie en strategie", Meppel: Boom.

Wassenberg, A.F.P., (1987) "Bij het scheiden van de overheid leert men de markt kennen", in: Schenk (red).

Weitzman, M., (1976), "The New Soviet Incentive Model", Bell Journal of Economics, vol. 7 , pp. $251-257$.

Wetenschappelijke Raad voor het Regeringsbeleid, W.R.R. (1980), "Plaats en toekomst van de Nederlandse Industrie", Rapporten aan de Regering, 'sGravenhage, Staatsuitgeverij.

Weijden, C.J, van der, "Toestaan of verbieden"?, Een beschouwing rond de Wet Economische Mededinging, Economisch Statistische Berichten, dd. 23/30-1981, pp. 1281-1285.

Weijden, C.J, van der, (1987), "Over toetreding, uittreding en effectieve mededinging", in: Admiraal en Blom (red).

Weijden, C.J. van der, (1988), Syllabus Doctoraal I Economische Orde, EUR, Rotterdam: Stichting Syllabi.

Whitley, R., (1987), "Taking firms seriously as economic actors: towards a sociology of firm behaviour", Organizational Studies, pp: 125-147.

Wilber and Harrison, (1978), "The Methodological Basis of Institutional Economics; 
Pattern model, Story-Telling, and Holism", Journal of Economic Issues, vol. XII, no. 1, maart, pp. 61-89.

Williamson, O.E., (1971), "The vertical integration of production; the market failure considerations, American Economic Review, 61, pp. 112-123.

Williamson, O.E., (1975), "Markets and Hierarchies: Analysis and Antitrust Implications", New York: Free Press.

Williamson, O.E., (1979), "Transaction-cost Economics: the Governance of Contractual Relations", Journal of Law and Economics, 22, pp. 233-261.

Williamson, O.E., (1980), "The Organization of Work, a Comparative Institutional Assessment", Journal of Economic and Business Organization, 1, pp. 1-38.

Williamson, O.E. en W. Ouchi, (1983), "The markets and Hierarchies Perspective: Origins, Implications, Prospects", in: Francis, Turk en Willman.

Williamson, O.E., (1984), "The Economics of Governance: Framework and Implication", Journal of Institutional and Theoretical Economics, 140, pp. 195223.

Williamson, O.E., (1985a), "Reflections on the New Institutional Economics", Journal of Institutional and Theoretical Economics, 141, pp. 187-195.

Williamson, O.E.,' (1985b), "The Economic Institutions of Capitalism"; New York: The Free Press.

Williamson, O.E., (1985c), "Employ Ownership and Internal Governance: a perspective", Journal of Economic Behavior and Organization, 6, pp. 243-245.

Williamson, O.E., (1987a), "Critical Perspectives on Organization Theories, Economics and Sociology: Promoting a Dialog", Paper ISA-RC 17, Conference, jully 1987.

Williamson, O.E. (1987b), "Transaction Cost Economics, the Comparative Contracting Perspective", Journal of Economic Behaviour and Organization 8, pp. 617-625.

Willis, M. (1972), "Rational Expectations - Fresh Ideas that Challenge some established views of policy Making", Federal Reserve Bank of Minneapolis Annual Repport 1977.

Willman, P., (1983), "The Organizational Failures Framework and Industrial Sociology", in Francis, Turk en Willman (eds).

Winden van, F., (1981), "On the Interaction Between State and Private Sector, a Study in Political Economics", "s-Gravenhage: J.H. Pasmans BV.

Wright, V., (1983), "Giscard, Giscardians and Giscardism", London: Allen and Unwin.

Wijers, G., (1982), "Industriepolitiek; een onderzoek naar de vormgeving van het overheidsbeleid gericht op industrielle sectoren", Leiden: Stenfert Kroese.

Yip, G.S., (1982), "Barriers to Entry: a corporate-strategy perspective", Lexington MA: Heath.

Zarader, R. (1983), "L'information" in: Bellon en Chevalier (eds).

Zantman, A., (1982), "Les Grands Axes de la Politique Industrielle Française au Seuil des Années 1980", Demain Etudes et Expansion, pp. 392-396.

Zielinski, J.G., (1973), "Economic Reforms in Polish Industry", London: Oxford University Press.

Zuidema, J.R., (1973), "Enige gedachten over economische orde; het beginsel van de ingebouwde teleurstelling", in Dezer Dagen, Begeer, Klaassen, Zuidema (red).

Zuidema, J.R., (1982), "Het vraagstuk van de economische orde of de série l'américaine, Maandschrift Economie, 46, pp. 92-116.

Zwan, van de, A., (1980), "Plaats en toekomst van de Nederlandse industrie", Antwoord aan de critici, Economische Statistische Berichten, dd. 24-9-1980, pp. 10741078.

Zwan, van de, A., (1982), "Institutionale Arrangementen en de Werking van het Marktmechanisme", ESB, 16-6-1982, pp. 600-605.

Zwan van de, A., (1983), "Terug naar de Werkelijkheid, Een Beschouwing over 
Ondernemingsbeleid en Marktstrategie" ${ }^{*}$ Economische Statistische Berichten 204-1983, pp. 332-336.

Zysman, J., (1977), "Political Strategies for Industrial Order: State Market and Industry in France", Los Angeles: University of California Press 1977.

Zysman, I. en S. Cohen, (1985), "Government Market and Growth", Cornell University Press. 


\section{CURRICULUM VITAE}

John Groenewegen werd geboren te Nootdorp op 16 maart 1949.

Volgde zijn middelbare schoolopleiding (HBS-A) van 1961 tot 1967 te Delft. Studeerde van 1967 tot 1974 economie aan de Nederlandse Economische Hogeschool (later Erasmus Universiteit) te Rotterdam. Deed doctoraal examen in de economischsociologische richting van de algemeen economische variant. Was in de periode 1972 tot 1974 als student-assistent werkzaam bij de vakgroep Economische Orde, Economische Organisatievormen en Institutionele Economie van de Erasmus universiteit. Vervulde zijn militaire dienstplicht van 1975 tot 1976 en trad in 1976 in dienst als beleidsmedewerker van de sociaal-economische sectie van de Stichting De Nederlandse Gezinsraad te 's-Gravenhage. Is sedert 1979 als wetenschappelijk medewerker verbonden aan de de Erasmus Universiteit te Rotterdam bij de vakgroep Economische Organisatievormen. Daarnaast is hij betrokken bij de korte termijn opleiding Japankunde van de Erasmus universiteit en het MBA en MBI-programma van de Rotterdam School of Management. Zijn onderzoekterrein betreft de vergelijking van economische stelsels, vraagstukken van industriële organisatie en industriebeleid en de problematiek van het strategisch management. Over die onderwerpen heeft hij in binnen- en buitenlandse tijdschriften gepubliceerd en samen met anderen boeken geredigeerd. Hij is voorzitter van de 'Studiekring Industriepolitiek' (STIP) van SISWO, 'international correspondent' van de 'Journal of Economic Issues', lid van de 'Steering Committee van de 'European Association for Political Evolutionary Economy' en 'managing en consulting partner' van de stichting GRASP (Group for Research and Advice in Strategic Management and Industrial Policy). 